\title{
ANTENOR FERREIRA CORRÊA
}

\section{Integração de Técnicas Analíticas como Princípio de um \\ Modelo Composicional}

Tese apresentada ao Programa de Pós-Graduação em Música, Área de Concentração Musicologia, Linha de Pesquisa Técnicas Composicionais e Questões Interpretativas, como exigência parcial para obtenção do título de doutor, sob a orientação do Prof. Dr. Amilcar Zani. 


\section{ANTENOR FERREIRA CORRÊA}

\section{Integração de Técnicas Analíticas como Princípio de um Modelo Composicional}

Tese apresentada ao Programa de Pós-Graduação em Música, Área de Concentração Musicologia, Linha de Pesquisa Técnicas Composicionais e Questões Interpretativas, como exigência parcial para obtenção do título de doutor, sob a orientação do Prof. Dr. Amilcar Zani.

São Paulo 
Banca Examinadora 
para

Edmundo Villani-Cortes 


\section{Agradecimentos}

À CAPES: Coordenação de aperfeiçoamento de pessoal de nível superior, importantíssima instituição de fomento à produção de conhecimento no Brasil, pela concessão de subsídio para a realização deste projeto;

Ao Professor Doutor Amilcar Zani, orientador desta pesquisa, pela confiança em mim depositada;

Aos meus familiares Antenor P. Corrêa, Neusa Ferreira, Isabella Corrêa, Regina Célia, Daniele Cristina e Damaris, pela paciência, compreensão e amor durante este período de ausência;

Aos amigos músicos Luis Afonso Montanha, Danieli Longo, Eliana Sulpício, Paulo Zorzetto, Beatriz Alessio, Carlos Sulpício, Lenita Portilho, Fernando Iazzetta, o quinteto de clarinetes Sujeito a Guincho (Sergio Burgani, Luca Raele, Luis Afonso Montanha, Edmilson Nery e Nivaldo Orsi), Miranda Bartira e o quarteto de cordas Nobilis (Silvia Velludo, José Quirino, Margareth Yahagi e Meryelle Maciente) que dispuseram de seu talento e competência para a realização do CD que integra este trabalho;

Aos compositores Paulo Chagas, Rodolfo Caesar, Denise Garcia, Silvio Ferraz, Jorge Antunes, Flô Menezes, Rodolfo Coelho de Souza, Edson Zampronha, Edmundo Villani-Côrtes, Antonio Ribeiro, Paulo de Tarso e Ronaldo Miranda pela ajuda fornecida por meio de entrevistas e valiosas conversas.

Aos amigos Luciano César de Morais, Mirian Megumi Utsunomiya, Margarida Fukuda, Wânia Storolli e Graziela Bortz, pelo apoio e estímulo. 


\section{Integração de Técnicas Analíticas como Princípio de um Modelo Composicional}

Resumo: Nesta pesquisa propõe-se a elaboração de um modelo composicional a partir da integração de três técnicas analíticas: tematicismo, estratificação e refuncionalização. Tem-se por hipótese que essas ferramentas de análise musical, per se unilaterais, são passíveis de associação gerando um novo modelo de composição que engloba os aspectos temáticos, harmônicos, texturais e formais necessários para a estruturação de um discurso musical inserido em uma estética pós-tonal. Os procedimentos analíticos não são tomados como prescrições, tampouco empregados como moldes estanques, mas usados como ponto de partida para o trabalho composicional. O modelo assim estabelecido permite ser desdobrado para o campo da didática musical na medida em que pode ser empregado como estratégia pedagógica nos cursos de composição. Espera-se, além do aporte eminentemente técnico composicional gerado com a constituição desse modelo, ampliar o alcance das ferramentas analíticas aqui consideradas e, ao mesmo tempo, contribuir com o incremento da literatura incidente aos assuntos composicionais, posto que neste projeto estão envolvidas considerações sobre a estética musical contemporânea e o ensino da composição.

Palavras-chave: composição musical, análise musical, pós-tonalismo, pedagogia da composição musical.

Abstract: In this research was proposed the creation of a model to musical composition accomplished by setting together three analytical techniques: thematicism, stratification, and refunctioning. The basic hypothesis suggests that analytical tools, per se unilateral, could be associated in order to generate a new model to musical composition. In this model will be integrated the aspects thematic, harmonic, of the texture, and formal that are necessary to structure a post-tonal musical discourse. The analytical proceedings are not taken like prescriptions, neither employed in a rigid way, but used like starting point for the compositional work. So established model will allow be transported for the field of the musical education in so far as it can be employed like pedagogic strategy in the courses of composition. It is hoped, besides the technical contributions produced with the constitution of this model, to enlarge the reach of the analytical tools presented, and at the same time, to contribute with the growth of the literature about compositional issues, since this project also deals with aesthetical and pedagogical subjects.

Key-words: musical composition, musical analysis, post-tonality, pedagogy of musical composition. 


\section{SUMÁRIO}

Introdução: Sobre teoria, modelo e princípios de base $\quad 1$

Capítulo 1: O Sentido da análise musical 34

Capítulo 2: Análise de segunda ordem $\quad 50$

Capítulo 3: Estratificação e Justaposição 86

Capítulo 4: Transformações temáticas 118

Capítulo 5: Função e refuncionalização 153

Capítulo 6: Comunicabilidade na música pós-tonal 205

Conclusões: A árvore, o fruto e a floresta 233

$\begin{array}{ll}\text { Referências } & 247\end{array}$

$\begin{array}{ll}\text { Anexos } & 256\end{array}$

Partituras das composições desenvolvidas com o método proposto.

1. Trilhas Sonoras (para percussão: marimba, 2 break drums, 3 pratos e bumbo a pedal)

2. Impressão sol poente (para piano)

3. Metralhadora (para quinteto de cordas)

4. Prelúdio 1 em Eb (para piano)

5. Prelúdio 2 (para piano)

6. Prelúdio 3 (para piano)

7. Chiromancer's hands doesn't have lines (para piano, 2 percussionistas, clarinete, trompete e sons eletroacústicos)

8. Jericó (para 2 percussionistas, trompete, sons eletroacústicos e transformação eletroacústica em tempo real)

9. Veredas do Sertão (para quinteto de clarinetes) 
Introdução

Sobre teoria, modelo e princípios de base 


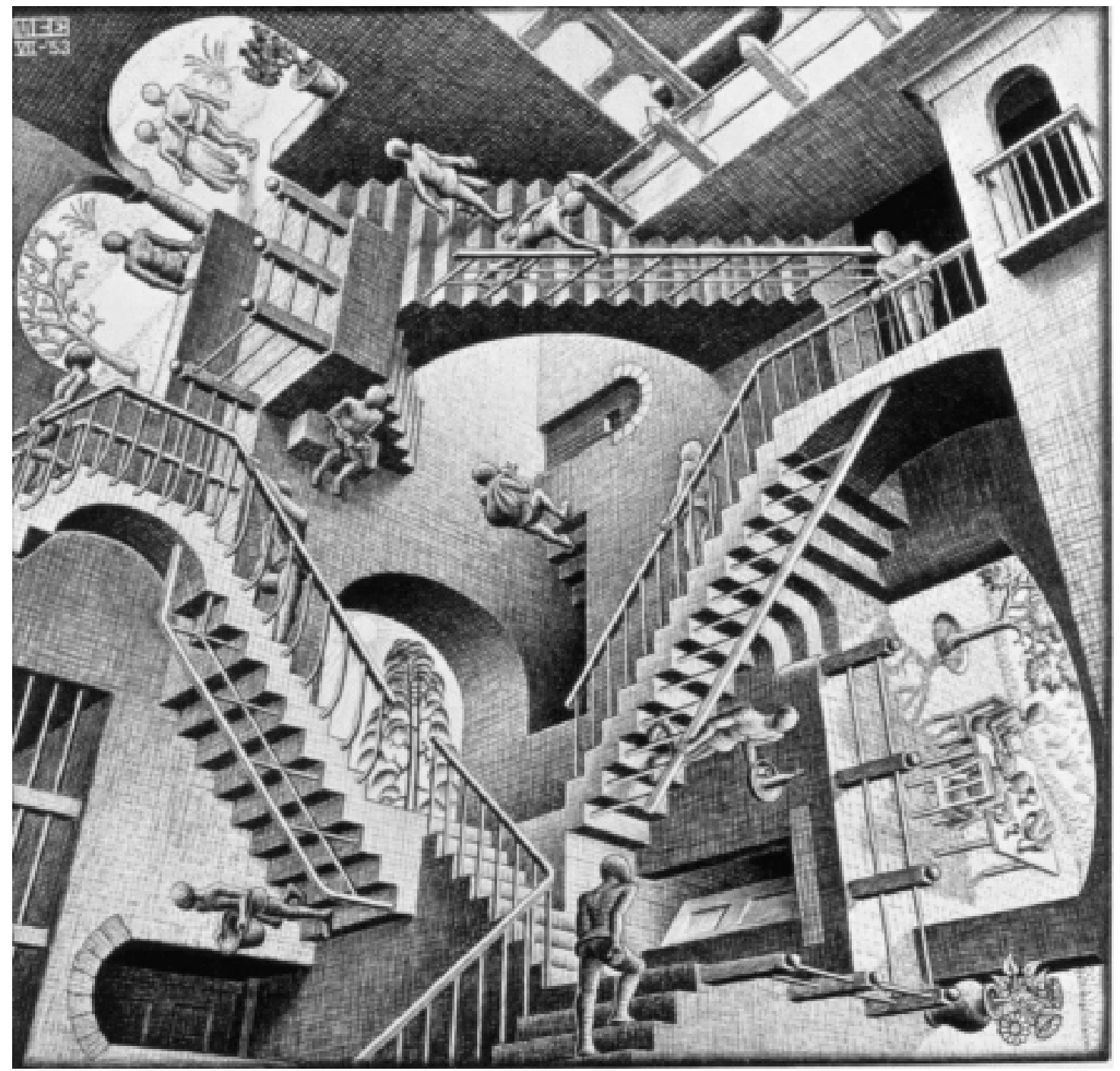

Maurits Escher: Relativity (1953) litografia. 


\section{- Teoria do Campo Unificado!}

$-\ldots$

O conferencista prosseguia com suas considerações finais, mas em minha cabeça aquela expressão ainda reverberava: Teoria do Campo Unificado.

Assim que a apresentação foi encerrada e a massa de pessoas que se aglomerava em volta do palestrante ia aos poucos se dissipando, criei coragem e me dirigi a ele:

- Tens mais um minuto professor?

- Na verdade não, mas . . . diga.

- Poderia esclarecer alguns aspectos da teoria que expôs?

- E você acha que um minuto bastaria para tais esclarecimentos? - caçoou ele.

- De fato não. - respondi meio sem graça - Foi apenas força de expressão.

- Expressão não é uma força. E ainda bem, porque se fosse, eu teria algo mais com o que me preocupar no sentido da unificação.

Não respondi, apenas observei-o e acompanhei-o enquanto deixava o auditório onde acontecera a conferência e seguia em direção à sala da diretoria. Na semana passada houve o professor de acústica afirmando que a série harmônica não existia. Agora essa estória de unificação teórica das forças da natureza eu não poderia deixar passar sem mais esclarecimentos.

Andei ao seu encontro e, enquanto caminhávamos, ele me disse:

- Na palestra de amanhã darei seqüência ao assunto.

- Eu sei. Infelizmente não poderei comparecer porque tenho concerto da orquestra onde trabalho.

- Você é músico !?

$-\operatorname{Sim}$.

- Minha mãe foi uma ótima pianista.

- E o senhor um ótimo violinista! - emendei.

- Ah! Antes fosse. - pareceu lamentar-se - Alguns diziam que eu tocava relativamente bem. Porém, não tive tempo para me dedicar aos estudos técnicos que o instrumento exige.

- É muita modéstia para quem já se apresentou até no Carnegie Hall.

- Ora, qualquer coisa que eu fizesse lá seria aplaudida. O concerto era beneficente.

- Bem, - disse tentando trazê-lo de volta ao motivo de minha interpelação - será que haveria outra oportunidade para conversarmos?

- Tenho que aguardar a pessoa que virá me buscar. Vou esperar por ele em um bar. Se você não se importar podemos conversar um pouco enquanto ele não chega. 
- Mas é claro que não me importo! - respondi em um misto de alegria e surpresa pelo convite.

Ele, então, deixou alguns livros na sala da diretoria e seguiu para os fundos da universidade.

- Professor, a saída é por lá.

- Mas o bar é para lá! - emendou imediatamente apontando o caminho.

- Pensei que não houvesse saída pelos fundos.

- A maioria das pessoas também pensa assim.

- Então ... não me diga que existe um bar nos fundos da escola !?

- Não conte para ninguém, é meio secreto. - arrematou em tom de zombaria.

- Essa escola é mesmo surpreendente.

Cruzamos o átrio em direção à parte sul do campus, em meio às veredas arborizadas. Ele andava rapidamente e eu tentava acompanhá-lo, ao mesmo tempo buscando algo inteligente para perguntar. Não podia perder a oportunidade de trazer à tona aquele assunto que me deixou perplexo.

- Chegamos. É aqui. - disse ele.

Tive que conter o riso, pois o professor parou defronte de uma portinha de madeira, de aspecto antigo, onde morava o zelador.

- Aqui é a zeladoria, professor.

Sem fazer qualquer comentário, bateu à porta.

Um homem de barba curta, usando óculos, terno e gravata apareceu e o cumprimentou efusivamente. Seu rosto me pareceu familiar, porém não conseguia me lembrar onde já havia visto aquela figura.

- Seja bem vindo Albert. - disse o homem.

- Como vão as coisas Kaluza? - perguntou-lhe o professor.

- Tudo muito bem - respondeu o anfitrião com um sotaque germânico.

- Este é meu convidado...

- Josephus. - completei apresentando-me aos dois.

- Por favor, entrem e fiquem à vontade. - convidou o homem.

Eu continuava atônito pela descoberta daquele lugar. Eu tinha hábito de caminhar pelo campus mas nunca notara qualquer indício da presença de um bar. Nenhuma entrega de bebidas ou movimentação de pessoas. Sempre acreditei que ali fosse o quarto do zelador. Às vezes tenho que admitir que só encontramos por aquilo que procuramos.

Tomamos assento em uma mesa ao canto. Um garçom rapidamente serviu chá ao professor.

- Você desejaria algo? - indagou o garçom. 
Não respondi, pois nem me dei conta da pergunta. Estava completamente perplexo com a decoração e, principalmente, com a arquitetura do local.

O garçom se afastou.

Se a descoberta de um bar já trazia certa confusão, a construção daquele lugar me deixou absolutamente perturbado. Havia escadas que iam e vinham do teto. Passagens parecidas com alçapões saíam das paredes em diversas direções. Algumas portas abobadadas davam para uma espécie de varanda donde se podiam enxergar as árvores do campus. Como se não bastasse, sob minha perspectiva, algumas mesas estavam inclinadas ou de "ponta cabeça”. Aquilo parecia um salão virtual como o holodeck do seriado Jornada nas Estrelas.

O professor Albert, notando minha cara de 'ponto de interrogação', comentou:

- Não é á toa que apelidaram esse bar de $13^{\mathrm{a}}$ dimensão.

- Absolutamente impressionante! - consegui balbuciar - Como é que . . .

- Não tente entender, apenas aprecie a "paisagem”. Deixe a fruição sobrepujar a razão.

- E como se explicaria uma coisa destas? - perguntei mesmo sabendo que não haveria resposta.

- Esse choque é normal em qualquer um que venha aqui pela primeira vez. - disse o professor tentando trazer-me de volta à realidade - Depois você acaba acostumando.

Dito isto, ele mesmo prosseguiu:

- Você é músico, então porque o interesse pela teoria do campo unificado?

Procurando abstrair as bizarrices que me rodeavam respondi:

- Meus interesses são composicionais. Durante sua conferência me ocorreu que, se um cientista pode vir a unificar todas as forças (ou interações, para usar seu linguajar) que compõem, atuam e regem os fenômenos do universo, quem sabe o mesmo poderá ser feito para a teoria da composição musical.

- Mas a composição não me parece algo lógico. Do contrário, parece estar ligada à inspiração. Certo?

Percebi que ele me testava, resolvi aceitar a provocação e afirmei:

- Os compositores são tão inspirados quanto os físicos.

Ele sorriu e eu continuei:

- Particularmente, vejo quaisquer artistas criadores e cientistas partilhando dos mesmos paradigmas e inquietações. Somente se diferenciam pelo produto final de seus processos criativos. No entanto, ambos oferecem novas maneiras de se contemplar o mundo que nos cerca.

- Mas em matéria de composição artística há fatores não quantificáveis. - ponderou ele. 
- Concordo que certas tomadas de decisões durante o ato criativo são difíceis de se explicar. Talvez seja esta a característica diferencial entre uma grande obra e as outras. Mas, não é por causa disto que não podemos tentar teorizar sobre o fato. Não concorda?

Percebi que ele olhava fixamente para a xícara de chá.

- Há algumas partículas em suspensão. - comentou de modo casual.

- Eu sei. E segundo sua própria explicação, baseada na teoria cinética, o movimento dessas partículas decorre da vibração das moléculas do líquido que, por sua vez, é influenciada pela temperatura e viscosidade do mesmo.

Com essa frase decorada das enciclopédias notei que acabara de ganhar sua atenção. Ele levantou o rosto, me fitou, e disse:

- Ok Josephus, continuemos nossa conversa sobre música.

- Prefiro falar da teoria do campo unificado. Sinceramente, professor, o senhor acha mesmo que ao falar em "prova da não existência de um campo central simétrico universalmente regular ..." alguém entendeu alguma coisa?

Ele riu e prosseguiu em tom formal:

- Talvez três pessoas entendam. Outros tantos irão para casa pensar e depois, mesmo sem compreender coisa alguma, passarão a criticar.

- O senhor não pode facilitar um pouco? Vamos do começo, não esqueça que está falando com um músico.

- Teorias de unificação - continuou ele - objetivam que todos os fenômenos compreendidos no universo, sejam estes de proporções cosmológicas ou do microscópico mundo subatômico, possam ser explicados por meio de uma única teoria. Uma teoria do campo unificado descreve em termos de um único campo todas as forças fundamentais entre partículas elementares.

- Então sua teoria engloba a força gravitacional, a força eletromagnética e as forças nucleares fraca e forte?

- Em 1916, quando vislumbrei essa possibilidade e dei início às pesquisas nessa área, as forças nucleares ainda não eram conhecidas. Eu intentava unificar a força gravitacional, regida pela teoria da relatividade geral, com o eletromagnetismo.

- Então o nome teoria do campo decorre do campo gravitacional e campo eletromagnético. - Sim.

Aproveitando a chegada do garçom, fiz um pedido enquanto pensava se realmente conseguira compreender alguma coisa. Então, comentei em tom de questionamento:

- Certas expressões advindas da física convivem atualmente no senso comum e talvez tenha apenas uma noção aproximada daquilo que devem significar. Quando penso em "campo gravitacional" e "campo magnético" me vem à mente uma imagem que acredito corresponder 
à definição destes. Mas talvez não compreenda o tema com profundidade necessária para entender a sua teoria.

- A idéia de campo surgiu na física da necessidade de se explicar algo novo à época, isto é, a maneira de interação entre grandezas na ausência de contato direto e sem meios aparentes de transmissão dessas interações.

Tentei organizar meus pensamentos e disse:

- Se eu jogar este copo naquela parede cheia de garrafas, provavelmente, irei quebrar alguma delas. Isto é um ataque pontual. Porém, se no lugar de um copo eu possuísse um imã gigante, e o apontasse para o balcão na tentativa de puxar para cá um talher, atrairia também outros objetos de metal localizados neste espaço. Essa segunda ação é uma força de campo.

Ele só me olhava, mas não acrescentou nada. Eu, quebrando o silêncio, perguntei:

- Então campo surgiu em oposição à partícula, pois campo existe por todo o espaço, enquanto partícula existe apenas em um único ponto e momento específicos?

- Mezzo. Um campo é a atribuição de uma quantidade física a cada ponto no espaço visualizado como se estendendo em todas as partes de uma grande região deste espaço, de modo que a sua influência seja ubíqua.

- Vamos devagar. O efeito de um campo é sentido em todo espaço, é uma ação à distância provocada por algo.

- Sim, mediante os efeitos provocados pelas próprias grandezas envolvidas no espaço circundante, variando sobre a região abarcada. Por exemplo, se pensar na atração gravitacional que o Sol exerce sobre a Terra, o cálculo da força dessa atração entre os corpos envolve as suas respectivas massas e a distância entre ambos.

- "Os corpos se atraem na direta proporção de suas massas e na inversa proporção do quadrado de suas distâncias”. - tentei formular o enunciado com sotaque britânico, mas ele não achou divertido.

- O conceito de campo permitiu atribuir magnitudes mensuráveis ao espaço que circunda a matéria, fazendo corresponder a cada ponto desse espaço valores que dependem unicamente da grandeza dos corpos que provocavam a interação e da localização dos pontos considerados. - Cálculo já determinado por Newton - acrescentei tentando mostrar algum conhecimento. - Até surgir o físico-químico Michael Faraday, também inglês, para aproveitar seu sotaque. - Mas Faraday não investigava sobre o magnetismo?

- Sim, só que antes dele se considerava que as forças gravitacionais, elétricas e magnéticas atuavam de modo instantâneo através do espaço vazio que separa as partículas em interação. Faraday não concordava com essa ação à distância, base da mecânica newtoniana. Ele imaginava que o espaço entre as cargas elétricas e os ímãs estivesse preenchido por 'alguma 
coisa', pois as forças exigem tempo e meios para serem transmitidas. Essa 'alguma coisa' eram os campos de força.

- Bela dedução.

- O mais brilhante é que, em 1831, Faraday comprovou ainda que campos magnéticos poderiam induzir campos elétricos e vice e versa. Atestou, então, que eletricidade e magnetismo não são fenômenos independentes, mas sim diferentes manifestações de um único campo, o campo eletromagnético.

- O mais fascinante é Faraday ter comprovado suas idéias experimentalmente, dados os parcos recursos tecnológicos da época.

- Além de tudo, essas idéias serviram de base para o físico escocês James Clerk Maxwell criar a primeira teoria unificada de campo com a introdução de equações para o cálculo matemático do campo eletromagnético.

- Primeiro veio a comprovação experimental e depois a explicação matemática?

- Sim. Em 1865 Maxwell provou matematicamente que os fenômenos eletromagnéticos são propagados em ondas pelo espaço com a velocidade da luz, e que, diferentemente das forças de Newton, propagavam-se a uma velocidade definida (c) que vale 300 mil quilômetros por segundo.

- E, como gosto de história, - comentei - não posso esquecer que desse modo Maxwell lançou as bases para a rádio comunicação, confirmada experimentalmente por Hertz em 1888 e desenvolvida com Marconi na virada do século.

- Permitindo que as músicas de todas as nações sejam apreciadas em todo o planeta.

- O que na verdade, infelizmente, não acontece.

- Aí teremos que falar de política e interesses financeiros de grandes corporações capitalistas, assunto que não me agradaria. Ando sem forças para a militância política.

- Em música temos também o conceito de campo, mas chamamos campo harmônico.

- E é viável uma analogia com o campo físico?

- Acho que sim, mas deixando de lado a atribuição de valores quantitativos. Veja só, se um campo é uma espécie de força que se faz sentir ao longo de uma região, posso transferir a idéia para a força que uma tônica exerce sobre os acordes que compõem seu campo harmônico. Quanto mais afastados do pólo principal, menor se fará sentir esse efeito atrativo, diminuindo o poder do campo.

- Mas isso só será verdadeiro para as músicas tradicionais?

- Sim, porque na música que é composta abdicando-se de um centro tonal, não existe uma hierarquização que permita eleger um só pólo como principal. Não há um núcleo único para atração gravitacional dos demais acordes. 
- Não vejo onde essas disciplinas se toquem. O que a teoria do campo unificado pode oferecer à composição musical?

- Eu esperava obter essa resposta depois dessa conversa.

Ele pareceu desapontado. Mas, como num golpe de sorte, me ocorreu uma idéia, e continuei:

- Acredito que Teorias, quer sejam da música ou físicas, trabalhem na busca de um princípio de base. O modelo newtoniano postulava que o universo era governado por forças que agiam instantaneamente, também concebendo o tempo e o espaço como grandezas absolutas. Esse modelo cedeu lugar ao novo conceito de campo de força.

- E, - ele rapidamente acrescentou - como você percebeu, eu agora tento unificar a força eletromagnética à força gravitacional tendo como princípio explicativo para o relacionamento entre todos os fenômenos físicos essa noção de campo.

- Sim, seu princípio de base é o conceito de campo.

- E o seu é ...?

- Mas você só faz perguntas difíceis. O princípio de base da composição é . . .

Como não encontrei nada pra falar, limitei-me a provocá-lo.

- O senhor poderia responder essa última questão aproveitando para contestar as críticas de Brecht.

- Não posso respondê-la, pois não sou compositor. Além disso, Brecht me criticava enquanto violinista. Então, vou pedir outro chá. - finalizou rispidamente.

Arrependi-me de ter trazido o assunto á baila. Não podia ter esquecido que sob o manto de cientista ainda pulsavam os melindres particulares aos violinistas. Decidi, assim, deixá-lo a sós.

- Professor, eu preciso ir ao banheiro, mas não sei se conseguirei subir a escada que sai do teto.

Ele respondeu parecendo um pouco menos hostil:

- É só esquecer que está no teto e você conseguirá. Tudo é questão do ponto de vista. Ela parece estar no alto para os observadores que estão abaixo. Quando você estiver lá vai achar que eu estou na parte superior.

- Como você já disse, não vou procurar entender, só “apreciar”. Mas o risco é tentar subir ao Parnassum e acabar enclausurado na Torre de Marfim.

Quando retornei, o professor Albert rabiscava em um pedaço de guardanapo.

- Já reparou - comentou ele - como tudo a nossa volta parece remeter aos gregos?

- Refere-se à arquitetura? 
- Também. Mas, eu pensava na maneira como nomeamos as coisas. O vocabulário proveniente do grego é enorme.

Não conseguia fazer a ligação com a conversa anterior. Ele, então, prosseguiu:

- Magnetismo é uma palavra grega.

- Ah! Agora conectei os assuntos. Se me lembro, os antigos gregos descobriram certas pedras raras naturalmente magnetizadas e chamaram-nas magnetitas.

- O nome magnetismo vem desta pedra magnetita que, por sua vez, deriva de Magnésia, um distrito em Thessaly, na Grécia.

- E também recordo que eles pensavam que estas pedras eram mágicas porque podiam atrair pequenos pedaços de ferro.

- E, além disso, sempre apontavam na mesma direção quando deixadas livremente penduradas em um cordão.

- De fato, eram muito observadores.

- A eletricidade já era, também, conhecida por eles.

- Como assim? Sempre achei que houvesse sido descoberta por Alexandre Volta, em 1800.

- Pense bem, - convidou ele - o termo elektron é grego.

- Curioso. Não havia pensado a respeito.

- Essa história iniciou-se com Tales de Mileto e desdobrou-se por mais de 2000 anos até Volta inventar a primeira pilha capaz de produzir eletricidade que corria constantemente através de um fio por longo tempo, criando assim a primeira corrente elétrica.

- Nossa teoria musical também possui herança grega. Pitágoras, série harmônica, modos, ethos, versificação, retórica, estética, métrica, etc.

- Você já tem aí um ponto de partida para sua empreitada composicional.

- Mas a música que faço é bem diferente, não guarda semelhança alguma com a música grega. Arrisco também dizer que é bem distinta da estética clássica.

- Não teria tanta certeza; mas, vamos partir dessa premissa. De qualquer maneira, você procura por um princípio de base, certo?

- Correto. Mas a série harmônica é um fenômeno acústico próprio dos sons. Acho que não pode servir como princípio gerador das relações musicais, pois o objeto sonoro é diferente do objeto musical. Sem mencionar os processos criativos, que são de base psicológica.

- Não abuse do jargão, - pediu o professor - lembre-se que não sou músico de profíssão.

- Assim como a física clássica newtoniana e a geometria plana euclidiana estavam postas em cheque no início do século XX, o paradigma da prática comum também era reformulado pelos compositores da época. Novas propostas de organização musical surgiram como, por exemplo, o dodecafonismo, que culminará no serialismo. No final da década de 40 o 
engenheiro francês Pierre Schaeffer irá causar uma revolução na música, conseguida por avanços na tecnologia de captação, gravação e transformação sonoras. A essa nova estética hoje damos o nome de música eletroacústica. Foi Schaeffer quem propôs os conceitos de objeto sonoro e objeto musical ...

- Você gosta mesmo de história, hein! - interrompeu-me, mas percebi o seu interessava.

- Todo músico tem muita história e inúmeras estórias pra contar. Somos um páreo duro para os pescadores - respondi.

Ele sugeriu:

- Do mesmo modo como me pediu anteriormente, vou propor que me defina alguns termos.

- Boa idéia! - animei-me, pois senti que o professor havia tomado gosto pelo assunto.

- O que você entende por princípio composicional?

- Não é uma resposta simples, mas vamos lá. Princípio, quando ligado ao tempo, refere-se ao momento em que alguma coisa tem origem. É o início, o começo.

- Desculpe-me interromper, - disse o professor - mas me dei conta de que essa palavra não vem do grego, mas sim do latim: principiu. Mas, prossiga por favor.

- Princípio - continuei - significa também a causa primária, a matéria constitutiva de uma coisa. O próprio Newton escreveu em 1687 seu Philosophiae Naturalis Principia Mathematica. Há outras acepções, mas, dentre estas, a mais pertinente às minhas propostas define princípio como razão, base ou fundamento sobre a qual se apóia o raciocínio e constitui um modelo para a ação.

- Interessante. - ele comentou - Você parte de uma definição próxima da filosofia para chegar a uma aplicação pragmática do conceito.

- Conseguimos achar uma utilidade para a filosofia. - ironizei.

- Isso foi fácil, quero ver você encontrar um filósofo para responder às questões por ele mesmo propostas.

- Neste bar talvez fosse possível! - brinquei novamente, conseguindo arrancar um esboço de sorriso da face do professor.

Empolguei-me e aproveitei para pedir outra bebida. O professor retomou:

- Vejo que você se interessa mesmo por Newton, não é Josephus?

- Pois é. - confirmei - Um sujeito que num insight explica por meio de uma única teoria a queda de um copo aqui no bar e o equilíbrio planetário do sistema solar tem mesmo minha admiração.

- Mas você sabe - complementou o professor - que Newton, além de formular a teoria da gravitação universal e as três leis do movimento, também foi responsável pela descoberta dos cálculos diferencial e integral e pela decomposição da luz branca num prisma. 
- Não há dúvida de que Newton possuía uma poderosa inteligência, apesar de ser descrito como muito antipático e de caráter um pouco duvidoso.

- Mas esses boatos não nos interessam tanto quanto suas contribuições. $\mathrm{O}$ criador deve ser julgado pela sua obra e não pela sua vida.

- Newton - eu acrescentei - foi agraciado em vida e até na morte, ganhando de Alexander Pope um dos mais belos epitáfios já escritos.

O professor aproveitou para declamar:

- "A natureza e suas leis ocultavam-se nas trevas. Então Deus disse: faça-se Newton! E tudo se iluminou”. De fato uma grande contribuição poética.

- E por falar em contribuição, - emendei - a publicação do Principia Mathematica foi custeada pelo amigo e astrônomo Edmund Halley, que hoje dá nome ao cometa.

- O que seria da ciência sem algum tipo de mecenato? - disse o professor com sarcasmo.

- O que seria das artes sem algum tipo de mecenato!? Não fosse o patronato, alguns compositores funcionários de universidades públicas já teriam mudado de profissão há tempos.

- Voltemos ao nosso raciocínio. - solicitou o professor - Já que você gosta de analogias, me diga quantas dimensões atuam em uma composição musical?

- Essa é mais fácil. - admiti - Mas a resposta é relativa. Desculpe-me pela apropriação do seu termo.

- Sem problemas, na verdade o termo não era original, Galileu já havia antecipado seu uso.

- Como assim?! Isso é novidade pra mim.

- Galileu foi o primeiro a sustentar que o movimento dos corpos ocorreria de maneira idêntica quer estivessem acontecendo em terra ou num barco deslocando-se pelo mar. O diferencial seria o ponto de vista do observador, que interpretaria a movimentação de maneiras distintas. Entendeu?

- Entendi. Digamos que o garçom ali possuísse uma bandeja voadora, tal qual um tapete mágico.

- Gostei da imagem, aliás você está captando o 'espírito' desse bar.

Não entendi o comentário, mas segui exemplificando com a intenção de mostrar para mim mesmo se havia compreendido de fato:

- Faz de conta que o garçom estivesse em pé nessa bandeja voando a uma velocidade uniforme, isto é, sem trancos. Se ele abrisse uma garrafa de champanhe arremessando a rolha verticalmente (paralelamente ao eixo de seu próprio corpo), do seu ponto de vista, ele veria a rolha subir sobre sua cabeça e descer retilineamente. De onde estamos sentados, nós veríamos 
a rolha descrevendo uma espécie de parábola, já que todo o sistema (bandeja, garçom e rolha) encontra-se em movimento.

- Muito bem! - declarou o professor Albert - Podemos voltar às dimensões envolvidas em música.

- Minha resposta - prossegui - é relativa no tocante a um aspecto: o ritmo. Mas, antes de falar sobre isto tenho que opinar sobre as outras dimensões. Em música temos como magnânima a dimensão tempo, posto tratar-se da arte temporal por excelência. Parafraseando Andrei Tarkovisky: "compor é esculpir o tempo".

- Bela definição.

- Concorrem também em música as dimensões verticais, horizontais e de profundidade.

- Pode se explicar!? - pediu o professor acendendo seu cachimbo.

- Vertical diz respeito às simultaneidades surgidas no decurso musical. Estas simultaneidades podem ser as diferentes vozes de uma polifonia, os acordes da harmonia ou quaisquer tipos de camadas sonoras postas em jogo no discurso composicional. A profundidade foi no início pensada como uma analogia entre o sistema tonal e o ponto de fuga da pintura. Todavia, julgo poder conceber profundidade em relação aos planos de estruturação da composição. Na existência de níveis estruturais, pode ser que alguns eventos musicais sejam percebidos pela intensidade com que disputam pelo plano de frente. Com isso, nossa escuta pode perceber eventos mais distantes ou mais próximos, similarmente à idéia de profundidade.

- Fale agora sobre a dimensão horizontal. - pediu o professor.

- Quando escrevo uma partitura estou usando as pautas em um sentido horizontal ...

Pela primeira vez ele riu pra valer, e comentou:

- Por essa eu não esperava. É a coisa mais rasteira que você disse hoje, foi uma piada, não foi?

- Na verdade foi um jeito de saltar para outro assunto, mas vi que não deu certo.

- Então vá lá, apresente suas idéias sem medo do erro.

- Para mim a dimensão horizontal refere-se à estruturação rítmica da obra. Embora pareça contraditório, porque o ritmo é a organização do parâmetro da duração do som. Porém, acho que as células rítmicas estendem o som horizontalmente. Inclusive, o ritmo está na dependência da métrica, uma unidade de medida espacial e não temporal. Além disso, de volta às origens, na Grécia o ritmo era dado pelos pés métricos da poesia, marcando sua posição métrica de acordo com a acentuação prosódica. Ora, essa contagem de sílabas fortes e fracas se dá linearmente. Falar em pés-métricos também remete à dança, arte manifesta no espaço. Esses entendimentos engendram na música a relativização temporal. O micro tempo próprio das células rítmicas e o macro tempo envolvido na duração total da obra apontam 
para percepções relativas do fenômeno tempo. Vamos dizer: um tempo diferido, horizontal, presente na escrita e um tempo psicológico da escuta da obra.

- Bem, eu como não acredito em tempo fora do espaço, tampouco em espaço sem tempo, sou levado a concordar.

- Aliás, se bem me lembro, o senhor enunciou que a matéria gera o tempo e o espaço. Do mesmo modo, o material musical gera a contextura espaço-temporal da composição.

- Muito espirituoso. - divertiu-se ele, mas não quis comentar minha falácia.

- Por falar em tempo, - aproveitei para fazer novo chiste - o senhor sabe qual é a semelhança entre um cantor e um filósofo?

- Posso imaginar algumas, mas dê a resposta.

- Ambos concebem o tempo como um conceito abstrato.

Ele sorriu e mudou de assunto formulando nova questão:

- Diga-me Josephus, quais as forças atuantes em composição?

- Gravitacional, eletromagnética, nuclear forte e nuclear fraca. Em física é mais fácil, a resposta está na ponta da língua, mas em música . . .

- Apele para a teoria da música?

- A bem da verdade não existe teoria da música - afirmei.

- Não!? - o professor fez de conta que se espantava.

- Se tomar a definição estrita de teoria, consistindo de uma hipótese sobre a manifestação, ou melhor, sobre o comportamento de fenômenos observados, de modo a poder formular leis que possibilitem controlar e/ou prever suas ocorrências, não poderei transportá-la para o âmbito musical, já que este tipo de objetividade e (olhei bem em seus olhos) determinismo, não encontram correspondentes em uma arte subjetiva, regida por convenções culturais e não por leis. Em música não há leis. Nem as supostas 'leis tonais' da harmonia funcional.

- Mas essa definição é própria das ciências exatas, talvez você deva escolher outra.

- Mas, já que falamos em Grécia, - continuei - a música fazia parte das ciências exatas: o quadrivium.

- Deixe a antiguidade clássica um pouco de lado e reflita como um homem do século XX ordenou o professor.

- De modo capitalista, traumático ou esotérico? - insinuei.

- Nenhum. - respondeu sorrindo o professor - Porém, de modo interdisciplinar.

- No lugar de teoria - continuei tentando ficar sério - seria correto falar em sistema musical, dado o escasso teor empírico comportado pelo fato musical. Como sistema vale para descrever qualquer todo organizado (como o sistema solar por exemplo) aplica-se bem em representar o complexo universo da música. 
- Então - sorriu ele - você não tem mais problema algum, pois já sentenciou que não poderá erigir uma teoria da composição, seja esta unificada ou mesmo desunida.

- Contudo, - permaneci alguns instantes em posição de fermata - posso tentar construir um modelo composicional.

- Mas os termos não são intercambiáveis? - perguntou o professor em tom de gozação.

- Não da mesma maneira como o são massa e energia. - retribuí a brincadeira - Segundo alguns pensadores (veja Delatre, por exemplo), teoria tem uma abrangência global, enquanto modelo refere-se a algo mais específico, mais particularizado, representando um âmbito bem delimitado e determinado.

Como o professor não comentara nada, eu prossegui:

- Neste modelo eu poderia propor um conjunto de procedimentos relativos ao tratamento das dimensões musicais de modo a embasar uma poética da composição.

- Seria um modelo para lidar com algumas forças composicionais de maneira unificada?

$-\operatorname{Sim}$

- Então, - reiterou o professor - terei de refazer minha questão: quais as forças atuantes em composição?

- Agora que, por meio do manuseio terminológico, já estou desculpado pela falta de rigor científico stricto sensu, posso tentar responder.

- Pois bem, estou ouvindo. - disse o professor Albert.

- Porém, exijo que me interrompa se estiver errado em algum aspecto.

- Sem problemas. - consentiu ele.

- Entendo como força o modo como os elementos interagem entre si, sejam estes elementos partículas atômicas ou estruturas gerativas da música. A força nuclear forte, por exemplo, ... - A força nuclear forte! Já percebo aonde essa conversa pode levar.

- Não gostaria de falar da mecânica quântica? - antecipei-me em perguntar para não correr o risco de desagradar-lhe novamente.

- Você sabe que tenho sérias reservas sobre o tema - confirmou o professor.

- Espero não chegar tão longe nos meus devaneios. Mas, confesso minha curiosidade pela sua reserva em tratar do assunto, pois este novo ramo da física foi fundado graças a você.

- A "matéria" é muito controversa.

Fez a frase piscando um olho e fitando uma mulher que passava. Ao que eu emendei: - O senhor é sutil, mas não é malicioso.

- Um cientista busca por certezas. E cálculos de probabilidades são úteis para o pôquer de sábado à noite ou para estimar as reações femininas, mas inconcebíveis para sustentar uma lei física. 
- Mudei de idéia, talvez o senhor seja malicioso.

- A situação chegou a tal ponto de hoje se falar em determinismo quântico!

- Já li a respeito, segundo Greene o conhecimento das funções de ondas de probabilidade da mecânica quântica permite determinar os estados quânticos em qualquer momento do futuro e do passado.

- Porém, - acrescentou o professor - o negócio é que o conhecimento do estado quântico vai determinar apenas a probabilidade de que um ou outro futuro possa produzir-se. Ao final, continua-se na mesma, pois não há determinação alguma, só prognósticos.

Sorri tentando contornar a situação e prossegui:

- Professor, o senhor me fez recordar uma situação embaraçosa. Quando eu era estudante no colegial, o professor de química apresentou a estrutura atômica à classe. Ele explicou que os átomos eram formados por elétrons (com carga negativa), prótons (com carga positiva) e nêutrons (com carga neutra).

- Pelo jeito faz tempo! - observou ele.

- Infelizmente, não faz tanto tempo assim. Então o dito professor de química continuou dizendo que os prótons e nêutrons ficavam no núcleo do átomo. Foi aí que caí na besteira de perguntar: "e por que os prótons não se dispersam, já que possuem cargas de mesmo sinal e, conseqüentemente, deveriam repelir-se?”. O professor disse que era por causa do nêutron. Então insisti: "por que os elétrons não são atraídos para o núcleo, já que as cargas opostas dos elétrons e dos prótons deveriam se atrair?". Dessa vez me respondeu que se eu não parasse de bancar o engraçadinho iria ser 'repelido' para a diretoria.

- Você está trazendo à tona lembranças do meu tempo no Gymnasium.

- Bem, não tive a intenção de trazer-lhe más recordações.

- Não diria que foram más, mas . . . Bem, conclua o que dizia.

- Tive que esperar por alguns anos, até ler em um livro na faculdade a explicação da força nuclear.

Professor Albert completou:

- "Uma força de atração mil vezes maior que a força de repulsão eletromagnética, capaz de manter os quarks dentro dos prótons e conservar prótons e nêutrons agrupados dentro do núcleo atômico".

- Nossa, uma definição idêntica à de Hawking. - me admirei.

- De quem?

- Deixe pra lá. O importante é saber que os elementos interagem entre si. Dito isto, preciso descobrir como se dá a ação entre os componentes musicais. O que os mantém coesos?

Foi a vez de o professor Albert responder com outra pergunta: 
- O que você chama de componentes musicais?

- Há vários, por exemplo, notas, células rítmicas, timbres, texturas, harmonia . . .

- Mas a melodia é o mais importante! - disse uma voz gutural vinda da mesa ao lado.

- Igor?!! Mas será possível? O que está fazendo aqui?

- Estava já há algum tempo escutando a conversa de vocês.

- Professor Albert, permita-me que lhe apresente meu colega . . .

- Como vai Igor? É uma grande satisfação conhecê-lo. - antecipou-se o professor estendendo-lhe a mão.

- A satisfação é toda minha professor. - retribuiu Igor.

Apressei-me em perguntar ao professor se ele consentiria que Igor se juntasse a nós. Ao que respondeu polidamente:

- De maneira alguma. Fique a vontade.

- Igor, - perguntei intrigado - desde quando você freqüenta este bar?

- O bar Gedanken é muito comentado entre as mentes criativas desta universidade, na qual, a propósito, ministrarei uma série de conferências. - respondeu Igor, posicionando sua cadeira.

- Vocês sabem que as idéias mais inovadoras surgiram após algumas rodadas de chope neste bar? - falou o professor Albert - Foi aqui, após várias doses em companhia de Nathan Rosen, que tivemos a idéia das 'pontes' capazes de ligar os universos, as quais os astrofísicos hodiernos, pouco criativos, dão o nome de 'buracos de minhoca'.

- Não é pra menos, - ponderei - esse lugar é mesmo propício para colocar a imaginação em liberdade.

Houve alguns instantes de silêncio, que atribuí ao meu comentário, pois a palavra 'liberdade' é muito cara aos seres humanos perseguidos. Foi a vez de Igor contornar a situação:

- Josephus, então você está incomodando o nobre professor com seus problemas.

- Não é incômodo algum. - adiantou-se o professor Albert em responder - Faz tempo que desejo falar de outros assuntos que não teorias físicas.

- Igor - eu prossegui - talvez você não saiba, mas além de físico e amante da música, o professor Albert é violinista.

- Muito interessante. - exclamou Igor de fato interessado - Recentemente escrevi um concerto para violino, talvez o professor queira apresentá-lo.

- Já parei de tocar há tempos. - lamentou o professor Albert - Então você também é compositor?

- E dos bons! - aproveitei para elogiá-lo - Aliás, em minha opinião, um dos melhores. A propósito, me ocorreu que vocês dois possuem muito em comum. 
- Sem exageros Josephus. - moderou Igor.

- É sério! - prossegui - Os dois revolucionaram seus respectivos campos de atuação no século XX; sofreram de perto as privações provocadas pelas duas grandes guerras; residiram na Suíça; após reformularem os paradigmas clássicos, foram criticados por conservarem atitudes próprias do classicismo; ambos se envolveram de modo direto ou indireto com o mito de Fausto; nenhum dos dois formou 'escola' ou deixou discípulos ou seguidores diretos; vocês são exilados morando nos Estados Unidos e (para não abusar da sua paciência) concluo enfatizando que ambos foram eleitos no rol das 100 pessoas mais influentes do século XX.

- Tudo bem Josephus, - assentiu o professor Albert - já entendemos. Mas gostaria mesmo de voltar a falar de música.

- Professor me diga, quais são seus compositores contemporâneos prediletos? - inquiriu Igor. - Mozart, Mozart e Mozart - respondeu o professor de modo sério.

- Mas não há nenhum de seu agrado dentre os compositores atuais? - eu insisti.

- Sim, Bach e Beethoven.

- Mas estes não são do século XX. - retruquei.

- Mas continuam sendo os melhores. - atestou solenemente o professor.

- E sobre Brahms? - foi a vez de Igor instigá-lo.

- Gosto principalmente de suas peças de câmara, mas a maioria de suas obras não me persuade interiormente.

- Bach, Beethoven, Brahms. Se for para falar nomes com a letra 'B' gostaria de citar dois de meus preferidos: Bartók e Berio. - disse já esperando alguma censura.

- Tenho muito apreço por Bartók e por suas pesquisas. - declarou Igor.

- Vocês são músicos mas não perdem a oportunidade de embutir algum tipo de objetividade em seu campo de atuação. Há pouco Josephus intentava edificar um modelo composicional unificado; agora Igor, você incluí a pesquisa dentre o métier do compositor.

O comentário do professor ficou no ar por alguns instantes. Então Igor veio com a frase:

- Em seu estado puro, a música nada mais é do que a livre especulação.

Eu não poderia perder a deixa e completei:

- Mas no estado impuro incorpora ritmos primitivos e rituais selvagens.

- Sem mais gozações. - contestou Igor - Já bastam as demonstrações de ignorância da pretensa crítica especializada.

Foi a vez de o professor manifestar-se:

- Esse caso prova que às vezes um suposto fracasso inicial servirá para o engrandecimento pessoal, além de, posteriormente, explicitar a idiotice alheia. 
- Em música - afirmei - o erro é tão importante quanto o acerto.

- Não só em música, mas em qualquer domínio onde exista vida inteligente! - arrematou o professor.

- A história - eu continuei - nos mostra uma série de 'fracassos' bem sucedidos, que vieram a influenciar toda uma produção subseqüente, como Les demoiselles d'Avignon de Picasso, a própria Le Sacre e a constante cosmológica.

- A constante cosmológica foi sim um erro. - sentenciou o professor.

- De maneira alguma. - contestei - Naquela época não havia instrumentos tecnológicos potentes para se detectar a expansão do universo. Porém, hoje em dia já foi observado que o universo está se expandindo aceleradamente há pelo menos 5 bilhões de anos. A força responsável por essa aceleração foi chamada de energia escura (um dos maiores mistérios da astrofísica moderna). Os cientistas acham que ela seja nada menos que a tal constante cosmológica, provando, assim, que o gênio estava certo mesmo quando errava.

O professor, então, sorriu discretamente.

- Se pudesse voltar no tempo - falei - gostaria de assistir a primeira apresentação da Sagração.

- Josephus, você gosta mesmo de ver "o circo pegar fogo". - ironizou Igor.

- Você não me entendeu. Eu queria presenciar a primeira "primeira". Aquela versão para piano a quatro mãos, tendo como pianistas ninguém menos que Stravinsky e Claude Debussy.

- Que por sinal, ficara de certa forma atemorizado depois de executá-la, dizendo que a peça lhe parecera um "furacão a arrancar nossas vidas pela raiz". Ravel também esteve lá neste dia. - completou Igor - Foi muito divertido.

- Caros amigos, - o professor nos chamava de volta à realidade- podemos concluir o assunto que vínhamos tratando?

- Por favor. - solicitei.

- Igor, - deu continuidade o professor Albert - nosso colega Josephus pretende propor um modelo integrado para composição musical. O que acha?

- Alguns artistas usam métodos criativos originários de sua própria inventividade. Outros precisam aprender algumas técnicas para poder dar vazão a sua vontade expressiva. Entendo, assim, que modelos são canais eficazes para a operação artística.

- Gostei da resposta Igor. - apressei-me em dizer - Principalmente porque acredito que os compositores e artistas em geral são movidos por uma vontade particular de se expressarem. E é lícito supor que mesmo os mais geniais precisem, no início, de certas diretrizes. 
- A questão - interpelou o professor Albert - não é a existência ou não de um modelo, mas sim de como fazê-lo de forma a não coibir a inventividade.

- Os compositores mais inventivos - considerou Igor - não deixaram métodos ou 'escolas'. Veja por exemplo Beethoven e Debussy.

- Todavia, - adiantei-me em interpelá-lo - é possível deduzir alguns dos processos que estes utilizavam e com isso estabelecer algumas balizas ou conjunto de procedimentos para nos auxiliar.

- Você procura construir um algoritmo composicional? - indagou o professor Albert.

Igor não me deixou responder e praguejou:

- Não me diga que irá se enveredar por caminhos informatizados e robóticos retirando da música seus últimos suspiros de humanidade!

Eu me antecipei ao professor e respondi:

- O termo algoritmo possui origem na matemática e, talvez em razão dessa procedência, faz pensar imediatamente em um tipo de processo envolvendo cálculos ou programas de computador. Eu carregava essa idéia até pouco tempo, quando fui alertado pelo compositor Rodolfo Coelho de Souza.

- De onde é esse compositor? - perguntou Igor.

- Do Brasil - respondi.

- É a segunda vez que ouço falar disso - comentou o professor.

- Deste compositor? - admirou-se Igor.

- Não, do Brasil. - respondeu o professor - Estive lá em 1925, se me lembro, para dar conferências. Fui ao Clube de Engenharia e na Escola Politécnica do Rio de Janeiro. Também fiz uma comunicação na Academia Brasileira de Ciências. País engraçado, no Clube de Engenharia o salão estava completamente tomado por embaixadores, generais do exército, representantes dos ministros e engenheiros, muitos deles acompanhados de suas esposas e filhos. Era evidentemente uma platéia apropriada para um espetáculo carnavalesco, mas não para uma conferência científica.

Novamente eu me adiantei e mudei a direção que a conversa tomava:

- Fique sabendo Igor, que foi no Brasil onde ocorreu uma das comprovações da teoria da relatividade. Houve um eclipse solar em 1919 que permitiu a uma expedição científica dupla (comandada pelo astrofísico e visionário inglês Sir Arthur Stanley Eddington), levada a cabo em Sobral no Ceará, verificar que o campo gravitacional solar fazia com que os raios de luz das estrelas se curvassem quando passavam nas proximidades do Sol. Exatamente como previsto nos cálculos da relatividade geral em 1917.

- Bem, - pediu Igor - voltemos ao algoritmo compositivo. 
- Quando pesquisei sobre o assunto, aprendi que o termo não se restringe ao domínio matemático-computacional e tomei contato com distintos tipos de algoritmos. De modo genérico algoritmo pode subentender qualquer conjunto de operações estabelecidas previamente com o propósito de se atingir um objetivo específico. Este objetivo pode ser a resolução de um problema matemático, a logística de transporte para se fazer entrega de mercadorias de maneira otimizada, o mapeamento de redes de comunicação, etc. De acordo com o teórico David Cope, em razão dessa abrangência "usa-se algoritmo quando uma atividade for reduzida a uma série de regras ou instruções que automatize esta atividade".

- E como isso é transferido para a música? - indagou Igor, intrigado.

- Na música - expliquei - algoritmos são empregados de diversos modos e especialmente na composição aparecem de forma variada. A maneira sugerida pelos teóricos para classificação destas formas é observar como o algoritmo participa do processo composicional. Assim é possível separar duas situações: os procedimentos que fazem e os que não fazem uso de computadores. As composições que se valem do computador permitem uma subdivisão: música composta pelo computador (quando o algoritmo é apto a tomar decisões próprias durante o processo de criação) e a música composta somente com a ajuda do computador.

- Acho que Igor já compreendeu. - interveio o professor Albert - E estamos certos de que seu modelo pode ser contado como uma espécie de algoritmo.

- Veja aqui Igor: - mostrei-lhe um desenho que acabara de fazer em um guardanapo.

\begin{tabular}{|c|c|c|c|c|c|c|c|c|c|c|c|c|}
\hline & & & & & & & & & & & & $C$ \\
\hline & & & & & & & & & & & $G$ & $G$ \\
\hline & & & & & & & & & & $F$ & $F$ & $F$ \\
\hline & & & & & & & & & $E$ & $E$ & $E$ & $E$ \\
\hline & & & & & & & & $A$ & $A$ & $A$ & $A$ & $A$ \\
\hline & & & & & & & $E b$ & $E b$ & $E b$ & $E b$ & $E b$ & $E b$ \\
\hline & & & & & & $A b$ & $A b$ & $A b$ & $A b$ & $A b$ & $A b$ & $A b$ \\
\hline & & & & & $B b$ & $B b$ & $B b$ & $B b$ & $B b$ & $B b$ & $B b$ & $B b$ \\
\hline & & & & $D$ & $D$ & $D$ & $D$ & $D$ & $D$ & $D$ & $D$ & $D$ \\
\hline & & & $F \#$ & $F \#$ & $F \#$ & $F \#$ & $F \#$ & $F \#$ & $F \#$ & $F \#$ & $F \#$ & $F \#$ \\
\hline & & $B$ & $B$ & $B$ & $B$ & $B$ & $B$ & $B$ & $B$ & $B$ & $B$ & $B$ \\
\hline & $D b$ & $D b$ & $D b$ & $D b$ & $D b$ & $D b$ & $D b$ & $D b$ & $D b$ & $D b$ & $D b$ & $D b$ \\
\hline$C$ & $C$ & $C$ & $C$ & $C$ & $C$ & $C$ & $C$ & $C$ & $C$ & $C$ & $C$ & $C$ \\
\hline
\end{tabular}


Ele limitou-se a olhar a tabela, sem nada comentar. Eu, então, segui:

- O compositor italiano do século XVII Giovanni Andrea Bontempi apresentou em 1660 um modelo para composição a quatro vozes por meio do qual uma pessoa completamente ignorante na arte da música poderia começar a compor. Nesta tabela que te mostrei, fiz uma espécie de paródia do modelo de Bontempi, só que transferido para o domínio atonal.

- E como é sua aplicação na prática? - perguntou o professor Albert.

- A tabela visa à formação de agregados acórdicos tendo em vista o estabelecimento de formações com maior ou menor tensão ou instabilidade sonora.

- De certa forma Persichetti e Costère já fizeram sistematizações semelhantes. - comentou Igor.

- Sim. - respondi - Mas, não me preocupo com a originalidade. A idéia é exemplificar um algoritmo composicional. A tabela é construída partindo do pressuposto que o menor número de batimentos entre os intervalos utilizados (conseguidos pela razão matemática mais simples) resulta em menor grau de tensão no agregado formado, e vice-versa. O grau de tensão diminui da esquerda para a direita e no sentido ascendente da tabela, levando em conta o número de notas utilizadas.

- Indicado pelas setas. - observou o professor Albert.

- Exato. - respondi.

- Eu quero ver como isso funciona musicalmente. - desafiou Igor.

Aceitei a provocação e pedi:

- Me dê ai Igor uma folha de papel pentagramado do seu bloco.

- Como você sabe que estou com o meu bloco?

- Papel pentagramado: - pronunciei com voz de locutor - Don't leave home without it. Acho mais fácil você esquecer seus suspensórios do que esse bloco.

Igor tirou uma folha de seu caderno e me entregou. Enquanto escrevia, mostrei-lhes o método original de Bontempi a partir do qual eu realizara a minha versão. 
From Giovarni Andrea Bontempi's (1624-1705) New Method of Composing Four Volces, by means of which one thoroughly lgnorant of the art of music can begin to compose (1660).

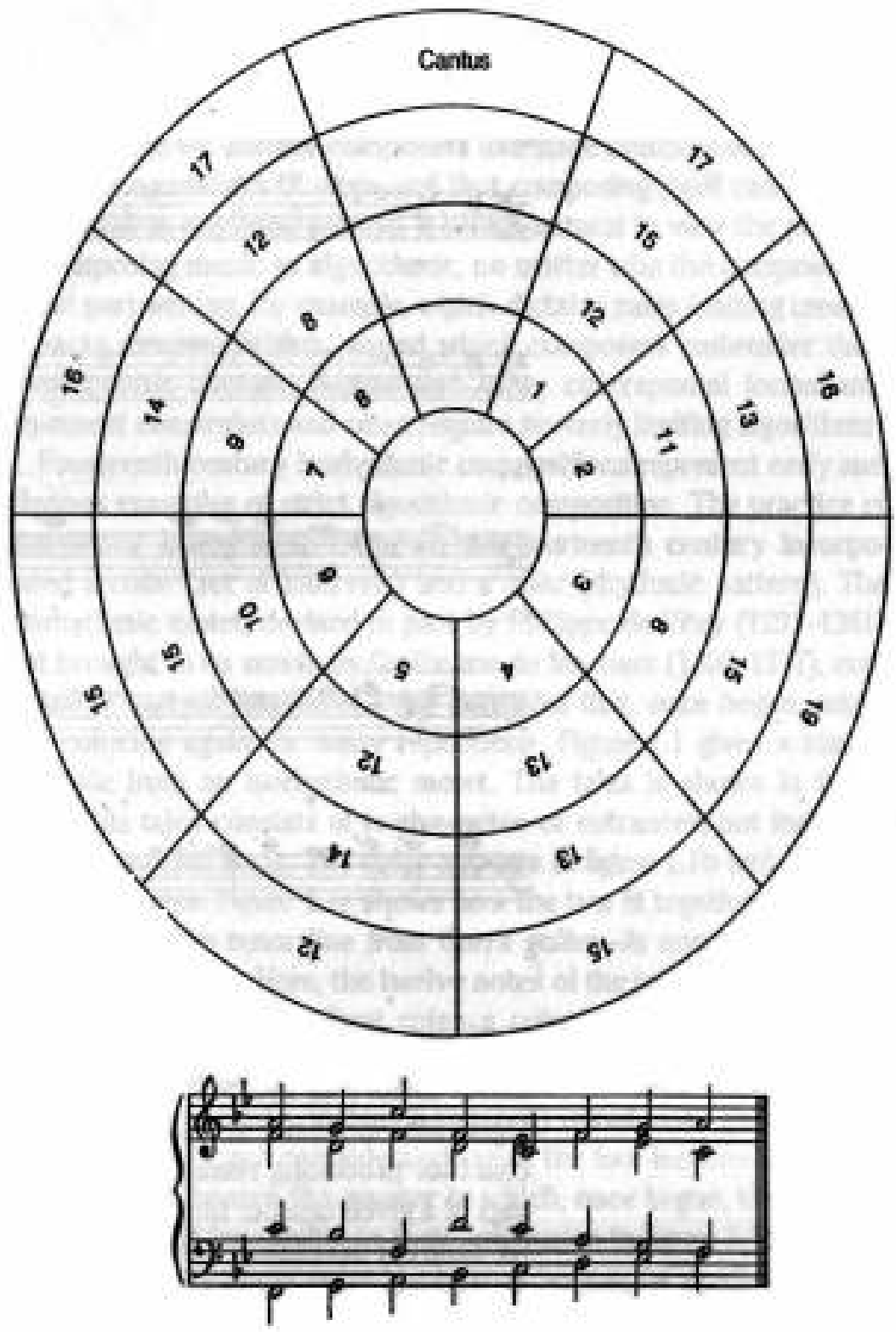

Ao terminar, entreguei-lhes a folha com as anotações musicais que fizera. Então foi a vez do professor pedir explicações:

- Como é isso aqui?

- Acompanhe observando a partitura e a tabela. - sugeri - Em um agregado de 2 notas, a menor tensão é o intervalo de $8^{\mathrm{a} J}$ (marcado com a letra $c$ ), extremos da tabela. A maior tensão, ainda com 2 notas, é o intervalo de $2^{\mathrm{a}} \mathrm{m}$ (letra $b$ ). Para um agregado constituído de 4 notas o agregado de menor tensão é o formado pelos intervalos de $8^{\mathrm{a}}, 5^{\mathrm{a}}$ e $4^{\mathrm{a}}$ justas (letra $g$ ), o 
de maior tensão é formado pelos intervalos de $2^{\mathrm{a}} \mathrm{m}, 7^{\mathrm{a}} \mathrm{M}$ e $4^{\mathrm{a}}$ aum (letra $f$ ). Assim se sucede até acumular o maior grau de tensão pela utilização de 13 notas (letra $k$ ).

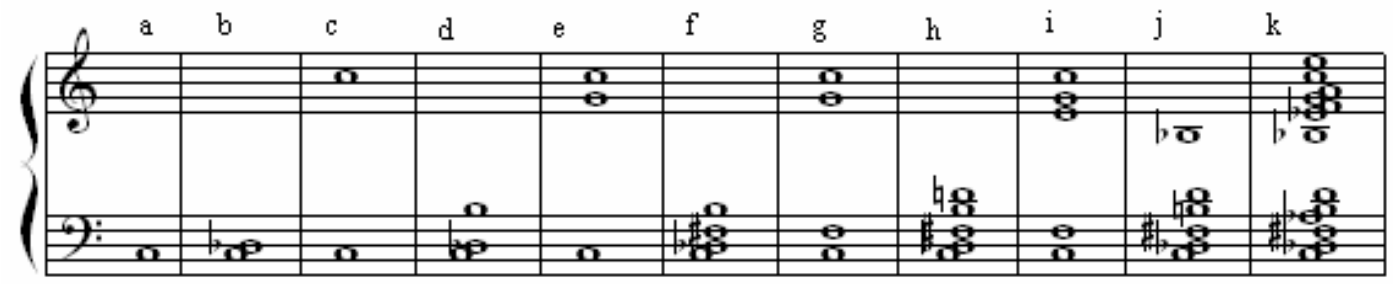

Igor foi o primeiro a se pronunciar:

- Obviamente, muitas objeções são possíveis, pois não é garantido que as relações matemáticas correspondam exatamente às expectativas perceptuais de aumento ou diminuição de tensão ou instabilidade. Além disso, a distância entre os intervalos influencia fortemente no tipo de batimento percebido, já que um intervalo composto diminui substancialmente a percepção de batimentos (usar uma $2^{\mathrm{a}} \mathrm{m}+4 \mathrm{aum}$ com a nota de base distante de mais de uma oitava vai amenizar a aspereza dos batimentos).

- Perfeitamente. - admiti - Contudo, chamo a atenção ao fato de que essa tabela tem a função de exemplificar um procedimento algorítmico no encaminhamento composicional, mesmo permitindo ser utilizada praticamente.

- E estando sujeita a controvérsias e contestações de base psicológica. - finalizou o professor Albert.

- Aliás, me lembrei que havia esquecido de responder a uma questão crucial para minha empreitada: como se dão as interações entre os elementos atuantes em uma composição.

- E só agora você vai tentar respondê-la? - inquiriu o professor em tom de zombaria.

- Exato.

- Vamos lá então. - impacientou-se Igor.

- Temo que a resposta não surpreenderá. As estruturas postas em jogo na composição interagem por meio de associações psicológicas. - declarei em tom simplista.

- Então você acredita que os componentes musicais, desde uma simples nota, até construções formais inteiras, passando pelas nuances timbrísticas e elaborações harmônicas, juntamente com o desenvolvimento temático, são unidas por critérios psicológicos e não acústicos?

Foi Igor quem indagou, mas ele mesmo não me deu tempo para resposta, completando:

- Não deixa de ser interessante! 
Professor Albert permanecia calado em seu canto, parecendo divertir-se com o assunto.

- Contudo, - prossegui - em música dependemos muito do nosso legado cultural, ou aprendizado, se preferirem. E em razão disto, somos mais propensos a captar padrões e não elementos isolados.

- Continue. - pediu o professor.

- Enquanto permanecemos neste ambiente, recebemos uma infinidade de estímulos auditivos. Porém, estes não são percebidos como música.

- E não o são de fato. - afirmou Igor categoricamente.

- Só que, imagine que escutássemos uma seqüência deste tipo:

Mostrei a eles um padrão rítmico que desenhara no guardanapo:

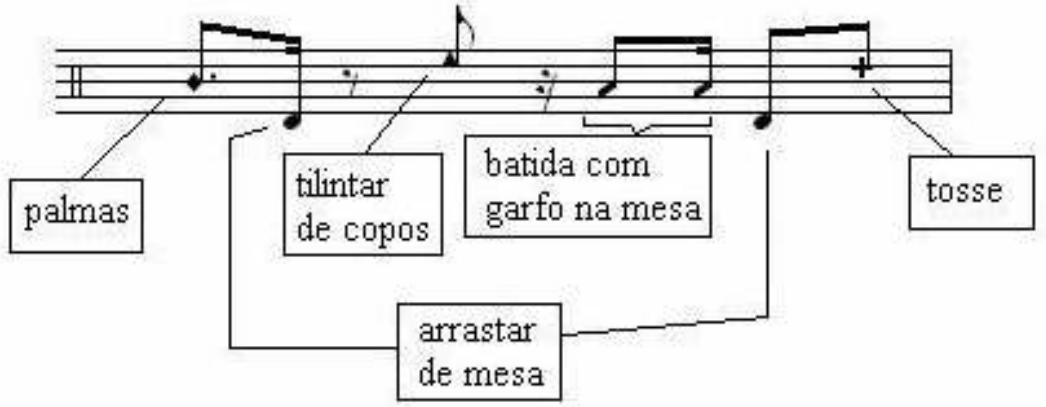

- Os sons provêm das mesmas fontes, ou seja, existem aqui no bar. E não seríamos levados a identificar nesta sucessão rítmico-sonora um padrão musical conhecido?

- Acho que sim. - confirmou o professor.

- Em minha opinião - eu continuava embalado - isso se deve ao fato de já termos armazenado na memória padrões similares para poder compará-los com os novos estímulos. A partir daí posso me certificar de que isso não é música, mas bem poderia ser porque se parece com algo que aprendi a identificar como música.

- Então, - questionou o professor - em razão da similaridade com modelos memorizados, até poderia considerar estes ruídos como música se os mesmos estivessem organizados no âmbito composicional?

- Certamente. - afirmei - Além disso, poderia conferir certo significado expressivo a estes ruídos.

- Não exagere. - afetou-se Igor.

- Imagine que eu tenha organizado os ruídos do bar de maneira semelhante a um rondó. Toco essa parte que escrevi, que vou chamar de $A$.

- Muito original. - ironizou Igor. 
- Depois apresento outra parte usando somente as garrafas. Em seguida repito a parte A. Proponho uma nova seção usando mesas e cadeiras percutidas. Re-exponho $A$. Faço uma nova variação . . .

- Tudo bem, - obstou Igor - já entendemos. Vá logo para a coda.

- Não tem coda. Estou tentando demonstrar um outro aspecto. Digam-me, depois de ouvirem a peça nesta seqüência: A $|\mathrm{B}| \mathrm{A}|\mathrm{C}|$ qual seria a próxima parte esperada?

- Pela lógica seria a parte $A$ novamente. - assentiu o professor.

- Mas o que aconteceria em suas mentes se no lugar de $A$ eu apresentasse algo totalmente novo e diferente como um solo de violino?

- Diria que você está bêbado. - arrematou Igor.

- Pois afirmo ser este o fator por impor significado à música. - contestei.

- Para mim - revidou Igor - você está tentando lidar com arte de acordo com cálculos estatísticos.

- Não é matemática ou arte; - retruquei - mas, trata-se de uma peculiaridade intrínseca à natureza do ser humano. Se tivesse um dado poderia demonstrar melhor.

- Eu tenho um dado aqui.

- Igor! - admirei-me - pra que você anda com dado no bolso?

Ele não respondeu, dirigiu-se ao professor Albert confrontando-o:

- O senhor joga dados, professor?

- O senhor não joga dados! Mallarmé é quem joga. - dessa vez o professor foi contundente.

- Por favor Igor - solicitei - jogue o dado.

Ele assim o fez e vimos que o mesmo caiu com o número 3 voltado para cima.

- Vou lhe pedir para jogar mais uma vez. Qual será o resultado do próximo arremesso?

- Por Zeus, é óbvio que não tenho como saber. - praguejou Igor.

- Professor nos ilumine. - pedi.

- Qualquer dos números têm 1/6 de probabilidade de vir a ocorrer.

- Mas você apostaria no número 3?

- Acho que não. - respondeu Igor intrigado.

- Isso porque o '3' já aconteceu. Mas imagine que ao lançar o dado por mais 5 vezes todos os resultados sejam o número 3 .

- Obviamente - deduziu Igor - o dado encontra-se adulterado.

- Vamos admitir que seja um dado honesto.

- Ficaria muito surpreso, certamente.

- E neste caso, se pedisse para você apostar no próximo resultado, em qual número apostaria? Lembre-se que todos os números têm igual probabilidade de ocorrer. 
- Acho que nesta situação absurda eu apostaria no 3. - balbuciou Igor contrariado.

- Porque agora você já dispõe de informações suficientes para fazer um prognóstico sobre o próximo resultado. Sua mente já criou expectativas de modo que não seria novidade se o próximo lance de dados resultasse no número 3. Todavia, ocorrendo qualquer outro número, você ficaria surpreendido. A norma virou exceção! E isso também é recíproco para a música.

O professor Albert, que permanecera em silêncio neste ínterim, pôs fim à discussão:

- Resumindo Josephus, você objetiva criar um modelo para composição cuja base unificadora das interações entre os componentes envolvidos nas diversas dimensões musicais se dê via associações psicológicas.

- Eu não teria conseguido enunciar de melhor maneira a minha ambição - confirmei.

- Mas falta esclarecer um aspecto - seguiu o professor -. No início de nossa conversa falamos sobre os princípios de base da ciência. Qual será o seu princípio?

- Tenho claro para mim que uma pesquisa envolve ao menos três fases: observação sistemática, estudo e experimentação. Em vista disto, meu ponto de partida e fundamento para aquilo que se constituirá enquanto modelo de ação compositiva será a análise musical.

- E eu 'tenho claro para mim' - arremedou Igor - que esta conversa tende a descambar para o hermetismo.

Pela primeira vez o professor Albert riu pra valer, dirigindo-se a Igor:

- Pelo que vejo, Igor, você não é adepto das práticas analíticas.

- "Exercícios escolásticos - declarou Igor - podem ser úteis para aqueles que se adestram estudando modelos. $\mathrm{O}$ academicismo não deve encontrar espaço fora do conservatório, os que esposam um ideal acadêmico produzem obras a rigor corretas, mas secas e desprovidas de sangue".

Então eu resolvi entrar na discussão:

- Discordo frontalmente. Uma análise pode modificar a escuta. Além disso, o diálogo entre músicos, estruturalistas e estudiosos das ciências cognitivas deu novos rumos à análise musical.

- "Julgar, questionar e criticar o princípio da vontade especulativa que está na origem de toda criação é, assim, definitivamente inútil”".

O professor, conciliador, pronunciou-se mudando o foco da discussão:

- Comentamos, en passant, a respeito da vontade do compositor em expressar-se por meio de sua arte. É por isso que vocês escrevem música?

- "Tenho um dever em relação à música, que é inventá-la". - adiantou-se Igor em responder.

- De minha parte - procurei ser sincero - escrevo porque gosto. Compor me deixa feliz, deve até ser uma espécie de pulsão. 
O professor Albert refletiu com certa nostalgia:

- Meu colega Sigmund dizia que o motivo de fazermos certas coisas é o fato de não poder fazê-las de outro modo. Somos aquilo que somos, porque devemos sê-lo em virtude de causas orgânicas.

- Além disso, - atestei - a cada peça que realizo exorcizo alguns fantasmas interiores e economizo nas sessões de terapia.

- Felicidade, pulsão, fantasmas, - desdenhou Igor - você não me enrola com essas baboseiras. Pelo contrário, fiquei penalizado e por isso vou te ajudar.

- Viva Josephus! - alegrou-se o professor Albert - Conseguiu um mestre de grande calibre. Igor antecipou-se em perguntar:

- Vocês conhecem a Tábua de Esmeralda?

- O que é que você está bebendo Igor? - não pude evitar a zombaria.

- Achei que havia citado o hermetismo no sentido de interpretação, e não na sua faceta esotérica. - tentou ponderar o professor, apesar de não conseguir esconder a risada; ao que Igor retrucou:

- Já que você, Josephus, não perde a oportunidade de desfilar conhecimentos de almanaque, deveria saber que cientistas como Giordano Bruno e filósofos como Roger Bacon debruçaram-se sobre questões do hermetismo.

- Minha dosagem de chope escuro ainda não está alta o suficiente para levar esse assunto a sério.

- Se bem me lembro, - retomou o professor - a Tábua de Esmeralda é um texto milenar atribuído ao semi-deus greco-egípcio Hermes Trimegistus.

- E também - resolvi entrar no jogo - é considerado como o texto impulsionador da alquimia européia, do ocultismo oriental e de toda tradição hermética posterior.

- Mas a estória não acaba aí. - dessa vez Igor foi categórico - Você bem sabe Josephus que dediquei boa parte de meu tempo pesquisando sobre a lenda de Fausto.

- Sim. - confirmei - Fausto realiza um pacto com o maligno. Nesse acordo, ele consente em entregar sua alma ao Diabo que, em troca, se tornaria seu servo por 24 anos. Findo esse prazo, Fausto é conduzido ao inferno.

O professor só escutava, achando graça e, talvez, imaginando aonde esta conversa poderia levar. Igor prosseguiu:

- O pacto com o ser maligno encontra-se na base de várias lendas oriundas de diferentes povos. Em 1587 foi publicado em Frankfurt Das Faustbuch (O Livro de Fausto), uma coleção de autor anônimo contendo diversos contos relatando as proezas de mágicos, 
feiticeiros e magos medievais conhecidos pelo nome de Fausto. Esse livro foi rapidamente traduzido e publicado em diversos países.

O professor resolveu se pronunciar:

- Fausto, no entanto, tornou-se célebre no mundo ocidental após a publicação do drama literário Fausto, de Goethe, em que se narra a aliança contraída entre Fausto que, no desejo de obtenção da eterna juventude, barganha sua alma com Mefistófeles.

- Só que Goethe - escarneceu Igor - fez a lenda tornar-se um drama de carolas. Ele introduziu outra personagem ao conto: a figura da mulher heroína. Além disso, na versão de Goethe, Fausto encontra a redenção graças a seus próprios esforços e méritos. Ao fim, sua alma é arrancada de Mefistófeles pelos poderes do Céu.

- Você precisa parar de beber. - disse eu - Não está mais se concentrando nos assuntos. O que isso tem a ver com a Tábua de Esmeralda?

- Calma! - pediu Igor - Vou chegar lá. Quando pesquisava sobre a lenda de Fausto acabei por descobrir onde se encontra a Tábua de Esmeralda.

Eu e o professor nos encaramos e, após uma fração de segundos, caímos no riso. Igor, no entanto, não se fez de rogado e prosseguiu:

- Andei demais para coletar materiais sobre a lenda e por isso acabei visitando inúmeros vilarejos ao sudoeste da Suíça. Em um destes recônditos locais conheci um velho músico que se dizia descendente distante dos Mendacem. Eu reparei que o velho até que possuía uma ótima moradia e notava-se claramente que gozava de uma vida confortável se comparado às condições paupérrimas daquelas cercanias. Após conversarmos sobre o mote de minha visita, indaguei-lhe se ganhava a vida de alguma outra maneira além da música, pois notara a superioridade de suas posses em relação aos demais cidadãos daquele povoado.

- Vai ver ele se elegeu para algum cargo político. - provoquei.

O professor Albert também aproveitou o ensejo para dar vazão a sua verve humorística:

- Quem sabe o velho trabalhava em alguma escola da região? Exercendo qualquer cargo, exceto o de professor.

Igor, sem fazer conta das nossas pilhérias, prosseguiu:

- O velho pensou um pouco e me confrontou: "vou lhe fazer três perguntas, se concordar com sua argumentação, em troca responderei às suas curiosidades".

- Você logicamente aceitou, pois não tinha mesmo nada a perder. - considerou o professor.

- Obviamente. - admitiu Igor - Assim foram as questões do velho e minhas respostas:

1) O é preciso para ser um bom compositor? 
Minha resposta: é preciso ter amor. O processo criativo exige uma força dinâmica, e que força é mais potente do que o amor? Somente pelo amor somos capazes de penetrar a íntima essência do ser.

2) O que um compositor deve fazer para ser reconhecido?

Prontamente contestei: o que dá o verdadeiro prestígio ao artista são seus imitadores. Pequenos artistas emprestam, grandes artistas roubam.

3) Onde reside a maior fonte de inspiração?

Revidei rapidamente: da encomenda de produtores ou de algum mecenas.

- Demonstrou muita argúcia e presença de espírito Igor. - declarou o professor.

Igor sorriu e comentou mordaz:

- Na verdade fiz o mesmo que nosso colega Heitor, atirei umas frases de efeito e inventei estórias mirabolantes como os repórteres adoram.

Igor, agora mais inspirado, continuou sua estória:

- Tive então minha vez de interpelar o velho compositor. Aproveitei para assuntar sobre os meios que lhe proporcionaram aquela situação confortável.

- Já antevejo o que vem por ai - disse o professor Albert.

- Ele, então, revelou-me que possuía a Tábua de Esmeralda.

- E você espera realmente que acreditemos nessa patacoada? - perguntei.

- Josephus - recriminou Igor -, você é muito seguro a respeito das coisas. Deixe-me terminar e depois decida continuar ou não com suas certezas.

- Esse negócio de velho, de Tábua e de Fausto é de longe a coisa mais bizarra que já inventou.

O professor aproveitou para digredir:

- Se as certezas da física atual estão baseadas no Princípio da Incerteza, o que mais poderemos achar bizarro?

- Ao contrário do pensamento de alguns, - seguiu Igor - a Tábua não é só um amontoado de códigos a serem decifrados, mas também um conjunto de procedimentos que, quando interpretados e aplicados corretamente, conduzem ao sucesso aquele que os realizou.

- Parece-me a descrição de uma apostila metodológica. - disse eu.

- Não faça pouco caso do desconhecido Josephus. O fato é que a Tábua tinha sua funcionalidade.

- E como esse velho conseguiu a Tábua? - interpelou o professor.

Igor balbuciou como quem conta um grande segredo:

- Foi-lhe legada através de seus antepassados e . . é ai é que a coisa fica estranha. 
- Professor, - perguntei - por acaso achou algo de lúcido até agora? Pois já viu que vai piorar!

O professor já não mais tentava disfarçar o riso. Igor continuava impassível ante nossas piadas:

- O vilarejo onde este velho morava era chamado de 'Lausodunon'. A história desse povoado remonta à época do Império Romano quando as unidades militares lá montaram um acampamento. Com o declínio do poderio de Roma o assentamento, já bem aumentado em tamanho, deslocou-se para o local onde Lausanne está localizada atualmente, às margens do lago Léman. Durante as guerras napoleônicas, em 1803, tornara-se a capital do recém formado cantão suíço Vaud e, posteriormente, foi encampada pela Federação Suíça. Porém, durante a Idade Média, a cidade foi governada pelo duque de Sabóia, pelo bispo de Lausanne até passar para subordinação de Berna de 1536 a 1798, período no qual um sem número de tesouros culturais, incluindo as tapeçarias penduradas na Catedral, foi transferido para Berna.

- Bonita estória, vovô Igor. - provoquei.

- Pare de caçoar Josephus, porque esta não é mais uma de sua coleção de efemérides. A Tábua de Esmeralda quase foi perdida neste roubo de relíquias, mas foi salva por Mendacem Abscondi, tio-avô do bisavô do velho. Essa família era clarum salterium facitore e dada a importância contumaz de sua ocupação foi poupada pelos Berna militibus, conseguindo assim preservar a Tábua.

- E o tal velho descendia dessa família?

- Sim, - confirmou Igor - ele foi um real plebis imaginarium descendit.

- E pelo que deduzo, - aproveitou o professor para manifestar-se no idioma tão caro aos cientistas - esse sujeito era também um salterium magister.

- Brilhante e correta dedução. - confirmou Igor.

- E esse ancião ainda está vivo? - perguntei.

- Não. Morreu sem deixar herdeiros.

Igor foi tão convicto ao responder que por pouco não passei a acreditar nessa estória maluca.

- E qual foi o fim da tal Tábua? - indagou o professor.

- Está comigo! - sentenciou Igor.

Em meio a gargalhadas, eu consegui dizer:

- Bem ensinava Baudolino di Galiaudo "o mundo premia os poetas que mentem apenas sobre coisas grandiosas".

- Deve ter custado uma fortuna. - provocou o professor.

- A Tábua não pode ser vendida. 
- Por que? - questionei.

Igor respondeu como se dissesse a coisa mais óbvia do mundo:

- Porque seu valor é inestimável. Aliás, minto, só há uma condição que permite a venda da tábua.

- Qual?

- Ela poderá ser vendida para aquele que conseguir estimar seu valor.

- Mas o valor da tábua não é inestimável? - perguntei confuso.

- Naturalmente. - respondeu Igor.

- Então nunca poderá ser vendida!

- Elementar meu caro professor.

- Então como fez para conseguir a Tábua? - voltei a confrontá-lo.

- A Tábua de Esmeralda só pode ser trocada por algo muito valioso.

- Não vá me dizer que barganhou a Tábua pela sua alma. - brinquei.

- Nem minha alma está à altura de fazer jus a tamanha relíquia - sentenciou Igor.

- Então . . . (eu e o professor encarávamos Igor já preparados para o que viria a seguir)

- A filosofia por detrás da Tábua é perpetuar seu legado. Assim não é dado a ninguém se apoderar dela para sempre, pois isso findaria a tradição. - explicou Igor.

- Diga logo - impacientou-se o professor - o que deu em troca dessa tábua?

- Algo muito valioso para mim ... meu Concerto para Percussão e Orquestra.

- Nunca ouvi falar dele, tampouco li a seu respeito em tratados de musicologia.

- Mas é óbvio, se o Concerto foi barganhado!!

- E onde você colocou essa tábua? - perguntou o professor.

- Está bem guardada. - completou Igor não se fazendo de rogado - Mas estou disposto a trocar a tábua com você Josephus.

- Oh! E a que devo a concessão de tal honraria?

- Como disse anteriormente, - esclareceu Igor - me senti penalizado pela falta de bons rumos em sua atuação composicional.

- E o que vai querer em troca?

- Você decidirá. Só lhe advirto que deve ser algo realmente valioso para você.

Às gargalhadas, finalizamos nossas bebidas. Professor Albert, então, pronunciou-se:

- Bem cavalheiros, assim como vocês, eu tenho que ir andando procurar pelo Santo Graal da física moderna: a Teoria da Grande Unificação.

- Eu o acompanho até a rua. - ofereceu-se Igor - E Josephus, minha proposta continua válida. 
Nos despedimos à porta do bar. Professor Albert e Igor seguiram pela alameda lateral. Eu caminhei devagar rindo sozinho e olhando os astros no firmamento ...

As idéias rodavam violentamente em minha cabeça não pela alta dosagem de chope escuro, mas pelo conteúdo da nossa conversa. Todavia, neste emaranhado epistêmico eu sabia muito bem qual seria meu próximo passo: colocar essas idéias no papel. Tratarei de questões ligadas à música com o objetivo de construir um modelo composicional tendo como princípio a integração de algumas técnicas analíticas. Este texto será permeado por aportes sobre percepção musical, visando a fornecer-lhe uma fundamentação nas ciências cognitivas. Como tenho predileção pela música do Brasil analisarei, predominante, a obra de compositores brasileiros. Em homenagem a esses notáveis cientistas/artistas, que me apresentaram a lugares fantásticos, usarei à guisa de epígrafe as gravuras de Maurits Escher, revolucionário merecedor de minha mais profunda reverência e admiração. Ao final, esse modelo será posto à prova valendo-se dele para compor obras de estética e formação variadas, e poderá até servir para a pedagogia da composição musical. Se assim não acontecer, ainda posso trocá-lo pela Tábua de Igor.

Deixei, então, a escola e fui para casa escrever minha tese. 
Capítulo 1

O SENTIDO DA ANÁLISE MUSICAL 


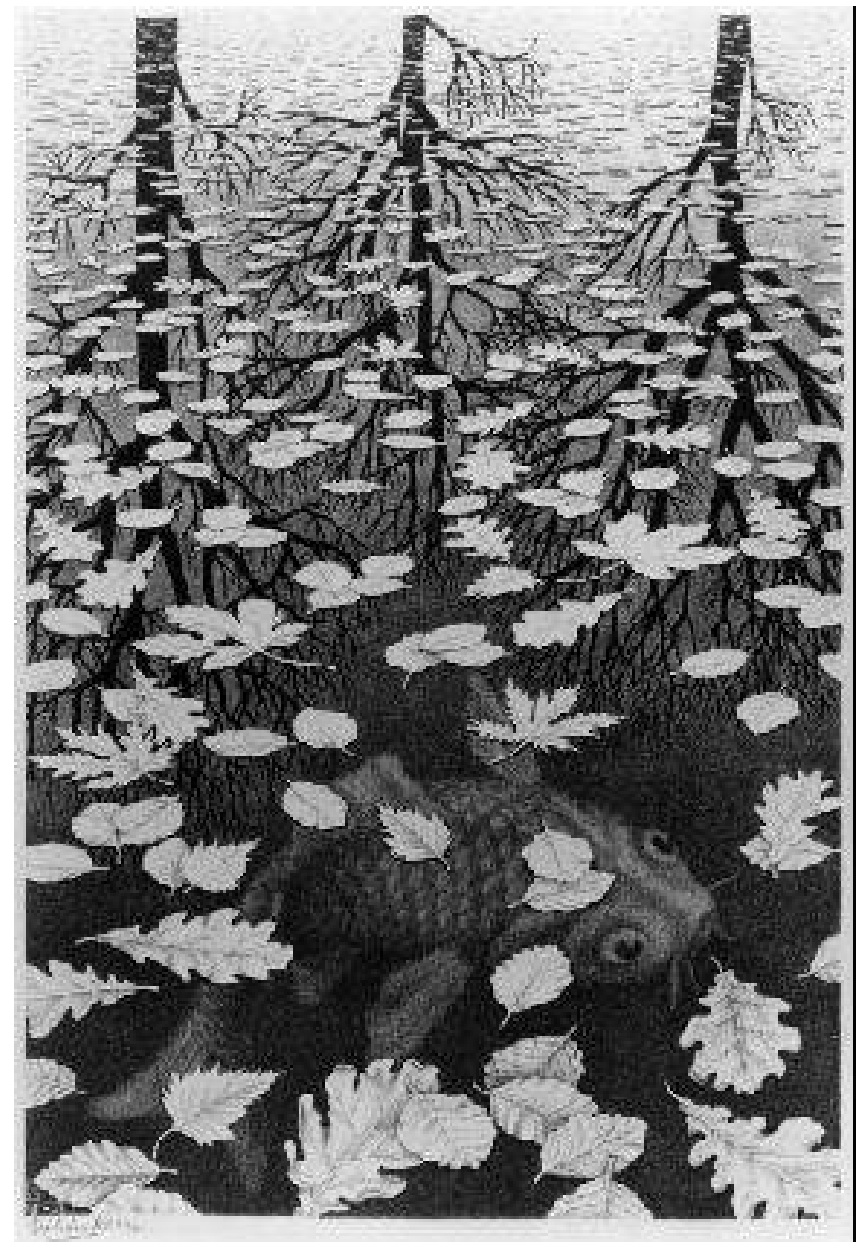

Maurits Escher: Three Worlds (1955, litografia). 


\section{Introdução}

Análise é entendida como o processo de decomposição em partes dos elementos que integram um todo. Essa fragmentação tem como objetivo permitir o estudo detido em separado desses elementos constituintes, possibilitando compreender quais são, que função desempenham e como se conectam de modo a gerar o todo de que fazem parte. Justifica-se esse procedimento por admitir-se que a explicação do detalhe sobre o conjunto conduz a um melhor entendimento global. No caso da música, o processo pode ser pensado em duas etapas básicas: identificação dos diversos materiais que compõem a obra em questão (as estruturas gerativas) e definição (constatação e explicação) da maneira como se articulam e interagem fazendo a obra "funcionar" (o processo composicional). Análise é decomposição. Composição é síntese.

Em maior ou menor grau, essa definição de análise musical é encontrada nas grandes obras de referência sobre música. Harvard Dictionary, The New Oxford Companion to Music, Science de La Musique, Dictionnaire de la Musique, Dizionario Enciclopedico Uneversale Della Musica e Dei Musicisti, são alguns exemplos de obras que compartilham dessa idéia. Entendimento semelhante também pode ser verificado em um dos maiores compêndios existentes sobre música, o Grove's Dictionary. Todavia, no Grove algumas curiosidades podem ser notadas. A primeira publicação do Grove ocorreu em 1878, contudo o verbete sobre análise musical só foi incluído na sua sexta edição, em 1980. Até então, a menção à análise musical era encontrada no verbete distantemente aparentado "notas de programa". As notas de programas eram definidas como "anotações em programas de concertos sobre a música a ser interpretada, também chamadas de notas analíticas" (1954, p.941). A edição de 1980 traz o verbete Analise assinado por Ian Bent, tópico também presente na versão online de 2001, mas com ligeiros acréscimos realizados por Anthony Pople.

O entendimento da análise musical como apresentado inicialmente é mantido no verbete original de Bent que, dentre outras considerações, apresenta a seguinte definição: "decomposição de uma estrutura musical nos seus elementos constitutivos mais simples e a investigação desses elementos no interior dessa estrutura" (BENT, 1980, p.340). Contudo, na publicação de 2001 o "peso" desse aspecto da definição é minimizado por meio de uma inversão de parágrafos na estruturação do texto. Geralmente, os verbetes do Grove obedecem um esquema de iniciar com um parágrafo introdutório contendo uma definição genérica do termo e depois ampliá-los, realizando um aprofundamento do assunto. Nesse parágrafo introdutório da edição de 1980, Bent começa com a definição acima citada e termina dizendo que a análise musical pode comportar a definição ampla de ser a "parte do estudo da música que tem como ponto de partida a música em si mesma, desvinculada de fatores externos" 
(BENT, 1980, p.341). Na edição de 2001, os parágrafos são invertidos, iniciando com a definição mais geral (estudo da música em si), o que faz com que essa idéia adquira uma maior relevância em detrimento da definição anterior da decomposição em partes.

Embora possa parecer apenas um pormenor, essa referida inversão aponta (propositadamente ou não) para uma das principais ocorrências presenciadas no campo da análise musical: sua emancipação e cristalização enquanto campo autônomo do estudo da música. Os três momentos citados do Grove são sintomáticos dessa situação: a análise musical, antes simples apêndices em notas de programas, caminha para avaliação da obra por meio da decomposição de sua estrutura nos seus elementos constituintes e, finalmente, adquire autonomia suficiente para poder prescindir dos diversos fatores que compõem o fato musical. Seria esse percurso reflexo de uma atitude positivista que ascenderia a análise ao estatuto de "ciência"? Se o fenômeno musical é um produto cultural como considerá-lo desvinculado do contexto que o gerou?

Bent deixa claro, pelos desdobramentos observados no seu texto, que está consciente dessas questões, e eu também sou cônscio da quase impossibilidade de realizar uma definição completa e absoluta do conceito de análise musical. Todavia, me proponho partir da síntese conceitual lograda por Bent e refletir sobre os fatores que possibilitaram a elaboração dessa definição. Em que contexto histórico foi formulada? Quanto, atualmente, a análise musical afastou-se ou não dessa definição? Para tanto, diversos textos de renomados autores sobre análise musical serão confrontados, servindo de base para as discussões e especulações aqui tratadas em busca desse sentido trilhado e comportado pela análise musical. Objetivo assim, a uma melhor compreensão das ocorrências e desdobramentos que se deram no campo da análise musical no século XX, realizado por meio de um acompanhamento mais detido em alguns escritos sobre esse assunto; todavia, as duas últimas edições do Grove's Dictionary servirão como eixo condutor deste capítulo.

\section{Três tópicos em destaque}

Dos três momentos anteriormente comentados (a passagem do uso da análise como auxílio nos programas de concerto, para procedimento de segmentação da música, e sua posterior emancipação) os dois primeiros são indicadores de instâncias específicas e podem ser entendidos como provenientes, respectivamente, das atitudes crítica (avaliação ou apreciação estética da música) e pedagógica (ligada ao ensino da composição). O terceiro passo, entretanto, ao colocar relevo na autonomia da análise musical, possui qual intuito ou proveniência? O que a música tem a lucrar com isso? Para tentar obter essas respostas retomarei, resumidamente, os dois momentos iniciais. 


\section{Análise e Crítica}

Bent situa os primórdios da análise musical na classificação realizada pelo clero Carolíngio, que consistiu na determinação dos diferentes modos usados na composição das antífonas de seu repertório litúrgico. Segundo Bent, os grupos de modos também recebiam uma subclassificação de acordo com sua finalidade - as diferentes aplicações dos tons da salmodia. Michel Huglo, autor do verbete Tonary no próprio Grove, ressalta que a compilação dos tonarius foi freqüentemente copiada em outros livros litúrgicos, tais como antifonários, graduais, tropários, etc., residindo ai a base para o vocabulário da teoria modal, na qual a descrição padrão dos modos litúrgicos se desenvolveu (cf: HUGLO, 1980, p.55). Vislumbrase ai, o primeiro indício de um procedimento analítico fornecendo fundamentos para uma teoria musical (assunto considerado adiante).

Dunsby e Whittall entendem, no entanto, que o tratado de Aristoxenos (século IV a.C.) já possui características que poderiam ser consideradas analíticas. Concordam, porém, que esses marcos (tratado de Aristoxenos e compilação do clero Carolíngio) constituem-se de uma forma muito incipiente da análise musical. A origem desta, como a entendemos atualmente, residiria na atitude estética de meados do século XVIII. Assim admitida, a análise encontrarse-ia desde sua origem vinculada à apreciação crítica de obras de arte. É fato, também, que qualquer análise traz um certo juízo implícito na atitude do analista. Os detalhes e pontos relevantes, a maneira e a extensão da discussão a estes dedicados e sua ordem de apresentação, são decisões particulares do analista que subentendem uma atitude crítica.

No final do século XVIII já é possível observar uma pequena expansão dos escritos sobre análise musical por conta da multiplicação de jornais e periódicos e pela aparição dos programas de concertos comentados. Um certo pioneirismo pode ser atribuído a J. Fr. Reichardt, um dos fundadores da Sociedade Berlim (1783), cujas notas sobre os concertos já tratavam de aspectos rítmicos, acompanhamento, melodia, harmonia, modulação, esta, muitas vezes abordada sobre os aspectos técnico e psicológico. No início do período romântico a análise musical continuou a tradição de Reichardt, atingindo o apogeu nas críticas escritas por Schumann e Hoffmann. Em seus textos, Hoffmann metodicamente distinguiu entre análise da técnica composicional e interpretação do conteúdo musical, marcando, assim, o fim da doutrina dos afetos. Ele escreveu para a revista AMZ - Allgemeine musikalische Zeitung - de 1809 até 1815 . Schumann, contemporaneamente a Hoffmann, enumerou os quatro pontos sob os quais uma obra deveria ser considerada: forma (conjunto, partes separadas, período, frase); composição musical (harmonia, melodia, escritura, estilo); de acordo com a idéia particular que o artista desejou representar; segundo o espírito que subjaz à forma, ao material e à idéia. Esses são exemplos que refletem o processo realmente compreendido como analítico, no qual 
o analista se debruça sobre uma obra específica e estuda seus componentes em separado almejando atingir uma melhor compreensão da sua totalidade. (Essa atitude reside até hoje, embora haja certas controvérsias com relação à divisão entre procedimentos analíticos e teóricos, que serão comentados adiante). Também era propósito dessa empresa analítica determinar que a natureza de um trabalho completo e a relação entre suas partes podem ser apreciadas estética e intelectualmente. Transparece, assim, a idéia de organicidade, em voga no período, princípio que preconizava tratar as obras de arte como organismos, cujas partes constituintes seriam absolutamente interdependentes e integradas.

Claro está que este intuito crítico, ao usufruir da análise, começa a buscar elementos objetivos para referendar os julgamentos subjetivos, antecipando a metodologia científica que, em meados do século XX, se pretendeu aplicar à música. É mais que adequado à música o pensamento manifestado por Jorge Coli ao comentar a característica presente em apontamentos críticos a respeito das artes em geral: "os discursos sobre as artes parecem, com freqüência, ter a nostalgia do rigor científico, a vontade de atingir uma objetividade de análise que lhes garanta as conclusões" (COLI, 1984, p.24). Esta atitude analítica também irá revelar a inadequação do entendimento da música em si mesma, pois todo o aparato cultural por ela envolvido é parte preponderante nas apreciações realizadas. É difícil para um crítico, por exemplo, na análise de uma obra, não compará-la com as outras que a antecederam. Nesse caso o conhecimento histórico é primordial. A importância da mediação histórica pode ser atestada simplesmente pelo fato de que os juízos estéticos sempre levam em consideração a tradição ou o desvio desta, avaliando a continuação de um modelo ou a originalidade da obra. Nos dizeres de Dahlhaus: "quando a música é subtraída do seu contexto, aspectos como novidade, genuinidade, epigonismo, deixam de existir, e tais critérios são bases para um julgamento estético" (cf: DAHLHAUS, 1977, passim).

O teor polêmico da ligação entre análise e crítica se fez sentir (muitas vezes de um modo não muito educado) há algum tempo atrás, nas repercussões obtidas pelo artigo de Joseph Kerman: How we got into analysis, and how to get out (1980). Sobretudo após a reimpressão deste artigo em 1994, uma enxurrada de "respostas" e "respostas das respostas" para esse trabalho tomaram conta do ambiente acadêmico, principalmente na Internet. No seu texto, Kerman tece considerações sobre a crítica musical como um todo $(\mathrm{O}$ artigo foi primeiramente publicado em 1979 sob o título The State of Academic Music Criticism) e conclui que a atividade de análise é, per se, uma atividade crítica. Segundo ele, o que aconteceu é que os músicos que lidam com análise não consideram essa atividade como crítica musical por duas razões. A primeira deve-se a uma espécie de preconceito nutrido contra a crítica jornalística, pois estas, na visão dos músicos, carecem de rigor e de 
profundidade intelectual, consistindo somente de um apanhado de impressões subjetivas. Assim, ao permanecerem no plano do juízo de gosto, pouco acrescentam ao leitor. O segundo motivo é que os analistas deliberadamente evitaram a formulação de juízos de valor (quando da realização de análises) por buscarem uma atitude de isenção, nos moldes das investigações científicas. Kerman aponta que as análises de músicas compostas, principalmente, a partir da década de 50 apresentam-se como "proposições estritamente corrigíveis, equações matemáticas, formulações da teoria dos conjuntos, etc.” (1980, p.312), indicando um esforço para alcançar um estatuto científico. Exemplificando essa constatação, remete ao livro de Allen Forte The Compositional Matrix, no qual o autor dizia ter meticulosamente excluído os termos indicativos de quaisquer tipos de valoração, como bom, ruim, legal, etc. Apesar disto, Kerman reafirma que a análise traz consigo algum tipo de apreciação e valoração estética.

Contudo, não foi somente pela junção da crítica à análise que esse artigo recebeu contestações. Outrossim, pelo fato de ter adjetivado alguns métodos de análise como "positivistas" e "reducionistas", Kerman provocou indignação nos schenkerianos de plantão, que por seu turno, viram-se no direito de rebater essa afronta, promovendo então a dita enxurrada de respostas contra Kerman. Entre as suas objeções, os discípulos de Schenker não queriam que o método analítico de seu mestre fosse tratado como "uma dissecação clínica de uma obra de arte viva que emula a metodologia da ciência racionalista" (KINTON, 2004). Segundo eles, a análise schenkeriana possui o grande mérito de ater-se a questões estritamente musicais (passando ao largo de abordagens semióticas, sociológicas e metafísicas), característica esta essencial à compreensão e formulação de uma teoria que demonstre as conexões existentes entre os planos de uma composição. Embates à parte, Kerman salienta que os métodos são produtos da própria época em que surgem e, conseqüentemente, passíveis de modificação e atualização no decorrer do tempo.

O acordo ou correspondência entre o artista e seu tempo permite aos elementos de sua técnica de composição serem interpretados como sinais históricos. A leitura de obras de arte enquanto evidências históricas fez surgir em cena mais uma personagem do julgamento estético. De um lado apresenta-se o sujeito fruidor, a quem se prescinde a existência de um conhecimento técnico prévio, pois bastam à formulação de juízo estético suas impressões. $\mathrm{Na}$ outra ponta, o julgamento histórico demanda a existência de uma autoridade competente para a avaliação da obra de arte, na qual o conhecimento técnico é indispensável para a realização da interpretação dos documentos históricos. Assim, análise e crítica associam-se. Isso conduziu ao entendimento de que a argumentação racional poderia modificar uma primeira impressão estética, o que também implicou em admitir que uma análise permite fundamentar um juízo artístico. 
Apesar do teor altamente técnico sugerir uma tendência moderna (especialmente séculos XIX e XX), a manifestação do juízo estético baseada em características internas da obra (sua estrutura formal e disposição de elementos estruturantes) remonta à Antigüidade Clássica com a poética aristotélica, na qual a poiésis era uma teoria do fazer e do produzir, atenta, portanto, a questões técnicas e alheia, em certo grau, a metáforas metafísicas e transcendentais. Essa idéia de poiésis será revivida no século XVIII com a associação, viabilizada pela análise, entre estética e produção artística. Nesta época os tipos e gêneros serviam tanto como parâmetros formais e estéticos, ou seja, a apreciação e julgamento de uma obra davam-se ao referenciá-la a um tipo específico. Quanto menos a música se afastasse do modelo, maior sua adequabilidade e melhor sua avaliação. Assim, a compreensão desses cânones tornava-se fundamental para os compositores. Dessa maneira a análise passa a ser uma ferramenta para a prática composicional.

\section{Análise e o ensino da composição}

“Análise é um procedimento de descoberta (...) é um meio de responder diretamente à questão "como isto funciona" (BENT, 2001). As afirmações são claras: o analista trabalha com o produto final (composição) e centra atenção na exploração da técnica composicional. A análise parte da obra e tenta compreender os artifícios do compositor que permitiram terminar com êxito sua empreitada. Pode-se dizer, então, que a análise caminha do particular para o geral. Da micro estrutura da obra são deduzidos os procedimentos técnico-composicionais utilizados pelo autor. É possível também afirmar que a coerência interna da composição é desvelada pela análise.

Curiosamente, esse entendimento simples também pode ser invertido, isto é, compreender a análise por meio da composição. Essa é a proposta de Nicholas Cook no seu Analysis Through Composition (1996). Cook é enfático em seu objetivo: "neste livro, não se pretende ensinar composição, mas planeja-se ensinar análise através da composição. Em outras palavras, composição é o meio e não o fim dessa proposta de aprendizado" (COOK, 1996, p.vii). A intenção didática de Cook baseia-se na sua concepção de que a análise tem recebido uma abordagem demasiadamente afastada da prática, fazendo com que os "estudantes, cuja vivência musical pode ser de fato limitada, também adotem uma abordagem supercerebral para com a análise, tendendo a enxergá-la como um tipo de atividade matemática sem vínculos diretos com a experiência de fazer ou ouvir música" (Ibid., p.vii). Novamente, é possível vislumbrar uma inversão de papéis no decurso da história da disciplina análise musical. A análise, que foi de início utilizada como ferramenta auxiliar da composição, vale-se desta para ser mais bem compreendida. 
A análise consolida-se como estudo disciplinar no momento em que os compositores (professores) foram requisitados a lecionar seu ofício. Cook descreve esse momento da seguinte maneira:

Durante o século XIX tornou-se normal que a composição fosse ensinada em classes nas escolas de música, ao invés de lições particulares como havia até então. Nesse sentido, o ensino da composição significou que professores confiassem cada vez mais aos livros a tarefa de guiar os estudantes nas suas experiências em composição. (COOK, 1987, p.10).

Cook assinala, também, que os cânones formais clássicos estavam contidos nesses livros, o que faz com que a origem desses modelos não remeta primordialmente ao orbe da análise musical, mas sim à história do ensino da composição. Com base nos livros, os alunos eram direcionados a compor de acordo com algum padrão formal. Da mesma maneira que um estudante de pintura aprendia copiando os mestres do passado, o aluno de música também deveria tentar reproduzir uma obra musical similar à de um grande compositor. Este sentido eminentemente aplicado da análise a serviço da composição é conservado até hoje, pois a metodologia de muitos cursos de composição tem por base a análise e reprodução de estilos de outros períodos.

Analisar uma obra musical consistia em abordar seus aspectos micro e macroscópico. O primeiro centrava-se na observação do conteúdo musical: melodia, harmonia, ritmo, etc. $\mathrm{O}$ segundo enfatizava a forma global da obra. A questão da forma revestiu-se como núcleo principal da investigação analítica, pois os teóricos partiam do princípio que uma obra musical podia ser segmentada em partes, e que essas divisões se articulariam no todo segundo certas características comuns. Assim, uma peça musical conteria certos padrões de construção similares que, depois de descobertos, podiam ser copiados. Sobrevive atualmente a idéia de que a verificação da ocorrência de padrões comuns de artifícios composicionais teria impulsionado a atividade analítica, embora autores como Dunsby e Whittall ponderem que a emergência da análise enquanto disciplina remonta ao gradual desenvolvimento da composição criada por um indivíduo, emancipada dos padrões de gêneros e tipos, ou seja, possuidora de caracteres particulares. A partir do momento que as técnicas dos compositores estivessem reveladas, não haveria necessidade de continuar analisando, bastaria reproduzi-las como na aplicação de uma receita de bolo. Porém, o fato das peças apresentarem qualidades peculiares exige a continuidade da tarefa analítica, pois toda nova obra conteria novas informações a serem descobertas. Ao encontro desse entendimento junte-se a opinião de Kerman, ao parafrasear o verbete Analysis do Havard Dictionary, dizendo que o "verdadeiro foco da análise é o elemento sintético e a significação funcional do detalhe musical" (KERMAN, 1980, p.313). Essa particularidade, em médio prazo, levou à criação de diversos métodos de análise musical. 
Assim, a discussão inicial proposta neste tópico pode ser retomada: a inversão de papéis preconizada no método de Cook. É possível pensar, inicialmente, na análise como ferramenta do ensino da teoria composicional. A metodologia dos professores era comparativa, ou seja, era solicitado aos alunos que analisassem as obras para que, a partir delas, pudessem desvendar e reproduzir as técnicas utilizadas pelos compositores. Com o passar do tempo, devido ao forte caráter pessoal das obras, mas, também, ao constante aumento da especificidade técnica contida nos textos sobre música, a empresa analítica perde esse conteúdo pedagógico, adquire um caráter especializado e desvincula-se da práxis composicional, tornando-se um ramo autônomo de estudos.

\section{A autonomia da análise musical}

Principalmente no século XX, diversas maneiras de se estudar a estrutura musical foram propostas, originando então vários métodos de análise. Dentre os especificados por Bent, em 1980, estão as análises: schenkeriana, temática, formal, funcional, da estrutura fraseológica, de categoria, característica, distributiva e teoria da informação. Certamente, o método de Schenker foi o mais influente entre os analistas, sobretudo nos Estados Unidos. Inicialmente intencionado para tratar de obras da prática comum, encontrou desdobramentos na música contemporânea. Griffiths assinala que "o pensamento de Schenker afetou até mesmo os compositores da música atonal nos EUA, e Babbitt buscou precisa e conscientemente implantar o modelo dos níveis schenkerianos em suas obras, de modo que, em seu caso, a análise antecede a composição" (GRIFFITHS, 1995, p.5). Apesar da grande disseminação das propostas de Shenker, o tematicismo de Réti e a teoria dos conjuntos de Forte tornaram-se importantes ferramentas analíticas para o repertório tonal e pós-tonal.

Dessa proliferação de métodos e modelos de análise musical resultaram duas conseqüências: a ascensão da primazia do método sobre a própria obra e o definitivo, embora confuso, apartamento entre teoria e análise.

Schenker já havia reclamado, quando tratando da dissociação entre prática e teoria, que a teoria da harmonia tornara-se tão sem efeito que era ensinada com exemplos criados especialmente para adequar sua proposta. Os analistas, na intenção de desvendar os segredos da estrutura da obra, não raro centraram mais interesse no modelo de análise que na própria realidade musical. Ocorrências desta espécie levaram Cook a lamentar que "o analista vem a acreditar que o propósito de uma peça musical é provar a validez do método analítico que aplica, ao invés de crer que a função do método é esclarecer a música; em outras palavras, quando ele torna-se mais interessado na teoria do que na aplicação prática”. (COOK, 1987, p.2). Em outra passagem confirmará: "basta dar uma olhada nos jornais atuais especializados em análise para descobrir que a grande relevância é posta sobre a formulação de métodos 
analíticos cada vez mais precisos e incrivelmente sofisticados, mais ou menos como um fim em si mesmos" (ibid., p.3). Ainda com relação à proliferação de métodos analíticos, Kerman menciona o discurso de Wallace Berry na posse deste na Society for Music Theory no qual reclamava uma mudança de postura por parte dos autores de artigos sobre teoria musical, cujo teor havia se convertido em uma verdadeira torre de babel, além de assumirem um caráter obscuro e dogmático. Esse estado de coisas ainda é notório atualmente, pois se pode perceber uma persistência entre setores da vanguarda em dedicar maior ênfase no discurso sobre o método envolvido na composição do que no próprio produto final. Não raro me parece que, após ter explanado sobre seu projeto composicional, o autor dispensa a própria audição da peça.

A referida separação de domínios entre teoria e análise pode ser vista como o último passo na cristalização da análise como campo autônomo dos estudos musicais. Análise seria uma parte da teoria musical? Ou são os procedimentos analíticos que viabilizam a edificação de uma teoria? A bem da verdade, as duas coisas ocorreram durante a história da música, embora essa nomenclatura não seja estritamente correta. Por teoria entende-se, strictu senso, uma proposição para organização de dados observados, cuja interpretação permitiria a formulação das leis que regeriam estes mesmos fatos. Observa-se que se tratando da música não há o estabelecimento de leis, no máximo os estudos revestem-se de caráter descritivo dos fenômenos observados, de modo que a definição rigorosa de teoria não se aplicaria neste caso. Mesmo Claude Palisca, no seu verbete para o Grove, ressalta que a teoria musical constitui-se como o estudo das estruturas da música, o que denota o aspecto não científico da realidade musical. Todavia, o uso desta terminologia encontra-se por demais arraigado tanto ao senso comum quanto em setores acadêmicos, de modo que continuarei a empregá-la, ressalvando que teoria não subentende explicação, mas apenas compreensão dos fenômenos musicais.

No ano de 1967, Edward Cone publicou na Perspectives of New Music um artigo intitulado Beyond Analysis. Embora o teor principal do seu texto versasse sobre as impossibilidades inerentes aos métodos de análise, passagens referentes a concepções sobre a natureza da análise e da teoria musical incomodaram alguns teóricos, especialmente David Lewin, que em 1969 publicaria, na mesma revista, uma resposta ao artigo de Cone, sob o título de Behind the Beyond. Neste trabalho, Lewin ofereceu uma boa diferenciação entre os conceitos de análise, teoria e crítica musicais, delimitando o campo de estudo de cada uma destas áreas, bem como, seus pontos de interseção; além de reafirmar o papel fundamental que teoria e análise têm na didática composicional. Para Lewin, a análise não pode fundamentar uma apreciação crítica em um sentido quantitativo, mas apenas ampliá-la qualitativamente. Com relação à diferenciação entre análise e teoria, Lewin atesta que a teoria 
musical examina, a princípio, abstrações musicais de caráter geral. As estruturas consideradas pela teoria são anteriores às obras, existem a priori, independentes até da própria materialização na obra consumada. A análise, por sua vez, trabalha com composições específicas, com o produto final, investigando seus componentes e suas articulações. O interesse de um teórico está direcionado, sobretudo, a conceitualizações genéricas; o analista, por sua vez, tende ao particular e pontual, ou seja, compreende as especificidades de cada peça em questão.

Embora toda definição seja passível de correções, o embate entre esses dois autores conduziu ao estabelecimento dos domínios relativos a cada um desses campos de estudo, além de atestar o que Cook chamaria de profisssionalização da análise musical ao sentenciar que "nos últimos vinte anos a análise musical tornou-se profissionalizada" (COOK, 1987, p.3). Essa profissionalização pode ser entendida, segundo Kerman, como tendo seu ponto de partida desde a década de 50, com os avanços da indústria eletrônica. Esses avanços facilitaram o acesso à música de concerto pela sua disponibilização em discos, com isso, houve um aumento geral do interesse por informações musicais, incentivando o aumento de publicações especializadas no assunto. Kerman refere-se a uma "explosão de artigos analíticos" a partir da década de 60. Esse incremento pode ser constatado na bibliografia utilizada por Bent no seu verbete para o Grove. Como notado por Duprat (1996), o número de publicações contendo a palavra análise, na referida bibliografia de Bent, contém 18 entradas na década de 50 e 80 entradas na década de 60; um acréscimo, de fato, relevante.

Ao lado desses aspectos teóricos, a referida autonomia adquirida pela análise musical é também notada no que diz respeito à desvinculação do ato analítico para com os aspectos críticos, composicionais e interpretativos (pois se admitia, e ainda admite-se, que a análise é uma importante ferramenta auxiliar da performance). Pode-se observar que cada vez mais as análises apontam para características diversas das composições sem preocupar-se com a sua aplicabilidade pragmática. Não estou afirmando que o estudo de qualquer objeto deva ter obrigatoriamente uma utilidade prática. Todo conhecimento é válido em si mesmo. Todavia, é fácil observar (sobretudo em dissertações na área da performance musical) que algumas análises apenas descrevem os acontecimentos, como se fora uma narrativa futebolística (saiu da tônica, passou pelo segundo grau, cruzou pela tonalidade relativa e chegou à região da dominante), sem apresentar posteriores conclusões a respeito de como aquela análise afetou ou influiu na maneira de tocar a peça. Ao que parece, faz-se uma análise tencionando descobrir a coerência interna de uma obra que já se sabia coerente. Este aspecto é comentado por Dahlhaus ao tratar de análises do tipo descritiva, ou seja, análises taxionômicas. Apontando para a inutilidade destas tautologias, ele argumenta que estas revelam muito 
acerca da teoria e quase nada a respeito da obra. Segundo ele, não basta apenas isolar (abstrair de elementos rítmicos, por exemplo) e enumerar os acordes, outrossim, é preciso que o caráter individual da estrutura harmônica e suas relações seja "expressamente demonstrado e articulado por uma interpretação da análise: uma análise de segunda ordem" (DAHLHAUS, 1983, p. 9. Grifo meu).

Entretanto, o outro lado da moeda pode ser representado pela vontade dos músicos em aterem-se a questões musicais, ou seja, tratar a música primordialmente em seus próprios termos, ao invés de relevar abordagens paralelas. Kinton resume esse estado de coisas da seguinte maneira: "nós temos uma crítica musical ideológica, uma crítica musical feminista, uma crítica musical hermenêutica, porém, não temos uma crítica musical musical" (KINTON, 2004). Mas mesmo esse afã em "falar da música na música" conduziria à sobrevalorização das ferramentas analíticas, pois "a análise parece muito ocupada com suas próprias técnicas internas, muito fascinada pela sua lógica peculiar e extremamente tentada por seus próprios pedantismos privados para confrontar a obra de arte sob seus próprios termos estéticos" (KERMAN, 1980, p. 312). E esta constatação pode explicar a citada independência adquirida pela disciplina análise musical.

\section{Existe a música em si mesma?}

A música considerada em si mesma refere-se à análise dos elementos que integram sua estrutura, como motivos, frases, períodos, seções, escalas, tonalidade, modulações, regiões, aspectos melódicos, harmônicos, polifônicos, texturais, rítmicos, entre uma série de outros componentes que poderiam também ser mencionados. Vale lembrar que nem todos os elementos podem ser percebidos apenas com a escuta, pois se assim fosse, não haveria necessidade da análise. É exatamente a existência de particularidades ocultas na música e não reveladas durante sua audição que propicia e origina as várias abordagens analíticas. Em razão disto, a análise não pode tratar-se exclusivamente de um processo intuitivo. Insights e inspirações são bem-vindos, pois tem seu valor como ponto de partida para o processo analítico. Porém, o analista deve basear-se em técnicas ou métodos que o permitam decidir seguramente sobre os parâmetros musicais postos em jogo, bem como, as funções que estes adquirem no discurso musical. Deste modo, a análise apresenta-se como uma atividade essencialmente intelectual, o teor subjetivo diminui, possibilitando ao analista abster-se de preocupações de sentimento ou expressão em termos extramusicais.

No entanto, considerações sobre a música em si mesma necessitam de um agente externo para interpretar o fenômeno: o analista. Esta exigência aumenta o problema da restrição do processo analítico à música nela mesma, já que a música age no intelecto do ser humano que a recebe. Essa característica possibilita a quem interpreta o fenômeno confrontá- 
lo de duas maneiras: psico-sensória e funcionalmente. $\mathrm{O}$ aspecto psico-sensório tratará de como a música é percebida pela mente humana, remetendo a questões cognitivas, psicológicas, neurológicas, estéticas, entre outras. $\mathrm{O}$ funcional $^{1}$ tenderá a tratar de sua utilidade e/ou finalidade, o que implicaria em acolher estudos ligados à sociologia, história, antropologia, filosofia, etc. Assim, valeria a questão: a música em si é aquela ouvida por um sujeito ou trata-se daquela fabricada pelo compositor e impressa no papel? Consciente dessas implicações, Bent admite que "a análise musical engloba um amplo número de atividades coligadas, que representam diferentes visões da natureza da música, dificultando uma definição dentro de seus próprios limites" (BENT, 2001, p. 1). Essa situação aponta para o paradoxo da análise musical: pretender analisar racional e objetivamente um fenômeno emocional e subjetivo.

Ao lado destas colocações, vale ressaltar que a música enquanto manifestação artística está envolta em um grande aparato cultural, compreendendo sua matéria prima, seus meios de produção e divulgação, sua linguagem própria, seus locais de transmissão e/ou representação, etc. Essa arte é constituída, portanto, por elementos culturais tão imprescindíveis quanto os próprios elementos materiais. Nas palavras de Jorge Coli "não há dúvida que o trabalho sobre a matéria, a habilidade artesanal, o domínio sobre o fazer são elementos constitutivos essenciais da arte, mas eles repousam sobre um pressuposto anterior: o da transformação da matéria numa expressão cultural específica" (COLI, 1984, p.118). Some-se a isso o fato de que uma análise será influenciada por características próprias do analista, quer seja este um musicólogo, compositor, crítico, intérprete ou historiador, que pode enfatizar ou minimizar aspectos da obra de acordo com seus próprios interesses. Estas considerações refletem a fragilidade da tentativa de abordar o fenômeno musical desvinculado de fatores externos.

\section{Conclusão}

A partir das primeiras décadas do século XX já pode ser vislumbrado uma espécie de "fechamento de foco" na objetiva teórica, pois os estudiosos gradativamente afastam-se dos assuntos globais e centram-se em questões direcionadas aos atributos específicos de determinada composição musical, impondo um elevado grau de especialização em seus estudos em detrimento da redução da abrangência do campo teórico. Conseqüentemente, vêse a ascensão da análise face ao eclipse das teorias globais, apontando, a princípio, para um maior interesse em assuntos composicionais, ou seja, no que diz respeito à produção artística. Uma frase sintomática de Kerman sintetiza este estado de coisas: "quando chegamos a nos

\footnotetext{
${ }^{1} \mathrm{O}$ conceito de função comporta outras acepções além da citada 'finalidade'. O entendimento do termo enquanto constituinte sintático implicando na relação de 'dependência entre partes' será abordado detidamente no Capítulo 5 .
} 
interessar pela arte moderna é necessário o envolvimento com os problemas ligados à sua criação" (KERMAN, 1987). A inserção de novas propostas de reflexão e de especulação acerca da sintaxe musical conduziu, em última instância, à discussão sobre os processos norteadores da produção musical, seu modus operandi. A reformulação ou reorganização da sintaxe musical reivindicou por parte dos teóricos e críticos o domínio dos procedimentos técnicos que se cristalizaram ao longo do século, fato que além de projetar a necessidade do conhecimento de processos de análise ampliou o leque de possibilidades de pesquisas sobre a linguagem musical. Vislumbra-se, assim, com esta passagem do macro para o microscópico, a gradual primazia obtida pelas ferramentas e métodos de análise.

Não obstante, como apontado por Duprat, em meados da década de 70 o número de publicações sobre análise decresceu, fato por ele constatado com base na observação do número de entradas com a palavra análise no verbete homônimo do Grove. Contudo, é preciso lembrar que no seu artigo Duprat desconsidera as reedições e publicações revisadas da literatura. $\mathrm{O}$ fato de haver publicações revisitadas de trabalhos anteriores indica a manutenção de interesse pelo assunto. Essa condição pode ser facilmente constatada atualmente. Em uma simples consulta à Internet, no sítio da livraria virtual Amazon (www.amazon.com), realizada dia 22 de abril de 2006, indicou a existência de 349 títulos de música com a palavra análise (a busca foi realizada a partir da expressão musical analysis); destes, mais de 200 foram publicados a partir de 1990. Essa série de novas bibliografias sobre o assunto demonstra que este mercado continua em alta.

Nesse decurso, várias vezes teoria e análise musicais confundiram-se e misturaram seus limites. Kerman, por exemplo, afirma: "teoria consiste na investigação daquilo que faz a música funcionar" (1987, p.3). Bent irá contrapor: "análise é o meio de responder diretamente à questão 'como isto funciona?"” (2001, p.5). Sobre composição Kerman irá dizer: "o alinhamento mais fundamental da teoria musical é com a composição musical" (1987, p.5). E como pode ser constatado nos expostos durante esse capítulo, a composição é aprendida e investigada principalmente por meio da análise.

Por fim, há uma certa similaridade na opinião de alguns musicólogos (Kerman, Babbitt, Gritten, Cook, entre outros) com relação ao fato de a análise musical ter revestido-se de um teor positivista, funcionando como espécie de comprobatório das pesquisas realizadas no campo musical. Esse domínio analítico foi visto, por muitos, como uma tentativa de transferência de um modelo científico para um campo cultural. Entretanto, vale ressaltar que ao denominar a análise musical como o lado positivista da música, Kerman referia-se a uma atitude positivista, isto é, à metodologia ou processo de condução de uma apreciação musical. Isto pode ser inferido, por exemplo, quando ele (argumentando sobre a separação existente 
entre análise e crítica musical) rebate a objeção de que a análise musical lida com metodologias objetivas, enquanto a crítica opera somente com juízos subjetivos, pois na literatura é possível perceber que os críticos de música (Schenker e Tovey são por ele mencionados) valeram-se da análise enquanto critério de valoração da obra. O que aconteceu é que recentemente os analistas conscientemente evitaram a emissão de juízos de valor com a intenção de lograrem uma análise o mais isenta possível; conseqüentemente, o foco principal acabou por ser projetado sobre o próprio método. Cook, por sua vez, comenta: "pessoalmente eu desaprecio a tendência da análise converter-se em uma disciplina quase científica em seu direito próprio, essencialmente independente de interesses práticos da performance, composição ou educação musicais" (COOK, 1987, p.3). Este estado de coisas pode ser facilmente verificado observando-se artigos e trabalhos de mestrado e/ou doutorado na área de música. É raro o trabalho acadêmico, sobretudo na área de performance, que não dedique várias páginas a considerações analíticas sobre a obra a ser executada sem, no entanto, mencionar de que maneira as análises realizadas influenciaram ou modificaram aspectos interpretativos $^{2}$.

No propósito imediato deste trabalho, seguirei no próximo capítulo justamente considerando a possibilidade de estender o âmbito imediato da análise (da chamada análise em si) com o intuito de promover a aplicação de ferramentas analíticas em processos de composição musical. Para tanto, iniciarei com um nível básico da análise, isto é, da análise puramente descritiva, comparando-o, posteriormente, com um plano de segunda ordem, de modo a extrair princípios que subsidiem processos composicionais.

\footnotetext{
${ }^{2}$ Essa foi uma das conclusões obtidas com o projeto Rumos da Análise Musical no Brasil, pesquisa realizada com apoio do CNPq pelo grupo de pesquisa no qual tomei parte (2005-2006). As conclusões deste trabalho constam no relatório técnico científico encaminhado e aprovado pelo CNPq, porém ainda aguardam publicação.
} 
Capítulo 2

\section{ANÁLISE DE SEGUNDA ORDEM}




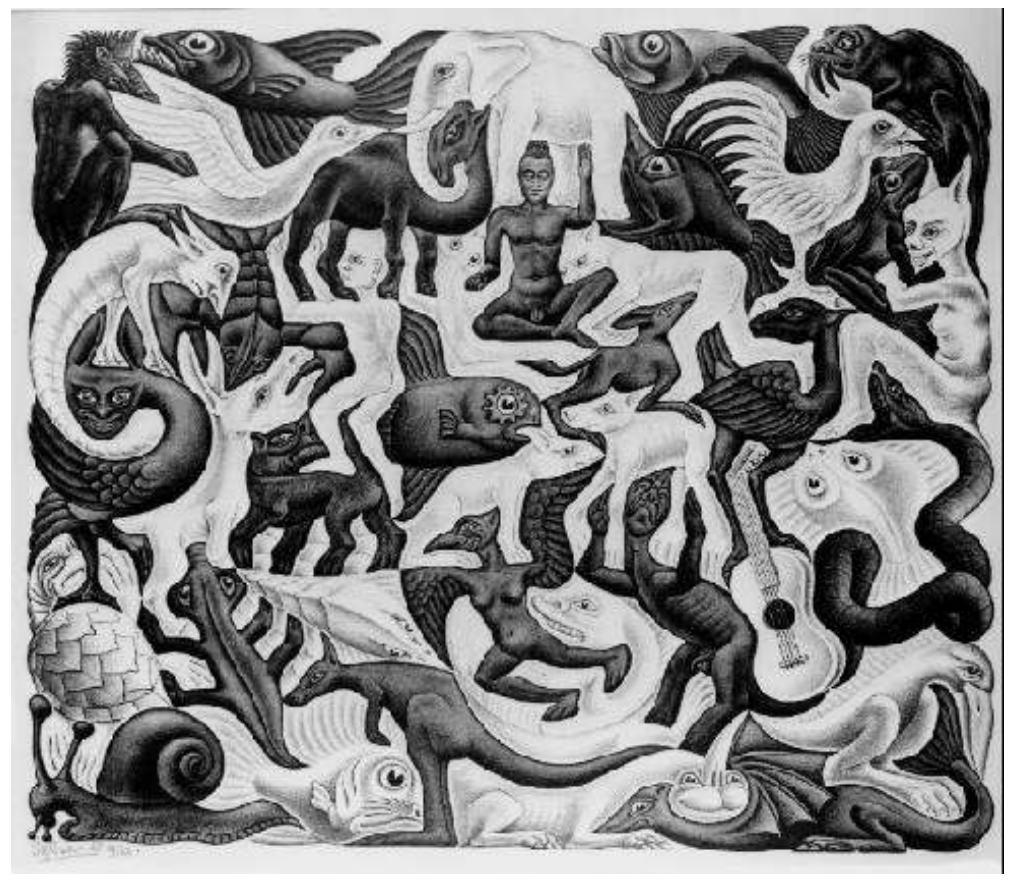

Maurits Escher: Plane Filling II (1957, litografia) 


\section{Introdução}

Análise de segunda ordem é uma abordagem analítica passível de ser empregada na confrontação de obras musicais, cuja característica distintiva é realizar uma espécie de reflexão sobre o método analítico em si, ou seja, promover uma hermenêutica da própria análise musical. Foi mencionada en passant pelo musicólogo alemão Carl Dahlhaus no seu livro Analysis and Value Judgment (originalmente publicado em $1970^{3}$ ). Esse procedimento não foi objeto de explanações diretas por parte de Dahlhaus, permanecendo, entretanto, a ser inferido por meio da investigação detida de seus escritos, da maneira como os seus textos são estruturados e do modo como suas análises musicais foram apresentadas.

Dahlhaus é uma personalidade de grande notoriedade e relevância na história da música. Autor de vasta bibliografia (entre estas alguns verbetes para o Grove's Dictionary) é considerado uma das maiores autoridades dentre os estudiosos que buscaram reunir música e filosofia, e seus escritos têm influenciado músicos e teóricos ao redor do mundo. Embora seja mais conhecido dos brasileiros pelos seus textos em estética ${ }^{4}$, Dahlhaus também realizou aprofundadas pesquisas nas áreas de historiografia, teoria e análise musicais. Um de seus livros mais destacados sobre análise musical é o citado Análise e Julgamento de Valor, no qual discute acerca da possibilidade de fundamentar a apreciação musical em critérios objetivos, tendo, assim, a análise musical como seu princípio de sustentação. Este livro é dividido em três partes: Premissas, Critérios e Análises. Na primeira parte, Dahlhaus se atém à diferenciação entre julgamentos de valor subjetivos e objetivos. No segundo capítulo, elenca uma série de critérios que podem sustentar um juízo estético. Entre outros, ele discorre sobre princípios formais, diferenciação e integração, analogia e compensação, abundância de relações (temáticas, motívicas, etc) e audibilidade. Na parte final, Dahlhaus oferece uma exemplificação de suas propostas para valoração estética ao elaborar críticas para algumas obras do repertório, tendo por base sua abordagem analítica.

E este é, portanto, o objetivo deste capítulo: apresentar o conceito dalhausiano de análise musical, exemplificado com análises de obras do repertório, e verificar seus possíveis desdobramentos e aplicações no plano da poética musical.

Dentre a ampla bibliografia considerada, dois livros constituíram-se como a fundamentação teórica principal: Analysis and Value Judgment, no qual o autor lançou sua idéia da análise de segunda ordem e realizou algumas análises musicais, e Schoenberg and The New Music, em que a problemática da tradição versus vanguarda foi tratada tendo por base critérios técnicos, estéticos, históricos e poéticos da linguagem musical.

\footnotetext{
${ }^{3}$ O original alemão Analyse und Werturteil foi publicado em 1970. Aqui usei a tradução inglesa de 1983.

${ }^{4}$ Talvez isto se deva ao fato de que o único livro de Dahlhaus traduzido para o idioma português seja, justamente, um livro de estética: Estética Musical. Lisboa: Edições 70, 1983.
} 


\section{Análise de Segunda Ordem}

Uma análise pode comportar, entre outras, finalidades teórica ou estética. Pode ser empregada para sustentar a edificação de um sistema ${ }^{5}$ de organização de fenômenos musicais e, também, fundamentar uma apreciação crítica. Dahlhaus conhecia a fundo essas facetas e, além de escrever muito a esse respeito, valeu-se de análises para promover juízos críticos sobre obras do repertório. Também observou que análises realizadas tanto por críticos quanto por músicos consistiam, em sua maior parte, de indicações de graus ou de funções dos acordes. O plano formal era tratado de modo semelhante, havendo apenas uma espécie de relato de seções e regiões tonais exploradas pelo compositor. Esses tipos de abordagens, além de carecer de profundidade, têm pouca utilização prática. Na opinião de Dahlhaus não passavam de tautologias já que "freqüentemente, análises musicais ou fragmentos analíticos (em sua maior parte descrições de harmonias e tonalidades) sofrem da obscuridade de suas propostas e conseqüentemente provocam a suspeita de que são desnecessárias" (DAHLHAUS, 1983, p.9).

Ao deparar com análises do tipo descritivas, percebe-se que estas revelam mais acerca da teoria analítica do que a respeito da própria obra. Isto se deve ao fato da análise acabar por constituir um procedimento taxionômico, em que um dado observado é reportado e/ou classificado segundo um modelo prévio. Isto fez com que Dahlhaus apontasse para a inutilidade desse procedimento, porque uma análise não deveria funcionar como demonstração ou prova de uma teoria nem como tradução para outro idioma de uma particularidade da obra. Argumentava que não bastava apenas isolar e enumerar os acordes, abstraindo-os de elementos rítmicos; outrossim, era preciso que o caráter individual da estrutura e das relações harmônicas fosse "expressamente demonstrado e articulado por uma interpretação da análise: uma análise de segunda ordem" (ibid, p.9). De outro modo, as análises tornar-se-ão meras aplicações de nomenclaturas ou rotulações "que não dizem nada, pois se tornam inobjetivas" (ibid, p.9). Se os elementos observados no plano musical são considerados como fatos ou dados empíricos, deve haver, então, uma interpretação desses dados. Esta hermenêutica da análise estaria a cargo dessa análise de segunda ordem preconizada por Dahlhaus, e indicaria a maneira organizacional subjacente ao relacionamento desses fatos, sua forma de integração e conexão, seu contexto e seu modus operandi.

\footnotetext{
${ }^{5}$ Uma teoria pode ser pré-condição (é necessário que haja um sistema teórico que norteie a realização de uma análise, por exemplo, o dodecafonismo) ou resultado de análises musicais (quando um modelo teórico é obtido pelas deduções efetivadas a partir da análise direta das obras; por exemplo, sistematização do contraponto de Palestrina realizada por Jeppesen).
} 
O problema que se apresenta de imediato é saber qual maneira ou abordagem utilizar na realização da interpretação da análise. Seria útil, portanto, primeiramente a definição de alguns termos.

Uma análise harmônica é uma comparação de um fato constatado com um modelo sugerido por alguma teoria. Por teoria entende-se uma proposição para o funcionamento, organização e ordenação das relações existentes nos fatos observados. Nesse sentido, uma teoria da harmonia, ao propor um modelo de ordem para o relacionamento sonoro, possibilita a compreensão dos chamados fatos harmônicos e permite que o entendimento dessas relações seja transmitido. No entanto, para essa consecução teórica não basta apenas indicar os elementos comuns, mas sim, promover a explicação das possibilidades de combinações feitas destes fenômenos. A harmonia não é uma instituição auto-suficiente, validada em si mesma, ela só tem seus aspectos comunicativo e significativo valorados se estiver amparada por um arcabouço teórico que organize e torne inteligíveis os fenômenos harmônicos por ela contemplados. Deste modo, torna-se possível a explicação dos fatos constatados bem como a posterior transmissão desse conhecimento (o que exige um denominador comum existente entre transmissor e receptor envolvidos nessa comunicação. Esse pano de fundo comum é justamente a proposta teórica).

Imagine-se, por exemplo, uma análise em que foram enumerados os graus de um determinado encadeamento harmônico. Em uma apreciação superficial, essa descrição servirá apenas para indicar os acordes utilizados, um procedimento simplesmente tautológico que não desvenda quaisquer mecanismos responsáveis por viabilizar a conexão entre esses acordes. No entanto, mesmo nesse nível analítico, um olhar mais detido pode revelar, entre outras coisas, movimentos de tensão e de resolução, possíveis modulações ou tonicizações locais, afastamentos da tonalidade principal, uso de regiões harmônicas próximas ou distantes do ponto de partida, funcionalidade entre as harmonias envolvidas. Esses elementos irão denotar a coerência interna do discurso musical, além de localizar a obra em determinado contexto estético ou estilístico. Outrossim, a observação dessas características pode ser útil para embasar um processo construtivo (vide adiante). O aspecto funcional é uma das possíveis maneiras de prosseguir para um nível interpretativo posterior, considerando, então, as relações que os acordes mantém entre si e para com o centro tonal, isto é, avaliando sua dimensão sintática.

Ao combinar sons de maneira lógica e expressiva, a música liga-se ao aspecto da comunicação, permitindo ser considerada como linguagem, decorrendo dai a possibilidade de ser analisada em termos de seus elementos básicos de construção e estruturação, ou seja, elementos sintáticos. Assim, a comunicação musical surge das implicações existentes entre os 
componentes estruturais (das estruturas gerativas) e formais (resultantes dos processos construtivos) da obra.

Um evento ordenado sintaticamente pode ser tomado como uma unidade e agir como um aspecto da organização formal em outro nível hierárquico, expandindo então seu significado. É justamente essa rede de relações, combinações e elaborações entre as estruturas gerativas, gerenciadas por processos construtivos, que viabilizarão a consecução total da obra e permitirão sua transmissão ao ouvinte. Tome-se, por exemplo, o tema de uma fuga. A estrutura gerativa é o próprio tema (ou sujeito, como nomeado em alguns livros). A princípio, este se trata de uma seqüência de notas dispostas em determinada ordem possuidora de sentido tendo por base uma harmonia específica; encontrando-se, portanto, em um nível estrutural básico (ou seja, o tema é entendido em referência á tonalidade que traz implícito). No entanto, no decurso musical serão introduzidos outros elementos que irão articular-se de algum modo com o primeiro tema, aumentando sua possibilidade de relações. Além disso, o primeiro tema sofrerá transformações, será retomado em outras regiões harmônicas e irá conectar-se a outros elementos, fatos que expandirão seus níveis de significação. O processo construtivo desse tipo de composição é um procedimento imitativo governado e articulado pelo desenvolvimento tonal, ou seja, o trânsito do tema por algumas regiões tonais e seu posterior retorno à região inicial. Com isso, essa rede de hierarquias iniciada com um tema foi ampliada até a consecução total da composição.

$\mathrm{O}$ relacionamento funcional ${ }^{6}$ já é, de fato, conhecido há tempos por aqueles que empregam o método de análise preconizado por Riemann. Nesta teoria os acordes são considerados segundo o tipo de vínculo que mantém para com a tônica. Já as relações existentes entre as progressões acórdicas, isto é, de acorde para acorde, remontam aos postulados de Rameau no seu tratado de harmonia (1722). A noção de progressão de fundamentais implicava que as notas reais escritas no baixo contínuo não eram as verdadeiras fundamentais dos acordes, pois estes, independentemente de encontrarem-se invertidos ou não, possuíam um baixo (ou nota fundamental natural e racional) subentendido. Este baixo implícito, por seu turno, era o elemento viabilizador das conexões entre os acordes. Esta formulação de Rameau foi por ele mesmo denominada de basse fondamentale, que na visão de Dahlhaus é uma teoria de progressões acórdicas. Note-se a correspondência deste princípio com o cartesianismo, que substituía a ordem real pela racional, ficando a cargo da razão a competência para organizar as sensações. A diferença entre as propostas de Riemann e Rameau é que este se concentrava nas distintas tendências que os acordes têm para progredir

\footnotetext{
${ }^{6}$ Sobre uma análise mais detida do conceito de função ver Função e Refuncionalização em Corrêa, 2006.
} 
(descer ou subir uma quinta, por exemplo), enquanto aquele definia estados ou estatutos harmônicos das tríades (T-D-S) em acordo (ou em função de) com um pólo tonal.

Tomando-se o Prelúdio $n^{\circ}$. 1 (C) do Cravo bem Temperado de Bach, observa-se que o mesmo possui uma concatenação entre acordes baseada majoritariamente em graus conjuntos diatônicos. O ritmo harmônico é periódico (a harmonia muda a cada compasso) e com isso torna-se um elemento de redundância e previsibilidade, "fornecendo assim uma base sólida para outros eventos musicais que ocorrerão" (CHRIST et al, 1980, p.234). Os acordes são articulados por meio de sucessivas alternâncias entre estabilidade e instabilidade, um processo modulatório intratonal (cf: RIBEIRO-PEREIRA, 2005) no qual determinadas notas são transfiguradas em razão do contexto harmônico (vide Exemplo 1-2). A concepção harmônica dessa movimentação, entretanto, é funcional, pois os acordes mantêm entre si um vínculo que permite referenciá-los à tônica principal da obra $(C)$. Com isso, mesmo em passagens com ligeiros afastamentos da tonalidade inicial, em que ocorrem tonicizações no nível estrutural secundário (compassos 6, 10 e 12 do Exemplo 2-2), é possível remeter os acordes ao nível hierárquico tonal primário, ou seja, $C$, pois a idéia básica do relacionamento harmônico permanece similar, encontrando sua fundamentação no ciclo de quintas. Por exemplo, na tonicização de $G$ (compassos 6-7 e 10-11 do Exemplo 2-2) o acorde de dominante (D7) encontra-se em um nível hierárquico secundário, mas articula-se com $C$ por meio da relação de quintas, posto que é V7/V/I (quinto grau com sétima do quinto grau de $C$ ). O próprio acorde de $C$ aparecerá com a função de dominante, devendo com isso ser reinterpretado fora do seu nível tonal primário, tornando-se um V/IV/I (quinto grau do quarto grau de $C$, ou mais eficazmente dominante da subdominante - D/S).

$\mathrm{O}$ aspecto perceptual também pode ser considerado nesse contexto, pois é possível entender que as dominantes secundárias implicam o próximo acorde, ocasionando, portanto, a expectativa sonora desse surgimento. Leonard Meyer faz notar que nos Prelúdios I e II do Cravo Bem Temperado a coerência estrutural é resultado do relacionamento funcional entre suas partes componentes, uma vez que estas se encontram articuladas por implicação, pois o início, embora possua um formato harmônico relativamente fechado, demanda elaboração (que ocorre na parte central, na qual um processo harmônico menos estável, mas objetivamente direcionado, move-se para uma tensão estabilizada sobre a dominante) e conduz à conclusão, que apresenta uma prolongada fórmula cadencial. 

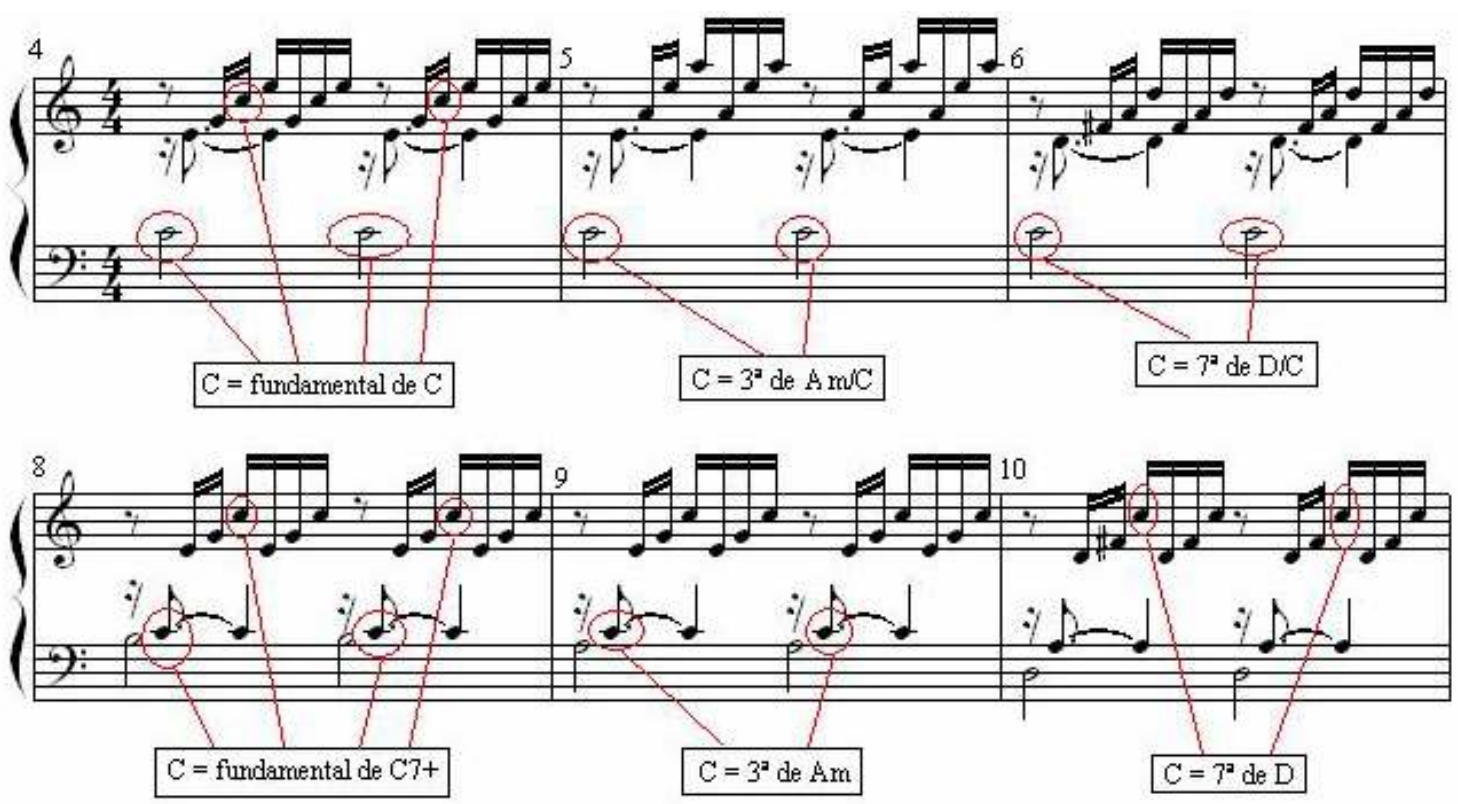

Exemplo 1-2: J. S. Bach, Cravo Bem Temperado, Prelúdio $n^{\circ}$. 1 (C), compassos 4-6 e 8-10. Modulação intratonal da nota $C$.

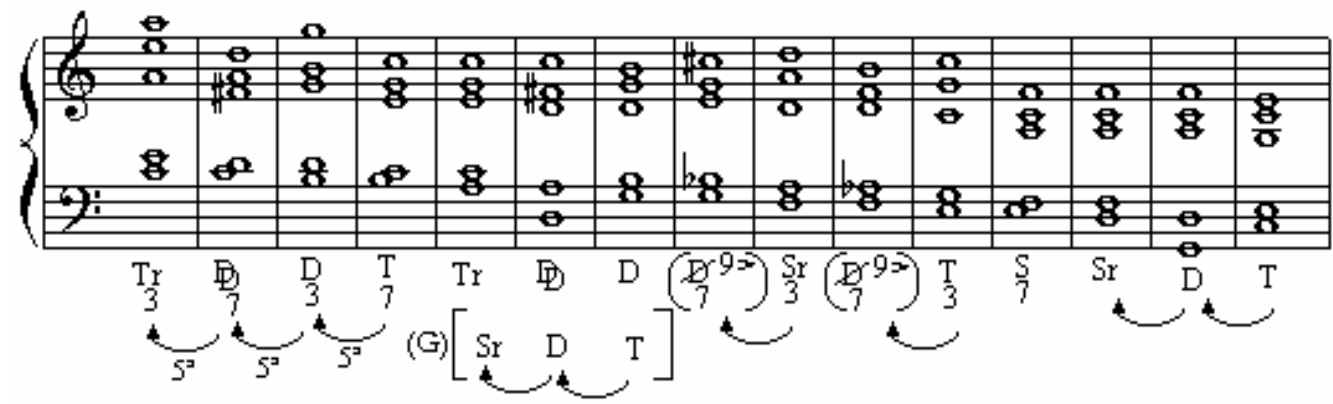

Exemplo 2-2: J. S. Bach, Cravo Bem Temperado, Prelúdio $n^{\circ} .1$ (C), compassos 5-19 (verticalização da movimentação linear). Conexão entre acordes baseada no ciclo das quintas.

Em posse desse entendimento analítico, ou seja, a interpretação funcional dos acordes utilizados que, modulados intratonalmente, revelaram ter por princípio de base uma relação baseada no ciclo das quintas, é possível refazer o processo construtivo, mantendo-se justamente sua arquitetura, porém, alterando algumas estruturas gerativas. O Exemplo 3-2 apresenta uma dentre as várias maneiras dessa realização. Percebe-se que a harmonia empregada neste exemplo é semelhante àquela utilizada por Bach no Prelúdio $n$. 1; as notas são moduladas intratonalmente e a relação funcional é preservada. Todavia, por meio do uso de pedais, notas de passagem, ornamentos, e pelo fato da movimentação melódica da figura motriz ser distinta do prelúdio de Bach, o resultado sonoro é completamente diferente, guardando pouca ou nenhuma semelhança com uma composição em estilo barroco. 


\section{Prelúdio n. 1}
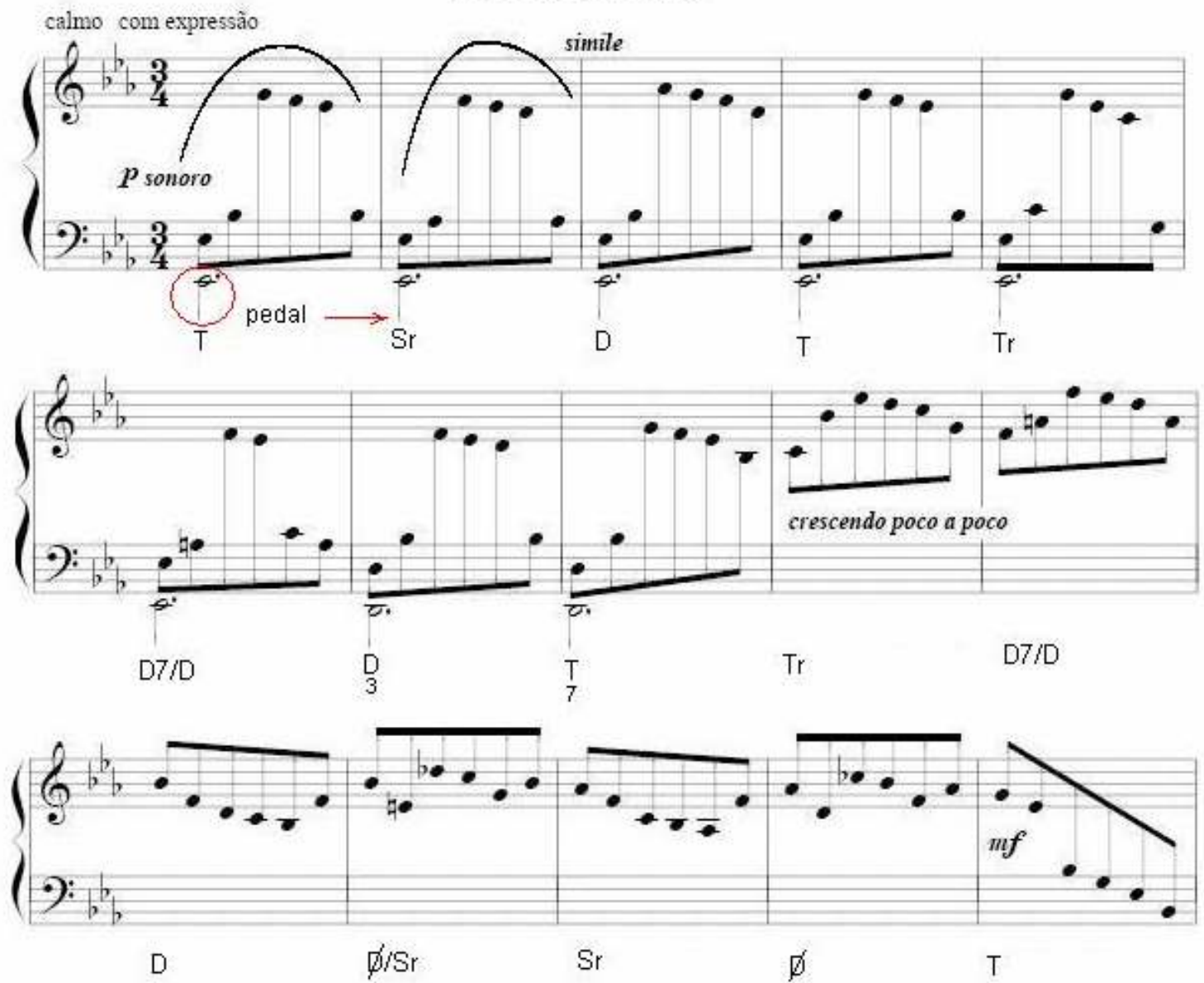

Exemplo 3-2: Antenor Ferreira, Prelúdio $n^{\circ} .1$ Eb, compassos $1-1$. $^{7}$

O princípio de base do Prelúdio 1 de Bach pode ser verificado em outras obras, mesmo no repertório do século XX. Um exemplo disto é o primeiro prelúdio de Alexander Scriabin, do seu Opus 11. Embora a harmonia usada nesta peça não seja tão explícita quanto a de Bach, a semelhança é notável. No Exemplo 4-2, Prelúdio $n^{\circ} 1$ do Opus 11 de Scriabin, observam-se alguns procedimentos que remetem ao Prelúdio 1 do Cravo Bem Temperado. Entre algumas homologias pode-se citar: relacionamento funcional entre acordes, conexão harmônica baseada no ciclo das quintas, uso de suspensões, acorde de sexta aumentada e o emprego do pedal.

\footnotetext{
${ }^{7}$ As partituras completas dos exemplos contendo obras de minha autoria, constantes neste e nos demais capítulos, encontram-se nos Anexos.
} 

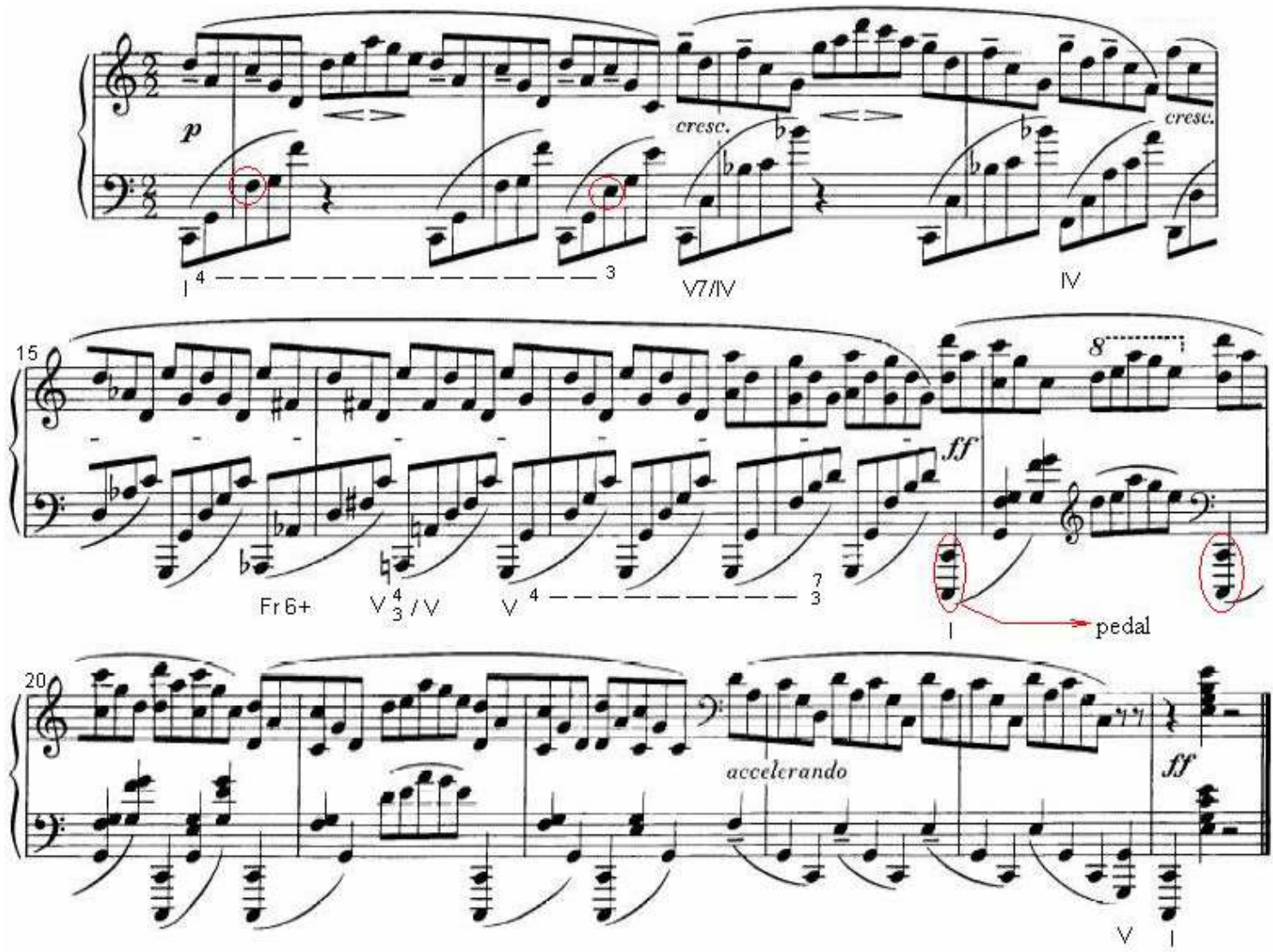

Exemplo 4-2: Scriabin, Prelúdio $n^{\circ}$. 1(C), Opus 11, compassos 1 - 4 e $15-25$.

O Prelúdio 1 de Bach, assim como os demais Prelúdios do Cravo, mantém a estrutura tonal no âmbito de relações harmônicas próximas à tonalidade principal da obra. Há ligeiros afastamentos que não vão, porém, além das tonalidades vizinhas. Este é um fato, grosso modo, característico das obras do período barroco e do início do clássico. Um dos primeiros passos na direção da expansão da tonalidade foi o uso das regiões mediânticas, isto é, regiões que guardam uma relação de terça (maior ou menor) para com a tonalidade principal da obra. Schubert e Beethoven muito se valeram desse procedimento. Para efeito da próxima análise, no entanto, tomarei o Prelúdio escrito por Maurice Ravel em sua obra Le Tombeau de Couperin, focando principalmente no uso motívico, avaliado com o método de análise conhecido como teoria dos conjuntos (pitch-class set theory).

Ravel escreveu Le Tombeau de Couperin unindo duas características em princípio antagônicas: nacionalismo tradicionalista e inovação. Esta foi sua única obra composta durante o período da primeira grande guerra e que também conclui sua produção para piano. Le Tombeau de Couperin é uma suíte escrita segundo a forma do século XVIII, época em que a escola francesa conheceu o seu apogeu, sobretudo, com François Couperin e Jean Philippe Rameau. Desse modo, Ravel ao homenagear François Couperin reverencia a música francesa 
deste período. Ravel resgata um estilo sem declinar, entretanto, de uma escritura moderna, pois mesmo com o sentimento nacionalista exaltado e com olhos para o século XVIII, Le Tombeau foi composta em uma época em que a tonalidade era abandonada pelos compositores que pesquisavam novas maneiras de expressão. Dentro dessa modernidade, o discurso musical de Ravel extravasa em renovação e elaboração, sobretudo, por expandir e estender a tonalidade por regiões harmônicas distantes da tonalidade inicial da obra ${ }^{8}$.

Continuando as observações relativas à análise de segunda ordem, considerarei apenas o Prelúdio desta suíte. Do ponto de visto macroscópico, o Prelúdio configura-se formalmente em duas partes de durações aproximadamente iguais:

A - compassos de 1 a 36 ( $1^{\text {a }}$ vez 33 comp. $2^{\text {a }}$ vez 29 comp. Total $=62$ compassos $)$

B - compassos de 37 a 97 (total 60 compassos)

$\mathrm{A}+\mathrm{B}=122$ compassos.

Grosso modo, permite-se considerar as duas partes como formas em arco, iniciando com pouca intensidade (dinâmica $p p$ ) e conduzindo a um ponto culminante $(\mathrm{PC})$ de grande intensidade (dinâmica ff) retornando novamente á intensidade inicial. As sucessões rumo aos pontos culminantes são mostradas nos Exemplos 6-2b (compasso 28) e 8-2a (compassos 8082). Os últimos quatro compassos da peça formam a Coda. Compreende-se então a direcionalidade implícita neste projeto composicional, visando ao alcance de tensão máxima nos dois pontos culminante, e o posterior decaimento dessa tensão.

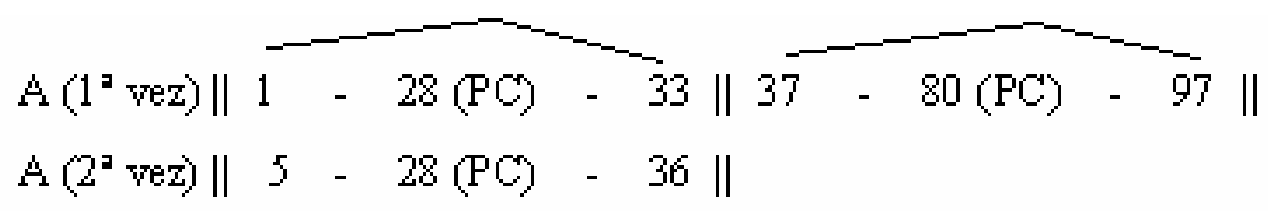

A estruturação harmônica pode ser considerada como um grande movimento único que parte e retorna à tonalidade de $E m$ tendo como pontos estruturais significativos suas tonalidades relativa $(\mathrm{G})$ e anti-relativa $(C)$, embora não haja cadência perfeita confirmando Em como tônica e este acorde só apareça em sua clara configuração triádica no final da obra (primeiramente arpejada e depois superposta - no penúltimo compasso da Coda):

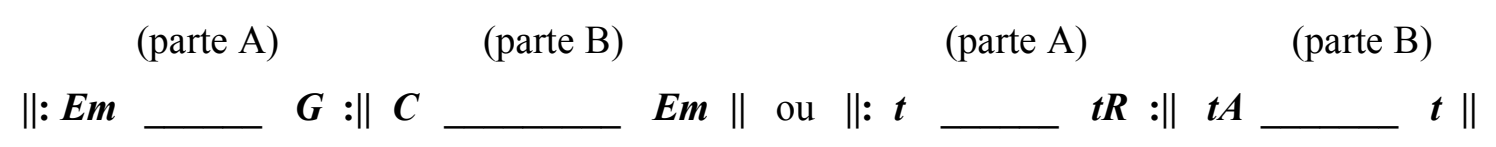

Em ambas as partes há a oposição diatonismo versus cromatismo. Na parte $\mathrm{A}$ uma primeira seção diatônica (compassos 1-13, vide Exemplo 5-2) é sucedida por outra onde a

\footnotetext{
${ }^{8}$ Os apontamentos que se seguem constam, em parte, em Le Tombeau de Couperin: Considerações analiticas e musicológicas, de autoria de Danieli Longo Benedeti e Antenor Ferreira. Anais do Simpemus 4, Curitiba, 2007.
} 
movimentação cromática prevalece (compassos 14-21, vide Exemplo 6-2a), seguindo-se nova seção diatônica. Na parte $\mathrm{B}$ verifica-se o mesmo procedimento, no entanto, os períodos de digressões cromáticas são maiores. Com isso, uma seção diatônica (compassos 37-52) é seguida por outra com 18 compassos nos quais o uso de cromatismos e harmonias sem relações tonais predomina (compassos 53-70). Segue-se, novamente, outra seção diatônica. De acordo com esse critério, as partes A e B permitem as seguintes subdivisões em seções.

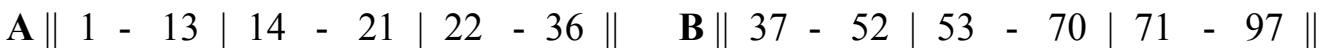

$$
\begin{aligned}
& \text { diatônica cromática diatônica diatônica cromática diatônica }
\end{aligned}
$$

O aspecto rítmico do Prelúdio de saída chama a atenção, pois põe em evidência um fluxo intermitente de semicolcheias que perpassará a obra até o fim. No interior desse fluxo dois elementos principais, a partir daqui denominados motivos, podem ser diferenciados (vide Exemplo 5-2): a seqüência intervalar do primeiro compasso (que, como ver-se-á adiante, trata-se de uma estrutura reiterada no decorrer da peça) $A-G-D-E-G-B$ (conjunto pentatônico que na tabela de Alen Forte recebe o número de 5-35) e o motivo de três colcheias ascendentes $A-B-C \#$ (por exemplo, compasso 7). Esses dois motivos, além de constituírem-se enquanto estruturas gerativas primordiais, também marcam pontos de secção da obra (imbricamento entre partes, seções e períodos). Um outro elemento composto de três semicolcheias e uma colcheia pontuada precedidas por um mordente superior, agora denominado motivo 1 abreviado (1ab), também merece destaque, dado sua recorrência em posições estruturais importantes da peça (compassos 2 e 10 Ex. 5-2). Semínimas pontuadas com mordentes também se configuram enquanto elementos gerativos importantes. Contudo, por serem empregadas somente em sucessões direcionadas para os pontos culminantes, não são consideradas como motivos.

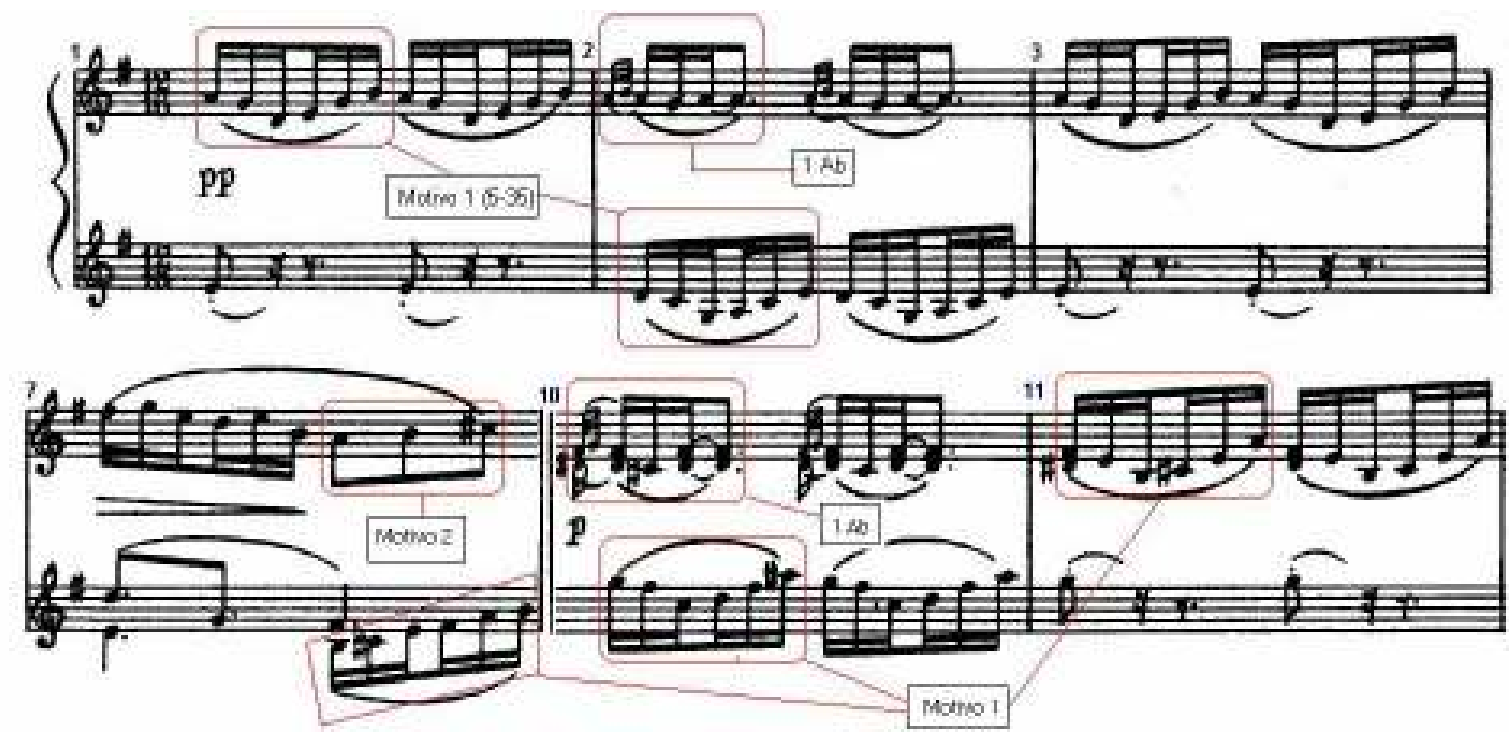

Exemplo 5-2: Ravel, Le Tombeau de Couperin, Prelúdio, compassos 1-3, 7 e 10-11. 


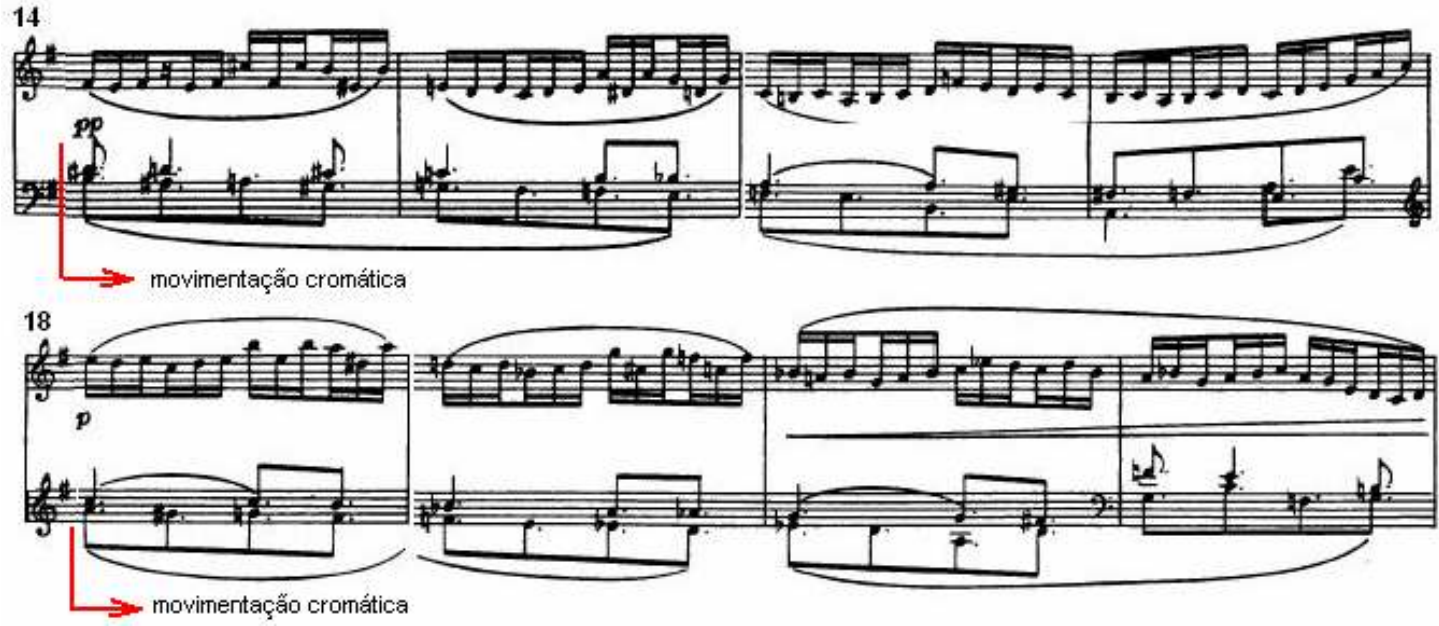

Exemplo 6-2a: Ravel, Le Tombeau de Couperin, Prelúdio, compassos 14-21. Movimentação cromática.

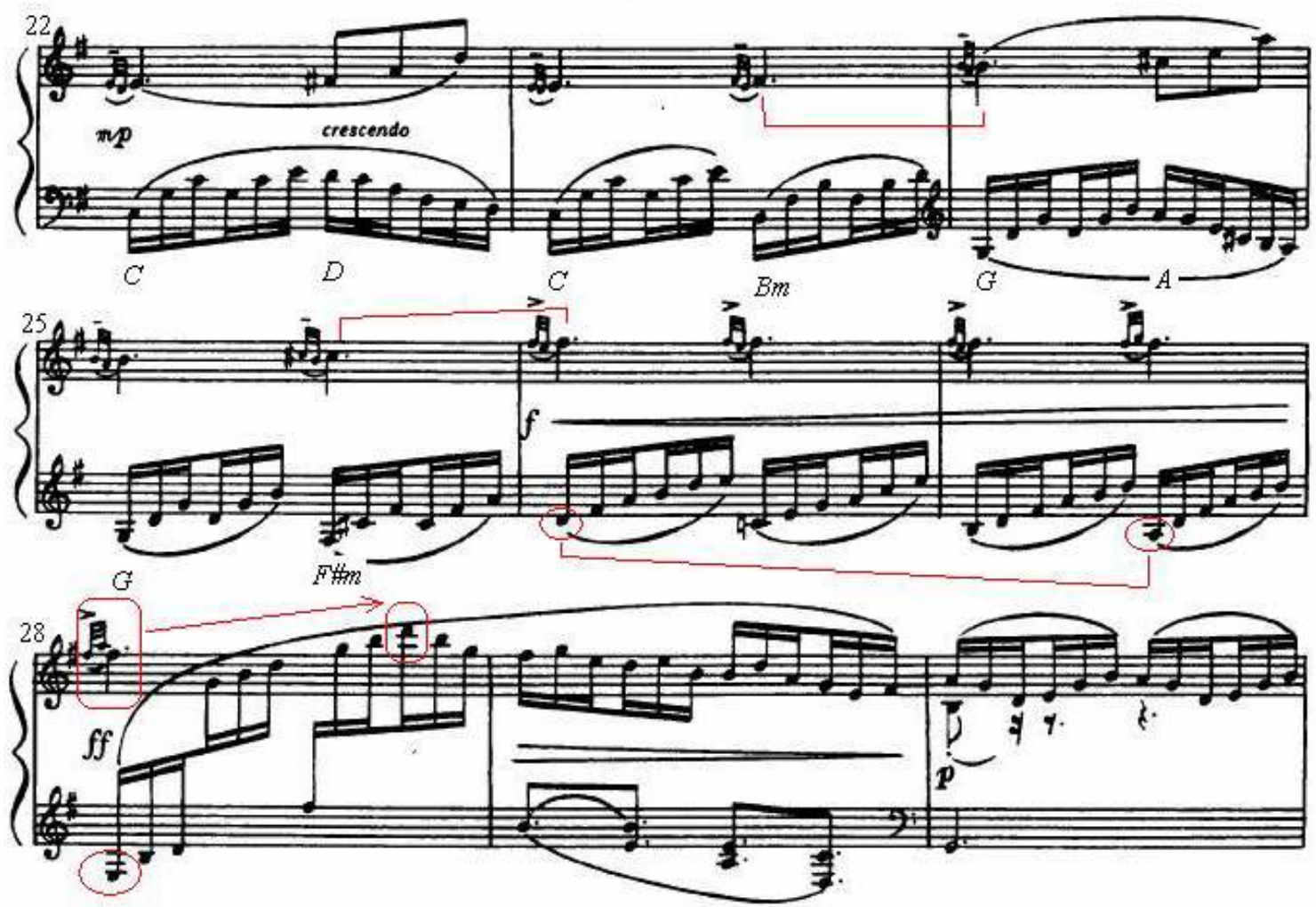

Exemplo 6-2b: Ravel, Le Tombeau de Couperin, Prelúdio, compassos 22-30. Estruturações baseadas no intervalo de quarta justa. Sucessão em direção ao ponto culminante da primeira parte.

Um esquema básico mostrando a divisão em partes e seções estruturais e apontando as principais ocorrências em cada uma destas é dado na tabela a seguir. Algumas das partes e compassos citados não constam nos exemplos oferecidos: 
Parte A

\begin{tabular}{|l|l|l|}
\hline Compassos & Função & Descrição \\
\hline $1-4$ & expositiva & Apresentação dos motivos 1 e 1ab. \\
\hline $5-9$ & transitiva & $\begin{array}{l}\text { Linha ascendente na voz superior }(C-F \#) \text {, apresentação do } \\
\text { motivo 2 e sucessão em direção à região da dominante }\end{array}$ \\
\hline $10-13$ & Desenvolvimental & $\begin{array}{l}\text { Chegada à região da dominante; sobreposição dos motivos } \\
1 \text { e 1ab em nova harmonia; nota } B \text { polarizada; primeira } \\
\text { formação triádica vertical da peça }(B)\end{array}$ \\
\hline $14-21$ & Transitiva & $\begin{array}{l}\text { Movimentação cromática nas vozes inferiores em direção à } \\
\text { confirmado por cadência V-I (c. 21-22) }\end{array}$ \\
\hline $22-27$ & Desenvolvimental & $\begin{array}{l}\text { Elaboração do motivo 2 e movimentação descendente do } \\
\text { baixo rumo ao ponto culminante }\end{array}$ \\
\hline $30-36$ & Reexpositiva & $\begin{array}{l}\text { Ponto culminante; ambigüidade } G-E m \\
\text { Volta do motivo 1, mas em nova região tonal; afirmação } \\
\text { cadencial de } G \text { (c. 29-30 cadência V-I em } G \text { ) }\end{array}$ \\
\hline
\end{tabular}

Parte B

\begin{tabular}{|c|c|c|}
\hline Compassos & Função & Descrição \\
\hline $37-43$ & Desenvolvimental & $\begin{array}{l}\text { Elaboração do motivo } 1 \text { na região de } C \text {; baixos em relação } \\
\text { de quartas }(\mathrm{T}-\mathrm{S}) \text {; motivo } 2 \mathrm{em} G\end{array}$ \\
\hline $44-47$ & Desenvolvimental & $\begin{array}{l}\text { Reapresentação dos três compassos anteriores, motivo } 2 \\
\text { transposto um tom abaixo - região de } B b\end{array}$ \\
\hline $48-52$ & Desenvolvimental & $\begin{array}{l}\text { Reexposição do motivo } 1 \text { na região de } A m \text { confirmada } \\
\text { cadencialmente }(\mathrm{V}-\mathrm{I}) \text {; pedal superior na nota } E \text {; retorno à } \\
\text { região de } C\end{array}$ \\
\hline $53-70$ & Desenvolvimental & $\begin{array}{l}\text { Desenvolvimento do motivo } 2 \text { por meio de harmonia sem } \\
\text { relações tonais e sem pólos tonais predominantes, porém } \\
\text { com pontos de relativo repouso em } D \text { e } A b \text {; }\end{array}$ \\
\hline $71-79$ & Transitiva & $\begin{array}{l}\text { Direcionamento para o ponto culminante valendo-se do } \\
\text { motivo 2; movimentação descendente do baixo }\end{array}$ \\
\hline $80-85$ & & $\begin{array}{l}\text { Ponto culminante e região de } A m \text {; movimento plagal em } \\
\text { direção à } E m\end{array}$ \\
\hline $86-93$ & Conclusiva & $\begin{array}{l}\text { Motivo } 1 \text { e 1ab retomados em } E m \text {; cadência plagal }(\mathrm{S}-\mathrm{T}) \text {; } \\
\text { movimentação em direção ao grave }\end{array}$ \\
\hline $94-97$ & Conclusiva & Coda \\
\hline
\end{tabular}

Outro ponto a ser destacado no projeto da peça é o uso do intervalo de $4 \mathrm{~J}$ como outra estrutura gerativa. De saída, o primeiro intervalo harmônico usado é a quarta $E$ - $A$ (vide Ex. 52). O primeiro compasso enfatiza a nota $E$ que se reveste como pólo principal da peça, no próximo compasso o motivo lab é destacado na voz superior, manifestando novamente a relação $4 \mathrm{~J} E-A$. É também notório o uso da cadência plagal no final da obra (comp. 85-86) e a presença da $4 \mathrm{~J}$ em pontos em que o motivo 1 é exposto ou reapresentado (por exemplo, compassos 1, 37 e 86). Dos compassos 22 a 25 (vide Ex. 6-2b) forma-se a seqüência de acordes harpejados $C-D-C-B m$ reapresentada $4 \mathrm{~J}$ abaixo em $G-A-G-F \# m$. Nos compassos 25 e 26 a transição para o ponto culminante possui uma seqüência ascendente na voz superior com as notas $C \#-F \#$ e uma seqüência descendente completa na voz inferior do baixo com o 
intervalo de $4 \mathrm{~J} D-A$ (comp. 26-27). Nos compassos 37 a 46 (não exemplificados) aparece o ciclo de quartas nas regiões empregadas $C-F-B b$. A partir do compasso 53 o motivo 2 é modificado e convertido em intervalos de quarta (por exemplo, compassos 53 e $54 D-G-C$ e compassos 56 e $57 C-F-B b$, vide exemplo 7-2. Obs: os compassos, não mostrados no exemplo, 54 e 57 são repetições dos comp. 53 e 56, respectivamente). Nos compassos 75,76 e 78 (Ex. 8-2a) a condução na voz superior para o ponto culminante é feita com três intervalos de 4J: $C \#-F \#-B$. Mais contundente na explicitação do intervalo de $4 \mathrm{~J}$, é a relação entre os pontos culminantes da obra. No primeiro há a sobreposição intervalar $E-F \#$ e a seqüência melódica segue ascendentemente até atingir a nota $D$. No segundo ponto culminante (compassos 80-82, Ex. 8-2a), essa sobreposição é $A-B$ e a seqüência segue até a nota $G$, indicando uma clara fundamentação no intervalo de $4 \mathrm{~J}$ :

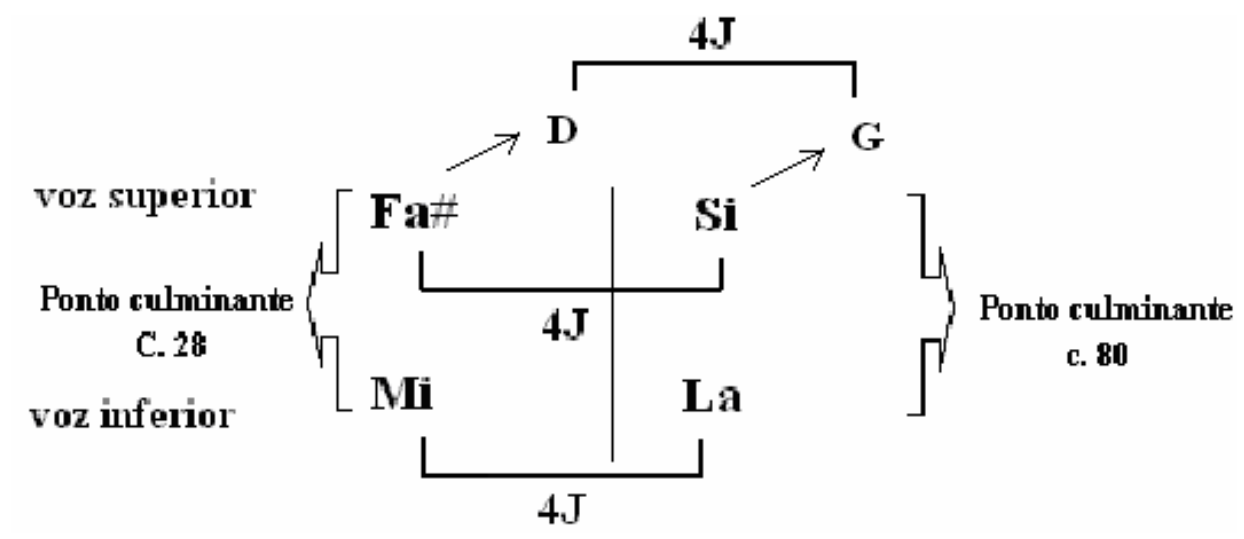

Assim, fica patente a importância estrutural dessa estrutura baseada no intervalo de quarta justa para a composição do Prelúdio.

Por fim, é digno de nota o uso do motivo 1 e as novas "harmonizações" que o mesmo recebe. Tomando-se inicialmente o conjunto original (5-35) $A-G-D-E-G-B$ verifica-se que este recebe os seguintes suportes harmônicos: $E$ (compasso 1) $G$ (compasso 30,50) e $C$ (compasso 37, 52). Como já mencionado, esse conjunto é reiterado no decorrer da peça. Variações deste conjunto são encontradas como apontado a seguir (estão excluídas algumas repetições):

Compassos 2, 31, $38-D, C, G, A, C, E$ (vide exemplo 5-2)

Compasso $7-B, C \#, E, F \#, A, B$ (vide exemplo 5-2)

Compasso $10-B, A, E, F \#, A, C \#$

Compasso $11-F \#, E, B, C \#, E, A$ (vide exemplo 5-2)

Compassos 47, $86-E, D, A, B, D, F \#$

Compasso $76-D, F \#, A, B, D, E$ (vide exemplo 8-2b)

Compasso 87 - B, $A, E, F \#, A, D$ (vide exemplo 8-2b)

Compasso $94-E$, $G, A, B, D$ (vide exemplo 8-2b) 

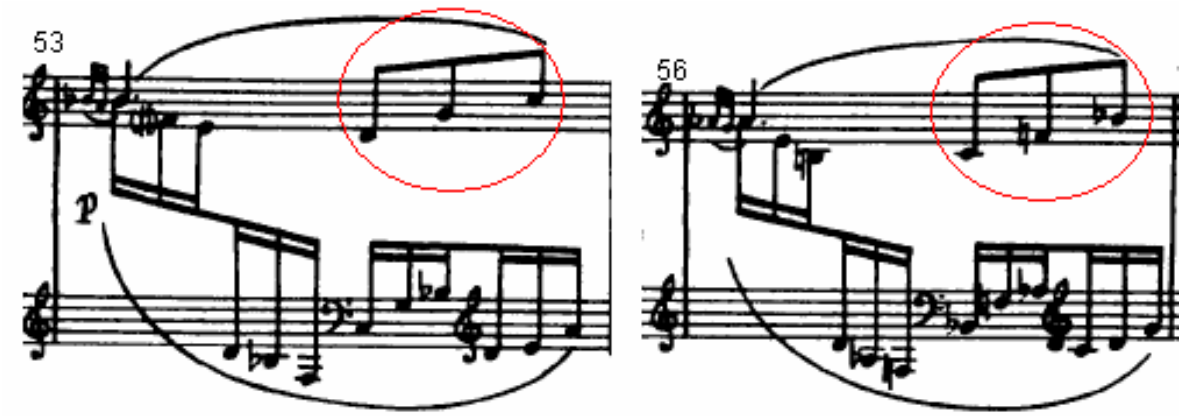

Exemplo 7-2: Ravel, Le Tombeau, Prelúdio, compassos 53 e 56 (motivo 2 convertido para 4J).
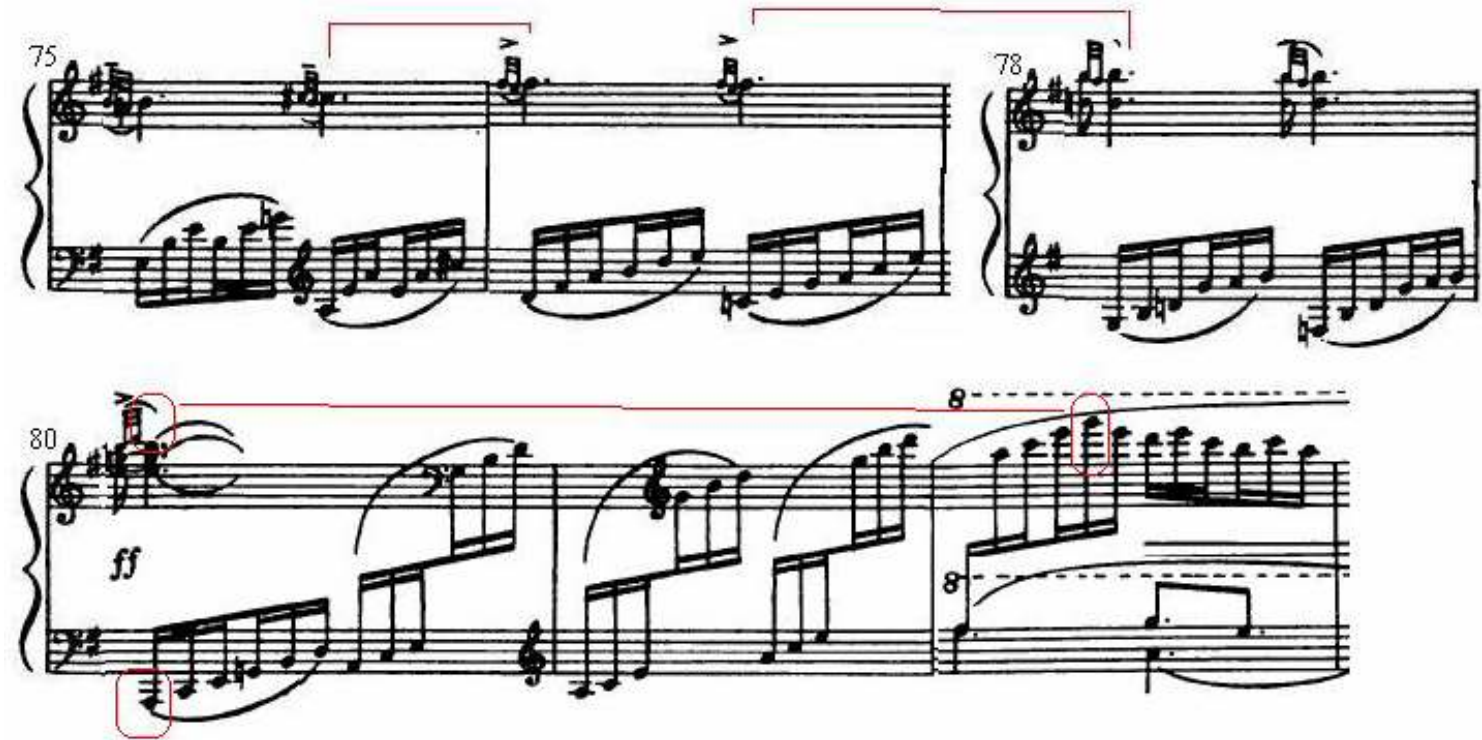

Exemplo 8-2a: Ravel, Le Tombeau, Prelúdio, compassos 75-76, 78, 80-82. Estruturações por intervalos de quarta e sucessão ao ponto culminante da segunda parte.

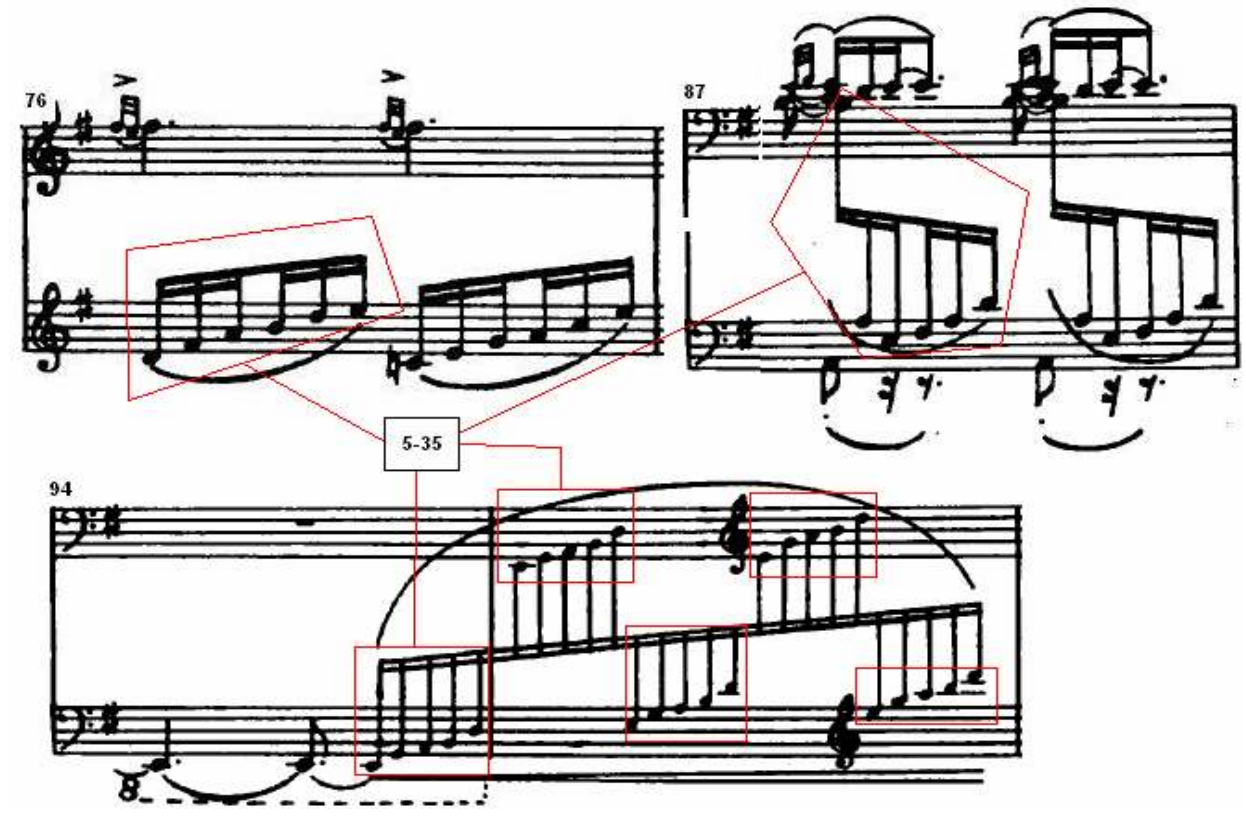

Exemplo 8-2b: Ravel, Le Tombeau, Prelúdio, compassos 76, 87 e 94 (reiterações do conjunto 5-35). 
Retomando resumidamente os pontos analíticos considerados, têm-se como estruturas gerativas desse Prelúdio: motivos (ou conjuntos), oposição diatonismo/cromatismo e o intervalo de 4J. O processo construtivo principal é o desenvolvimento. Não obstante, Ravel opera este desenvolvimento por regiões mais afastadas do ponto de partida, levando à impossibilidade de se promover uma relação tonal entre essas regiões. Para relembrar somente uma dessas impossibilidades pergunta-se, qual tipo de vínculo harmônico poderiam guardar as regiões de $E m$ e de $A b$ ? Ou $E m$ e de $B b$ ? O diferencial de Ravel reside não somente na sua constatada habilidade desenvolvimental, mas justamente na expansão que impinge ao discurso harmônico, artifício esse que, anteriormente, nas mãos de Wagner, Liszt e Mahler, entre outros, levaram à saturação o sistema tonal.

Como mencionado, um dos procedimentos utilizados para a expansão da tonalidade foi o uso das relações mediânticas. Mantendo em mente os aspectos analisados no Prelúdio de Ravel, associados à possibilidade da expansão do discurso harmônico intermediado por esse tipo de relação por terças, é factível realizar a transposição desses entendimentos para o plano composicional. Assim, de modo similar ao feito com o Prelúdio de Bach, no próximo exemplo manterei o processo construtivo de Ravel (desenvolvimento) vinculado ao uso da região das mediantes, preservando também algumas estruturas gerativas à maneira de Ravel, como o uso de conjuntos e de um intervalo em especial, no caso o de terça, como elemento estrutural; o Exemplo 9-2 demonstra esse processo. Observa-se a saturação pelo uso de dois conjuntos principais, 5-20 e 5-27, que são conduzidos por regiões harmônicas que guardam entre si relações mediânticas (T, M e bSM). Nos compassos exemplificados, estas são harmonizações correspondentes aos acordes de $B b, D / A$ e $F \#$ (ou $G b$ ), mas no decorrer da obra serão usadas como regiões harmônicas das distintas seções. Esses conjuntos principais mencionados predominam por toda a peça, em momentos são usados simultaneamente, indicando o acordo entre ambos, outros momentos os mesmos se opõem. Embora muitas vezes a construção harmônica não esteja implícita no primeiro plano, permanece latente no plano de fundo estrutural da obra, determinando a condução dos motivos principais de acordo com as relações de terças em direção ao ponto culminante. Um diagrama básico das regiões percorridas na peça é:

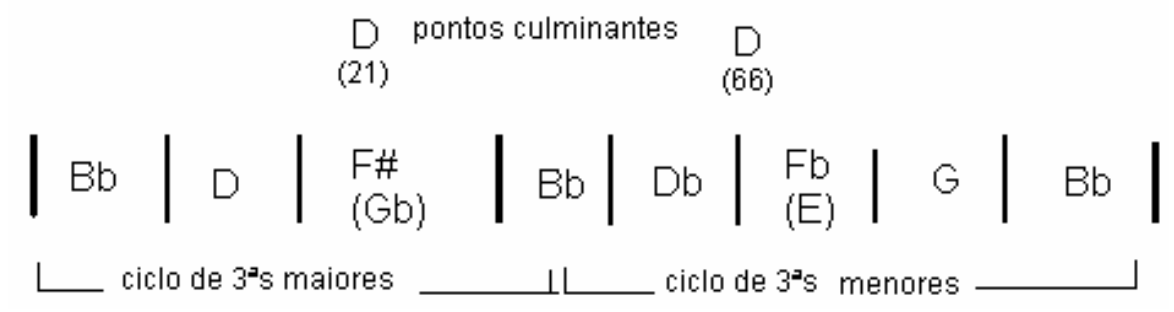




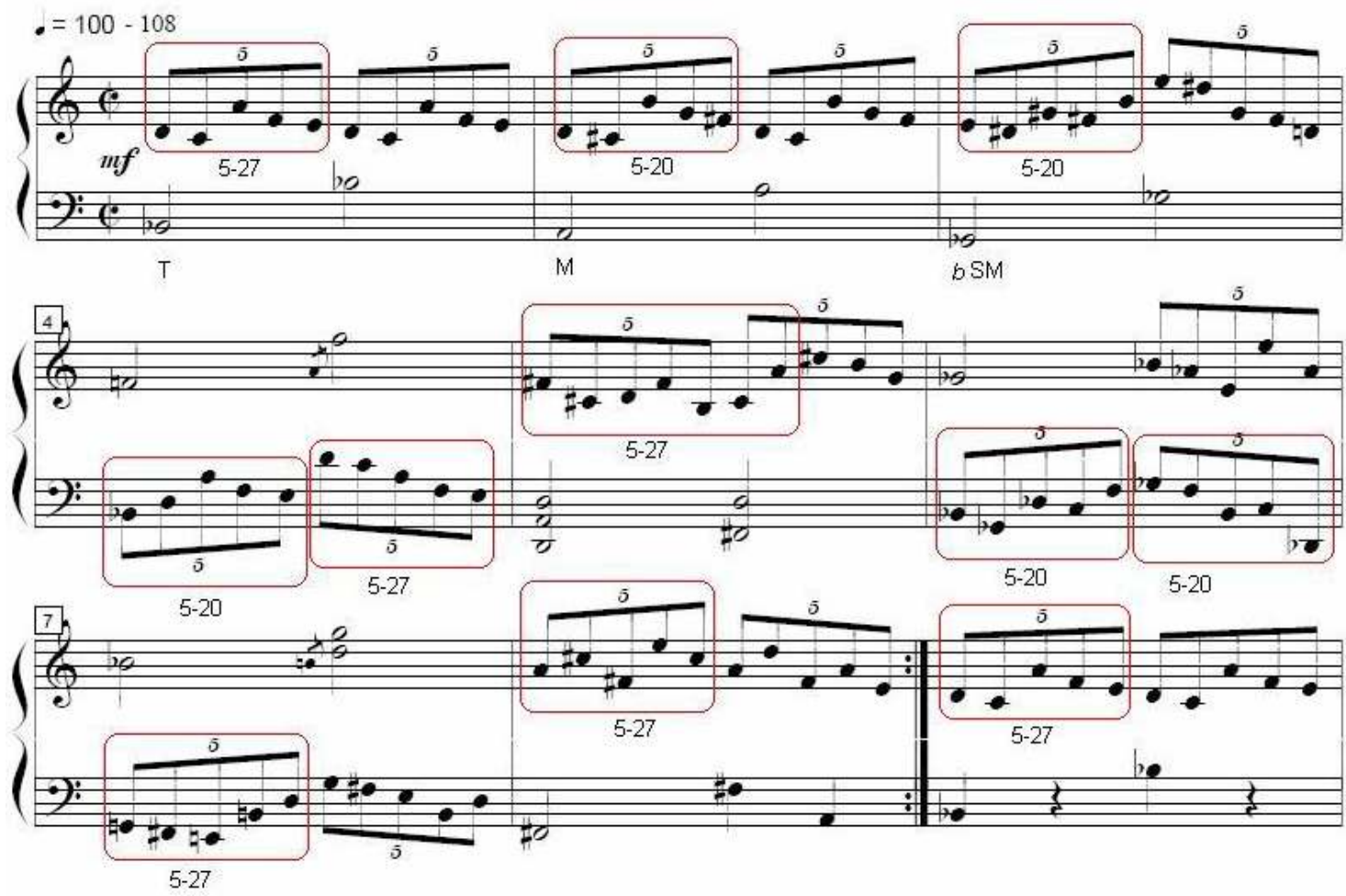

Exemplo 9-2: Antenor Ferreira, Prelúdio $n^{\circ}$. 3, compassos 1 -9

Demonstra-se, assim, neste último exemplo, mais uma possibilidade do intercâmbio analítico e composicional.

\section{Música e impressionismo}

Algumas aproximações podem ser feitas entre a pintura impressionista e a música escrita, sobretudo na França, na virada do século XIX para o XX e, também, durante as duas primeiras décadas deste. Esses paralelos não têm aqui o objetivo de promover uma classificação estética inserindo estas ou aquelas composições no âmbito estilístico surgido com os pintores impressionistas. Debussy, inclusive, pareceu discordar daqueles que propuseram classificar sua música como impressionista, alegando que suas obras pertenceriam mais a um universo onírico. O que proponho é comparar alguns aspectos técnicos que podem ser posteriormente usados com finalidades composicionais. Para tanto, alguns trechos de obras serão considerados dedicando-se uma apreciação mais detida sobre $L e$ vent dans la plaine, terceiro número do primeiro livro prelúdios de Debussy.

Dois aspectos são cruciais na pintura impressionista: dissolução da perspectiva e tratamento da 'luminosidade' da cena retratada. Sobre este tratamento da luz, são célebres as 18 telas da Catedral de Rouen nas quais Monet pinta o mesmo cenário, porém visto de maneiras distintas em acordo com os efeitos causados pela transição da luz no decorrer do dia. Desse modo, Monet representa distintamente o mesmo objeto, conseguindo um fantástico 
efeito de luminosidade entre os quadros, captando os sensíveis matizes de cor gerados pelas diferentes incidências da luz solar sobre as pedras da catedral. A perspectiva, neste contexto, passa a não ser o elemento mais notável na representação pictórica, pois o novo enfoque traz para o primeiro plano a questão da cor e da luz. É possível, então, traçar um paralelo entre música e pintura sob estes dois aspectos, pois a música também apresenta a dissolução da funcionalidade tonal e apresenta o timbre como importante elemento estrutural.

A funcionalidade e o processo de tensão/distensão do sistema tonal eram responsáveis por conferir direcionalidade à composição. A ausência destes provocou a emancipação ou afastamento dos modelos formais tradicionais, porque a composição passa a ser concebida como um fluir contínuo, pois o instante seguinte não é igual ao passado, como a luz que incidia sobre a catedral mudando a cada momento. Assim, padrões baseados em exposição, desenvolvimento e reexposição necessitavam ser reformulados. Chegou-se, deste modo, à substituição de repetições estruturais (de partes ou seções musicais) pela sucessão de episódios, um processo pensado como transformação sonora gradativa.

Uma maneira simples e direta de esboçar o paralelo entre tratamento da luz e do som é apresentar um tema (usado aqui em sentido amplo, podendo referir também a um motivo, uma melodia ou frase, ou mesmo a uma única nota - vide adiante) sob diferentes "luminosidades", isto é, com distintos timbres ou harmonias - artifício, de fato, já muito utilizado. Este tratamento não é a mesma coisa que transpor um tema para outra região, mas sim, manter um tema que a cada reaparição recebera uma nova 'iluminação'. Em outra oportunidade (CORRÊA, 2006) já havia comentado o uso deste procedimento feito por Debussy no Prélude a l'aprés-midi d'un faune no qual a melodia da flauta é harmonizada com diferentes acordes a cada re-exposição. Esse procedimento também pode estar restrito a uma única nota, como é o caso do prelúdio La fille aux cheveux de lin (Exemplo 10-2), neste a nota $D b$ surge como sétima do arpejo de Ebm, para depois tornar-se a quinta do acorde de $G b 7$ (compasso 8) e nona do acorde de $C b$ (compasso 28).

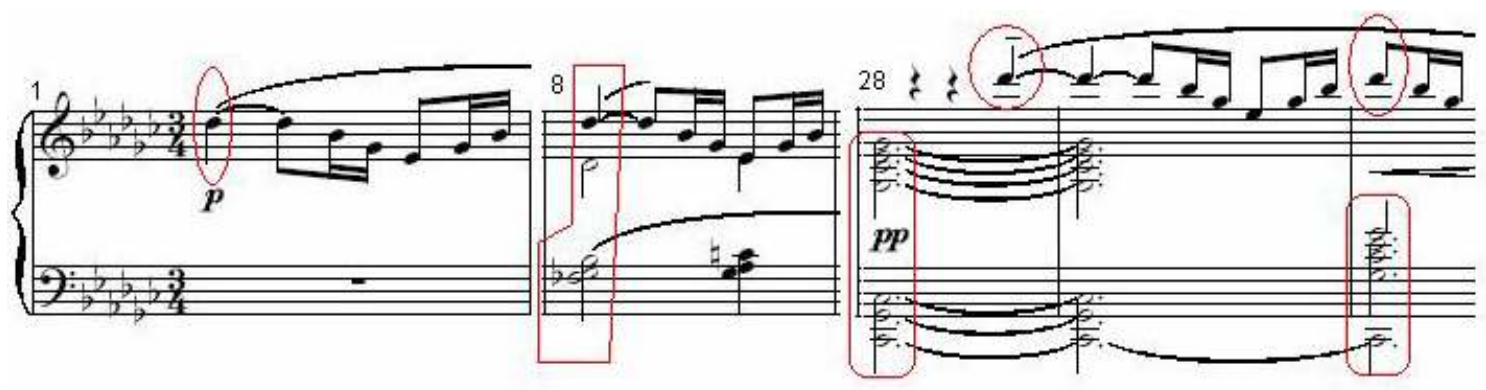

Exemplo 10-2: Debussy, La fille aux cheveux de lin, compassos 1, 8 e 28. Diferentes pesos harmônicos adquiridos pela nota $D b$. 
O mesmo tipo de alteração na 'luminosidade' pode ser observado em Le vent dans la plaine. De saída, é apresentada uma figura em sextinas que será reiterada durante a obra (vide comp. 1 do Ex. 11-2), esta figura contém duas classes de alturas: $B b$ e $C b$. Após um corte súbito interrompendo o fluxo de sextinas, esse grupo reaparecerá (compasso 13) transposto uma oitava abaixo. A movimentação rítmica permanece igual, porém há a substituição do $B b$ pelo $B b b$ (comp. 15), conferindo, assim, uma nova luminosidade à esse grupo sonoro.

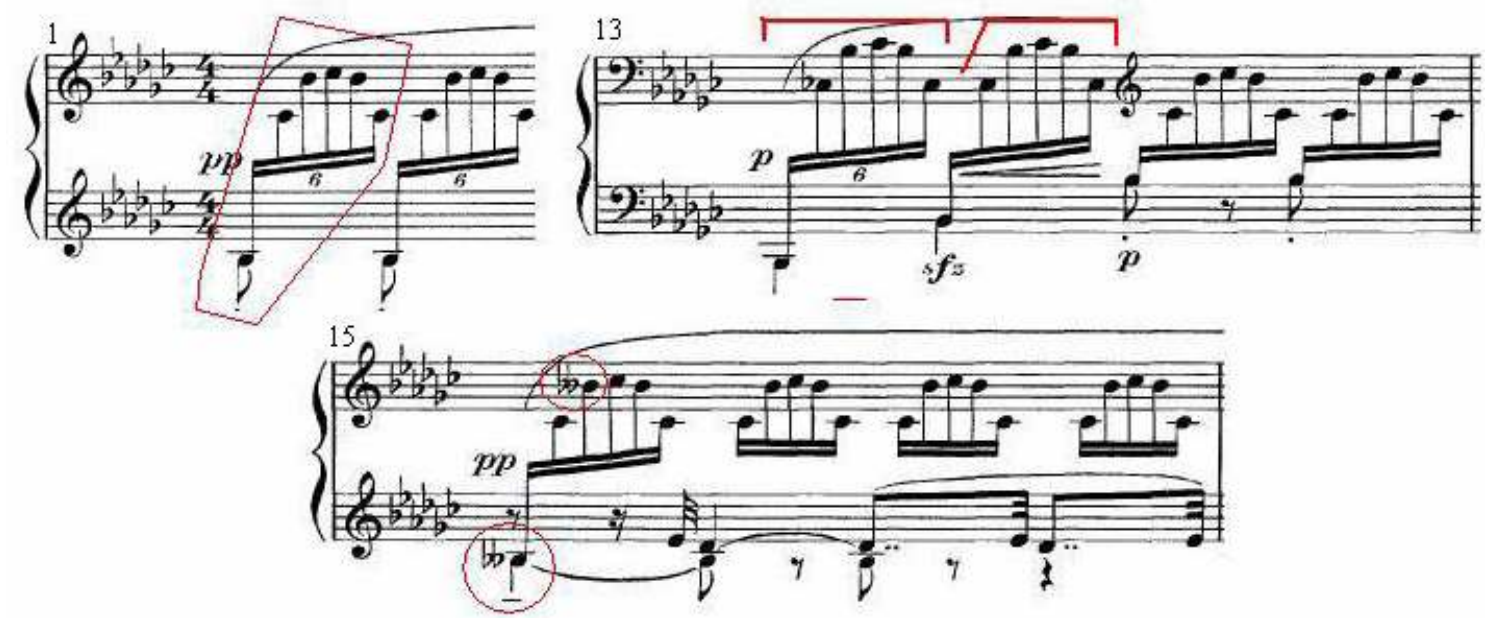

Exemplo 11-2: Debussy, Le vent dans la plaine. Compassos 1, 13 e 15.

Embora possua uma polarização da nota $B b$, esta peça não pode ser considerada tonal, pois vários são os procedimentos não tradicionais empregados, como acordes sem terça, acordes desfuncionalizados e movimentação cromática, entre outros. Da mesma maneira que o Prelúdio $n^{\circ} .1$ de Bach, há a figuração rítmica como elemento unificador apresentada desde o início (sextinas de semicolcheia) e reiterado praticamente por toda a música - possivelmente uma idéia pictórica conotando o movimento do vento, mas antes disso, associada ao comentado aspecto do impressionismo enquanto fluxo continuado. A estrutura deste motivo de acompanhamento já impede alusões tonais, posto que é composta do intervalo de semitom $B b-C b$ separado por sétima maior (vide Ex. 12-2). Esse motivo rítmico principal é modificado em altura para adequar-se às novas regiões harmônicas e impingir-lhe uma nova luminosidade; no entanto, a célula rítmica permanece inalterada. (Essas modificações de alturas da figuração rítmica podem ser observadas nos exemplos seguintes: passando de $B b-$ $C b$ para $B b b-C b$ no compasso 15, Ex. 11-2. A subtração do intervalo de sétima entre semitons no compasso 22, Ex. 12-2. Uso do intervalo de quinta justa a partir do compasso 31 , Ex. 15-2).

Destaca-se do plano de fundo em sextinas um material temático composto de quatro notas (Ex. 12-2, assinalado na clave inferior), lembrando o uso da escala pentatônica feito por 
Debussy em outras obras. O tema é também alterado para adaptar-se a novas propostas harmônicas, sendo transposto ou ligeiramente alterado (por exemplo, compassos 19 e 20, transposição um tom acima na frase que encera a primeira parte da obra, ver Ex. 14-2).
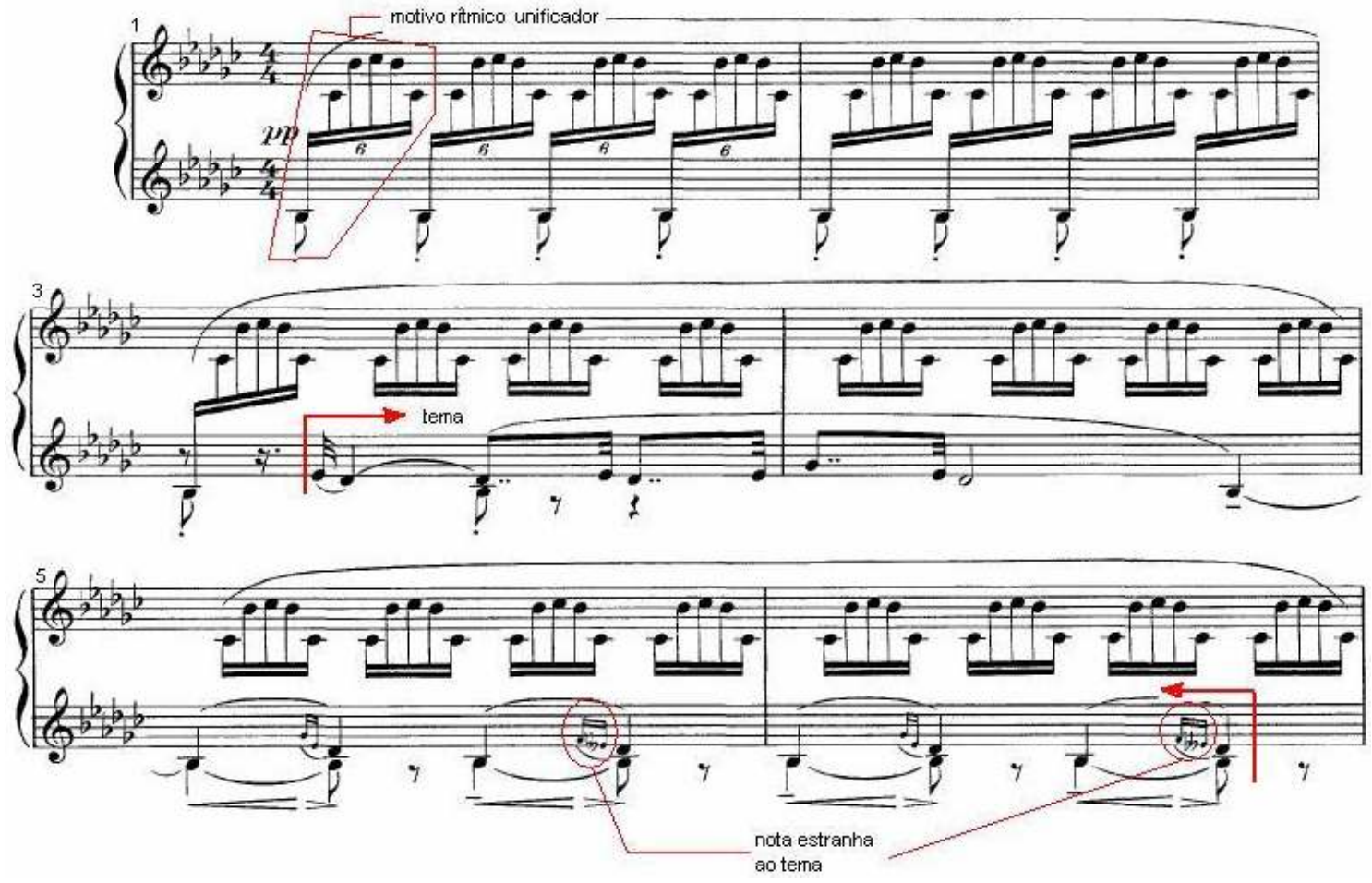

Exemplo 12-2: Debussy, Le vent dans la plaine, compassos 1-6, motivo rítmico principal, e tema.

Opondo-se ao fluxo rítmico intermitente, há a ocorrência de cortes súbitos (compasso 9 Exemplo 13-2) que rompem a movimentação de sextinas alterando-as para colcheias. Embora no corte exista um forte contraste com o ritmo inicial, a unidade sonora é conservada pelo uso de agregados harmônicos construídos com notas extraídas do tema. Nestes agregados, somente a nota $C$ não se fazia presente no tema inicial (vide Exemplo 13-2).

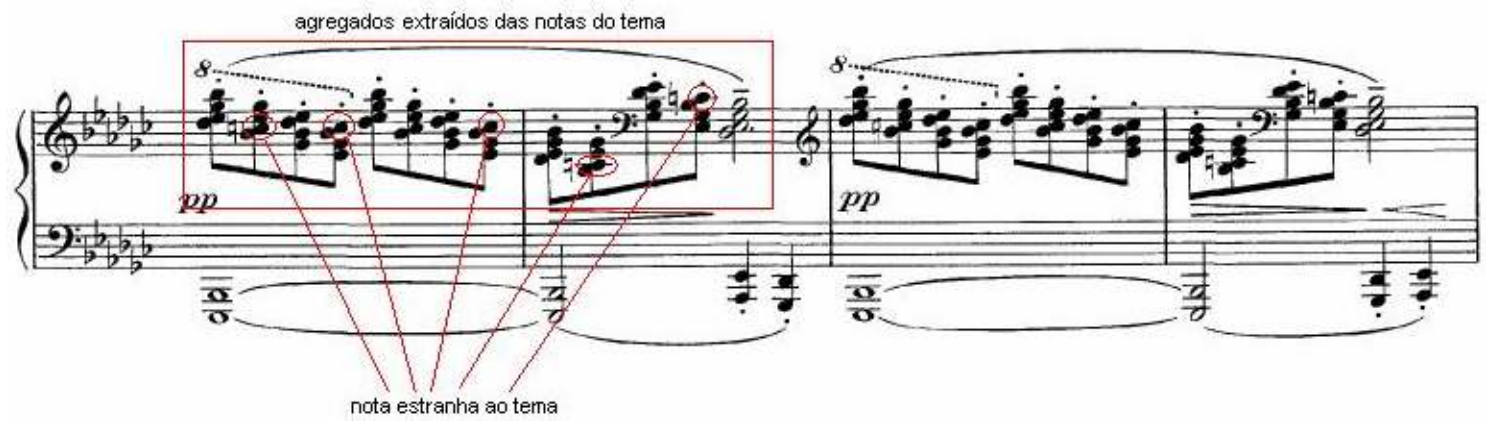

Ex. 13-2: Debussy, Le vent dans la plaine, compassos 9-10, corte, agregados harmônicos extraídos das notas do tema e acréscimo de nota estranha aos agregados. 
Como comentado sobre a dissolução funcional, há na segunda parte da obra o uso destes materiais destituídos de função tonal, como por exemplo a seqüência de acordes $\mathrm{Dm} / \mathrm{F}$ - $G / B-D m / F-D b$ (compasso 21$)$. O uso de agregados sem terça ou com terça implícita: $G$, $D b, F$ (compassos 22 e 24) no qual a nota $B$ do motivo rítmico implicaria em uma acorde de $G$ com quinta abaixada. Da mesma maneira que a nota $C \#$ implica no acorde de $A 7$ no compasso 24 (vide Ex. 14-2). Há ainda o agregado não repertoriado $A b, D, G b$ (compasso 25) que não permite, ou ao menos problematiza, sua classificação por sobreposição de terças, ao lado da movimentação de intervalos de quintas (compassos 22-27).
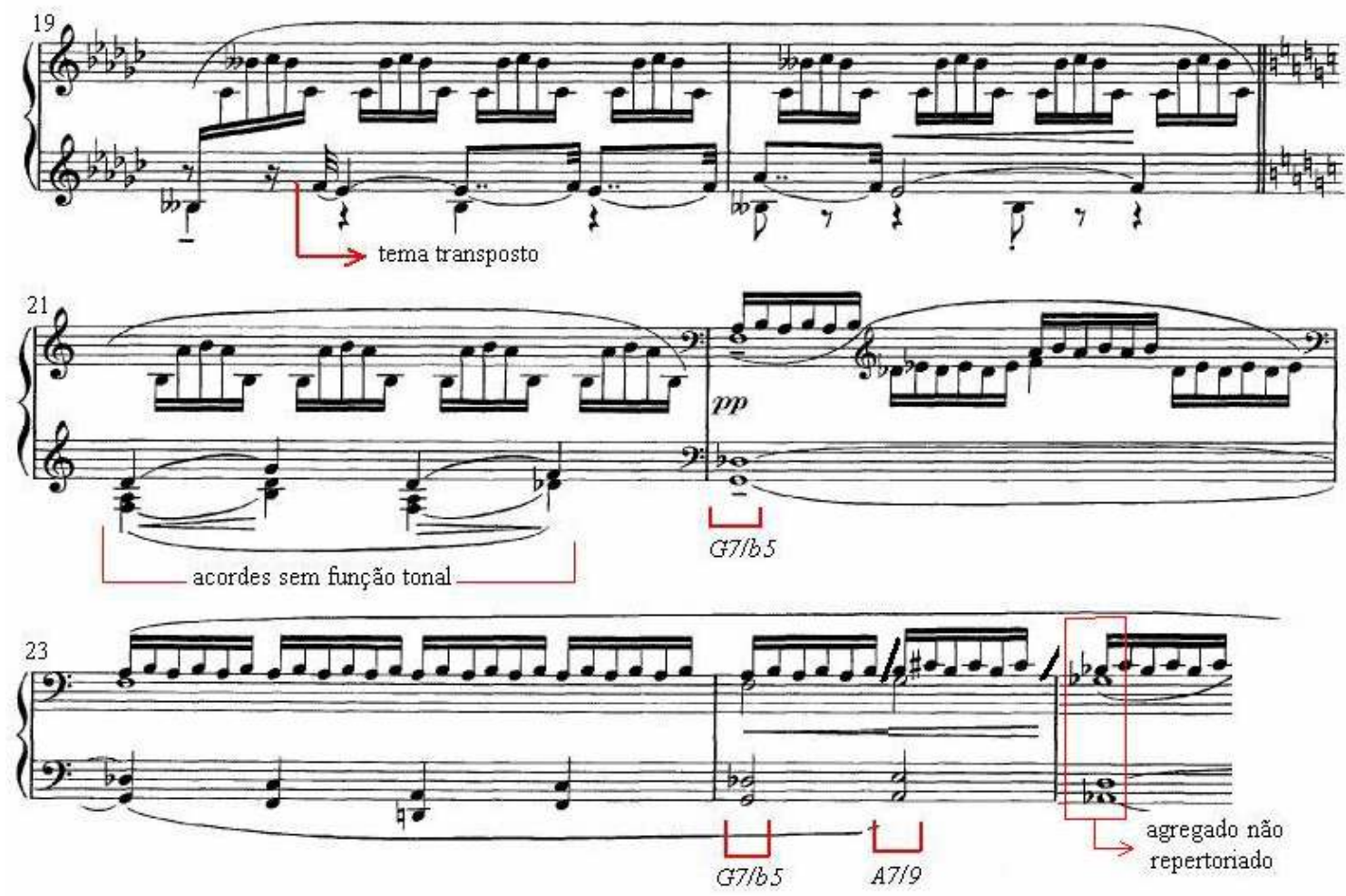

Ex. 14-2: Debussy, Le vent dans la plaine, compassos 19-25, tema transposto, acordes sem função tonal, acordes implícitos, agregado não repertoriado.

Na seção central da peça (compasso 28) há o retorno da armadura de clave inicial, permitindo neste ponto a consideração de um pólo em $G b$, já que este acorde aparece sempre em tempo forte e com maior duração. Todavia, a sucessão de acordes que se segue impinge ambigüidade à passagem. Contudo é possível perceber que a sucessão é direcionada para o compasso 34 onde ocorre uma espécie de recapitulação transposta dos materiais rítmico e temático iniciais. Toda a sucessão, iniciada a partir do compasso 28 até 34, pode ser descrita em:

$|G b| G b-F b m-D b-F b m|G b-B b b| G b|G b-F b m-D b-F b m| G-B|G \#|$

Note-se, que o movimento do baixo desta mesma sucessão sugere a tríade de $\mathrm{Gbm}$, pois a tríade de $\mathrm{Fbm}$ possui baixo em $\mathrm{Bbb}$. Assim, atentando somente para a condução do 
baixo nos compassos 29-31 temos: $|G b-B b b-D b-B b b| G b-B b b|G b|$. Esta seqüência, acrescida dos dois últimos acordes $(G$ e $B)$, conduz à região de $G \#$ indicando a relação por terças usada por Debussy, isto é, o trânsito por relações mediânticas (Exemplo 15-2).
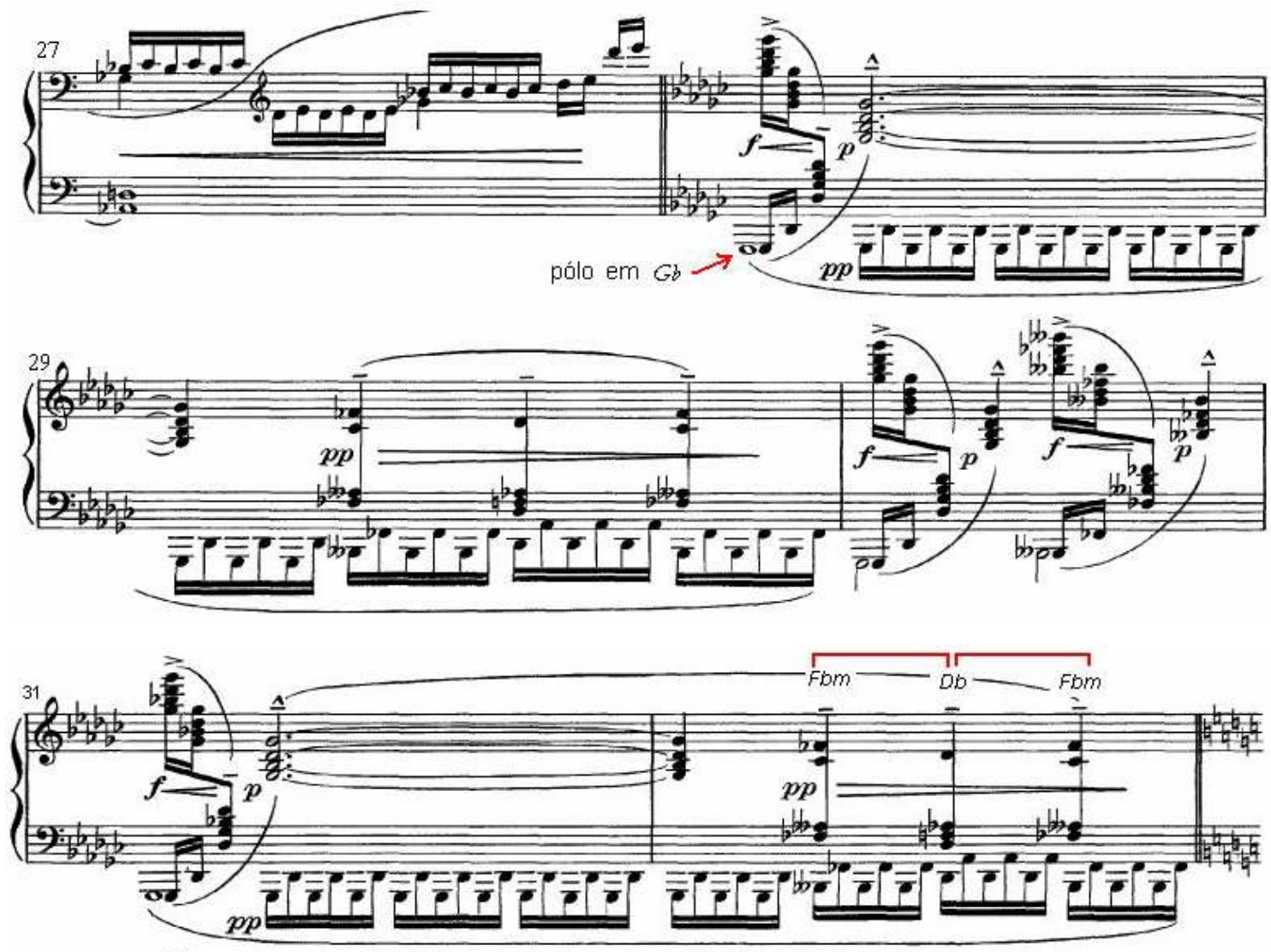

Gb

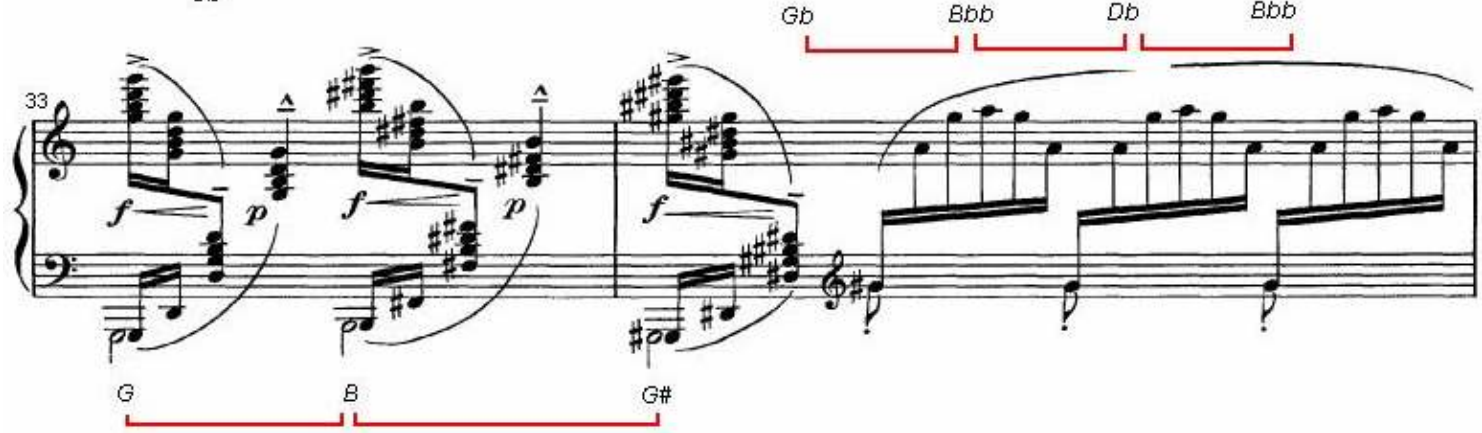

Ex. 15-2: Debussy, Le vent dans la plaine, compassos 27-34, pólo em $G b$ e relações mediânticas.

Após recapitulação do material inicial em $G \#$ a movimentação cromática é intensificada (a partir do compasso 38, não mostrado no exemplo). Há recapitulação do tema na região de $E$ e novamente a movimentação cromática até o retorno (compasso 44) dos materiais originais conforme expostos na parte inicial da obra. Esta re-exposição final é acrescida de novos elementos (vide Exemplo 16-2), como uso de pedal e sucessão cromática de tríades $(C b-C-D b-D)$. Essa recapitulação modificada pela incorporação de novos materiais está em sintonia com a idéia de fluxo contínuo característica do impressionismo. 


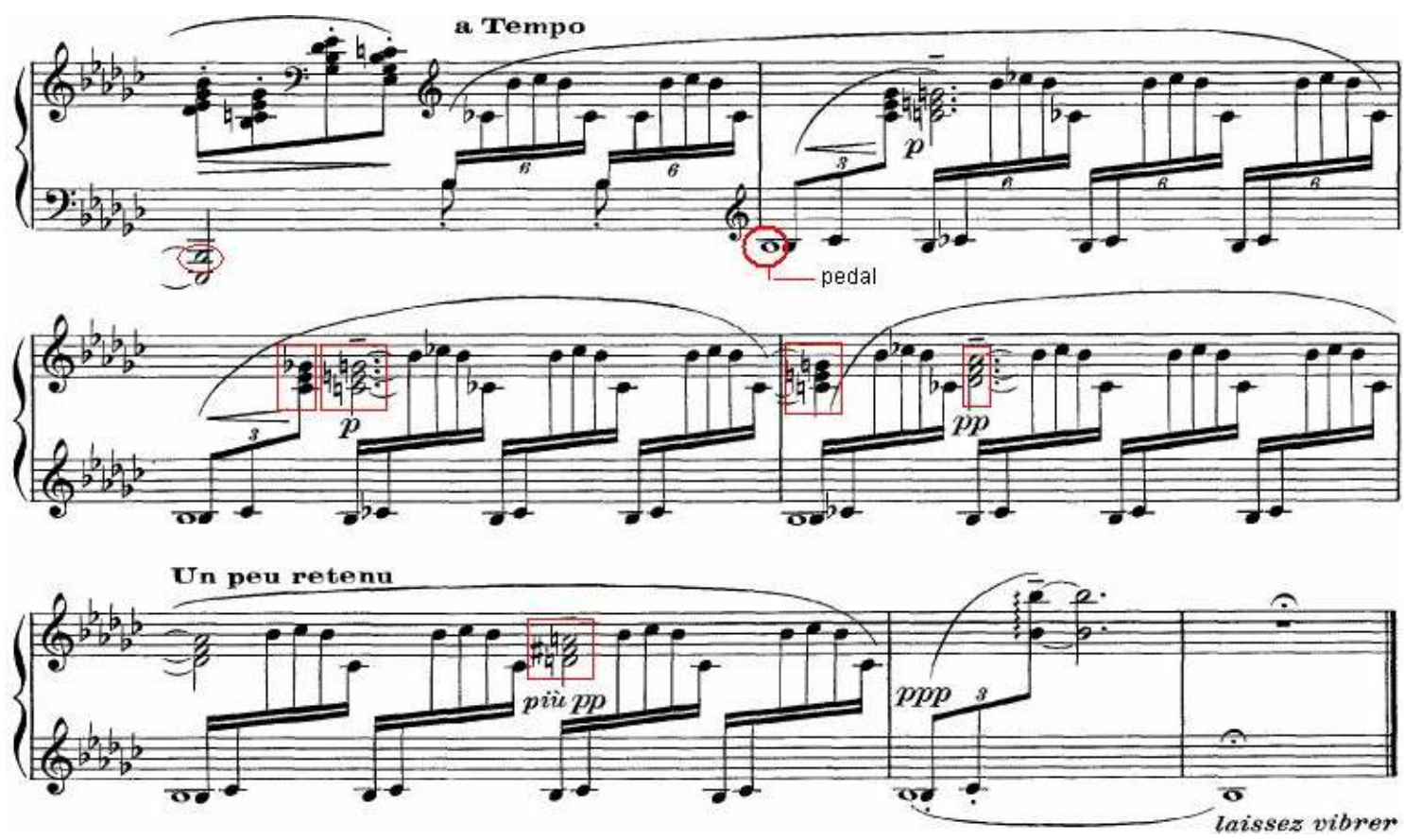

Ex. 16-2: Debussy, Le vent dans la plaine, compassos 53-59, pedal, sucessão cromática de acordes.

$\mathrm{Na}$ ausência da harmonia tonal, a atribuição da primazia a uma dada nota em relação às demais, de modo que esta venha a se configurar como espécie de pólo, deve ser feita mediante alguns critérios. Em Le vent poder-se-ia tomar dentre esses parâmetros a reiteração, o destaque rítmico e posição métrica que determinadas notas adquirem no discurso musical. Esses parâmetros, dentre outros, foram classificados por Parks (1989) como meios de consecução tonal em Debussy. Como em Debussy a tonalidade não é conseguida por métodos tradicionais como harmonia e condução melódica, Parks nomeou os artifícios indutores da percepção tonal levando em conta o meio com o qual a tonalidade foi imposta. Esses meios são descritos como ênfase quantitativa, invariância, ênfase qualitativa, linearidade e ênfase implícita.

No prelúdio Le vent dans la plaine a simples repetição não faz com que a nota $B b$ revista-se enquanto pólo tônico, mesmo porque nos 8 primeiros compassos na díade $B b-C b$ (usada no grupo reiterado de sextinas) a nota $C b$ aparece um número maior de vezes. Contudo, a posição métrica da nota $B b$, recaindo sempre em tempos fortes do compasso, determina sua primazia em relação ao $C b$. Destacam-se, assim, dois meios de ênfase quantitativa: reiteração e acentuação.

$\mathrm{Na}$ ênfase qualitativa, grupo ou grupos de alturas destacam-se por meio da disposição e do contexto. La fille au cheveux de lin, por exemplo, introduz de saída um material melódico iniciado no arpejo $D b-B b-G b-E b$ que é o arpejo do acorde de $E b m 7$ (vide Exemplo 10-2, compasso 1). Contudo, como as notas limites, inicial e final, da melodia são $D b$, esta 
acaba por adquirir proeminência em relação às demais, fato que permitiria classificá-la enquanto pólo tonal. Todavia, nesta peça em particular Debussy mostra maestria e sensibilidade não só por compor uma peça tão sublime, mas também pela maneira com que gera e conduz as expectativas perceptuais. Isto se dá, sobretudo, pela ambigüidade criada entre os discursos melódico e harmônico. $\mathrm{O}$ acorde arpejado é de $E b m 7$, a nota em destaque (pela ênfase qualitativa) é $D b$, contudo, esta será harmonizada no final da frase com o acorde de $G b$, atingido por movimento cadencial plagal $(C b-G b)$. Estes procedimentos concorrem para a dissolução da percepção de um único centro tonal.

De modo sumarizado, as seguintes estruturas gerativas do prelúdio de Debussy podem ser elencadas: motivo rítmico reiterado; tema em pentatônica; corte; agregados acórdicos extraídos das notas do tema; acréscimos de notas estranhas ao tema e aos acordes; uso de cromatismos e efeitos de tonicização; acordes desfuncionalizados. O processo construtivo compreende um fluxo contínuo por entre regiões harmônicas sem relações próximas, por onde um material temático baseado na escala pentatônica é conduzido e às vezes transposto; algumas conexões baseadas em relações mediânticas; movimentação rítmica como elemento unificador, relacionamento acórdico no lugar do funcional. Estes processos associados a outros recursos encontrados em Debussy, como a movimentação paralela de acordes e a extensão tonal por meio da incorporação aos acordes de notas consideradas estranhas pela harmonia tonal, foram empregados de modo a elaborar a composição a seguir (vide Exemplo 17-2), demonstrando mais uma vez a operação de derivações de elementos a partir da análise e seu uso posterior para a criação de outra obra. 

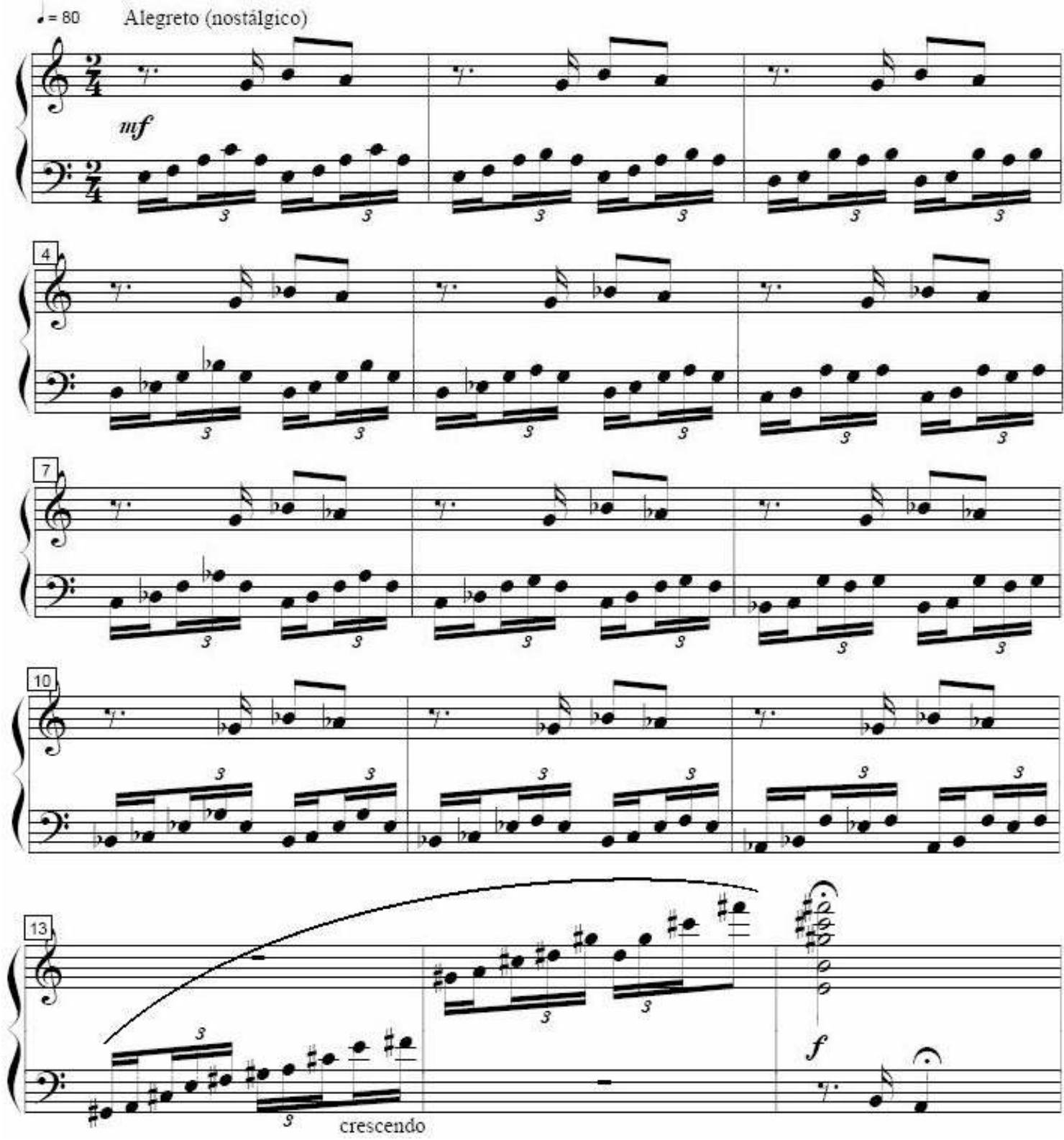

Ex. 17-2: Antenor Ferreira, Impressão sol poente, compassos 1 - 15.

Diferentemente do funcional, no relacionamento acórdico as conexões ocorrem a partir da movimentação linear de entidade para entidade envolvidas na passagem em questão. $\mathrm{O}$ cromatismo, ao invés do ciclo das quintas, é o agente de integração desse artifício, já que a condução acórdica não implica a primazia de algum pólo de atração. Os Prelúdios de números 2 e 4 do opus 28 de Chopin são exemplos do relacionamento acórdico, cuja movimentação é majoritariamente cromática. No Exemplo 18-2 é mostrada uma progressão baseada no relacionamento acórdico. Trata-se de uma sucessão iniciada em um acorde de $F$ com sétima no baixo cuja concatenação é realizada, predominantemente, por meio de cromatismos, fazendo com que o senso tonal, isto é, a indução para um pólo de atração, seja enfraquecido. 
Nota-se também que as harmonias usadas não pertencem exclusivamente ao campo harmônico de $F$, este é estendido pelo acréscimo de acordes de outras regiões tonais, expansão facilitada no relacionamento acórdico, pois se dá diretamente, sem haver necessidade de acordes pivôs ou confirmações cadenciais típicas de relações funcionais.
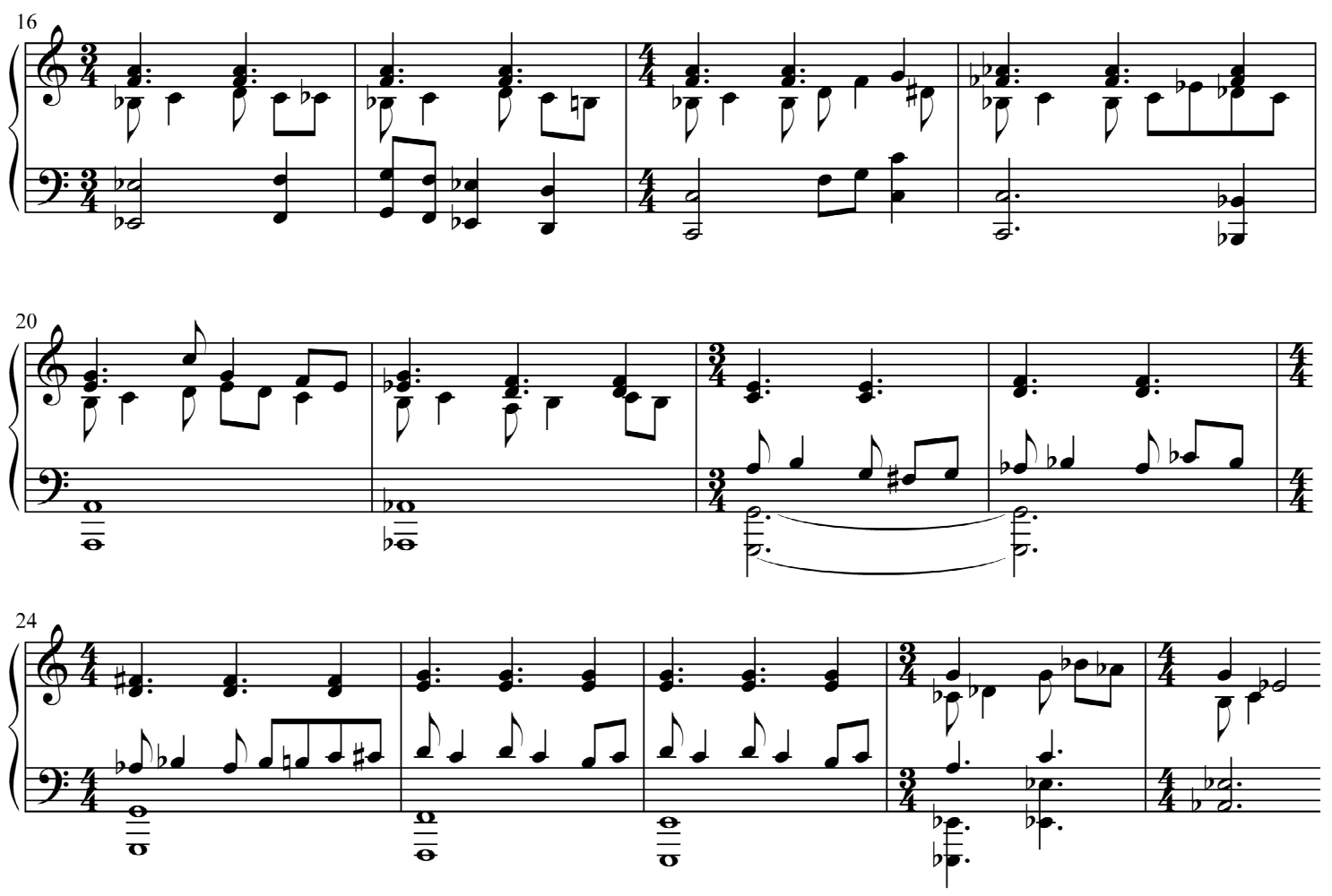

Exemplo 18-2: Camargo Guarnieri, Sonata N. 3 para Cello e Piano, II Movimento, Compassos 16-28 (parte do piano). Relacionamento acórdico.

Novamente, tendo por ponto de partida a análise de segunda ordem, é possível reproduzir esse processo composicional, empregando o uso da relação acórdica. Mostra-se no Exemplo 19-2 como uma harmonia inicial é expandida de modo a não guardar vínculos com algum pólo de atração nem denotar um campo harmônico exclusivo - embora os acordes possam ser analisados por superposição de terças. Há um fluxo contínuo, iniciado no primeiro compasso com o acorde de Em, que perpassa integralmente a composição, concluindo com o retorno desse acorde ao final da obra. Somente nesse momento, então, torna-se possível vislumbrar em retrospecto a direcionalidade implícita nesse fluxo. Os acordes usados podem ser classificados no sistema tonal por meio da sobreposição de terças, todavia, a maneira destes se conectarem não é funcional, mas sim por meio de uma relação de proximidade. Nesta peça há a inserção de novos elementos motívicos constituindo camadas entre as duas mais externas inferidas da análise. A primeira camada aparece no registro intermediário desde o primeiro compasso (grupo de semicolcheias) e o segundo estrato surge no registro agudo a 
partir do compasso 9. Essa idéia da composição em camadas será discutida com mais detalhes no próximo capítulo, todavia já é aqui introduzida demonstrando antecipadamente o assunto e exemplificando como os procedimentos deduzidos da análise musical podem ser estendidos no processo composicional com a associação de novas estruturas gerativas (vide Ex. 19-2).
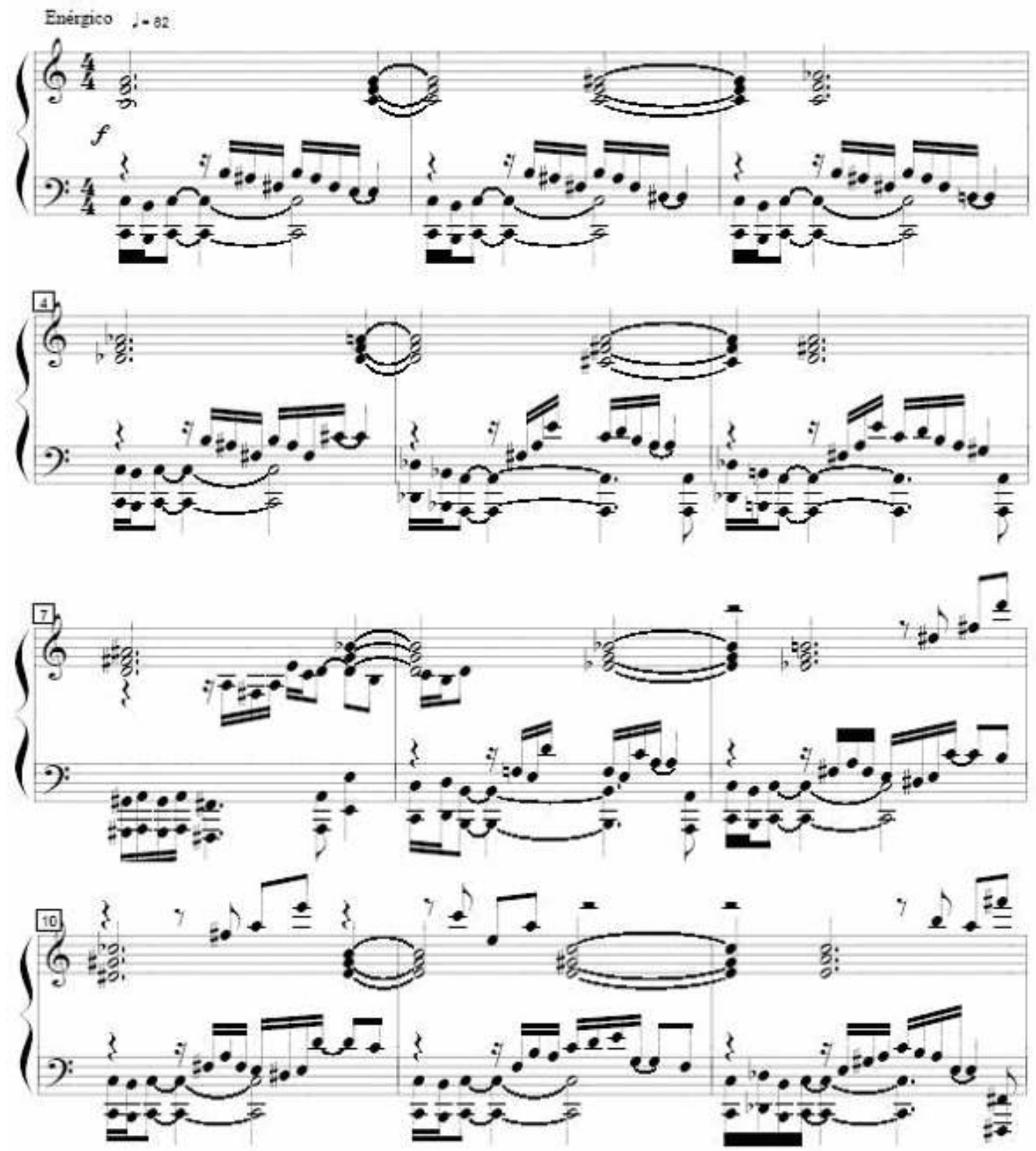

Exemplo 19-2: Antenor Ferreira, Prelúdio N. 3 (compassos 1-12).

A partir, principalmente, do pós-romantismo, o relacionamento funcional foi gradualmente substituído pelo acórdico. Não era o interesse principal dos compositores manter vínculos com um único pólo tonal, mas sim, expandir o discurso harmônico por regiões inusitadas, explorando tonalidades cada vez mais afastadas do ponto de partida. Em 
médio prazo, esta tendência conduziria à fragmentação do sistema tonal e impulsionaria o engendramento de diversos artifícios composicionais, como pandiatonicismo; tonalidades expandida, suspensa e flutuante; atonalidade e pantonalidade ${ }^{9}$; entre outros. Essa situação demandaria a criação de outras proposições analíticas para explicar as relações existentes entre as entidades acórdicas, pois estas não mais comportavam explicações nos modelos teóricos vigentes. Uma questão a ser considerada seria, por exemplo, que princípio de base permite a articulação entre entidades acórdicas ou aglomerados sonoros envolvidos no discurso musical pós-tonal? Qual a lógica, ou psicológica, subjacente a essas progressões?

Sobre esse estado de coisas, Dahlhaus verifica que:

Na Música Nova do século XX, a idéia de processo harmônico foi universalmente degradada em favor da noção de sistema harmônico, mas sem abolir a relação dialética existente entre sistema e processo. A variação de ênfase é tão claramente aparente no dodecafonismo de Schoenberg e, mais especialmente, Webern quanto é nos métodos de camadas ou de estratificação desenvolvidos por Stravinsky. (Dahlhaus, 1990, p.69).

Processo é definido como o conjunto de atos por meio dos quais se realiza uma operação qualquer. Trata-se de uma seqüência contínua de fatos apresentando certa unidade ou que se reproduzem (desenvolvem) com certa regularidade. Assim, o discurso harmônico, enquanto desenvolvimento continuado, consistir-se-ia de um conjunto de etapas ordenadas com um objetivo a ser atingido: a consecução tonal. O que equivale a afirmar que o discurso tonal é teleologicamente orientado. Além disso, compreendido historicamente, isto é, no conjunto seqüencial do pensamento musical, a harmonia deixa transparecer a concomitância entre o pensamento de época (Zeitgeist) e as modificações ocorridas no decurso temporal. A passagem de um estágio para outro (por exemplo, no acolhimento de dissonâncias ou no uso funcional renovado) é entendida linearmente e não de forma intercalada e abrupta. Esse percurso teve no cromatismo seu principal elemento dinâmico, expressivo, integrador e impulsionador. Enquanto forma processual, a harmonia ao compor o caráter teleológico do discurso musical também abarca os contrastes ocorridos neste caminho. A forma sonata é um exemplo disso, cujo parâmetro impulsionador é o pensamento dialético, opondo no tempo regiões tonais contrastantes e vale-se do desenvolvimento temático para expandir o alcance dessas regiões. Neste entendimento, admitindo-se a idéia de forma sonata configurada em tese-antítese-síntese, caberia à harmonia a fundamentação desta proposta, já que disporia no tempo apresentação, contraste e reexposição sintetizada das regiões tonais. Esse dinamismo,

\footnotetext{
${ }^{9}$ Sobre uma conceituação mais detida sobre esses procedimentos ver Estruturações Harmônicas Pós-tonais (2006), Capítulo 5 ou Poliônimo In: Revista Opus 11 (2005).
} 
no entanto, está ausente no dodecafonismo e no serialismo ${ }^{10}$ (esse assunto será retomado no Capítulo 4).

Essa condição processual, no entanto, foi substituída pela noção mais perene e atemporal de sistema de interações ${ }^{11}$, isto é, um conjunto de elementos interconectados por atributos quaisquer. Em um sistema, a multiplicidade de conhecimentos, ou reunião de princípios, é coordenada e articulada segundo uma idéia de totalidade, não havendo uma direcionalidade implícita, pois os componentes do sistema, em tese, não subentendem entre si uma orientação do tipo causa e efeito.

O dinamismo próprio do sistema tonal, implícito na resolução de tensões pelos movimentos de sensível, é suprimido nos sistemas não hierárquicos como o serial, no qual as doze notas da gama temperada são similares no que se refere a primazias funcionais. No discurso pós-tonal, de modo geral, a propensão dinâmica dos cromatismos é nivelada, anulando a expectativa gerada pela resolução dessas tensões cromáticas. Dahlhaus aponta que isto é válido tanto para Stravinsky quanto para Schoenberg, pois:

Enquanto a tensão interna do que nós chamamos de harmonia estática stravinskyana é devida a esse elemento dinâmico suprimido, a harmonia de Schoenberg (como a sistematização da técnica dodecafônica pode ser interpretada) é conseqüência (...) do cromatismo do Tristão, e representa, similarmente, um fenômeno de neutralização. A conexão entre acordes, em que um segundo acorde apresenta as notas da escala cromática ausentes no primeiro, está baseada no princípio da complementaridade - a adição de partes para compor um todo (Dahlhaus, 1990, p.69).

É necessário, todavia, amenizar essa afirmação, já que a argumentação de Dahlhaus tem como base a neutralização do cromatismo enquanto elemento dinâmico no fluxo musical. E de fato, considerado somente pelo ponto de vista da harmonia, dá-se a supressão da direcionalidade pois não existe a orientação harmônica funcional, já que a oposição entre tônica e dominante queda-se ausente. Não há essa hierarquia na harmonia de Stravinsky e muitas vezes esses acordes acontecem simultaneamente. Porém, em suas músicas é notória a presença de um discurso teleológico, e ele próprio afirmava ser a música uma sucessão de impulsos em direção a um ponto de repouso. Todavia, essa orientação dava-se pela direcionalidade implícita nas frases melódicas e pela retomada e conexão de blocos anteriormente justapostos (tópico discutido no Capítulo 3). Similarmente, Schoenberg fazia uso de formas tradicionais em suas peças, como a forma sonata, por exemplo, o que também indica a organização funcional e teleológica do discurso musical. Dahlhaus acrescenta ser difícil identificar o momento em que esse aspecto dinâmico do movimento de sensível, que

\footnotetext{
${ }^{10}$ É sabido que a forma sonata foi usado pelos compositores ligados ao dodecafonismo. Todavia, as objeções feitas por Dahlhaus referem-se aos aspectos estruturais, e não aos dialéticos, como esclarece a citação anterior. ${ }^{11} \mathrm{O}$ acorde-centro de Scriabin (também chamado de acorde místico) é um exemplo deste tipo de pensamento harmônico (veja adiante).
} 
dominou inicialmente esse tipo de harmonia processual e objetiva (no que diz respeito à existência de um conjunto de regras guiando a condução harmônica), foi relegado em favor de relações acórdicas complementares subjetivas (baseado nas sonoridades peculiares dos agregados acórdicos). "O cromatismo dinâmico-processivo é substituído por uma complementaridade estática-estrutural tais como as existentes entre as notas ou complexo de notas de uma série dodecafônica: complementaridade cuja característica estética essencial é poder, em princípio, ser revertida no tempo" (idem, p.70). A possibilidade desta reversão no tempo deve-se justamente ao comentado caráter não teleológico, isto é, ao fato de que não há uma direcionalidade implícita nos agregados acórdicos não tonais como há na harmonia tonal. Essa articulação via complementaridade será demonstrada nos exemplos a seguir.

Fazendo uso de uma de suas formações arquetípicas ${ }^{12}$ (Exemplo 20-2, arquétipo de $3^{\text {a }}$ e $7^{\mathrm{a}}$ ), Webern apresenta três agregados sonoros (clave de sol) que juntos compõe-se de nove notas do total cromático. As três notas ausentes são articuladas na voz mais grave (clave de fá), completando o total cromático. No Exemplo 21-2, mostra-se que determinadas coleções sonoras também apresentam essa relação de complementaridade, uma escala octatônica é complementada pelas notas do acorde diminuto, ou seja, as notas não presentes na escala octatônica formam um acorde diminuto. Uma melodia construída com uma escala pentatônica pode ser harmonizada por agregados pandiatônicos construídos com as notas da escala diatônica, que são as sonoridades complementares da escala pentatônica. Percebe-se, então, que diferentemente da teoria funcional, na qual os acordes distinguiam e relacionavam-se pelas funções harmônicas desempenhadas, nas concepções sistêmicas (sobretudo após a emancipação da dissonância e conseqüente neutralização do dinamismo implícito no cromatismo) as relações passam a ser de complementaridade e não dialéticas (dialética no que se refere a um sentido de oposição, antítese), já que a formação posterior complementa a anterior ao invés de se opor funcionalmente.

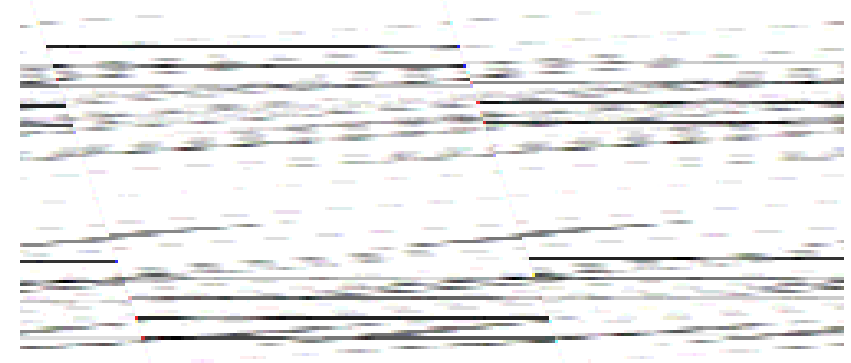

Exemplo 20-2: Webern, Gleich und Gleich, Opus 12, no. 4, compasso 18.

\footnotetext{
${ }^{12}$ Sobre formações arquetípicas ver MENEZES, 2002, p.314. Sobre o arquétipo $3^{\mathrm{a}+7^{\mathrm{a}}}$ ver CORRÊA, 2006, p.64.
} 


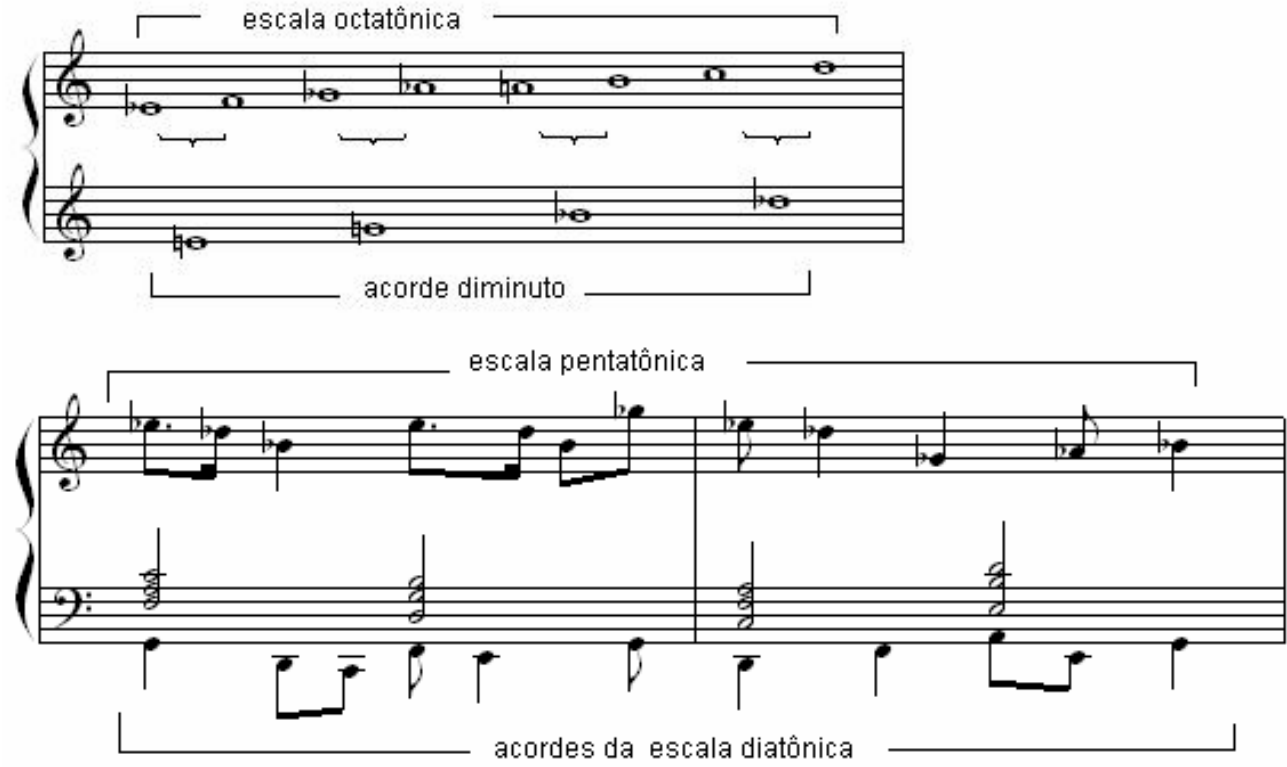

Exemplo 21-2: Sonoridades complementares: acorde diminuto complementa a escala octatônica e acordes pandiatônicos complementam a melodia construída na escala pentatônica.

Valendo-se do seu conhecido agregado sonoro formado pelas notas $C-F \#-B b-E-A-D$, Scriabin realiza um procedimento similar. Curiosamente, esse agregado sonoro é denominado de várias maneiras: acorde místico (termo atribuído por Arthur Eaglefield Hull, em 1916, ao que tudo indica, deduzido dos interesses teosóficos de Scriabin), acorde centro (Kangzentrums, cf: Dahlhaus, 1987, p.203), acorde tonalidade (teóricos franceses), acorde de Prometheu (por ser o conjunto de notas utilizado para gerar as harmonias da obra Prometeu: Poema do Fogo de Scriabin - termo cunhado por Leonid Sabaneyev). Não obstante, esse conjunto também é entendido como agregado ou acorde sintético. Um acorde sintético é construído empregando as notas de uma escala sintética - aquela que não pode ser enquadrada nas escalas e modos convencionais. Lidas na disposição escalar mais próxima, o conjunto das notas do acorde centro ficaria: $C-D-E-F \#-A-B b$. Diversos autores (por exemplo, DALHAUS, 1990, p.204) sugerem que essa formação trata-se de um acorde de sétima da dominante (C-E$B b$ ) acrescido de nona $(D)$ e décima terceira $(A)$; o $F \#$ é explicado como quinta abaixada ou como décima primeira aumentada. O próprio Scriabin não concebia esse grupo de notas de maneira rígida e fixa, mas por várias vezes alterava ou variava essa formação. Em sua Sonata $O p$. 64 modifica o grupo para $C-F \#-B b-E-A-D b$, inclusive Vincent Persichetti construiu o que chamou de escala prometeu napolitana, realizando essa mesma modificação da nota $D$ para $D b$ (variação que pode ser observada no segundo compasso do exemplo a seguir). Intitulações à parte, o agregado de Scriabin fornece uma matriz geradora melódica e harmônica para exemplificar o procedimento de complementaridade. 
Scriabin utiliza as notas dessa matriz para construir entidades acórdicas, podendo empregar todas as seis notas ou uma parte dela. Porém, o importante é que as várias derivações são feitas a partir desse grupo matriz. Quaisquer combinações simultâneas ou subconjuntos podem ocorrer, sejam estas compostas de três, quatro, cinco ou seis notas, tendo qualquer destas notas como 'fundamental'. Esse processo faz com que o acorde-centro tornese uma das estruturas gerativas da composição, fornecendo tanto seu conteúdo harmônico quanto motívico. Dahlhaus comenta que "o acorde centro forma a substância da textura musical, a partir do qual todos os motivos melódicos, na forma de acordes quebrados, são derivados" (DAHLHAUS, 1990, p.204). Geralmente ocorre que quando determinadas notas do acorde-centro são usadas, as notas ausentes serão empregadas posteriormente de modo a complementar essa matriz estrutural. Esse uso não precisa necessariamente obedecer a uma ordem determinada, já que as notas do grupo de base não possuem uma funcionalidade implícita, podendo seguir ou ser seguidas de qualquer outra nota ou grupo de notas da matriz. No exemplo seguinte (Ex. 22-2), é possível notar que o acorde-centro de Scriabin, agregado inicial do primeiro compasso (indicado como conjunto 6-34), constitui-se como estrutura predominante na peça. Esse conjunto inicial é gradativamente variado de modo a dar lugar às novas formações acórdicas encampando as sonoridades complementares, no entanto, é evidente sua importância estrutural como matriz geradora de novas entidades. Observe-se que os motivos melódicos no registro mais agudo são, geralmente, sub-conjuntos da formação principal.

Essa é então a principal diferença entre as formas processual e sistêmica. Aquela implicando em uma orientação direcional, enquanto nesta a estruturação teleológica (própria da harmonia funcional) é subtraída. É possível notar que Dahlhaus não acreditava no retorno da forma processual. Em contrapartida, admitia a possibilidade dos novos complexos acórdicos serem compreendidos intelectual e perceptualmente, resgatando, assim, possíveis relações implicativas, numa espécie de direcionalidade do tipo causa e efeito:

Certamente, se desejamos fazer justiça estética ao complexo de técnicas de superposição na Sagração da Primavera (...), devemos não falhar ao apreciar que a neutralização da funcionalidade tonal dos acordes não deve ser entendida como determinada (um fato autocontido que nós temos que aceitar pelo que ele é), mas como um procedimento que pode ser compreendido. Quando uma tônica é mutilada funcionalmente por ter uma dominante colocada sobre ela, o ouvinte deve tornar-se consciente que isto é o resultado de um conflito e não apenas um fato mudo. (DAHLHAUS, 1990, p.69). 


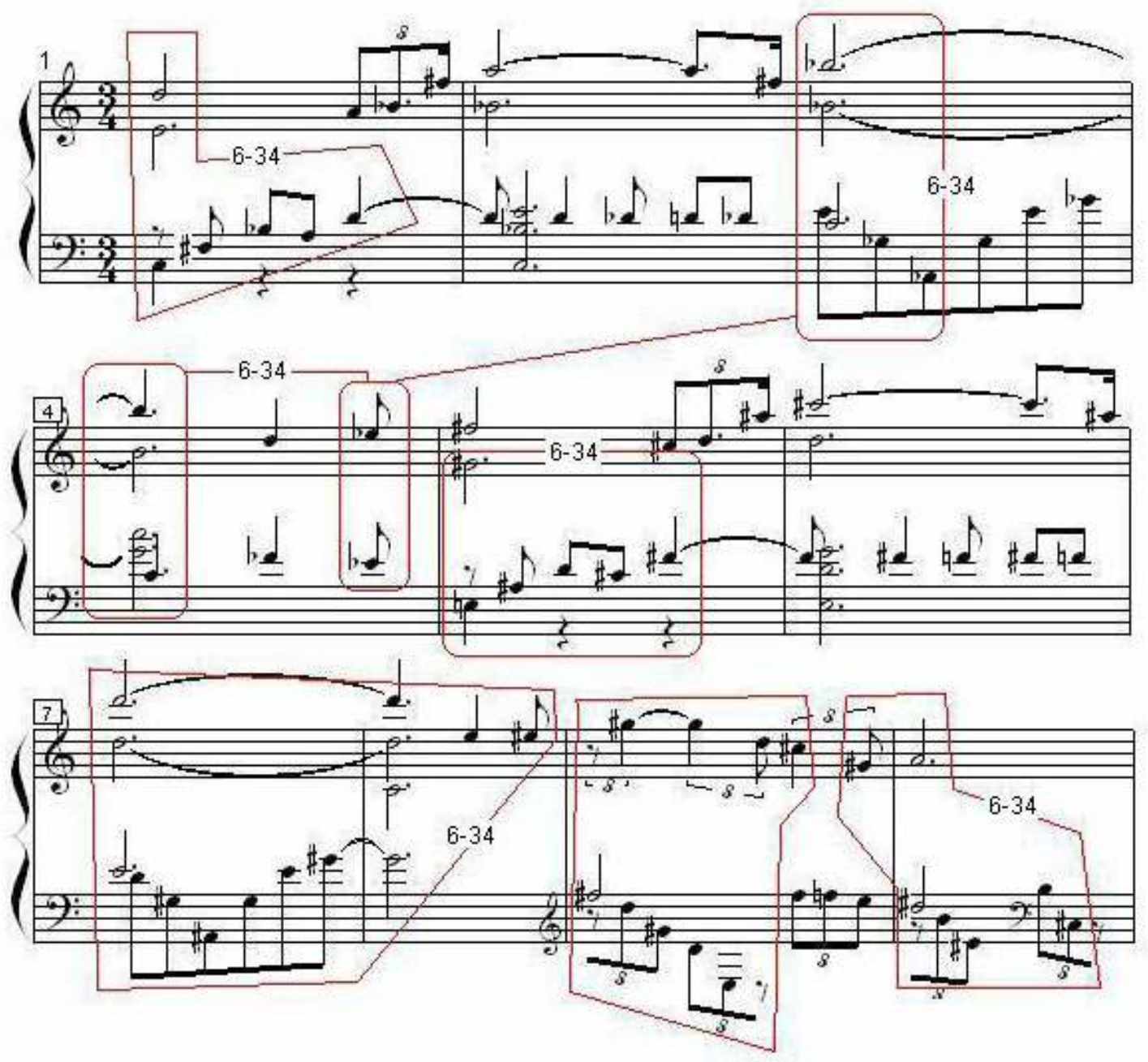

Exemplo 22-2: Scriabin, Two Poems, Opus 69, no. 1, compassos 1-10. Transformações graduais do acorde centro (conjunto 6-34, estrutura gerativa principal da obra) de modo a encampar as sonoridades complementares.

“A percepção de estímulos físicos como constituintes de um padrão ou de uma forma resulta da habilidade humana em relacionar as partes constituintes entre si de uma maneira inteligível e significativa” (MEYER, 1956, p.157). Para engendrar uma impressão formal uma ordem deve se estabelecida, na qual os estímulos individuais tornam-se parte de uma estrutura maior e realizem distintas funções dentro dessa estrutura. Os agregados usados por Stravinsky têm, segundo essa concepção, que ser entendidos de acordo com o contexto total da obra, e não apenas em relação ao agregado em si. Com isso tem-se que a interpretação de um acorde segundo a harmonia tradicional, indicando se o mesmo trata-se de uma tônica com uma dominante justaposta, não faz sentido, pois a funcionalidade de tal agregado foi subtraída. Contudo, segundo Meyer, por tratar-se de uma característica vital do comportamento humano, temos a tendência de interpretar eventos de uma maneira prognóstica ou ao menos probabilística, em termos de antecedente e conseqüente, causa e efeito, meios e fins. Uma 
seqüência temporal de eventos é particularmente susceptível a tais interpretações, resultando que determinados agregados ou complexos de acordes sejam entendidos no discurso musical mesmo na ausência de uma funcionalidade harmônica. Em geral, quanto mais semelhantes em tipo e próximos no espaço e no tempo estiverem dois eventos, e quanto mais freqüentemente eles forem experimentados em uma ordem particular, mais possivelmente o primeiro evento será entendido como implicando, ou como sendo signo, do segundo. Conseqüentemente, também serão interpretados como relacionados funcionalmente. "Se o estímulo não é percebido como sendo similar, então ele vai falhar em criar coesão ou em formar um grupo ou unidade, e será percebido como separado, isolado, e não significará nada” (MEYER, 1956, p.158). A reflexão sobre esse mecanismo implicativo e funcional presente no discurso musical será realizada mais detidamente nos Capítulos 5 e 6 .

\section{Conclusão}

O intuito deste capítulo foi promover uma reflexão sobre a proposta de análise de segunda ordem. A idéia da análise de segunda ordem foi apresentada por Dahlhaus como substituto das análises musicais de cunho meramente descritivo, chamadas por ele de tautológicas. Assim, na tentativa de dar um passo adiante, ele preconiza uma interpretação da análise. Optei por direcionar essa proposta para o campo composicional, embora de certo, existam outras abordagens e desdobramentos possíveis para a aplicação desse pensamento, utilizando-se da análise como auxiliar da interpretação ou mesmo enquanto base para formulação da crítica estética.

Pelo exposto durante esse capítulo, demonstrou-se que a análise de segunda ordem (a análise aprofundada e crítica dos dados musicais) permite desvendar o caráter subjacente à estrutura da obra musical, bem como os mecanismos de conexão e articulação inerentes aos elementos constitutivos desta obra. Desse modo, tendo como ponto de partida a análise musical, foi possível determinar as estruturas gerativas postas em jogo na obra musical e os processos construtivos que articulam, governam e gerenciam essas estruturas, conferindo-lhes sua forma final.

Em face desse entendimento, o processo analítico inicial pôde ser transferido para o plano composicional e permitiu ser refeito a posteriori, valendo-se da manutenção ou alteração dos componentes envolvidos. Dentre combinações e desdobramentos possíveis podem ser exemplificados: a manutenção de estruturas gerativas e modificação do processo construtivo; a manutenção do processo construtivo e substituição das estruturas gerativas; a transformação parcial desses parâmetros; o acréscimo de novas estruturas àquelas inferidas da análise, uso de inversões de estruturas ou dos processos construtivos. 
Desse modo, dá-se o primeiro passo para a comprovação da hipótese aqui perseguida, ou seja, a afirmação de que a análise musical pode servir de base para a consecução de um modelo de composição. Além disso, da maneira como exposta, também permite ser utilizada eventualmente como ponto de partida para uma pedagogia composicional, na qual procedimentos técnicos são desvelados e refeitos de modo criativo, e não simplesmente para se realizar uma cópia de um estilo característico, pois as estruturas gerativas e os processos construtivos deduzidos a partir de análises devem ser reconstruídos de modo renovado e diferenciado.

Tratou-se aqui de algumas abordagens analíticas. Todavia, há diversos outros pontos a serem contemplados pelas distintas ferramentas de análise. No plano formal, por exemplo, as propostas de estratificação e de justaposição podem servir de suporte para esse engendramento. Este assunto será tratado no capítulo seguinte. 
Capítulo 3

ESTRATIFICAÇÃO E JUSTAPOSIÇÃO 


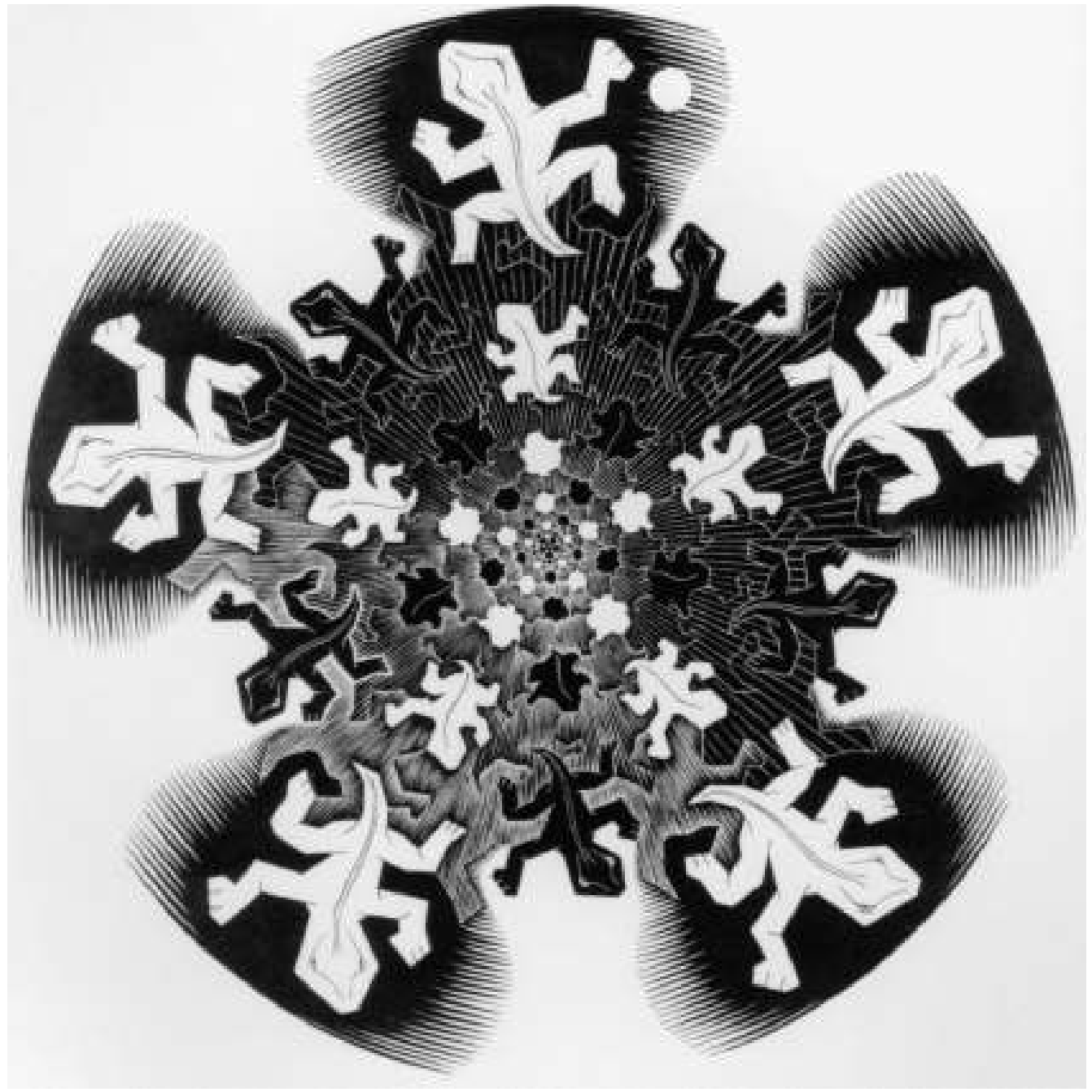

Maurits Escher: Development II (1939, primeira versão, xilogravura) 


\section{Introdução: O princípio da estratificação de Edward Cone}

No ano de 1962 deu-se a primeira edição de uma das mais prestigiosas revistas sobre música: Perspectives of New Music. Neste número inaugural constava o ensaio "Stravinsky: the progress of a method" de autoria do grande teórico norte-americano Edward T. Cone (1917-2004). Esse trabalho receberia nova publicação dez anos depois, na coletânea de artigos Perspectives on Schoenberg and Stravinsky (1972, p. 155-164), editada por Benjamin Boretz e pelo próprio Cone ${ }^{13}$. Foi neste ensaio que Cone apresentou pela primeira vez seu conceito de estratificação como recurso para a análise das obras de Stravinsky.

Estratificação, segundo Cone, é o processo composicional empregado por Stravinsky na maioria de suas obras, e consiste em uma espécie de construção em camadas ou áreas musicais justapostas no tempo. Essas camadas são separadas por rupturas no fluxo discursivo, sofrendo uma espécie de "editoração", sendo novamente "emendadas" na parte subseqüente desse método, batizada por Cone de conexão. Esse processo possui uma terceira parte na qual todos os estratos apresentados no decurso musical são unificados, conduzindo a obra à sua resolução. Esta última fase foi chamada de síntese e constitui-se como a parte do método responsável pela coerência estrutural da obra. Cone apresentou seu modelo tendo por base a análise de fragmentos de três obras de Stravinsky: Sinfonias para Instrumentos de Sopros, Serenata em A (para piano solo) e Sinfonia dos Salmos.

Para além da proposta original e conteúdo apresentados no trabalho de Cone, este texto é um marco da nova abordagem metodológica que se instituía na musicologia norteamericana dessa época. Esta nova maneira analítica instaurou a atitude positivista no tratamento das obras musicais e influenciou toda geração de teóricos ligados ou não à música de vanguarda. As repercussões dos artigos da Perspectives of New Music, juntamente com o recém inaugurado Journal of Music Theory (vinculado à universidade de Yale), são até hoje motivo de considerações em trabalhos históricos, teóricos e musicológicos. Anthony Gritten, por exemplo, considera que "a análise de Cone da Sinfonias para instrumentos de sopro apresentada no Progress of a Method foi, retrospectivamente, o momento pivô no desenvolvimento da teoria musical e da análise na América do pós-guerra" (GRITTEN, 1998, p.4). Outrossim, Kerman, no capítulo Análise, Teoria e Música Nova do seu famoso livro Musicologia (1987), ofereceu uma descrição panorâmica, mas aprofundada desse momento especial vivido pela musicologia norte americana.

O início do pensamento científico e a subseqüente tomada da análise musical como método investigativo, à maneira positivista, teve como elemento impulsionador a inauguração

\footnotetext{
${ }^{13}$ Realizei uma tradução integral do artigo original de Edward Cone (revisada pela professora Graziela Bortz) que foi publicada no periódico Música Hodie, Vol. 7, № 1, 2007.
} 
das duas revistas mencionadas, bem como o teor dos artigos que eram veiculados, sendo significativo para o momento não só aspectos musicais que assinalavam, mas principalmente, a maneira como a pesquisa era desenvolvida e os resultados expressos. Neste sentido, fica evidenciado o porquê da influência exercida pelo artigo de Cone sobre os teóricos norteamericanos, pois independentemente de se concordar com suas proposições analíticas para o confrontamento da obra de Stravinsky, o aspecto metodológico instaurado foi de tal monta que ainda hoje se faz presente no meio musicológico.

Por conta dessas características, o artigo de Cone permanece como valiosa fonte histórica e importante recurso analítico. Seus aspectos históricos lançam luz sobre um período de transição vivido pela musicologia norte-americana que encontraria também repercussão no plano internacional. Essa incorporação do pensamento positivista à música pode ser verificada atualmente. Basta para sua comprovação uma rápida apreciação dos métodos escolhidos para condução de trabalhos acadêmicos na área de música que intentam um transporte de metodologias das áreas exatas e sociais para o âmbito artístico e educacional. Discorrer a respeito dessa constatada importância histórica do artigo de Cone está além do escopo deste trabalho. Todavia, algumas características técnicas apresentadas por ele constituem uma boa opção para a análise de peças não só de Stravinsky, mas de quaisquer compositores que façam uso de procedimentos composicionais baseados em descontinuidade do discurso, rupturas súbitas do fluxo musical e métodos de bricolagem. Passo, então, a tecer considerações sobre alguns desses procedimentos técnicos e teóricos.

\section{Estratificação}

Chama a atenção, de saída, a terminologia empregada por Cone, sobretudo o próprio título do método: estratificação. Esse termo é normalmente entendido como a sobreposição de planos ou camadas, tendo surgido na geologia para designar a estrutura originada pela acumulação progressiva de qualquer material (rochosos, minerais, vulcânicos, arenosos, cristalinos, causado por precipitação química ou decantação, entre outros) tendendo a formar camadas definidas por descontinuidades físicas e/ou por passagens bruscas ou transicionais de mudanças de textura, estrutura ou quimismo. 


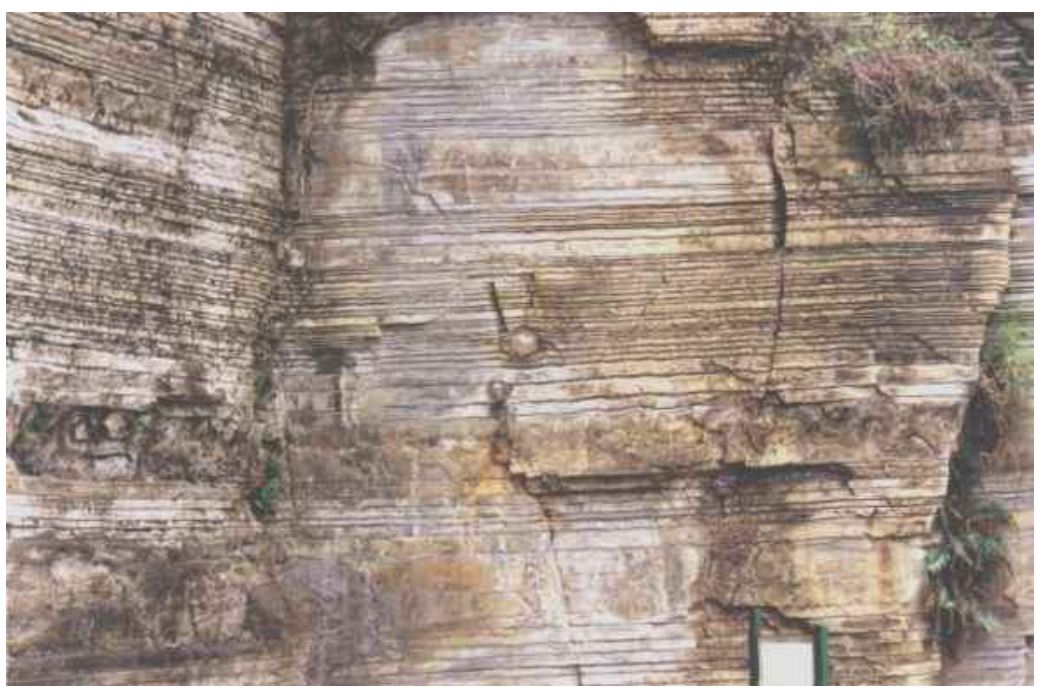

Figura 1-4: Estratificação peculiar encontrada em Itu (SP) denominada Varvito. Resulta do acúmulo de camadas alternadas constituídas de fino-siltito (lâmina clara) e siltito/argilito (lâmina escura).

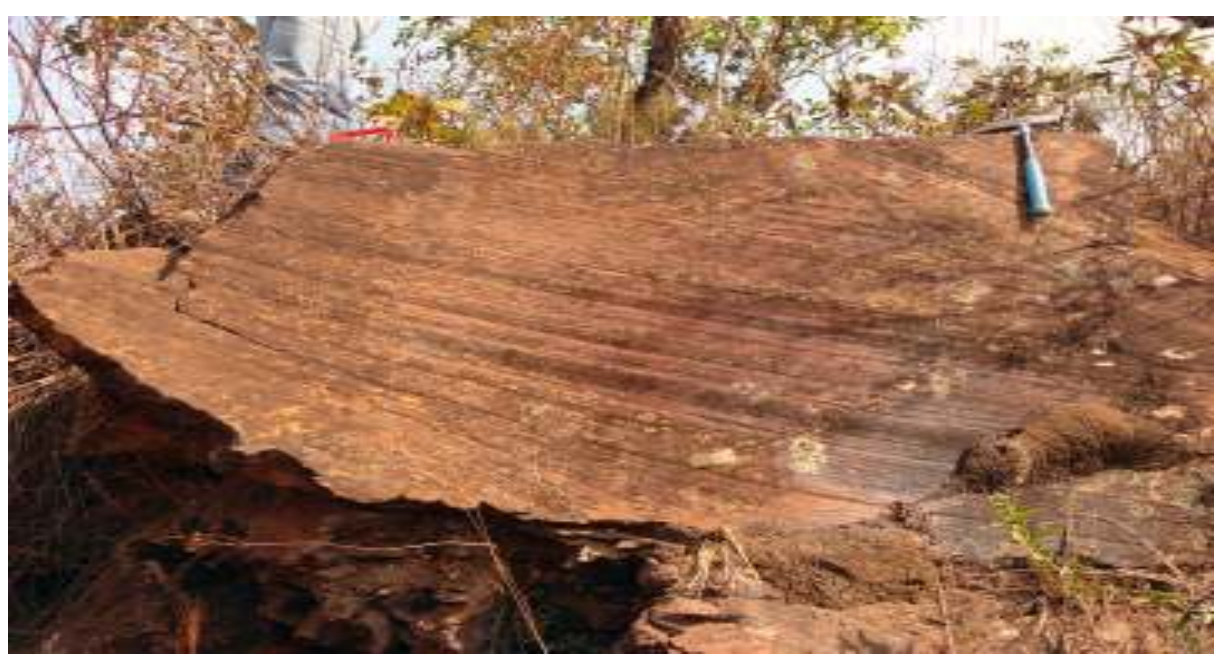

Figura 2-4: Estratificação cruzada em quartizito.

As ciências sociais importaram o termo para designar as diferentes classes sociais de determinadas culturas, ou meios socioeconômicos, fato comprovado na vasta literatura sobre estratificação social. Mas, Cone refere-se ao termo como a justaposição no tempo de blocos musicais. A condição para a identificação desses blocos é o corte, já que esses blocos normalmente são introduzidos de forma abrupta. Neste sentido, teríamos uma série de partes ou seções expostas linearmente, o que em última análise não constitui uma construção em camadas. A própria definição de justaposição é esclarecedora, implicando naquilo que é adjacente ou está em disposição lado a lado; o que é posto em contigüidade.

Com isso, as idéias de corte e justaposição trazem embutidas os conceitos de descontinuidade e disjunção. Inclusive na gramática, justaposição é um processo de formação 
de palavras pelo qual novas palavras são criadas pela junção de duas ou mais palavras já existentes. Duas formas de composição são possíveis, por justaposição e por aglutinação. A composição por aglutinação ocorre quando duas ou mais palavras se unem para formar uma nova palavra e ocorre alteração na forma ou na acentuação das palavras originais. Ex.: fidalgo (filho + de + algo), aguardente (água + ardente). A justaposição ocorre quando duas ou mais palavras se unem sem que ocorra alteração de suas formas ou acentuação primitivas. Ex: guarda-chuva, segunda-feira, passatempo.

O cineasta soviético Sergei Eisenstein (cujos métodos de montagem serão objetos de análise neste capítulo) chamava a atenção para o interessante fato de que conceitos abstratos podem ser criados pela justaposição de dois conceitos concretos. As figuras de linguagem são bons exemplos dessa constatação. As expressões, testa-de-ferro, perna-de-pau e espírito-deporco, para citar alguns exemplos, possuem sentidos semânticos distintos dos significados imediatos relacionados aos substantivos que compõem cada uma das expressões. Quando se usam figuras de linguagem semelhantes, seus significados devem ser interpretados posto tratarem de metáforas - "coração de pedra", por exemplo, pode referir-se a pessoa sem compaixão, inclemente.

A confusão inicial surgida com a adoção da nomenclatura proposta por Cone é esclarecida no modo como ele apresenta sua análise. Como ilustração, imagine-se, por exemplo, a seqüência de quadrados abaixo:
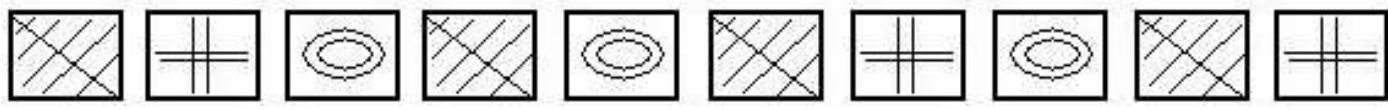

Em um rápido lançar de olhos, observa-se uma série de figuras justapostas, isto é, dispostas horizontalmente lado a lado. A repetição das figuras parece se dar de modo arbitrário. Porém se os mesmos quadrados forem dispostos verticalmente, além de uma construção em camadas, surgirá um possível padrão 'lógico': A-B-C - A-C - A-B-C - A-B. Padrão esse que rompe a série ternária $(\mathrm{A}-\mathrm{B}-\mathrm{C})$ pela inserção de grupos binários (A-B ou AC), como mostra a figura a seguir:

A
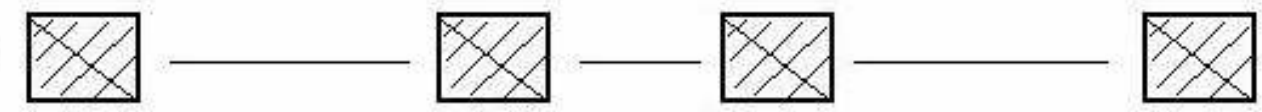

B
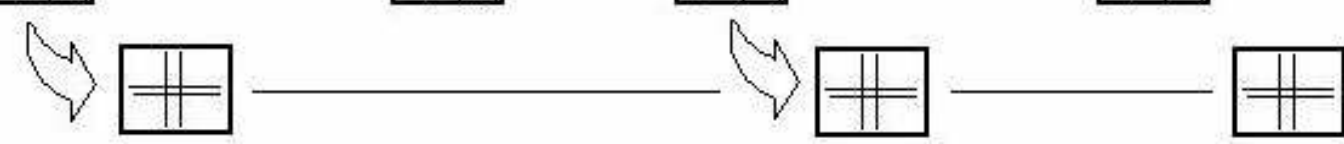

C
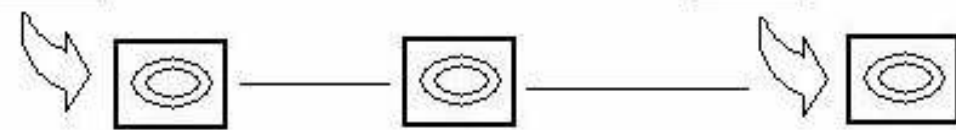
Uma disposição similar foi pensada por Cone para a música, que dispôs em camadas as seções ou blocos musicais antes justapostos, realizando, assim, a primeira parte do seu método chamada de estratificação.

A estratificação, como proposta por Cone, é a separação de idéias musicais, no espaço sonoro. Essas idéias encontram-se justapostas no contínuo musical, mas são representadas graficamente dispostas em camadas. Além disso, Cone sugere a possibilidade dessas camadas serem 'lidas' de maneira horizontal, ou seja, os blocos separados formariam sentido unificado quando tocados em seqüência. Por exemplo, imagine-se que as camadas $\mathbf{A}, \mathbf{B}$ e $\mathbf{C}$ da figura anterior sejam blocos musicais. Se esses blocos fossem tocados linearmente, isto é, só a camada $\mathbf{A}$, ou só o estrato $\mathbf{B}$, os mesmos conteriam um sentido lógico em si, como se formassem uma única parte musical (começo, meio e fim). Por isso, este tipo de estratificação implica em contrastes abruptos ou sutis gerados por mudanças de registro, instrumentação e na estruturação rítmica. Petrushka é uma das grandes obras de Stravinsky e, também, considerada por alguns teóricos como o protótipo de seu método de estratificação, nela é possível fazer uma abordagem preliminar de uma das maneiras como se dá esse processo.

$\mathrm{Na}$ Cena I de Petrushka, Stravinsky retrata quatro situações. A primeira delas, o início da obra (vide redução no Ex. 1-3), apresenta a Fête populaire de la semaine grasse (festa popular da Semana Santa) festejo mais conhecido como Carnaval. Similarmente, a tradução inglesa usa a palavra Shrovetide termo equivalente a Carnaval (do latim carne levare, adeus à carne). Essa festa seria a oportunidade de fartar-se dos prazeres da carne antes do período de abstinência de 40 dias. O intuito, então, dessa festa é celebrar o início da quaresma. A segunda situação, mostra um grupo de farristas bêbados que passam dançando (Ex. 2-3, correspondente ao número 5 do $\operatorname{score}^{14}$ ), toda essa atmosfera festiva e de comemoração é transmitida pela música pulsante de Stravinsky. Surge, na terceira situação, o Mestre de Cerimônias entretendo a multidão do alto de seu balcão (número 7 do score similar ao $\mathrm{n}^{\circ} 9$ mostrado no Ex. 3-3). Há uma curta recapitulação da música da primeira situação (vide Ex. 33, quatro compassos anteriores ao $\mathrm{N}^{0} .9$ de ensaio) que é abruptamente interrompida, retornando a música do Mestre de Cerimônias (número 9 do score). No próximo momento, quarta situação, um tocador de realejo aparece entre a multidão com uma dançarina. A música acompanha a cena, por meio de um corte súbito e da inserção de um novo bloco musical (Ex. 3-3, quatro compassos antes ao $\mathrm{N}^{\circ}$. 10 de ensaio). A seguir, novamente a música do Mestre de Cerimônias rompe abruptamente a atmosfera instaurada.

É fácil notar que a sucessão dos distintos blocos musicais é feita em relação direta com as ocorrências da cena. Quando uma nova situação ou personagem surge, a música é

\footnotetext{
${ }^{14}$ As indicações a seguir referem-se à partitura orquestral de Petrushka publicada pela Dover, 1988.
} 
imediatamente alterada para acompanhar e ressaltar a ação dramática. Esse princípio de integração entre música e cena não é novidade alguma, e pode, no mínimo, ser remetido às óperas do século XVII. Porém, sua absorção na técnica de Stravinsky funcionará como ponto de partida para a consolidação de seu método e posterior uso em obras abstratas, isto é, aquelas que não possuem contraparte extramusical.

O primeiro momento de Petrushka é instrumentado para flautas, clarinetes e trompas (Exemplo 1-3), com intervenções melódicas dos celli. Outros instrumentos são introduzidos gradualmente, gerando um crescendo de densidade, conservando um caráter de certa forma indefinido, principalmente pelo uso de trinados nos clarinetes e trompas, que não explicitam uma configuração harmônica em particular. Esse crescendo culmina no segundo momento cênico, com a entrada dos farristas bêbados (Ex. 2-3). Esse bloco contrapõe-se ao anterior pela mudança de textura (formando agora uma textura em uníssono, realizada pelo tutti orquestral que adensa uma linha melódica, resultando em um grande bloco harmônico), métrica (ternário anterior torna-se binário) e rítmica (as linhas diversificadas do primeiro momento são substituídas pela homorritmia).

O terceiro bloco surge na aparição do Mestre de Cerimônias. As transformações ocorrem na métrica, no andamento e caráter (neste momento mais agressivo e imponente). $\mathrm{O}$ grande tutti é reduzido após um esforçando sobre a nota $B b$ distribuindo a instrumentação para o acompanhamento de violinos e violas (díade $D-E$ ) com um pedal em $B b$ sustentado pelo fagote e trompa. O Exemplo 3-3 mostra essa mesma modificação cênico/musical em ponto mais avançado da peça, em que a instrumentação é um pouco diferente, contudo, são claras as diferenças entre os blocos musicais justapostos (ver a passagem do come prima para o número 9 de ensaio, sforzato sobre a nota $B b$ distribuída para trombone, tuba, tímpano, celli e baixos). O próximo momento cênico introduz o tocador de realejo e a dançarina. As mudanças são mais radicais, pois se dão em praticamente todos os parâmetros: caráter, andamento, ritmo, métrica, densidade, textura, instrumentação e, inclusive, gênero (Stravinsky introduz uma valsa, o que fez com que alguns teóricos entendessem essa passagem como citação ou intertextualidade).

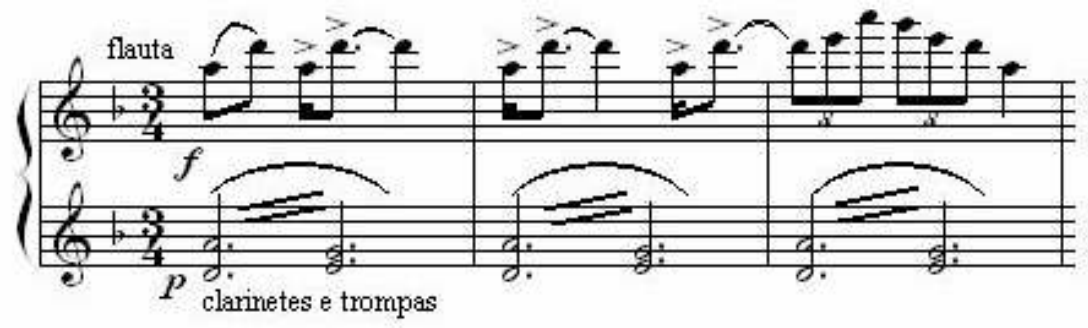

Exemplo 1-3: Stravinsky, Petrushka, Cena I, redução dos compassos 1-3. Início da peça. 


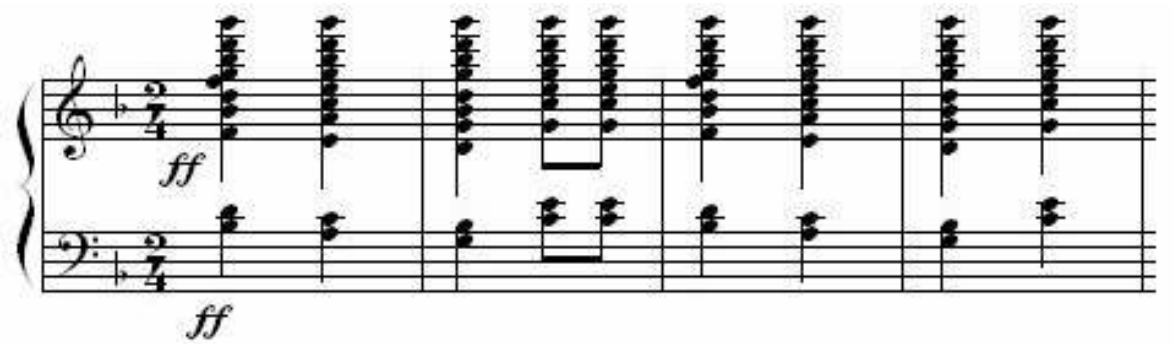

Exemplo 2-3: Stravinsky, Petrushka, Cena I, redução, número 5 de ensaio. Entrada dos farristas bêbados.

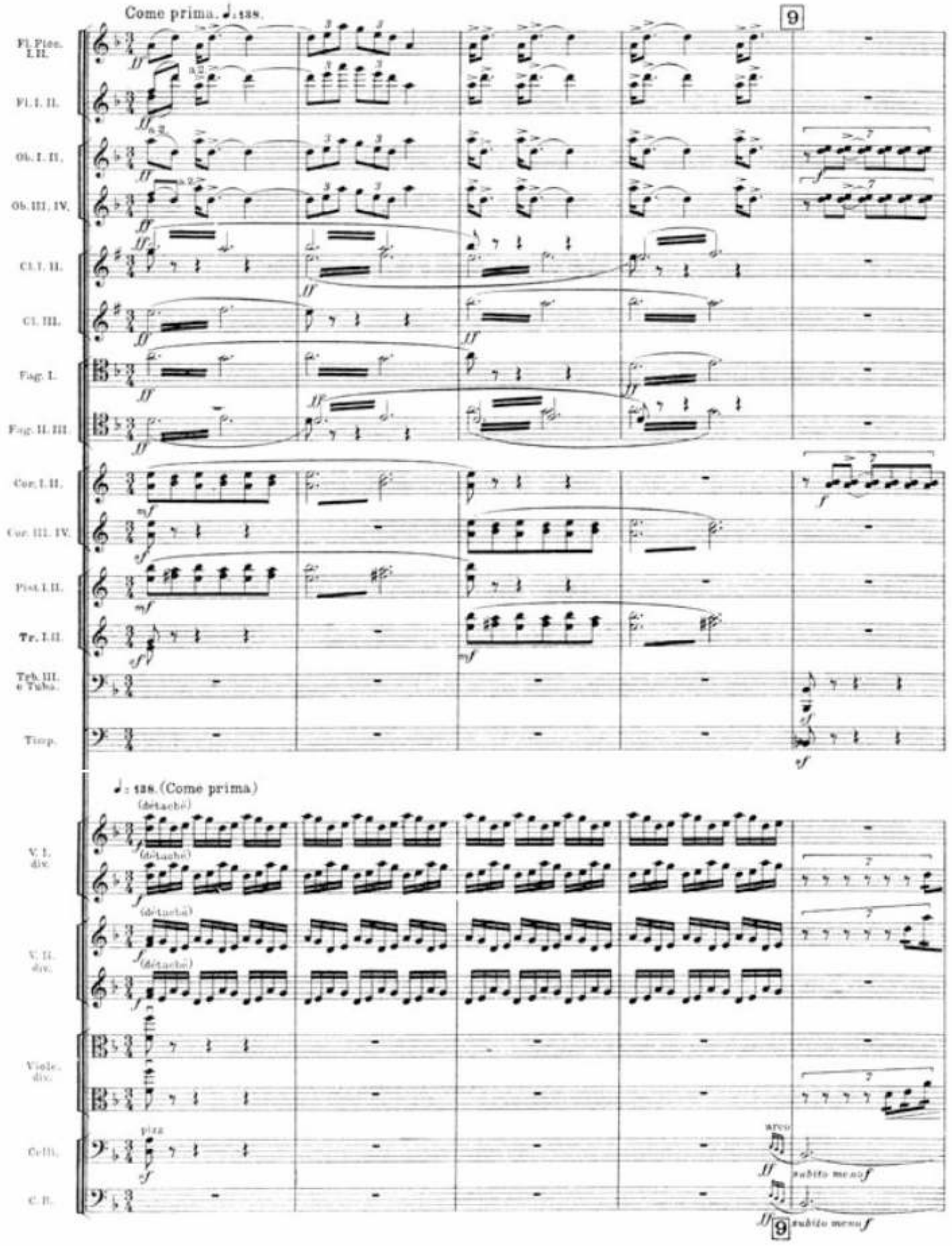



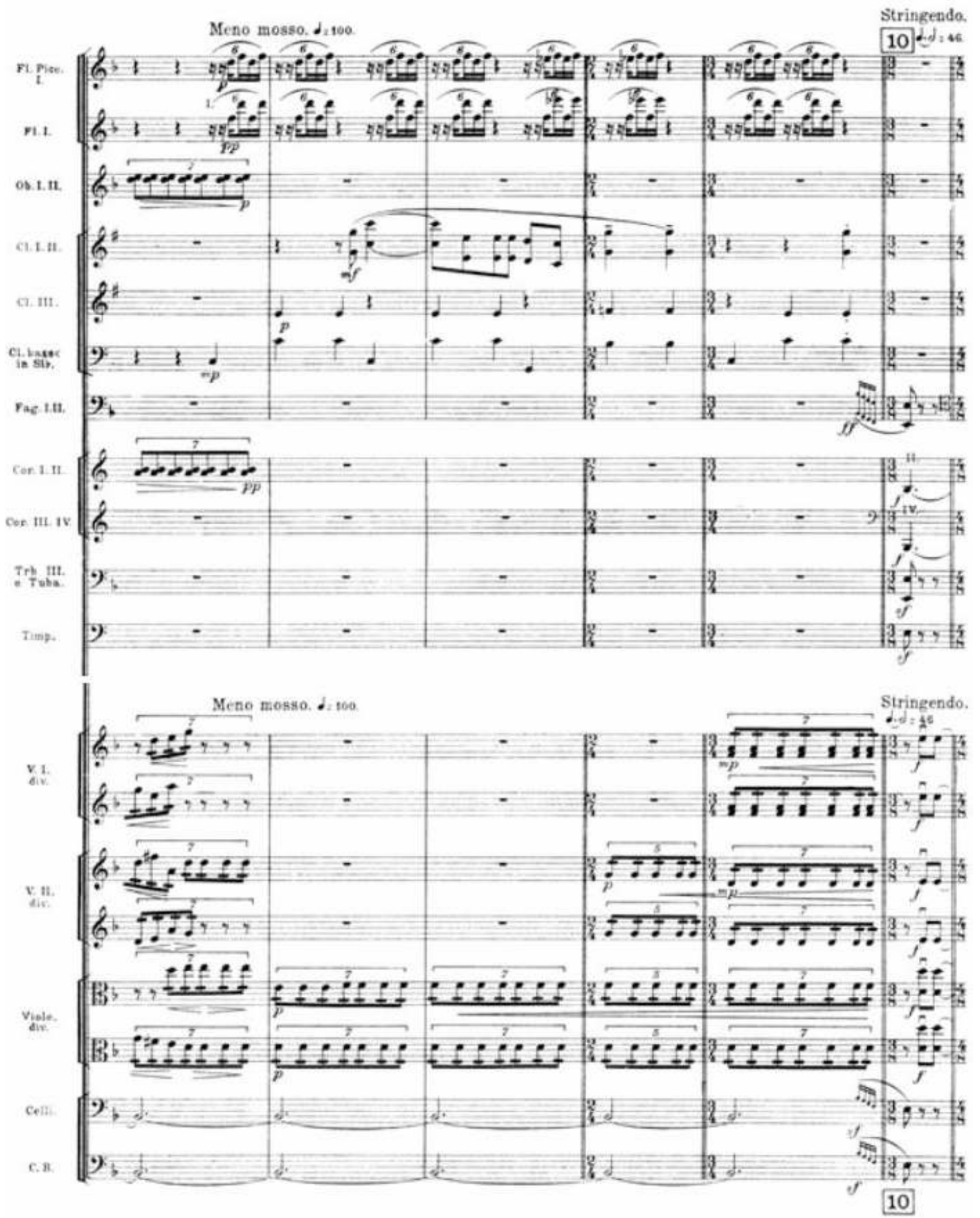

Exemplo 3-3: Stravinsky, Petrushka, Cena I (números de ensaio 8 - quatro compassos depois - 9 e 10), três blocos justapostos em acordo com as ações cênicas.

A justaposição dos blocos musicais no caso de Petrushka cumpre uma função de ambientação teatral, pois as mudanças na música são geradas em analogia às modificações cênicas. A originalidade do artigo de Cone foi justamente analisar como essa concepção permaneceu nas obras 'abstratas' de Stravinsky, ou seja, nas peças que não foram compostas para teatro ou balé. 
Todavia, há outras possibilidades de pensar o processo de estratificação. Uma dessas maneiras dá-se pelo engendramento de uma linha independente em meio a um dado contexto musical. Stravinsky usa muito desse procedimento em obras como A História do Soldado e Pulcinella, nas quais cria um ostinato no acompanhamento que neutraliza o fluxo tonal e desarticula a melodia de seu acompanhamento, "tornando a música estática ao invés de progressiva" (STRAUS, 1990, p.58). No exemplo seguinte (Ex. 4-3), a linha melódica do trompete é acompanhada por alguns instrumentos de percussão. Um dos percussionistas (linha da alfaia e prato) marca basicamente os pulsos (ou divisões do pulso) das respectivas fórmulas de compasso. O outro grupo de instrumentos (surdo e bongôs) possui um estrato independente, distinguindo-se justamente pelo ostinato criado que acontece em uma métrica própria. Esse recurso faz com que essa linha esteja em defasagem em relação aos demais instrumentos, porém, lhe impinge autonomia.

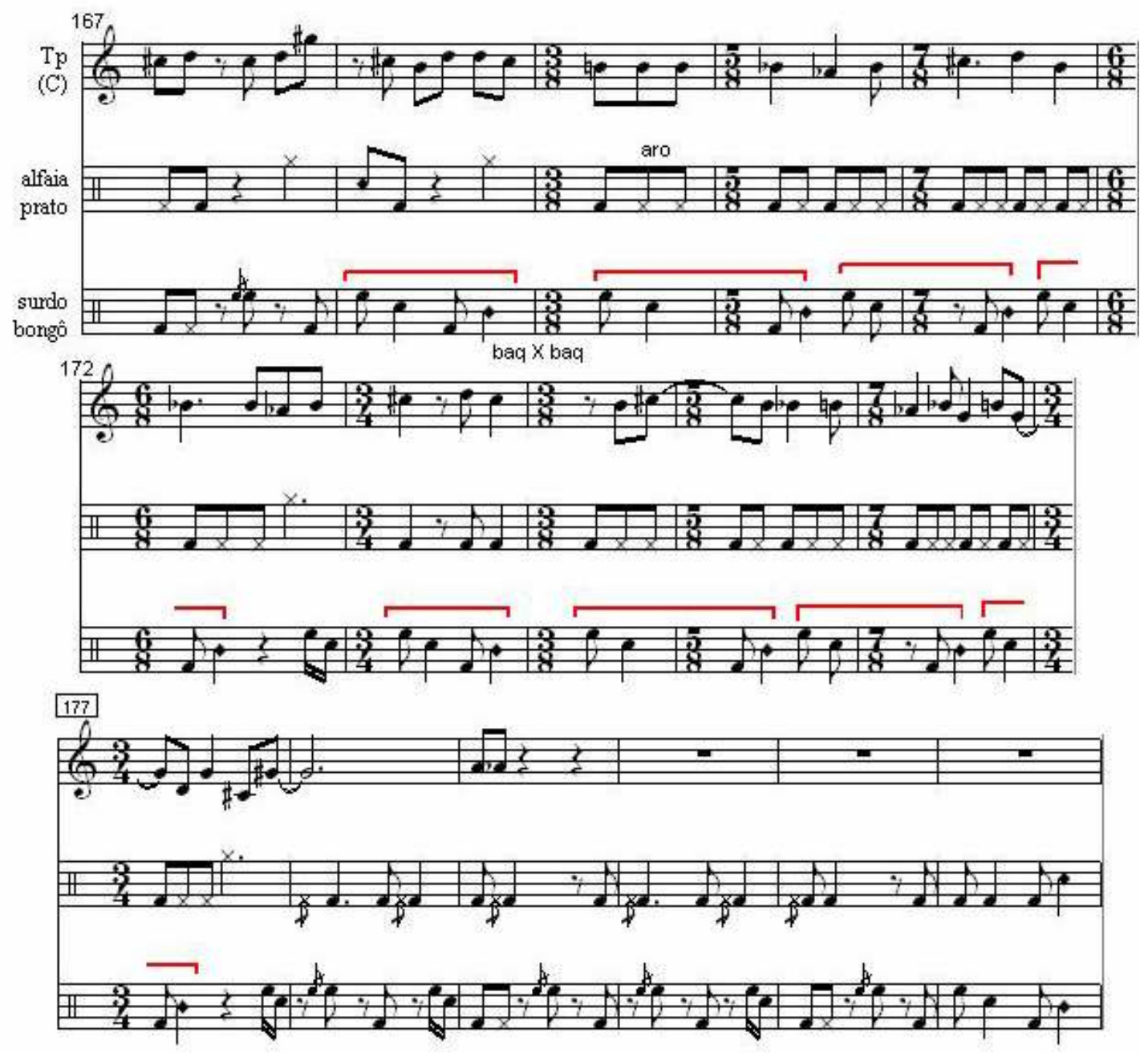

Exemplo 4-3: Antenor Ferreira, Jericó, comp. 167-182. Camadas formadas pela recorrência do padrão rítmico. 
Uma outra possibilidade de se lidar com o princípio da estratificação é tomar o termo literalmente e constituir camadas totalmente independentes no âmbito sonoro, como as deposições ou sedimentações geológicas. Essas camadas são apresentadas simultaneamente e podem dar a impressão de que não são complementares, funcionando como se dois ou mais eventos apenas compartilhassem o mesmo espaço sonoro, sem qualquer motivo ou ligação explícita. Uma das grandes (e talvez pioneiras) obras a fazer uso desse artifício é The Unanswered Question (1906 - mas só publicada em 1940) de Charles Ives.

Jan Swafford, biógrafo de Ives, entende a peça como uma colagem de três camadas distintas, proximamente coordenadas. Segundo Swafford, Charles Ives chamava a obra de "drama cósmico". Esse drama é desenvolvido em três camadas, cada uma destas possuidoras de parâmetros próprios de estruturação.

O plano de fundo, ou camada mais interior (Ex. 5-3), apresenta o naipe de cordas em uma textura basicamente acórdica (harmonia triádica, perfeitamente analisável segundo o sistema tonal), com dinâmica piano e caráter tranqüilo. De acordo com Ives representaria o "silêncio dos Druídas, que sabem, vêem e ouvem nada" [the Silences of the Druids-who Know, See and Hear Nothing]. Esse silêncio é rompido pelo trompete solo (Ex. 5-3, compassos 16-17), que em sua camada intermediária formula a pergunta enigmática sobre "a perene questão da existência”. Essa questão é refeita mais seis vezes (total de sete intervenções do trompete), sempre com a mesma frase atonal, no mesmo registro e com dinâmica piano, exceto a última intervenção, que se dá em pianíssimo e deixa a pergunta no ar. O naipe de madeiras, na camada mais externa (Ex. 5-3, compassos 20-21), emite tentativas de resposta à questão perene. Estas respostas vão tornando-se cada vez mais agitadas e impositivas. As seis respostas do naipe de madeiras partem da dinâmica $p$ e vão até $f f f$, o andamento desta camada também é modificado, iniciando em adágio e terminando em presto. Correlatamente, no plano das alturas há a ampliação de registro em direção ao agudo e um aumento no grau de caoticidade causado pelo uso conjunto de células rítmicas diferentes (polirritmia). Dessa maneira, as três camadas são muito bem estabelecidas, diferenciadas e definidas.

O título completo desta obra dado por Ives em 1906 foi A Contemplation of a Serious Matter or The Unanswered Perennial Question. Ives retornou à obra em 1908 e entre 1930 a 1935 trabalhou em uma versão para orquestra. Porém, a primeira apresentação só ocorreu em maio de 1946, executada pela Orquestra de Câmara dos estudantes da Juilliard School, conduzida por Theodore Bloomfield. A partir dessa apresentação, alguns músicos conheceram e passaram a comentar a obra. Segundo Bernstein, as madeiras representam as respostas humanas que se impacientam cada vez mais e tornam-se desesperadas, até perderem 
inteiramente sua significação. Ao lado dos aspectos filosóficos, a obra aponta para uma característica do século XX, o embate entre o tonalismo e o atonalismo, uma corrente de compositores trabalhando com a música atonal, concomitante a uma vasta produção tonal.
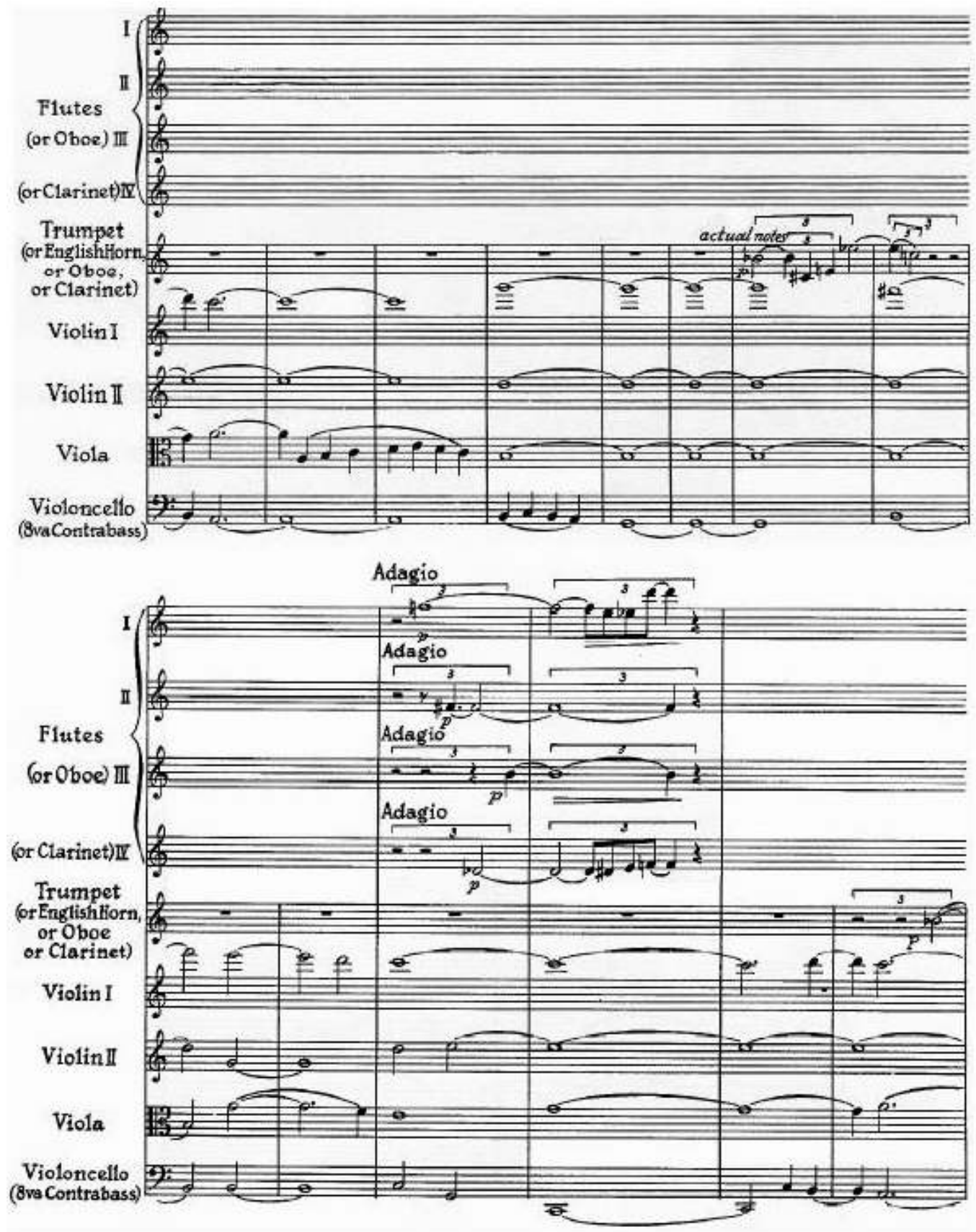

Exemplo 5-3: Charles Ives, The Unanswered Question, comp. 10-23. Camadas interior (cordas), intermediária (trompete) e exterior (madeiras).

O uso simultâneo de diferentes estratos desta obra poderia também ser justificado pelo teor extramusical que comporta, ou seja, o programa filosófico existencial que engloba. Logicamente, esse programa não é percebido no ato da escuta, já que a música está longe de envolver características descritivas ou associativas incontestes. Com isso, a peça deve ser 
entendida sob o prisma essencialmente musical (ou abstrato, como prefere Cone), consolidando o procedimento de construção em camadas que não fazem analogias ou paralelos com propósitos cênicos. Embora no plano poético o programa filosófico possa ser contado como justificativa para essa a construção em camadas.

Usei um meio quase similar a este tipo de construção em camadas em duas de minhas composições eletroacústicas mistas: Chiromancer's hands doesn't have lines e Jericó. Na primeira os sons eletroacústicos provém de uma única fonte: uma mola. Esses sons são transformados de modo a configurarem uma camada com texturas distintas, alternando entre sons contínuos, granulares, flutuantes (semelhantes a senóides), glissandos e pontuais (atacados e curtos), criando uma direcionalidade no âmbito textural que parte do som sustentado e chega até o pontual, como mostra a Figura 3-3. No entanto, essa camada não é apresentada nessa maneira 'lógica' na composição, pois optei por dispor essas texturas em outra ordem, como se tivessem sido embaralhadas. Assim, a apresentação das diferentes texturas desta camada eletroacústica segue uma ordenação arbitrária que sumariamente pode ser descrita nesta série: flutuantes, granulosos, pontilhistas, contínuos e glissandos (respectivamentes representados pelas letras a, b, c, d e e da Figura 3-3). Os demais instrumentos acústicos, por sua vez, possuem partes próprias, articuladas e complementares entre si, que não guardam nenhuma relação direta com a camada eletroacústica.
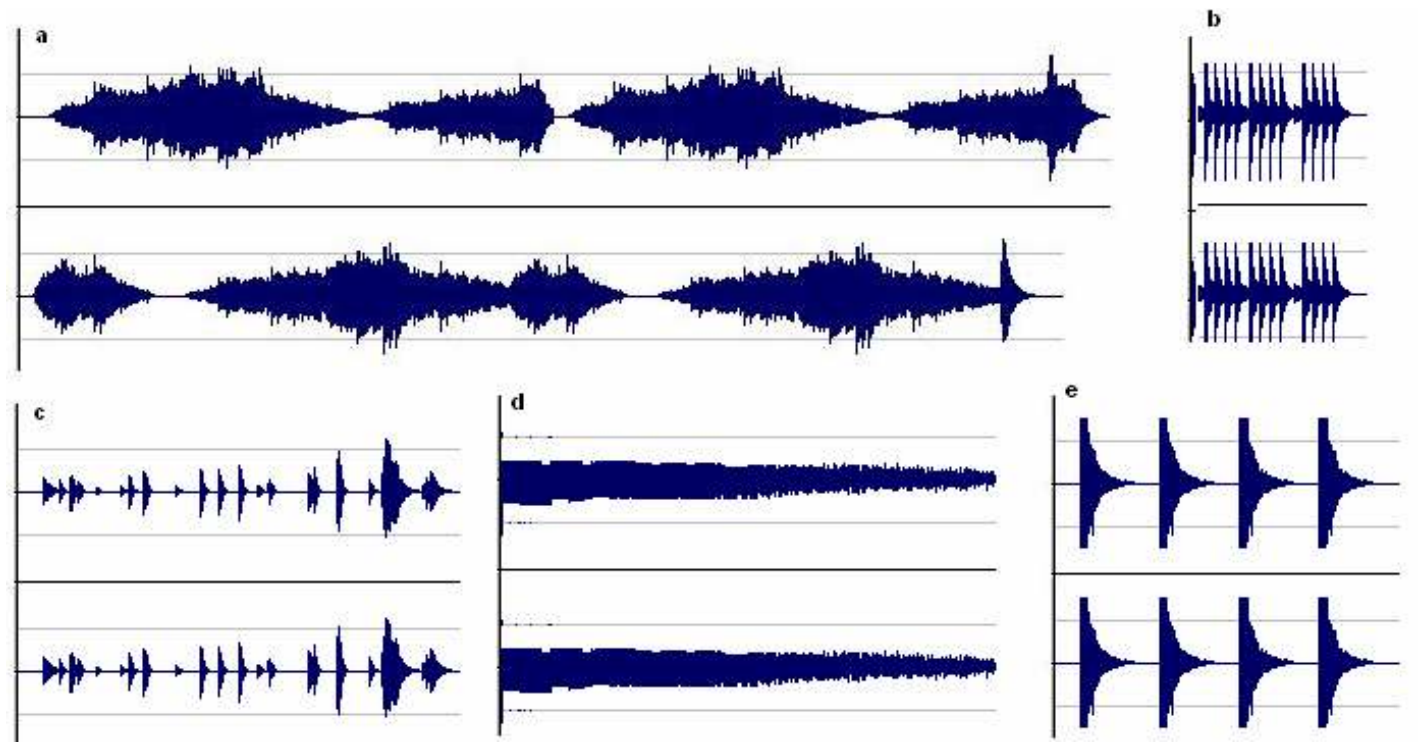

Figura 3-3: Antenor Ferreira, Chiromancer's Hands Doesn't have lines, camadas de sons eletroacústicos.

Na minha peça Jericó, o procedimento é similar, valendo-se de uma camada de sons eletroacústicos (representando a muralha da cidade bíblica Jericó) que perpassa toda a composição. Os instrumentos acústicos tocam suas partes simultânea e independentemente a essa camada de sons gravados. A unidade entre essas camadas, em princípio, autônomas, se 
dá no desfecho da peça, momento em que o trompete (obviamente representando as trombetas do exército de Josué) derruba a muralha, que vem abaixo em um glissando longamente dilatado no tempo, como sugere a figura 4-3.

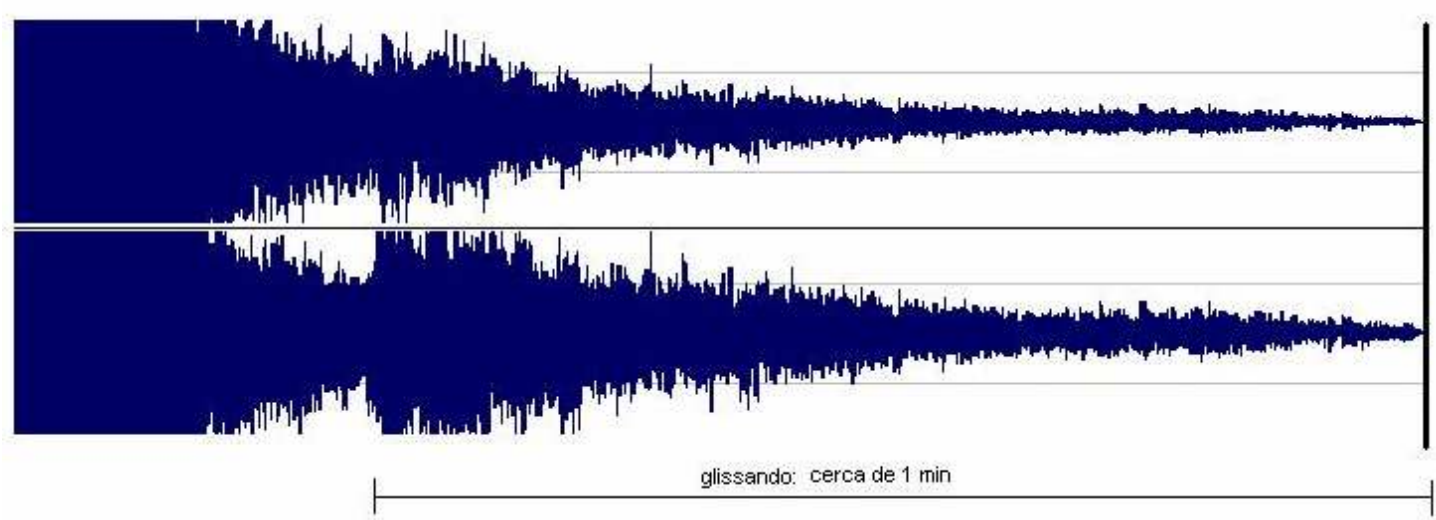

Figura 4-3: Antenor Ferreira, Jericó. Glissando na camada de sons eletroacústicos no momento final da obra.

Nos procedimentos descritos até agora, somente exemplifiquei uma das fases da proposição de Cone, a estratificação. No entanto, mais duas fases compõem esse recurso: conexão e síntese.

\section{Conexão}

A fase de conexão, segundo Cone, diz respeito à influência que uma idéia exerce sobre a música apesar de sua fragmentação. É uma etapa de articulação. As camadas justapostas podem estar conectadas por uma relação métrica ou intervalar (por exemplo, quando um intervalo em específico é utilizado para separar as camadas que se justapõem). Similarmente, como os blocos justapostos são divididos em tamanhos distintos, um bloco menor continua a exercer influência sobre as partes maiores, uma vez que elementos de conexão permanecem perceptíveis. Em sua análise da Sinfonias para Instrumentos de Sopro Cone ressalta a importância adquirida pelo intervalo de quinta justa na conexão de algumas seções da peça. No exemplo seguinte, extraído de minha peça Trilhas Sonoras (Ex. 6-3), ocorrem diversas justaposições contrastantes. No entanto, essas partes possuem um elo estabelecido por uma única nota: $B$. 


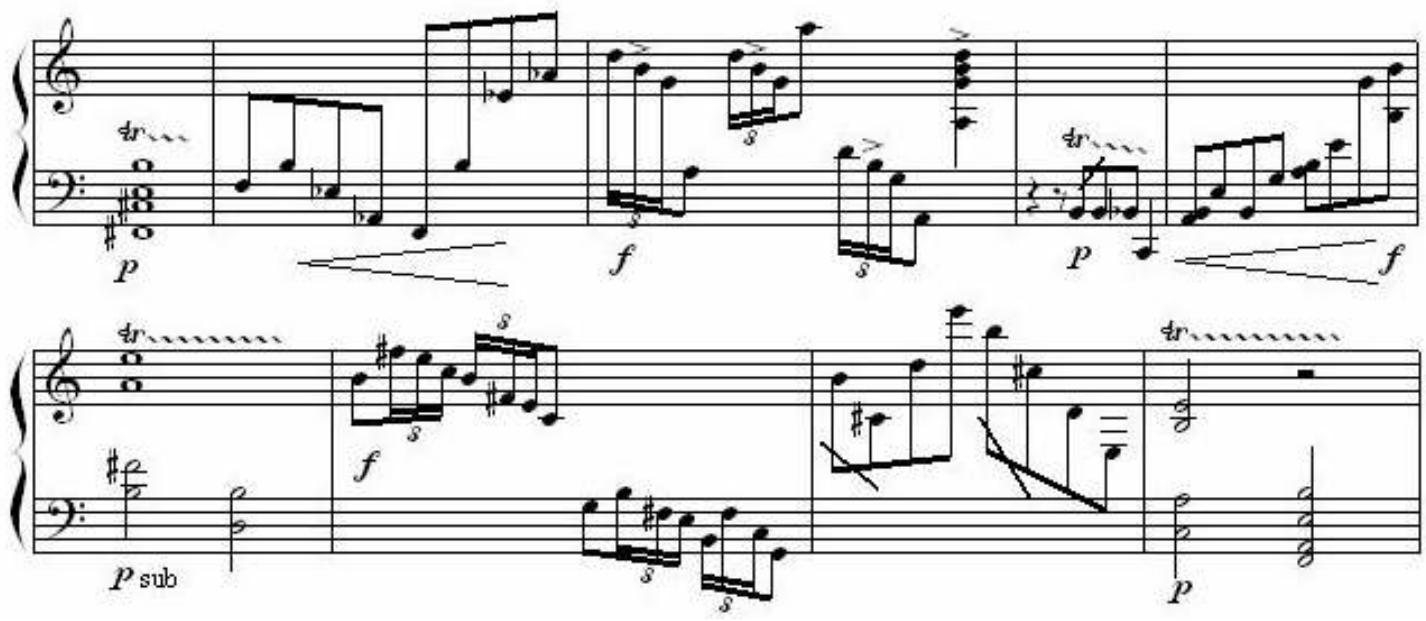

Exemplo 6-3: Antenor Ferreira, Trilhas Sonoras, parte de marimba, justaposições conectadas pela nota $B$.

Sobre a fragmentação, uma melhor explicação pode ser conseguida em a analogia com a pintura cubista, sobretudo, da fase do Cubismo Analítico (1909), caracterizado pela desestruturação da obra em todos os seus elementos. No Cubismo, conexão ocorre quando o material é deslocado em partes menores e reunido de modo que os contornos apareçam entre essas partes disjuntas. Ela cria uma forte distorção visual e o fruidor é levado a perceber a figura retratada, mas muitas vezes essa percepção não é imediata. "Decompondo a obra em partes, o pintor registra todos os seus elementos em planos sucessivos e superpostos, procurando a visão total da figura, examinado-a em todos os ângulos no mesmo instante, através da fragmentação dela" (www.historiadaarte.com.br). A pintura seguinte (Figura 5-3) exemplifica esse procedimento.

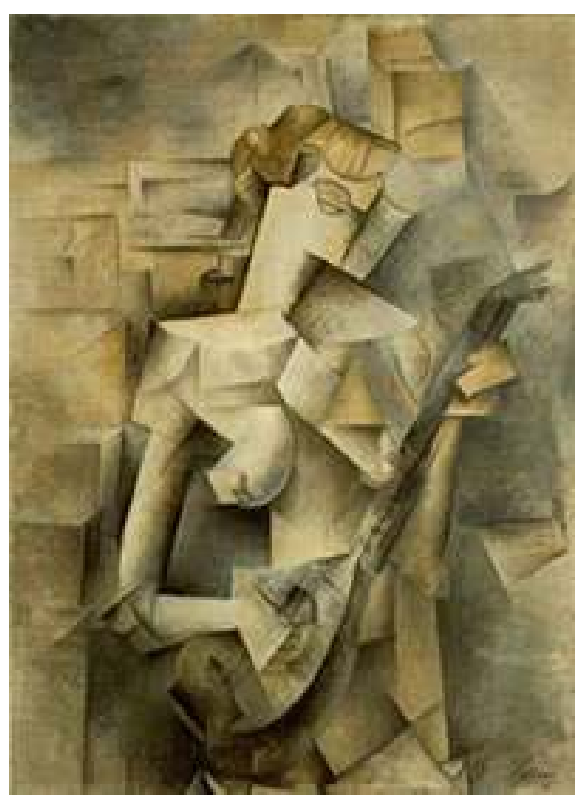

Figura 5-3: Pablo Picasso, Garota com Mandolim (1910) 
Uma analogia musical desse processo pode ser conseguida, entre outros métodos, por meio da fragmentação temática. Neste procedimento, pedaços de temas, ou motivos, são dispostos na composição; esses fragmentos, porém, são transformados, isto é, modificados por artifícios variados, como aumentação, diminuição, inversão, variação timbrística, entre outros, de maneira que esses fragmentos ainda preservem alguma identidade com o original. O Exemplo 7-3 apresenta o tema original utilizado na minha obra Jericó. O processo construtivo primordial é a transformação temática. Assim, o tema será apresentado pelo trompete no compasso 23, no entanto, já fora introduzido anteriormente em seu esqueleto rítmico pelos dois percussionistas no compasso 19 (vide Exemplo 8-3), já uma espécie de transformação realizada pela abstração do parâmetro das alturas. No decurso da obra, diversos fragmentos do tema são distribuídos pelos instrumentos, fragmentos esses que, embora variados, assemelham-se à primeira ou segunda parte do tema (indicadas pelas letras a e b nos Exemplos 7-3 e 8-3).

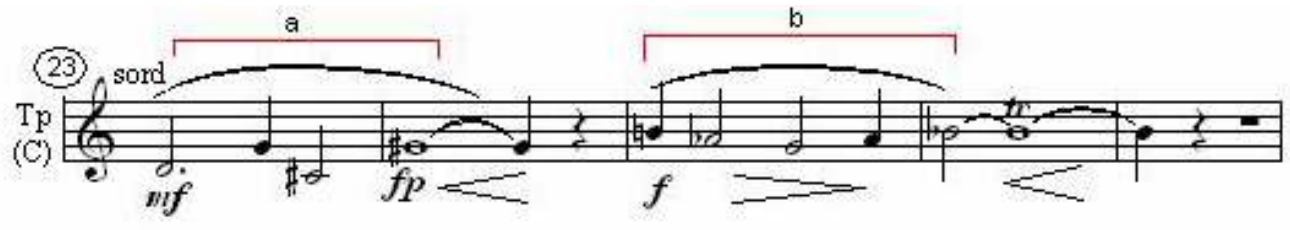

Exemplo 7-3: Antenor Ferreira, Jericó, compassos 23-26, tema principal.
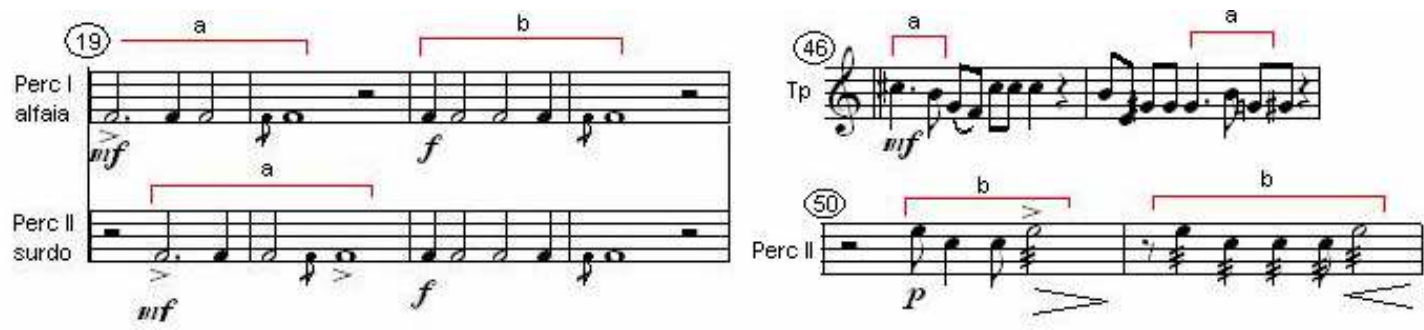

Exemplo 8-3: Antenor Ferreira, Jericó, compassos 19-22, 46-47, 50-51, fragmentos do tema.

Esse procedimento guarda semelhança com a referida conexão do cubismo, pois o material musical (tema) é fragmentado e transferido para partes menores no espaço musical, mas continuam a preservar certa identidade com o original de onde foram extraídos.

O conceito de conexão não implica somente em fragmentação, mas também faz pensar nas possibilidades de união e articulação dos blocos musicais. Vários teóricos têm apontado para a correspondência entre a justaposição em música e as técnicas de montagem usadas no cinema. O método de estratificação de Stravinsky teria, assim, paralelo com as técnicas usadas no início do cinema. Sergei Eisenstein (1898-1948) teorizou sobre as técnicas de montagem e corte empregadas por ele e por outros cineastas. Suas idéias serão apresentadas brevemente, a seguir, e servirão como fio condutor para levantar algumas propostas de transposição para o domínio musical. 


\section{Teorias da montagem}

Eisenstein entendia a montagem como processo de significação e não como simples suceder de cenas. Toda a sua teoria acerca do significado de um filme situa-se em torno da montagem, que seria responsável pela atribuição de sentido ao filme e, ao mesmo tempo, teria um sentido em si mesma, além de constituir-se enquanto elemento diferencial entre o cinema e as demais artes. Poderia exemplificar esse entendimento da seguinte maneira:

Imagine-se uma cena em que uma mulher encontra-se parada em frente a um espelho, trajando um vestido preto, estaticamente olhando para seu reflexo. Esta cena é sucedida por outra que mostra um túmulo em um cemitério. O espectador pode, então, vir a deduzir que a mulher é uma viúva ou outra pessoa preparando-se para um funeral. Se a mesma cena da mulher for sucedida por outra que mostre um palco com piano, estantes de partituras e instrumentos musicais, o espectador entenderá tratar-se de uma musicista aprontando-se para um concerto ou recital. Ainda, se a primeira cena for seguida de outra que contenha uma mesa com vinho, velas, uma suave música ambiente, o espectador pensará tratar-se de um possível encontro amoroso. Enfatize-se que uma mesma cena, seguida de outras distintas, deu origem a três significações diferentes. Esses sentidos foram criados pelo próprio espectador, pois não havia indicativos desses significados nas cenas. Reitera-se, o sentido foi construído na mente do observador. Experiências deste tipo foram realizadas pelo cineasta Kuleshov, provando que o significado de uma seqüência pode depender tão somente da relação subjetiva que cada espectador estabelece entre imagens ou planos que, em princípio, não possuem qualquer relação.

Entretanto, se a cena da mulher de preto em frente ao espelho fosse seguida por uma outra em que se vê um macaco empoleirado em um galho, não haverá conexão evidente, ao contrario, há desconexão, ruptura. $\mathrm{O}$ espectador ficará na dependência de mais uma situação para tentar relacionar os eventos. Neste último caso, há um corte no fluxo significante. Essas são algumas das possíveis situações que apontam para a utilização da montagem enquanto processo de significação.

As teorias da montagem de Eisenstein enfatizam esse aspecto de construção de sentido, optando por uma concepção dialética do choque entre os planos, nascendo daí a sua significação. Buscam, assim, os estímulos corretos que operaram no espectador as reações emocionais desejadas. Eisenstein classificou os tipos de montagem em: métrica, rítmica, tonal, atonal (também referida em alguns textos como harmônica), intelectual e vertical. Não é possível deixar de notar a semelhança com o vocabulário musical, parentesco este que não é coincidência pois Eisenstein conhecia música desde infância, já que sua mãe Yulia Ivanovna Eisenstein era pianista e fazia questão de educá-lo com muita sofisticação. Segundo biógrafos, 
"para Eisenstein seu pai fora um filisteu e representava os valores burgueses, e a sua mãe as artes e o refinamento. A mãe forneceu-lhe ampla cultura, enquanto seu pai incitou sua rebeldia" (BERGAN, 1997). O contato com a música, tão evidente nos seus filmes, parece ter influenciado seu pensamento cinematográfico, fato respaldado nesta classificação de montagens. Alguns desses tipos são sumariamente descritos a seguir com o propósito de embasar as sugestões para montagens musicais.

A montagem métrica é definida como aquela que tem por base o comprimento real dos fragmentos justapostos. Eisenstein diz que "os fragmentos são unidos de acordo com seus comprimentos numa fórmula esquemática correspondente à do compasso musical" (EISENSTEIN, 1990, p.77). Neste tipo de montagem, o conteúdo da cena não guarda relação com o comprimento do fragmento, mas encontra-se subordinado a este. Tem uma característica mecânica e tem a ver com a criação de uma sucessão de imagens sem qualquer intento intelectual. As tomadas podem ser dispostas, por exemplo, de 5 em 5 segundos, gerando uma certa estaticidade, ou alternadas em 5, 4, 3 e 2 segundos, de maneira a gerar tensão.

A montagem rítmica está relacionada com a movimentação interna da cena, importando, em parte, o conteúdo da mesma. "O movimento dentro do quadro impulsiona o movimento de montagem de um quadro a outro" (Ibid., p. 79). Um lago ondulante tem um tipo de movimentação, enquanto que soldados marchando terão outro. Esses ritmos peculiares a cada fragmento são usados como conectores dos planos justapostos, de modo a gerar proximidade ou contraste. A montagem rítmica (inerente às movimentações particularidades da cena) não se desvincula da métrica (que legisla sobre a totalidade dos fragmentos). Desse modo, na montagem rítmica estão presentes os dois tipos de movimento: o dos cortes de montagem e o real no interior dos planos. Um personagem correndo pode surgir num fragmento de curta duração. Ao passo que a ondulação lenta de um lago pode ter uma duração longa, dando estaticidade à cena. Surgem assim os critérios de concordância e conflito na montagem desses dois movimentos. A cena na escadaria de Odessa, no filme $O$ Encouraçado Potemkin é um exemplo deste tipo de montagem, pela forma como Eisenstein coloca em contraste o ritmo criado pelo corte métrico de montagem e o ritmo dos passos dos soldados que avançam pela escadaria abaixo.

A montagem tonal refere-se principalmente ao conteúdo do quadro. A analogia com o sistema tonal em música é possível. No sistema de tonalidades existe um pólo privilegiado que serve como eixo estrutural do discurso. Ao redor desse eixo são construídas as relações de tensão, conflito, afastamento e retorno. Similarmente, a montagem tonal se dá ao redor de uma temática predominante, que pode ser o conteúdo emocional e a sua atmosfera 
sentimental. Porém, também abarca demais aspectos da cena, como cor, luminosidade e medida. A montagem tonal possui um alto grau de subjetividade já que põem em jogo as sensações emocionais suscitadas pelo quadro, sensações que não podem ser tratadas matematicamente, como na montagem métrica. $\mathrm{Na}$ montagem tonal, "trabalha-se com combinações de variados graus de suavidade de foco ou graus variados de agudeza", sendo que o principal indicador para reunião dos fragmentos "está de acordo com seu elemento básico - vibrações óticas de luz (graus variados de sombra e luminosidade)" (Ibid, p. 80). Assim como o sistema tonal em música, a montagem tonal elege um eixo dramático como referencial e estrutural, possibilitando afastamentos e conflitos.

A montagem atonal (também chamada de harmônica) é a menos compreendida pelos comentadores de Eisenstein, que se limitam a reproduzir citações dos seus textos. Nesta montagem, o cineasta precisa considerar seu eixo dramático e as divergências que se sobrepõem a este, do mesmo modo como a série de harmônicos se superpõe a um som fundamental. Com isso, as dissonâncias intrínsecas aos vários elementos da cena, como conteúdo emocional, cores, sons, etc, adquirem gradações, e são tomadas hierarquicamente como base para a justaposição dos quadros. As concepções de Eisenstein não são muito claras neste caso, tendo confessado que a descoberta da montagem atonal deu-se posteriormente ao seu filme $A$ linha geral, com o qual foi possível a detecção dos conflitos entre planos, que ocorreu somente com a visão do movimento, isto é, depois do filme montado na totalidade. Pode-se dizer que na montagem atonal o eixo dramático condutor não é estabelecido de modo explícito, mas deve ser deduzido como resultante de uma confluência de fatores.

Em face dessas considerações, acredito ser possível a sistematização de alguns procedimentos de conexão entre os blocos musicais tendo por base os artifícios de montagem fílmica descritos. Tentarei esboçar alguns apontamentos a esse respeito, ciente das diferenças existentes entre as percepções visuais e aurais. Como ponto de partida é preciso ressaltar que a idéia é conectar blocos musicais autônomos, isto é, blocos que contrastam e são percebidos como independentes entre si. Em geral, esses blocos surgem como rupturas no fluxo narrativo, e são percebidos como divergentes, posto que apresentam ritmos, métricas, dinâmicas, andamentos, registros, estruturação das alturas e caracteres particulares. Esse aspecto não é problemático, sendo até desejado no discurso fragmentário. Porém, o que se propõe é uma maneira de integrá-los sob um mesmo denominador, ao menos no desfecho da obra, para que sejam percebidos como participantes de um mesmo contexto. Obviamente, essa idéia diminui a carga subjetiva inerente às poéticas fragmentárias.

$\mathrm{Na}$ proposição das montagens métrica e rítmica, as diferentes durações dos blocos musicais, bem como suas distintas estruturas rítmicas, poderiam ser transformadas de modo a 
adequar comprimentos de frases, temas ou motivos, andamentos, durações e células rítmicas de modo a tornar semelhantes os blocos musicais, ficando os contrastes relegados aos outros parâmetros (altura, registro, dinâmica e caráter).

O aspecto sugerido pelas montagens tonal e atonal são aqui entendidos não em relação ao sistema tonal, mas ao caráter expressivo da obra (que acabam por envolver todos os parâmetros musicais, não só os de altura) e aos possíveis contrastes e conflitos a ele relativo. Tom é entendido como inflexão, o que leva à percepção do caráter. Um bloco musical pode ter um caráter mais lírico, outro mais enérgico. Podem ainda divergir quanto à própria estrutura interna, sugerindo uma maior organização ou uma disposição mais caótica. De acordo com o registro e dinâmica podem também sugerir agressividade (região aguda em dinâmica forte) ou contemplação. Essas características poderiam ser gradativamente transferidas entre os diversos blocos justapostos de modo a diminuir suas divergências, criando ao fim, uma espécie de grande bloco que encamparia as incongruências dos demais, levando-os a uma espécie de síntese final.

Os exemplos seguintes tentam mostrar possíveis modos de conexão de blocos musicais segundo o processo de montagem. O Exemplo 9-3 apresenta três partes distintas que poderiam ser justapostas em uma peça. O bloco 1 tem registro amplo, dinâmica forte, andamento rápido, caráter allegro, estrutura rítmica característica e usa seis notas da escala cromática. O bloco 2 difere-se deste sobretudo em caráter (calmo), textura (acórdica), uso de trillos e uso de notas não presentes no bloco 1 , pois esse novo conjunto de notas completa o total cromático. O contraste principal do bloco 3 é a textura pontilhista, registro agudo, além disso, o uso de intervalos dissonantes cria uma sonoridade mais áspera. O Exemplo 10-3 mostra uma das possíveis conexões entre os blocos 1 e 2, criando uma construção cujos estratos interpenetram-se, pois os trillos característicos do bloco 2 são gradativamente assimilados pelo bloco 1. Da mesma maneira, o Exemplo 11-3 faz convergir, por meio da estratificação, os blocos 1 e 3, a tessitura aguda e textura pontilhista do bloco 3 se superpõe no bloco 1, assim os blocos são trazidos para um contexto comum.

Ao propor o método da estratificação como princípio composicional de Stravinsky, Edward Cone baseou-se majoritariamente da análise da Sinfonias para Instrumentos de Sopro, concluída em 1920, mas revista e reeditada em 1947. Segundo Robert Craft (amigo e biógrafo de Stravinsky), a estréia da Sinfonias provocou um certo escândalo em meio à opinião popular, porque "a introdução da peça parecia um burro que vocifera!" (CRAFT, 1992, p.373). Sintomático (como ver-se-á adiante) é que esta obra foi dedicada a Claude Achille Debussy, morto em 1918. Como homenagem a Debussy, a Revue Musicale encomendou e publicou uma série de trabalhos para piano de Stravinsky em memória de 
Debussy. Essa antologia comemorativa foi estreada em Paris no dia 24 de Janeiro de 1921 (Cf: CRAFT, 1992, p.380), e uma das peças desta antologia foi usada por Stravinsky no coral final da Sinfonias.
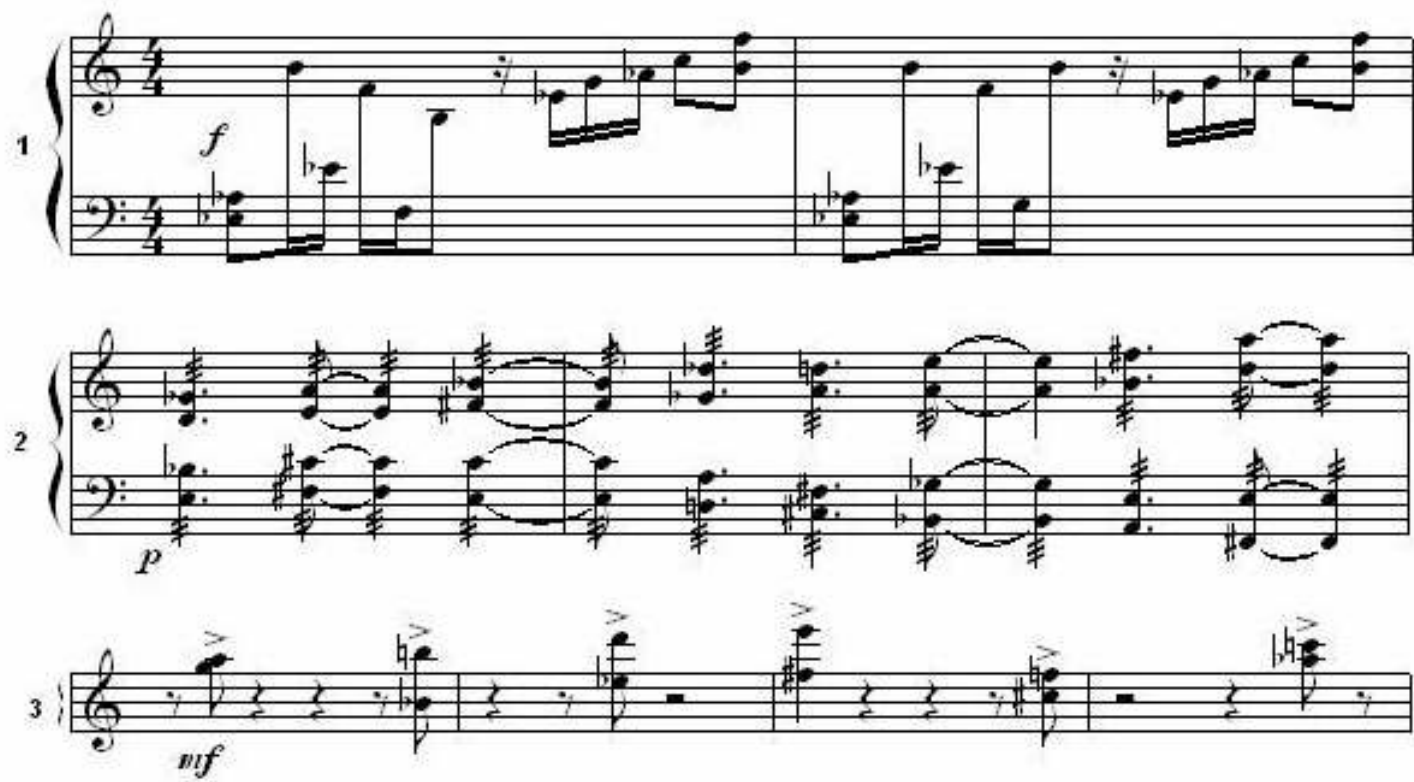

Exemplo 9-3: Três blocos musicais contrastantes a serem conectados.

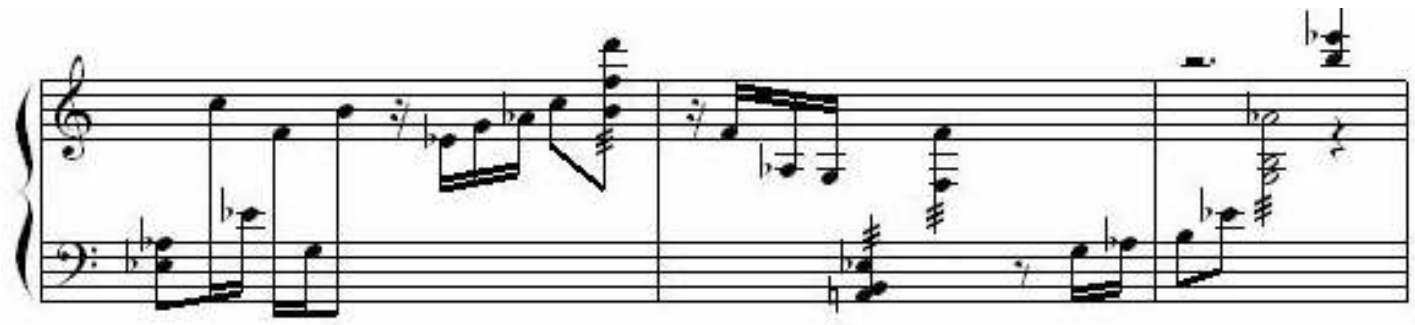

Exemplo 10-3: Montagem e conexão dos blocos 1 e 2.
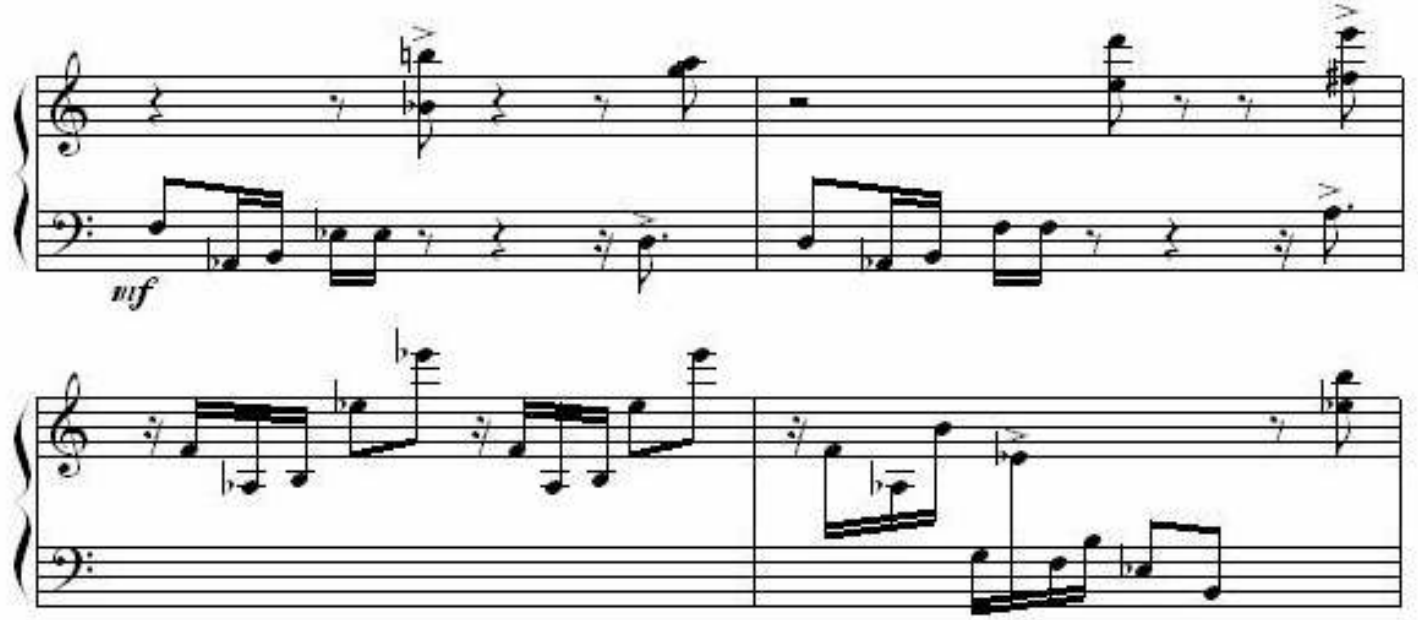

Exemplo 11-3: Montagem e conexão, via estratificação, dos blocos 1 e 3. 
A Sinfonias para instrumentos de sopro foi e é considerada por muitos como o arquétipo do procedimento de estratificação, visto agora sob a perspectiva cinematográfica de montagem e corte. Contudo, outros autores (por exemplo, McFarland em Debussy: the origins of a method) afirmam que esse tipo de procedimento tem seu início, justamente, com Debussy, tendo no Prelúdio Ondine o modelo germinal. Fica, então, a questão se Stravinsky teria derivado seu procedimento a partir das obras de Debussy, pagando-lhe, então, tributo na dedicatória da obra ${ }^{15}$.

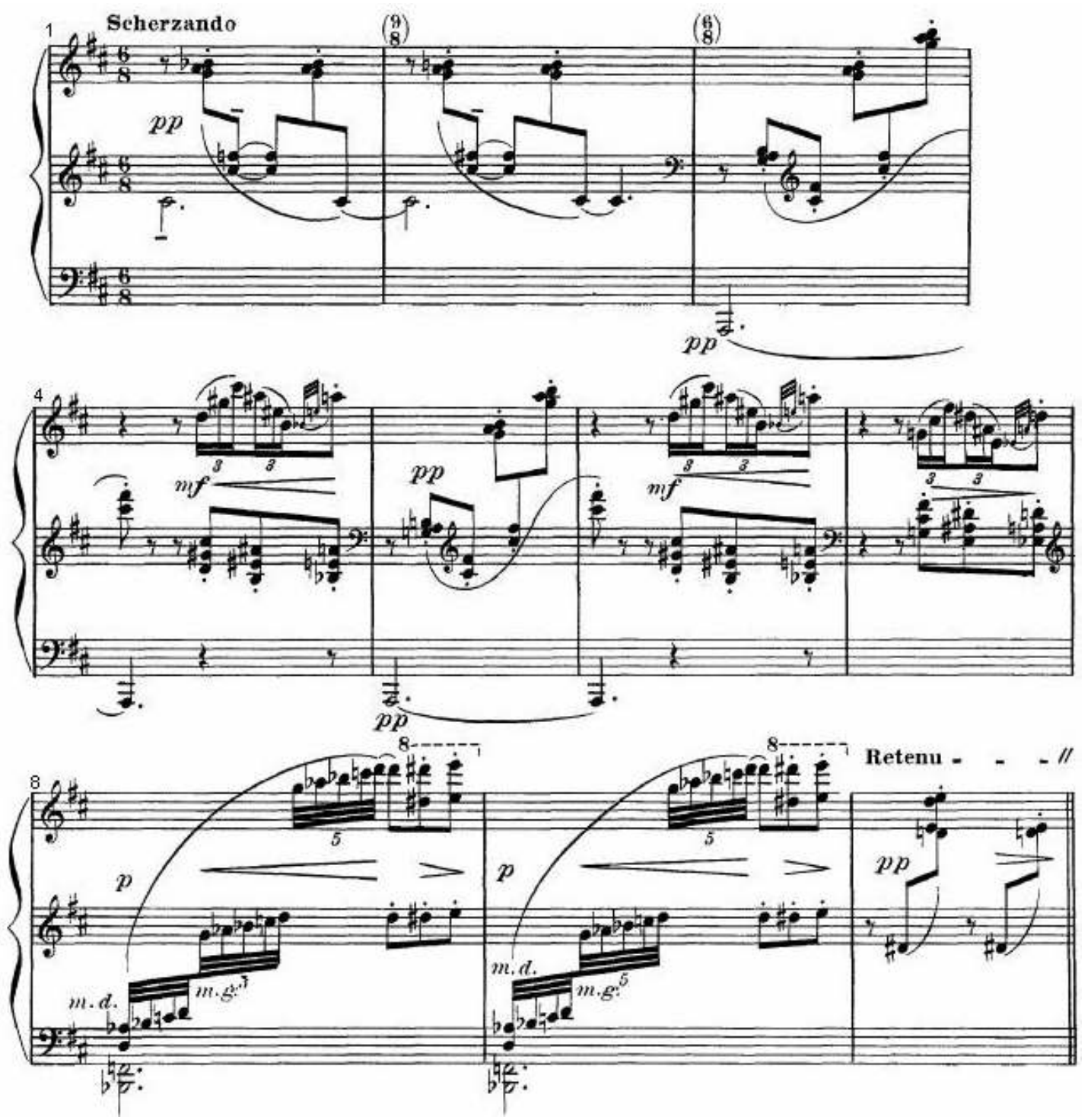

Exemplo 12-3: Debussy, Ondine, compassos 1-10, blocos justapostos.

\footnotetext{
${ }^{15}$ A respeito do uso intencional e sistemático do procedimento de justaposição, é interessante uma declaração do próprio Stravinsky ao esclarecer o procedimento composicional de uma de suas peças. Este comentário consta no texto de Nicolas Nabokoff "Natal com Stravinsky”, para a coletânea Stravinsky de Edwin Corle (1949, p.123168). Stravinsky descreve a composição da fuga de Orpheu desta maneira: "Note que eu cortei a fuga com um par de tesouras [...] eu introduzi esta curta frase da harpa, como dois compassos de acompanhamento. Depois, as trompas seguem com a fuga como se nada tivesse acontecido. Eu repeti isso a intervalos regulares, aqui, depois ali [...]. Você pode eliminar esta interrupção do solo de harpa, emendar as partes da fuga e o resultado será uma peça completa" (apud CONE, 1972, p.164).
} 
Em Ondine, de fato, já é possível notar visualmente os distintos blocos justapostos. O bloco A (compassos de 1 a 3 ) tem $C$ como a nota mais grave que caminha para a nota $A$ ligada ao bloco B (compasso 4), permanecendo como espécie de pedal no retorno de A (compasso 5), articulando-se novamente com o bloco B (compassos 6 e 7). Essa nota pedal exemplificaria o artifício de conexão descrito por Cone, já que cumpre o papel de elemento de ligação entre estes dois blocos. O bloco $\mathbf{C}$ é introduzido (compassos 8 e 9) interpolado entre $\mathbf{B}$ e A rompendo o fluxo mais bruscamente. O bloco A é re-exposto (compasso 10) porém com perfil modificado e tendo $D \#$ como a nota mais grave. As partes justapostas diferenciam-se, principalmente, pela figuração rítmica, cujos valores diminuem sistematicamente até o compasso 9, dando a sensação de acelerando. Porém, as diferenças também operam no âmbito da textura, densidade e do registro (A inicia no registro médio, passa pelo registro grave em $\mathbf{B}$ e é expandido em direção à região aguda no bloco $\mathbf{C}$ ). Essas justaposições são mostradas no Exemplo 12-3.

Willy Corrêa de Oliveira (Cf: 1979, p.101), no entanto, vai mais atrás e apresenta Beethoven, especificamente na Sonata Apassionata (Op. 57, $\mathrm{N}^{\circ} 23$ ), como precursor, avant la lettre, do procedimento de montagem. O Exemplo 13-3 mostra alguns blocos justapostos extraídos da Apassionata. Note-se a diferença entre cada uma destas partes justapostas e as distintas montagens do bloco $\mathbf{B}$ do compasso 4 para 5 e do 23 para 24 .
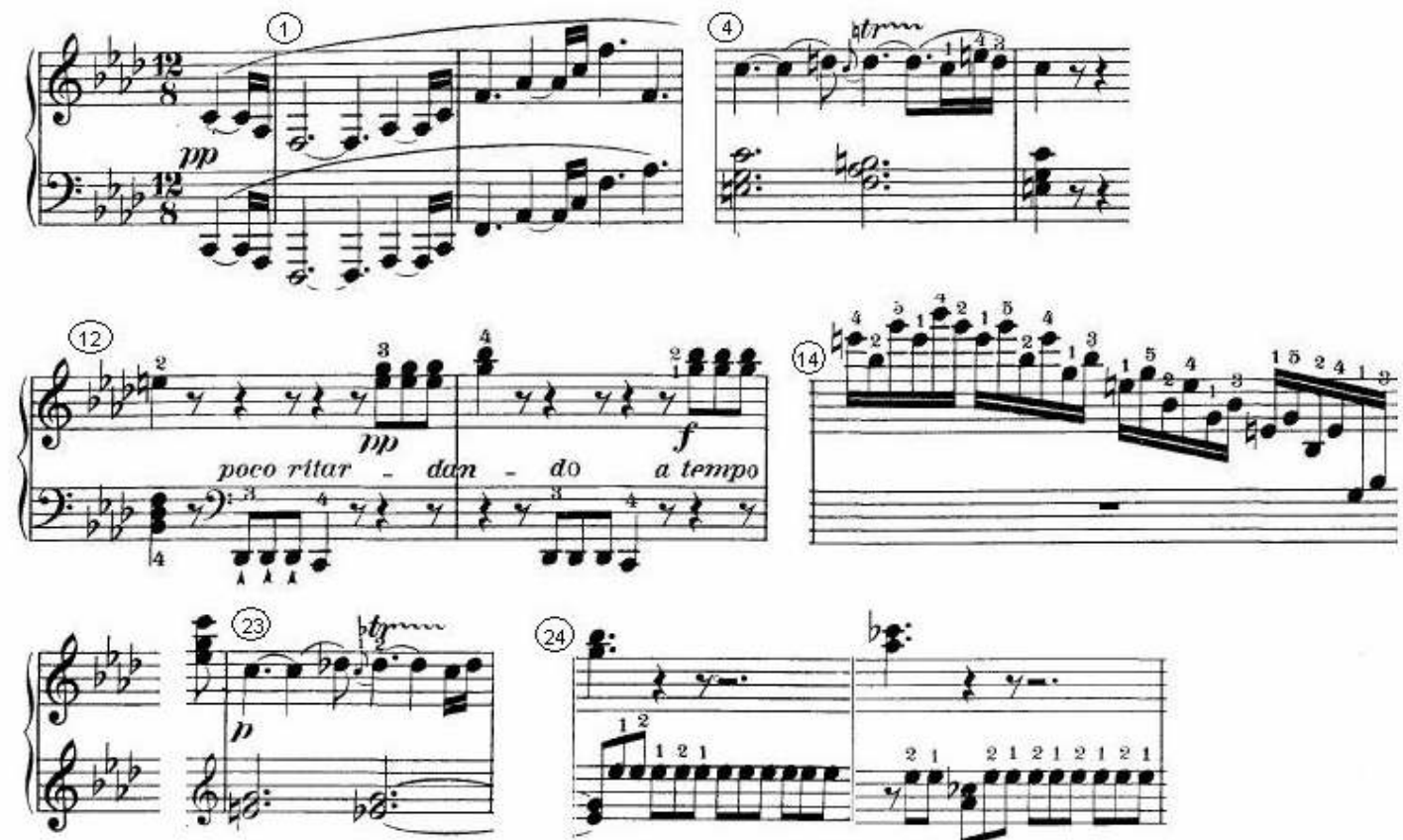

Exemplo 13-3: Beethoven, Sonata Op. 53 Apassionata, blocos justapostos. 
A partir das considerações até aqui realizadas, vislumbro a possibilidade de engendrar uma sistematização mais abrangente dos procedimentos de justaposição e estratificação, assimilando os artifícios de montagem cinematográfica. A esses apontamentos acrescentarei a terceira parte do método de Cone: a síntese.

\section{Síntese}

A síntese é a fase que unifica todo o processo, sendo responsável pela coesão das camadas divergentes, de modo a permitir uma associação lógica entre elas. A síntese normalmente implica na redução e transformação de um ou vários parâmetros sonoros. $\mathrm{O}$ resultado da síntese é que elementos contrastantes, como altura, registro, dinâmica e instrumentação são colocados em relação de maior proximidade entre si. Pode ocorrer de um único estrato assimilar os demais, encampando ritmos contrastantes, melodias contrapontísticas ou harmonias a ponto de funcionarem como um todo unificado. No Exemplo 11-3 já se havia operado uma espécie de síntese. Um outro exemplo de síntese oferecido por Cone em seu artigo é a assimilação de dois estratos da Serenata em Lá de Stravinsky (Ex. 14-3). Segundo Cone, "o enunciado inicial dos dois estratos estabelece o contraste imediato: A possui dinâmica forte, é relativamente agudo em tessitura e baseado no modo frígio. B possui dinâmica piano, é grave em tessitura e mais cromático, movendo-se a partir do modo frígio para uma tonalidade maior" (CONE, 1972, p. 161).
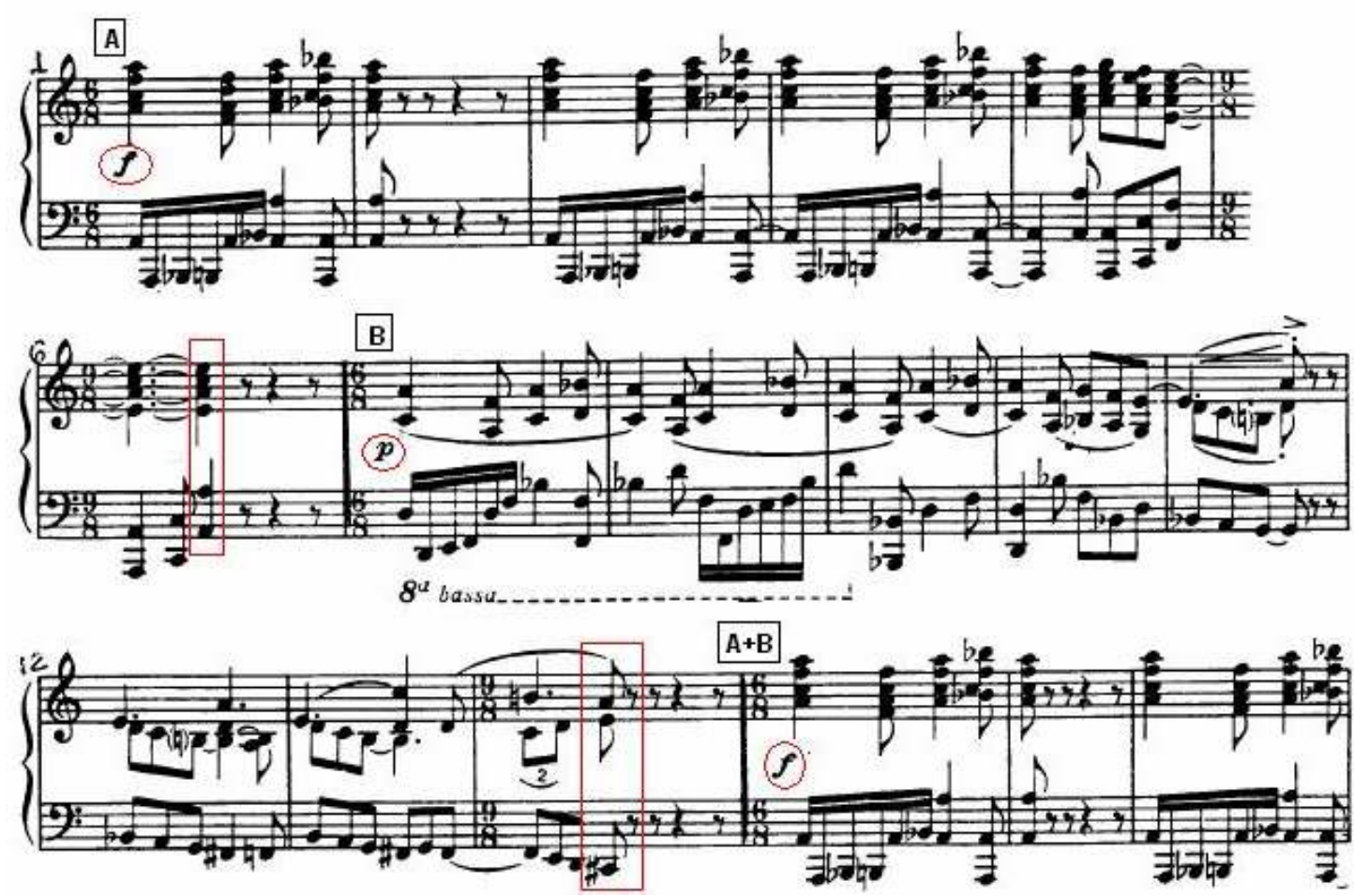

Exemplo 14-3: Stravinsky, Serenata em Lá, Hymne, comp. 1-17, justaposição dos blocos A e B. 
Percebe-se que essa é uma leitura bem particular de Cone, ficando exposta à contestação por parecer querer forçar uma interpretação adaptada à sua proposta de estratificação. Porém, sem entrar no mérito de sua análise, considere-se, a seguir, alguns pontos visando exclusivamente ao entendimento da síntese, terceira parte do modelo de Cone.

O que Cone chama de "mais cromático" é a concomitância entre as notas $B$ e $B b$ (compassos 11, 12 e 13) e F e F\# (compasso 12) do bloco B. No bloco A o cromatismo $B$ $B b$ funcionava como espécie de nota de passagem, já que Cone entende o emprego do modo frígio em $A$, contendo, portanto, a nota $B b$ como nota do modo e $B$ como nota estranha ao modo. Já no bloco B, a nota $B$ é sempre articulada com a nota $G$, ao passo que $B b$ é concomitante com a nota $D$, sendo notas reais às respectivas formações. (Isso permite, inclusive, corrigir um erro de impressão na primeira nota da clave de Fá do compasso 13, que deveria estar grafada $B b$. Um olhar mais detido também irá revelar um erro no primeiro compasso da música, onde o segundo acorde da clave de Sol, lido de baixo para cima, não deveria ser $F-A-D-F$, mas sim $F-A-C-F$, formação que será reiterada nos compassos seguintes).

Atento a essas peculiaridades, Cone intentará a compreensão da síntese considerando a integração dos antagonismos inerentes aos blocos. Desse modo, o estrato A ao direcionar sua tessitura para o grave e modificar sua dinâmica para piano, está incorporando características do bloco B. Similarmente, o bloco B ao tornar-se mais diatônico agrega características do bloco A. Esses são alguns dos aspectos que promovem a síntese das justaposições iniciais. Nas palavras de Cone:

o estrato A executa um passo importante ao encontro da unificação no compasso 52, onde pela primeira vez interrompe-se a dinâmica forte, seguindo-se em piano, um nível dinâmico associado exclusivamente à área $\mathbf{B}$. Nos compassos 63-65 A invade a tessitura grave e o franco cromatismo de B. (...) A oposição estabelecida nos compassos iniciais não somente explica as interrupções imediatas tão características deste movimento, como também realça as divergências dentro das seções maiores (CONE, 1972, p.161).

No Exemplo 15-3, observa-se a síntese final da Serenata em Lá. Nos compassos 60 até 66 nota-se o uso do pedal na nota $F$ em um contexto totalmente diatônico (o pedal em $F$ e o diatonismo acontecem desde o compasso 52 não mostrado no exemplo). A dinâmica é forte desde o compasso 59, mas em 65 após a intensificação cromática é anotado um piano súbito. No compasso 70 o cromatismo da seção $\mathbf{B}$ apresenta a dinâmica até então associada ao bloco A. A partir do compasso 72, há alternância entre diatonismo e cromatismo e arpejos amplos englobam os registros grave e agudo (associados a $\mathbf{B}$ e A, respectivamente). Esses são alguns dos artifícios que promovem a integração dos blocos. 

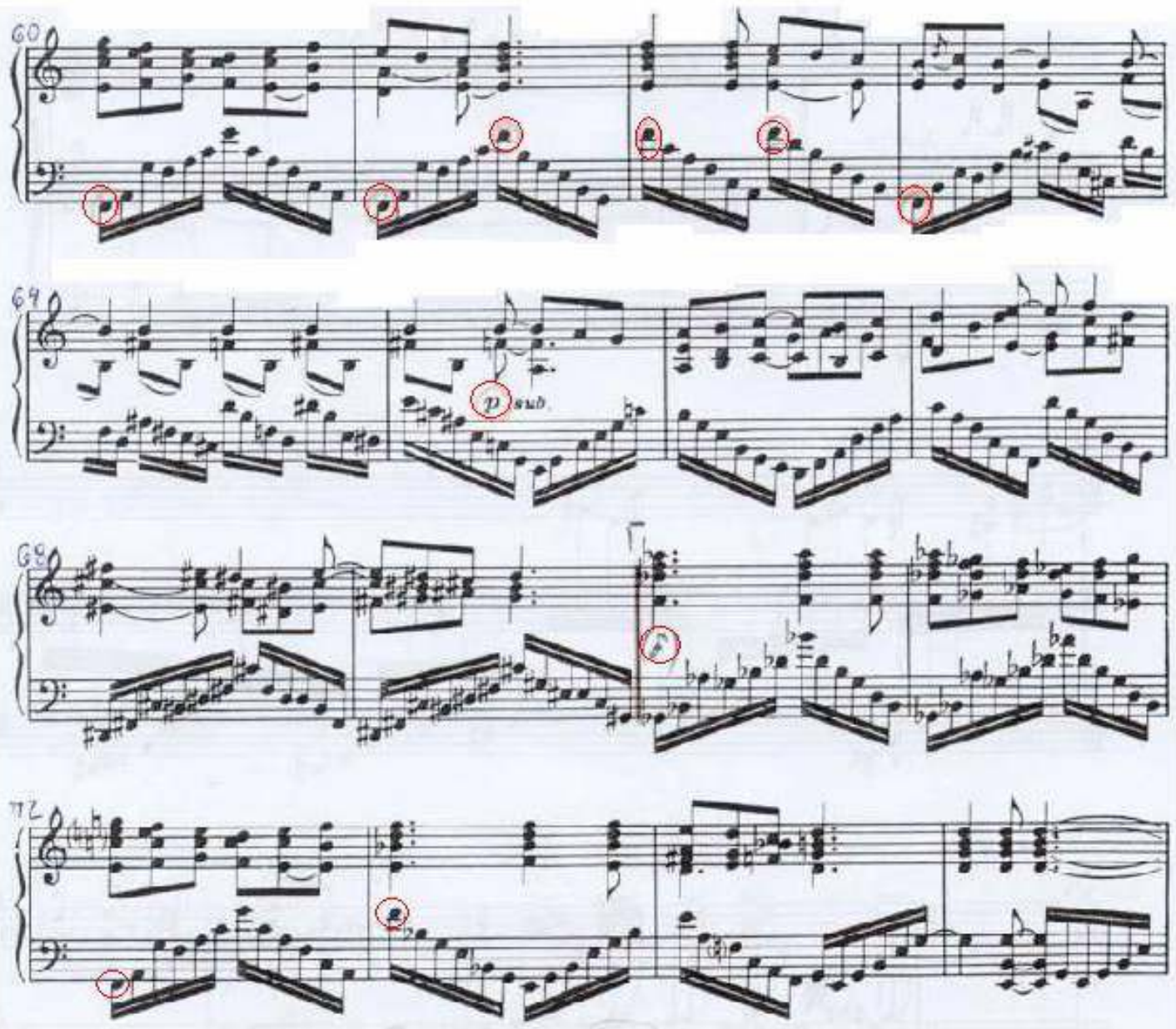

Exemplo 15-3: Stravinsky, Serenata em Lá, Hymne, comp. 60-75, síntese dos blocos A e B.

O exemplo seguinte é extraído do meu Prelúdio $N^{o} 2$ e intenta demonstrar uma operação semelhante desse processo. $\mathrm{Na}$ síntese desta peça, os estratos convergem para o último compasso onde a sucessão de acordes da camada 2 e as linhas melódicas das camadas 1 e 3 são encampadas pela harmonia de $E m$. A camada 3 realiza a célula rítmica da camada 1 (notas $B-A \#-F \#-E$ ), freando sua própria movimentação rítmica. A camada 1 finaliza a frase melódica também em $E m$ (notas a partir do compasso 23: $E-G-F \#-E-E$ ). A camada 2 apresenta a tríade $B-D \#-F \#$ (quinto grau de $E m$ ), todavia, no compasso 24 a nota $G$, da resolução, é antecipada. A camada 4, mantém o acorde invertido, da mesma maneira como no início da obra, mas agora na camada 2 (tríade $B-E-G$ do compasso 1), isso de certa maneira enfraquece o sentido cadencial V-I das outras camadas, porém, preserva o caráter harmônico ambíguo presente ao longo da peça. Pode-se pensar, então, que as camadas realizam sua síntese ao convergirem para uma única harmonia ou pólo tonal comum, mas isso só acontece no último compasso da peça. 


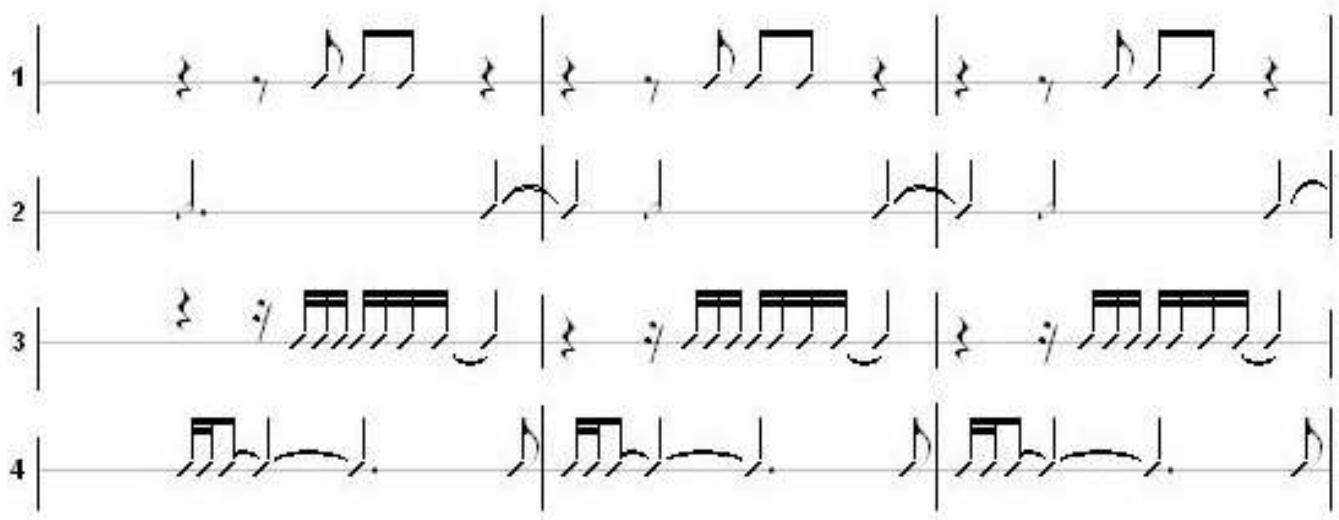

Exemplo 16-3: Antenor Ferreira, Prelúdio 2, estrutura rítmica das quatro camadas.
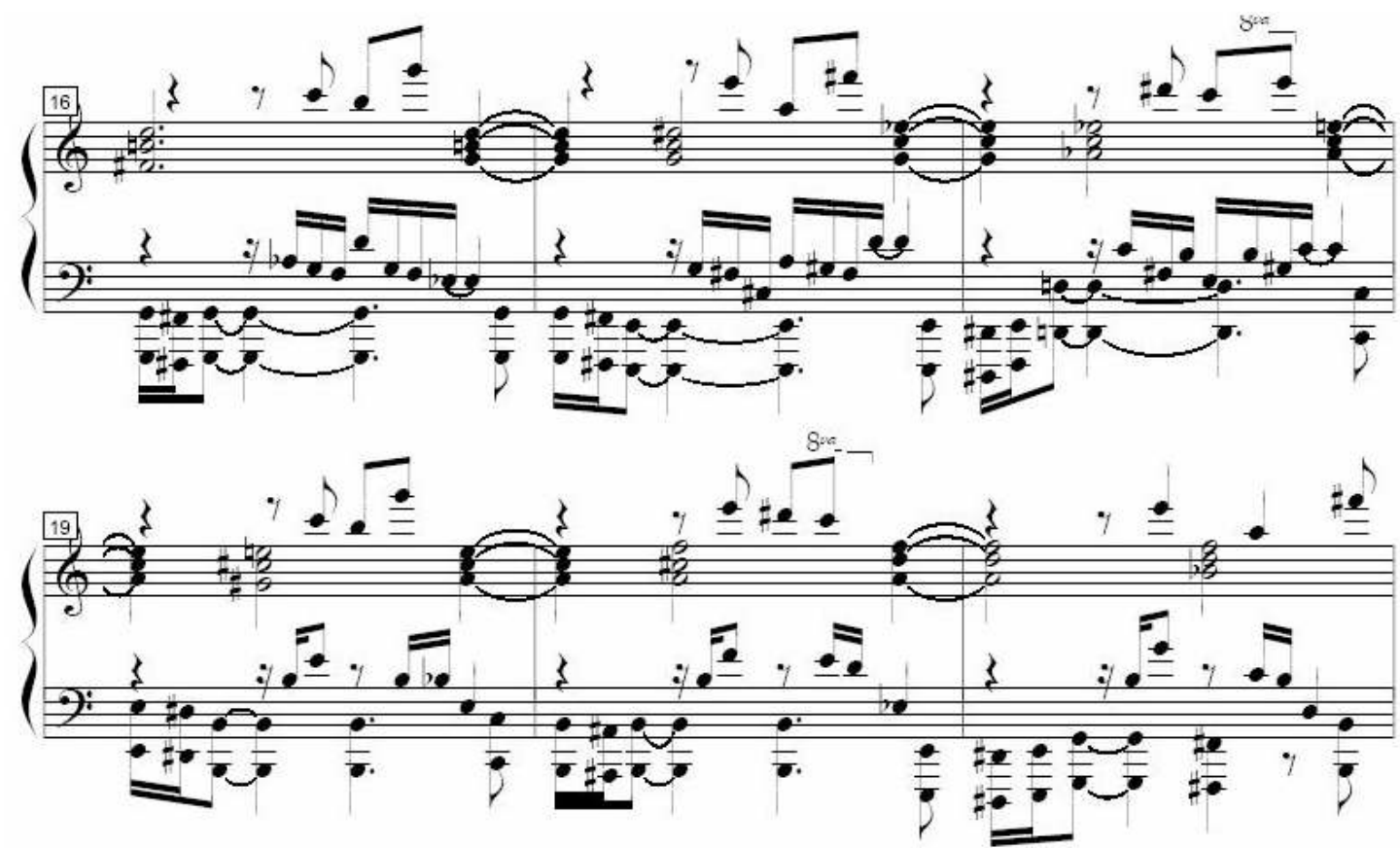

Exemplo 17-3: Antenor Ferreira, Prelúdio 2, comp. 16-21, separação das quatro camadas musicais.

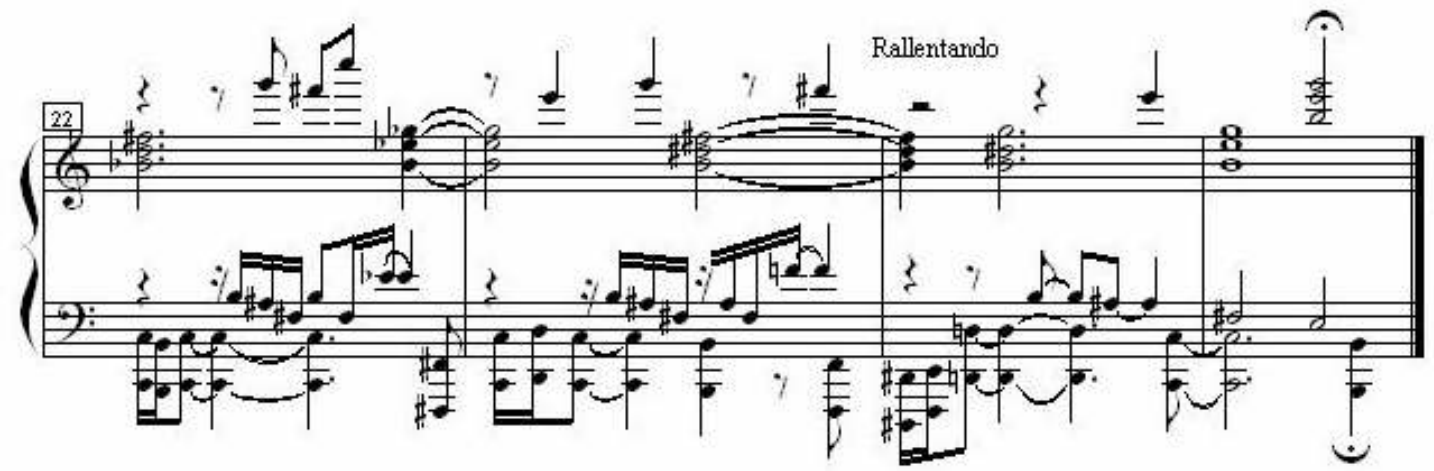

Exemplo 18-3: Antenor Ferreira, Prelúdio 2, compassos 22-25, síntese da quatro camadas. 


\section{Outra possibilidade analítica}

Como foi possível notar, a justaposição de blocos opera, principalmente, com severas rupturas do fluxo discursivo. Isso faz implicar que, a princípio, não se perceba uma relação funcional entre as partes, pois função implica na dependência de algo (uma quantidade, por exemplo) em relação à outra coisa, é a regra que conecta relações de determinado termo ou grupo de termos com outro termo ou grupo de termos. No discurso musical baseado em rupturas e fragmentações, as conexões podem ser produzidas pelo compositor ou construídas pelo ouvinte (como no exemplo da montagem cinematográfica). Todavia, o fato de não haver conexões evidentes entre os blocos justapostos, impedindo uma apreensão funcional imediata, inviabiliza considerar essas justaposições sintaticamente. Isso se deve ao fato das combinações sintáticas possuírem alto grau de dependência, o que não acontece nas justaposições aqui analisadas. As seções que se alternam rompendo subitamente o fluxo linear dificilmente poderiam ser associadas por meio de uma sintaxe. Em vista dessa particularidade, autores têm sugerido abordar esse tipo de poéticas fragmentárias por meio de outro processo de combinação: a parataxe.

Parataxe e hipotaxe são formas de construção gramatical que combinam e organizam as frases, orações, sentenças e períodos. Diferenciam-se em razão da maneira como conectam esses componentes, podendo se dar por meio de subordinação (hipotaxe) ou coordenação (parataxe).

A palavra parataxe, tomada etimologicamente [para - proximidade / taxis - arranjo, ordem], opõe-se a hipotaxe [hipo - sob]. Consiste na conexão de constituintes lingüísticos (frases ou categorias sintáticas) por coordenação [ou coordenação assindética], enquanto na hipotaxe temos a conexão de frases por subordinação (o que implica que haja uma relação de dependência sintática). O termo hipotaxe pode ser mesmo traduzido como "submissão" ou "sujeição", sinônimos de subordinação que trazem mais imediatamente à lembrança o sentido seqüestrado pelo uso gramatical dessa última. Por contraste, parataxe adquire uma conotação de liberdade, de desprezo à hierarquia, a princípio sintática, que pode ser expandida, como metáfora, para outros domínios (ÁVILA, 2006).

Como na hipotaxe as frases apresentam subordinação, existe uma relação de dependência entre elas, assim, as frases são articuladas com o uso de conjunções (se, quando, de maneira que, apesar de que, etc) ou pronomes relativos. Já na parataxe não há necessidade deste tipo explícito de ligações. "Numa construção paratática as partes são justapostas sem conectores lógicos entre elas. A eventual relação lógica que a justaposição estabelece deve ser deduzida da relação semântica das partes, uma vez que não há conectores indicativos do tipo de subordinação" (SOUZA, 2007, p.76).

Essa característica da não existência de conectores lógicos abre a possibilidade de se pensar na correspondência entre as músicas que se valem do tipo discursivo ora discutido, isto é, composições baseadas em procedimentos de justaposição ou mesmo em obras que se valem 
de montagens, colagens e bricolagens. Myriam Ávila, tendo por base o texto de Adorno, comenta:

Adorno, com ouvido musical, interna-se nos meandros da forma como portadora ela mesma de um sentido. Sua experiência como pianista e compositor lhe permite nesse momento buscar uma alternativa de leitura que só depois pode alcançar uma formulação especulativa em moldes filosóficos. Interessantemente, sua exposição começa com um enunciado paratático: "Grande música é sintese não-conceitual; esta é a imagem originária da poesia." Já aqui temos de entender a parataxe de forma ampla, como propõe o próprio Adorno mais adiante. Não apenas a construção sintática prescinde de um conectivo que justifique a passagem de uma proposição à seguinte, como a equivalência inexplicada entre música e poesia manifesta-se peremptoriamente, ao modo da discutida fórmula horaciana ut pictora poesis ${ }^{16}$ (ÁVILA, 2006).

Se aquilo válido para a pintura vale também para a poesia, porque não para as demais artes? A música, nesse sentido, acompanha as tendências literárias do início do século XX (embora o aspecto da parataxe já se encontrasse presente em autores clássicos) e os discursos paratáticos ganham espaço não só com Adorno, mas em razão da estética fragmentária típica do que hoje chamamos de pós-modernismo. Anacronismos à parte, acredito que a figura gramatical da parataxe oferece mais uma possibilidade para compreensão das obras que se valem deste tipo de construção. Myriam Ávila comenta a respeito da expansão do uso desse conceito:

a ampliação sem precedentes do termo parataxe vai significar uma agudização da percepção crítica da contemporaneidade. A parataxe, na proposta de Adorno, escapa às "figuras micrológicas" do texto, como elas se identificam nos exemplos citados, e que ainda pertencem ao comportamento filológico, passando a nomear toda justaposição de inconciliáveis e toda ruptura injustificada, mesmo que compreendam grandes porções de texto. Abandonos de argumentação, imagens desconexas, interpolações gratuitas, tudo compartilharia do caráter paratático. Tais figuras representariam, em termos de linguagem, o deparar atônito do sujeito com sua própria impossibilidade de significar num mundo em que a linguagem foi domesticada de forma extrínseca por instâncias alheias a ele (ÁVILA, 2006).

Em música popular, o uso da parataxe nas letras é comum. Porém, é interessante observar que essa construção não se limita aos aspectos das frases, mas pode abranger todo o texto, por meio da justaposição das estrofes. Na seguinte frase da Valsa Brasileira de Chico Buarque: "vivia a te buscar porque pensando em ti corria contra o tempo", existe uma conexão frasal hipotática realizada pelo conector "porque". Já em: "doutor, jogava o Flamengo eu queria escutar. Bastou, mudou de estação começou a cantar”, da música Incompatibilidade de Gênios de João Bosco e Aldir Blanc, não há conector entre as frases, tratando-se de uma construção coordenada por parataxe, exigindo que o sentido entre as frases seja intuído pelo ouvinte (ou leitor). Isso reivindica uma atitude mais ativa e participativa, já que o ouvinte deve interpretar aquilo sugerido na letra da música, e não apenas recebê-la de maneira passiva. Observe-se o próximo texto:

\footnotetext{
16 “Assim como a pintura é a poesia”. Aforismo proferido por Horácio (I a.C.) em Ars poetica verso 361.
} 
O chefe da polícia pelo telefone manda me avisar que na Carioca tem uma roleta para se jogar.

Ai, ai, ai, deixa as mágoas para traz ô rapaz,

Ai, ai, ai, fica triste se és capaz e verás.

Tomara que tu apanhes, não tornes a fazer isso,

tirar amores dos outros, depois fazer teu feitiço.

Olha a rolinha, voou, voou, se embaraçou, voou, voou,

caiu no laço, voou, voou, do nosso amor.

Porque esse samba (sinhô, sinhô) é de arrepiar (sinhô, sinhô),

põe perna bamba (sinhô, sinhô), mas faz gozar (sinhô, sinhô).

Esta é a letra daquele que é considerado o primeiro samba gravado no Brasil: Pelo Telefone (1917), cuja autoria foi disputada pelos compositores Donga e Sinhô (curiosamente, houve também a disputa sobre tratar-se mesmo de um samba, pois o anúncio feito pelo locutor da gravadora Casa Edison apresentava um samba carnavalesco. Já Mauro de Almeida, autor oficial da letra, chamou-o de tango-samba, e Donga, autor da melodia, referia-o como um samba amaxixado. Sinhô, requerente da autoria do samba, achava que era um tango. Cf: CALDEIRA, 2007, p. 12). Note-se que as cinco frases do texto não possuem ligação óbvia entre si, são cantadas duas vezes cada, de modo a configurarem-se como estrofes. Constituem, portanto, como blocos justapostos em uma combinação paratática típica. Vale notar também o recurso da citação criado na última estrofe fazendo referência ao próprio compositor, e a apropriação de temas folclóricos, como é o caso da quarta estrofe.

Resumindo o exposto a respeito de justaposição poder-se-ia entendê-la como o inverso da transição. Justaposição implica em ruptura, contraste, ao passo que transição pressupõe suavidade. A justaposição é analisada sob o prisma da parataxe e os processos transitivos são mais próximos da abordagem sintática.

O que se propôs nesse último tópico foi uma espécie de transporte entre as construções características do ambiente literário para o musical, construções estas cuja análise poderia ser lograda valendo-se de combinações paratáticas. Não obstante, as características e as possibilidades de ruptura em meio ao discurso composicional ora tratadas sugerem, em um primeiro momento, agir de encontro à compreensão da obra, justamente por se absterem de conectores lógicos. No entanto, mesmo no âmbito desses procedimentos de justaposição, as atividades perceptuais e cognitivas continuam a operar e a promover ligações de base psicológica. Do contrário, não se lograria êxito na tentativa de se estabelecer qualquer tipo de comunicação em música. Os aspectos ligados à comunicação serão tratados no Capítulo 6, todavia, antes de adentrar a esse terreno controverso, outras considerações se fazem 
necessárias de modo a alicerçar as futuras discussões. Prosseguirei, então, tratando das possibilidades do estabelecimento de sentido em música tomando como partida as transformações temáticas, assunto do próximo capítulo. 
Capitulo 4

TRANSFORMAÇÕES TEMÁTICAS 


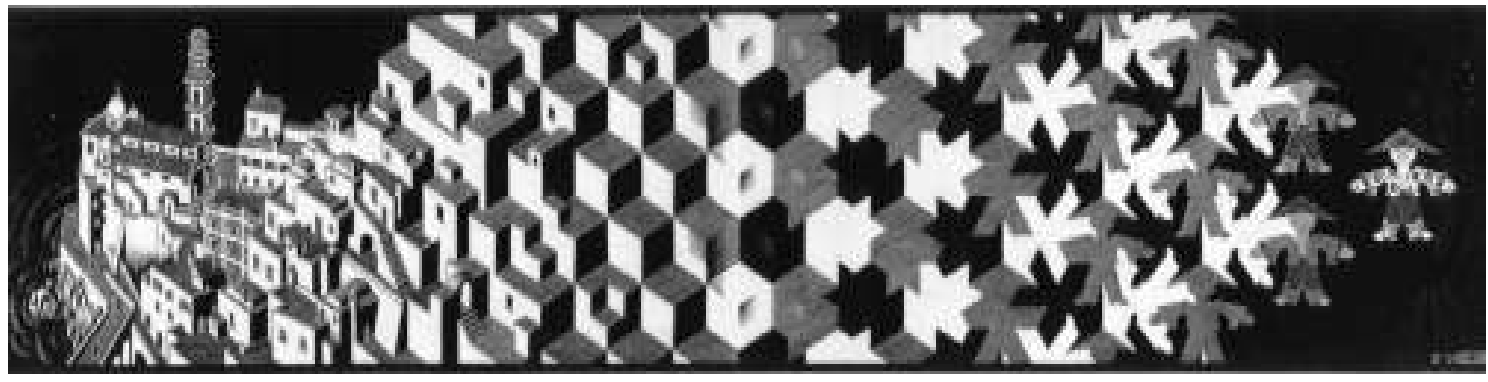

Maurits Escher: Metamorphosis I (1937, xilogravura impressa em duas folhas)

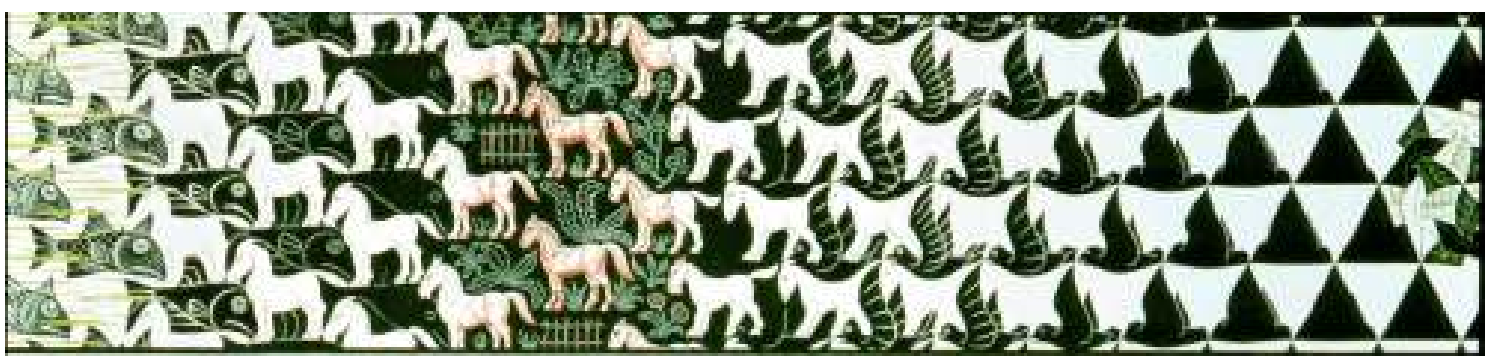

Maurits Escher: Metamorphosis III (1967-1968, xilogravura impressa a partir de 33 blocos sobre 6 placas combinadas) 


\section{Introdução}

É possível postular, quase à guisa de um senso comum, que a música moderna, sobretudo desde o início do século XX, exigiu a renovação da atitude de escuta então arraigada aos padrões estabelecidos pela música tonal. Essa nova atitude demandou, por sua vez, o desapego dos hábitos associados ao "fruir musical tradicional" e requisitou uma maior familiaridade com os novos códigos introduzidos pela estética que se instaurava. Esta proximidade com o código composicional foi exigida visando ao entendimento musical, pois uma vez que as obras não mais se encontravam baseadas no sistema de tonalidades, fez-se necessário buscar outros pontos de apoio para conduzir e balizar a percepção. O novo discurso musical surgido dava-se a partir do material musical, dispensando o equilíbrio formal tradicional, substituindo melodias por séries, resgatando e incluindo inusitadas formações escalares, renovando o pensamento harmônico e acolhendo o acaso. Essas e demais transformações ocorridas sobre a poética musical incidem diretamente sobre sua contra parte estética, trazendo distintas implicações à recepção da obra. Assim, encontrar critérios e elementos que favoreçam ao entendimento musical é tarefa justificada, embora nada fácil.

A despeito da não utilização do sistema tonal, pode-se constatar que o uso de temas e motivos permanece presente na música contemporânea, diferenciando-se, no entanto, somente na maneira como estes são tratados. Os artifícios de variação e desenvolvimento típico dos compositores clássicos encontram correspondência nos procedimentos de transformação temática atuais. Processos esses que não descartam o uso de motivos e temas como estruturas gerativas. O emprego desses elementos, bem como a análise dos processos de transformação a que são submetidos, apresentam-se como parâmetros significativos para o balizamento cognitivo e perceptual envolvidos na recepção da obra.

Em face dessas considerações, este capítulo é desenvolvido mesclando dois aspectos inseparáveis da música contemporânea: poético e estético. Questões ligadas à produção da obra musical focam o recurso composicional específico do desenvolvimento temático/motívico e seus processos renovados de transformações, enquanto os aspectos estéticos valem-se deste mesmo recurso de maneira a auxiliar na compreensão da obra e a criar pontos de apoio perceptuais em meio ao discurso musical pós-tonal. Não obstante, o objetivo principal é investigar a permanência do uso de motivos e temas na música contemporânea, bem como analisar processos de variação, desenvolvimento e demais tipos de transformações motívica e temática. Embora o interesse central seja eminentemente técnico, essa proposta também é permeada por reflexões estéticas, na medida em que fornece elementos para especular sobre recepção e crítica da música contemporânea, fatores estes ligados à comunicação musical, que serão discutidos no Capitulo 6. 
O corpo teórico da parte composicional fundamenta-se na idéia do tematicismo. Este conceito foi apresentado e desenvolvido por Rudolph Réti, sobretudo em seu The Thematic Process In Music (1951), encontrando desdobramentos posteriores na obras de diversos autores, citados ao longo do presente texto. A concepção tematicista busca analisar a totalidade da obra musical como derivada de um enunciado temático principal, que seria responsável por engendrar e formatar os gestos e as relações subseqüentes entre as estruturas rítmicas e sonoras. Essa proposta encontra eco em diversos teóricos da pós-tonalidade (como Forte, Saltzer, Babbitt, Lewin, entre outros) com a ressalva de que estes substituem o conceito de tema por motivo, diferenciação esta que será tratada no decorrer do capítulo. A concepção de 'música motívica' é largamente comentada por diversos teóricos, no entanto, a referência principal deste capítulo será Introduction to post-tonal theory (1990) de Joseph Straus.

Os aspectos estéticos e críticos encontram respaldo na proposição de Roger Scruton (1997) e Joseph Kerman (1987), respectivamente. A abordagem estética de Scruton foca-se essencialmente em parâmetros da música, diferentemente da obra de outros estetas que, costumeiramente, prendem-se a aspectos históricos e a questões filosóficas ligadas ao pensamento de cada época, pouco se dedicando a considerações realmente musicais. Scruton, por outro lado, atém-se à recepção do repertório partindo essencialmente de critérios inerentes à própria música, como por exemplo, características sonoras, timbrísticas, estruturais, rítmicas, tonais, entre outras. Esse posicionamento está em sintonia com a já mencionada atitude de renovação da escuta, reivindicada pela música contemporânea. A contra parte "crítica musical" respalda-se em Kerman, que preconiza o uso da análise musical como um dos parâmetros norteadores para avaliação e valoração de uma obra musical. O ponto de contato entre estes dois autores se dá pela exigência de um exame detalhado dos eventos que concorrem para a apreciação musical, pois para que os aspectos musicais envolvidos na fruição de uma obra sejam dimensionados é preciso que sejam estudados, isto é, detectados, identificados e discutidos, o que implica necessariamente na análise musical.

Antes de adentrar a particularidades técnicas embutidas na proposta de transformações temático-motívicas, introduzirei brevemente alguns apontamentos ligados aos aspectos perceptuais.

\section{Recepção, percepção e compreensão}

Stravinsky é lacônico: "a música não expressa nada além dela mesma” (apud CRAFT, 1984, p.91). Schoenberg, por sua vez, ao comentar a idéia geralmente aceita de que a música teria a capacidade de expressar algo exterior a ela mesma, disse que "do ponto de vista puramente estético [a música] não expressa nada de extra-musical" e segue: "do ponto de vista psicológico, porém, nossa capacidade de associações mentais e emotivas é ilimitada" 
(SCHOENBERG, 1993, p. 119). Esta afirmação, ao bipolarizar a percepção musical, oferece duas vertentes para o confronto de um discurso musical: a estética e a psicológica. Esta bipartição implica em considerar o pólo psicológico como subjetivo, posto que é incontrolável por parte do compositor por tratar-se de uma construção própria do sujeito fruidor, pois as associações emotivas não se encontram no plano racional. $\mathrm{O}$ aspecto estético, por sua vez, denotaria objetividade, porque se atém a elementos intramusicais, tecnicamente manipulados e organizados no plano composicional.

A colocação da estética em um âmbito objetivo é menos paradoxal do que pode parecer. Estética entendida como o estudo do 'belo' implica em juízo de valores. Um juízo de gosto comporta uma carga subjetiva acentuada, já que pressupõe decisões pessoais. Um juízo artístico, contudo, promove a referida valoração estética alicerçada em critérios objetivos, pois a apreciação deste 'belo' é realizada avaliando-se os elementos intrínsecos à obra, restando pouca, ou nenhuma, relevância a preferências particulares e às associações extramusicais surgidas durante a escuta. Reencontra-se assim, o que Dalhaus (Cf. 1991, p. 123) salientava com respeito ao que definiu como a imediatidade mediada pela reflexão, ou seja, o imediatismo de uma primeira sensação advinda da contemplação artística, efêmera que o é, "mergulha na reflexão", pois o momento de contemplação não é desvinculado das nossas experiências e referências anteriores, mas está inexoravelmente atrelado ao juízo histórico. Uma escuta não é absolutamente pura ou isenta, mas compreende uma carga histórica e cultural apreendida e vivenciada no meio social onde o indivíduo convive. Desse modo, é possível afirmar que a subjetividade é, em verdade, intersubjetiva, pois pressupõe aprendizado e acordo mútuo entre pares de um mesmo ciclo sócio-cultural. Ninguém é capaz de dizer se gosta ou não de alguma coisa com a qual não teve oportunidade de travar contato.

Com esse exposto, compreende-se que a atividade da percepção musical traz em si os aspectos do meio musical em que foi criada, já que a "experiência musical ocorre somente no interior de uma cultura, cuja tradição de escuta e interpretação formata nossas expectativas" (SCRUTON, 1997, p.239). Na cultura ocidental, essas expectativas durante séculos foram ${ }^{17}$ engendradas pelo sistema tonal. Todavia, as experiências sonoras de renovação da linguagem musical surgidas desde o início do século XX trouxeram novas propostas em substituição ao modelo tonal, fato este que interferiu na tradição de escuta ocidental e apresentou novos problemas ao entendimento musical. Neste momento, cumpre indagar que hábitos de escuta eram esses e de que maneira facultavam o entendimento de uma obra musical.

\footnotetext{
${ }^{17}$ A bem da verdade as expectativas ainda são geradas pelo sistema de tonalidades, pois a produção musical veiculada cotidianamente nos diversos meios de difusão sonora é majoritariamente tonal.
} 
Em 1939 Aaron Copland publicava seu livro What to listen for in music, trabalho no qual assumia a tarefa de "expor com a maior clareza possível os fundamentos da escuta inteligente da música" (COPLAND, 1986, p.7). Copland sugeriu que a escuta musical ocorreria em três planos distintos assim nomeados: sensual, expressivo e puramente musical. O plano sensual, aquele pertencente aos sentidos, envolve apenas as sensações imediatas despertadas pela música e está restrito às primeiras impressões, já que não pressupõe desdobramentos racionais. O plano expressivo refere-se à capacidade de significação musical, quer seja esta a expressão de idéias musicais ou mesmo de algo extramusical. Claro que o compositor pode contribuir com essas sugestões, sobretudo quando a peça traz um título que implique em possíveis correspondências extramusicais. Por exemplo, o ouvinte ao ler o título Jeux d'eau, peça para piano de Ravel, pode ficar induzido a promover associações musicais que lembrem um rio ou fluxo de água corrente. Em certa medida o plano expressivo assemelhasse à proposta de Schoenberg anteriormente comentada, isto é, à possibilidade de ocorrerem associações psicológicas ocasionadas durante a escuta. O terceiro plano da escuta musical proposto por Copland (o plano puramente musical) trata dos elementos da estrutura musical bem como dos seus processos de composição.

Sem discutir o mérito ou a pertinência da proposição de Copland, a apresentação de suas idéias permite efetuar uma dedução que, de tão óbvia, às vezes é negligenciada. Os planos sensual e expressivo, em tese subjetivos, são afetados pelo plano puramente musical (controlado pelo compositor), pois qualquer alteração deste modifica parâmetros de escuta nos outros planos. Uma obra reflete a maneira de escuta do compositor já que este é o primeiro ouvinte de sua própria obra. Isto traz implícito, conseqüentemente, a quase que inevitável modificação de elementos estruturais durante a produção da obra, pois à medida que é produzida é também alterada de acordo com a vontade do autor - característica esta que incidirá no modo de escuta da obra acabada. O processo de composição traz embutido uma escuta gerenciada pelo compositor, que está atento a aspectos puramente musicais. A questão permanece, embora agora mais direcionada: de que maneira os elementos puramente musicais viabilizam o entendimento da obra?

Por entendimento musical "compreende-se uma atividade cognitiva de organização mental que congrega elementos sonoros e os registra como sons musicais dispostos em uma ordem tonal" (SCRUTON, 1997, p.211). A configuração (ou gestalt) formal realizada racionalmente faz com que percebamos sons musicais interagindo em uma moldura temporal, ao invés de apenas percebê-los como meras seqüências de notas. Como já referido, o paradigma ocidental para a organização tonal há séculos tem sido o sistema de tonalidades. 
Tonalidade é mais que uma maneira de organizar melodia e harmonia projetadas em uma única sonoridade central, também é mais que um relacionamento entre harmonias ou uma maneira particular de controlar a condução melódica. A tonalidade afeta todos os aspectos da música, incluindo fraseologia, forma, interação entre melodia e harmonia, textura, orquestração, dinâmica, articulação, estruturação do tempo (ritmo, metro e o senso de continuidade e movimento), mesmo a maneira como nomeamos alturas e intervalos. Se uma peça não é tonal, então muitos desses aspectos musicais adquirem novas características (LESTER, 1989, P.2).

Na citação de Lester, alguns dos parâmetros responsáveis pelo entendimento musical são mencionados (frases, texturas, harmonias, etc.). Ao lado destes, a dinâmica implícita na resolução das dissonâncias, a própria formatação dos acordes por superposição de terças e as características intervalares presentes na construção de melodias também podem ser incluídos (cite-se, à guisa de exemplo, as prescrições para a construção de um cantus firmus). Esses elementos e a maneira como são dispostos na composição foram os responsáveis por gerar os hábitos de escuta vinculados à tonalidade. É possível pensar, em razão disso, que temos a tendência de realizar comparações entre os elementos apresentados no discurso musical, associando-os em razão de suas similaridades ou afastando-os pela da falta das mesmas.

Eventos sonoros, uma vez ordenados rítmica, melódica e harmonicamente como eventos musicais, permanecem em relações perceptíveis uns para com outros. Uma frase pode ser ouvida como uma variação, versão, ou elaboração; ela pode responder ou completar outra frase. E nosso entendimento dessas relações é comparável ao nosso entendimento do gesto (SCRUTON, 1997, p.230).

Todavia, como se dá perceptualmente a organização lógica desses parâmetros musicais?

De acordo com Schoenberg, a resposta àquilo que permite e viabiliza logicamente o encadeamento entre os sons está na série harmônica: "todos os fenômenos musicais podem ser referenciados à série harmônica, de maneira que todas as coisas parecem ser a aplicação das mais simples ou mais complexas relações desta série" (SCHOENBERG, 1985, p. 271). Um entendimento semelhante é encontrado em Helmholtz, que também imputava à serie harmônica a razão da afinidade entre os sons. Ambos autores entendem a existência de conformidades entre os elementos da estrutura musical e a série harmônica, tendo por argumento o pressuposto de que só elementos similares permitem ser unidos. Alois Hába, entretanto, refuta essa idéia, alegando que só a série harmônica não basta para viabilizar a lógica e continuidade das idéias musicais, pois assim sendo, os sons separados por pausas não encontrariam um nexo compreensível pelo fato da nossa memória não poder reter seus atributos harmônicos. Hába supõe que esta lógica é tornada possível por meio de relações associativas de base psicológica. A retenção de fatores sonoros na memória é um meio de concatená-los. Esta situação é assim descrita: 
A continuidade do processo musical reside no impulso criador central, que se desprende na sucessão orgânica dos sons, consumindo-se. As relações sonoras deste impulso central atravessam e sobrepassam também os incisos temporais (pausas) e unificam a concepção musical do acorde. Se os harmônicos fossem a causa principal da sucessão dos acordes, então a menor pausa destruiria esta sucessão. Pelo contrário, sabe-se pela práxis que são precisamente as pausas que completam a plenitude do discurso musical. Isto ocorre através de relações associativas (HÁBA, 1984, p. 6).

Schenker também prescinde da série harmônica e confere ao motivo a responsabilidade pela associação de idéias em música. Segundo ele, o uso do motivo subtrai à música subordinações extrínsecas à sua natureza, como por exemplo, subserviência aos textos, à dança, ao teatro, etc. Em contrapartida, permite associações intrínsecas, isto é, realizadas interna e diretamente sobre os próprios motivos; assim, não se faz mais necessário à música tentar imitar padrões da natureza. Schenker define motivo como uma série recorrente de sons, constituindo-se como célula germinal única e singular da música como arte, e afirma: "a música tornou-se arte, no sentido real da palavra, somente com a descoberta e uso do motivo" (SCHENKER, 1980, p.4). O emprego de motivos permite iterações, e estas, por sua vez, engendram as formas.

Somente por repetição uma série de sons pode ser caracterizada como algo definido. Somente a repetição pode demarcar uma série de sons e sua proposta. Repetição é a base da música como arte. Ela cria a forma musical assim como a associação de idéias a partir de um padrão da natureza cria outras formas de arte (SCHENKER, 1980, p. 5).

Analogamente ao discurso verbal, que necessita de um assunto a ser discutido, o discurso musical faz uso de temas e motivos como idéias a serem postas em debate, idéias que são apresentadas e desenvolvidas musicalmente. Uma peça que apenas propõe uma ampla variedade de temas sem, contudo, desenvolvê-los, correrá o risco de não ser compreendida, pois muita informação é informação nenhuma (como desde muito aponta a teoria da informação) e isso ocorre em razão da ausência de expectativas, já que quando tudo tem probabilidade de ocorrer, tudo será esperado e nada causara surpresa - que é o parâmetro quantificador da informação. Com intuito de amparar e melhor fundamentar essa concepção, apresentarei a seguir alguns aspectos associados ao uso de motivos, temas e procedimentos de transformação temática empregados em ambiente pós-tonal.

No contexto tonal tradicional pode-se entender motivo como a menor idéia musical passível de ser identificada. Um motivo é um padrão intervalar, rítmico ou mesmo rítmicointervalar, caracterizado pelo seu contorno (ou perfil) que se constitui enquanto a menor figura rítmico-melódica utilizada como elemento de estruturação da composição. Todavia, como ressalta Douglass Green, "nem toda figura ou fragmento melódico é um motivo. Para que atue como um elemento de construção e constitua-se enquanto motivo deve aparecer ao menos duas vezes, embora seu reaparecimento não precise ocorrer na forma original" 
(GREEN, 1965, p.31). Assim, a prescrição da repetição já implica em variação, pois do contrário o discurso se tornaria monótono e desinteressante. Na definição de Réti, motivo é "qualquer elemento musical, seja este uma frase melódica, fragmento ou somente uma característica rítmica ou dinâmica, que por ser repetida e variada no decurso da composição, ou de uma seção, assume uma função estruturadora no projeto composicional" (RÉTI, 1951, p.11). Na música pós-tonal, motivo estende suas implicações e passa a envolver e ser envolvido em todos os aspectos estruturais, inclusive o formal (quando a forma é resultante da estruturação motívica, vide adiante). Buscando desvencilhar-se de implicações tonais, os autores sugeriram adotar o nome conjunto em substituição a motivo para designar grupos de alturas responsáveis pela estruturação da música não tonal.

Tema, em contrapartida, por vezes adquire o mesmo sentido que frase, período ou melodia. Algumas definições realçam o fato do tema ser construído de motivo(s). No propósito deste trabalho o uso dos termos tema e motivo será equiparado, pois compartilho da definição de Réti ao entender que o peso não deve ser posto na definição das palavras, já que melodia, período, motivo e tema são seqüências lineares de alturas e durações entendidas em si, portanto, percebidas como entidades autônomas. O foco passa a residir na função desempenhada pelos mesmos. Conseqüentemente, independente do nome atribuído pelo compositor, na medida em que uma frase, frase melódica ou período adquirir uma função motívica, isto é, servir a propostas de construção (exercer o papel de estrutura gerativa) e de desenvolvimento (ser passível de variação, transformação, prolongação, etc) os mesmos serão entendidos e tratados de maneira intercambiável ${ }^{18}$. Fica claro, portanto, que o aspecto chave na conceituação e diferenciação tematicista é o fato do tema ser usado como elemento estruturante. Pensemos, como exemplo, em uma composição que apresente uma linha melódia calma, singela e muito expressiva, como o solo de corne inglês da Sinfonia $n^{\circ} 9$ Novo Mundo de A. Dvörak. Neste caso esta linha será definida como melodia justamente porque não é desenvolvida durante a obra, mas é apenas repetida como espécie de refrão dentro da convenção de forma canção. Por outro lado, o primeiro movimento da mesma sinfonia será entendido como tema, pois a linha melódica se presta a vários tipos de desenvolvimento no âmbito formal deste movimento.

Não obstante, o termo tema parece ter sido deixado de lado pelos teóricos da póstonalidade, em razão de remeter a formas musicais tradicionais, como a sonata, o tema com variação, etc. Em 'De l'ambiguité de la notion de "thème" pour l'analyse musicale'? (1988)

\footnotetext{
${ }^{18}$ Curiosamente, há quem entenda o contrário, ou seja, que o tema (ao invés do motivo) comporta o papel característico de receber variações, como nesta definição: "uma célula melódica constitui um motivo se apresenta função temática, ou seja, se é desenvolvido ao longo do discurso e se é responsável pela unidade e pela sonoridade particular da obra" (BITONDI, 2006, p. 40).
} 
Nicholas Cook aponta que mesmo entre os analistas da forma sonata (Tovey, Schenker, Rosen) o termo "tema" foi gradativamente substituído por "área tonal”. Dessa maneira, a forma sonata passa a ser entendida enquanto um jogo de tonalidades, ao invés de um confronto entre primeiro e segundo temas. Como decorrência desse novo entendimento, "o conceito de tema tornou-se perigoso em explicações analíticas sérias da forma sonata" (COOK, 1988, p. 30).

Esse abandono da primazia do tema enquanto parâmetro analítico principal deveu-se, sobretudo, ao fato do tema constituir-se como um elemento de superfície, àquilo que é percebido mais imediata ou evidentemente. No século XVIII a forma sonata fora concebida como uma estrutura em duas partes caracterizadas pelas distintas regiões harmônicas apresentadas e pela oposição engendrada entre elas. No século XIX, com o início da expansão da tonalidade por regiões harmônicas afastadas, projeta-se sobre o tema uma nova importância na realização de contrastes e enquanto determinante formal. Os analistas do século XX, principalmente os adeptos do schenkerianismo, estavam mais atentos a tratar das estruturas organizacionais, ou seja, ir além dos dados de superfície e penetrar no plano de fundo, no alicerce ou formação de base que sustenta e dá coerência à obra. Entretanto, como será discutido adiante, o uso de temas e motivos pode desempenhar ambos papéis, funcionando tanto como elemento de articulação entre as relações de superfície (estruturas gerativas) quanto substrato organizacional (processos construtivos). Além disso, na medida em que se avança nesta proposição, a elaboração temática considerada mais amplamente poderá também envolver o aspecto cognitivo, servindo como parâmetro auxiliar na compreensão musical, alcançando, por fim, a possibilidade de emprego enquanto ferramenta da crítica musical que, tendo na análise musical seu princípio condutor, permitirá encampar os aspectos comunicativos como critério de valoração estética.

Vale lembrar que a forma sonata, principal motivo dessas distintas interpretações, continuou a ser utilizada em ambiente não tonal. Muitos compositores tornaram-se alvos de críticas por se valerem de modelos formais tradicionais, como a sonata. Logicamente não é fácil a reconstrução deste modelo em um contexto atonal, justamente pela ausência das relações harmônicas que lhe dava sustentação. "Na forma sonata, o evento estético central do movimento inteiro é o retorno do tema principal na segunda parte, calculado para dar-se simultaneamente ao retorno da tônica" (Grove, 1980, p.497). E essa é mais uma das razões que coloca em evidência o desenvolvimento temático, porque os compositores no século XX tiveram que renovar os antigos aspectos ligados aos modelos formais no que dizia respeito aos procedimentos harmônicos (não mais presentes na música atonal) associados a novos meios de tratamento dos temas e motivos. Reacionários ou não, o fato é que o uso da forma sonata 
pelos compositores contemporâneos provou que esse modelo não apenas continuava funcionando mas, também funcionava como elemento técnico composicional favorecedor da percepção da música complexa. Para uma análise mais detalhada dessa situação passarei a tratar de aspectos da poética composicional.

\section{Tema e planos estruturais}

Adentrando a características mais especificamente técnicas, pode-se pensar em uma maneira bem básica de associação entre tema e estrutura harmônica.

O exemplo a seguir demonstra como um tema apresentado a princípio enquanto estrutura gerativa, captado como elemento de superfície, também pode ser concebido como estrutura de base da composição (Exemplo 1-4).

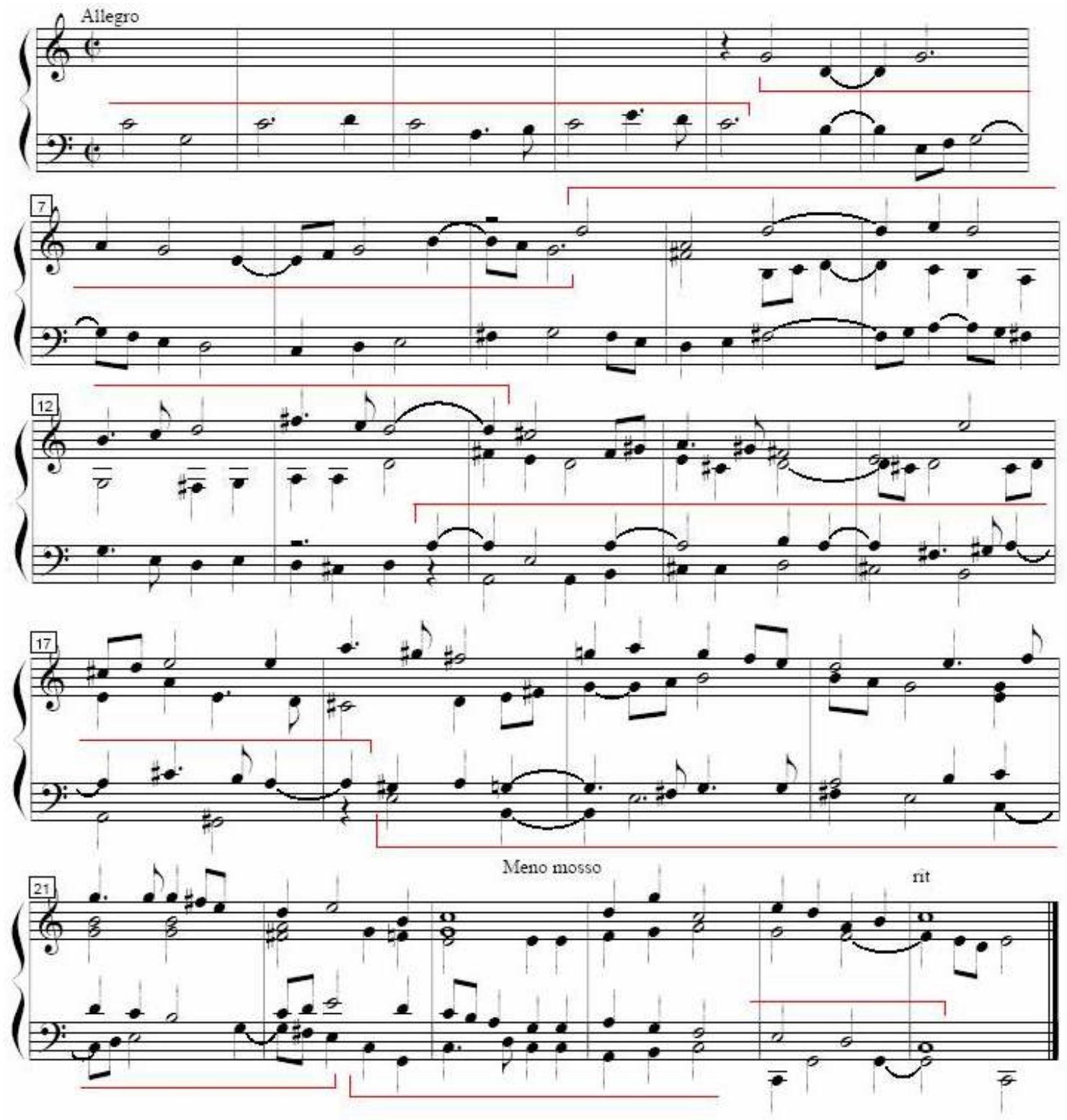

Exemplo 1-4: Estrutura do tema gerencia as entradas imitativas do Cânone. 
O exemplo 1-4 trata-se de um pequeno cânone em diapente, cujo tema é apresentado em $C$ (compassos 1-5), seguindo-se a primeira imitação em $G$ (compasso 5), a segunda em $D$ (compasso 9), a terceira em $A$ (compasso 13), a quarta em Em (compasso 19) e a última retornando a $C$ (compasso 22) em diminuição. Desse modo, as regiões harmônicas compreendidas pelas entradas imitativas seguem a seqüência seguinte:

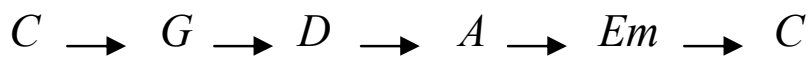

Essa seqüência não só confere direcionalidade como também determina a forma da peça. Essa determinação estrutural não é arbitrária, mas sim, retirada, justamente, da construção melódica do próprio tema usado como gerador das imitações. Olhando o tema mais detidamente, observa-se que o mesmo possui as notas correspondentes àquelas usadas nas imitações, ou seja, à exceção de ornamentos (notas de passagem $B$ e $D$, colcheias dos compassos 3 e 4 , respectivamente) as entradas imitativas estão organizadas em correspondência com a estrutura melódica do tema. Assim, um elemento de superfície (o tema) governa a estrutura de base geral da peça.

\section{Artifícios de transformação temática}

No quarto capítulo de seu livro, Réti demonstra (tendo como base principal as obras de Beethoven) vários recursos de transformação temática utilizados tradicionalmente. Entende que antes do período clássico o mecanismo de elaboração composicional restringia-se basicamente aos usos de imitação e de variação. Contudo, desde o período clássico, o método básico de desenvolver idéias musicais passou a ser a transformação temática. Enquanto os procedimentos de imitação (modificada ou não) e de variação eram usados isoladamente, os artifícios de transformação são empregados em combinação. Seguirei identificando os mecanismos de transformação temática apontados por Réti, para posteriormente compará-los com outros artifícios transformacionais empregados na pós-tonalidade. Como Réti oferece diversos exemplos de obras clássicas, irei abordar os procedimentos priorizando, na medida do possível, analisar peças mais atuais mesmo ao comentar mecanismos tradicionais, já que estes são de largo uso na modernidade.

1. Inversão: movimentação contrária, ascendente torna-se descendente e vice-versa.

$\mathrm{Na}$ técnica dodecafônica, inversão implica em alteração intervalar e mudança do movimento. Assim, a inversão de uma quarta justa ascendente $(C-F)$ resulta em uma quarta justa descendente $(C-G)$. Porém, para Réti a inversão está atrelada à inversão intervalar (onde a terça maior é a inversão da sexta menor, por exemplo) e aparecerá sempre associada à reversão (a última nota de um padrão torna-se a primeira do novo padrão, equivalente ao retrógrado da técnica serial). Dessa maneira, inversão implica em mudança de direção (ou 
movimentação contrária) e retrogradação, pois a última nota de uma seqüência será a primeira da próxima. Por exemplo, no fragmento seguinte, extraído da sonata para piano de Camargo Guarnieri, a mão direita do pianista realiza uma sucessão de blocos acórdicos superpostos em quartas, segue-se uma movimentação descendente partindo da nota $D$ até a nota $A$. A seguir, a movimentação é invertida, partindo de $A$ e chegando em $D$. Percebe-se que a nota final de um padrão foi usada para iniciar o outro, implicando na movimentação contrária e na retrogradação.

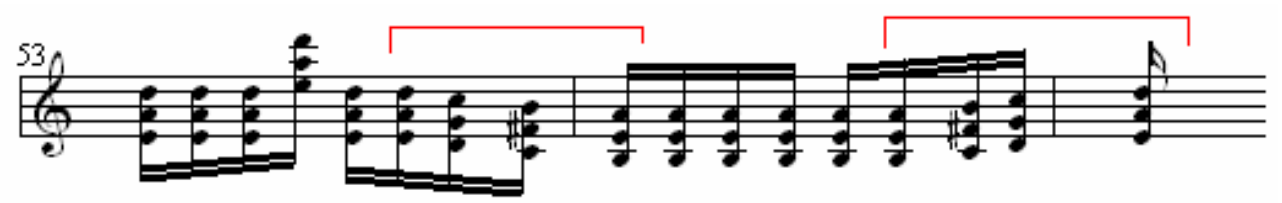

Exemplo 2-4: Guarnieri, Sonata para piano, compassos 53-54, mão direita. Inversão segundo a concepção de Réti.

Imbuído desta concepção de inversão, os compositores da pós-tonalidade encontraram novas maneiras para trabalharem o conceito. Na mesma obra, Guarnieri emprega o princípio da inversão com mais liberdade. Na apresentação do tema (vide Exemplo 3-4), o mesmo é "harmonizado" com aglomerados acórdicos construídos com intervalos de quintas e quartas justas (que ocorrem sempre linearmente) e com outro agregado constituído da junção dos intervalos de quarta aumentada e quinta justa (ocorrentes sempre verticalmente). É interessante notar que a inversão da quarta justa é a quinta justa, e vice-versa; assim, nesta passagem uma ocorrência linear de quintas justas descendentes é sucedida por outra, agora invertida, de quartas justas ascendentes, um artifício que mantém a idéia de inversão proposta por Réti. Além disso, uma seqüência linear não precisa ser apresentada na forma completa para ser estabelecida, mas pode ser modificada de maneira a encampar alguns intervalos verticalmente. No compasso 5 (Exemplo 3-4), na série de quartas $E-A-D-G-C-F$ as notas $A-D$ e $C-F$ aparecem simultaneamente, o que não descaracteriza a sucessão de quartas. O Exemplo 3-4 mostra essas inversões, variações e o agregado acórdico citado.
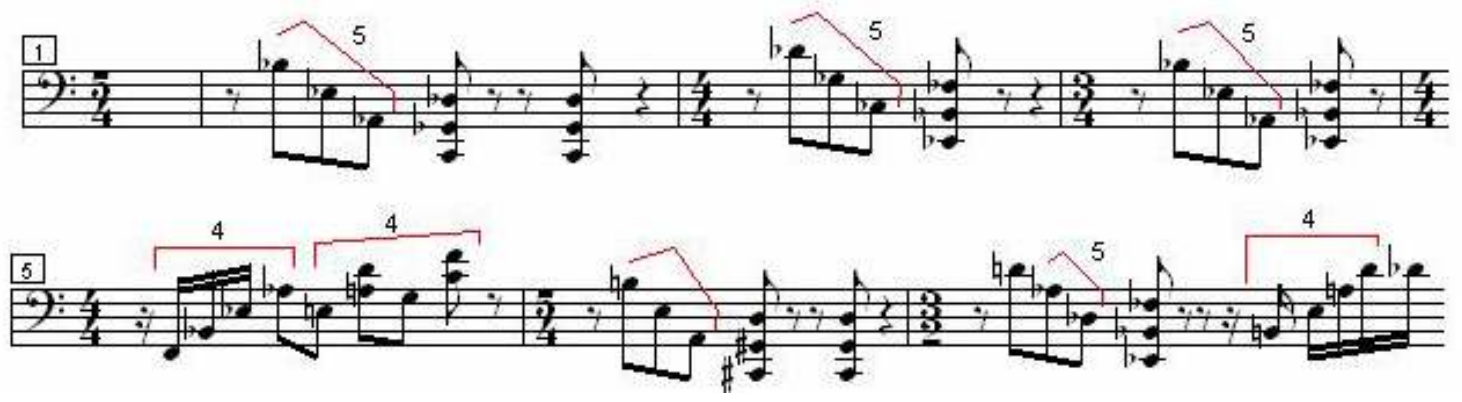

Exemplo 3-4: Guarnieri, Sonata para piano, compassos 1-7, mão esquerda. Inversões (5J e 4J) e agregado acórdico $(4 \mathrm{aum}+5 \mathrm{~J})$. 
2. Modificação de durações: transformações geradas pelo emprego de diminuição e aumentação de valores de duração já eram de uso freqüente no repertório tradicional desde, pelo menos, a renascença. Todavia, esse procedimento é mantido pelos compositores contemporâneos. O Exemplo 4-4 demonstra o processo de diminuição e de aumentação, extraídos da II Sinfonia de Camargo Guarnieri. Esses artifícios podem também receber certa renovação, por exemplo, quando o compositor não realiza a aumentação ou diminuição de todo o tema, mas apenas de parte dele, havendo um misto de modificação e manutenção que diversifica o processo. O Exemplo 5-4 mostra um pequeno excerto da Sonata para piano de Guarnieri na qual esse procedimento é empregado. Note-se que no tema (compasso 1) as notas $G \#-B-A$ têm valores de colcheia, ao passo que no compasso 13 são diminuídas pela metade, porém o resto do tema é preservado na forma original, há assim uma diminuição parcial do tema. A seguir, a forma diminuída será usada como mote para uma nova seqüência (compasso 14).
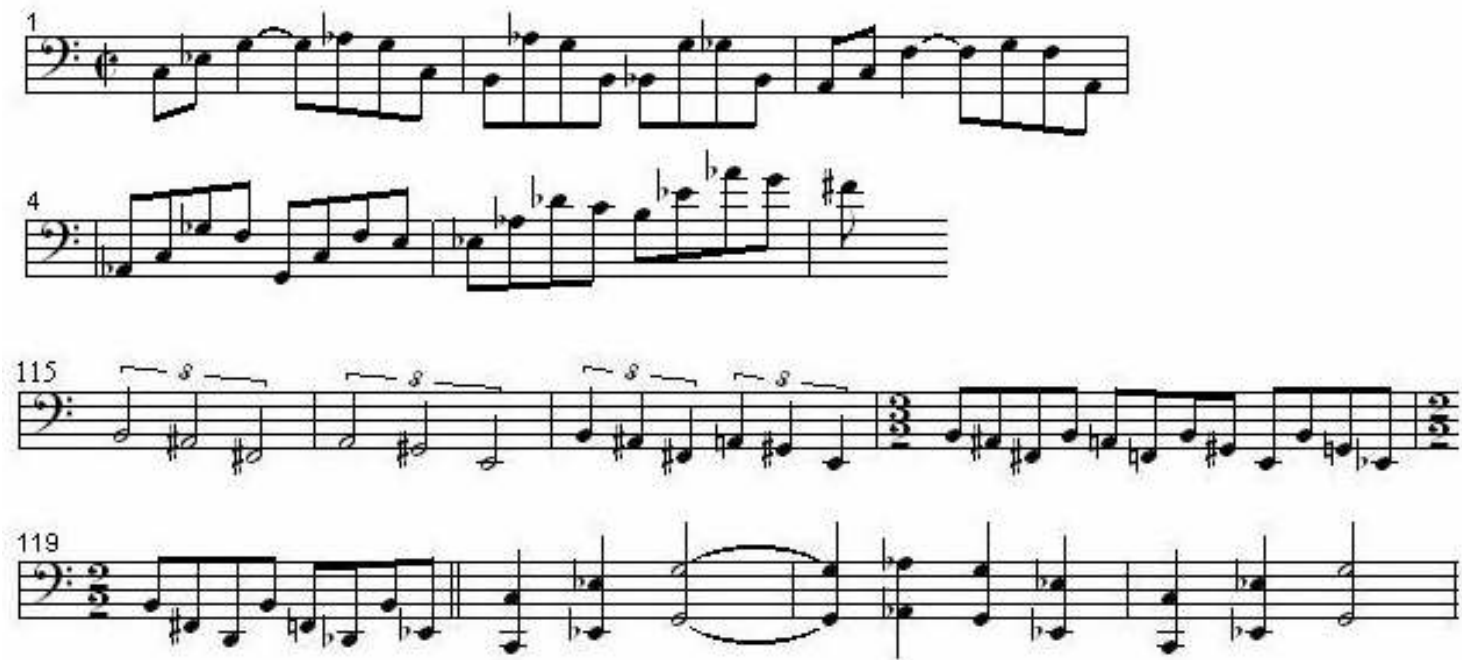

Exemplo 4-4: Guarnieri, Sinfonia $n^{\circ}$ 2, Uirapuru. Primeiro tema (compassos 1-6). Artifício de diminuição (compassos 115-119). Tema em aumentação (compassos 120-122).

Percebe-se, então, que mudanças de ritmo e de tempo (aumentação e diminuição) não precisam ser realizadas literalmente, mas pode haver pequenos desvios rítmicos contando ainda a possibilidade de acréscimos de células rítmicas diferentes entre as células que compõem o tema. 

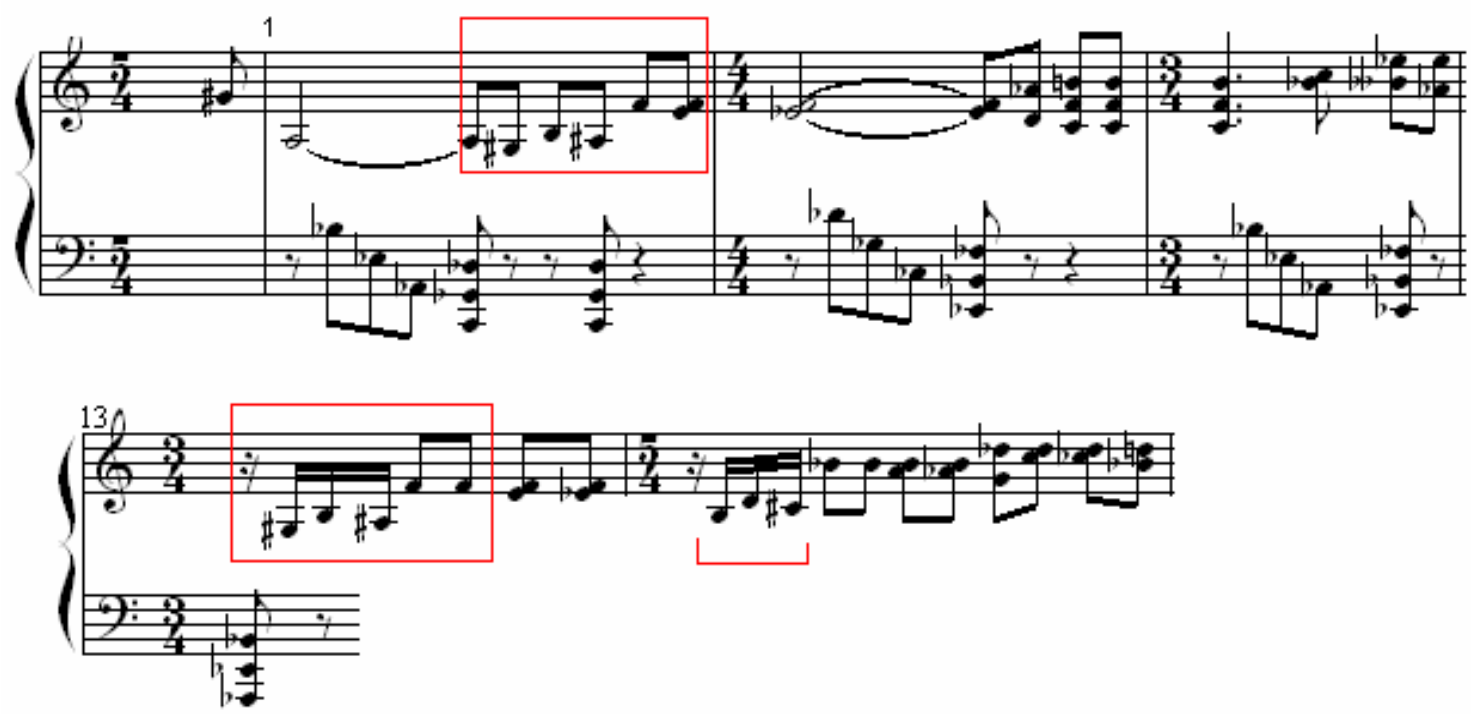

Exemplo 5-4: Guarnieri, Sonata para piano, compassos 1-3 e 13-14, diminuição parcial do tema.

Uma outra possibilidade para variação, também ligada à transformação da estrutura rítmica do tema, é o artifício de prolongação. Há distintas possibilidades deste artifício, mas o mais comum é o acréscimo de notas ao tema original. No exemplo 6-4 (fragmento de minha peça Trilhas Sonoras) o tema é apresentado nos 3 compassos iniciais (pentagrama superior), na seção seguinte, compassos 36 e 39 (pentagrama inferior), o mesmo é prolongado por meio da reiteração rítmica de uma das notas do tema. Esse procedimento transfere o foco do parâmetro da altura para o domínio rítmico.

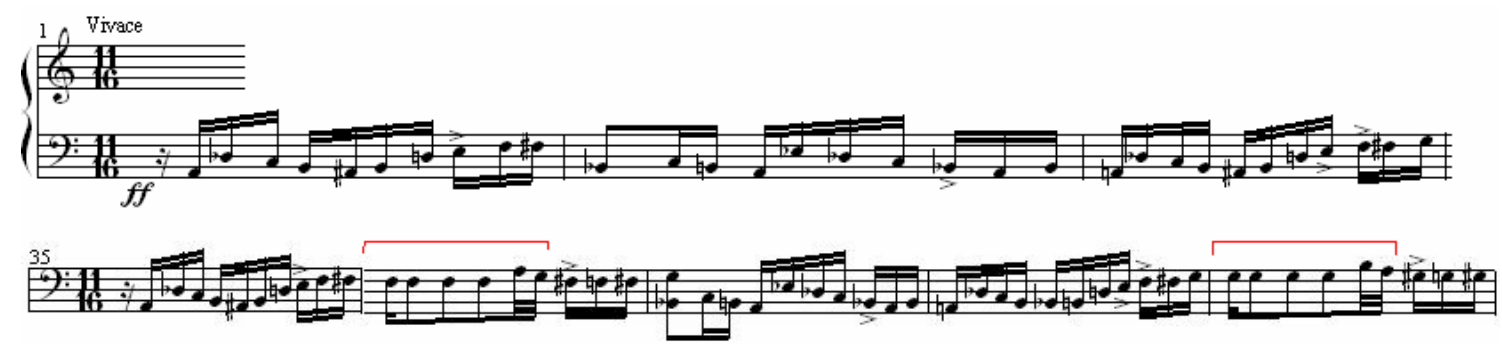

Exemplo 6-4: Antenor Ferreira, Trilhas Sonoras, compassos 1-3 e 35-39, prolongação do tema pela repetição de nota e reiteração rítmica.

O mesmo artifício de prolongação acontece na sonata de Guarnieri. O tema tem entre seus elementos característicos uma sucessão cromática assinalada no Exemplo 7-4 e transferida para um pentagrama adicionado acima (notas sem hastes). No compasso 63 essa sucessão cromática é prolongada pelo uso conjunto dos artifícios de reiteração e repetição. 

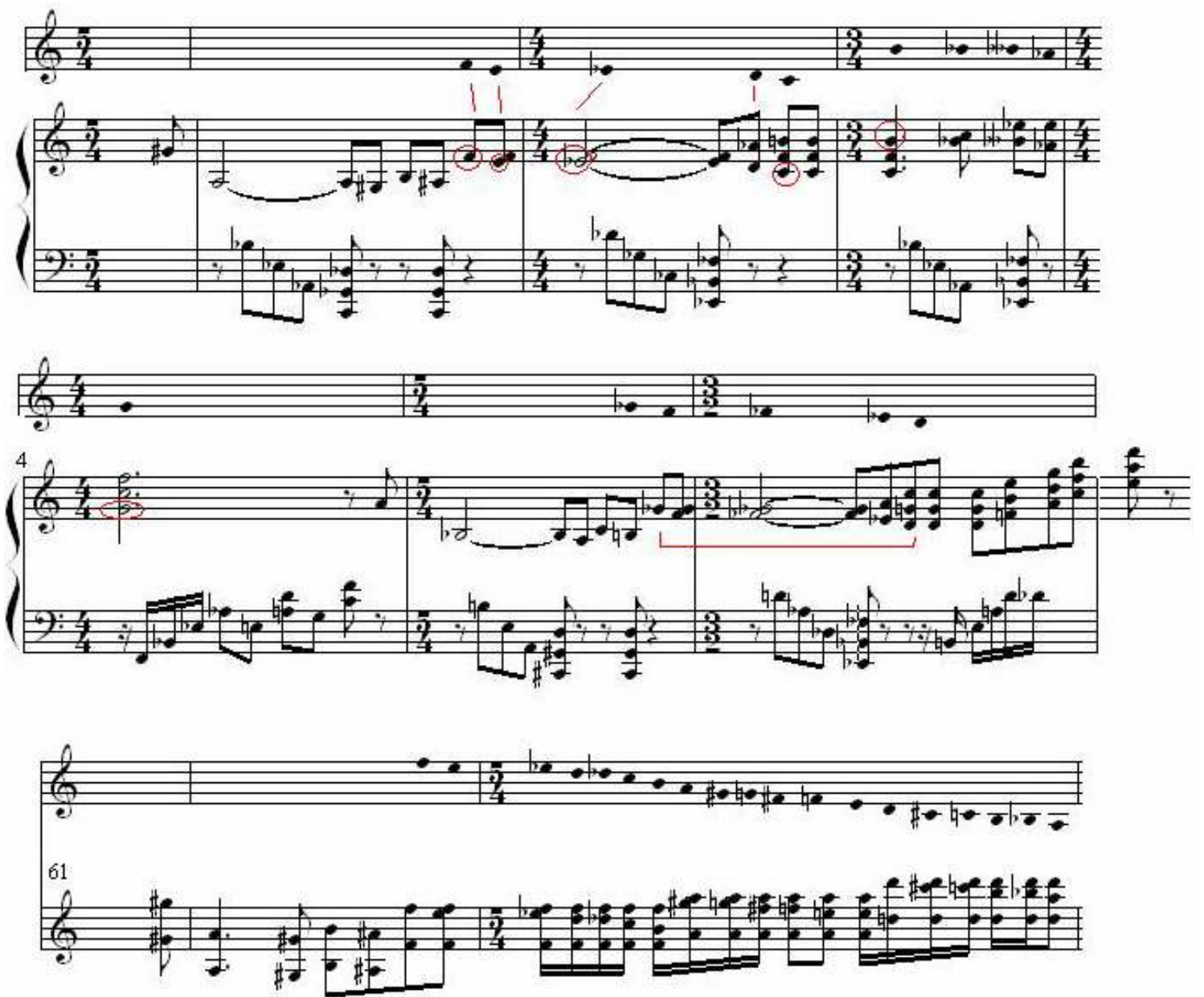

Exemplo 7-4: Guarnieri, Sonata para piano I, compassos 1-6 e 61-63, prolongação da sucessão cromática do tema associada á repetição de notas e reiteração rítmica.

Mudanças métricas apresentam-se como outra possibilidade para transformações da estrutura rítmica. Modificações das posições métricas forte e fraca e variação de acentuação também ocasionam transformações de caráter e conformação de perfil da célula original. No Exemplo 8-4 são mostradas duas transformações: transposição de alturas e mudança métrica. No compasso 32 o segundo tema do segundo movimento da Sonata de Guarnieri aparece pela primeira vez, camuflado pelo acompanhamento e pelo modo como é apresentado em uma voz intermediária. No compasso 49 o tema passa para o registro agudo, transposto um tom acima, porém em uma métrica completamente modificada. Vale notar que esse tema será utilizado como sujeito da fuga no terceiro movimento desta peça. 


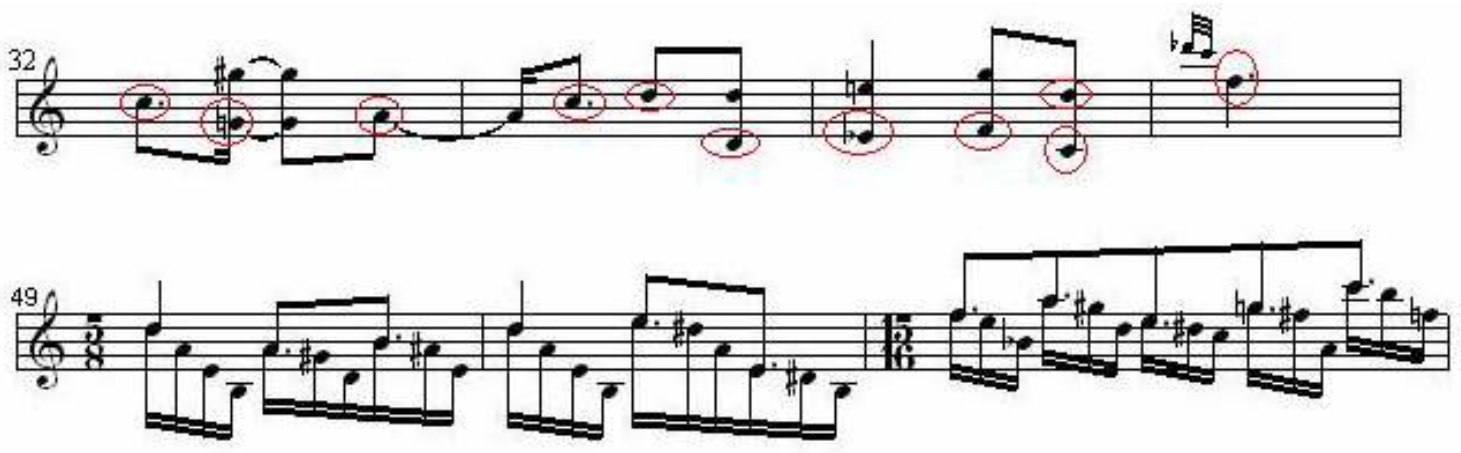

Exemplo 8-4: Guarnieri, Sonata para piano II, compassos 32-35 e 49-51, transposição do tema e transformação por mudança de métrica.

3. Intervenção: intercâmbio de notas de um padrão temático de maneira a produzir um novo formato. Atualmente esse procedimento é denominado permutação (que será exemplificado adiante). Trata-se de uma modificação na maneira de apresentação das notas do tema, alternado o local onde originalmente estariam. Uma seqüência como $D, A, G \#, E b$ quando sujeita à intervenção proposta por Réti poderia resultar em: $B b, E, F, B$. O que aconteceu é que a sucessão original $D, A, G \#, E b$ foi permutada em $G \#, D, E b, A$ e depois transposta um tom acima. Se substituíssemos a mesa seqüência original por números de acordo com a ordem de apresentação das alturas a visualização torna-se mais evidente; assim, $D, A, G \#, E b$ numerada como 1,2,3, 4 resulta na intervenção $3,1,4,2$, a seguir a nova série é transposta um tom acima. Na Sonata de Guarnieri ocorre um procedimento similar. O primeiro tema do segundo movimento é mostrado no Exemplo 9-4 (vale de saída notar a semelhança com o tema do primeiro movimento Ex. 5-4). Este tema é constituído de duas frases que, mesmo na ausência da tonalidade, são sonoramente afins. Os fragmentos no exemplo marcados com as letras $a, b$ e $c$ são responsáveis por essa afinidade posto resultarem do processo de intervenção. Esses fragmentos possuem uma estrutura intervalar comum, sujeitadas ao mecanismo de permutação no qual $b$ e $c$ são derivados de $a$. Os números no pentagrama inferior do exemplo referem-se à cardinalidade de semitons entre intervalos adjacentes, das respectivas letras, postas em ordem normal (forma mais compacta de se anotar um conjunto de classes de alturas). A ordenação compacta permite notar que o conteúdo intervalar desses conjuntos apresenta certa similaridade. Assim, o procedimento de permutação foi realizado somente modificando a sucessão de intervalos envolvidos indo da letra $a 2^{\mathrm{a}} \mathrm{m}, 4^{\mathrm{a}} \mathrm{J}, 2^{\mathrm{a}} \mathrm{m}$ para $b$ e $c 2^{\mathrm{a}} \mathrm{m}, 2^{\mathrm{a}} \mathrm{m}, 4^{\mathrm{a} J}$, simples permutação que gera formações aparentemente distintas, porém com notável afinidade sonora. Ressalta-se também a sucessão cromática presente no tema (assinalada no colchete inferior do exemplo), característica esta onipresente nos três movimentos da obra, responsável por conferir unidade formal, sonora e, conseqüentemente, perceptual. 

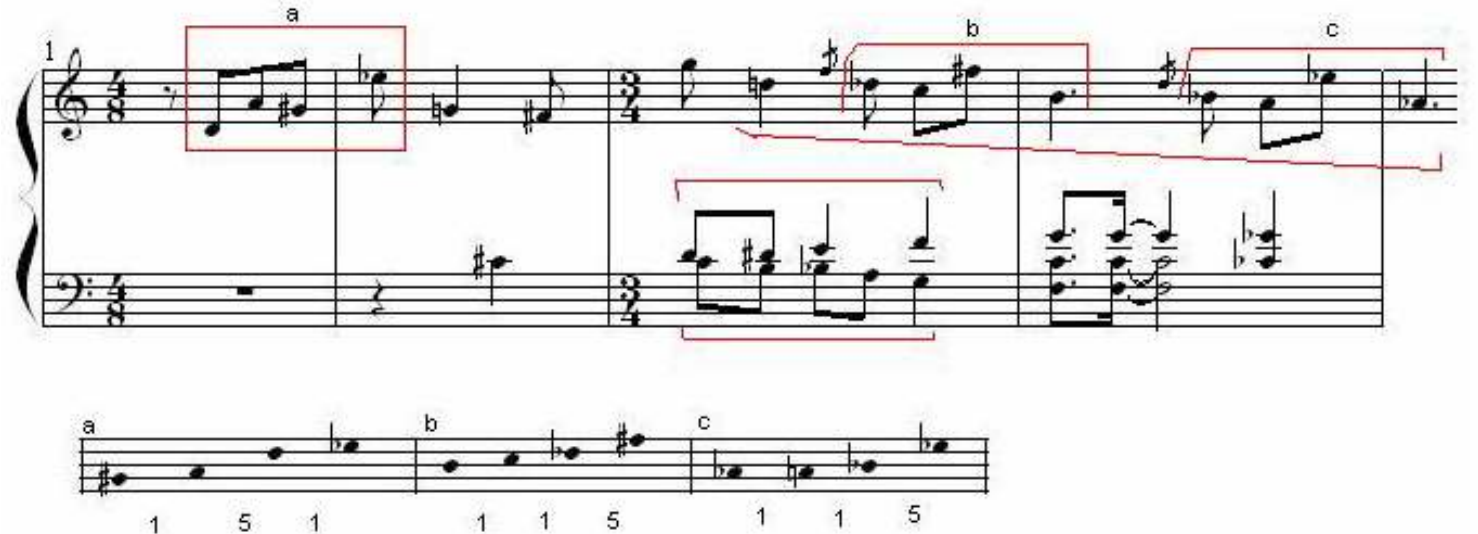

Exemplo 9-4: Guarnieri, Sonata para piano II, compassos 1-5, intervenção temática.

4. Motivos permitem ser expandidos com acréscimo de figurações, alterando sua configuração original. Esse procedimento será demonstrado adiante (vide exemplo 19-4).

5. Estreitamento: supressão de elementos do tema;

6. Preenchimento: acréscimo de elementos ao tema;

7. Corte: subtração de notas, ornamentos ou valores;

Essas três últimas maneiras de transformação temática enumeradas são auto-evidentes, não carecendo de explicações exaustivas, sendo classificadas por Réti como processos de afinamento e de preenchimento temático. Um pequeno exemplo é dado a seguir mostrando o processo de estreitamento temático ocasionado pela diminuição de valores rítmicos associado à subtração de notas do tema original. O tema original foi mostrado no exemplo 9-4 (compassos 1-3), no compasso 19 (Ex. 10-4) o mesmo tema é sujeito a diversas modificações, como permutação, alteração de registro e métrica. Porém, nota-se o estreitamento mais radical pela transformação das notas $G$ e $E b$ em notas ornamentais e principalmente pelo corte que retirou do tema as notas $A, G$ e $F \#$. O mecanismo de preenchimento seria o inverso deste processo.
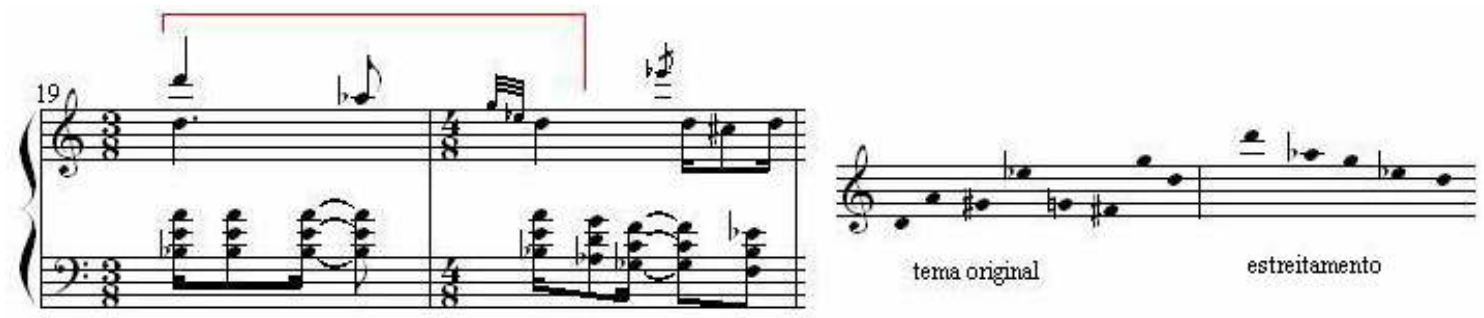

10-4: Guarnieri, Sonata para piano II, compassos 19-20, corte e estreitamento temático. 
8. Outro artifício que poderia ser catalogado dentre esses últimos recursos comentados é o que Réti denomina compressão temática. Neste mecanismo o padrão temático é transformado de modo a ocupar um espaço menor, é como se um tema fosse apresentado em uma espécie de versão abreviada.

9. Identidade de contorno temático: notas do perfil melódico são diferentes, mas o contorno permanece similar. Esse procedimento será demonstrado adiante (Ex. 22-4) ao comentar o uso de redes harmônicas para derivação de notas a partir de um padrão temático inicial.

10. Mudança de harmonia: um mesmo motivo é harmonizado de diferentes maneiras. Esse processo já é bastante conhecido, tendo sido utilizado na música tradicional. Uma renovação mais substancial aconteceu em finais do século XIX concomitante com a estética impressionista de pintura. Do mesmo modo como os pintores buscaram retratar a mesma cena sob diversas luminosidades, os compositores re-ambientavam temas modificando a harmonia. Há exemplos de sobra em Debussy (vide Ex. 10-2), contudo uma outra possibilidade para esta idéia é não harmonizar o tema com acordes edificados por superposição de terças, mas valerse de outras construções. O Exemplo 11-4 mostra esse artifício em um extrato da Rapsódia para percussão e orquestra do compositor Ney Rosauro. O tema é apresentado em duas harmonizações: inicialmente só na orquestra (acordes em terças, compasso 36-40) e depois no vibrafone (acordes em quartas, compasso 80-85).

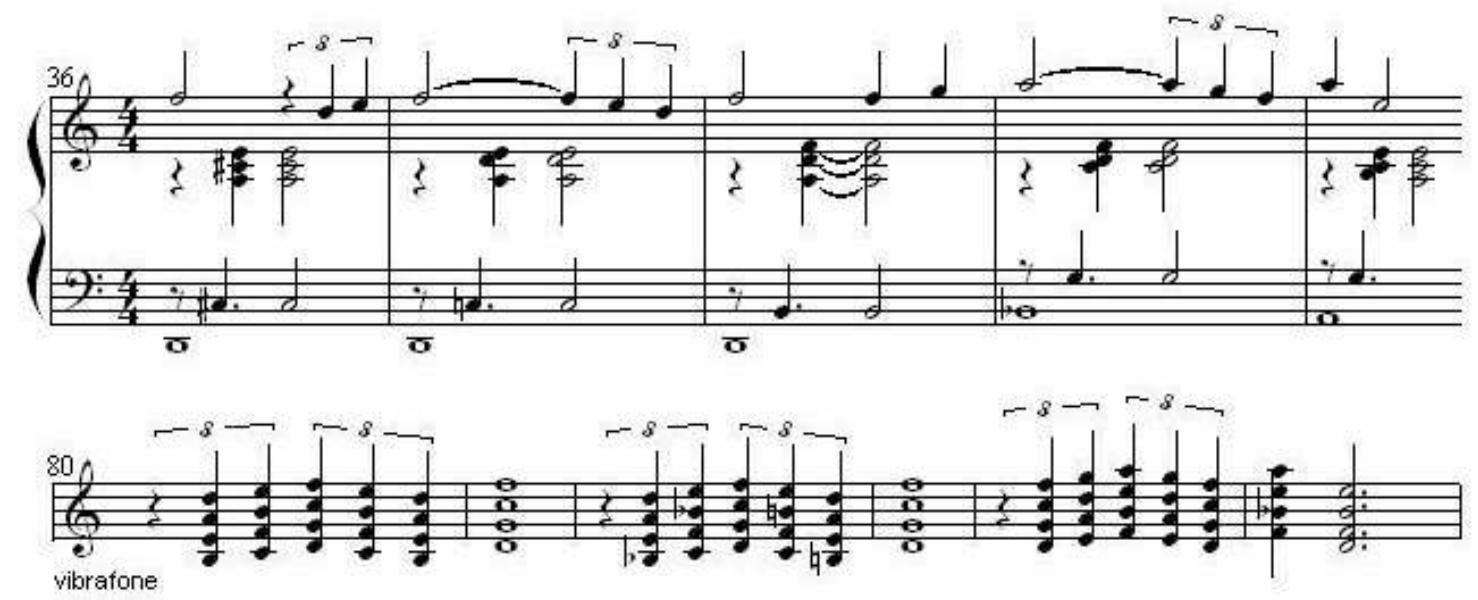

Exemplo 11-4: Ney Rosauro, Rapsódia para percussão e orquestra, compassos 36-40 e 80-85, rearmonização do tema por acordes em superposição de quartas.

11. Acréscimo ou subtração de acidentes: as notas são conservadas, porém recebem alterações, isto é, são bemolizadas, sustenizadas ou tornadas naturais. No exemplo a seguir, as notas assinaladas não pertencem a nenhuma transposição do sujeito desta fuga (terceiro movimento da Sonata para piano de Guarnieri), ocorre que há somente a adição de bemol nas notas $A$ e $C$ transformando a proposta temática inicial por meio do simples acréscimos de 
alterações. O compasso 12 do Exemplo 12-4 apresenta o sujeito original, e o compasso 79 o sujeito transposto e novamente transformado pela bemolização das notas.
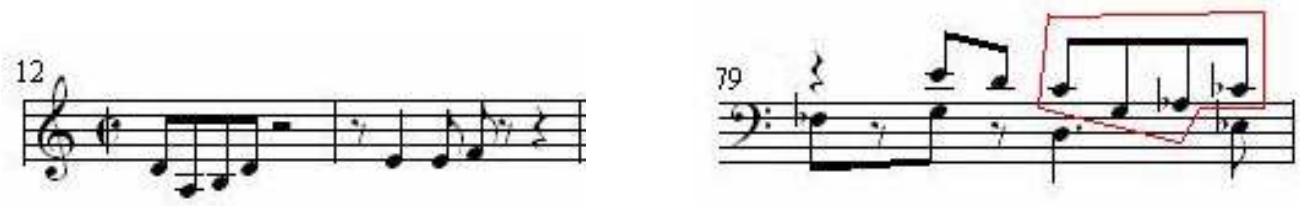

Exemplo 12-4: Guarnieri, Sonata para piano III, compassos 12-13 (sujeito da fuga) e 79 sujeito transformado pelo acréscimo de acidentes.

A idéia de organicidade, ou seja, a estruturação integral da obra por meio de um único motivo gerador, perpassa o texto de Réti, cujo intuito é demonstrar como compositores compartilhavam dessa concepção e de que maneira aplicavam isso à peça. Assim, Réti entende haver uma relação de derivação entre os temas empregados durante a composição, sendo que estes diversos temas são sempre resultantes dos processos de transformação de um único tema gerador. Esse processo também é encontrado nas composições denominadas motívicas, sobretudo as do início do século $\mathrm{XX}$, período do atonalismo livre anterior à promulgação da técnica dodecafônica. A grande crítica feita ao trabalho de Réti reside justamente neste aspecto da derivação, pois os críticos (por exemplo, Meyer e Cook) entendem que muitas de suas interpretações são demasiado forçadas, havendo uma omissão deliberada de elementos do tema em algumas análises de modo a conformar os mesmos com sua proposta tematicista.

Contudo, é possível notar que a idéia de organicidade encontra-se presente e manifesta-se de maneiras distintas nas composições. Uma das maneiras usadas por Guarnieri na Sonata para piano para estabelecer uma unidade absoluta entre os três movimentos foi manter um aspecto característico do tema no interior dos diferentes movimentos. Neste caso, esse elemento característico é a sucessão de semitons descendentes, conforme mostrado nos exemplos anteriores (vide exemplos 5-4, 7-4, 8-4, 9-4). Em sua Sinfonia $n^{o} 2$ a maneira de conseguir essa organicidade foi preservar a unidade de caráter nos contextos em que os diferentes temas eram apresentados. Há uma clara diferença de caráter entre o primeiro e o segundo temas do primeiro movimento dessa sinfonia, o primeiro é enérgico, vigoroso, enquanto o segundo é lírico e nostálgico. Para manter o caráter vigoroso no ambiente do tema lírico, Guarnieri reitera no acompanhamento a figura rítmica usada na apresentação do primeiro tema, desse modo, o segundo tema ocorre com ambiência dupla: nostálgica e enérgica. No Exemplo 13-4a esses aspectos são apresentados por meio de uma partitura reduzida. Os compassos de 1 a 9 expõem o primeiro tema (enérgico). Nos compassos 74 a 81 os violinos expõem o segundo tema (trata-se na verdade de uma segunda apresentação, pois o 
segundo tema já fora apresentado pelas trompas no compasso 46, mas é repetido pelos violinos. Optei aqui pela segunda exposição pois acredito enfatizar sem dubiedade o caráter lírico deste tema). Note-se que o segundo tema é acompanhado pela figuração rítmica em colcheias, realizada pelas madeiras (flautas, oboés e clarinetes, estes soando onde escritos). Esta figuração é muito semelhante àquela realizada na apresentação do primeiro tema, só que agora tem sua função modificada, revestindo-se enquanto elemento de acompanhamento, mantendo, assim, o caráter vigoroso em ambos os temas.

Buscando uma derivação pelas vias de Réti, poderia dizer que a figuração rítmica das madeiras é uma inversão modificada do próprio tema. Os intervalos usados para construção do tema provém de um arpejo ascendente de $C m$ (vide compasso 1, Ex. 13-4). A resposta das madeiras (compassos 6 e 8), por sua vez, é uma descida por intervalos de quartas; permitindo, então, pensar em uma proposta tonal $\left(3^{\mathrm{a}} \mathrm{s}\right)$ ascendente respondida de maneira atonal $\left(4^{\mathrm{a}} \mathrm{s}\right)$ descendente, realizando assim a inversão do tema. $\mathrm{Na}$ apresentação do segundo tema, as madeiras mantém a figuração característica, porém, adquirem um estatuto harmônico, já que funcionam como acompanhamento, havendo novamente a idéia de inversão (tonal $\mathrm{x}$ atonal) na medida em que essa figuração desvincula-se do teor atonal presente nos intervalos de $4^{\mathrm{a}} \mathrm{s} \mathrm{e}$ incorpora atributos tonais, como os acordes em $3^{\mathrm{a}} \mathrm{s}$, que são articulados pela nota $B$ que tem também o papel de pedal superior.

Vale ressaltar ainda que essa figuração rítmica contém a célula motívica empregada para construção da melodia do segundo movimento, solo de corne inglês (no mesmo exemplo 13-4, já escrito com as notas reais). Ao longo desse segundo movimento fragmentos dos temas 1 e 2 do primeiro movimento serão retomados, inclusos entre os acordes do acompanhamento, como segunda melodia ou mesmo como citação direta. No terceiro movimento, apesar da indicação Festivo o caráter enérgico é ainda muito evidente. As acentuações percussivas do primeiro movimento são retomadas, além disso, o uso da figuração rítmica característica do primeiro movimento é mantido. No exemplo 14-4 são apresentados o primeiro tema do terceiro movimento (exposto nos metais) e a figuração rítmica característica, presente ao longo da Sinfonia, aqui tocada por pícolos e oboés. Esses aspectos denotam a idéia de organicidade e conferem unidade à composição. Todavia, um outro fator contundente na consecução da unidade temática e formal dá-se pelo uso da configuração intervalar como agente estrutural. Guarnieri realiza isso ao disseminar conformações intervalares características ao longo das seções da peça. O exemplo 13-4b demonstra uma expansão intervalar extraída do final do primeiro tema (compasso 7) e depois estendida no acompanhamento do segundo tema na já citada figuração rítmica das madeiras (compassos 74-75). No exemplo os números acima das notas referem-se ao número de 
semitons entre intervalos adjacentes. Essa expansão é engendrada associada a uma movimentação cromática descendente. $\mathrm{O}$ emprego desses mecanismos projeta os elementos micro estruturais para o orbe da construção macro formal.
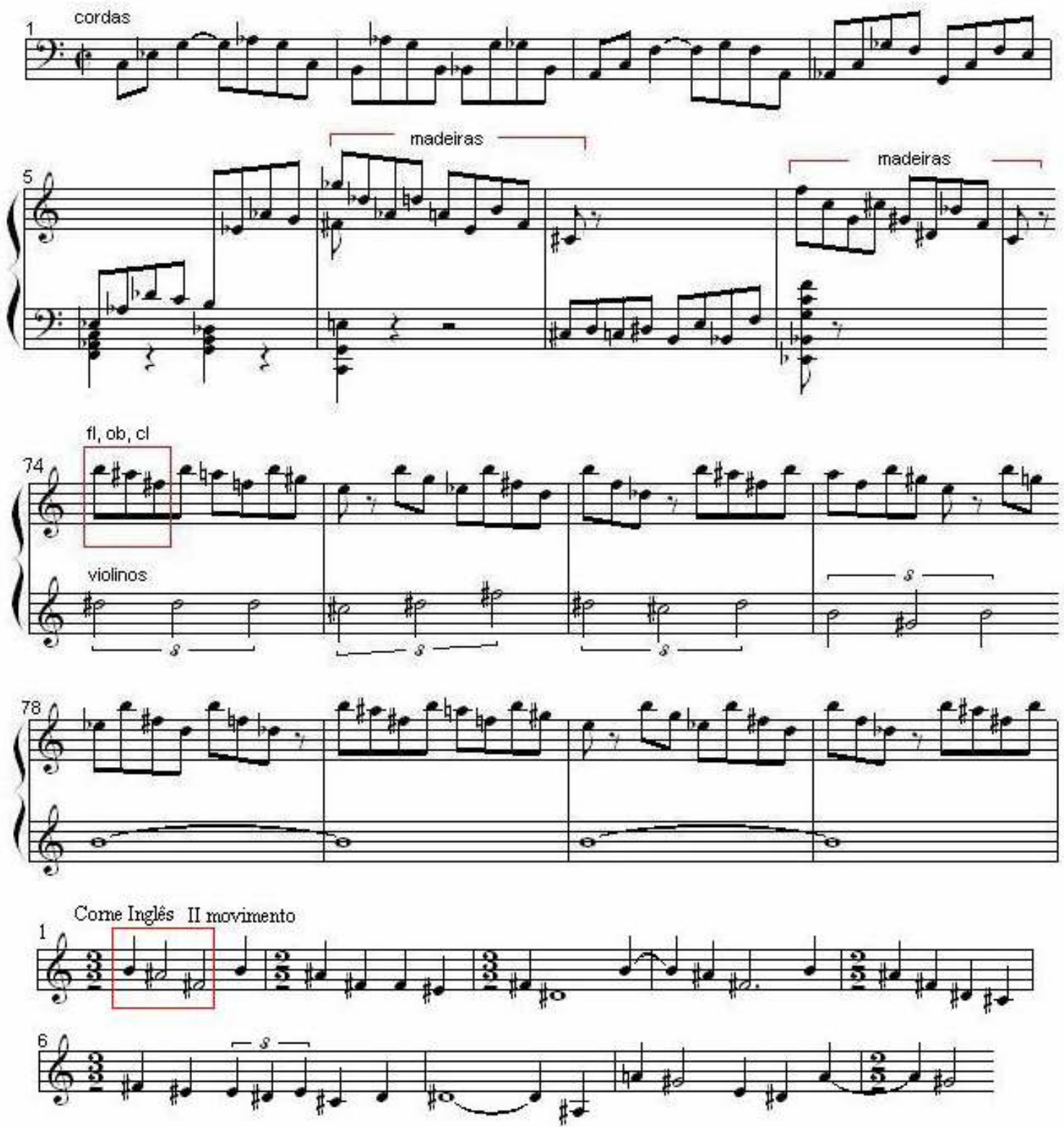

Exemplo 13-4a: Guarnieri, Sinfonia $n^{\circ}$ 2, Uirapuru. Primeiro movimento: tema (compassos 1-9), segundo tema (compassos 74-81). Segundo movimento: melodia do corne inglês (compassos 1-9) extraída da figuração rítmica das madeiras (compasso 74).
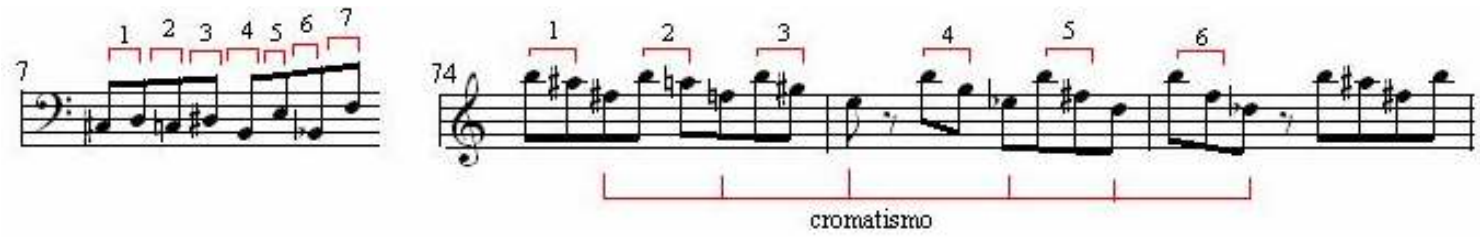

Exemplo 13-4b: Guarnieri, Sinfonia $n^{\circ}$ 2, Uirapuru, expansão intervalar (comp. 7) e associada ao movimento cromático descendente (comp. 74-75). 


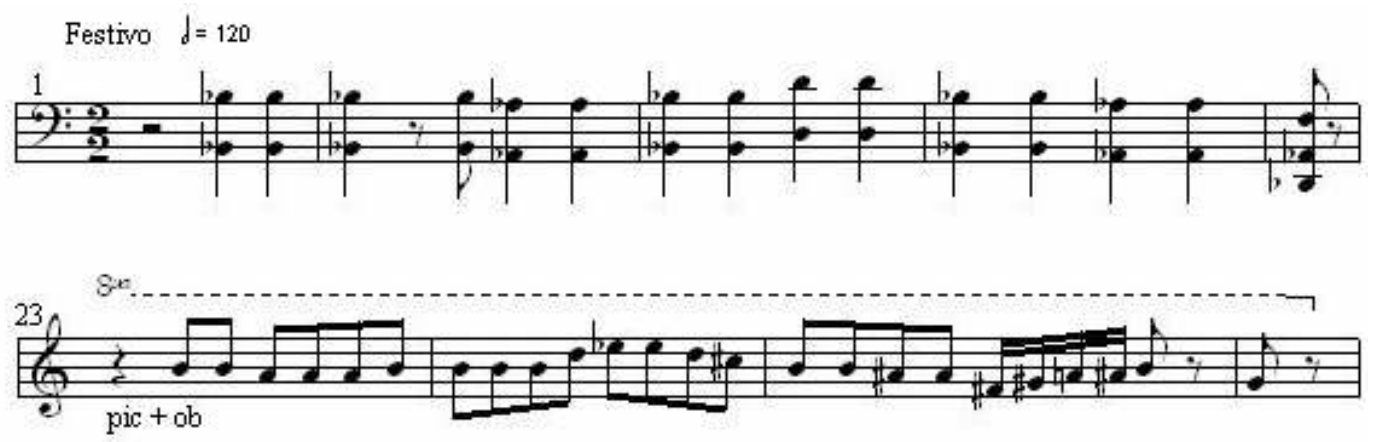

Exemplo 14-4: Guarnieri, Sinfonia ${ }^{\circ}$ 2, Uirapuru III, tema do terceiro movimento (comp.1-5) exposto nos metais e retomada da figuração rítmica característica do primeiro movimento (comp. 23-25).

Mais exemplos dos artifícios relatados por Réti podem ser encontrados em seu livro The Thematic Process in Music especialmente no Capítulo 4. Na música pós-tonal outros modos de transformações podem ser identificados como, deformação temática, permutação, dissolução temática e intercâmbio entre classes de alturas. A seguir, ofereço alguns exemplos de procedimentos de transformações temáticas mais característicos do repertório moderno.

O Exemplo 15-4 expõe o tema inicial extraído de minha peça Jericó (para trompete, percussão, sons eletroacústicos e transformação em tempo real). É um tema simples composto de dois seguimentos de frase que servirá aqui para exemplificar os procedimentos de transformação. Todos estes mecanismos a serem analisados, bem como suas resultantes, foram utilizados para composição dessa obra.

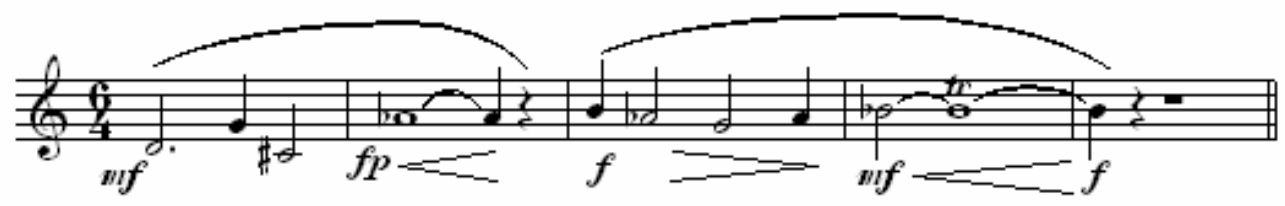

Exemplo 15-4: Antenor Ferreira, Jericó, tema original, compassos 23 a 27.

No Exemplo 16-4 há uma mudança de direção no padrão inicial (compasso 1 do exemplo) o salto de $4 \mathrm{~J}$ ascendente é convertido em $5 \mathrm{~J}$ descendente (somente mudança de registro, sem modificar a cardinalidade do intervalo). No terceiro compasso ocorre uma inversão (no sentido aplicado pela teoria dodecafônica): intervalo de $3 \mathrm{~m}$ descendente torna-se $3 \mathrm{~m}$ ascendente e vice-versa. As duas semifrases encerram-se com uma sensibilização da última nota (acréscimo de uma nota meio tom abaixo da nota de finalização).

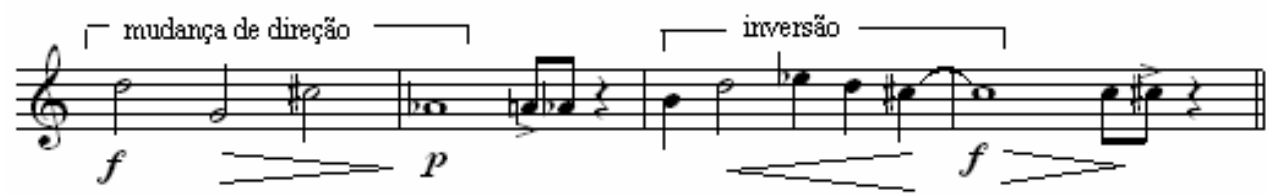

Exemplo 16-4: Antenor Ferreira, Jericó, modificação de direção e inversão do tema inicial (compassos 29-32). 
O Exemplo 17-4 demonstra o emprego da permutação. Trata-se de uma permutação simples, onde notas adjacentes trocam de posição. Existem várias maneiras de realizar a permutação; neste exemplo, a seqüência original com nove notas $1,2,3,4,5,6,7,8$, 9 é transformada em 2, 1, 4, 3, 6, 5, 8, 7, 9 (a última nota não sofre permutação).

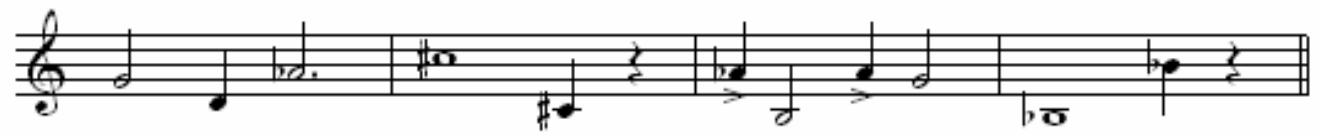

Exemplo 17-4: Antenor Ferreira, Jericó, permutação simples das notas do tema original.

O mesmo procedimento é usado por Guarnieri na fuga da Sonata para piano. O sujeito original (vide Exemplo 12-4, compassos 12 e 13) tem suas notas permutadas junto com uma pequena alteração rítmica nos compassos 17 e 18. O Exemplo 18-4 mostra como se dá essa permutação apresentando como ficaria o sujeito original se fosse fielmente transposto para $D b$ e a troca de posições das alturas como realizada por Guarnieri (vide numeração abaixo das notas).
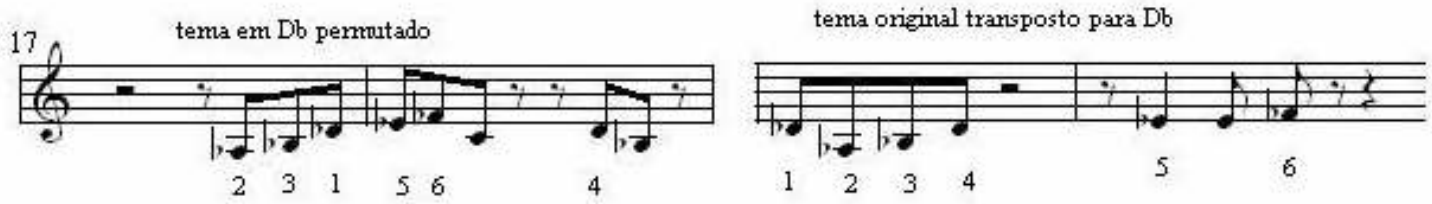

Exemplo 18-4: Guarnieri, Sonata para piano III, compassos 17-18

Uma das maneiras de transformar o caráter de um gesto inicial é o acréscimo de ornamentos. No Exemplo 19-4 alguns ornamentos são acrescentados ao tema inicial. No Exemplo 20-4 os ornamentos são incorporados ao tema, podendo, posteriormente, ser objetos dos demais artifícios de transformação, como retrogradação, inversão, etc.

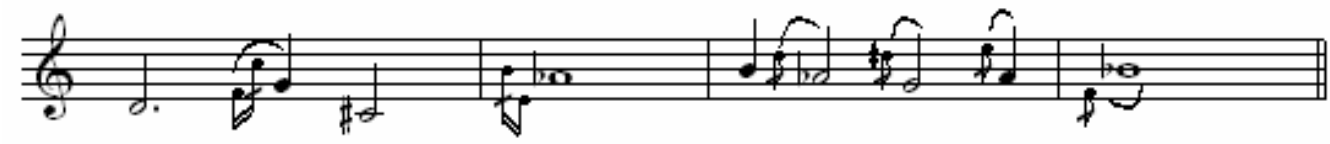

Exemplo 19-4: Antenor Ferreira, Jericó, (compassos 34-37) acréscimo de ornamentos ao tema original.

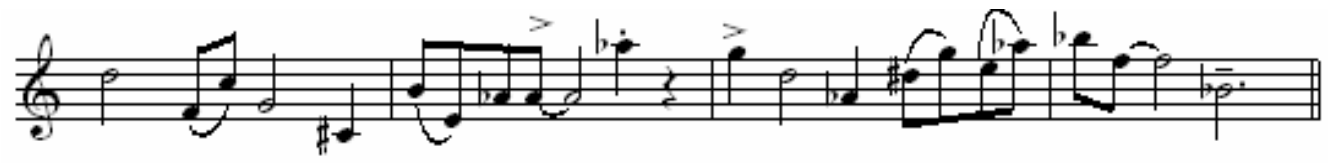

Exemplo 20-4: Antenor Ferreira, Jericó, incorporação de ornamentos ao tema inicial. 
Artifícios de transposição são de vasto uso no repertório tradicional e serial. No próximo exemplo (21-4), há a transposição um pouco diferente, na qual apenas algumas notas do padrão original são transpostas, neste caso a primeira nota de cada compasso foi transposta meio tom acima, tratando-se portanto de uma transposição não literal. Existem inúmeras possibilidades para esse artifício e quaisquer notas ou seqüências de notas podem ser escolhidas para serem objetos de transposição.

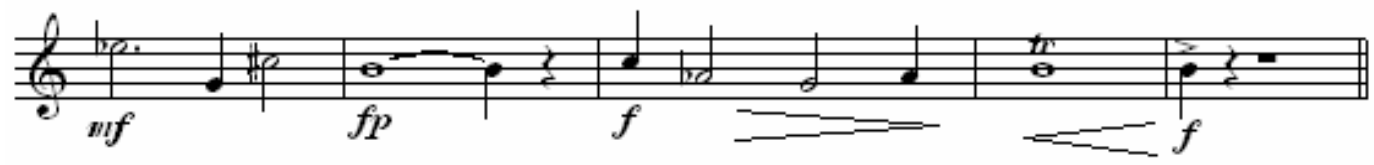

Exemplo 21-4: Antenor Ferreira, Jericó, transposição em um semitom da primeira nota de cada compasso.

Transformação por meio de redes harmônicas. O sistema de redes harmônicas foi criado pelo compositor belga Henri Pousser e trata-se de um procedimento de extração de notas em uma rede de projeção intervalar. Tem-se uma espécie de sistema de eixos cartesianos no qual é criada uma rede combinando-se diferentes intervalos. Uma rede pode ser projetada horizontalmente com intervalos de quinta justa e verticalmente usando intervalos de sétima maior, tendo o seguinte resultado (Ex. 22-4a):
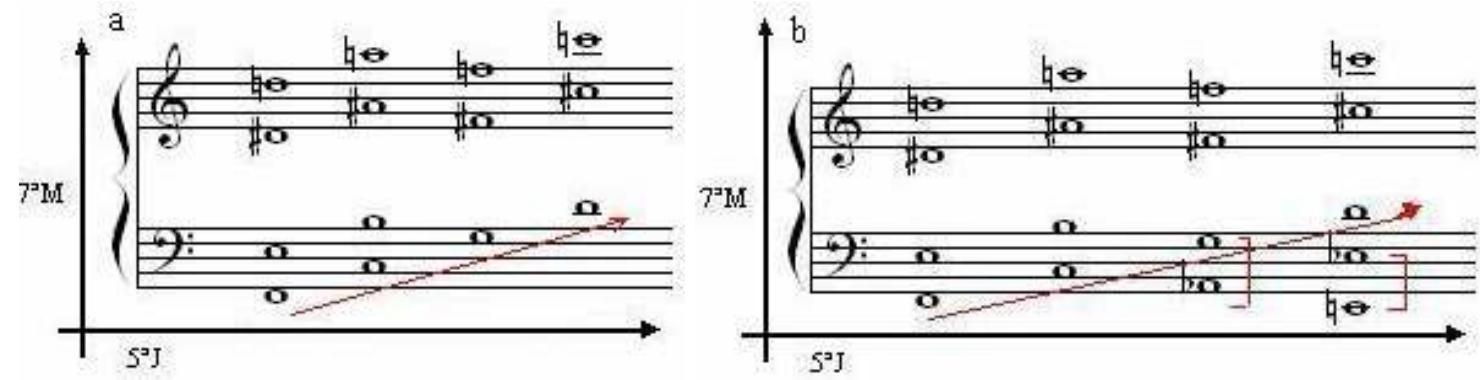

Exemplo 22-4a: rede harmônica formada pelos intervalos de $7^{\mathrm{a}} \mathrm{M}$ e $5^{\mathrm{a}} \mathrm{J}$. Exemplo 22-4b: rede harmônica formada pelos intervalos de $7^{\mathrm{a}} \mathrm{M}$ e $5^{\mathrm{a} J}$ estendida para o registro grave.

Neste exemplo, a rede foi iniciada com a nota $F$ e ascendeu até $D$, porém, é possível adicionar mais intervalos preenchendo os registros da rede abaixo do eixo ascendente (linha obliqua do exemplo), bastando para esse preenchimento, colocar as notas no registro inferior guardando a mesma medida intervalar $-7^{\mathrm{a}} \mathrm{M}$ neste caso. Há a possibilidade de trabalhar com um terceiro eixo, mas não se trata aqui de explorar esse procedimento em profundidade, mas sim, demostrar mais um expediente para variação temática.

Construindo uma rede com as notas do tema original da peça Jericó (Ex. 15-4) usando como eixo os intervalos de $4^{\mathrm{a}} \mathrm{J}$ e $4^{\mathrm{a}}$ aumentada teríamos (Ex. 23-4): 


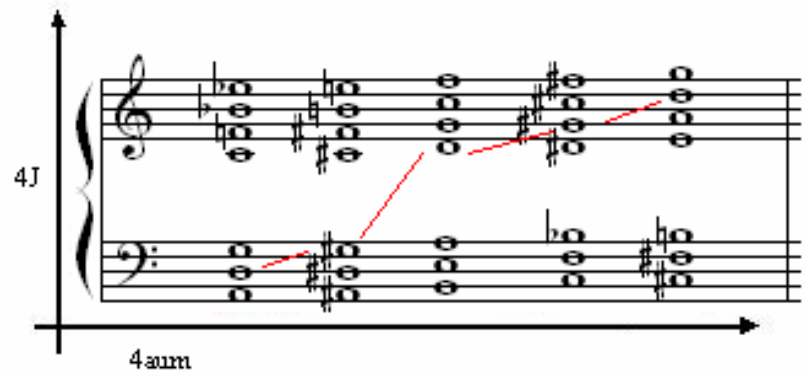

Exemplo 23-4: rede harmônica formada pelos intervalos de $4^{\mathrm{a}} \mathrm{J}$ e $4^{\mathrm{a}}$ aum derivada dos dois primeiros intervalos do tema de Jericó (vide Ex. 15-4).

O procedimento seguinte para derivação de notas seria selecionar notas em uma outra rede construída com eixos intervalares diferentes. Essas notas seriam escolhidas porque guardam a mesma posição que as notas do tema possuem na rede inicial. Para facilitar a visualização vou transferir a rede para duas tabelas. A primeira tabela representa exatamente a rede harmônica do exemplo 23-4 (eixos de 4J e 4aum), a segunda tabela é formada com os eixos de $5 \mathrm{~J}$ e $3 \mathrm{~m}$.

\begin{tabular}{|c|c|c|c|c|c|c|c|}
\hline 1 & 2 & 3 & 4 & 5 & 6 & 7 & \\
\hline$D$ & $E b$ & $E$ & $F$ & $F \#$ & $D b$ & $\boldsymbol{G} \#$ & $\mathrm{a}$ \\
\hline$A$ & $B b$ & $B$ & $C$ & $C \#$ & $\boldsymbol{A}$ & $D \#$ & $\mathrm{~b}$ \\
\hline$E$ & $F$ & $F \#$ & $G$ & $\boldsymbol{G} \#$ & $E$ & $B b$ & $\mathrm{c}$ \\
\hline$B$ & $C$ & $C \#$ & $\boldsymbol{D}$ & $D \#$ & $B$ & $G$ & $\mathrm{~d}$ \\
\hline$F \#$ & $G$ & $\boldsymbol{G \#}$ & $A$ & $B b$ & $F \#$ & $C$ & $\mathrm{e}$ \\
\hline$C \#$ & $\boldsymbol{D}$ & $D \#$ & $E$ & $F$ & $G \#$ & $G$ & $\mathrm{f}$ \\
\hline $\boldsymbol{G} \#$ & $A$ & $B b$ & $B$ & $C$ & $C \#$ & $D$ & $\mathrm{~g}$ \\
\hline
\end{tabular}

Vê-se que as notas do tema ocupam as coordenadas 4-d, 4-c, 3-d, 5-c, 3-b, 7-a, 2-e, 3-e, 7-c.

\begin{tabular}{|c|c|c|c|c|c|c|c|}
\hline 1 & 2 & 3 & 4 & 5 & 6 & 7 & \\
\hline$B$ & $G$ & $D \#$ & $B$ & $G$ & $E b$ & $\boldsymbol{B}$ & $\mathrm{a}$ \\
\hline$E$ & $C$ & $G \#$ & $E$ & $C$ & $\boldsymbol{A b}$ & $E$ & $\mathrm{~b}$ \\
\hline$A$ & $F$ & $C \#$ & $A$ & $\boldsymbol{F}$ & $D b$ & $A$ & $\mathrm{c}$ \\
\hline$D$ & $B b$ & $F \#$ & $\boldsymbol{D}$ & $B b$ & $F \#$ & $D$ & $\mathrm{~d}$ \\
\hline$G$ & $E b$ & $\boldsymbol{B}$ & $G$ & $E b$ & $B$ & $G$ & $\mathrm{e}$ \\
\hline$C$ & $\boldsymbol{A b}$ & $E$ & $C$ & $A b$ & $E$ & $C$ & $\mathrm{f}$ \\
\hline $\boldsymbol{F}$ & $D b$ & $A$ & $F$ & $D b$ & $A$ & $F$ & $\mathrm{~g}$ \\
\hline
\end{tabular}

As coordenadas da tabela 1 resultam nas seguintes notas da tabela 2:

$4-\mathrm{d}=D, 4-\mathrm{c}=A, 3-\mathrm{d}=F \#, 5-\mathrm{c}=F, 3-\mathrm{b}=G \#, 7-\mathrm{a}=B, 2$-e $E b, 3-\mathrm{e}=B, 7-\mathrm{c}=A$. 
A escolha destes eixos intervalares para construção da série pode ser arbitrária, todavia optei por utilizar a estrutura intervalar do próprio tema, obedecendo a seqüência de intervalos do mesmo, como mostrado no Exemplo 24-4:

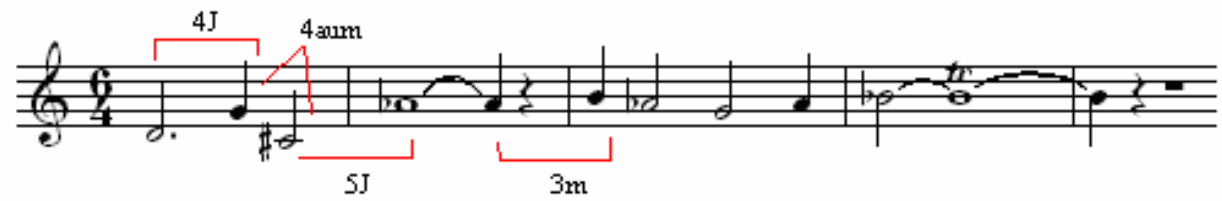

Exemplo 24-4: tema e estrutura intervalar geradora das redes harmônicas das tabelas 1 e 2 .

Das notas derivadas a partir da rede harmônica (eixos e $5 \mathrm{~J}$ e $3 \mathrm{~m}$, tabela 2 ) surge uma nova configuração temática (Ex. 25-4). Observa-se que o tema original e a versão derivada da rede harmônica guardam identidade de contorno temático, pois perfil melódico permanece similar, embora as notas sejam diferentes.

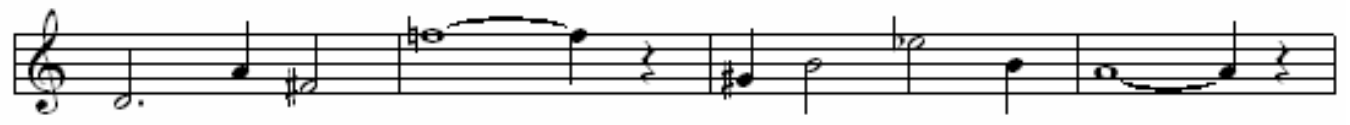

Exemplo 25-4: variação temática resultante da aplicação da rede harmônica da tabela 2.

O Exemplo 26-4 emprega a variação rítmica (talvez a transformação que mais descaracterize o tema original) associada a alguns artifícios usados anteriormente, como incorporação de ornamentos, transposição, etc.

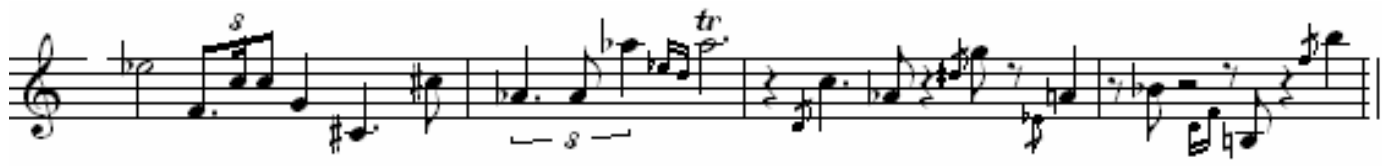

Exemplo 26-4: uso simultâneo de vários tipos de transformação.

Os próximos procedimentos de transformação temática são retirados da peça para piano Canto de Eshu (2008) de Paulo Chagas. A obra é iniciada com a apresentação do tema principal, extraído de uma melodia de Eshu; porém, essa apresentação não se dá de um modo tradicional e já comporta uma peculiaridade: a exploração de sonoridades por meio do uso do pedal do piano. As exatas indicações de mudança de pedal fazem surgir um bloco sonoro oriundo da sustentação das notas do tema, cujas notas $D, A, E, G$ e $B$ permanecem soando dos compassos 3 a 6 e as notas $E, D, A$ e $G$ soam nos compassos 7 a 10. Com o uso desse artifício de sustentação, ocorre uma espécie de harmonização do tema, harmonia esta realizada pelas próprias classes de alturas presentes no tema, é como se o tema harmonizasse a si mesmo (vide Exemplo 27-4 compassos de 1 a 10).

O tema pode receber uma espécie de adensamento pelo acréscimo de intervalo(s), gerando, de acordo com o(s) intervalo(s) usado(s), uma variação textural relativa aos 
batimentos resultantes do acréscimo dessa(s) nova(s) sonoridade(s). Se o intervalo adicionado for muito dissonante irá gerar mais batimento com as notas do tema, e vice-versa. O Exemplo 27-4 mostra esse procedimento de adensamento gerado pelo acréscimo do intervalo de $5^{\mathrm{a}}$ justa sob o tema (compassos de 10 a 20) e o posterior dobramento da sonoridade na oitava imediatamente inferior (compassos 21 a 28). Esse adensamento, associado à referida sustentação do pedal do piano, leva à formação de novas sonoridades aderidas ao tema inicial, que vai gradualmente adquirindo novos "coloridos", realizando um interessante processo de transformação timbrística.
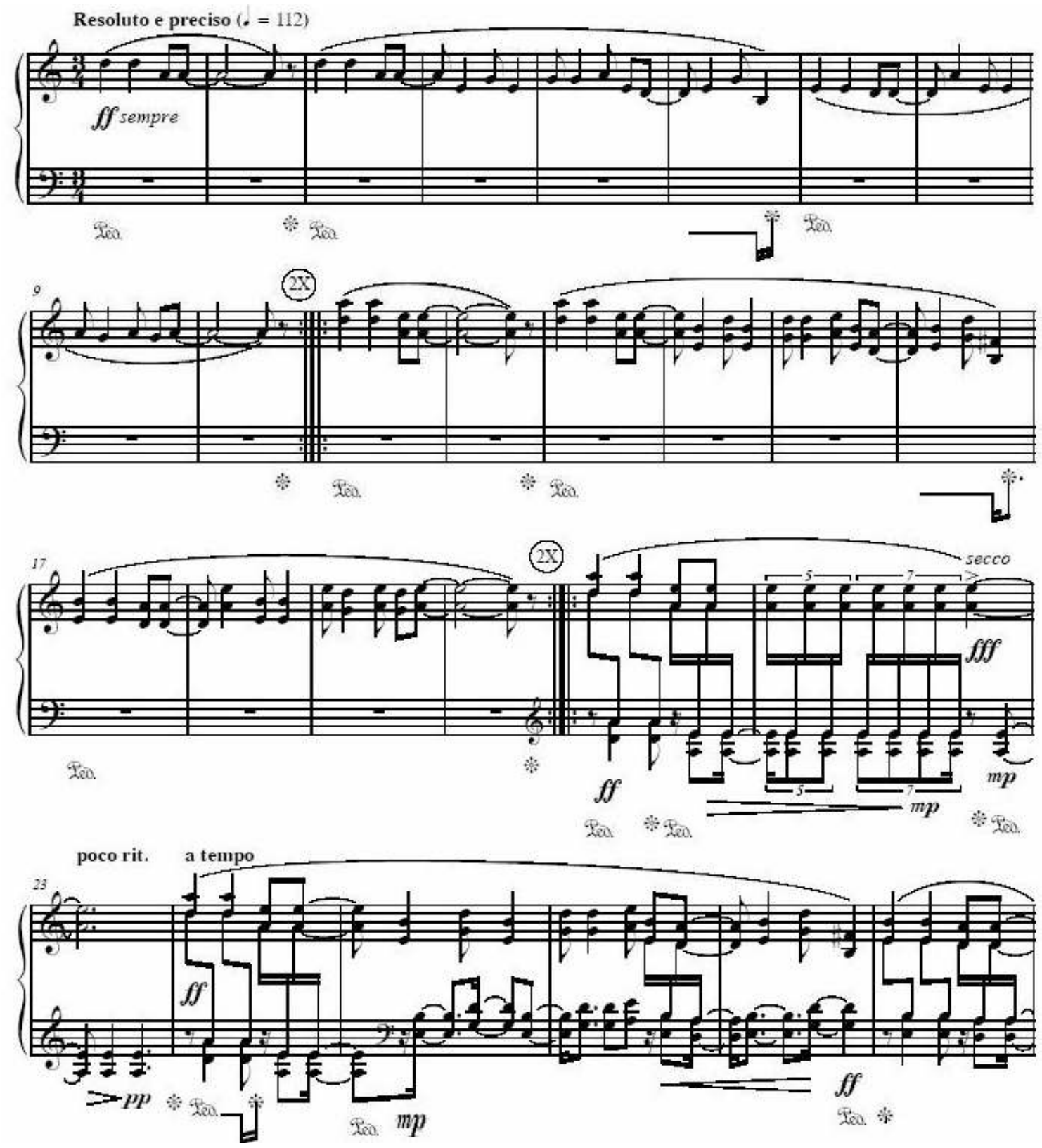

Exemplo 27-4: Paulo Chagas, Canto de Eshu, compassos 1-28, transformação temática por adensamento e variação timbrística. 
Transposições já são usadas há muito tempo, todavia, em um contexto não tonal as transposições se dão de maneiras distintas do tonalismo como já comentado no Exemplo 21-4. O tema pode ser transposto em parte ou somente em algumas de suas notas. Outrossim, uma transformação temática pode ser efetuada realizando transposições diferentes em partes distintas do tema. Uma série de doze notas, por exemplo, pode ter transposta em uma $3^{\mathrm{a}}$ menor somente as notas de números $1,3,5,7$, e 9 (os números referem-se à entrada das notas na série). Em outra seção, as notas que não foram transpostas podem sê-lo só que desta vez $3^{\mathrm{a}}$ menor abaixo. São inúmeras as possibilidades. No Exemplo 28-4 o tema parece estar transposto uma quinta justa acima, quando, na verdade, apenas as duas primeiras notas o são (nota $A$ ), ficando as demais transpostas uma quarta aumentada. O Exemplo 29-4 (próxima página) especifica melhor esse artifício, mostrando novamente o tema original, o resultado da sua transposição quinta justa acima, e a manutenção desta transposição apenas na nota $A$. O restante do tema recebe um outro transporte que poderia ser explicado pela transposição meio tom abaixo da seção transposta quinta justa.

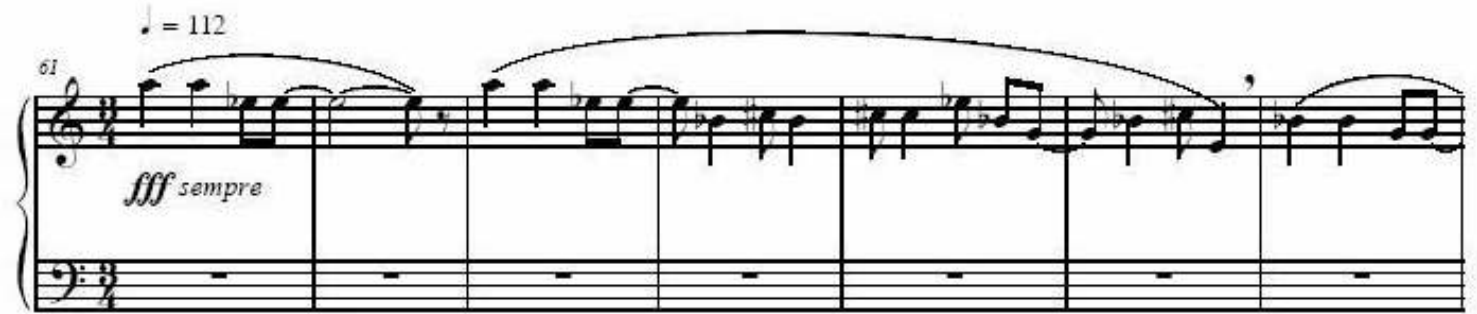

(no changing of teas)

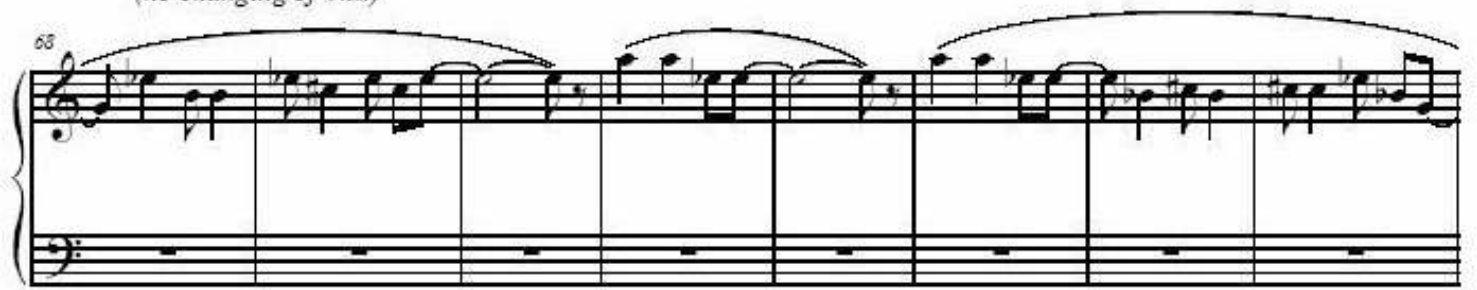

Exemplo 28-4: Paulo Chagas, Canto de Eshu, compassos 61-75, transformação temática por transposições conjuntas.

Outra possibilidade para transformação temática dá-se pela utilização de notas não derivadas de processos de transposição, mas provenientes de uma coleção sonora particular. Um tema construído com as notas de uma escala diatônica, por exemplo, pode ser harmonizado com acordes extraídos de uma coleção pentatônica (coleção complementar da escala diatônica). Assim, em novo momento, o tema poderá ser refeito com as notas desta coleção pentatônica, harmonizado ou não com as notas da escala heptatônica. Essas coleções não precisam ser coleções repertoriadas, como as conhecidas pentatônicas, hexatônicas, octatônicas, etc, mas podem ser quaisquer aglomerados ou entidades como os arquétipos de Webern ou o acorde místico de Scriabin, por exemplo. Um procedimento similar é mostrado 
no Exemplo 30-4. Novamente o tema original é relembrado (pentagrama a). No pentagrama inferior (b) nota-se que a estrutura rítmica do tema original é preservada, no entanto, as notas são trocadas por outras extraídas do agregado acórdico que as sustenta (notas $C \#, D, G, G \#$ do exemplo), realizando assim nova transformação temática.
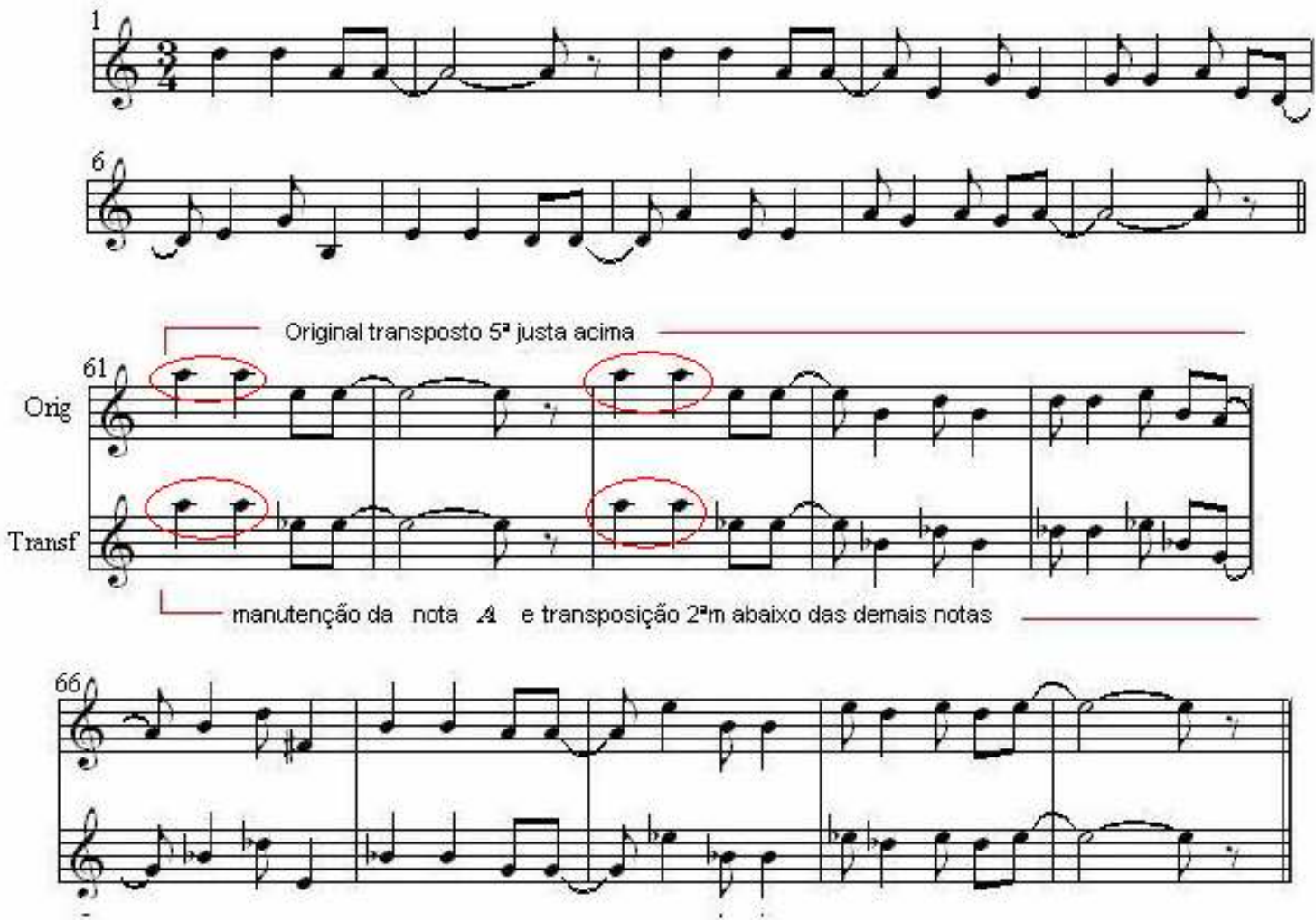

Exemplo 29-4: Paulo Chagas, Canto de Eshu, compassos 1-10 e 61-70, tema original, transposição $5^{\mathrm{a} J}$ e transformação por transposições conjuntas.
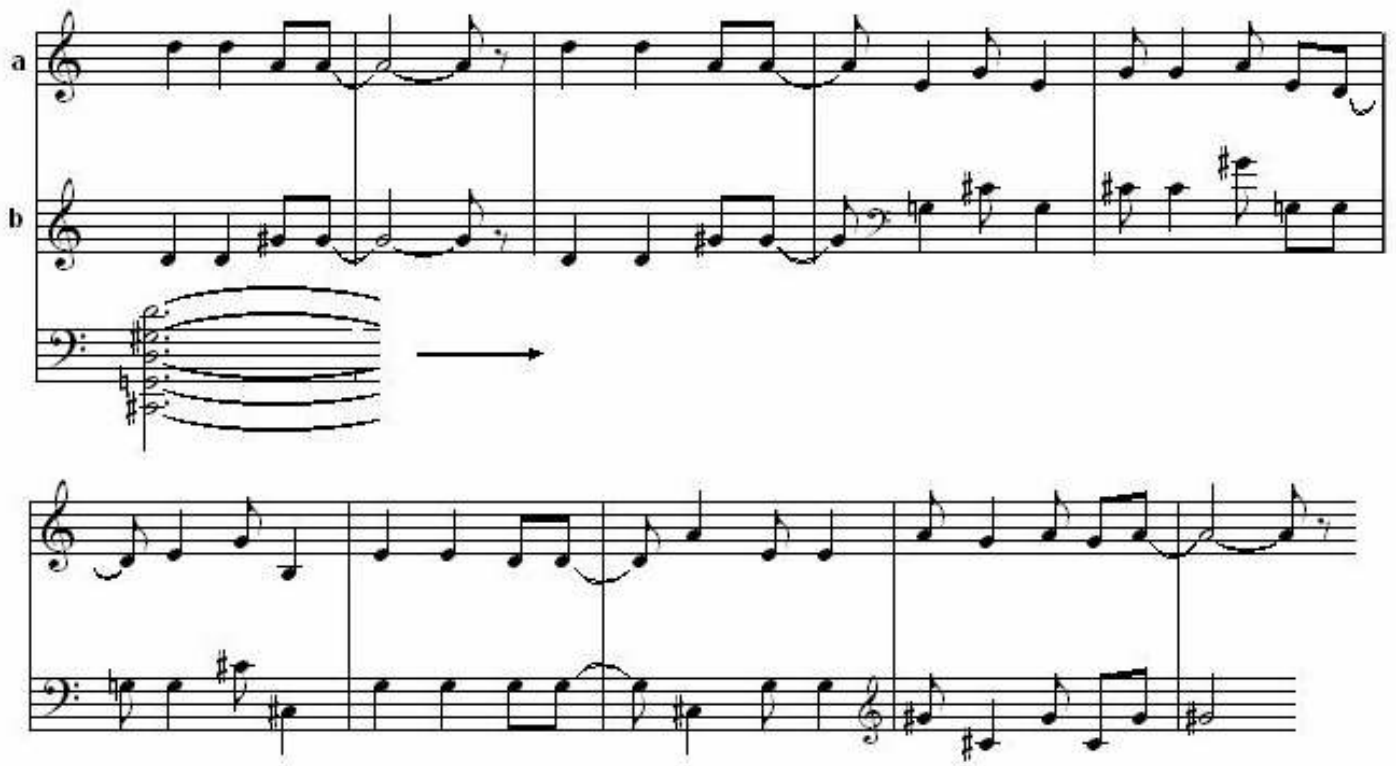

Exemplo 30-4: Paulo Chagas, Canto de Eshu, compassos 129-138, tema original (a) e transformação deste (b) por notas extraídas da coleção sonora $C \#, G, D, G \#, D$ que a seguir é também usada para harmonizá-lo. 
Um procedimento inverso à transformação das alturas seria manter as notas e alterar o ritmo, o que de certo modo é realizado por Ligeti em Música Ricercata. Essa obra, assemelhada a um álbum de prelúdios, trata-se de onze peças para piano solo nas quais Ligeti vale-se da seguinte direcionalidade: a primeira peça é composta com 2 notas, a segunda com 3 , e assim por diante até completar o total cromático na décima primeira peça. Neste projeto, a competência técnica do executante é levada ao extremo, pois a pseudo limitação do plano das alturas é compensada pelo modo como os conjuntos de notas são elaborados e desenvolvidos ritmicamente. Aliado ao desenvolvimento rítmico, Ligeti trabalha outros parâmetros composicionais, explorando toda a tessitura do instrumento, os diversos modos de ataque e sustentação, bem como todas as possibilidades dinâmicas, tendo como resultante inúmeras combinações timbrísticas. Implícita nessas transformações está a idéia de "dessignificação" ou re-significação do objeto sonoro, como proposto por Schaeffer para a música concreta. No caso da Musica Ricercata, os objetos musicais são as distintas coleções de alturas usadas em cada peça. A terceira peça do álbum, por exemplo, vale-se das notas das tríades menor e maior de $C(C-E b-G$ ou $C-E-G$ vide Exemplo 31-4 compassos 1-5 e 6-8). Estas alturas recebem intensa manipulação, como se fora um objeto concreto, mostrando distintos ângulos e possibilidades desse objeto (diferentes registros, diversas ressonâncias, novas resultantes harmônicas) até que o mesmo perca as possíveis alusões tonais comportadas pelas coleções triádicas originais. Há, assim, uma saturação semântica do objeto, onde a tríade em si perde totalmente o significado e deixa de ser percebida como tal.

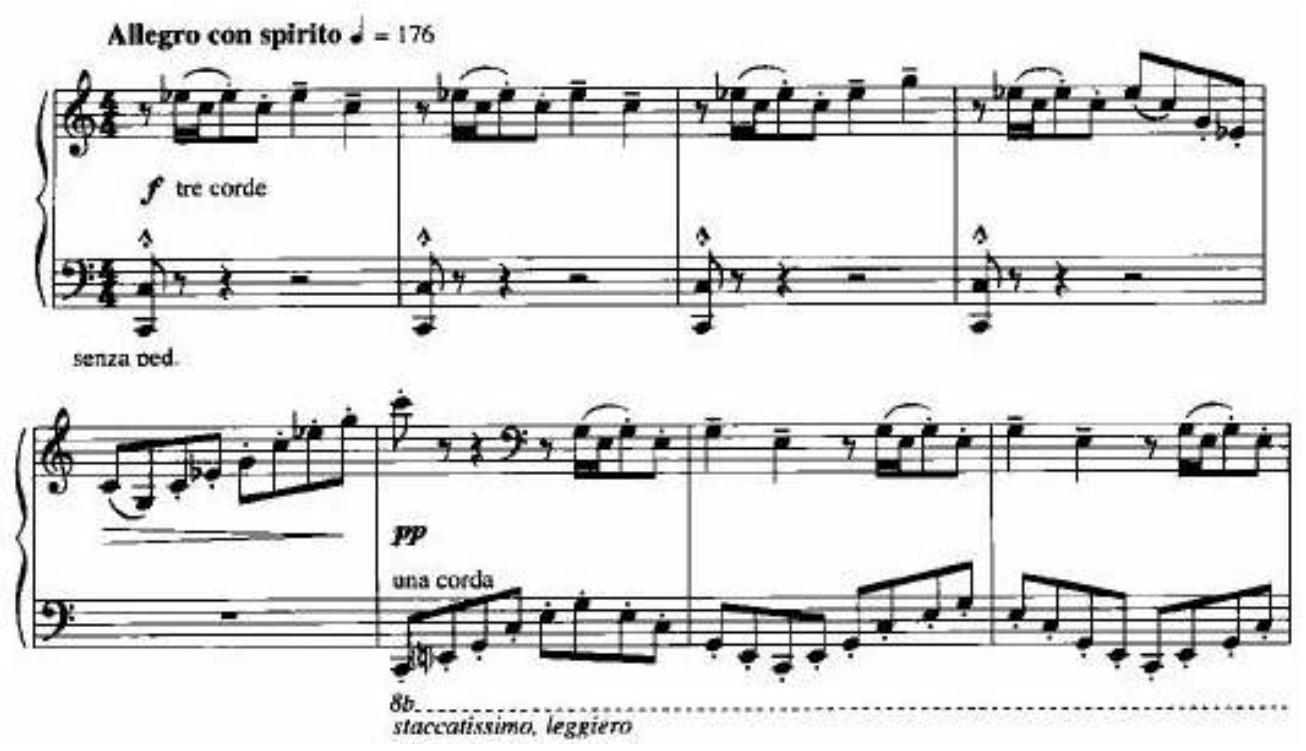

Exemplo 31-4: Ligeti, Musica Ricercata III. Coleções iniciais "sugerindo" as tríades de $C m$ e $C$.

O primeiro número de Música Ricercata é construído praticamente com uma única nota $(A)$, pois a segunda nota $(D)$ aparecerá uma única vez, recebendo somente um ataque, 
sustentado nos quatro últimos compassos da peça. Tendo como material sonoro uma única classe de altura para construção motívica, Ligeti concentra-se em empregar variações rítmicas. O deslocamento rítmico é um dentre os diversos artifícios de transformação empregados por Ligeti. No Exemplo 32-4 mostra-se a introdução do motivo rítmico a ser transformado (o foco é o ritmo, já que se trata de uma única nota, mas logicamente o aspecto melódico pode ser levado em conta). No Exemplo 33-4 demonstra-se como a estrutura rítmica inicial do motivo é transformada de maneira a gerar as variações.

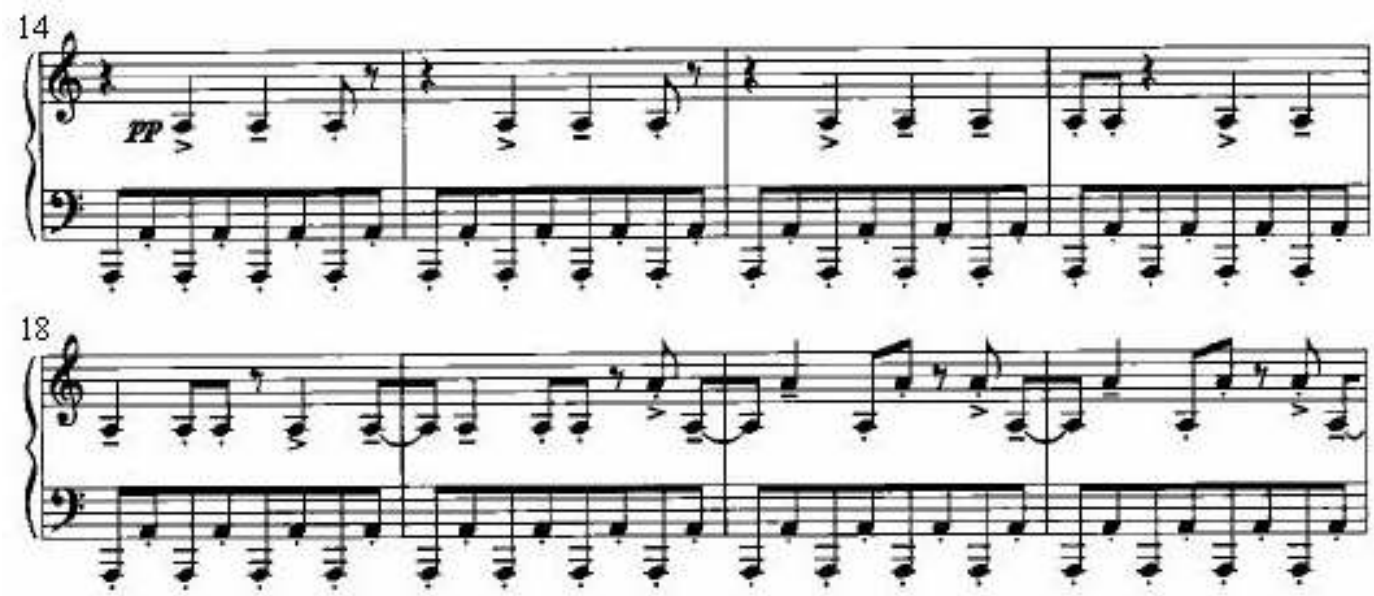

Exemplo 32-4: Ligeti, Musica Ricercata I, compassos 14-21, apresentação do motivo.
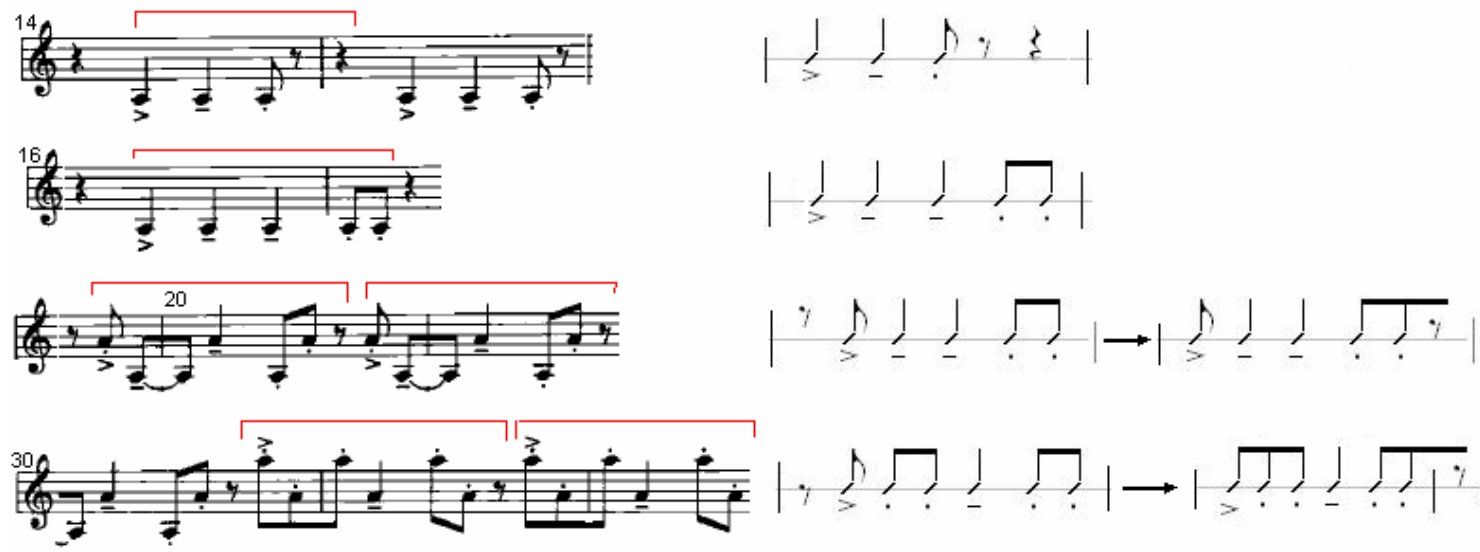

Exemplo 33-4: Ligeti, Musica Ricercata I. Transformações do padrão rítmico inicial.

Nos Exemplos 32-4 e 33-4, percebem-se alguns dos procedimentos adotados por Ligeti na realização de deslocamentos rítmicos. Ao motivo rítmico inicial são agregados novos valores conseguidos pela transformação de pausa em som. Do mesmo modo, a conversão de som em silêncio gera um novo padrão. Um reagrupamento rítmico (como mostrado no compasso 30 do Exemplo 33-4) pode modificar substancialmente o motivo inicial, principalmente quando associado a deslocamentos que causam sobreposições 
métricas. O padrão inicial usado por Ligeti, na verdade, já é deslocado, pois ocorre no segundo tempo, sugerindo de saída uma sobreposição métrica. A mão esquerda do pianista (mostrada no exemplo 32-4) executa um ostinato de colcheias que preenche todo o compasso (o ostinato é iniciado no compasso 13 e perpassa, praticamente, toda a peça) e afirma a fórmula 4/4. Contra essa métrica quaternária Ligeti irá sobrepor outras métricas, polimetria esta constituída pelos artifícios de reagrupamento e de deslocamento do padrão rítmico inicial.

Valendo-se também de transformação do padrão motívico inicial, Ligeti realiza um acelerando (a partir do compasso 52), que se dá pela simples supressão de valores do padrão rítmico transformado, como mostrado no Exemplo 34-4.

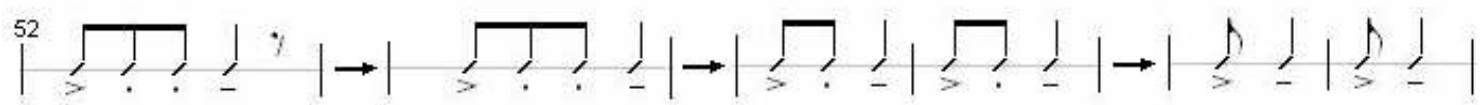

Exemplo 34-4: Ligeti, Musica Ricercata I. Acelerando realizado com supressão de valores do padrão rítmico transformado.

Os artifícios ligados à variação do parâmetro da duração são muito variados, podendo contemplar inúmeros procedimentos de transformação. Alguns dos aspectos comentados para o plano das alturas permitem extrapolação para o domínio rítmico, como retrogradação, corte, estreitamento, compressão, preenchimento, ornamentação, permutação, etc. Novos processos criados por compositores modernos (como o tempo isotrópico do minimalismo, o tempo suspenso de Ligeti, a modulação métrica de Elliot Carter) adicionaram novas ferramentas a esses procedimentos conhecidos, fornecendo ricas opções para o trabalho elaborativo no campo da duração.

Outros parâmetros do som como timbre, textura e intensidade também são eficazes e, de fato, muito utilizados dentro dos procedimentos transformacionais. Transformações do timbre incorporariam ao tema original distintos modos de ataque, que poderiam receber acréscimos de trilos, tremolos, acentuações, staccatos, diversos golpes de arco (instrumentos de cordas) ou de embocadura (instrumentos de sopro), que promoveriam alterações timbrísticas no tema. As possibilidades são incontáveis. $\mathrm{O}$ uso da interpolação também pode ser contado sob o ponto de vista das transformações temáticas, quando novo fragmento, ou parte, é inserido em meio ao tema de modo a modificá-lo sem, no entanto, abstraí-lo totalmente das características que permitam referenciá-lo ao material original.

\section{Considerações finais}


Livros e tratados de composição ligados à prática comum há tempos apontam diversas maneiras de variação temática. Schoenberg em seu Fundamentos da Composição elencou mecanismos de variação motívica. Segundo ele, o ritmo pode ser transformado:

1. Modificando-se a duração das notas;

2. Repetindo-se algumas notas;

3. Repetindo-se determinados ritmos;

4. Deslocando-se os ritmos para pulsações diferentes;

5. Acrescentando-se contratempos;

6. Modificando-se o compasso;

Os intervalos são mudados:

1. Modificando-se a ordem ou direção original das notas;

2. Acrescentando ou omitindo-se intervalos;

3. Preenchendo-se os intervalos com notas auxiliares;

4. Abreviando-se o motivo mediante a eliminação ou condensação de notas;

5. Repetindo-se certos padrões;

6. Deslocando-se alguns elementos para outros pulsos. (Cf: SCHOENBERG, 1993, p.37-38).

Percebe-se, apesar de algumas redundâncias, tratamentos similares aos aqui comentados, apontando para a importância desses procedimentos para a escritura composicional. Não obstante, os artifícios citados por Schoenberg e em outros métodos de composição remontam ao repertório tradicional, valendo então a indagação do por quê mencionar esses processos no âmbito desta tese que se centra no repertório pós-tonal. Justifico tal proposta pelo fato dos compositores contemporâneos terem descoberto novas maneiras e procedimentos de elaboração musical, gerando novos artifícios e/ou reformulando modelos tradicionais, incorporando essas novas ferramentas ao discurso pós-tonal. Enfatizo, assim, que na música pós-tonal os procedimentos de transformação temática continuam sendo de largo uso, e a importância de estudá-los visa não só à prática de aspectos técnicos composicionais, mas também à compreensão da obra.

A partir do momento em que algum dado musical é introduzido o compositor pode prosseguir com a repetição literal deste, adicionar um novo material contrastante ou, então, partir para a transformação desse material original. Aqui tratei dessa terceira via, ou seja, a transformação temática. É certo que os procedimentos de variação e desenvolvimento motívico são utilizados desde muito no repertório tradicional, e acredito que a razão para o emprego desse tipo de tratamento composicional não está restrita ao domínio técnico por parte do compositor, mas também pelo fato de favorecerem à percepção e ao entendimento musical, que desse modo consegue encontrar e estabelecer relações no decurso musical. 
Justamente porque o discurso pós-tonal se dá a partir do material é que devemos focar nossa percepção aos elementos musicais e aos seus modos de manipulação. A música contemporânea propõe novas e diversas maneiras de escuta, que por sua vez dificultam, em um primeiro momento, a apreensão formal. Alguns compositores chegam inclusive a renegar o trabalho formal ao segundo plano, aspecto que não deixa de ser curioso, pois uma música que se pretende especulativa não deveria descartar, tampouco deixar a cargo das associações psicológicas, os parâmetros ligados ao seu entendimento.

As discussões e exemplificações expostas durante esse capítulo apontam para a manutenção de recursos de transformação temático/motívica no repertório contemporâneo. $\mathrm{O}$ emprego desses procedimentos apresenta-se como critério para a compreensão musical, fornecendo parâmetros significativos para o balizamento cognitivo e perceptual envolvidos na recepção da obra. Não obstante, objetos musicais (temas, agregados, resultantes timbrísticas, etc) quando postos em jogo revestem-se de funcionalidade, na medida em que devem ser considerados como desempenhando algum tipo de papel no âmbito integral da composição (repetição, contraste, transformação). Essa característica implica em considerações funcionais, realizadas no capítulo seguinte. 
Capítulo 5

Função e Refuncionalização 


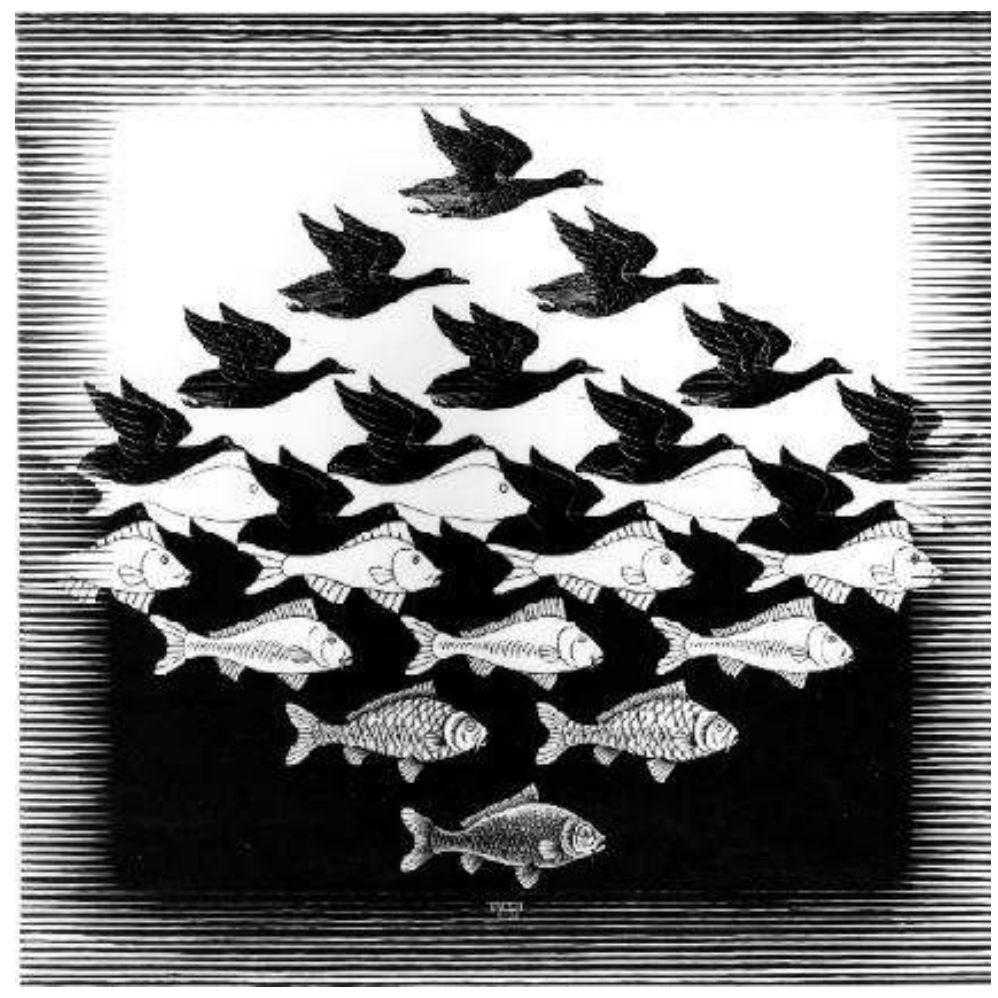

Maurits Escher: Sky and Water I (1938, xilogravura). 


\section{Introdução}

A palavra função, no contexto musical, em um primeiro momento remete à harmonia funcional elaborada por Hugo Riemann no final do século XIX. Todavia, o conceito não se restringe ao âmbito harmônico, podendo ser observado no orbe total da estrutura musical compreendendo motivos, agregados acórdicos, frases, seções, etc. Função implica em relação, interdependência, interação, finalidade, papel desempenhado. A definição matemática de função, entendida como a grandeza que se determina pelo valor, ou em razão do valor de outra(s) grandeza(s) variável(eis), aponta rapidamente para o sentido de dependência. Em outras áreas, o termo leva a pensar em propósito: quando se pergunta "qual a função deste texto?" estou querendo saber qual a finalidade do mesmo no âmbito total do projeto no qual está inserido. Declarar que um indivíduo teve uma função contumaz em uma dada situação, significa dizer que o papel ou atuação dessa pessoa naquele evento foi de suma importância. O que se percebe, de saída, é que o conceito é abrangente e em música permite alguns desdobramentos.

A escuta musical tem início com a percepção de estímulos sonoros captados durante a fruição da composição. Esses estímulos são organizados pelo cérebro, que irá lhes conferir um sentido musical. Este processo torna possível diferenciar os estímulos musicais dos demais estímulos sonoros captados pelo aparelho auditivo. Dessa atividade tem-se a passagem do domínio de objetos meramente sonoros para objetos musicais, sendo que na impossibilidade dos eventos sonoros serem interpretados musicalmente não há como falar em música. Conseqüentemente, os estímulos percebidos como objetos musicais precisam comungar de algum tipo de relação entre si para tornar possível seu entendimento enquanto partes de um mesmo contexto, isto é, devem ser compreendidos como elementos constituintes da mesma música. "Amplamente falando, funcionalismo em música pode ser definido como as implicações que um evento musical (seja este um som, um motivo, uma frase ou uma seção) tem para algum outro evento musical, seja em seu próprio ou em outro nível hierárquico" (MEYER, 1994, p.296). Se um elemento não permitir promover qualquer tipo de relação para com os outros componentes da composição, será percebido como disperso, desconexo, algo alheio ao contexto imediato. A trajetória intrínseca a essa situação de 'interdependência necessária’ entre objetos musicais é assim descrita por Meyer:

A percepção de estímulos físicos como constituintes de um padrão ou de uma forma resulta da habilidade humana em relacionar as partes constituintes entre si de uma maneira inteligível e significativa. (...) Para engendrar uma impressão formal uma ordem deve ser estabelecida, na qual os estímulos individuais tornem-se parte de uma estrutura maior e realizem distintas funções dentro dessa estrutura. Se o estímulo não é percebido como sendo similar, então ele vai falhar em criar coesão ou em formar um grupo ou unidade, e será percebido como separado, isolado, e 'não significará nada'. Idéias contrastantes, sem nenhum tipo de 
similaridade, produzem dispersão, mas não disparidade; difusão ao invés de divergência; novidade no lugar de variedade (MEYER, 1956, p.157-158).

A afirmação de Meyer faz notar algo interessante. Não se impede o uso de novos elementos durante a composição, pelo contrário, a existência destes é imprescindível. Porém, a proliferação de novos materiais sem conexão com aqueles já apresentados não produzirá variedade, mas novidade gratuita. A ausência de relações entre as idéias musicais tende a torná-las dispersas e difusas. No lugar da disparidade, sinônimo de diversidade, tem-se a desordem, sinônimo de dispersão. O dicionário Michaelis, entre outros significados, registra para 'dispersão' a seguinte definição: distribuição espacial desordenada de qualquer organismo fora do seu lugar de origem; desvio, quase sempre a esmo, da trajetória desejada. Assim é possível entender as objeções e diferenciações feitas no final da citação de Meyer (dispersão x disparidade; difusão x divergência; novidade x variedade), o que também faz lembrar a frase de Stravinsky: o excesso gratuito deteriora a substância (cf: 1996, p.22).

Na linguagem verbal, uma seqüência de estímulos, ou seja, de palavras, é interpretada primeiramente de acordo com o significado semântico de cada componente, que é imediatamente relacionado com o termo subseqüente de modo a promover o entendimento da estrutura (seja esta frase, oração, período). Em construções sintáticas (como observado no Capítulo 3) esses componentes são ligados por meio de conectores lógicos (conjunções, pronomes relativos). Em estruturações paratáticas não há conectores aparentes, devendo o sentido ser construído, em geral, semântica ou metaforicamente. Mas mesmo nessas situações paratáticas o cérebro constrói o sentido por meio de operações funcionais, avaliando a interdependência entre os termos componentes da estrutura. Na célebre frase "vim, vi, venci" os termos não são conectados sintaticamente, pois cada um dos verbos possui um significado em si mesmo não implicando necessariamente o próximo. Não há, a princípio, uma relação de causalidade ou subordinação entre os membros da frase. O cérebro, todavia, consegue construir o entendimento desta simplesmente porque existe um sentido subjacente, não limitado aos significados primeiros dos distintos verbos, que permite entendê-los semanticamente e relacioná-los funcionalmente, conferindo-lhes um sentido causal, uma direcionalidade.

Há casos em que os significados primeiros são transformados de modo a gerar um novo significado. A palavra "nuvem" é um substantivo, significando um aglomerado circunscrito de água em estado gasoso condensada na atmosfera. A palavra "branca", por sua vez, refere-se inicialmente a uma cor, tratando-se de um qualitativo. Juntando-se as duas palavras na expressão "nuvem branca" entender-se-ia aquela massa de vapores de água que possui como atributo a cor branca. Basta, no entanto, uma simples inversão na ordem das 
palavras: "branca nuvem", para gerar uma nova percepção, tornando o texto mais poético que o anterior (Jakobson diria que lhe foi atribuída uma função poética), pois a segunda estrutura é menos ocorrente na linguagem falada. Esse artifício está na base de trocadilhos, figuras de linguagem e expressões de várias línguas, um procedimento também usado por Paulo Leminski em sua frase "nuvens brancas passam em brancas nuvens", processo construtivo típico de refuncionalização que impingiu uma nova significação aos membros da frase, ou seja, logrou a criação de novos sentidos na conservação dos mesmos componentes.

Em música, diferentemente da linguagem verbal, não há significados primeiros para os membros de uma frase, as notas ou motivos não são palavras com conteúdo semântico unívoco (exceto quando se trata de objetos auto-referenciais, como o tiro de canhão na Abertura 1812 de Tchaikovsky). O cérebro somente constrói o sentido musical na medida em que no ato da escuta pode aferir alguma relação entre as partes integrantes. A percepção de ordem se dá por meio da captação, associação e relação dos estímulos sonoros de modo que estes venham a gerar uma estrutura articulada e organizada. Com isso, os elementos apercebidos durante a escuta são interpretados de acordo com a função que desempenham, sendo analisados na relação que mantém com o evento antecedente e estimando os possíveis acontecimentos precedentes. $\mathrm{Na}$ impossibilidade de o sistema cognitivo promover essas relações, os eventos serão entendidos como divergentes e não geradores de expectativas.

Esse último parágrafo pode ser considerado como uma apresentação sintética do pensamento de Meyer sobre a significação musical (idéias tratadas de modo mais detido no próximo capítulo), descrevendo um percurso que se inicia com a percepção dos objetos musicais e caminha para a significação por meio de um processo prognóstico tendo por pano de fundo o estilo: "Uma vez que um evento musical implica ou é signo de algum outro evento musical somente para um observador ou ouvinte, a percepção de relações funcionais é o resultado de inferências feitas pelo auditor sobre as possíveis implicações de um evento musical" (MEYER, 1994, p.297). A interpretação funcional de um evento por parte de um ouvinte depende, então, "de sua experiência com o estilo musical, das características formais e sintáticas do evento em si, e da natureza do processo mental humano" (Ibidem, p.297).

Em sistemas erigidos funcionalmente, a existência de relações entre as estruturas gerativas postas em jogo no discurso musical (sejam estas pequenos elementos, como motivos, ou seções formais completas) promove a articulação, conexão e ordenação perceptual desses componentes que, congregados na totalidade da obra, possibilitam a construção do sentido musical. Como a ocorrência desta funcionalidade compreende todo o orbe composicional (do objeto musical à forma global), considerarei a seguir algumas dessas fases isoladamente, iniciando com as estruturas acórdicas; porém, deve-se sempre ter em 
mente que o objetivo dessas análises é estender as relações e coordenações para todos os domínios estruturais que compõem uma obra musical.

\section{Função Harmônica}

No Riemann Musik Lexikon encontra-se a seguinte definição de função: “conjunto das diversas significações que um acorde pode tomar no desenvolvimento lógico da frase musical, conforme a relação que ele mantém com a tônica estabelecida" (RIEMANN, 1967, p.311). As 'significações' referidas por Riemann tratam-se do que ele denominou como funções principais (T, S e D) e funções secundárias ( $\mathrm{Tr}, \mathrm{Ta}, \mathrm{Sr}, \mathrm{Sa}, \mathrm{Da}, \mathrm{Dr})$. É fácil notar a dependência que as funções secundárias mantém para com as principais, pois aquelas são determinadas a partir destas. Assim, dominante e subdominante distam-se uma quinta justa da tônica, enquanto as relativas distam-se uma terça (maior ou menor) de suas respectivas funções principais. Esse sistema funcional de certa forma encontra respaldo no conceito de função matemática descrito no início deste capítulo, onde dadas grandezas são determinadas por valores de outra grandeza, criando uma relação de dependência.

Sempre achei curioso o fato de haver uma diferenciação no ensino da harmonia entre as chamadas harmonias funcional e tradicional - ou graduada. Essa separação leva a entender que a harmonia graduada não é funcional, quando na verdade também é. Reparando-se na nomenclatura atribuída aos diferentes graus da escala constatar-se-á que os mesmos são derivados das relações que mantém para com o primeiro grau, a tônica. Isto denota a dependência entre os graus e indica sua funcionalidade já que são determinados em 'função' de uma grandeza de base: a tônica. O Exemplo 1-5 mostra a dependência mantida para com a tônica pelos demais graus bem como as grandezas usadas para suas derivações.

No Exemplo 1-5 indica-se o modo de derivação da nomenclatura na harmonia graduada. Essa derivação é realizada em função de um pólo principal: tônica. Os outros graus recebem seus nomes de acordo com a distância intervalar que mantém para com o pólo principal (T). Assim, dominante (D) encontra-se uma quinta justa acima da tônica. A subdominante (SD) uma quinta justa abaixo da tônica. Mediante (M) dista de uma terça acima da tônica, enquanto submediante (SM) uma terça abaixo da tônica. O mesmo vale para supertônica (ST) e subtônica (SbT) distando, respectivamente, do intervalo de segunda acima e abaixo do pólo principal. 


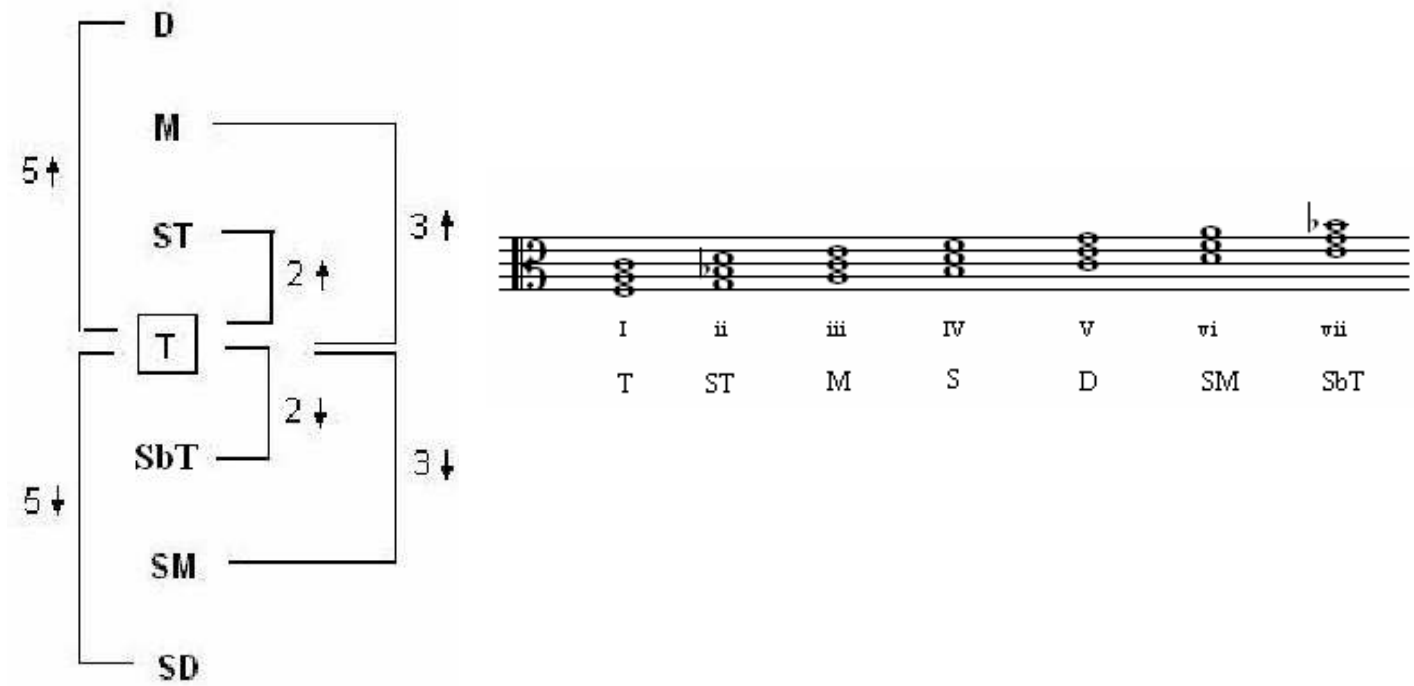

Exemplo 1-5: relações funcionais na harmonia graduada. Campo harmônico triádico de $F$. Os graus são derivados em razão da dependência que mantém para com a tônica.

O conceito função ao ser transposto para o domínio da harmonia musical provocou alguns mal-entendidos. Observe-se o seguinte trecho extraído do ótimo livro Techniques and Materials of Music escrito por três autores:

$\mathrm{Na}$ prática comum, os acordes tendem a progredir em padrões consistentes e previsíveis. Função, assim, refere-se à tendência de um acorde progredir para outros acordes. Esse sistema de relação acórdica é chamado funcionalidade diatônica. Na música tonal os graus mais fortes da escala são o primeiro e o quinto, e as harmonias construídas sobre eles exercem um controle primário sobre a forma musical. Estas harmonias são normalmente encontradas em pontos estruturais cruciais: início (I), pontos cadenciais (V-I) e final (I). Estes definem os objetivos harmônicos das frases e os maiores pontos de chegada (secções) na forma de uma obra tonal. A harmonia de subdominante (pré-dominante ou preparação da dominante) é também de importância crítica: esta classe de acorde é geralmente encontrada em pontos climáticos da peça, conduzindo [setting up] a chegada na dominante. Todas as outras harmonias, embora importantes para linha melódica e ornamentação, são subsidiárias para a definição da forma. As tríades da tônica, subdominante e dominante são geralmente referidas como "tríades primárias". Todas as outras tríades podem ser entendidas como decorativas ou substitutas destas harmonias essenciais. A tríade de supertônica (II) geralmente terá função de preparação da dominante, em uma progressão análoga à IV-V. A tríade de supertônica pode ser entendida como quase dominante da dominante, pois a relação de quinta descendente é correspondente à relação dominante-tônica. As tríades de mediante e submediante são usadas menos freqüentemente do que as tríades primárias (I, IV e V) e tem menor significância para a construção da estrutura musical. Podem ser pensadas como embelezamento ou substituição das harmonias mais fundamentais e são geralmente encontradas em seqüências (BENJAMIN et al, 2003, p.229).

Entendimentos similares do conceito de função em harmonia, prescrevendo a existência de uma lógica implícita aos encadeamentos acórdicos, não deixam de ser controversos. O princípio funcional, enquanto método de derivação, é de fato próximo do conceito matemático de função, indicando a interdependência entre os termos de uma 
estrutura. Contudo, não determina que concatenações entre acordes estejam estabelecidas $a$ priori pelo sistema funcional. O fato de ser observado em composições tonais incontáveis seqüências ii-V-I, não torna essa seqüência uma obrigação sistêmica. Na verdade seqüências e sucessões padronizadas são convenções pertinentes a quaisquer culturas.

A intenção de tratar a harmonia como ciência exata promoveu objeção por parte de teóricos. Dahlhaus, por exemplo, apontava para a ausência de uma relação causal nas progressões harmônicas, já que nestas não existe dependência entre seus termos, ou seja, não há uma obrigatoriedade de que um acorde seja seguido por um outro em específico. Como pode ser inferido do Exemplo 1-5 e da definição de função formulada por Riemann, o que existe de matemático é um procedimento de derivação de termos (acordes) em função de um outro termo (no caso musical: a tônica; pólo principal gerador da gama diatônica). As funções harmônicas apresentam uma relação de dependência para com o pólo principal, sendo que na variação deste pólo, também serão modificadas as funções dos termos a ele relacionados, condição que satisfaz a prescrição matemática de dependência. Porém, uma padronização dos encadeamentos, nos quais um acorde $x$ teria necessariamente que ser seguido por um determinado acorde $y$, encontra-se ausente do pensamento riemanniano.

A idéia de função enquanto 'atributo' também permite analogia para o domínio musical. Genericamente falando, alguns elementos possuem propriedades intrínsecas e extrínsecas.

Características intrínsecas implicam que a função esteja incorporada ao elemento de modo que o mesmo não a modifique em situações distintas. Assim, alternando-se o contexto, não há alteração das características do objeto. No entanto, a recíproca pode não ser verdadeira, pois o contexto pode ser alterado na presença do objeto (por exemplo, o sistema imunológico é afetado pela presença de um vírus). Segundo Cook, no mundo visual os objetos possuem seis atributos perceptuais: tamanho, cor, forma, posição, orientação e luminosidade. No domínio musical, sete são os atributos perceptíveis de um objeto apresentado: altura, ritmo, contorno, tempo, timbre, intensidade e localização espacial (Cf: COOK, 2001, p.214). A transformação desses atributos afeta o objeto de diferentes maneiras, e como se verá adiante, as transformações rítmicas e de contorno, de acordo com o grau de variação que impingem às estruturas musicais, são as que mais retiram o objeto de sua identidade original. Todas essas são características intrínsecas aos objetos.

As características extrínsecas são aquelas pertinentes ao sistema e não ao objeto, o que me parece corresponder ao caso da música. No sistema tonal, por exemplo, independentemente dos acordes e encadeamentos utilizados o modelo harmônico funcional não sofrerá alterações. Contudo, de modo contrário, as entidades acórdicas (objetos) terão 
suas funções alteradas na variação do contexto (caso freqüente em modulações). Esta propriedade permite pensar nos processos modulatórios intra e inter tonais.

Em uma modulação intratonal há a transformação, ou re-significação, do elemento na variação do contexto imediato. É o que acontece no Prelúdio 1 do Cravo Bem Temperado de Bach (mostrado no Capítulo 2, Exemplo 1-2), onde a nota $C$ é mantida no percurso harmônico, mas adquire diferentes significações, pois o contexto imediato de qual faz parte, isto é, os acordes aos quais a nota é integrada, são variados de modo que esta mesma nota $C$ seja objeto de reinterpretações na medida em que passe a ser fundamental, terça, quinta ou sétima desses acordes. Na modulação intertonal o contexto é mantido, isto é, os graus do campo harmônico são os mesmos, mas os acordes são variados, implicando no que se entende por transposição. Essa distinção é assim salientada por Ribeiro-Pereira:

Impõe-se relembrar aqui uma distinção elementar — conceptual e terminológica - que decorre do paradigma da modulação harmônica: o adjetivo "modulatório" refere-se em geral ao processo de transformação harmônica (ou mudança de sentido) de qualquer padrão tonal, enquanto que "modulante" denota em particular uma inflexão (ou mudança) de tonalidade. A primeira é intratonal; a segunda, intertonal (RIBEIRO-PEREIRA, 2007). Assim, na melhor tradição teórica e compositiva, poderá agora definir-se compreensivelmente o conceito de modulação como a reinterpretação do sentido harmônico de um padrão tonal — quer seja nota, intervalo ou segmento melódico (RIBEIRO-PEREIRA, 2005, p. 2).

No Capítulo 2, observou-se que Dahlhaus entendia haver na música do século XX a substituição do processo harmônico para o que denominou sistema harmônico. Essa variação do processual para o sistêmico implicou, sobretudo, na derivação de acordes a partir de uma formação ou agregado inicial qualquer. A maneira adotada por Scriabin como meio de efetuar essa derivação foi o denominado acorde-centro, ou seja, o emprego de uma formação sonora de base (um complexo ou aglomerado acórdico), a partir do qual é possível extrair diferentes acordes pela variação da escolha das notas. Se na harmonia tonal fora possível postular a relação compartilhada entre os acordes em razão de pertencerem ao mesmo campo harmônico, a relação entre os agregados acórdicos extraídos de conjuntos geradores teve sua base no fato de que estes agregados provêm de uma fonte sonora comum, o acorde-centro por exemplo. Outros compositores valeram-se dessa proposição, dentre eles é possível detectar um uso harmônico semelhante em Ernst Widmer que preconizava, enquanto elemento unificador da composição, a formação de conjuntos complexos a partir de uma "idéia básica", permitindo, assim, diversos modos de conexões. No Exemplo 2-5 é mostrada uma das maneiras de extração de entidades acórdicas a partir de um conjunto inicial. Nos compassos de 9 a 11 a série utilizada para estruturação da peça é apresentada no piano ${ }^{19}$. A partir do

\footnotetext{
${ }^{19}$ Essa série é uma referência à Seresta para Piano e Orquestra (1965) de Camargo Guarnieri, obra para a qual tenho uma predileção especial e que marca uma mudança de estágio na sua produção, evidenciada pelo abandono da tonalidade.
} 
compasso 41 a série é verticalizada de modo a gerar acordes que neste caso, são similares a uma formação arquetípica weberniana (vide adiante), constituída de intervalos de $4^{\mathrm{a}} \mathrm{s}$ justas e aumentadas. Como não se trata de uma obra serial, em stricto sensu, os acordes não surgem necessariamente na mesma ordem da série, algumas notas são deixadas ausentes $\left(7^{\mathrm{a}}\right.$ e $8^{\mathrm{a}}$ notas da série, por ex.) e outras são invertidas, como no compasso 42, no qual a nota $G$ é modificada tornando-se a nota mais grave da formação, ao passo que se fora usada na exata ordem serial deveria ser a terceira nota do acorde $C \#-F \#-G$ (este, procedimento comum no dodecafonismo).
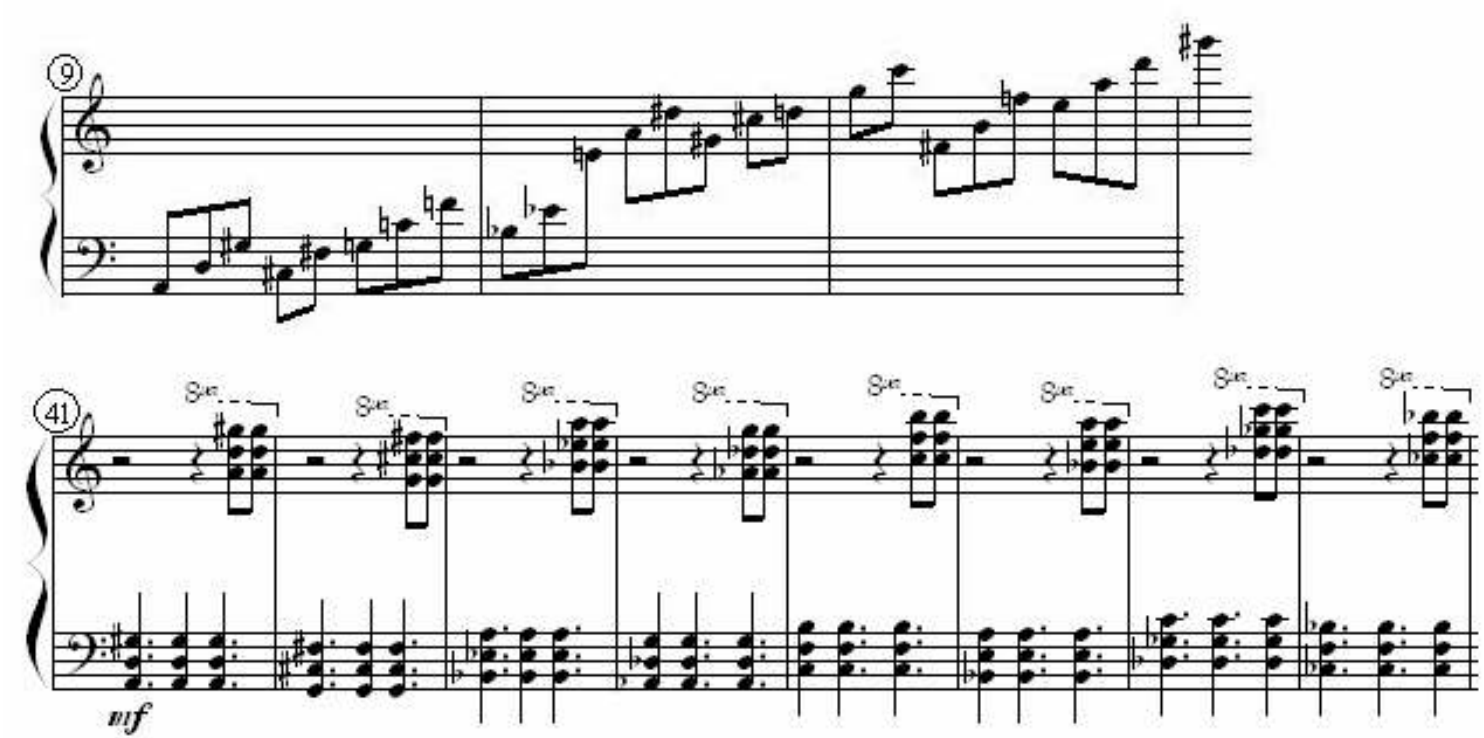

Exemplo 2-5: Antenor Ferreira, Chiromancer's hands doesn't have lines, compassos 9-11 e 41-48. Série principal e extração de agregados acórdicos a partir desta.

Não obstante, o uso dessas novas formações acórdicas trouxe como problema teórico o fato de não permitirem classificações dentro de um sistema harmônico tonal. Todavia, a idéia de funcionalidade não precisa necessariamente ser descartada, podendo encontrar-se presente nestes novos ambientes tanto teórica, embora de maneira renovada, quanto perceptualmente, na medida em que os eventos apresentem relações entre si passíveis de serem apreendidas no ato da escuta. O teórico e professor da Universidade de Miami Paul Wilson, em seu livro The Music of Bela Bartók, avalia a permanência da funcionalidade no repertório do século XX, em especial nas obras de Bartók, e descreve os elementos que concorrem para o estabelecimento de uma função harmônica tonal, com vistas a serem tomados como parâmetros para o transporte do conceito de função para o ambiente pós-tonal (cf. WILSON, 1992, p.33-39):

1. Uma função harmônica é exercida por notas específicas dentro de uma certa gama. A posição que cada nota ocupa no interior desta gama é essencial na determinação de sua função; 
2. Cada nota da gama é geradora e controladora de uma coleção de outras notas do interior da gama (por exemplo uma fundamental que gera um dado acorde por superposição de determinados intervalos);

3. O exercício e a identificação da função dependem de algum comportamento ou ação musical. Uma função harmônica realiza tarefas específicas na estrutura musical e de acordo com o tipo de tarefa desempenhada é que as funções podem ser designadas.

Verificam-se cinco comportamentos funcionais distintos empregados pela harmonia tonal diatônica: tônica, dominante, subdominante, preparação da dominante e substituição ou extensão da tônica.

De acordo com Wilson (cf. 1992, p.35-39), uma função tônica abarca quatro atividades distintas:

a) é o objetivo sonoro principal para um processo musical;

b) é um evento crucial para o desencadear do processo musical, apesar de não exclusivo;

c) é geradora de outros sons (algumas teorias entendem que esta função cria toda a gama diatônica);

d) é o centro estável neutralizador das tensões opostas entre dominante e subdominante (em um contexto riemanniano).

$\mathrm{Na}$ proposição de Wilson, a música não-tonal irá considerar como "tônica" o desiderato [goal tone], a meta ou objetivo sonoro pretendido. Este objetivo pode não coincidir com o som (nota e/ou acorde) de início, pois o mais relevante será o evento para o qual se direciona o fluxo discursivo. Os "acordes" são, em sua maioria, formações esporádicas de superfície, não lhes cabendo, portanto, a função de atestar ou confirmar um centro tônico estrutural. A ausência de escalas fixas, ou a utilização de todo o total cromático, impossibilita a atribuição de estatutos hierárquicos e a constituição de tônicas secundárias. Todo desiderato será, então, entendido como "tônica" já que não há uma tônica principal permitindo a constituição de tônicas locais em diferentes níveis harmônicos, como se dá na música tonal.

Os exemplos a seguir demonstram o deslocamento entre registros realizando a distensão por meio do estancamento e estabilização da movimentação rítmica sobre determinada nota que neste momento ganha destaque e é percebida como repouso, cumprindo a função de desiderato do trecho em questão. Os três exemplos seguintes (3-5, 4-5 e 5-5) foram extraídos da dissertação de Matheus Bitondi que versa sobre o conceito de melodia na música contemporânea. Bitondi analisou três obras significativas do repertório moderno (In Freundschaft de K. Stockhausen, Dialogue de l'ombre double de P. Boulez e Sequenza IXa de L. Berio) e chama a atenção para o fato de os compositores se valerem com abundância deste tipo de movimentação rítmica visando à distensão em um ponto de chegada específico. 
Talvez, o mais evidente desses procedimentos direcionais herdados da tradição seja o deslocamento no registro, a partir de um estado de menor tensão (geralmente associado ao registro grave) em direção a um estado de maior tensão (geralmente agudo). De maneira mais sutil e gradual ou mais brusca e direta, este procedimento é encontrado com abundância em todas as peças aqui analisadas. (BITONDI, 2006, p. 41).

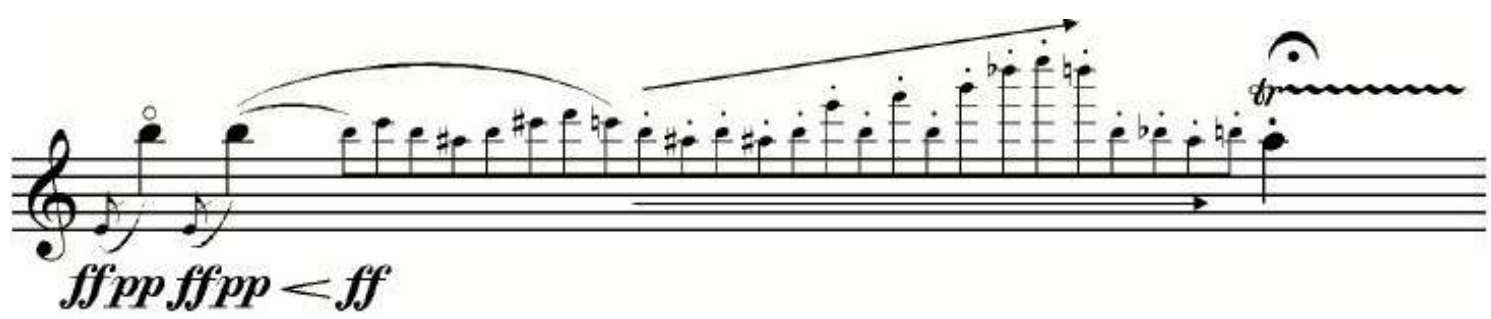

Exemplo 3-5: Stockhausen, In Freundschaft (pag. 5, sistema 6)

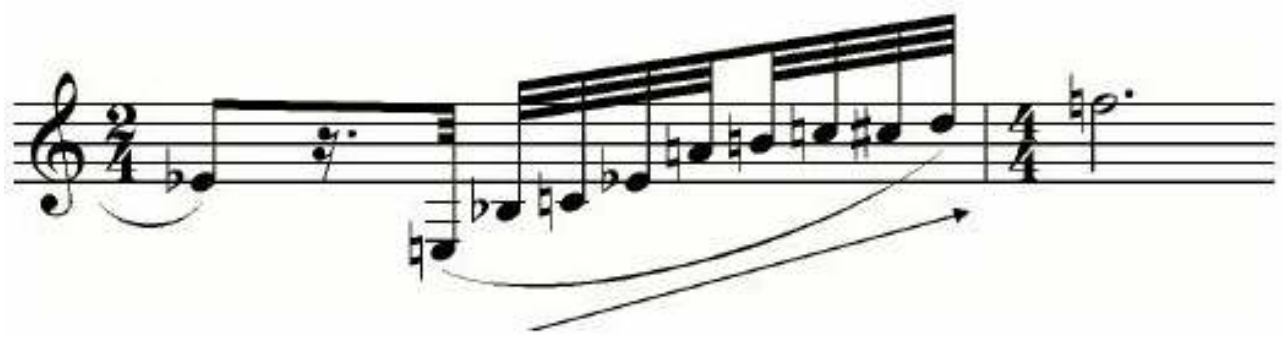

Exemplo 4-5: Boulez, Dialogue de l'ombre double (transição de IV a V, comp. 16-17).

Vale observar que as relações de intensidade integram-se a esta movimentação rítmica e conferem um maior sentido de distensão sobre a classe de altura que finaliza a movimentação. Bitondi menciona essa conexão intrínseca nesses termos:

Também como na música tradicional, o movimento direcional dentro do registro é, geralmente, acompanhado por um movimento direcional da dinâmica. Assim, em todas as peças aqui abordadas, uma subida gradual das alturas ao registro agudo vem, na maior parte das vezes, acompanhada de um crescendo de dinâmica e vice-versa. (BITONDI, 2006, p. 71).

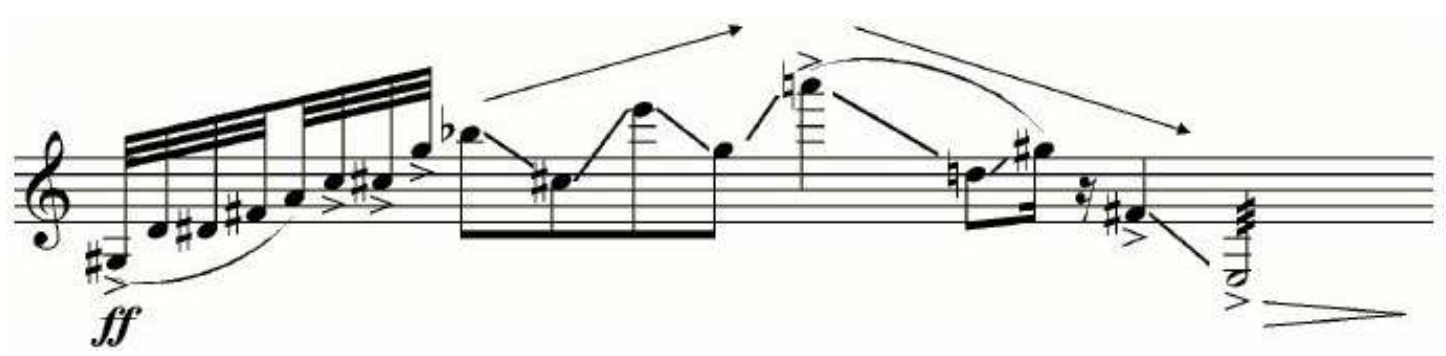

Exemplo 5-5: Berio, Sequenza IXa (pag. 7, sistema 1)

O mesmo tipo de sucessão ascendente, acompanhada de uma intensificação em dinâmica, estabilizando em uma nota de maior duração é também observada no Exemplo 6-5. 


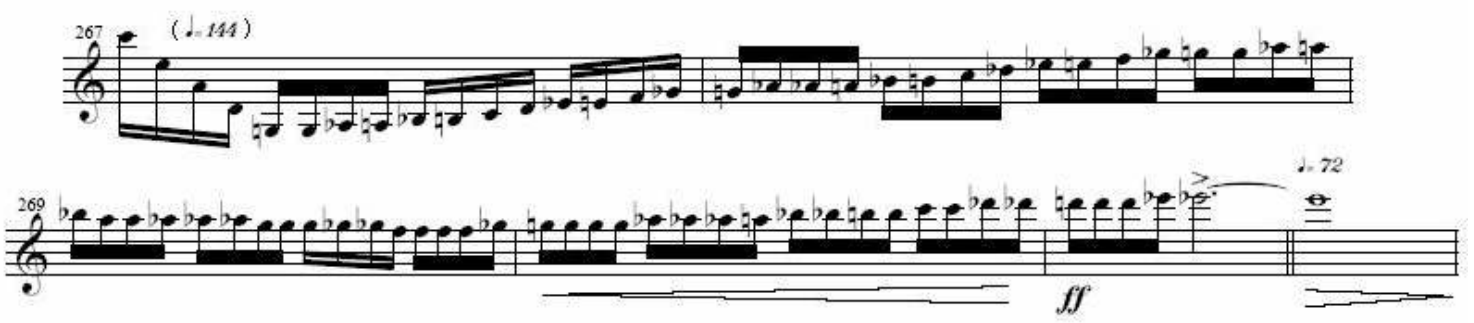

Exemplo 6-5: Paulo Chagas, Circular Roots, compassos 267-272,

O exemplo a seguir (Ex. 7-5) demonstra ainda a idéia do desiderato, mas empregado de uma maneira diferente, senão curiosa. Trata-se de um fragmento de minha peça Trilhas Sonoras onde uma tensa seqüência ascendente cria a expectativa musical de chegada e estabilização em algum lugar. E de fato há esta estabilização, só que ela não se dá em uma nota ou acorde, mas simplesmente em um ataque de prato e, embora suprimindo o parâmetro altura, a expectativa perceptual de repouso ainda se realiza, pois a função, ou refuncionalização, do desiderato enquanto elemento neutralizador da tensão criada pela sucessão anterior é atingida.

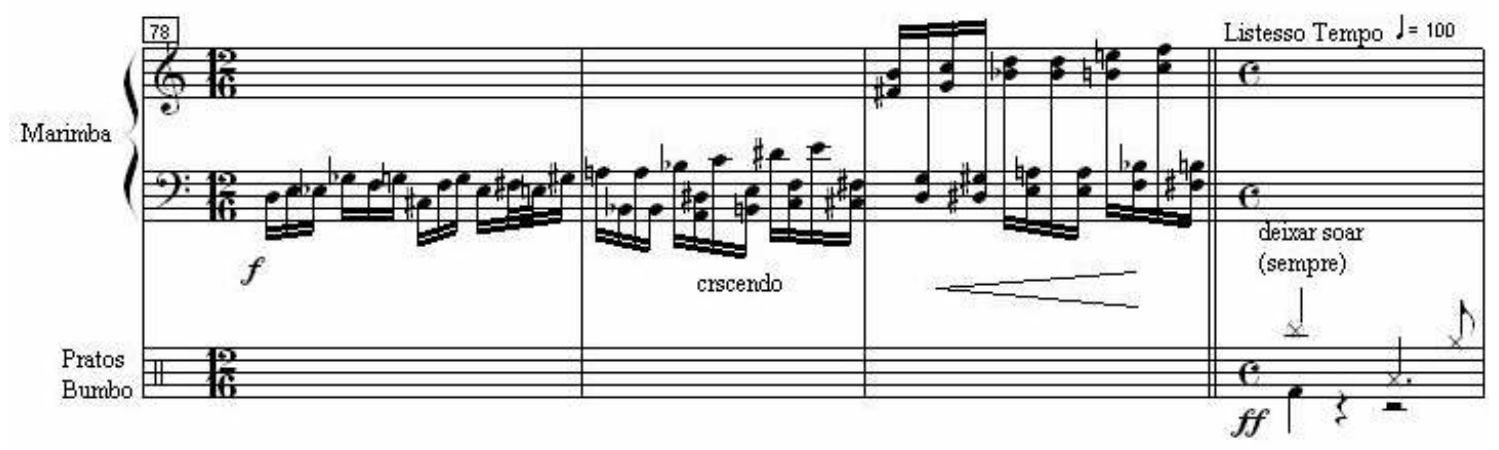

Exemplo 7-5: Antenor Ferreira, Trilhas Sonoras, compassos 78-81, sensação de resolução de uma seqüência instável sobre um desiderato no qual o parâmetro altura é suprimido.

Um aspecto de importância contumaz quando se trata do repertório pós-tonal é o impacto que distância e duração exercem na determinação das funções. Admitindo-se a existência de múltiplos pólos de atração em músicas pantonais, a porcentagem de tempo do discurso musical destinada a cada um destes pólos pode implicar em considerá-los como eventos principais (na medida em que se estabelecem enquanto centros locais da atividade harmônica) ou secundários (transitórios). Essa primazia temporal é um dos componentes do sistema analítico de Schenker resultando no seu conceito de prolongamento, que em geral "refere-se às maneiras em que um componente musical - uma nota (prolongamento melódico) ou um acorde (prolongamento harmônico) - permanece em efeito sem ser literalmente reapresentado a todo momento. (...) Essencialmente, uma harmonia dada é prolongada pelo 
tempo em que a sentimos controlar uma passagem em particular" (Forte e Gilbert, apud LACERDA, 1997).

Funções de substituição ou extensão da tônica implicam em prolongação do discurso por meio de uma separação entre o início e o objetivo final esperado. Para Wilson, extensão aplica-se somente às extensões diretas de eventos iniciais, enquanto substituição sugere a alteração de eventos cadenciais e desideratos. Um exemplo de extensão são as seções de variações, ou seja, partes do discurso musical em que certas características do evento inicial estejam conservadas e outros elementos tenham sido alvo de alterações, mas apesar disto, ainda permitam a identificação do evento inicial. A substituição, por seu turno, só se torna possível na existência de uma expectativa sobre o evento final. Substituição sugere algo similar a uma cadência de engano, na qual a expectativa da ocorrência de determinado evento é frustrada.

A função dominante, por sua vez, envolve somente uma ação especial, a criação de instabilidade que requer o desiderato para sua resolução. A preparação da dominante pode ser entendida como possuindo função de elaboração.

Procedimentos de preservação funcional podem ser observados em grande parte do repertório do século XX. Na peça a seguir tem-se uma sucessão de acordes presentes no encerramento da seção que antecede a cadência da marimba (instrumento solista deste concertino de Radamés Gnattali). Alguns acordes dessa sucessão podem ser facilmente classificados por superposição de terças, como nos compassos 205, 206 e 207 do exemplo, respectivamente $E m 7, A \#^{\circ} / E$ e $D m 7$. Os compassos 208 e 209 , porém, já não se encaixam tão facilmente nesse modelo. Nestes compassos se dá a passagem de uma construção triádica para a estruturação acórdica por justaposição de quartas. Note que o aglomerado do compasso 208 $(B b-E b-A b-B)$ funciona como pivô, gerando a tensão para resolução na formação em quartas do compasso 209 (E-A-D-G-C). A sensação de resolução ou de chegada nessa estrutura por quartas se faz com o auxílio da movimentação em meio tom descendente das notas do violino

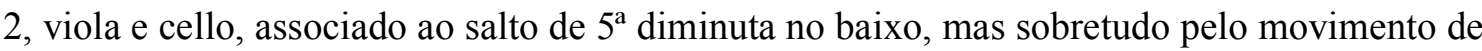
sensível gerado pela nota estranha à formação por quartas do compasso $208, B$ natural, que resolve na nota $C$ do compasso 209. Neste caso, embora não se tenha como classificar o agregado harmônico no sistema tonal, percebe-se que a função de dominante foi preservada, na medida em que houve uma tensão gerada e, posteriormente, resolvida. 


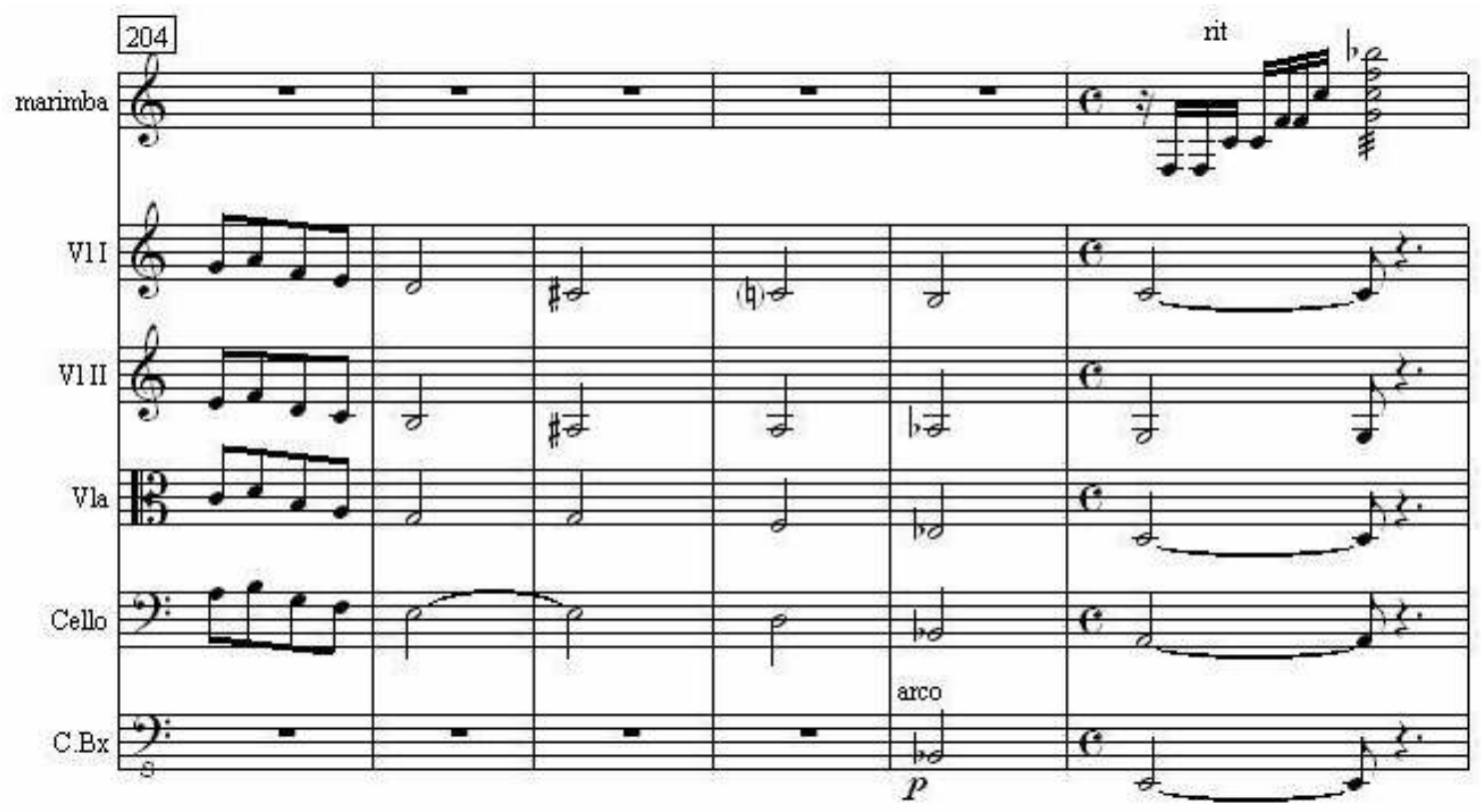

Exemplo 8-5: Radamés Gnattali, Divertimento para marimba e orquestra de cordas, compassos 204209. Resolução de tensão entre agregados não classificados no sistema tonal.

Um procedimento similar pode ser encontrado em obras do período denominado atonal livre, ou da atonalidade não sistêmica, por referir-se a obras antecedentes à promulgação da técnica dodecafônica. O Exemplo 9-5 mostra a primeira canção do Op. 4 de Webern. Nota-se que de maneira geral às terminações de frases do canto corresponde uma espécie de movimentação cadencial na parte do piano. Essa pontuação se dá pelo movimento de tons e semitons entre as notas componentes dos agregados sonoros do acompanhamento. Observa-se que no final de frase no compasso 3 o agregado harmônico inicial (compasso 1, do grave para o agudo, notas: $E, G \#, C \#, F)$ é resgatado, porém acrescido da nota $B$. A formação que antecede esse agregado encontra-se em relação de tons e semitons para com o mesmo, realizando uma espécie e tonicização com a seguinte condução:

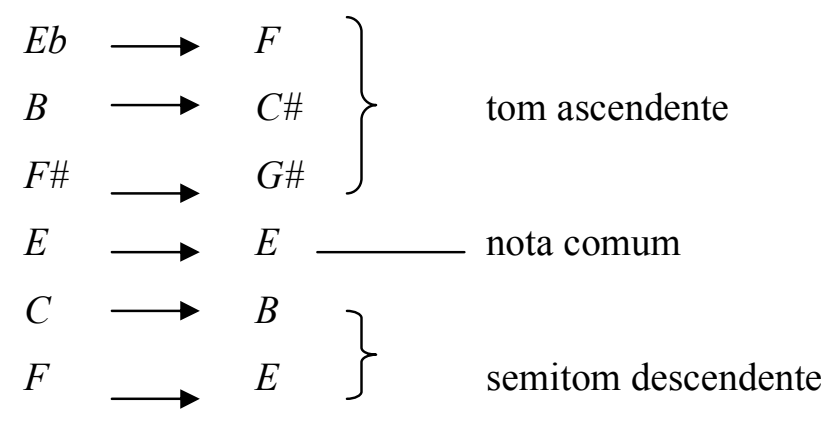



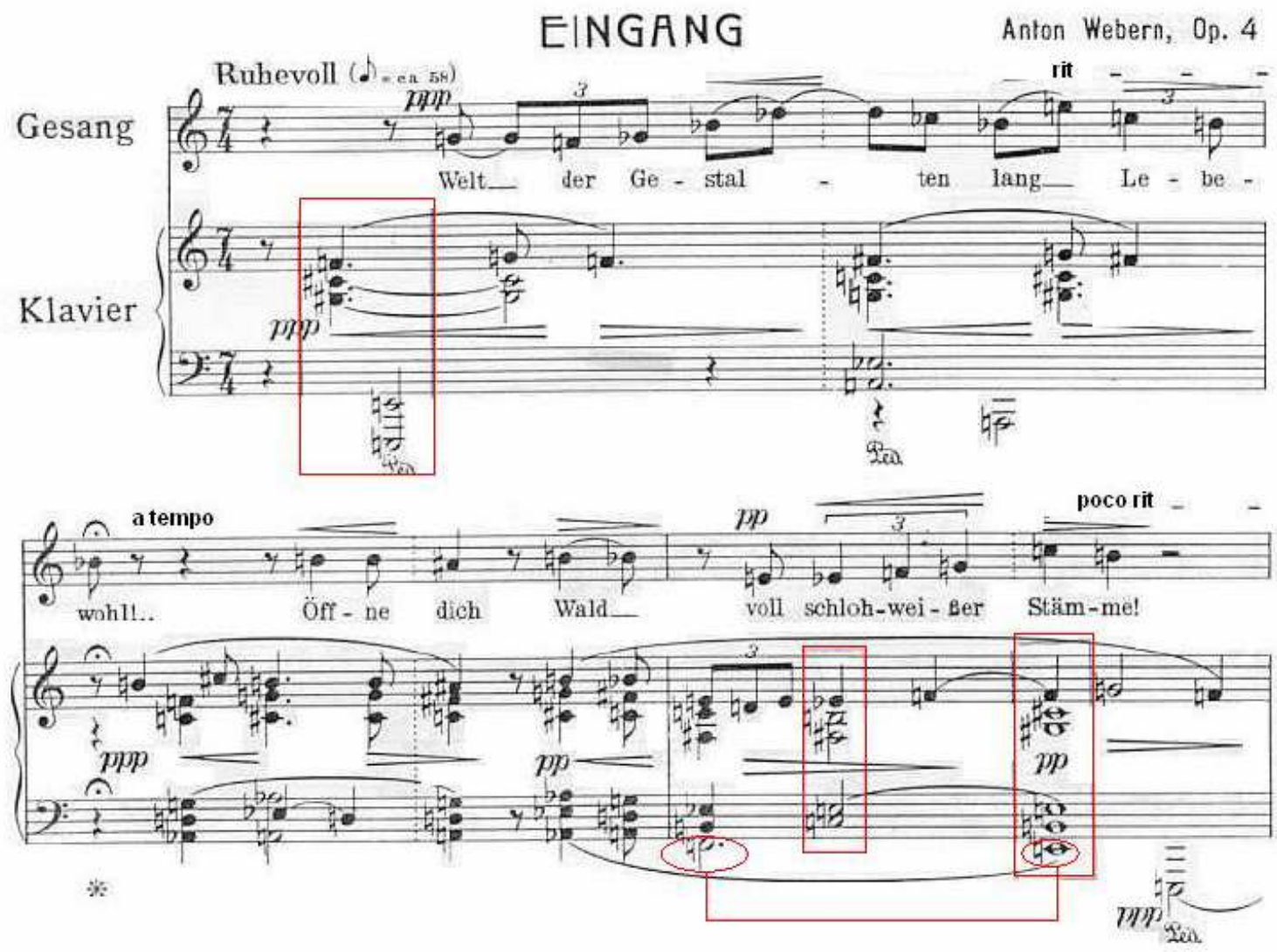

Exemplo 9-5: Webern, Fünf Lieder Op. 4 n 1 , compassos 1-3. Movimento 'cadencial' realizado pela tonicização por tons e semitons do agregado inicial.

Nota-se que essa movimentação cadencial é reiterada nessa peça, também podendo ser observada em outra passagem, mostrada no Exemplo 10-5, indicando mais duas finalizações de frases e suas cadências correspondentes no acompanhamento. No compasso 12 todas as notas do agregado caminham por semitom, à exceção da nota do baixo $(F \#)$ que une as duas formações como nota comum. Na harmonia popular esse tipo de movimento recebe o nome de aproximação cromática. Ao final da peça, o agregado harmônico inicial retorna no compasso 14 precedido do movimento 'cadencial' similar ao executado anteriormente no compasso 3. 


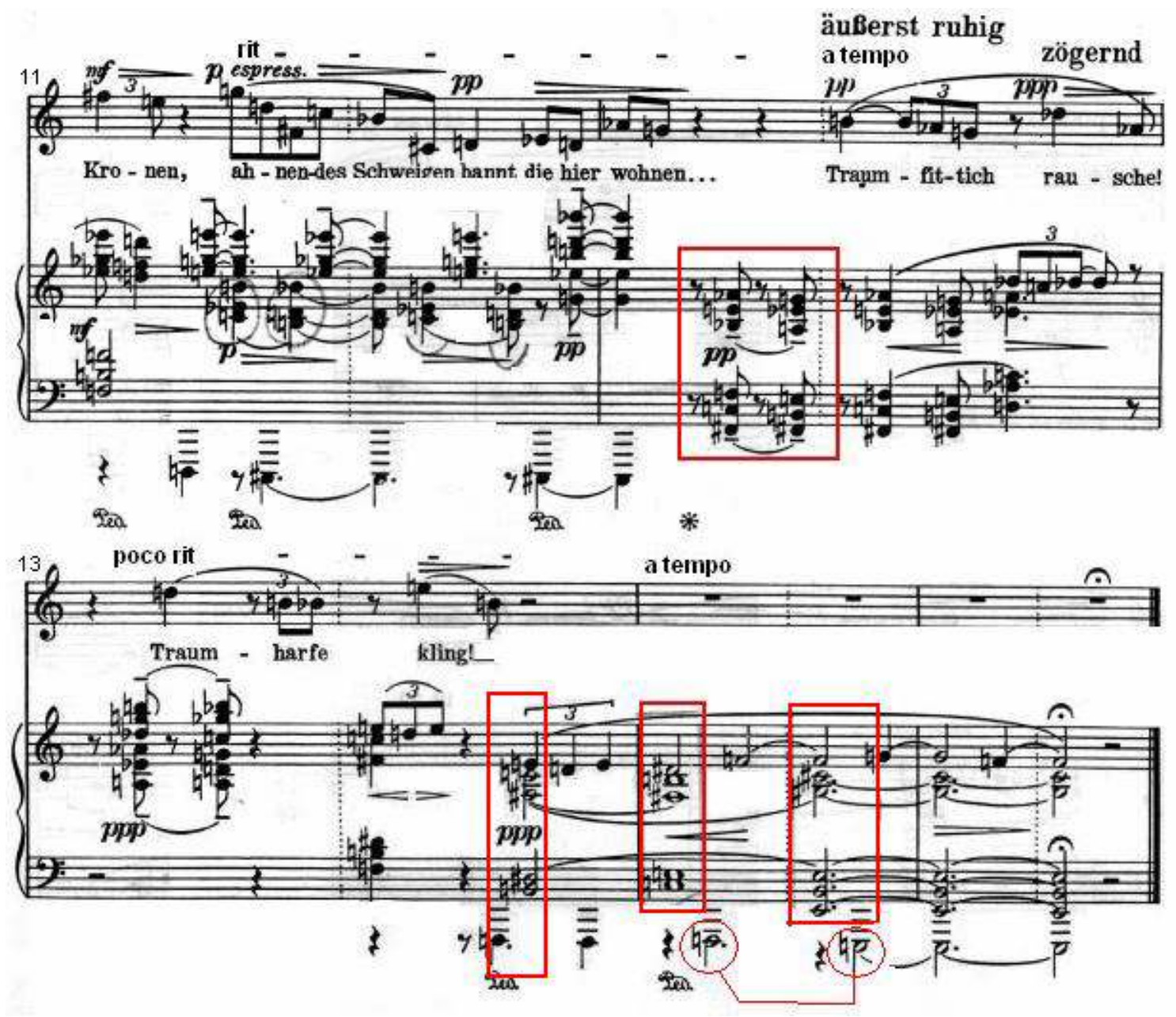

Exemplo 10-5: Webern, Fünf Lieder Op. 4 nº 1, compassos 11-16. Movimento 'cadencial' realizado pela tonicização por tons e semitons.

A existência de formações não repertoriadas na teoria harmônica tonal só se constitui enquanto problema teórico, não envolvendo, necessariamente, contrapartes perceptuais. Isso se dá porque a percepção, na medida em que a música se desenvolve, forma expectativas em acordo com o estilo da obra em execução. Isso quer dizer que expectativas não são geradas pelo uso da harmonia tonal, mas em razão do que é ouvido no momento. Assim, do mesmo modo que não se espera o uso de uma frase atonal após uma introdução tonal, causará surpresa o surgimento de um encadeamento de tríades após o estabelecimento de uma ambiência atonal. Desse modo, entende-se que o cérebro trabalha processando as informações recebidas no momento, independente da familiaridade ou não do ouvinte com o repertório apresentado. Em vista disso, passagens como a de Vers la Flamme de Scriabin, mostrada no Exemplo 11-5, fazem com que o ambiente instaurado nestes compassos iniciais induza a percepção a esperar alguma continuação similar. Neste exemplo também, a despeito das formações acórdicas baseadas em intervalos de trítonos (conjuntos 4-25), a expectativa é a 
continuidade da sonoridade, gerando inclusive, a possibilidade de pensar em notas estranhas a esses agregados. Disso resulta que as primeiras notas dos compassos 5 e 11 (valores de colcheia) sejam percebidas como espécies de apojaturas das respectivas formações por trítonos. Isso promove também a faculdade de relacionar essa passagem em função das 'harmonias' envolvidas, de modo que se venha a perceber uma estruturação em três frases (indicadas no exemplo com os números 1, 2 e 3 ) divididas em razão das mudanças dos agregados acórdicos.
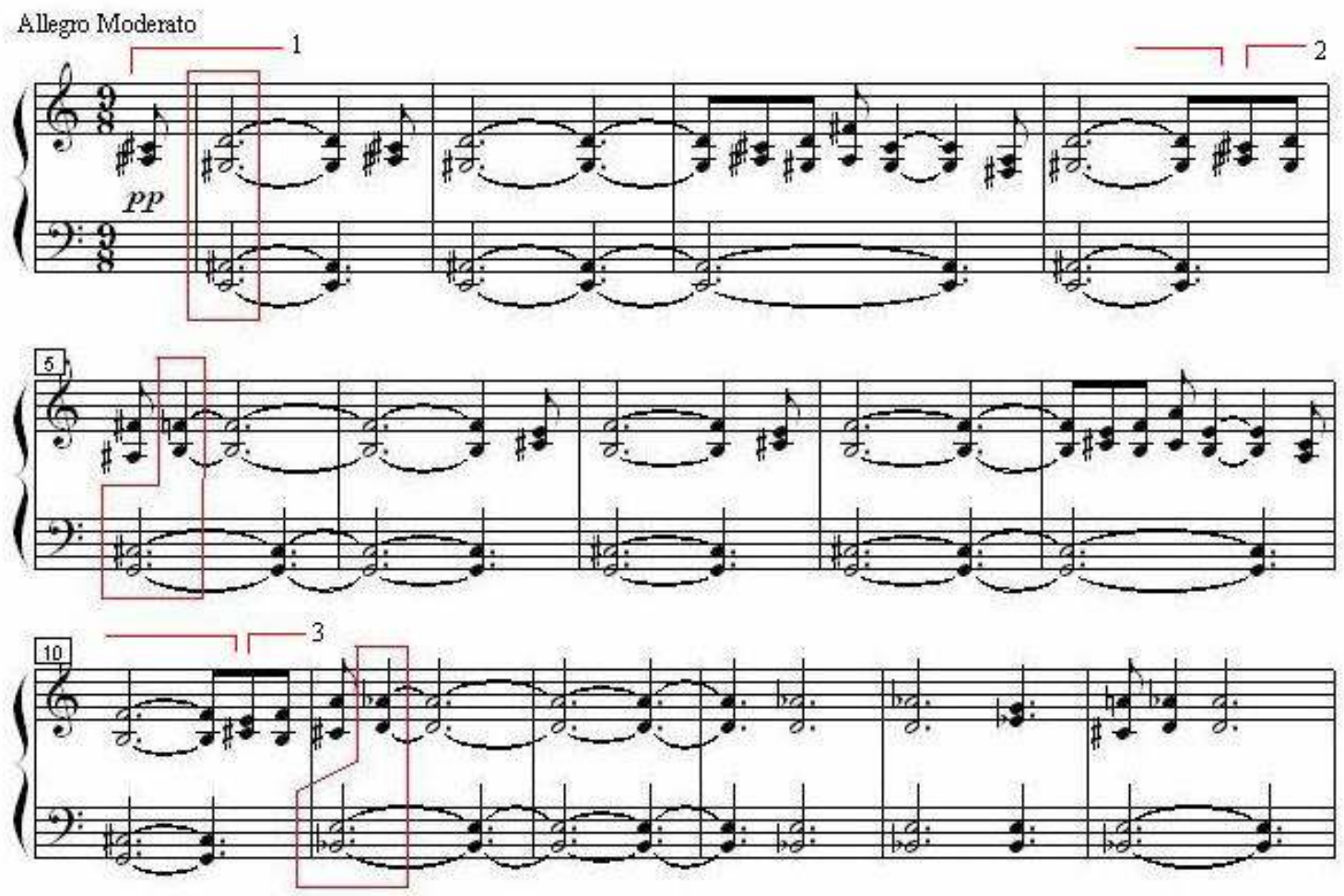

Exemplo 11-5: Scriabin, Vers la Flamme Op.72, compassos 1-15.

Nessa concepção de refuncionalização, a preponderância recai sobre a percepção, possibilitando que uma função possa ser exercida por qualquer formação, agregado ou entidade harmônica, desde que sua característica intrínseca seja mantida. Uma função de dominante, por exemplo, comporta a peculiaridade da geração de tensão ou instabilidade em meio ao discurso musical, causando a expectativa da resolução dessa situação em uma situação mais estável. Alguns autores adotaram, inclusive, certos arquétipos como substitutos dos acordes tonais. Tive a oportunidade de discorrer sob alguns desses modelos em meu livro Estruturações Harmônicas Pós-tonais, no qual elenquei algumas formações sonoras recorrentes em obras de alguns compositores. O Exemplo 12-5 mostra uma dessas formações preferidas por Webern, agregado formado pelos intervalos de $3^{\mathrm{a}}$ e $7^{\mathrm{a}}$. Esses dois intervalos podem tanto ocorrer como maiores ou menores, e sua configuração também pode ser 
remanejada para $7^{\mathrm{a}}$ e $3^{\mathrm{a}}$. Por falta de nomenclatura convencionada para classificar essas formações, os teóricos acabam por batizá-los do modo que melhor lhes parece. Florivaldo Menezes denomina os agregados harmônicos recorrentes como arquétipos. Outros preferem falar em entidades harmônicas. Na falta de consenso terminológico acabei por chamar as formações como as mostradas no exemplo 11-5 de arquétipo de $3^{\mathrm{a}}+7^{\mathrm{a}}$.

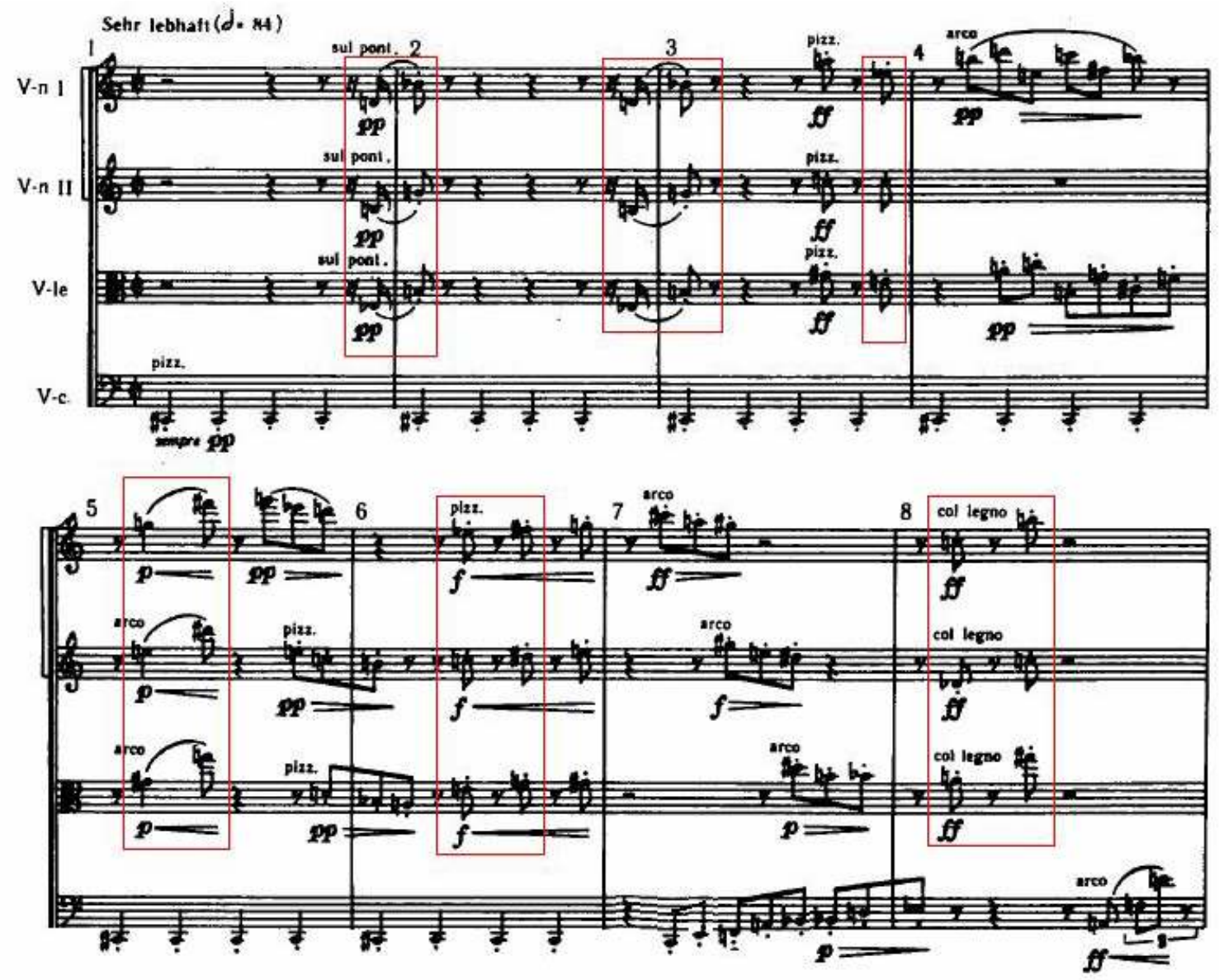

Exemplo 12-5: Webern, Cinco peças para quarteto de cordas, Op.5, n.3, compassos 1-8. Arquétipos de $3^{\mathrm{a}}+7^{\mathrm{a}}$.

É preciso lembrar que somente a formação empregada não é suficiente para o desempenho da função. Para que um comportamento como 'dominante' seja perceptível é preciso haver um vínculo com os outros fatores musicais, como tempo, dinâmica e ritmo. Por vezes o aspecto rítmico é mais preponderante que o parâmetro das alturas na realização de tensão ou instabilidade. No âmbito das alturas, porém, artifícios de tonicizações podem promover similaridades à função de dominante. Bartók, por exemplo, realizava um movimento cadencial substituindo o acorde de dominante pelo acorde distanciado de um trítono da formação utilizada como pólo principal da obra. No exemplo seguinte (Ex. 13-5), segunda canção do Op.4 de Webern, nota-se que, de modo semelhante ao citado nos exemplos 9-5 e 10-5, o final da frase do canto se dá em concomitância com o acompanhamento. Dessa 
maneira, é possível uma analogia com o movimento de resolução cadencial associando as notas do agregado harmônico, perfil (descendente no canto), tempo (ritenuto), ritmo e intensidade.

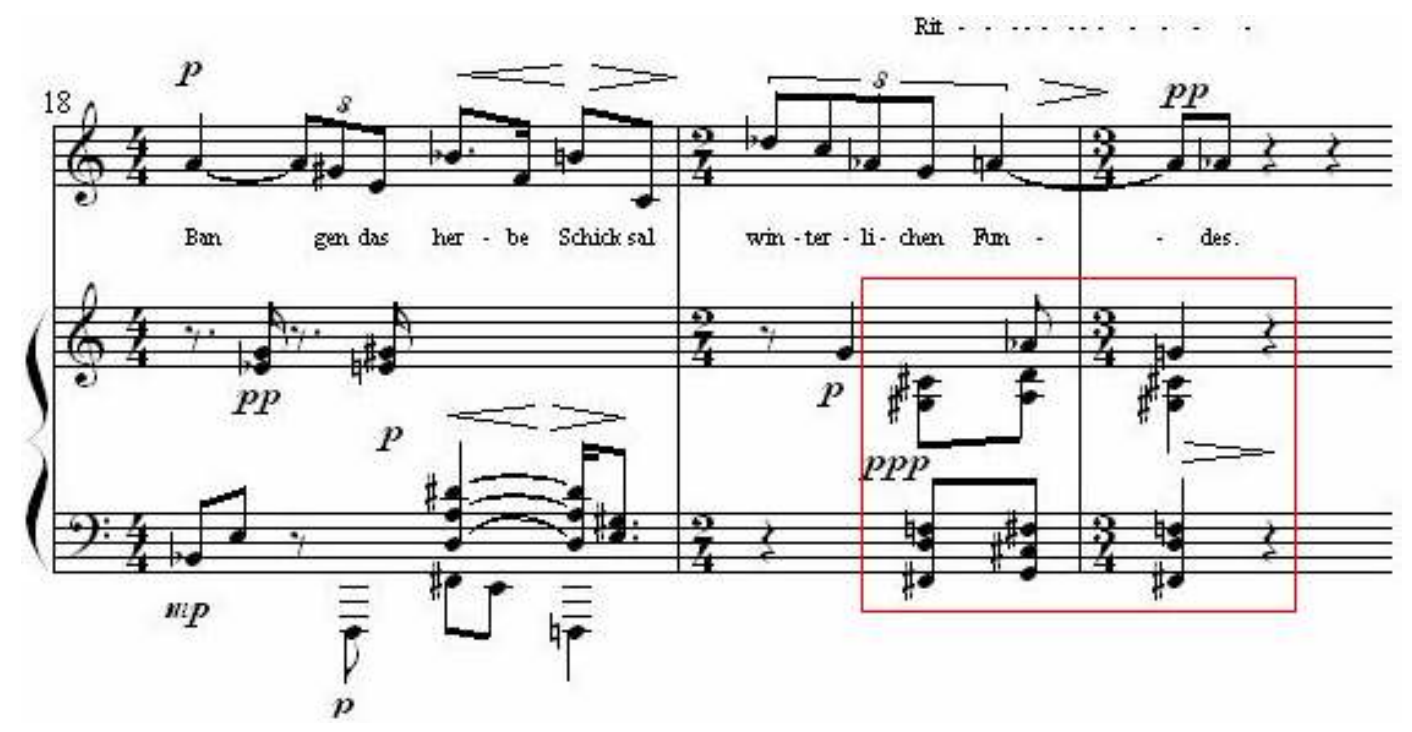

Exemplo 13-5: Webern, Fünf Lieder Op. $4 \mathrm{n}^{\circ}$ 2, compassos 18-20. Movimento 'cadencial' de resolução da frase associando vários parâmetros estruturais.

No âmbito da refuncionalização discutido até aqui é importante ressaltar que as obras consideradas apresentam, em maior ou menor grau, um claro sentido direcional, permitindo, assim, postular a existência de estruturas que desempenham funções identificáveis. No entanto, há passagens musicais onde o senso de direcionalidade não é evidente ou, simplesmente, não se faz presente. Desse modo, a atribuição funcional é impossibilitada, pois a identificação de desideratos em meio a um fluxo contínuo é complicada, dificultando, com isso, impingir função dominante a outras estruturas. Contudo, embora não haja pólos, hierarquias tonais ou forte sensação de distensão ou estabilização sobre algum ponto (onde um movimento direcional ou fluxo de tensão é interrompido), algumas notas podem adquir proeminência em razão das ênfases quantitativa e qualitativa que recebem no decurso musical $^{20}$. Um dos procedimentos mais eficazes de ênfase quantitativa é a repetição de uma determinada classe de altura. A reiteração de uma altura chama a atenção sobre a mesma, atribuindo-lhe preponderância em relação às demais classes de alturas.

O Exemplo 14-5 mostra a repetição da nota $G$ (nota escrita), linha do clarone, na obra No Encalço do Boi, de Silvio Ferraz. Essa reiteração permite aferir ênfase e entender essa classe de alturas como referencial, já que as outras convergem para ela. Além disso, a linha

\footnotetext{
${ }^{20}$ Retomando: Richard Parks, em seu estudo sobre as obras Debussy, observou que a tonalidade é conseguida por outros métodos que não a harmonia e a condução melódica. Nomeou, então, os artifícios indutores da percepção tonal segundo o meio com o qual a tonalidade é imposta. Esses meios são descritos como ênfase quantitativa, invariância, ênfase qualitativa, linearidade e ênfase implícita (Cf: PARKS, 1989).
} 
melódica é construída de modo a estabelecer ao menos três camadas diferenciadas. A primeira se dá no registro próximo à classe de alturas reiterada $G$ (nota que inclusive é tonicizada pelo $F \#$ reforçando sua função enquanto pólo). A segunda no registro médio acima da nota $D$. O terceiro plano é o mais agudo, surgindo no final do terceiro sistema, compreendido entre as notas $E b$ e $F \#$. Com isso, a escuta é induzida a uma percepção polifônica desta passagem. Essa percepção de distribuição em planos distintos tem por base um princípio gestáltico de agrupamento (Cf: COOK, 2001, p.32), pois a percepção tende a agrupar as coisas segundo proximidade, assunto discutido adiante.

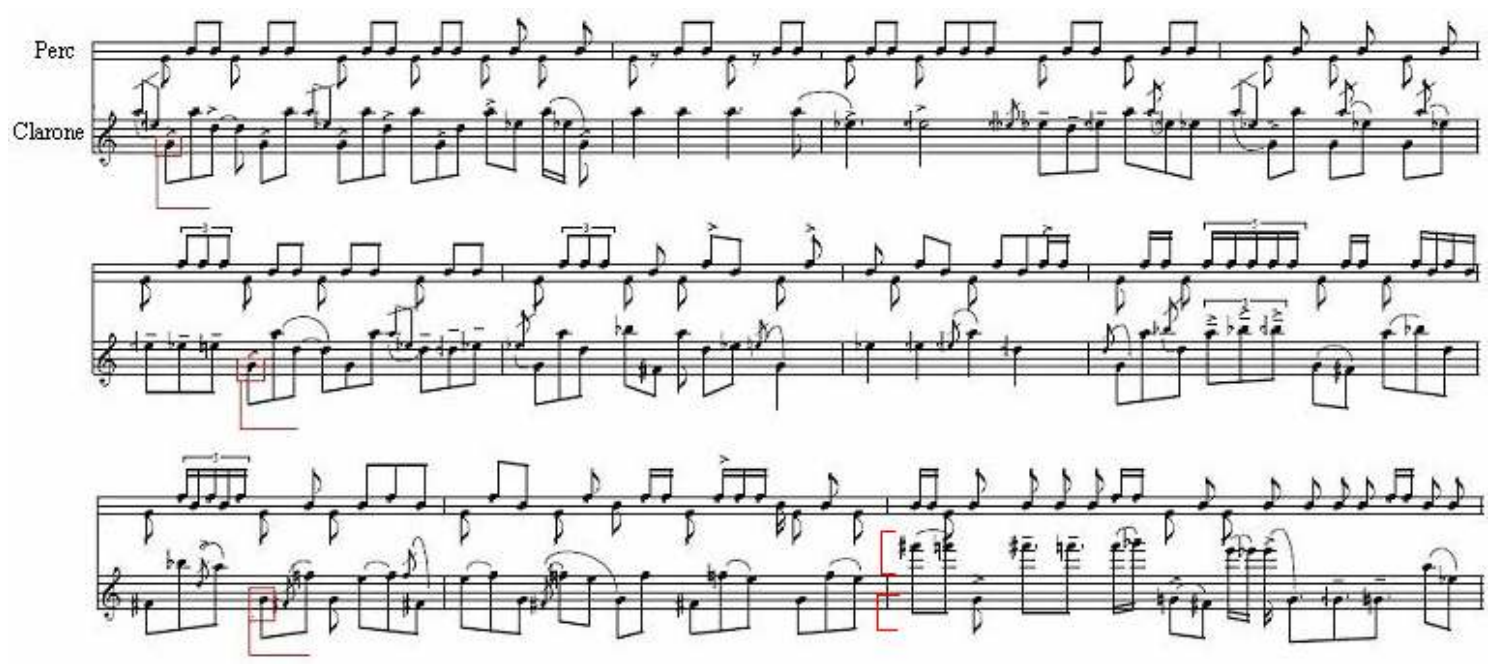

Exemplo 14-5: Silvio Ferraz, No encalço do boi, (início). Reiteração da classe de altura $G$ e distribuição polifônica entre planos melódicos.

\section{Funções Formais}

É comum encontrar em livros de análise musical a classificação das seções de uma obra de acordo com a função que as mesmas desempenham no âmbito global da composição. Considero útil e esclarecedora a classificação funcional de partes (frases, períodos, seções), sendo denominadas como expositivas, desenvolvimental, elaborativa, de prolongação, transitiva, aditiva (acréscimo de novos materiais), contrastante, re-expositiva ou de recapitulação e ornamental. Na literatura encontra-se também o designativo 'seção subsidiária', porém não se trata de uma função, mas de uma qualificação.

Algumas das definições são evidentes por si, como a função expositiva, que tem por finalidade expor o material a ser trabalhado na composição. Ao passo que re-expositiva é justamente a reapresentação desse material inicial, que pode ocorrer de maneira renovada. Funções de desenvolvimento e elaborativa objetivam a expansão do material musical inicial de acordo com algumas operações, como transformações (tratadas no Capítulo 4). Há partes 
em que acontecem adições de novos materiais (por interpolação, por exemplo) ou de estruturas derivadas das anteriores, estas partes possuem função aditiva. Se o material for totalmente novo de modo a contrastar com os já expostos a função será, então, contrastante. O Exemplo 15-5, o segundo número da Musica Ricercata de Ligeti, intenta mostrar algumas dessas funções em ambiente não tonal.

É preciso antes relembrar a proposta de Ligeti nesta obra: levar ao limite as possibilidades e recursos do instrumento. Os quatro primeiros compassos apresentam o material principal da composição, constituído de duas classes de alturas: $E \#$ e $F \#$, que possuem função expositiva. Trata-se de um período contendo duas frases que partem de $E \#$ chegam em $F \#$ e retornam para $E \#$. Os compassos 2 e 4 são quase semelhantes (diferindo-se apenas pela duração da última nota), enquanto o terceiro compasso quebra a estruturação rítmica e une as frases dos compassos 3 e 4 . Os compassos de 5 a oito compõem um novo período, também constituído de duas frases. No quinto compasso o material exposto é variado em densidade, timbre, intensidade, textura e registro, embora permaneça o mesmo no que diz respeito às classes de alturas e às estruturações métrica, rítmica e fraseológica. Desse modo, os compassos de 5 a 8 possuem função aditiva, pois o material acrescentado é variado a partir daquele já apresentado na parte expositiva. Os compassos de 9 a 12 podem ser pensados com possuidores de função elaborativa, pois de certo modo ampliam ou dão novas 'versões' ao material já apresentado. Como se fosse a mesma idéia, mas dita de outra maneira. O último período desta primeira parte da música é uma repetição do segundo período, possui, assim, função re-expositiva. Nesta primeira parte da peça há uma estruturação de períodos configurada como $a-b-a^{\prime}-b$. Note-se que a recapitulação literal é da parte $b$, o que não se esperaria em uma obra tonal, por exemplo. O compasso 17 , embora seja um momento de silêncio, cumpre um importante papel, pois detém a função transitiva. As funções transitivas têm como objetivo conectar seções musicais. Desse modo, são geralmente partes instáveis do discurso musical. Na música tonal as seções de transição apresentam instabilidade harmônica, contrastes dinâmicos, ritmos fragmentados e agitados, visando induzir a percepção a suspender a sensação de repouso já estabelecida por uma tônica, de modo a conduzir e preparar a chegada em uma outra região harmônica. Nessa música de Ligeti, todavia, todos esses atributos são transferidos para um compasso de pausa, que suprime a movimentação rítmica e põe em suspenso as expectativas já engendradas pelo material exposto até então. Um único compasso de silêncio gera toda tensão típica da função transitiva. 

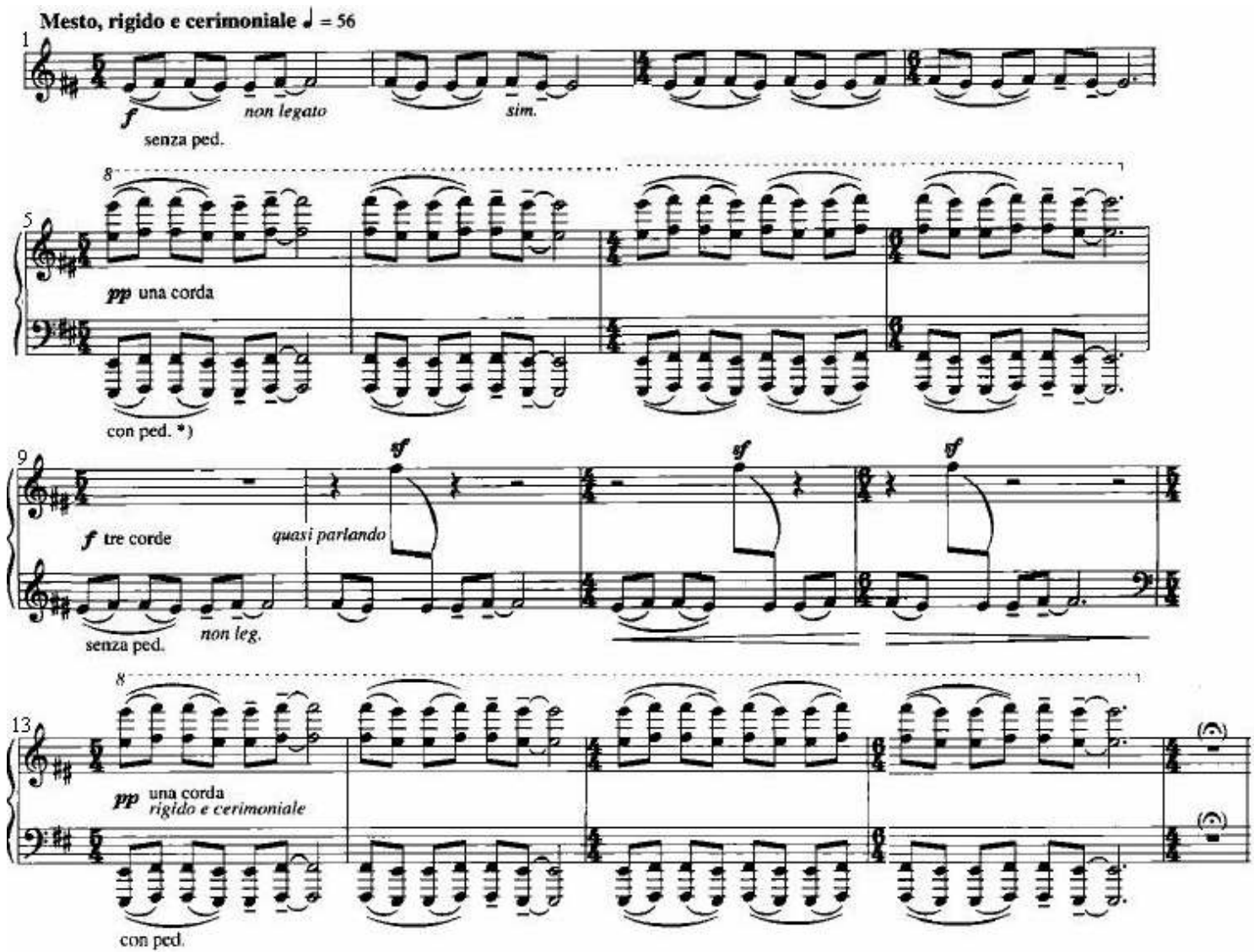

Exemplo 15-5: Ligeti, Musica Ricercata II, compassos 1-17. Exemplificação de funções expositiva, aditiva, re-expositiva e transitiva.

Os compassos 18 a 24, mostrados no Exemplo 16-5, constituem a segunda seção da obra. A função é evidentemente contrastante. O material é totalmente novo, isto é, uma nova classe de altura é apresentada: G. Demais parâmetros são também contrastantes como intensidade, tempo, densidade, textura, ritmo, métrica e registro. Esses compassos realizam um acelerando escrito resultando num efeito textural granular pela reiteração rápida da nota G. A seguir, há uma construção estratificada onde o material da segunda seção (textura granular) é mantido em uma camada aguda simultaneamente a apresentações de fragmentos do material da primeira seção (classes de alturas $E \#$ e $F \#$ ) em outro estrato no registro grave. Os compassos 29 a 32 (não mostrados no exemplo, mas similares aos compassos de 13 a 16, indicados no Exemplo 15-5) têm função re-expositiva, novamente recapitulando o segundo período da primeira seção da obra. O compasso 33 (Exemplo 17-5) tem função conclusiva, constituindo uma espécie de coda, também reapresentando, concomitantemente, os materiais das duas seções anteriores. Porém, neste compasso Ligeti vale-se da relação de simetria ao expor o material da segunda parte de forma invertida, ou em espelho. No início da segunda seção acontecia um acelerando escrito. Neste compasso, porém há um rallentando, invertendo, portanto, o evento anterior. 


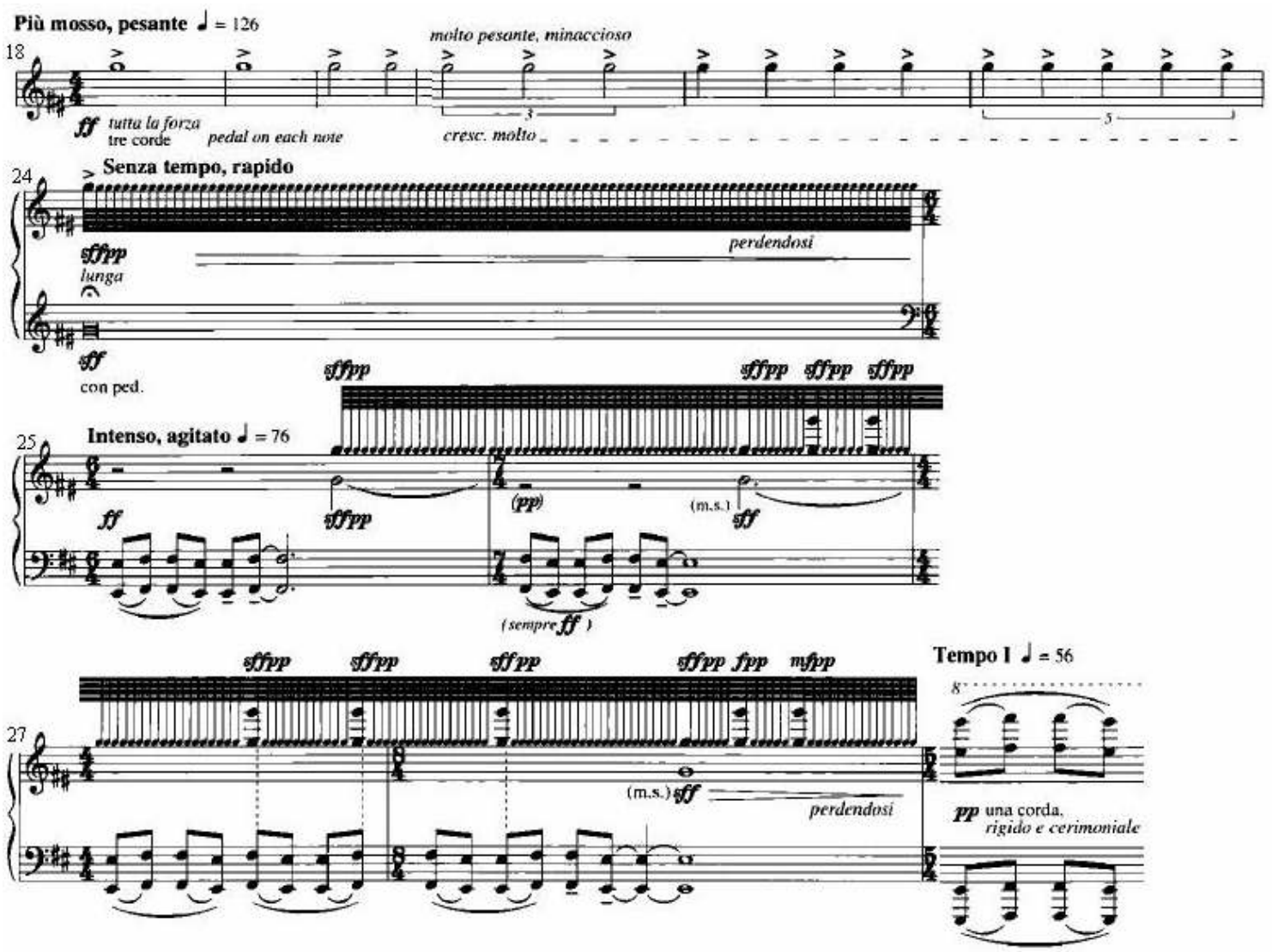

Exemplo 16-5: Ligeti, Musica Ricercata II, compassos 18-29. Exemplificação de função contrastante.

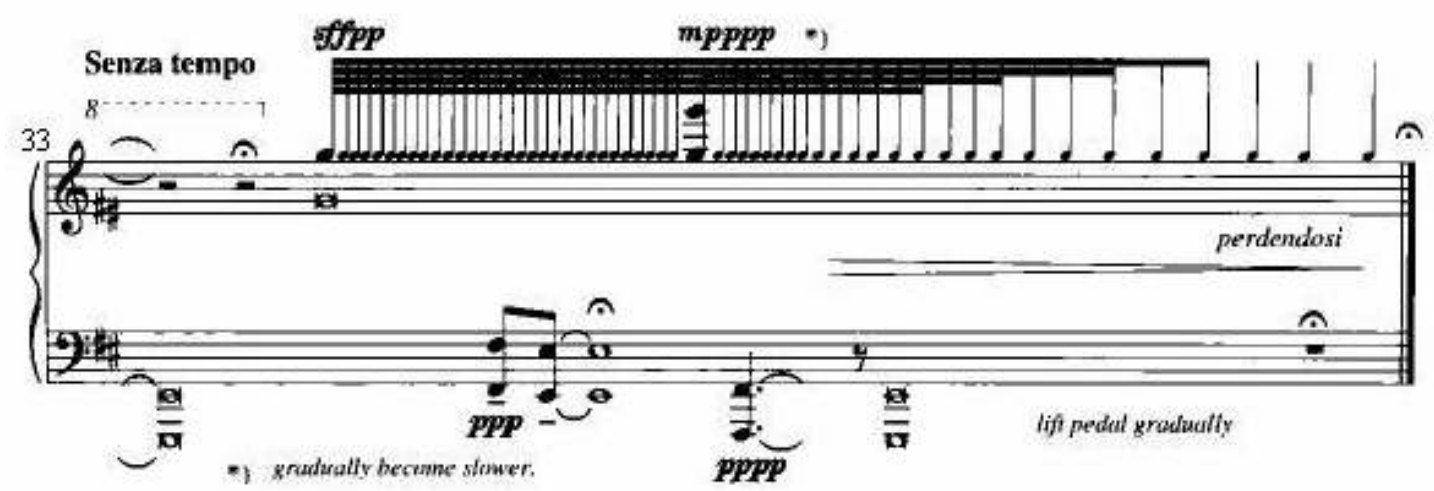

Exemplo 17-5: Ligeti, Musica Ricercata II, compasso 33. Exemplificação de função conclusiva.

A função de prolongação harmônica (comentada a seguir) também possui contrapartida em domínio pós-tonal, porém, esse entendimento é refuncionalizado substituindo o elemento harmônico pelo gestual.

De certo a palavra gesto remete, num primeiro momento, a um movimento corporal, como acenar, balançar a cabeça, etc. No entanto, o conceito pode ser ampliado de modo a abarcar não só a linguagem corporal (mímicas), mas também pronúncias verbais (inflexões da 
fala), representações gráficas, configurações sonoras e "qualquer coisa mais que incorpore uma expressão compreensível" (SHERMAN, 1989, p.145). A idéia de gesto veio á tona no repertório musical das duas primeiras décadas do século $\mathrm{XX}$, período em que os limites do sistema de tonalidades haviam sido totalmente expandidos e os compositores pesquisavam modos de substituir a harmonia tonal. Teóricos que se dedicam ao estudo deste repertório (vide Baur ou Sherman) valem-se do conceito de gesto como valiosa ferramenta para compreensão dessas obras. De modo geral, nessa literatura, o gesto musical é definido como "uma pequena idéia musical, quase como um motivo, possuidora de identidade melódica e rítmica" (BAUR, 1985, p.244). Sherman complementa dizendo que "o gesto musical possui duas propriedades básicas: uma configuração musicalmente funcional que dá forma a uma idéia musical discernível” (SHERMAN, 1989, p.146). Esse entendimento é válido também para a análise da música tonal, todavia, interessantes são os desdobramentos que o uso dessa idéia pode trazer. Assim, é possível pensar que um gesto inicial pode ser projetado ao longo da composição pela repetição de seu formato básico ou por versões transformadas deste. A unidade composicional estará assegurada desde que características do gesto sejam preservadas em graus tais que a percepção ainda seja capaz de identificá-los. Com isso, há uma similitude entre a noção de prolongação e projeção gestual.

$\mathrm{Na}$ prática comum, eram encontrados como artifícios de prolongação harmônica a adição de ornamentos às notas do acorde, o uso de pedal, a reiteração de padrões melódicos, uso de arpejos e passagens escalares. O Prelúdio $n^{\circ} 15$ do Cravo bem Temperado, mostrado a seguir, exemplifica alguns desses procedimentos. Note-se de saída o uso de arpejos e a prolongação da harmonia inicial de $G$ durante os três primeiros compassos pelo uso do pedal, embora as notas da 'melodia' (na clave de sol) sugiram outros acordes (como $C$ e $F \#^{o}$ além do próprio $G)$. No compasso 4 a harmonia de $A(\mathrm{D} / \mathrm{D})$ implícita no baixo é prolongada em uma seqüência escalar na clave de sol ( $D-E-F \#-G-A-B-A-G)$, esta por sua vez, ornamentada pelas notas $C \#-D$. Esse procedimento é de certa forma reiterado no compasso 5, mas em registro invertido. 

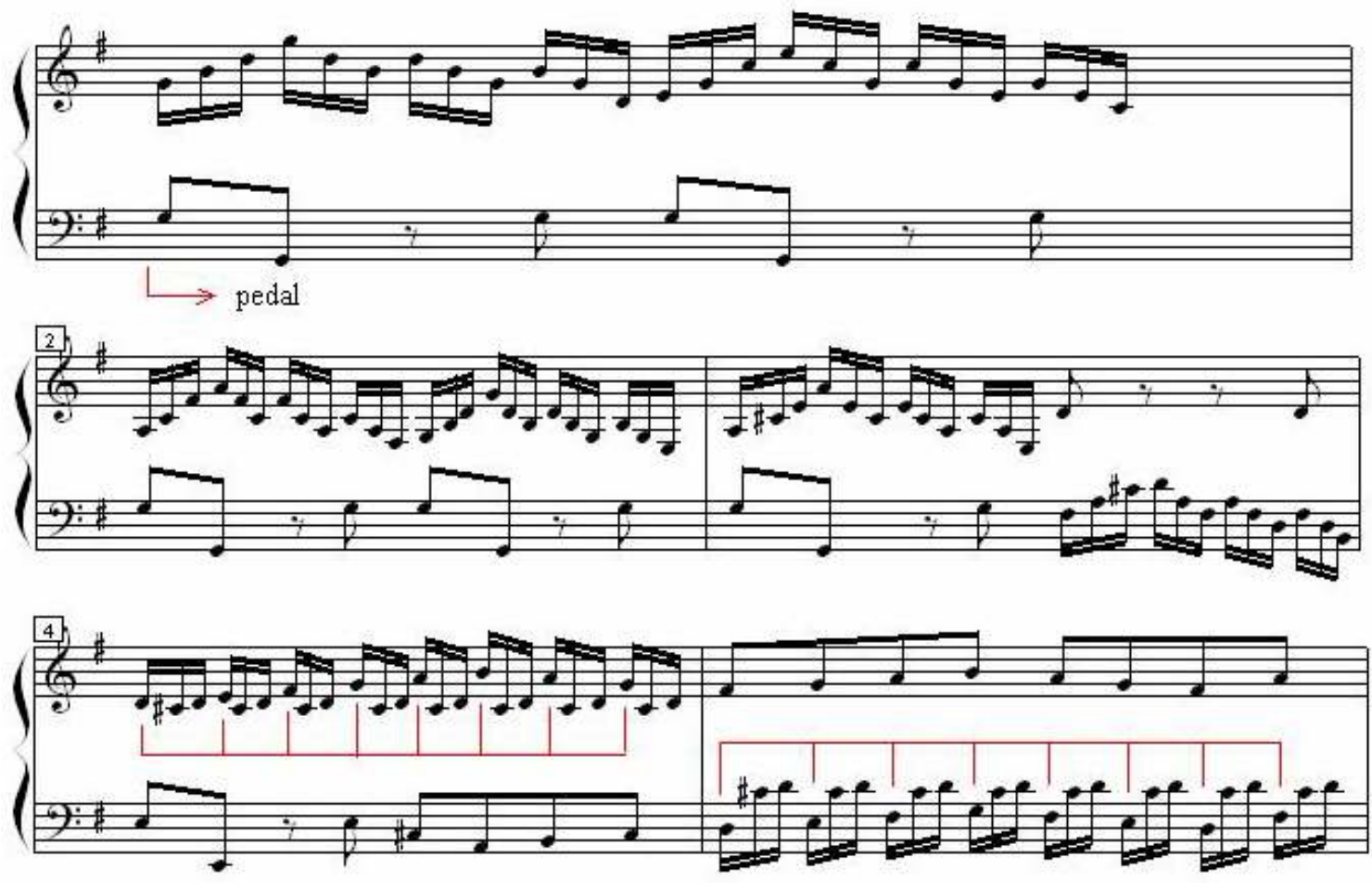

Exemplo 18-5: Bach, Prelúdio nº 15 G, compassos 1-5, artifícios de prolongação harmônica.

Semelhantemente, a idéia de prolongação encontra-se presente na obra seguinte, extração dos compassos iniciais de minha peça Trilhas Sonoras. Embora não se trate de uma música tonal, a idéia de prolongação se dá pela preservação do gesto inicial, que parte e retorna para a nota $A$, nota mais grave da peça, expandindo o registro em direção ao agudo até o acréscimo de um novo material que modifica um pouco esse gesto no compasso 9 (não mostrado no exemplo). Assim é possível entender que o compasso 1 tem função expositiva e os compassos de 2 a 7 cumprem a função de prolongação gestual. A segunda metade do compasso 7 mais o compasso 8 tem função transitiva, pois conduzem a um novo material a ser desenvolvido na obra. 

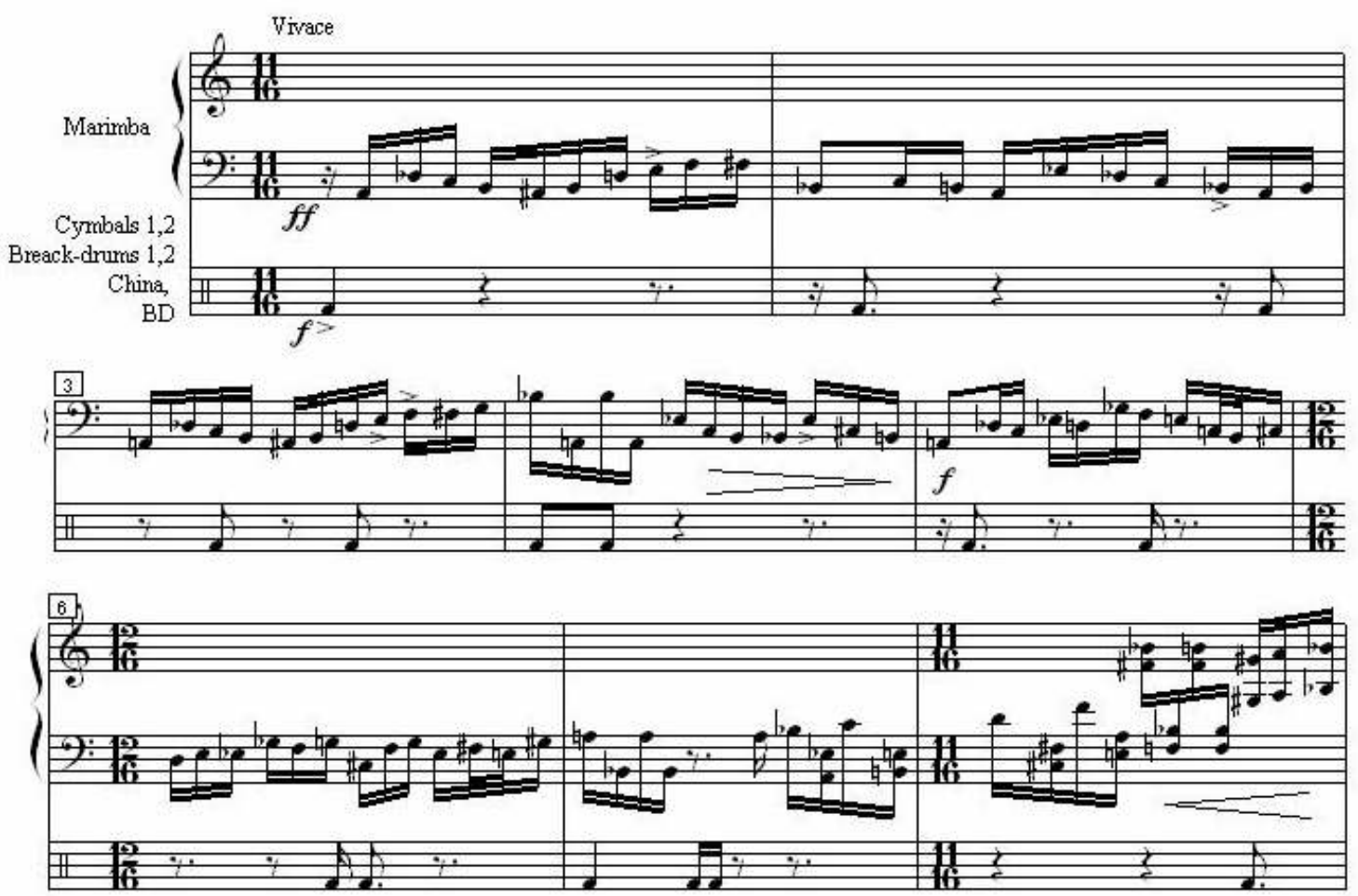

Exemplo 19-5: Antenor Ferreira, Trilhas Sonoras, compassos 1-8, prolongamento do gesto inicial.

\section{Relações funcionais}

Para o estabelecimento de relações funcionais é necessário que estruturas musicais permitam ser conectadas de alguma maneira, isto é, os objetos musicais precisam articular-se de modo a serem ouvidos como partes integrantes da mesma obra. Essa conexão implica que eventos sejam agrupados segundo alguns critérios. Alguns desses parâmetros tem base nos estudos da psicologia gestaltista e podem ser empregados dentre as possibilidades de agrupamento que fazem os diferentes objetos se relacionarem. Roger Shepard (em Cognitive Psychology and Music, capítulo do livro organizado por Perry Cook) aponta os seguintes princípios gestalticos de agrupamento: proximidade, similaridade, simetria, boa continuação e fato comum (Cf: COOK, 2001, p.32). Assim, a percepção tende a agrupar as coisas segundo:

1) Proximidade: a distância é fundamental para se promover a associação entre eventos. Coisas colocadas próximas são passíveis de serem agrupadas como pertencentes ao mesmo conjunto. Eventos muito separados são percebidos como isolados. Na medida que a velocidade de apresentação dos eventos aumenta estes se tornam mais próximos até o momento de serem percebidos como um padrão único. No caso de eventos melódicos, uma grande separação entre notas faz com que estas sejam entendidas como isoladas. Diminuindose a distância estas passam a compor um padrão melódico. Aumentando-se mais a proximidade pode resultar em percebê-las como ornamentação e, posteriormente, como 
amálgamas. Um trilo é um tipo de amálgama entre dois sons que não são percebidos separadamente, o que é percebido é o efeito resultante. O Exemplo 20-5 demonstra esse processo de agrupamento em razão da proximidade dos eventos (obs: no exemplo está implícito a manutenção do mesmo andamento para todos os compassos).

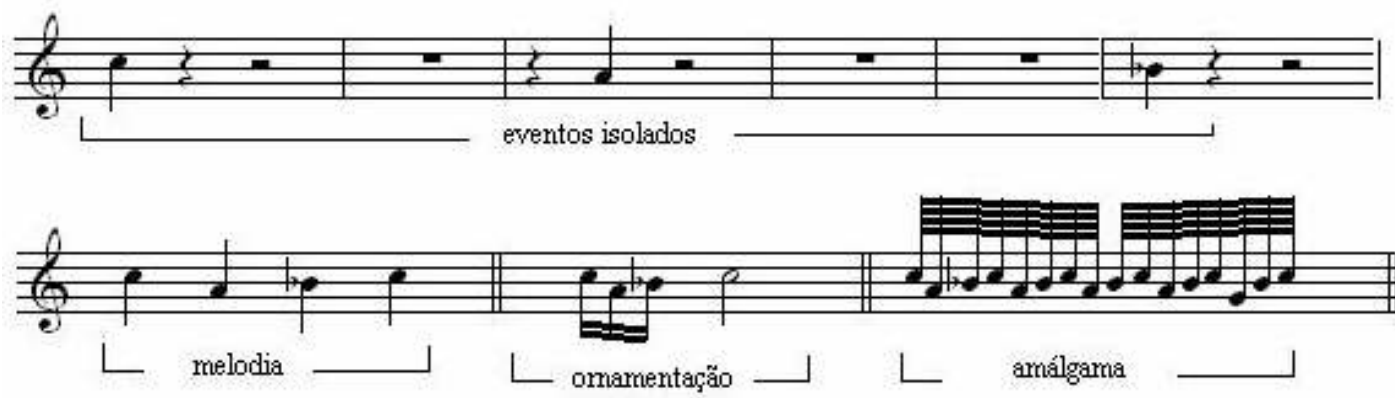

Exemplo 20-5: agrupamento segundo proximidade. (a) Eventos isolados; (b) constituição de um padrão melódico; (c) percepção como ornamentação; (d) amálgama dos sons.

Em razão dessa possibilidade de agrupamento pela proximidade, torna-se possível a realização de intenções polifônicas em instrumentos monódicos, técnica muito explorada por Bach em suas Partitas e Sonatas para violino solo. Processos semelhantes de agrupamentos por proximidade são observados nos fragmentos seguintes. No Exemplo 21-5, os compassos iniciais (extraídos de minha peça Metralhadora para quinteto de cordas) podem ser percebidos como constituídos de dois eventos diferentes, separados pelo princípio da proximidade. As notas agudas da viola compõem uma linha melódica $(G-F \#-F-E)$ diferenciada do acompanhamento, realizado pela repetição das notas $G-D$ no registro mais grave. O mesmo tipo de separação ocorre no Exemplo 22-5, nos momentos assinalados.

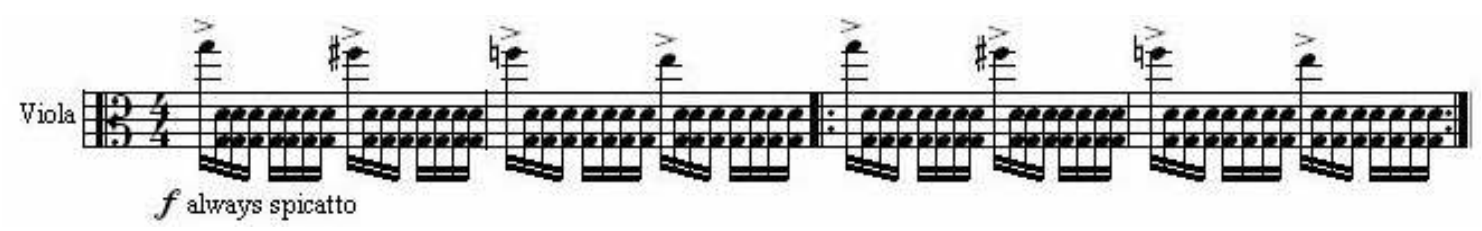

Exemplo 21-5: Antenor Ferreira, Metralhadora, compassos 1-4, agrupamento segundo critério de proximidade.

Nesses exemplos também pode ser identificada uma espécie de construção estratificada, resultante da possibilidade de compreender diferentes linhas em meio a um fluxo monofônico. O mesmo artifício pode ser percebido no Exemplo 14-5, de Silvio Ferraz.

2) Similaridade: em objetos igualmente espaçados, aqueles que são similares são, provavelmente, mais relacionados. Quando objetos não se diferem por proximidade, apresentando um espaçamento regular, a percepção pode agrupá-los pelo grau de semelhança 
que apresentam. Um bom exemplo disso é a alternância de acordes entre madeiras e cordas na passagem do primeiro movimento da Sinfonia 5 de Beethoven (Exemplo 23-5). A percepção opera no agrupamento desses eventos em razão da semelhança timbrística, separando sopros e cordas.
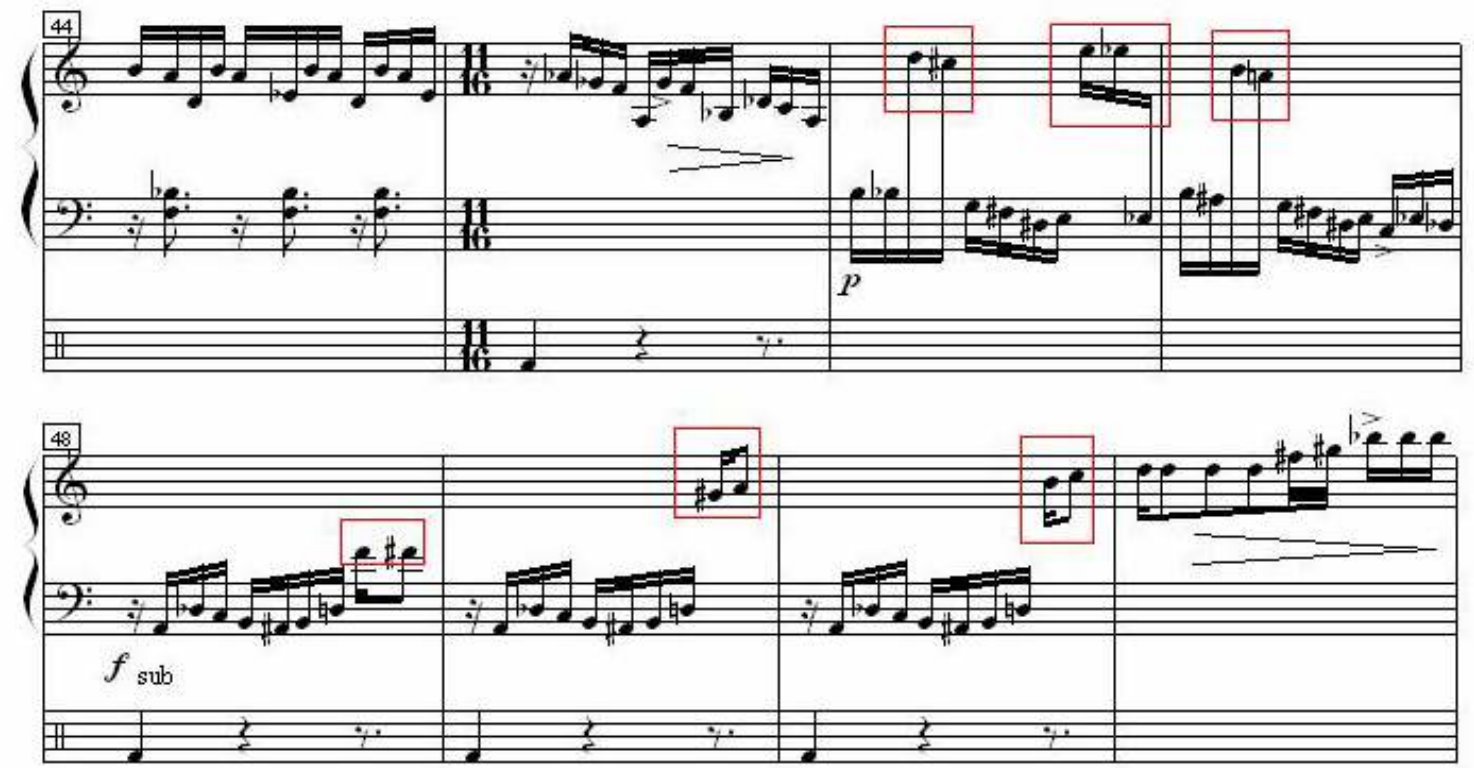

Exemplo 22-5: Antenor Ferreira, Trilhas Sonoras, compassos 44-51, agrupamento segundo critério de proximidade.

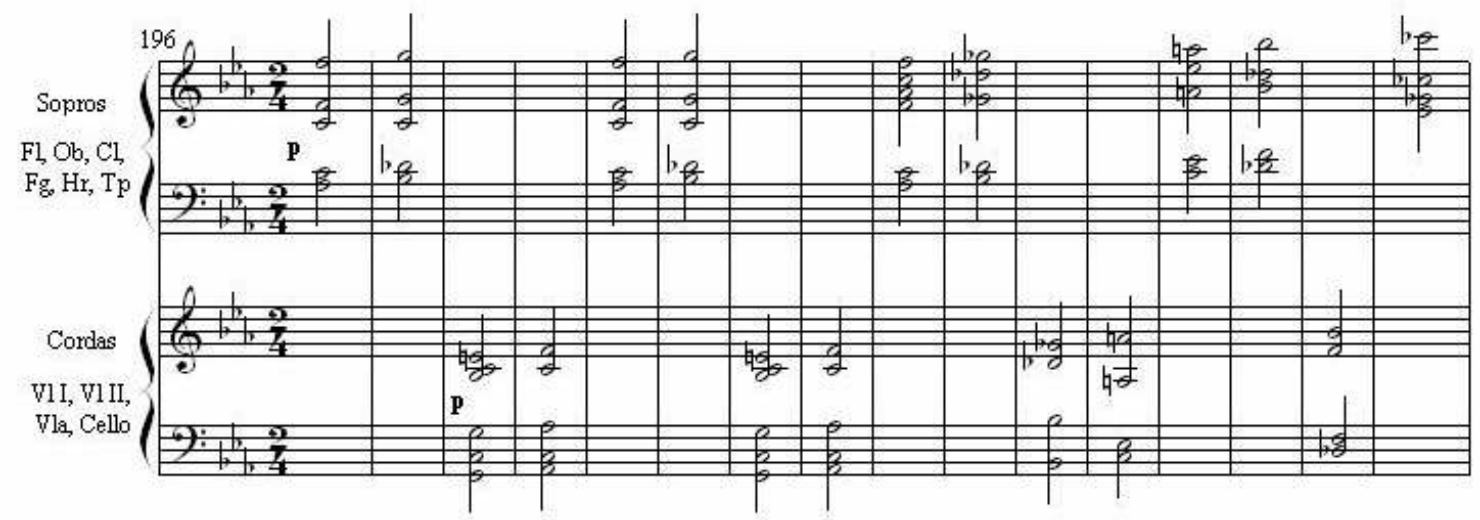

Exemplo 23-5: Beethoven, Sinfonia 5, I, compassos 196-211. Agrupamento por similaridade.

Semelhante agrupamento perceptivo via similaridade é mostrado no Exemplo 24-5, Catacumbae dos Quadros de uma Exposição de Mossourgsky. As sonoridades são selecionadas e relacionadas por semelhança tímbrica, já que a distância entre os eventos é similar, de modo que não se pode agrupá-los segundo o critério da proximidade. 


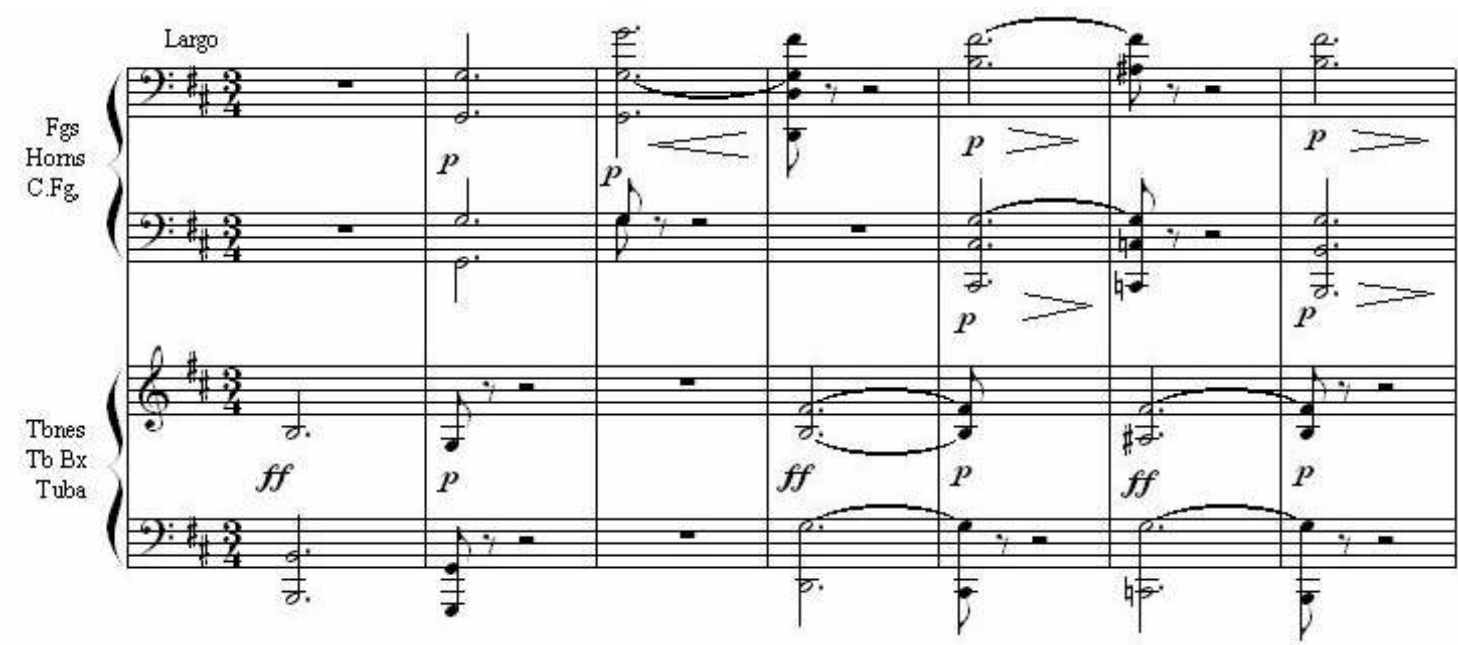

Exemplo 24-5: Mossourgsky, Quadros de uma Exposição, Catacumbae, orquestração de Ravel. Agrupamento por similaridade.

Meyer faz uso desse mesmo princípio de seleção e agrupamento, todavia, adota a nomenclatura relações de conformidade. "Por relações de conformidade eu me refiro simplesmente àquelas em que um evento musical discreto e identificável é relacionado a outro evento qualquer por similaridade" (MEYER, 1973, p.44). O objetivo de Meyer é buscar os princípios gerais que facultam a compreensão e viabilizam a explicação de uma obra musical. Nas suas palavras: "esclarecer como os vários tipos de relações tonais em uma composição particular são compreendidos e apreciados por ouvintes sensíveis e experientes" (ibidem, p.x). Desse modo, Meyer vai coletando elementos para servirem como fundamentos da sua idéia de significação em música. Um destes princípios são essas relações de conformidade, que concorrem para formatação das expectativas musicais. Partindo da proposição de Meyer, mas transferida para o ambiente pós-tonal, intento, no exemplo seguinte, observar características presentes nas relações de conformidade de modo a verificar como se agregam ao conceito de função na coordenação das estruturas musicais.

Nos cinco primeiros compassos do próximo exemplo (Ex. 25-5), Musica Ricercata VI, os motivos reiterados em registros diferentes são percebidos como relacionados por conformidade por possuírem semelhança rítmica e o mesmo conteúdo intervalar. $\mathrm{O}$ fato de o metro ser deslocado a partir do compasso 3 não impede o relacionamento dos eventos, que continuam a ser associados dado a conformidade entre os padrões rítmicos e melódicos. $\mathrm{O}$ compasso 6 rompe a redundância dos padrões estabelecidos e prepara a adição do novo material no compasso 7. A partir deste compasso, até o de número 12 , os eventos são relacionados entre si, porém percebidos como distintos daquelas estruturas apresentadas no início. Adiante, compasso 20, é possível entender uma sobreposição dos dois grupos. No compasso 23, o material introduzido no grupo 2 é reapresentado com modificações 
(intensidade, registro, textura), porém, continua a ser percebido como pertencente ao mesmo agrupamento justamente por possuir relação de conformidade. Esta é, então, uma exemplificação sumária da idéia de relação de conformidade preconizada por Meyer.

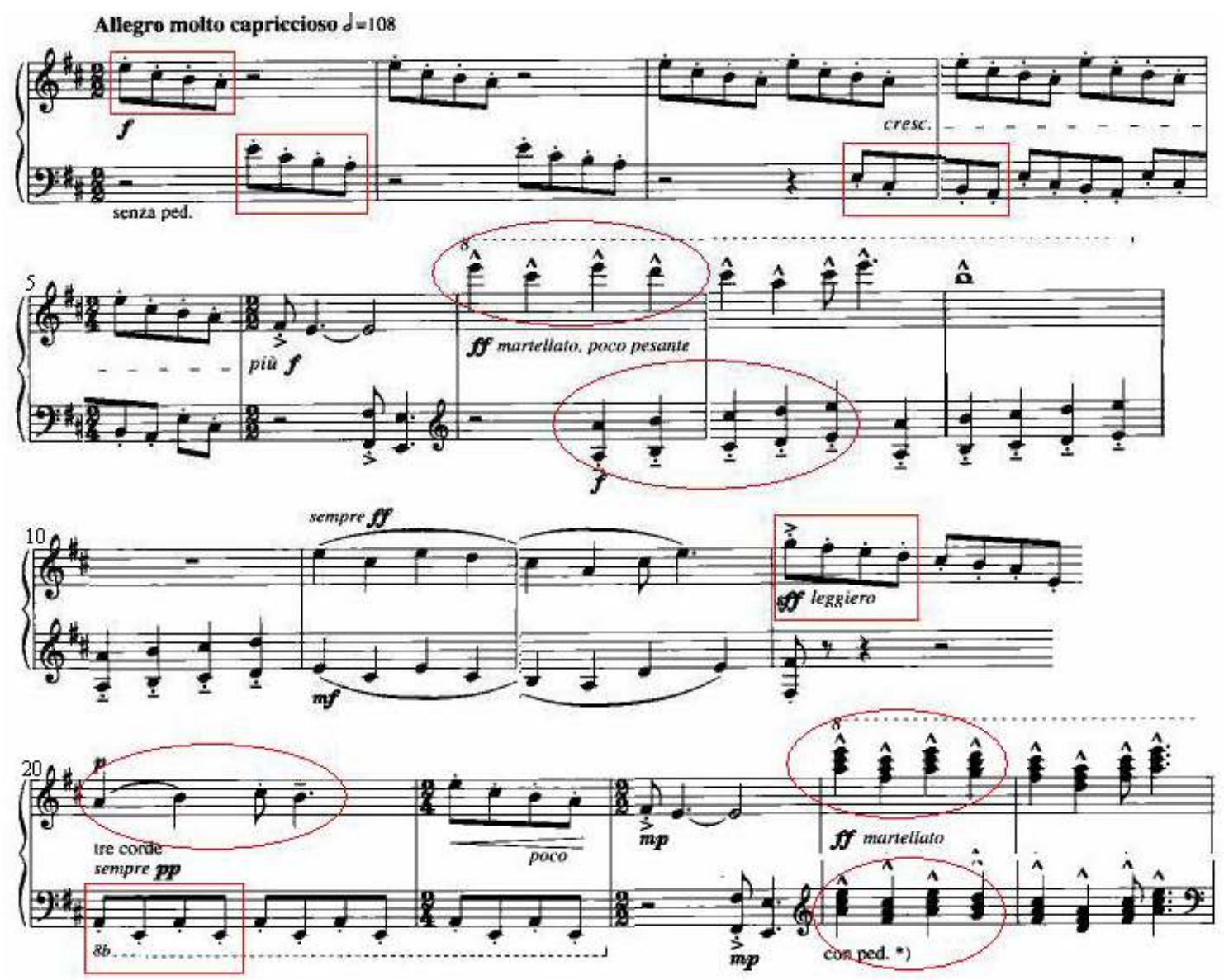

Exemplo 25-5: Ligeti, Musica Ricercata VI, compassos 1-13 e 20-24. Relações de conformidade.

3) Simetria: a simetria não é esperada em eventos aleatórios, assim a ocorrência de simetria aponta para a existência de relação entre objetos. É comum observarmos em conversas cotidianas que quando ocorre uma rima as pessoas logo chamam a atenção para esse fato e não é raro ouvir o comentário “nossa, até rimou!". Essa surpresa se dá porque não se espera o uso de rimas na linguagem falada, e quando acontece é de modo não intencional. Diferentemente seria se fosse o caso de um poema, onde rimas e assonâncias são previstas. De modo similar, a ocorrência de simetria em eventos aleatórios é rara. Por essa razão, simetrias são tidas como fatos intencionais, revelando a relação entre os elementos. Isso faz com que a percepção entenda esses eventos simétricos como pertencentes a um mesmo grupo.

Antes de dar prosseguimento é preciso notar que simetria, quando em contexto artístico, remete à idéia de proporção, equilíbrio, arranjo harmonioso entre as partes que compõem o todo. A própria etimologia da palavra favorece esse entendimento, pois deriva 
dos radicais gregos ' $\sin$ ' = unido, relacionado e 'metron' = medida, donde tem-se medida relacionada. Todavia, em um sentido lato, simetria é definida como a operação ou conjunto de operações realizadas em um objeto cujo resultado é congruente com o original. Desse modo, o objeto submetido a certas transformações é invariante no que concerne a seus elementos característicos. Existem basicamente quatro operações geométricas que resultam em simetria: reflexão, translação, rotação e reflexão deslizante, essas são denominadas isometrias constituindo as aplicações que transformam uma figura geométrica em uma outra cujas distâncias entre os pontos e a amplitude dos ângulos estejam mantidas. Existem transformações cujo resultado, embora simétrico, altera as dimensões dos objetos inicial e final, estas operações são chamadas de automorfismos, tendo dois procedimentos padrões: dilatação e contração (em música conhecidos por aumentação e diminuição).

Certamente a transformação isométrica mais conhecida é a bilateral ou reflexiva. Este tipo de simetria é realizado por meio de uma projeção ao redor de um eixo cujas resultantes, em lados opostos desta linha divisória, são similares. O desenho a seguir, extraído de uma gravura de Escher, ilustra a simetria reflexiva. Nota-se que a figura da letra 'a' é simétrica quando refletida em seu eixo vertical, ao passo que a mesma figura 'b' não resultará simétrica se projetada em seu eixo horizontal, já que os pontos da parte inferior do eixo não podem ser mapeados um a um em sua parte superior. Uma analogia musical poderia ocorrer como no Exemplo 26-5, no qual um eixo imaginário na nota $D$ divide os grupos simétricos:

a)
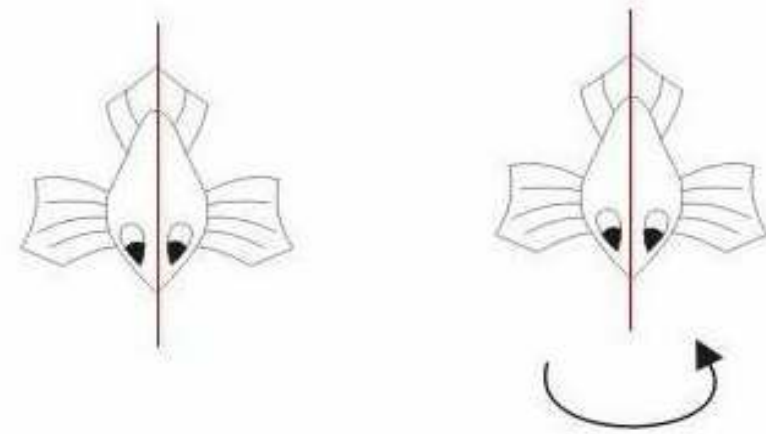

b)
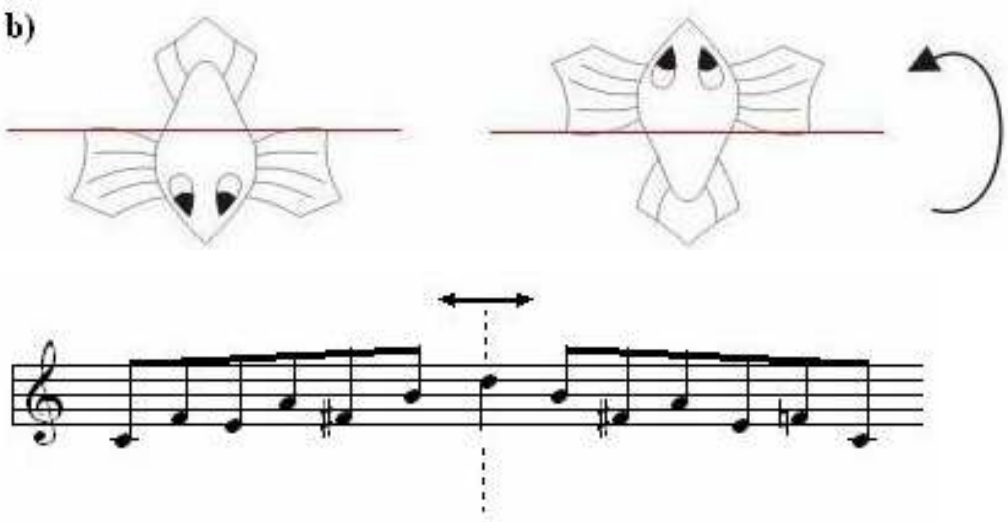

Exemplo 26-5: simetria reflexiva de uma sucessão de notas em torno de um eixo vertical. 
No Exemplo 26-5 a nota $D$ reveste-se como um eixo vertical imaginário em torno do qual ocorre o espelhamento do primeiro grupo de notas. O mesmo eixo poderia também ser posicionado horizontalmente, resultando no procedimento musical conhecido como inversão:

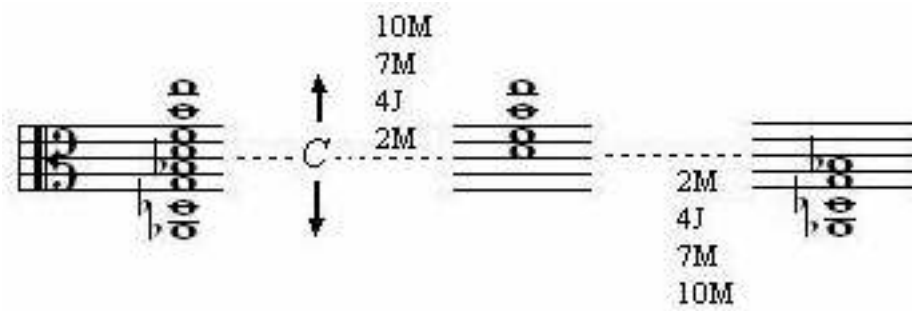

Exemplo 27-5: simetria reflexiva em torno de um eixo horizontal.

No Exemplo 27-5 as notas do acorde são projetadas ao redor de um eixo na nota $C$ (ausente do acorde, inclusive) de modo que os intervalos resultantes acima e abaixo deste eixo sejam os mesmos. Esse procedimento recebeu de Persichetti (cf: 1985, p.174) o nome de harmonia em espelho, constituindo-se como um bom artifício para a geração de agregados acórdicos ausentes do campo harmônico tonal. Esse processo de reflexão (inversão) pode ser aplicado linearmente, o que de fato já é conhecido como uma das possibilidades da técnica dodecafônica. Como exemplificação não usarei séries invertidas, mas modos. É curioso notar que os modos gregorianos quando invertidos resultam em formações distintas, porém correspondente a outro modo. A inversão do jônico é o frígio, do mixolidio o eólio e do lidio o lócrio. $\mathrm{O}$ único modo que sob reflexão resulta nele próprio é o modo dórico, portanto, o único modo simétrico. Talvez seja esta mais uma das razões que fizeram com que os religiosos considerassem-no como o mais perfeito dos modos e mais propício para o louvor.

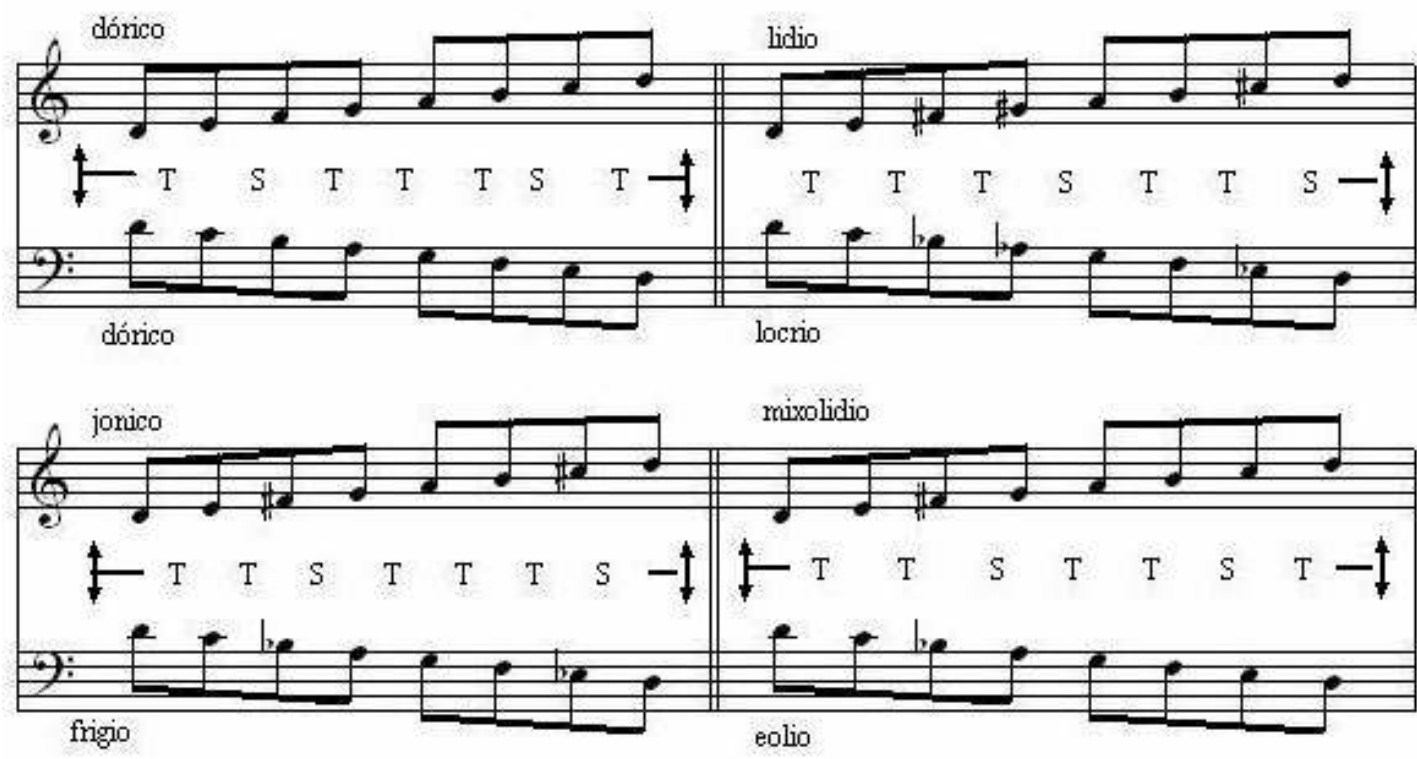

Exemplo 28-5: operação de reflexão (inversão) dos modos gregorianos. 
A simetria por rotação é realizada imaginando-se um ponto central em uma figura que é girada em distintos ângulos, se os resultados forem congruentes a figura é dita simétrica. A estrela mostrada na figura seguinte somente resultará inalterada por rotação se girada nos ângulos de 90, 180 e 270 graus. O mesmo vale para a gravura de Escher:

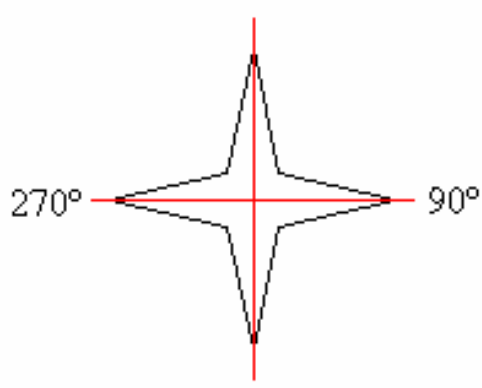

$180^{\circ}$

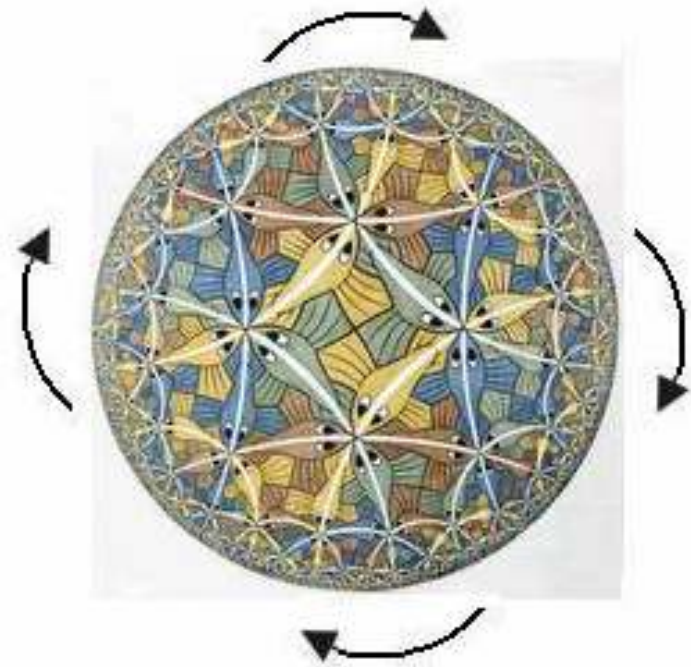

O teórico norte americano Larry Solomon ao tentar transferir esse tipo de simetria para o plano musical valeu-se da rotação do pentagrama, de modo que acaba por considerar simétricos por rotação os resultados deste tipo (letra 'a' do exemplo):

(a)

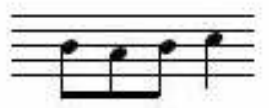

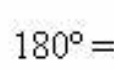

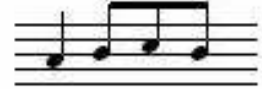

(b)

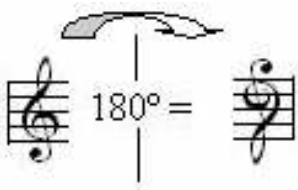

Contudo, se o pentagrama houvesse sido desenhado com a clave, esta estaria de 'cabeça para baixo', como na segunda figura (letra 'b' do exemplo). Por curioso que possa parecer, Bach se valia desse artifício para escrever cânones e imitações. A seguir mostram-se trechos extraídos de cânones de sua Oferenda Musical (cf: SOLOMON, 2002) onde as claves de Dó e de Sol são notadas de "cabeça para baixo", ficando a cargo do executante desvendar a maneira correta de interpretá-los.

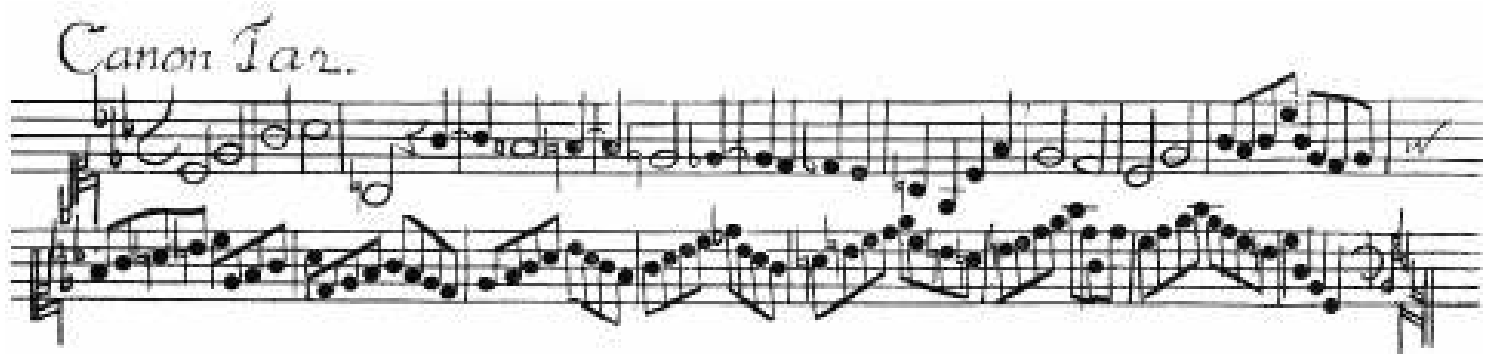

Exemplo 29-5: Bach, Oferenda Musical, cânone a duas vozes. Notação original com claves de "cabeça-para-baixo". 

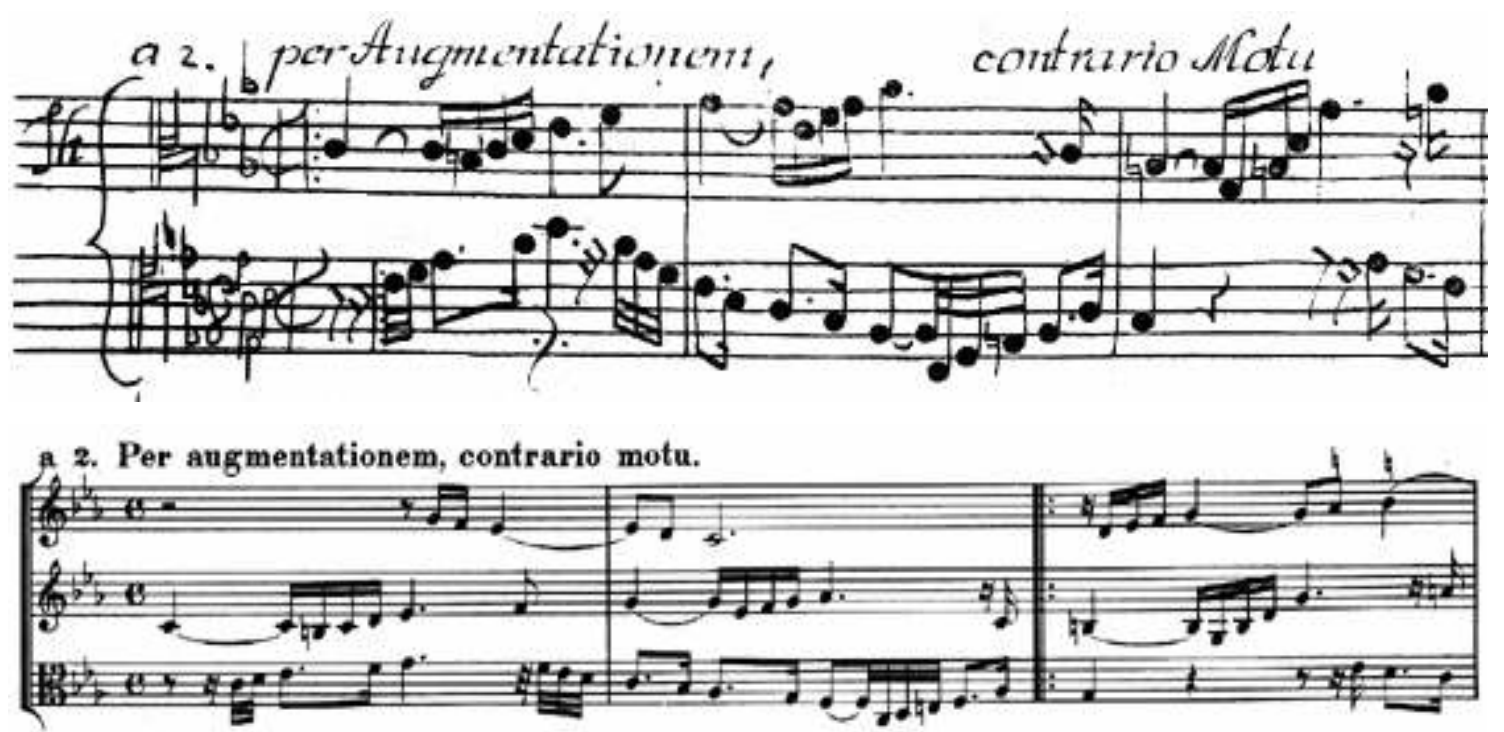

Exemplo 30-5: Bach, Oferenda Musical, compassos 1-3. Cânone a duas vozes por aumentação e movimento contrário. Notação original (acima) e realização proposta por Larry Solomon (abaixo).

$\mathrm{Na}$ operação de rotação proposta por Solomon os intervalos obtidos e a direção do movimento serão distintos do modelo inicial. Todavia, ainda é possível realizar um procedimento mais próximo da analogia circular de modo a conservar inalteradas direção e cardinalidade dos intervalos. Se tivermos uma projeção esquemática do círculo das quintas ao redor de um disco, seria possível girá-lo de modo a obter classes de alturas distintas, porém simétricas. No Exemplo 31-5 mostra-se a operação de rotação feita em diferentes ângulos. Partindo de uma formação inicial $C-F-E$ observa-se que essas classes de altura ocupam no círculo as posições $-1,+4$, isto é, partindo de $C$ encontra-se a nota $F$ descendo 1 nível e a nota $E$ subindo quatro níveis (sempre contados a partir de $C$ ). A posição de $30^{\circ}$, por exemplo, é ocupada no disco pela classe de alturas $G$. Ao realizar a mesma operação, $-1,+4$, será obtido $G-C-B$, que é simétrica em direção de movimento e cardinalidade intervalar à formação inicial. Qualquer movimento de rotação nos ângulos que se some $30^{\circ}$ (isto é, $60^{\circ}, 90^{\circ}$, etc) fornecerá resultados simétricos, alguns resultados são mostrados no Exemplo 31-5.
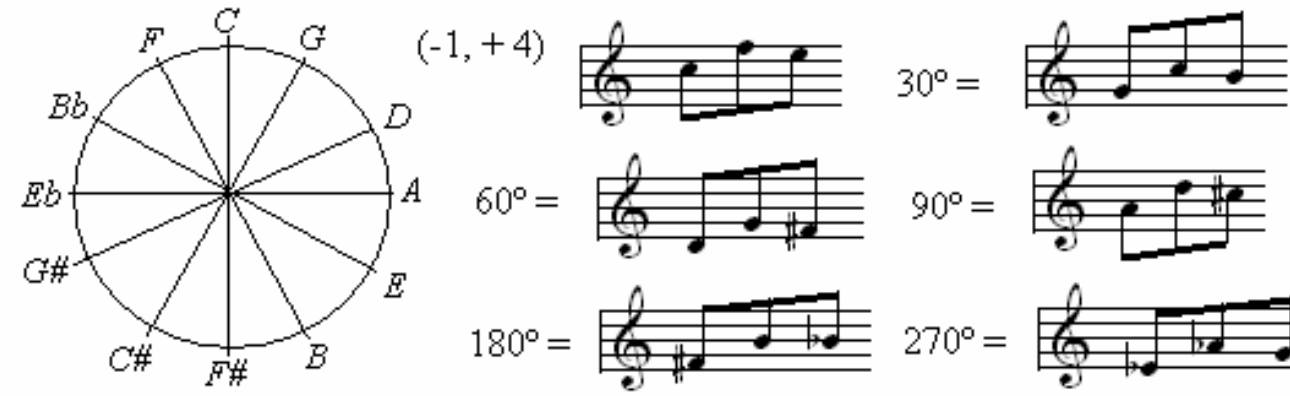

$90^{\circ}=$

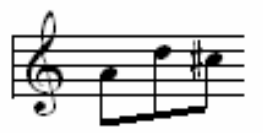

$180^{\circ}=$

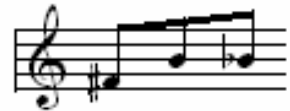

$270^{\circ}=$

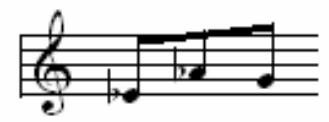

Exemplo 31-5: operação de rotação ao redor do círculo das quintas. 
Ao invés do círculo das quintas, se for utilizada uma sucessão cromática, os resultados também serão simétricos, havendo somente diferença na posição das classes de alturas ao redor do disco. Note-se que as posições ocupadas pela formação inicial $C-F-E$ são obtidas pela operação $+5,+4$, de modo que os grupos projetados via rotação devem obedecer a esse mesmo procedimento, como mostra o Exemplo 32-5. (Esse procedimento é similar à operação de transposição real em música).

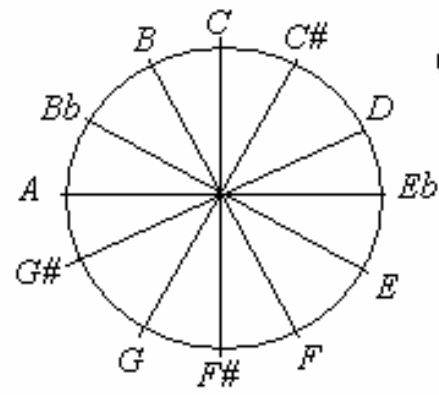

$$
(+5,+4)
$$
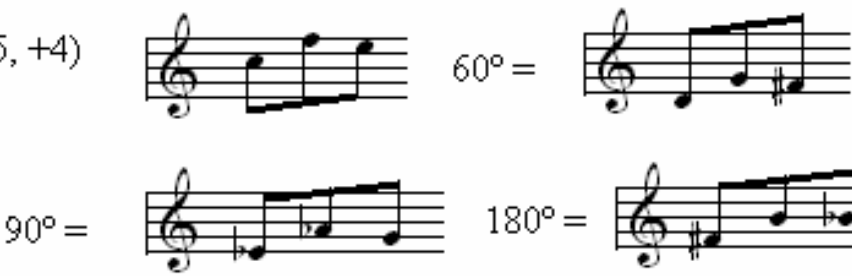

$180^{\circ}=$

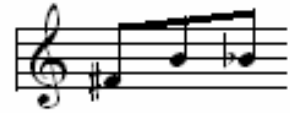

$210^{\circ}=$

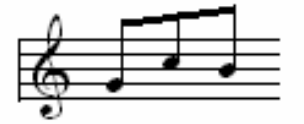

$270^{\circ}=$

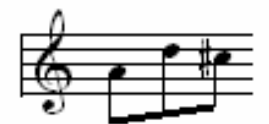

Exemplo 32-5: operação de rotação ao redor do círculo cromático.

A simetria por translação implica no deslocamento ao longo de um eixo ou linha horizontal, movendo todos os pontos de um objeto no plano preservando direção e distância entre eles. O resultado são motivos repetitivos como a figura seguinte:
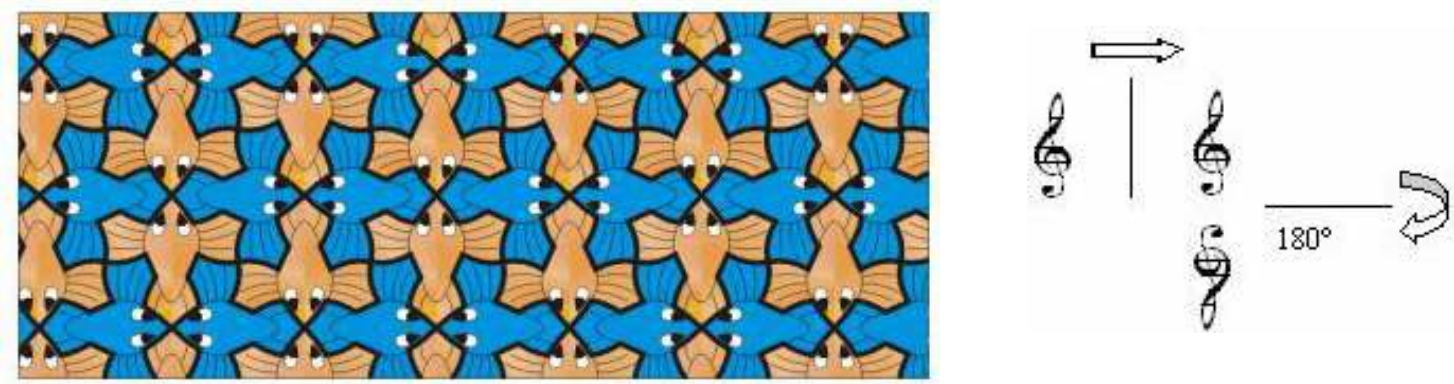

Uma analogia musical da simetria por translação pode ser feita com um baixo de Alberti, como mostrado no Exemplo 33-5 'c'. A movimentação rítmica do Exemplo 33-5 ' $a$ ', mostrada esquematicamente em ' $b$ ', também fornece um padrão simétrico por translação. Ao associar as operações de translação e de reflexão será obtida uma estrutura simétrica como mostrada em ' $a$ '. Nesse procedimento, a figura é transladada e depois invertida, gerando o tipo de isometria conhecido como reflexão deslizante. Esta, trata-se portanto de uma dupla operação: primeiro a figura é projetada por translação em seu eixo vertical, para depois ser refletida sob seu eixo horizontal, como também mostrado na clave de sol ao lado da figura anterior. 

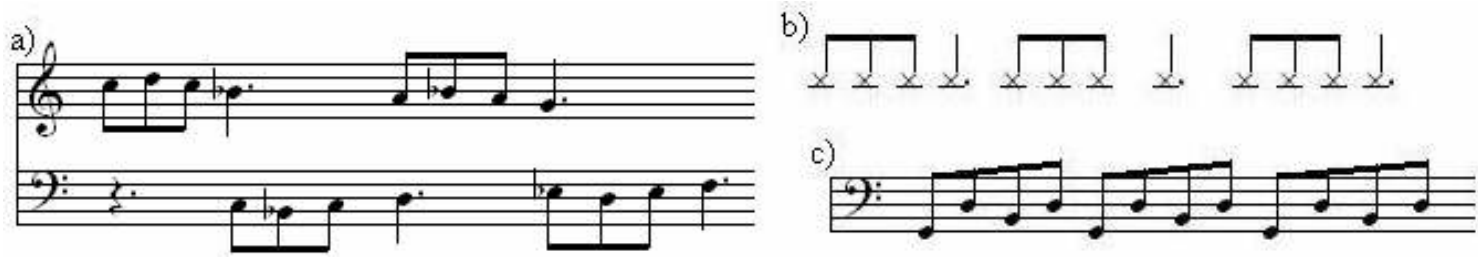

Exemplo 33-5: operações simétricas de translação e reflexão deslizante.

A simetria em música no que concerne ao plano composicional não é novidade. A questão complica quando se intenta saber se relações de simetria podem ser captadas na escuta da obra. Embora haja muitas divergências, de minha parte, tendo a pensar que relações simétricas de curto prazo são perceptíveis. Fato que não se verifica em longas extensões temporais. Assim, uma seqüência melódica ascendente (do tipo mostrado no Ex. 26-5) seguida de outra descendente pode ser percebida e agrupada segundo o critério de simetria. Frases curtas de configuração a-b-a também podem ser ouvidas e relacionadas pelo mesmo princípio; o mesmo vale para justaposições de grupos contrastantes e recapitulação em curto prazo de tempo. Contudo, partes ou seções longas são verificáveis como simétricas a partir de análise, que posteriormente deve afetar a escuta, mas são de difícil percepção somente na fruição, sem apoio intelectual. Claro que é possível a percepção de seções recapituladas, como na escuta de um choro de Pixinguinha, por exemplo. Nesta situação, se as seções forem apresentadas com uma configuração tradicional tipo |A |B |A |C | A |, o ouvinte percebe com certa facilidade a divisão em três partes e seus respectivos retornos, ocorrendo a percepção de simetria. Porém, esse tipo de composição tem uma duração relativamente curta se comparada com um Rondó de uma Sinfonia. Em obras de grande extensão temporal, essa assimilação tornar-se-á mais difícil não só pelos aspectos mnemônicos exigidos, mas também porque em geral essas partes serão reapresentadas com variações, de modo que se podem perceber as semelhanças, mas só um ouvinte treinado dará conta das relações de simetria.

Solomon também defendeu em sua tese de doutoramento que as relações de simetria são determinantes no processo composicional ${ }^{21}$. Postulou, assim, que "a simetria é um princípio predominante da organização composicional, atravessando as fronteiras internacionais do estilo, história e etnia, ou seja, de fato, a maioria das relações encontradas na música é baseada em simetria" (SOLOMON, 2002). Em seu trabalho objetivou demonstrar relações de simetria envoltas em, praticamente, todas as estruturas musicais como, por exemplo, identidade tímbrica, imitação, forma sonata, organum paralelo, formações escalares, acordes espelhados, círculo das quintas, etc. No entanto, suas demonstrações se deram no

\footnotetext{
${ }^{21}$ Symmetry as a compositional determinat. Originalmente publicada em 1973 e revisada em 2002. Disponível em : www.solomonsmusic.net .
} 
plano teórico da composição, cujas belíssimas análises apontavam para a existência de relações de simetria no âmbito estrutural da obra. Em sua abordagem à Música para cordas percussão e celesta de Bartók, Solomon aponta o emprego da seção áurea e de séries de Fibonaci como meios composicionais. Esse uso compreende tanto a estrutura fraseológica quanto a forma total da peça. O sujeito da fuga, primeiro movimento da obra, é usado para indicar o emprego da seção áurea no âmbito da frase. Este sujeito é mostrado no Ex. 35-5.

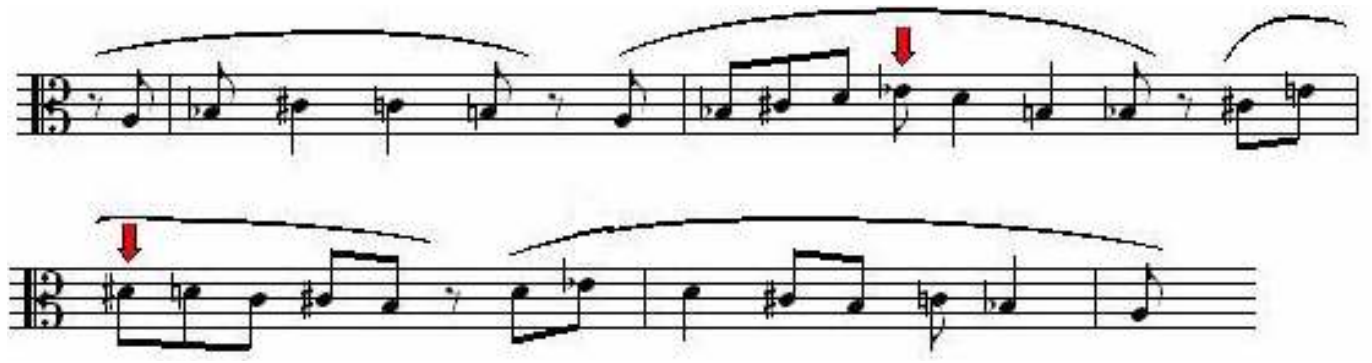

Exemplo 35-5: Bartók, Musica para cordas percussão e celesta I. Sujeito da fuga.

Solomon faz notar que o sujeito possui um pólo em $A$, nota que inicia e finaliza sua exposição. A nota $E b$ trítono do pólo $A$, ocupa posições que coincidem com o cálculo da seção áurea. Se contadas todas as colcheias do sujeito, incluindo as pausas, o resultado será 38. Calculada o segmento áureo o resultado será 24,5 . Observa-se então, que $E b$ recai sobre a $23^{\mathrm{a}}$ colcheia da seção áurea positiva e sobre $24^{\mathrm{a}}$ colcheia da seção áurea negativa (contada a partir do fim). Resultados estes bem próximos que levam a sugerir esse cálculo como base da estrutura fraseológica deste sujeito. Um esquema fornecido por Solomon dessa operação é mostrado a seguir:

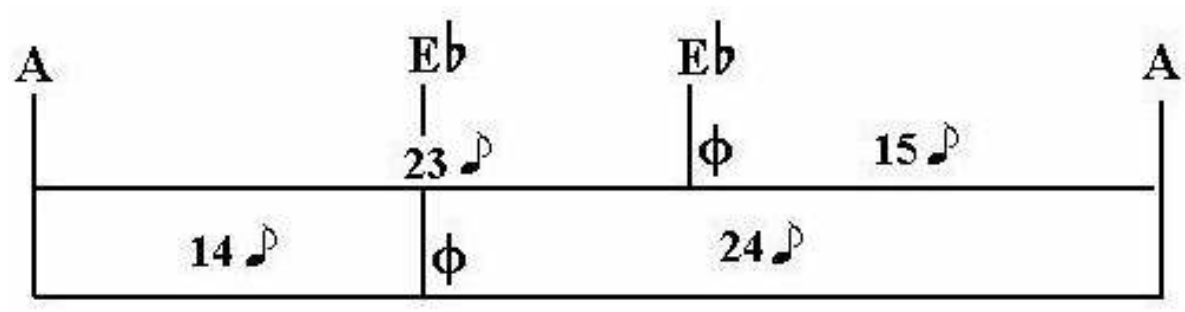

Exemplo 36-5: Bartók, Musica para cordas percussão e celesta I, esquema da estruturação do sujeito da fuga tendo por base o segmento áureo (cf: SOLOMON, 2002).

Se o esquema anterior for comparado com a forma total do primeiro movimento, a idéia da seção áurea como elemento estruturador ganhará mais fundamento. Para tanto, devese ter em conta que esta fuga expõem diversas entradas do sujeito em diapente e sub-diapente, partindo de $A$ e seguindo pelo ciclo de quintas ascendente e descendente até atingir a nota $E b$, trítono de $A$ e ponto mais afastado deste pólo. A cada nova apresentação do sujeito 
corresponde também um aumento nos níveis de intensidade, densidade e registro. Ao atingir o clímax de intensidade dá-se a operação de reflexão, as imitações são invertidas (entradas no registro agudo são transferidas para o grave, e vice-versa), níveis de intensidade, registro e densidade vão diminuindo até alcançarem novamente o pólo em $A$ que iniciou o movimento. Uma representação esquemática dessa forma é fornecida no exemplo a seguir, os números indicam a contagem de compassos.

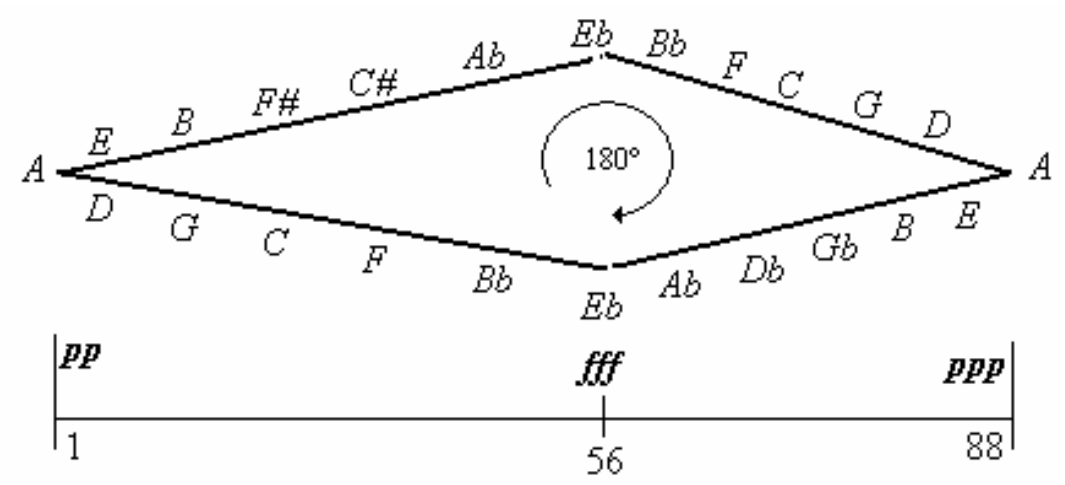

Exemplo 37-5: Bartók, Musica para cordas percussão e celesta I, esquema da estruturação formal do primeiro movimento (cf: SOLOMON, 2002).

Embora de modo sumário, com essa esquematização (Ex. 37-5) é possível perceber o plano composicional concebido em acordo com a seção áurea desde o nível fraseológico (Ex. 36-5) até o formal. Fica clara a intenção de Bartók em partir de um pólo, atingir o ponto culminante de maior intensidade e densidade em posição compatível com o cálculo da seção áurea e depois realizar uma reflexão desta primeira parte de modo a projetá-la na parte seguinte, invertendo os eventos anteriores até retornar ao pólo de partida. Há outras estruturas simétricas nesta obra não comentadas aqui. Todavia, fica a pergunta: essas relações de simetria são perceptíveis durante a escuta da obra? Eu acredito ser difícil a apreensão destas relações só pela audição, do mesmo modo penso não ser possível perceber a relação simétrica presente nas séries utilizadas por Webern, como na Sinfonia Op. 21, nas Variationen Op.30 e no Quarteto Op.28. Essas operações são bons recursos composicionais no que concerne à arquitetura da obra, mas estão longe de fornecer uma apreensão imediata da simetria como observada nas artes visuais.

4) Boa continuação: a percepção tende a considerar como parte de um mesmo grupo objetos colineares ou dispostos de modo a completar ou continuar (dar prosseguimento) o anterior. Eventos são comumente relacionados pela boa continuidade. Contrastes súbitos são normalmente interpretados como ruptura de fluxo. Em vista disso, o cérebro avalia fortemente 
os eventos segundo o perfil ou contorno que, juntamente com o ritmo, compõe os atributos intrínsecos mais identificáveis do objeto musical, sendo que sua transformação subtrai de modo mais radical o objeto de sua caracterização inicial. Observe a figura seguinte:
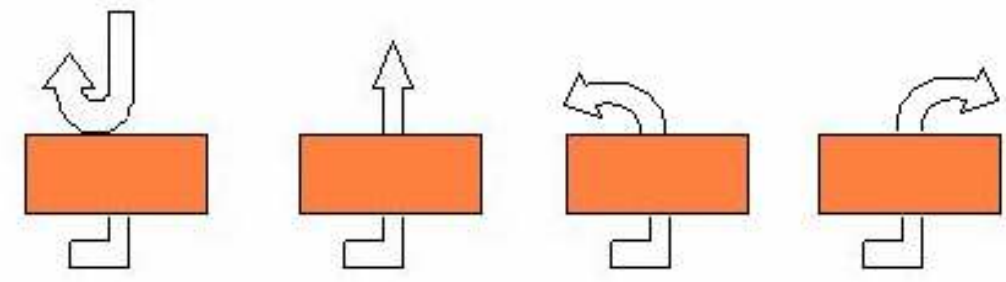

Dentre as quatro figuras o cérebro interpreta a segunda como apresentando o movimento mais contínuo, ou seja, a continuação do movimento na segunda figura é mais lógica entre as demais. De igual maneira, uma linha melódica que progride suavemente com um contorno do tipo:

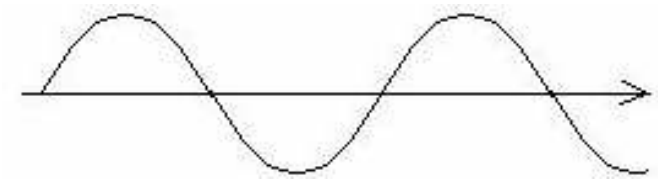

não é esperada continuar assim:

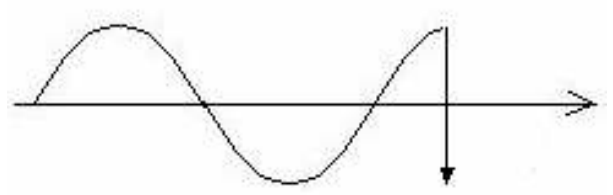

Em posse desta idéia, o compositor pode usá-la a seu favor de acordo com a sensação pretendida: fluir suave ou descontinuidade, valendo-se desse artifício para combater a monotonia. No trecho seguinte (Ex. 38-5), dá-se a passagem de uma seção contendo várias justaposições de materiais contrastantes (o Exemplo 2-6 do próximo capítulo mostra essas rupturas no fluxo musical) para outra seção re-expositiva que resgata o gesto inicial da obra. Associado ao processo de modulação métrica, os grupos e linhas antes conflitantes são trazidos para um perfil similar, fazendo com que sejam articulados em razão da continuidade do fluxo. 

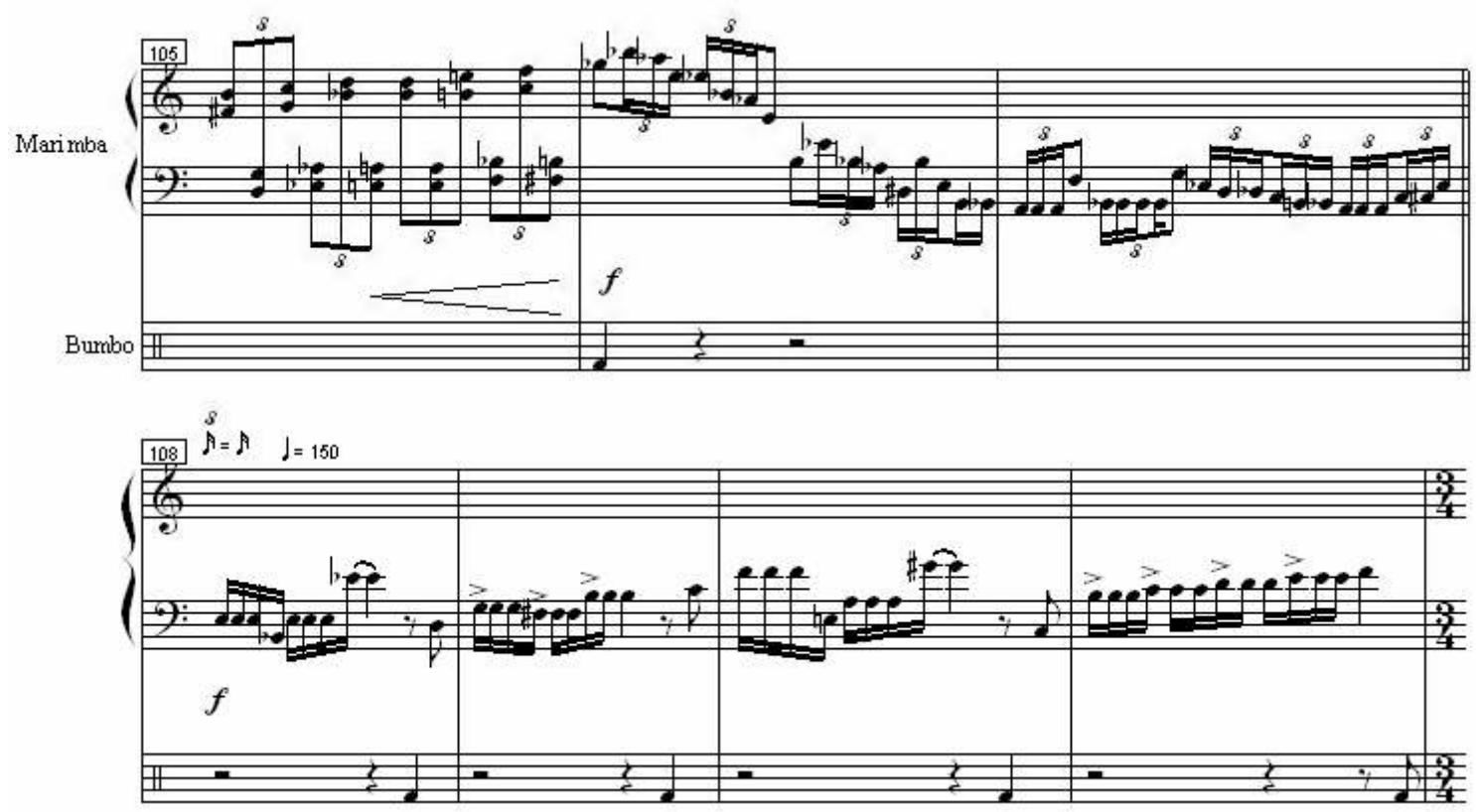

Exemplo 38-5: Antenor Ferreira, Trilhas Sonoras, compassos, agrupamento segundo critério de boa continuidade.

5) Fato comum: implica que objetos que se movem conjuntamente são plausíveis de serem conectados. Em objetos atrelados nota-se que a movimentação de um faz com que o outro também se mova. Assim, se é levado a entender que ambos apresentam algum tipo de elo, permitindo relacioná-los pelo princípio do fato comum. A Lua e a Terra, por exemplo, estão relacionadas pelo mesmo critério, pois a órbita lunar dá-se em função da atração gravitacional exercida pela Terra. Um asteróide que passe pelo sistema solar, todavia, não terá essa relação comum, embora esteja presente no mesmo contexto. O exemplo musical oferecido por Cook é o fato das séries harmônicas de diferentes fontes sonoras não se fundirem na percepção. Ou seja, as notas dos diferentes instrumentos são percebidas separadamente durante sua diacronia musical. Isso permite a diferenciação tímbrica, pois se assim não fosse, dois instrumentos tocando juntos teriam seus respectivos timbres fundidos em um só. Para satisfação da nossa percepção isso não ocorre, e o fluir melódico de um flauta pode ser agrupado e diferenciado do piano, por exemplo, segundo o critério do fato comum.

\section{Conclusão}

Função foi um conceito que nasceu na teoria harmonia, o que fez com o termo acabasse por incorporar referências eminentemente verticais. Contudo, seu sentido musical mais abrangente de "relações entre sons" não deve ser perdido. A palavra harmonia também significa ajuste, acordo entre partes não raro conflitantes que, quando unidas, passam a formar um todo harmonioso. Na mitologia grega Harmonia é filha de pais antagônicos: Ares, deus da guerra e da violência, e Afrodite, deusa do amor e da fertilidade. Harmonia, que é grega, casa- 
se com Cadmo que possui origem bárbara, realizando assim a conciliação dos opostos. Transferindo essa metáfora para os assuntos aqui tratados, foi possível entender que essa conciliação pode se dar em qualquer sistema em que haja oposições. É justo pensar em uma situação musical instável que requer conciliação, harmonização, em uma seção de estabilidade. Desse modo, o orbe eminentemente acórdico é estendido de modo que a concepção da harmonia e as funções que implica sejam extrapoladas para domínios maiores como períodos e seções.

Como foi visto, a função tônica, desiderato em ambiente pós-tonal, não demanda a existência de uma nota ou pólo para estabilizar uma situação. A sensação de chegada a um objetivo se dá mesmo na ausência de alguma classe de altura, como mostrado no Exemplo 75, em que o desiderato suprime o parâmetro nota e põe em seu lugar um simples ataque de prato, saindo da instabilidade para a estabilidade gerada pela percepção de chegada no desiderato. Uma construção similar de 'transição e chegada' pode ser percebida neste fragmento de Atmospheres de Ligeti (vide Exemplo 39-5). É clara a movimentação ascendente rumo a um ponto a ser atingido, no entanto, a percepção de chegada não se dá pela expectativa de uma nota ou acorde em particular. A situação de transição é resolvida com o alcance do registro super agudo nos pícolos, independentemente da classe de altura na qual a ascensão é interrompida (que poderia até ser outra, tom ou semitom acima ou abaixo) e a sensação de que um ponto foi alcançado se faria presente (mesmo porque o uso de microtons impede, neste contexto da micropolifonia de Ligeti, o surgimento de expectativas de resolução sobre algum pólo tonal).
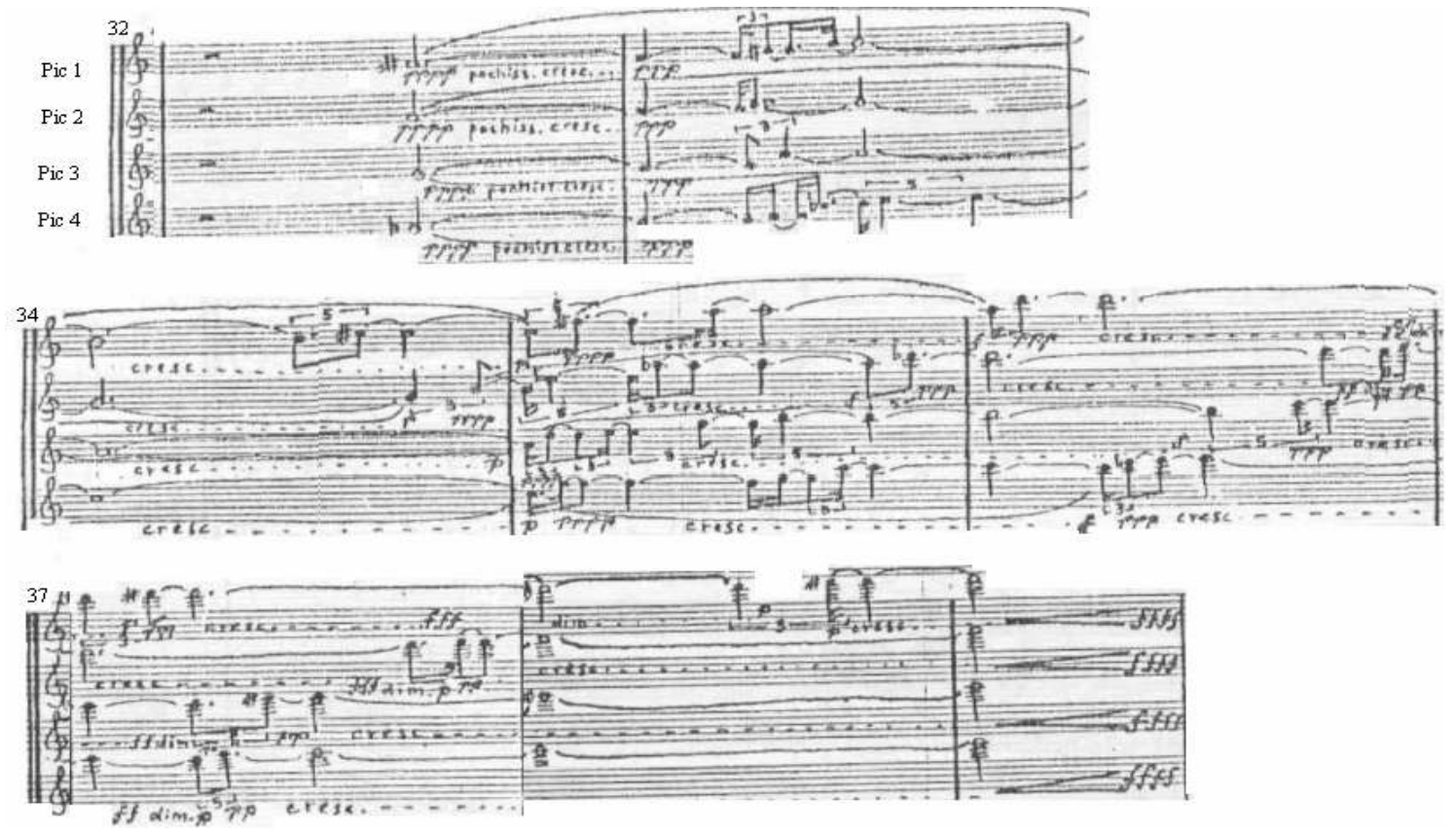

Exemplo 39-5: Ligeti, Atmospheres, compassos 32-39, ascensão dos picolos para o registro super agudo 
A construção desse sentido de transição e chegada, similar à expectativa causada em uma resolução cadencial tonal, é uma expectativa musical, ou seja, é engendrada pelas relações entre as estruturas musicais. A compreensão da ordem tonal (ou seja, daquilo que é próprio dos sons musicais) em uma cadência tonal gera uma expectativa de resolução em um ponto específico, trata-se de uma expectativa musical. Isto se difere de uma expectativa intelectual, por exemplo, como a previsão de surgimento de uma nota ainda não apresentada em uma série dodecafônica.

Aliado aos aspectos perceptuais, deve-se salientar a importância do ritmo na construção de sentido. Gestos bem formatados ritmicamente favorecem a um melhor entendimento porque o contraste rítmico é mais violento e separador. A memória rítmica é soberana, pois se as alturas são modificadas e o perfil rítmico é conservado, o gesto é percebido como relacionado (como demonstrado no Capitulo 4, em especial na técnica de transformação por redes harmônicas). Em uma situação inversa, total modificação da configuração rítmica e manutenção das alturas, a resultante será de contraste, oposição. Um exemplo dessa situação é mostrado a seguir, retirado de minha peça Chiromancer's Hands doesn't have lines, onde é possível observar que em diferentes passagens classes de alturas similares são combinadas com estruturas rítmicas distintas de modo a fornecem contrastes contundentes (o andamento é o mesmo nas três passagens).

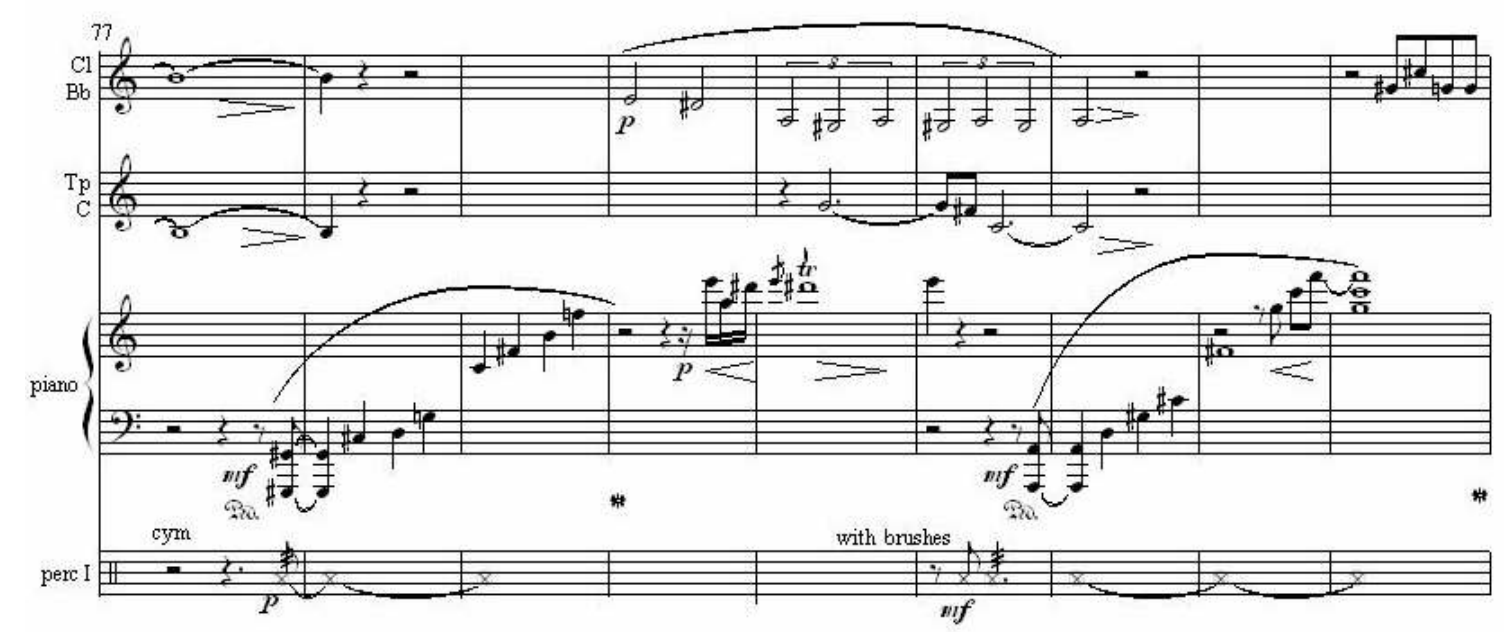

Exemplo 40-5: Antenor Ferreira, Chiromancer's Hands doesn't have lines, compassos 77-85. Manutenção de classes de alturas e modificação da estruturação rítmica. 

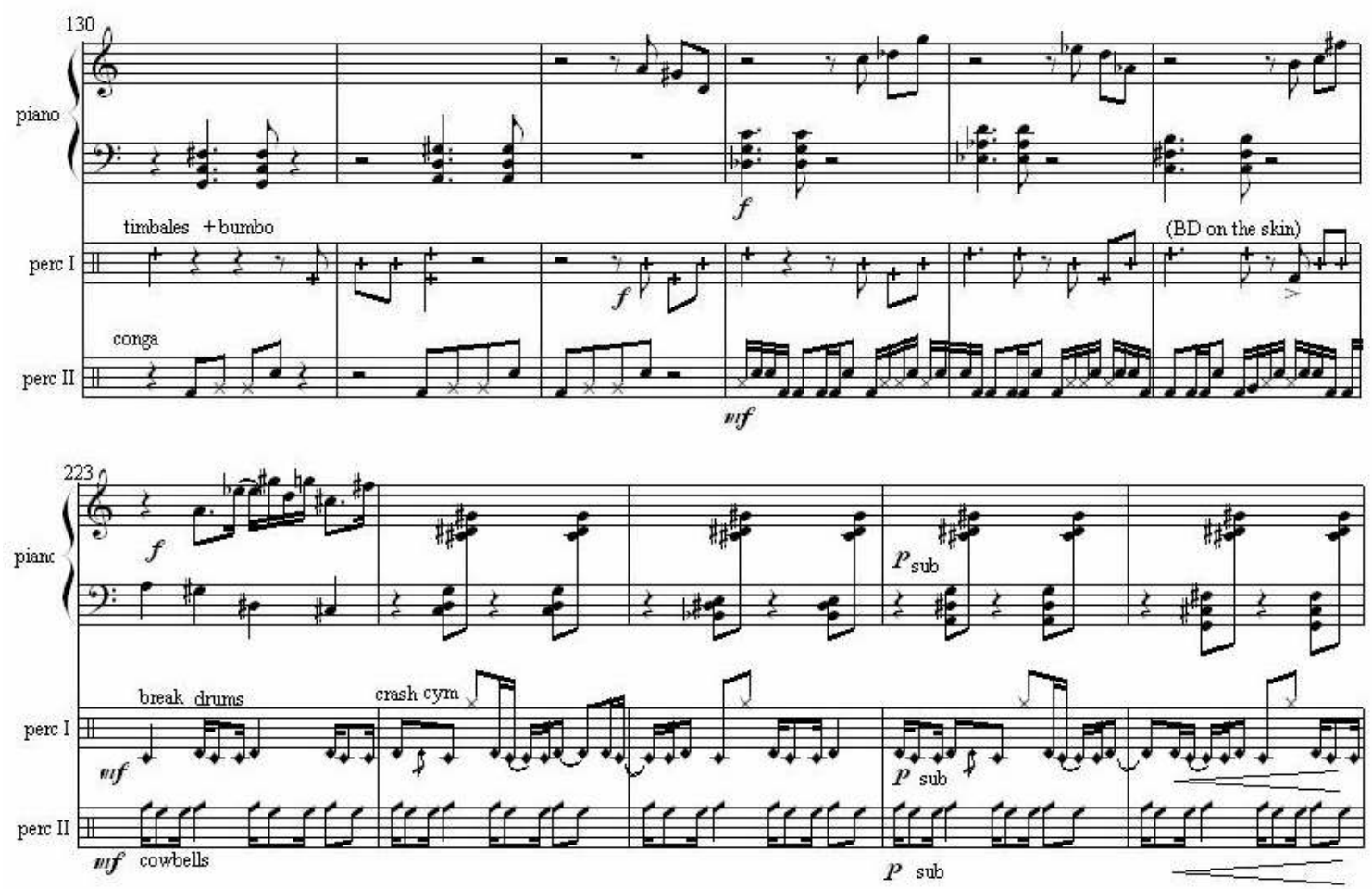

Exemplo 40-5 (continuação): Antenor Ferreira, Chiromancer's Hands doesn't have lines, compassos 130-135; 223-227. Manutenção de classes de alturas e modificação da estruturação rítmica.

A preponderância do fator duração também não pode ser esquecida. Uma função pode ser subtraída pelo manuseio temporal. A sensação de tensão provocada por uma função dominante pode ser demovida com o alargamento da duração atribuído á formação que comporta essa função, de modo que o senso de instabilidade seja enfraquecido e perdido, de modo a ceder lugar à estabilidade, pois a percepção não espera mais pela resolução da tensão. Há vários exemplos desse artifício na literatura. A seguir mostro um trecho extraído de meu quinteto para clarinetes Veredas do Sertão que contém esse procedimento. O acorde de dominante da dominante $(F \# 7 / 9 / 13)$ é afirmado e sustentado e por um período relativamente longo de tempo (a partir do compasso 7 do exemplo), de modo que a expectativa de resolução desse acorde seja dirimida, dado justamente essa dilatação temporal. 

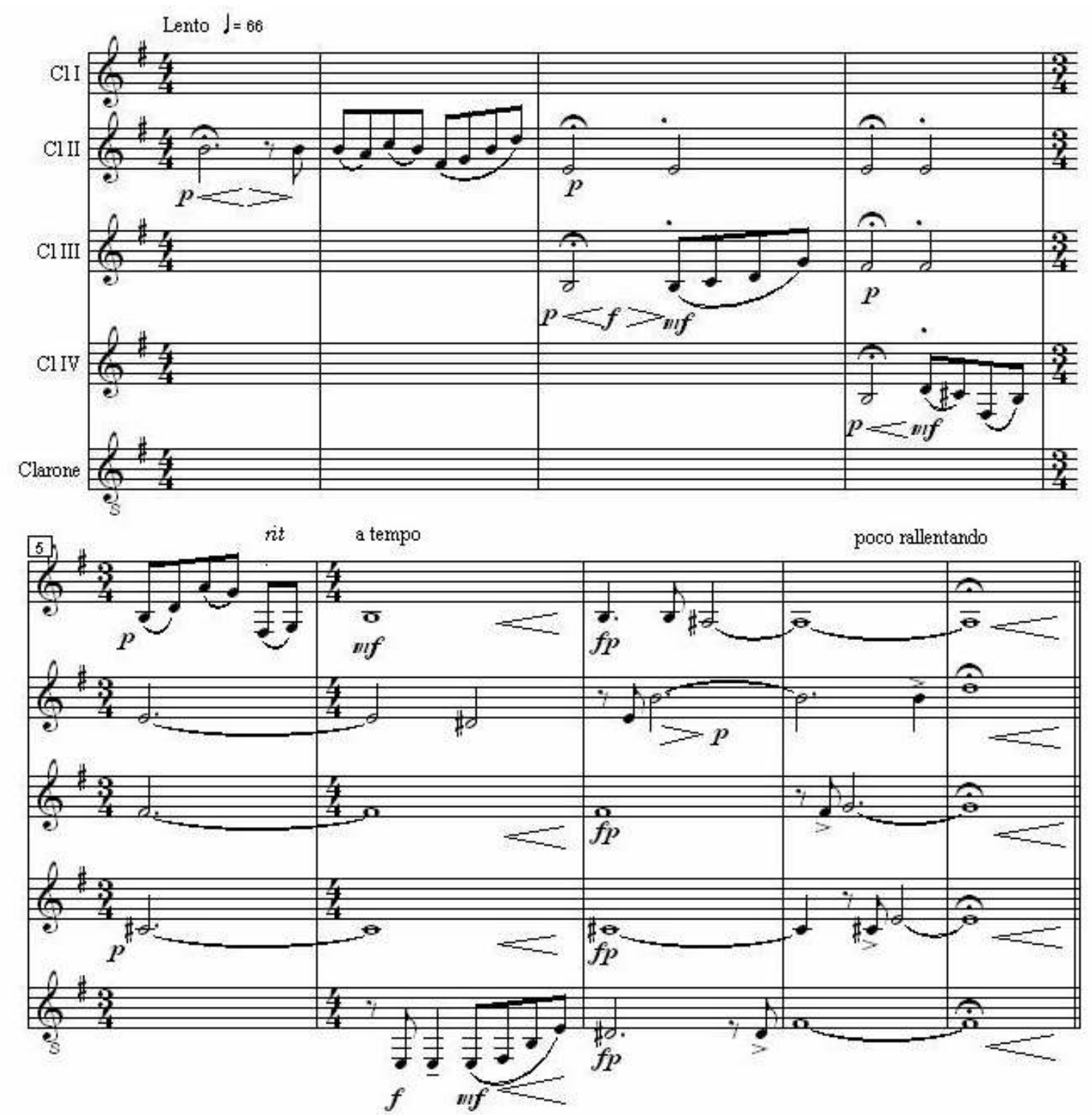

Exemplo 41-5: Antenor Ferreira, Veredas do Sertão, compassos 1-8, cancelamento da expectativa de resolução da função dominante por dilatação temporal.

O conceito de função aqui trabalhado refere-se às relações de ordem implicativa entre elementos sonoros, sejam esses as estruturas harmônicas ou lineares (frases, seções, etc.). A noção de função está tão arraigada ao orbe vertical do discurso musical que alguns autores chegam a diferenciar funcional e não funcional pelos respectivos termos harmônico e linear (cf: Benjamin et al, 2003). 'Linear', nesse modo de compreender, seria interpretado como decorativo, isto é, aquelas adições aos acordes que não são estruturais (apojaturas, retardos, 9as, 11 as, etc.). A intenção neste texto, no entanto, foi transpassar esse domínio harmônico da idéia de função, por meio de um entendimento extensivo da noção de linearidade, significando os sistemas de classificação nos quais os componentes são dispostos como derivados de, ou implicados por, outros componentes da mesma estrutura. A própria definição 
de estrutura, compreendida como a congregação de relações lógicas, racionais e interdependentes entre elementos de modo a criar uma ordem, já aponta para a consistência dessa abrangência do sentido de função.

Encampar a linearidade no âmbito funcional remete à técnica, tão cara a Schoenberg, da variação progressiva [developing variation]: processo de geração de material a partir de uma idéia básica ou uma configuração fundamental - cujos processos de transformação temática associados foram aqui comentados no capitulo anterior. Nota-se, também, que se encontra subentendida a condição teleológica do discurso musical, pois as interações, derivações e relações entre as estruturas gerativas integrantes da obra musical são interpretadas segundo sua direcionalidade, já que um evento é tido como decorrente de um fato antecessor.

No interior da funcionalidade, um mesmo objeto musical (o tema, por exemplo) pode ainda ser reapresentado em contextos diferentes, de modo que continue a ser percebido como o mesmo, embora de maneira renovada, refuncionalizada. Os novos contextos se dão por adição ou pela imbricação (via estratificação) de justaposições anteriores. Nestes novos ambientes, o material original continua a ser reelaborado (via artifícios de transformação), mas mantém características que permitem identificá-lo perceptualmente. Retomando Meyer, para engendrar uma impressão formal uma ordem deve se estabelecida, na qual os estímulos individuais tornam-se parte de uma estrutura maior e realizem distintas funções dentro dessa estrutura. Se o estímulo não é percebido como sendo similar, então ele vai falhar em criar coesão ou em formar um grupo ou unidade. Essa refuncionalização das estruturas musicais possui vários modos de ocorrer e algumas relações serão apontadas nos exemplos seguintes.

Desde o início, no número 7 da Música Ricercata, impõe-se uma clara distinção do tipo fundo (acompanhamento) e figura (linha melódica). Um grupo de notas centrado em $F$ é repetido durante toda a peça, estabelecendo-se enquanto acompanhamento. A esse grupo, uma linha melódica construída sobre $C$ dórico é apresentada. Esses grupos se diferenciam por pólo, dinâmica, registro e, principalmente, andamento. Ligeti recomenda que a figuração do acompanhamento deve ser executada independentemente do ritmo da linha melódica, e para não induzir concomitância métrica entre os grupos não coloca barras de compasso na parte do acompanhamento. Vários aspectos dessa melodia podem ser considerados segundo todos os critérios aqui comentados. A boa continuidade garante que a melodia continue a ser identificada como relacionada ao ser estendia em registro ( $C-F-G$ marcados 'a' no Ex. 42-5). O critério da proximidade leva a distinguir notas principais das notas de passagem (valores de semicolcheias marcadas 'np'). Artifício de simetria reflexiva também pode ser encontrado, como indicado no exemplo por reflexão. Porém, o critério da similaridade predomina, 
diferenciando ao menos dois agrupamentos na linha melódica e possibilitando interpretar a nota $C$ como pólo (indicados 'a' e 'b' no exemplo).

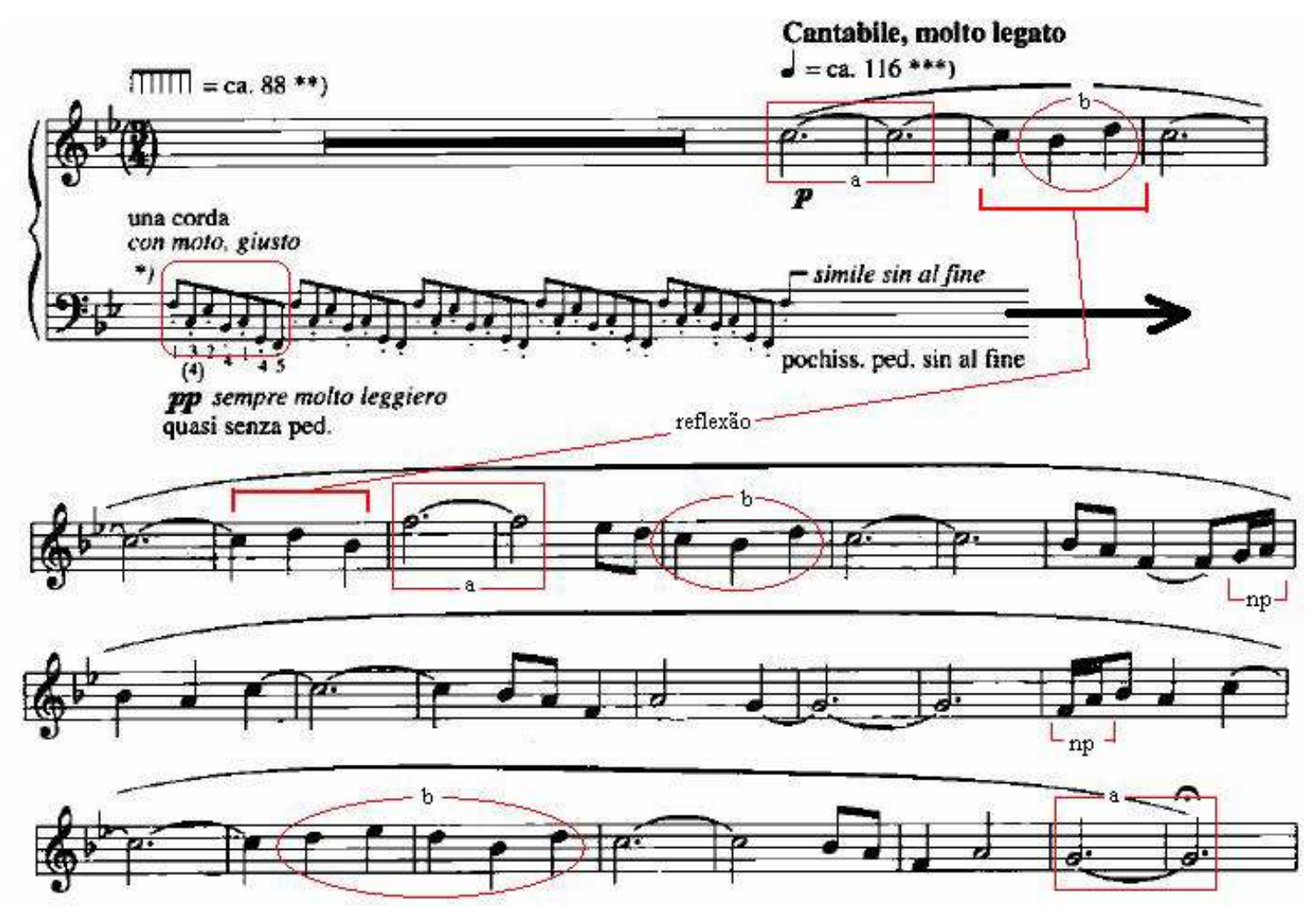

Exemplo 42-5: Ligeti, Musica Ricercata VII, primeira seção, relações entre as distintas estruturas.

Esta primeira seção possui clara função expositiva. Segue-se a esta, uma nova seção cuja linha melódica anterior permanece idêntica em quase todos os parâmetros, contudo vem transformada em textura e densidade por meio da adição de uma nova linha melódica. $\mathrm{O}$ material inicial, apesar de similar, é reinterpretado segundo esse novo contexto (vide Exemplo 43-5).

Uma terceira seção é apresentada modificando-se o registro da linha melódica inicial, porém mantendo suas relações intervalares. A textura é novamente transformada, pois a segunda melodia realiza procedimentos imitativos em relação à melodia principal. Assim, o material inicial torna-se passível a nova refuncionalização em razão da modificação do contexto em que é reapresentado (vide Exemplo 44-5). 

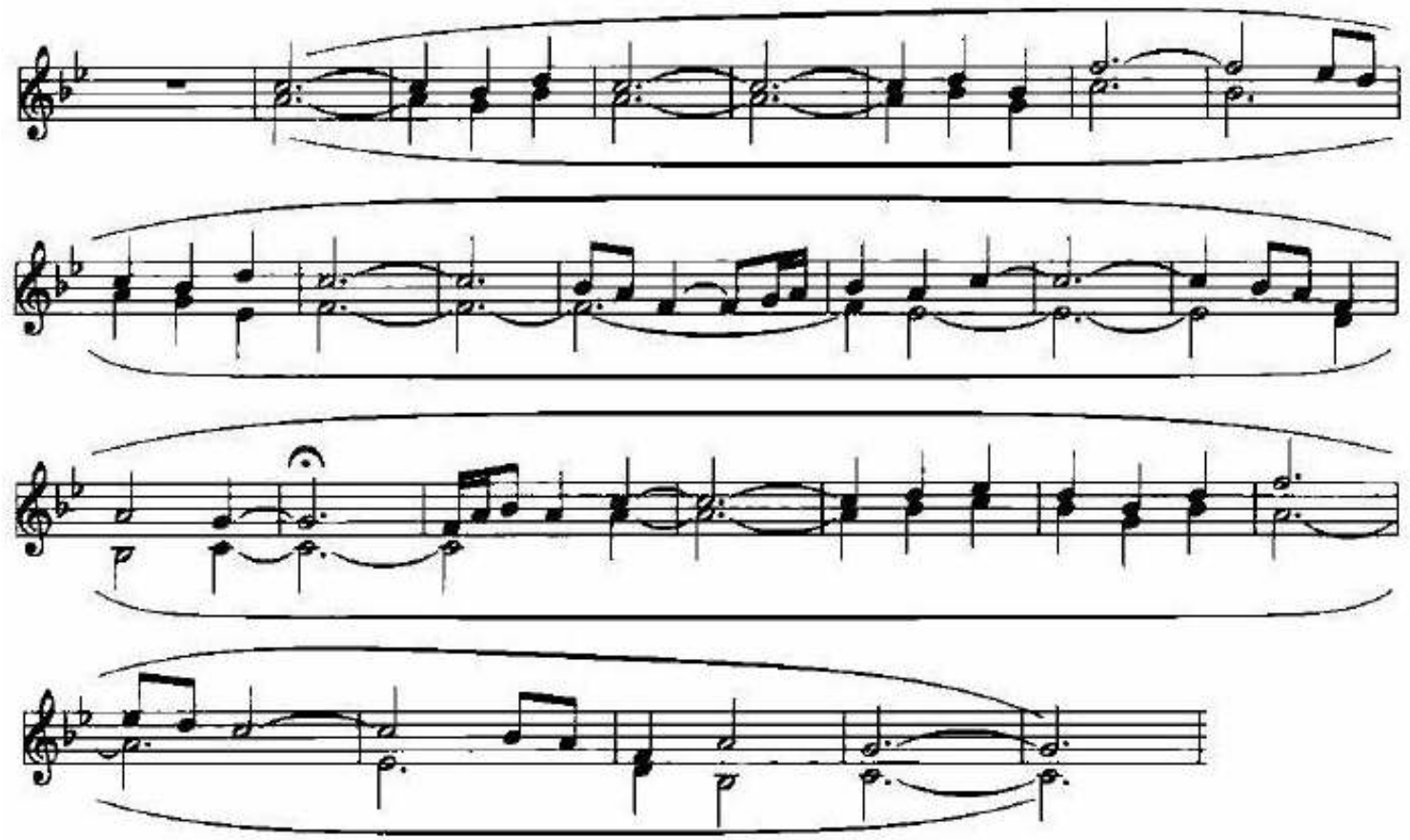

Exemplo 43-5: Ligeti, Musica Ricercata VII, segunda seção, transformação de densidade e textura.

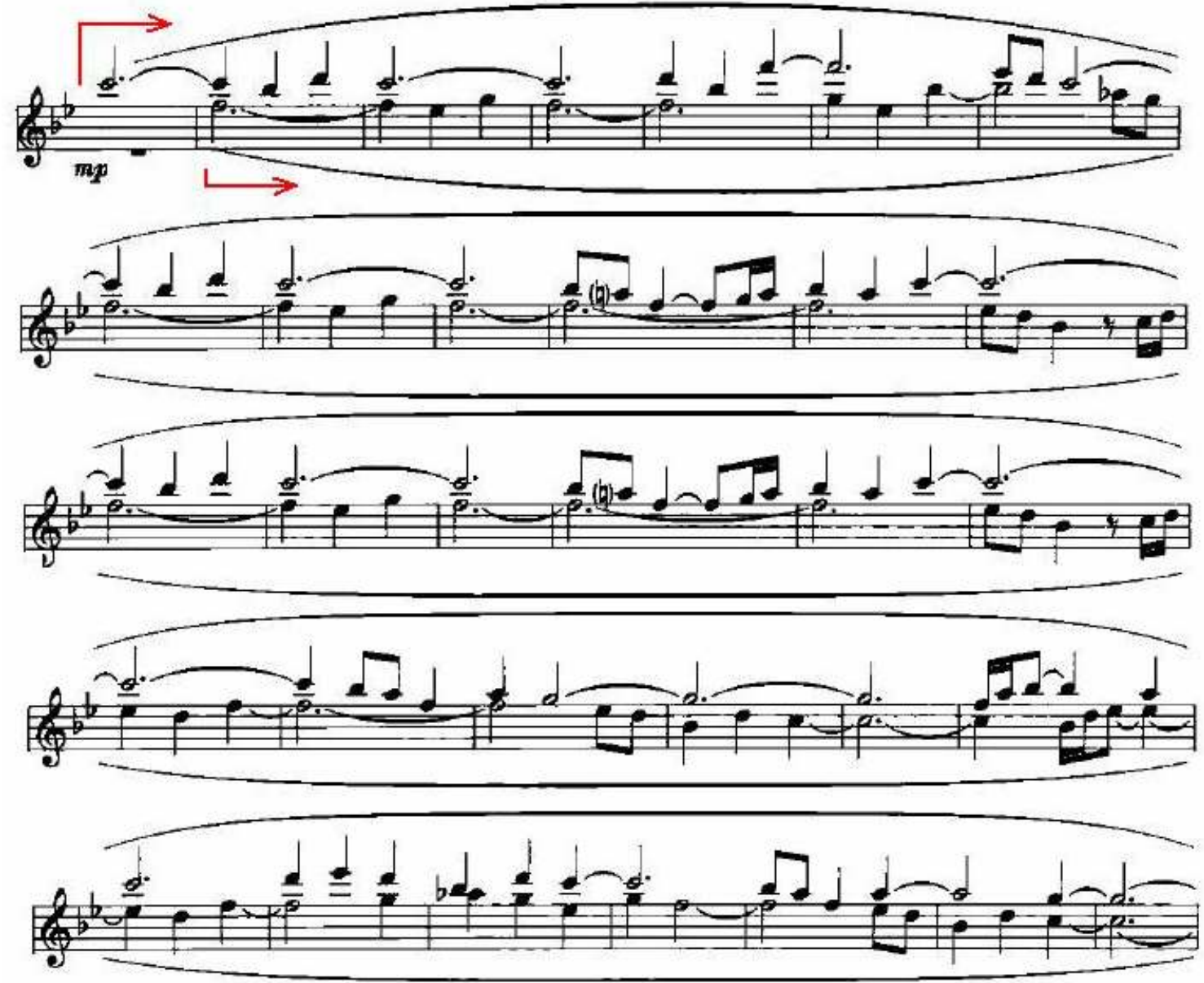

Exemplo 44-5: Ligeti, Musica Ricercata VII, terceira seção, refuncionalização via transformação de registro e textura. 
$\mathrm{Na}$ quarta seção é realizada a estratificação pela apresentação simultânea das três seções anteriores (ainda associada à figuração de acompanhamento iniciada desde o primeiro compasso da música). O novo contexto se dá pela imbricação dos materiais antes expostos, contudo, mantendo características que permitem identificá-los e relacioná-los perceptualmente. Dessa maneira, todos os materiais são refuncionalizados pois são passíveis de nova re-significação neste novo contexto (vide Exemplo 45-5).

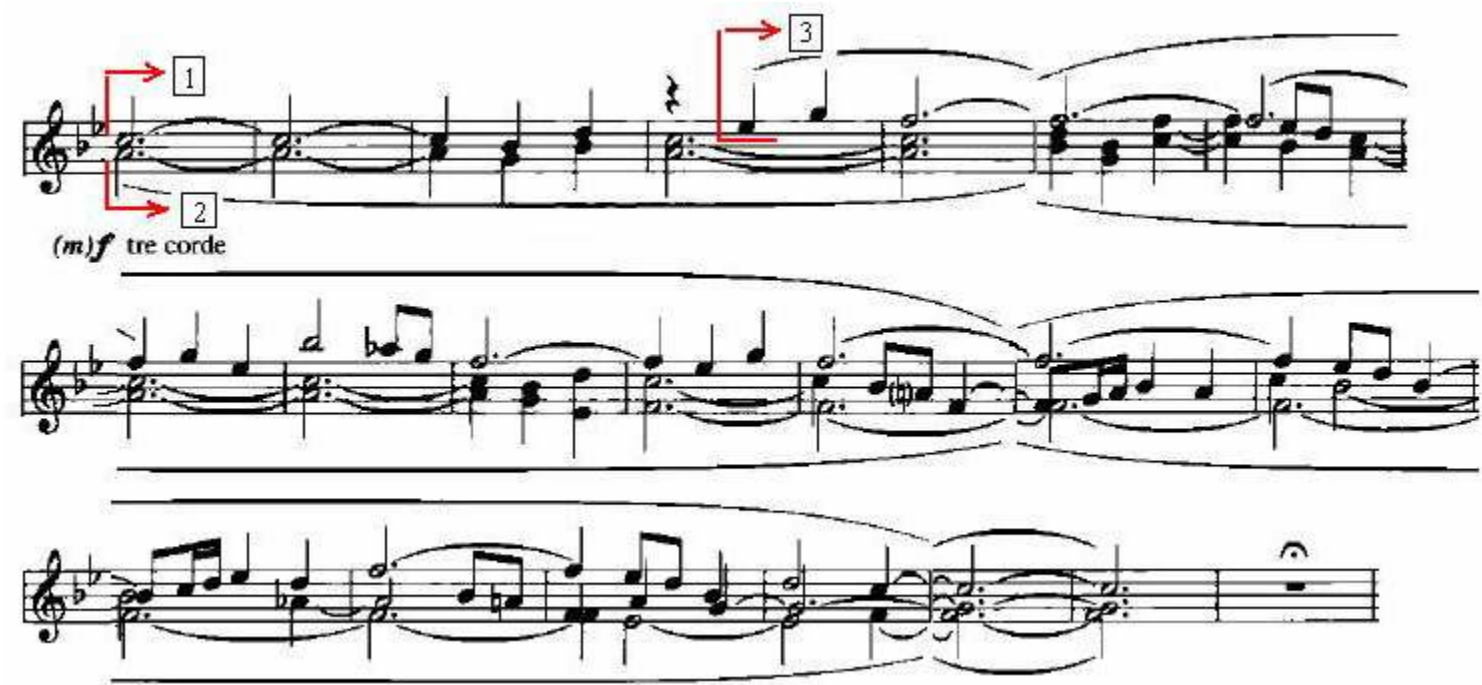

Exemplo 45-5: Ligeti, Musica Ricercata VII, terceira seção, refuncionalização via transformação de registro e textura.

A seção que finaliza a obra poderia ser contada como espécie de construção por reflexão, já que recapitula fragmentos da terceira e segunda seções e transpõe para o primeiro plano o grupo de acompanhamento variado em registro. Com isso a configuração formal da peça toda poderia ser entendida como A | B | C | D | C | B | A | evidenciando, assim, sua planificação simétrica. Talvez seja por razões como esta que Ligeti afirmou que Musica Ricercata contém influências de Bartók e Stravinsky.

A idéia de refuncionalização enquanto possibilidade de re-significação, ou nova construção de sentido para as estruturas apresentadas na obra, constitui-se como um procedimento enriquecedor dentro do modelo composicional aqui proposto. Como última demonstração desta idéia (associada ao discorrido no Capítulo 3 sobre estratificação, mais especificamente, no que concerne à síntese de partes anteriormente justapostas), aponto a seguir seu emprego em uma de minhas peças.

O mote dessa composição foi utilizar instrumentos de percussão sem altura definida (bumbo, pratos e break drums) junto com a marimba, por sua vez, com alturas definidas. Contudo, estes instrumentos deveriam congregar o todo de modo a não diferenciar as 
estruturações por alturas e tímbricas. A obra possui quatro partes. A primeira destas é fechada em si e altamente organizada no que concerne á continuidade e direcionalidade. $\mathrm{Na}$ segunda parte, no entanto, diferindo fortemente da primeira, acontecem somente justaposições de blocos musicais frontalmente contrastantes, de modo a não serem percebidos como aparentados sonoramente. Enfatiza-se, nesta segunda parte, a ruptura e a fragmentação. $\mathrm{Na}$ terceira seção o material também é novo, tratando-se de uma linha melódica no grave unida aos sons agudos da marimba e break drums e uma linha de bumbo independente. A quarta seção realiza a síntese das partes anteriores, trazendo os blocos justapostos no interior de relações de maior proximidade e de boa continuidade, tornando-os mais similares. Espero, assim, lograr a síntese das seções anteriores e possibilitar nova construção de sentido musical para as estruturas e partes antes expostas.

O Exemplo 46-5 mostra fragmentos de estruturas gerativas apresentadas no decorrer das três seções da obra (marcadas com números de 1 a 6). No Exemplo 47-5, estas estruturas são mostradas trazidas em relações de maior proximidade, de modo a induzir a percepção à não mais compreendê-las como rupturas e justaposições do fluxo musical, mas enquanto um único grupo coordenado.
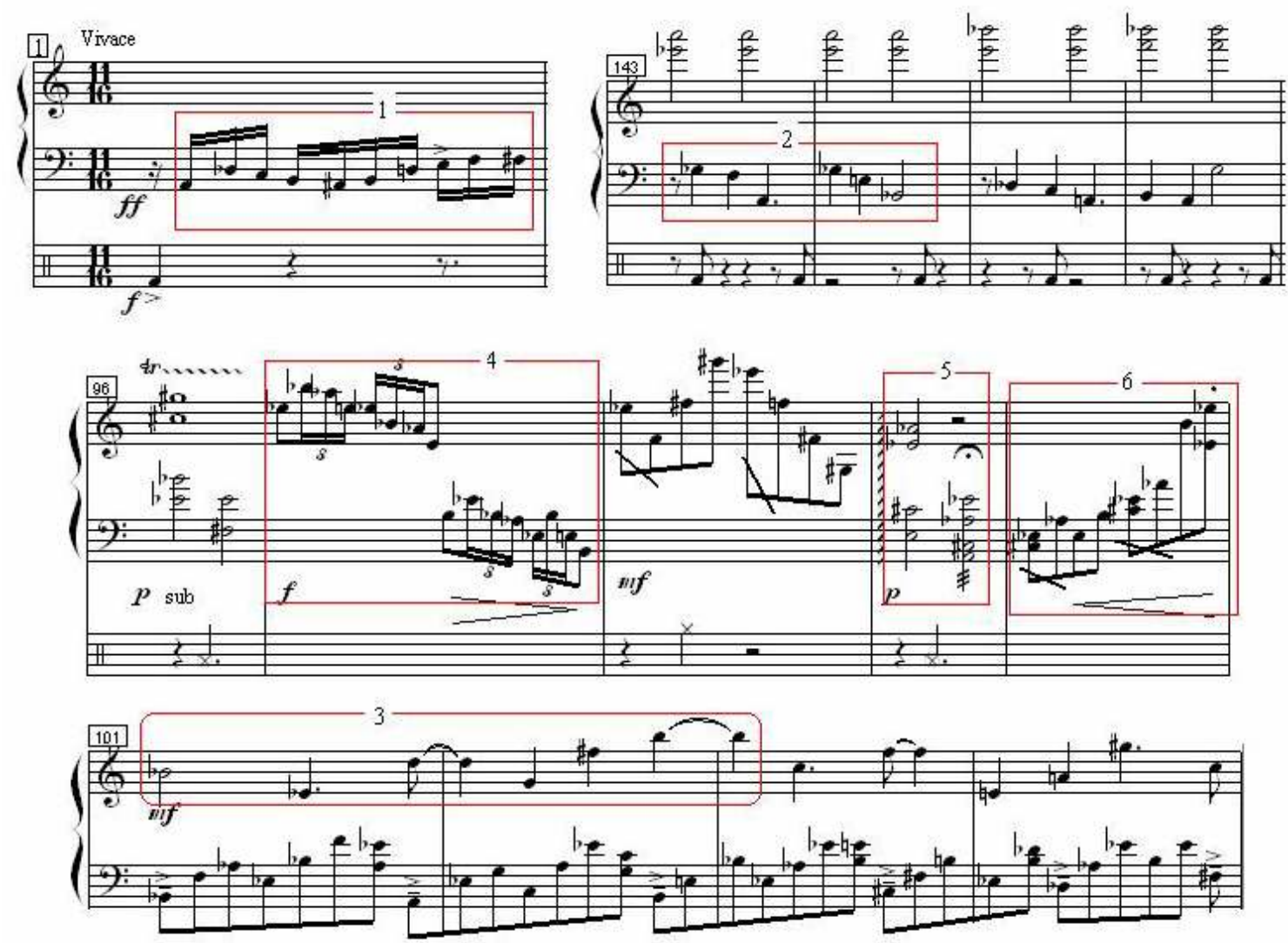

Exemplo 46-5: Antenor Ferreira, Trilhas Sonoras, compassos 1, 96-1014, 143-146. Fragmentos de estruturas gerativas e blocos musicais justapostos em três seções da obra. 

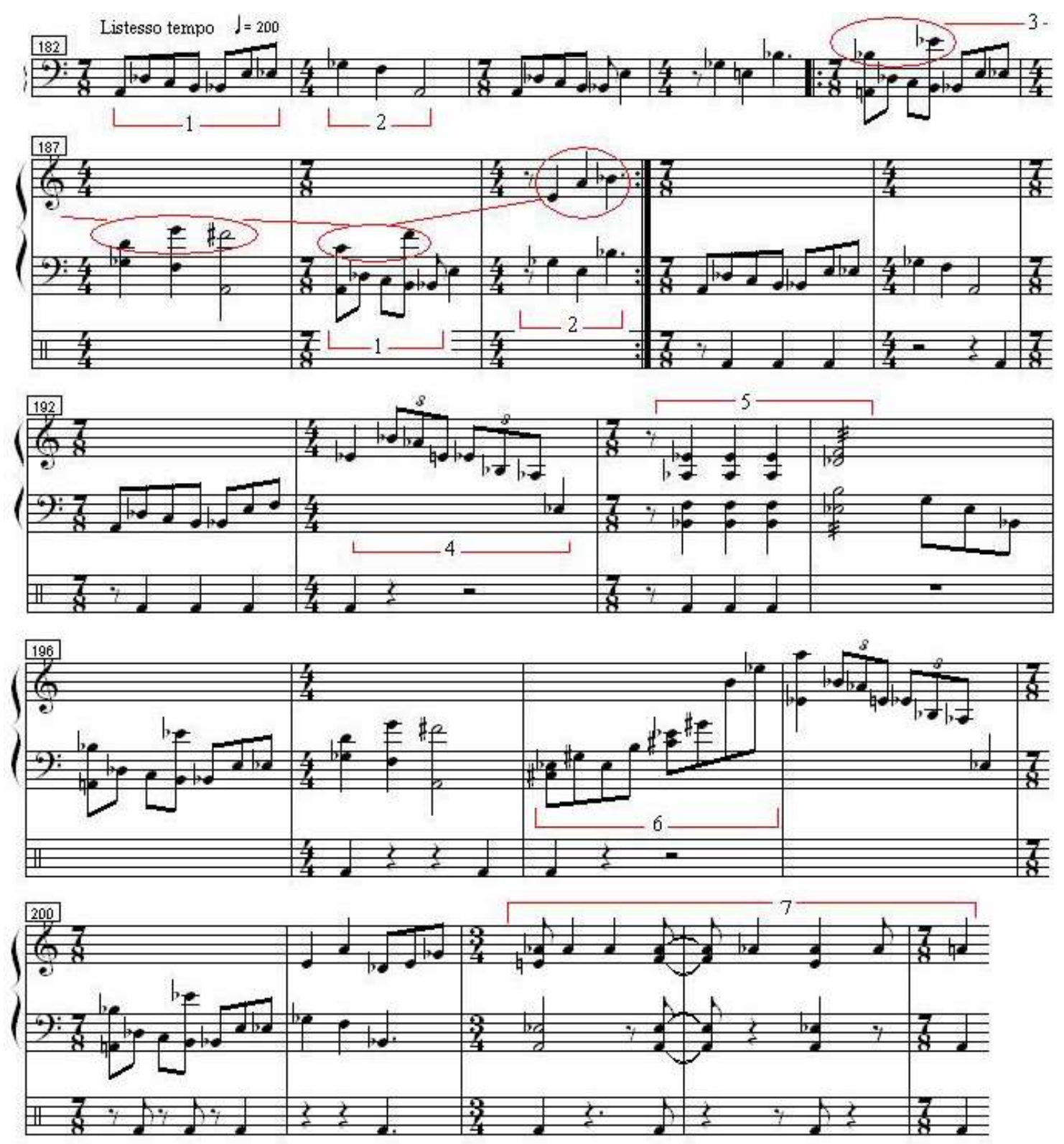

Exemplo 47-5: Antenor Ferreira, Trilhas Sonoras, compassos 182-204, quarta seção da obra. Síntese de alguns dos blocos anteriormente justapostos.

A concepção de funcionalidade tem como condição básica a existência de relações entre objetos ou eventos musicais de modo a constituírem um todo coordenado. Por conta disso, Meyer entende haver uma diferença de pontos de vista entre alguns compositores e teóricos que acabam por estabelecer abordagens distintas da concepção funcional. Essa divergência levou-o a dividir em dois grupos aqueles que se debruçam sobre o tema: tradicionalistas e formalistas, por um lado, e transcendentalistas por outro (Cf. 1994, p.294). Os tradicionalistas e formalistas postulam que a comunicação musical surge das implicações existentes entre os componentes estruturais e formais da obra. Os transcendentalistas admitem 
que "as relações implicativas, o processo musical direcionado para um objetivo e a visão teleologicamente orientada da comunicação não possuem um papel relevante em sua estética" (MEYER, 1994, p. 295). De minha parte acho correto imaginar que um compositor tenha um propósito estabelecido ao inserir em sua música um determinado elemento (seja um acorde, uma sonoridade, uma seção, etc.). Assim, é lícito perguntar: qual a função disto? Essa questão não subentende uma visão utilitarista do mundo na qual tudo deve possuir uma serventia, mas sim, que em uma boa obra nada é obsoleto ou casual.

Ao fim, essa reflexão não pode desconsiderar o fato mais importante da arte musical: a percepção. Uma música é composta de sons, e estes só se dão a conhecer no ato da escuta, portanto aspectos cognitivos ligados á percepção musical não podem ser postos fora de um projeto composicional. "Em um sistema funcional percepção envolve ordenação e seleção, enquanto na estética não funcional esposada pelos transcendentalistas percepção é passiva e não seletiva” (MEYER, 1994, 296). No meu modo de pensar, a escuta musical não precisa apenas ser uma atividade contemplativa, de entrega descomprometida aos estímulos sonoros, mas pode demandar uma atitude ativa, buscando penetrar nos meandros da composição de modo a promover a construção de sentido durante o discurso musical. Esses apontamentos conduzem a um assunto de certa forma polêmico no âmbito da composição musical: as possibilidades comunicativas de uma obra. Esse tópico será tratado no próximo capítulo, pois entendo que um projeto no qual se ambicione a constituição de um modelo composicional (cuja contribuição é servir para gerar obras musicais que, por sua vez, irão apresentar a outras pessoas as questões e especulações musicais sugeridas por um compositor) não possa se furtar a considerar os aspectos da comunicabilidade. 
Capítulo 6

COMUNICABILIDADE NA MÚSICA PÓS-TONAL 


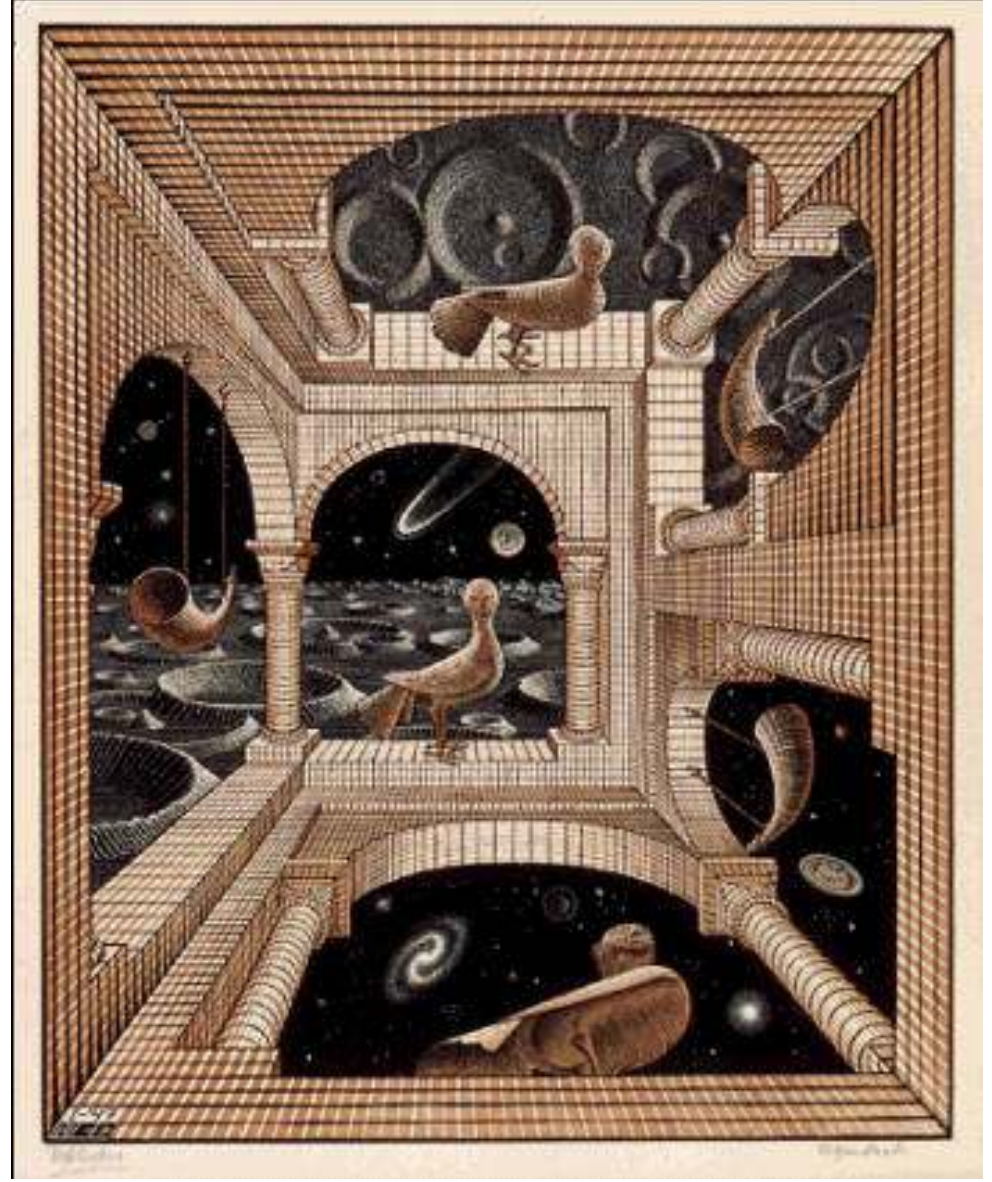

Maurits Escher: Autre Monde (1947, gravura de madeira e xilogravura em preto, avermelhado e marrom, impresso em 3 blocos) 


\section{Introdução}

Vários compositores e teóricos da música contemporânea entendem a necessidade do resgate da comunicação entre autor e audiência. Jorge Antunes, por exemplo, diz:

a música contemporânea busca desesperadamente a comunicação imediata com o público de hoje. Aparentemente a maioria dos compositores não mais pretende escrever cartas à posteridade sem a espera de resposta. A busca de uma comunicação efetiva com o público é bastante lógica, coerente, compreensível e necessária. Tenta-se conquistar o público o mais amplo possível e para isto são usados os mais diversos métodos (ANTUNES, 2003).

O alegado motivo desta perda da comunicabilidade é o alto grau de cerebralismo presente nas obras musicais de vanguarda (sobretudo, desde a promulgação da técnica dodecafônica por Arnold Schoenberg em 1925 e seu posterior desdobramento no serialismo integral da segunda metade do século XX), obras que por vezes não são mais consideradas como manifestações artísticas, mas sim como experiências ou proposições matemáticas. $\mathrm{Na}$ grande parte dessas obras os compositores apartavam-se de todos os resquícios da prática comum e partiam de um sistema a priori que, se por um lado conferia coerência interna às peças, também exigia dos ouvintes o conhecimento dos códigos regentes desse sistema, do contrário, a compreensão da obra estaria comprometida. Ao que parece, esse tipo de atitude vem sido contestada por compositores atuais, os quais têm voltado suas preocupações à retomada da comunicação com o ouvinte, descartando, para tanto, a exigência de familiaridade técnica e adotando outros métodos mais "humanos". Jorge Antunes, continuando sua argumentação citada inicialmente, esclarece:

Alguns desses métodos, bastante vulgares, não merecem ser matéria de análise porque se revestem de intenções menores, mercantilistas. Mas outros, em que o valor estético continua a prevalecer e em que as estratégias e convicções se voltam à humanização do discurso musical, merecem atenção e análise aprofundadas. Essa humanização da sintaxe e do conteúdo da construção musical tem levado muitos compositores a adotarem prioritariamente algumas práticas que andaram abandonadas neste século: a intuição, a invenção livre e a espontaneidade. Dessa forma, os manifestos e os comentários técnicos de programa passam a ser abandonados. As grandes teorias que antecedem a obra musical não mais têm lugar. Assim, uma nova música desponta amedrontando os detentores do poder da arte-oficialvanguardista-européia e os herdeiros do cerebralismo bouleziano (ANTUNES, idem).

A questão da comunicação musical poderia ser encarada simplesmente afirmando que a música não precisa comunicar coisa alguma, ela existe e se basta como tal sem pretensões de ser veículo portador de mensagens, sejam estas ideológicas, estéticas ou de qualquer natureza. Esta postura, por outro lado, me parece contraditória, pois suponho que um compositor quando dá sua obra a conhecer o faz porque deseja compartilhar algo com alguma comunidade, seja esta formada por outros compositores, intérpretes ou público. Etimologicamente, comunicar significa tornar comum; portanto, se alguém não almeja comunicar não deve apresentar nada, mas sim confinar seu produto ou idéia à privacidade de 
sua gaveta. O problema surge quando se pensa que deva existir um conteúdo objetivo a ser comunicado pela música e recebido de modo unívoco pela audiência. Desde quando o ideário romântico foi posto em cheque pelos estetas de finais do século XIX (sobretudo Hanslick, legando ao século XX a assertiva da ineficácia do compositor em transmitir sentimentos, mas sim um conteúdo formal) e o abandono do sistema tonal pelos compositores eruditos fomentou a pesquisa por novos processos de construção musical, o problema da comunicação musical instaurou-se definitivamente. Assim, seria lícito perguntar o que o repertório anterior comunicava. E a resposta serve não só para a tradicional, mas também para a 'nova' música: dar algo a conhecer é tornar algo comum, fato que automaticamente gera comunicação e abre portas para distintas possibilidades de entendimentos, inquietações, diálogos, debates, etc.

Essa questão poderia ser pensada ainda por outro ângulo, partindo da pergunta: o que é uma obra de arte?

Baseado nos escritos do esteta Max Bense, em especial o seu Pequena Estética (1975) no qual trata dos aspectos comunicativos da estética, pode-se entender a criação artística como sendo a passagem de um conjunto de materiais para um objeto artístico finalizado. Bense usa os termos repertório e produto, propondo o seguinte esquema básico:

\section{Repertório $\longrightarrow$ Produto}

Repertório refere-se ao conjunto de elementos materiais com os quais o artista trabalha (cores, palavras, sons, madeira, etc.) e o produto é o objeto de arte realizado. Prefiro usar os termos materiais, no lugar de repertório, e objeto artístico, no lugar de produto, para evitar confusões com a nomenclatura musical já estabelecida. Nesta proposta, a criação artística é um rearranjo dos elementos materiais, ou melhor, uma recombinação organizada a partir de um conjunto inicial de materiais. Esse processo pressupõe, obrigatoriamente, a seletividade, realizada pelo artífice, dado a vastidão de possibilidades oferecidas pelo conjunto de materiais. Portanto, a concreção do objeto de arte mostra uma maneira particular de recombinação dos elementos iniciais, fato que em si já é um tipo de comunicação, pois comunica uma das possibilidades de seleção e recomposição dos materiais. Na medida que o artista mostra em sua obra uma combinação particular dos materiais, está desvendando o processo criativo viabilizador da concreção daquele objeto de arte, ou seja, como se deu a passagem do estado "repertório" para o estado "produto", dai Bense afirmar ser o "fenômeno criativo um caso especial do processo comunicativo" (BENSE, 1975, 93).

Este processo de criação artística também pode ser descrito como a passagem de um estado de latência para o domínio real (sensorial talvez fosse a palavra mais adequada). Essa última idéia faz lembrar a frase atribuída a Michelangelo, que comentando sobre a realização de uma de suas estátuas, disse ter apenas retirado os excessos de mármore, pois na verdade a 
estátua já se encontrava lá dentro. Anedotas à parte, o processo não é tão simples. Um monte de argila (material) pode conter em latência ou em potência (para recordar Aristóteles) um vaso (produto). Todavia, a transformação e passagem de um domínio para o outro se dá pela mão do artesão (mediador). Estendendo a analogia para o campo musical, poder-se-ia dizer que os sons (e todos os materiais implicados, como altura, timbre, texturas, etc) representam o ponto de partida, mas a transformação (seleção, combinação) destes para produzir uma obra pode ocorrer de inúmeras maneiras. Neste momento surge a figura do compositor (mediador), cujo processo criativo operado é comunicado ao receptor. Um conjunto inicial de materiais em estado caótico é organizado para gerar um produto artístico, um processo compreendido basicamente em duas etapas. A etapa final é ordenada (pois o objeto de arte possui uma estrutura formal definida), a etapa inicial, porém, contêm variáveis. Como se encontraria o estado inicial do conjunto de materiais que o mediador tem a sua disposição? Segundo Bense, estes poderiam estar totalmente desorganizados ou organizados. "No primeiro caso, trata-se de uma produção de ordem a partir de desordem, e no segundo, da produção de ordem a partir de ordem" (ibidem, p.94).

Uma situação inicial na qual o conjunto de elementos materiais já possua uma certa ordem pode ser verificada em condições em que preexista certo tipo de estruturação ou sintaxe governando estes materiais, o que me parece o caso da música da prática comum. Os materiais usados para composição não se encontram em total desordem, os sons já apresentam certas estruturações, sistematizações e paradigmas prévios. Uma composição tipo coral de Bach, por exemplo, já compreende modelos a priori que permitem ser tomados como materiais composicionais, é o caso dos acordes. Os diversos tipos de escalas e os padrões rítmicos análogos aos pés métricos da poesia, também são exemplos dessa ordem regular preestabelecida. Neste âmbito, permite-se entender que os compositores contemporâneos prescindiram dessa ordem regular inicial atribuída aos materiais, fazendo com que o foco do processo de transposição do conjunto de materiais para o domínio artístico (a obra musical) fosse direcionado para o interior do próprio material, ou seja, o objeto artístico tornou-se uma imersão para dentro do som (material inicial), resultando no que é chamado por alguns de "composição sonora". Esta característica, de certo modo, diminuiu a carga discursiva comportada no processo anterior, trazendo conseqüências para a compreensão musical e, eventualmente, para a comunicação.

Rogério Costa lembra que é possível elencar no interior de um processo discursivo dois tipos de elementos: distintivos (que não carregam significados) e significativos. Os acordes podem ser contados como matéria prima composicional constituindo-se enquanto elementos distintivos, com a possibilidade de adquirirem sentido no contexto de um 
encadeamento, desse modo "só o discurso é que estabeleceria a função, o nexo, o sentido dos eventos sucessivos" (COSTA, 2004, p.83). E reside aí uma das características da música ocidental que perdurou pelo menos por 250 anos, até que alguns compositores passaram a investir consubstancialmente nas unidades não significativas (o procedimento arquetípico dáse, definitivamente, em Debussy) ocorrendo, então, a "valorização das sonoridades dos acordes, do som desvinculado de seu contexto lingüístico, molecularização (é assim que se chega, no limite, às propostas de $\mathrm{P}$. Schaeffer de objeto sonoro e na música de G. Scelsi que propõe uma viagem por dentro do som). Neste contexto é que não há mais um predomínio da discursividade" (ibidem, p.83). Por outro lado, em compositores cujas obras denotam afastamentos mais ou menos radicais do paradigma tonal como, por exemplo, Schoenberg, Webern e Scriabin, o uso de estruturações discursivas não foi de todo rejeitado, apontando ser esta uma característica musical importante que não deve ser desprezada.

No esquema proposto por Bense para a criação artística (passagem do repertório ao produto), nenhuma menção é feita ao receptor da obra. Isto é esclarecido pelo fato de sua proposta estética centrar-se no objeto, ao invés de almejar descrever estados estéticos subjetivos particulares aos fruidores. Ele enfatiza que uma "teoria objetiva dos estados estéticos deve, de início, compreender e descrever apenas o que aparece no objeto dado e não no sujeito contemplante" (BENSE, 1975, p. 50). Obviamente, há autores cujas propostas de reformulações estéticas concentram-se na recepção do objeto artístico, predominando, nessa esfera, a figura do receptor. Propostas deste tipo reivindicam o envolvimento do sujeito no processo comunicativo, o receptor tem de ser afetado de algum modo. Este envolvimento na música implicaria em respostas emocionais, psicológicas, intelectuais ou físicas por parte do ouvinte. "Sem o envolvimento das pessoas a quem os estímulos são direcionados, a comunicação não é possível. Conseqüentemente, comunicar não é função da obra, do artista criativo ou do executante. É o ouvinte que se comunica com a obra e com o artista" (SHERMAN, 1989, p.228).

Após esses aportes iniciais, tentando confrontar a questão da comunicabilidade por dois ângulos diferentes, em cujo percurso alguns caminhos a serem percorridos neste texto já foram indicados, retornemos ao problema lançado inicialmente, isto é, ao resgate da comunicação na música contemporânea, abordado agora pela vertente cognitiva e centrado em aspectos específicos da música - vertente esta que se constituirá como a principal fundamentação para as hipóteses discutidas no decorrer deste capítulo.

$\mathrm{Na}$ tentativa de uma nova comunicação, algumas correntes pós-modernistas parecem sugerir um retorno ao estilo composicional tonal do passado. Esta postura não encontra justificativa em alguns setores de vanguarda que, por seu turno, não querem descartar os 
ganhos para a escuta musical advindos das propostas de renovação da linguagem composicional do começo do século XX, sobretudo as ligadas à citada composição sonora. Propõem, então, uma reformulação do pensamento estético intrínseco à arte moderna, renovação esta que não pretende desconsiderar os aspectos e impactos perceptuais envolvidos na recepção da obra de arte, tampouco retornar aos estilos tradicionais. Esta nova postura simplesmente afirma que a percepção da obra musical deve caminhar ao lado de preocupações técnicas composicionais. Assim, para ocorrer o citado resgate da comunicabilidade musical no âmbito da música complexa, há a necessidade de se adotar novos critérios e parâmetros balizadores que podem ser encontrados nas ciências da cognição e da informação.

Em 1994, Leonard Meyer realizou uma revisão do seu livro Music, the arts, and ideas, publicado pela primeira vez em 1967, no qual apresenta uma série de reflexões envolvendo, entre outros assuntos, a percepção e a cognição da música complexa. Meyer desenvolve um rol de tópicos que concorreriam para a compreensão e significação musicais, tendo por base a psicologia gestaltista e a teoria da informação. A hipótese principal de sua argumentação é que a fruição da música envolve processos prognósticos, oriundos do aprendizado (que traz implícitos fatores culturais) e da experiência individual com os diversos estilos, os quais norteariam a escuta e, conseqüentemente, a compreensão musical. Ao longo de seu texto encontram-se diversas comparações entre as músicas tonal e serial com intuito de avaliar a diferença nos graus de cognição que estes repertórios envolvem. A preocupação com os aspectos perceptuais e cognitivos manifesta-se em diversos autores, David Rosenboom, por exemplo, corrobora:

Dada a atenção dos compositores contemporâneos à natureza básica da experiência musical, eu acredito ser apropriado enxergar o ato da composição musical, ao menos em parte, como um ato de modelagem cognitiva musical. Eu proponho que examinemos a composição do século XX sob essa luz. Nós devemos ver a ação composicional como uma tentativa de criar realidades musicais ordenadas, às vezes, inteiramente únicas, completa com seus próprios conjuntos de paradigmas, considerando como a música funciona, como é percebida e como a informação musical é processada no cérebro. Assim, deve partir do ponto de vista do compositor em construir novos paradigmas para percepção, concepção, propriocepção e memória musicais. Em outras palavras, nós assumimos que o compositor começa com um modelo cognitivo de música já proposto e então cria música consistente com esse modelo. Com essa informação nós devemos estar aptos a aumentar nosso entendimento da música do século XX e testar o sucesso de experimentos musicais de uma maneira mais embasada (ROSENBOOM, 1987).

Proponho aqui, tendo por base principal os escritos de Meyer confrontados e complementados com outros autores, considerar os aspectos envolvidos na recepção e na compreensão da música de modo a criar alguns critérios que sirvam como balizas para o plano composicional objetivando reativar a comunicação entre compositor e ouvinte da obra musical contemporânea. Para tanto, inicio com definições dos conceitos envolvidos, 
seguindo-se incursões nos textos de Meyer (complementados com estudos no campo da cognição e da teoria da informação) de modo a elencar aspectos envoltos na compreensão e comunicação musicais, finalizando com sugestões para a possível extrapolação destes pontos para o campo composicional e mais especificamente para o modelo desenvolvido neste projeto. Estas reflexões estendem e complementam os pontos discutidos no capítulo anterior na medida em que tratam de relações entre estruturas gerativas e materiais musicais.

\section{Compreensão e significação}

Para muitos a música não é para ser entendida, mas somente apreciada. Outros tantos, no entanto, repetem e revalidam a questão: o que é entender uma música? Há várias tentativas de resposta, mas para os fins perseguidos neste trabalho considere-se a sugestão do esteta Roger Scruton: "compreender música é em parte uma atividade cognitiva: uma atividade de organização mental que congrega sons e registra-os como tons, arranjados em uma ordem tonal” (SCRUTON, 1997, p.211). Embora inicial, essa definição já traz algumas implicações. A primeira (vai aqui uma visão particular) é a não ocorrência em língua portuguesa da diferenciação, existente em outros idiomas, entre 'som' e 'tom'. Em português, a palavra 'tom' adquire um significado errôneo quando substitui 'tonalidade'. É comum (mesmo entre os músicos) ouvir a frase "em que tom você canta essa música?", quando o correto seria em qual tonalidade. 'Tom' deveria referir-se exclusivamente à medida intervalar formada por dois semitons. Contudo, este significado da palavra é atestada pelo uso e, com isso, abonado pelos dicionários (o novo Michaelis contém 14 possibilidades para este termo), que também designam como 'tom' a referência ao caráter ou inflexão de voz; assim, diz-se "dirigiu-se à platéia em tom doutoral", ou "repreendeu-o em tom áspero". Há, logicamente, o uso feito pelas artes plásticas como "tom pastel", entre outros. No inglês, como dito, há a distinção entre tom e som (tone e sound). Sound é aquilo captado pelo sentido da audição, ao passo que tone implica no estatuto musical que o som adquire, isto é, altura, timbre, duração e intensidade inseridos no contexto da música. Assim, tone é um som que existe no domínio musical, similar ao que Schaeffer designava como objeto musical (tone) e objeto sonoro (sound). Desse modo, fica esclarecida a definição de Scruton "congregar sons e registrá-los como tons", pois implica justamente na atribuição de sentido musical a uma ordem sonora.

A segunda implicação terminológica da frase de Scruton reside no entendimento de 'ordem tonal'. Se a intenção é fornecer uma definição abrangente, então essa expressão não pode simplesmente restringir-se às sucessões pertencentes ao sistema tonal (mesmo porque, vale lembrar, tonal refere-se àquilo que é próprio dos sons, em oposição, por exemplo, a rítmico, pertencente ao ritmo, ou timbrístico, particular ao timbre). A possibilidade da disposição ordenada de elementos não se limita à tonalidade clássica, podendo ocorrer em 
quaisquer sistemas sintáticos musicais como o sistema modal, por exemplo. E mesmo o serialismo integral é tido como altamente estruturado ${ }^{22}$. Cabe, porém, a ressalva fundamental de que o importante é a atribuição desta ordem pelo cérebro durante o ato da escuta. Com isso, é lícito pensar que a compreensão musical é a organização impingida no processo cognitivo aos eventos sonoros de modo que estes adquiram sentido. Esta aquisição de sentido implica que os componentes da música compartilhem alguma espécie de relação, pois do contrário correm o risco de serem tidos como díspares, não pertencentes ao mesmo contexto. A compreensão musical pode ser então tomada analogamente a qualquer sistema de comunicação em que estejam envolvidos mensagem e decodificação.

Comunicação é aqui entendida como o compartilhamento de algum dado ou conteúdo. A mensagem que se deseja tornar comum está inscrita na composição musical sob a forma de relações musicais, cujo entendimento é levado a cabo pelo ouvinte no processo perceptual e cognitivo. Portanto, compreender é desvendar ou construir sentido, sendo essa construção realizada por meio da associação entre sons, ou seja, pela habilidade humana de relacionar os eventos sonoros. Ressalvo, novamente, que não se espera na recepção musical uma construção de sentido idêntica e unívoca entre todos os ouvintes, mas sim, que todos consigam formar algum tipo de compreensão durante a apreciação da mesma obra.

Esta atividade organizacional é realizada no percurso que se inicia com a percepção do som enquanto estímulo físico e segue com sua posterior inserção como membro constituinte de um padrão ou de uma forma sonora musical. Para engendrar uma impressão formal uma ordem deve ser estabelecida, na qual os estímulos individuais tornem-se parte de uma estrutura maior e realizem distintas funções dentro dessa estrutura. Esse processo resulta da habilidade cognitiva em "relacionar as partes constituintes entre si de maneira inteligível e significativa" (MEYER, 1956, p.157). Além de revelar sua base gestaltica, Meyer faz acoplar neste último entendimento o aspecto da compreensão com a significação. Mas, o que é, pois, o significado musical?

Obviamente o assunto é amplo para intentar discussões exaustivas no âmbito deste trabalho, o próprio Meyer dedicou um livro inteiro ao tema. Todavia, algumas considerações são necessárias para a continuação desta exposição.

Segundo Meyer, "o significado musical surge quando nossas respostas habituais esperadas são retardadas ou bloqueadas - quando o curso normal dos eventos estilísticomentais é perturbado por alguma forma de desvio" (MEYER, 1994, p.10). O som, após ser registrado e acolhido como objeto musical, adquire uma configuração e é inserido em um

\footnotetext{
${ }^{22}$ A própria definição de estrutura é útil no contexto desta argumentação, designando a congregação de relações entre elementos de modo a criar uma ordem, ou também "o conjunto de relações lógicas e racionais que se deixam descrever sob a forma de leis" (Jakobson, apud Pomian, p. 151).
} 
contexto musical. Este contexto forma o pano-de-fundo para o desenvolvimento da obra e a sua existência engendra o fluxo de expectativas, isto é, os prováveis modos de continuação e desfecho, e os 'desvios' deste fluxo. A partir desse ponto, o cérebro passa a analisar o desenrolar dos acontecimentos musicais de maneira probabilística, avaliando continuidade e contraste segundo os desvios impostos ao curso dos eventos. De acordo com Meyer (cf: 1994, p.10), são possíveis três maneiras de desvios: retardo (o evento conseqüente não surge no momento esperado), incerteza (ambigüidade de uma situação precedente não permite certeza sobre a conseqüente) e surpresa (o evento conseqüente surgido era improvável). Assim, "reformulando o enunciado anterior, o significado musical surge quando uma situação antecedente, que requer a estimativa de prováveis modos de padrões de continuação, produz incerteza sobre a natureza temporal e tonal do conseqüente esperado" (MEYER, 1994, p.11).

Do parágrafo anterior fica clara a ligação proposta por Meyer com a Teoria da Informação. Vale dizer que comunicação e informação, embora interdependentes, são coisas distintas. Comunicação está associada à compreensão, enquanto a informação associa-se a materiais formais e conceitos, envolvendo a medida da probabilidade da ocorrência de eventos (que vai gerar a significação na proposição de Meyer). Informação é qualquer configuração pura e intercambiável de dados que não tem sentido fora deles mesmos. Quando um fluxo de eventos ocorre, ele gera expectativas de prováveis modos de prosseguimento e conclusão. Se tudo transcorre como esperado e o fluxo de eventos encerra-se da maneira prevista, o nível de informação é baixo (neste caso tende a zero). Do contrário, quando o fluxo é concluído de uma maneira inusitada, causando surpresa, o grau de informação é alto. Porém, em ambos os casos houve comunicação, pois a mensagem contida no fluxo de eventos foi compreendida e possibilitou, inclusive, prever acontecimentos futuros. O significado é, então, aquilo implicado pelo processo comunicativo e inferido pelo receptor. Umberto Eco diz que “se entre dois eventos já se sabe qual irá ocorrer, então já há informação" (ECO, 2001, p.10) Em música a situação poderia ser sumarizada em: dados musicais (notas, harmonias, timbres, padrões rítmicos, temas, etc) são transmitidos quando a música é percebida e analisada pelo cérebro. Nesse processamento se dá a compreensão musical, ou seja, o relacionamento dos dados entre si. Em razão do contexto em que estão inseridos, estes dados compreendidos engendram um fluxo de expectativas, que por sua vez serão responsáveis pelos níveis de informação. Um nível alto de informação gera a significação.

Ao exposto sobre o significado musical, um elemento importante deve ser acrescentado: o estilo. O estilo (ou as normas estilísticas) cumpre o papel de uma espécie de background perceptual, formando o cenário para o desenvolvimento do enredo musical, e é a partir do estilo que as expectativas são formatadas e desviadas. "O estilo constitui o universo 
do discurso dentro do qual o significado musical surge" (MEYER, 1994, p.7). Essa situação pode ser ordenada como segue: percepção e registro de eventos sonoros em um contexto musical, cuja existência é viabilizada pela experiência com determinado estilo, que engendrará probabilidades de continuação, criando assim expectativas e frustrações no desenvolvimento da obra. Daí Meyer entender que "uma vez que um estilo musical tenha se tornado parte das respostas habituais de compositores, intérpretes e ouvintes iniciados ele pode ser considerado como um sistema complexo de probabilidades" (ibidem, p.8).

A familiaridade com o estilo induz e auxilia a percepção a operar de maneira prognóstica e esperar certos modos de continuação e desfecho. Todavia, esse contexto ou pano de fundo gerado pela familiaridade estilística pode se estabelecer durante a própria execução da obra. Imagine-se uma composição desconhecida pelo ouvinte, algo étnico, como a música dos aborígines australianos, por exemplo. Depois de alguns momentos escutando suas músicas a percepção é capaz de captar padrões e formar prováveis conclusões. Este ponto, acredito, não invalida a proposta de Meyer, pois há o percurso que parte da percepção à geração de expectativas, podendo ser entendido como uma espécie de "familiaridade" estilística de curto prazo. E mesmo na música ocidental esse processo poderia ser verificado. Considere-se um ouvinte conhecedor do repertório clássico escutando uma resolução cadencial como mostrada no Exemplo 1-6. Seria correto supor que ele aguardasse uma resolução convencional como ocorre na letra $a$. Se resolvida de modo evitado, como se dá na letra $b$, causaria surpresa. Porém, imagine-se a situação em que a resolução $b$ tenha sido apresentada quatro vezes como finais de frase, sempre na mesma seqüência, dentro de um mesmo período. Qual seria a expectativa nesta situação? Não seria o ouvinte induzido a aguardar a resolução $b$ pela quinta vez? Nesta nova condição, a resolução convencional causaria mais surpresa, aumentando o nível de informação e gerando significação. [No exemplo 1-6, as notas soam onde estão escritas. Os instrumentos são: oboé (Ob), dois clarinetes $(\mathrm{Cl})$ e fagote $(\mathrm{Fg})]$.

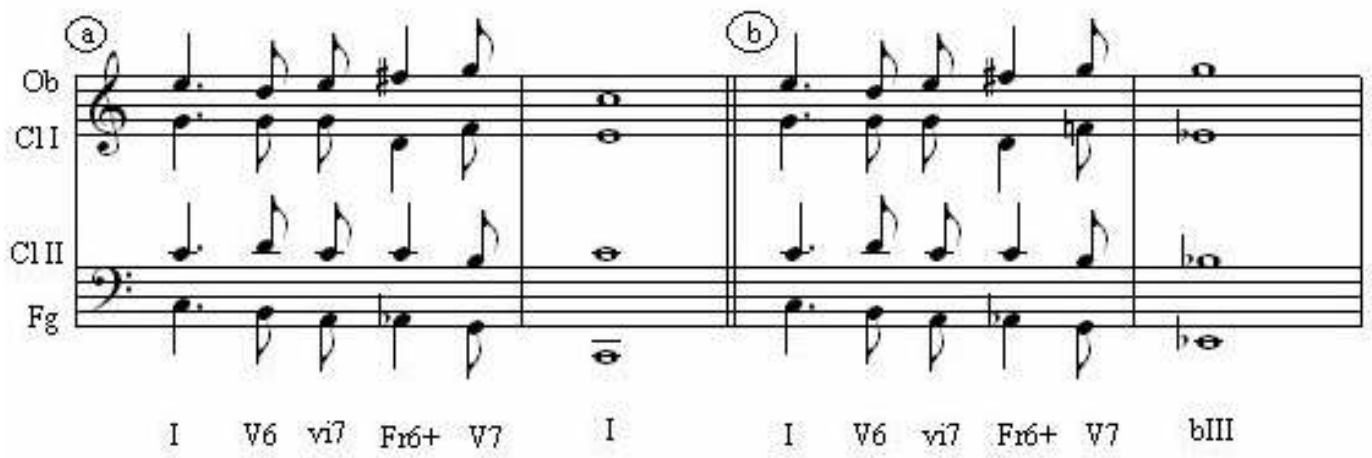

Exemplo 1-6: duas resoluções cadenciais: a) convencional, b) evitada. 


\section{Significação musical e teoria da informação}

O aspecto prognóstico envolvido no processo de compreensão musical é a base para a associação entre significação e informação, pois quanto maior a certeza sobre a possibilidade de um evento vir a ocorrer futuramente, maior será o impacto se algum tipo de desvio acontecer. Esse princípio permitiu a Meyer lançar a hipótese de que "as condições psicoestilísticas que proporcionam o significado musical, seja este afetivo ou intelectual, são similares àquelas que comunicam informação" (MEYER, 1994, p.5). Ao lado dessa natureza probabilística do estilo musical, outros paralelos podem ser notados com a teoria da informação, como a importância da incerteza na comunicação musical e a operação do processo Markoff (ver adiante).

De acordo com a teoria da informação (cujas bases foram formuladas, sobretudo, pelo matemático norte-americano Claude Shannon), a quantidade de informação contida em uma mensagem é medida pela probabilidade de incerteza na relação antecedente versus conseqüente. A partir de dados antecedentes, eventos conseqüentes adquirem graus de probabilidade. O menos provável é menos esperado (e seu aparecimento causará maior surpresa). Quando uma situação antecedente é altamente organizada, a liberdade de escolha do conseqüente é baixa, portanto o grau de informação também é baixo. Ao passo que uma situação caracterizada por alto grau de incerteza, cujos conseqüentes sejam equiprováveis, possui taxas de informação e de entropia elevadas. Assim, quanto maior liberdade de opções para um conseqüente, maior será o grau de incerteza e maior a informação. Relembrando que a palavra informação na teoria da comunicação difere do que é entendido normalmente como significado, dizendo respeito não ao conteúdo semântico literal de uma mensagem, mas àquilo que a mensagem poderia, probabilisticamente, comunicar. Esse processo assemelha-se ao que em física é conhecido por entropia, ou seja, é a medida da desordem ou aleatoriedade de um sistema; é o número de reorganizações das partes de um sistema que deixam a aparência geral inalterada; "é a tendência dos sistemas físicos tornarem-se cada vez menos organizados e mais e mais perfeitamente embaralhados" (WEAVER, página da web sem data).

Informação e entropia da mensagem relacionam-se diretamente e são calculadas matematicamente pela teoria das probabilidades. A aplicação de cálculos de probabilidades aos dados coletados estatisticamente é chamada estocástica. Assim, diferindo de um sistema determinista, o processo estocástico é aleatório e tem resultados equiprováveis, onde cada uma das variáveis em jogo possui função própria e não necessita estar relacionada no resultado futuro do processo, sendo calculada em razão da distribuição de sua probabilidade.

Pode-se perceber que o procedimento estocástico compreende uma alta taxa de indeterminação, pois uma situação inicial pode gerar inúmeras possibilidades de continuação, 
embora algumas sejam mais prováveis que outras. Uma cadeia de Markoff (nome do matemático russo Andrei Markov) é um caso especial do processo estocástico. Em uma cadeia de Markoff a lei das probabilidades encontra-se na dependência de um valor assumido em um determinado instante, ao invés de compreender toda a evolução anterior do sistema. Os estados anteriores desse sistema são irrelevantes para a predição dos estágios posteriores, desde que o estado atual seja conhecido. Embora possa parecer controverso, Meyer entende que o fato da música constituir-se similarmente ao processo Markoff permite ramificações práticas. Na medida em que a música se desvela, a probabilidade de uma conclusão esperada aumenta, pois a percepção já conta com um número maior de dados para efetuar essa previsão. Portanto, incerteza e informação diminuem. No início de uma música, no entanto, não há ainda material para o cérebro derivar possibilidades de continuação, existe o que Meyer denomina incerteza sistêmica. Com o desenvolvimento da obra e a percepção do estilo, o grau de previsão aumenta e informação diminui. No entanto, a interferência do compositor aparece, pois este controla os níveis de informação (inclusive com intuito de combater o tédio e a obviedade) por meio da incerteza designada, compensando o decréscimo das expectativas (já que estas se tornam mais previsíveis) e do significado.

É preciso salientar que sistemas altamente entrópicos, com baixo grau de previsibilidade, não garantem níveis altos de informação. Isso se dá porque para haver informação é necessário que haja expectativa. E em sistemas equiprováveis, às vezes o cérebro não consegue estimar ou atuar probabilisticamente. É preciso um mínimo de redundância para viabilizar a compreensão e possibilitar a derivação de expectativas. Quando tudo pode acontecer nenhuma situação em especial será mais ou menos esperada, diminuindo a carga informativa.

Um exemplo no qual exploro essa possibilidade entrópica ocorre na segunda parte de minha peça Trilhas Sonoras (Exemplo 2-6). Há uma primeira seção na qual as estruturas gerativas encontram-se bem organizadas e propiciam a formação de expectativas em razão de comporem um contexto com sonoridades características e próximas - em um sentido gestual. Segue-se a segunda parte carregada de blocos justapostos. Blocos que por sua vez não guardam similaridades perceptualmente evidentes, pois se diferenciam em registro, andamento, caráter e, sobretudo, ritmo. Dado os aspectos contrastantes entre esses blocos justapostos, a percepção não forma prognósticos sobre o que pode suceder, captando então rupturas e desconexões. A idéia neste caso é opor uma seção altamente ordenada e aparentada sonoramente, à outra seção de alto grau entrópico, quebrando as expectativas geradas até então. Todavia, ao longo da obra estes blocos contrastantes vão sendo conectados e trazidos para relações de maior proximidade, sendo objetos de síntese na última parte da peça. 

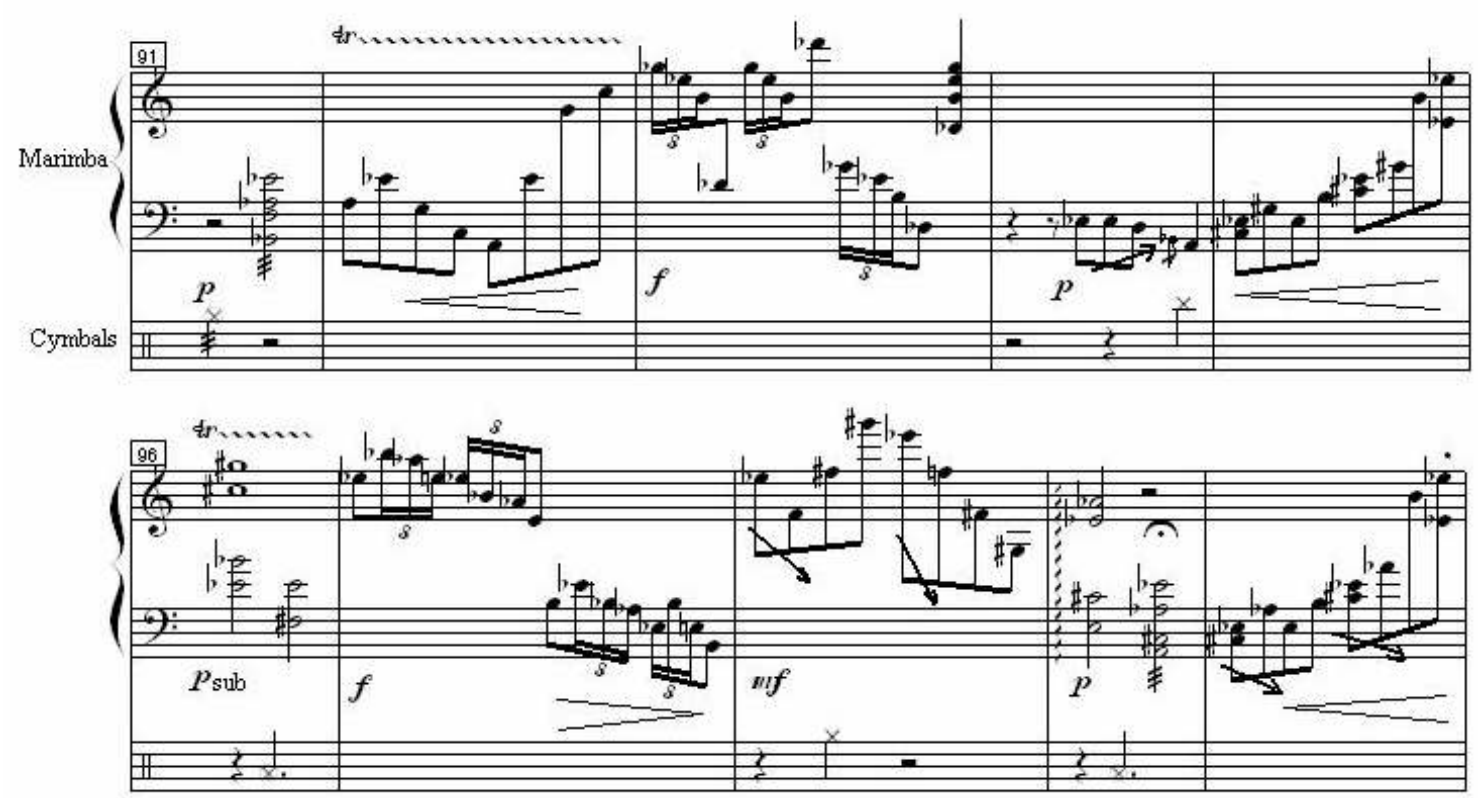

Exemplo 2-6: Antenor Ferreira, Trilhas Sonoras, compassos 91-100, justaposição de blocos.

Além destas, outras aproximações com a teoria da informação podem ser realizadas. A medida que a percepção e a compreensão do mundo ocorrem (em grande parte por meio de modelos e padrões estabelecidos convencionalmente), estas se tornam agentes estruturadores ativos deste mundo, uma vez que têm influência na organização posterior dos estímulos valendo-se, justamente, de modelos aprendidos. A este ciclo percepção-aprendizadorepercepção Meyer dá o nome de redundância perceptual. Em música, o nível de aprendizado que um ouvinte possui com as normas e procedimentos intrínsecos a determinado estilo irá afetar a compreensão das obras, pois quanto mais enfronhado com o estilo em questão, maior a percepção de ordem. Isso implica que as expectativas oriundas da escuta serão previsíveis em igual medida à quantidade de informações sobre o estilo possuída pelo ouvinte. Essa situação poderia levar, obviamente, ao comentado decréscimo no nível de informação de uma obra. Contudo, existe a relativa desordem ou aleatoriedade imposta pelo compositor que complementa a redundância perceptual, esta cadeia e eventos Meyer denomina informação perceptual.

Redundância reveste-se como importante componente do processo de comunicação, constituindo-se como "a parte de uma mensagem que é determinada pelas regras estatísticas aceitas que governam o uso de símbolos em questão, e não pela escolha arbitrária do emissor" (MEYER, 1994, p.16). Esse substrato comum que Meyer chama de redundância, também poderia ser pensado como convenção. As "regras que regem o uso dos símbolos" são as convenções partilhadas pelos interlocutores, sem as quais qualquer comunicação seria impossível. Convenção pressupõe acordo, combinação, pacto, procedimentos ou 
características tácitas compartilhadas entre indivíduos. Pode ser estabelecida por padrão de comportamento gerado por simples hábitos e não porque haja uma lógica matemática inexorável ou mesmo crença absoluta no significado atribuído. Convenção permite reconstruir mensagens na ausência de partes desta, e esta particularidade também é citada por Meyer, ressaltando a capacidade epistemológica de refazer frases quando na mensagem original estejam ausentes letras ou palavras. Do mesmo modo, segundo ele, a percepção pode recriar situações musicais onde notas ou estruturas sejam omitidas. Por exemplo, é possível o entendimento harmônico em instrumentos não harmônicos (violino, flauta), pois já há uma convenção sobre esse conceito. A linha melódica: $C-E-G$ / B-D-G / Bb-D-G / A-C-G executada em um fagote é carregada de sentido harmônico subentendido, embora não haja acordes sustentados. Igualmente, podemos perceber uma intenção polifônica nas Partitas $e$ Sonatas para violino solo de Bach porque já temos um acordo prévio a respeito do que é polifonia, de modo a poder recriá-la no ato da escuta mesmo na ausência de uma segunda voz ou de sustentação harmônica. Convenções são conjuntos de características ou processos subscritos por um determinado grupo, constituindo-se, assim, como componentes culturais. Um dos aspectos incidentes na música experimental e que concorre para a perda da comunicabilidade é a ausência de convenções prévias, ou seja, o compositor abre mão de “contratos" e propõe a incursão sobre o material sonoro sem nenhum tipo de diretriz prévia para guiar a compreensão. Não há, portanto, um núcleo comum de substratos ou acordos auxiliando a construção de sentido musical, situação que acarretará a dificuldade em promover ligações entre os materiais apresentados. "E assim ele [o artista] chega ao ponto de falar um idioma sem relação como o mundo que irá ouvi-lo. Sua arte torna-se realmente única, no sentido em que é incomunicável, fechada por todos os lados" (STRAVINSKY, 1996, p. 72).

Para se viver em sociedade é necessário o conhecimento e a aceitação de convenções. A habilidade em distinguir uma coisa de outra vem do aprendizado. Aprendizado pressupõe convenções, já que é realizado no interior de uma cultura, portanto é intersubjetivo. Convenções e hábitos geram expectativas. Expectativa é o conhecimento resultante de um determinado conjunto de circunstâncias, é uma espécie de certeza de que sob certas condições algo irá ocorrer. De modo mais preciso: "na dependência de 'x' circunstâncias, é grande a probabilidade de que 'y' venha a ocorrer" (SHERMAN, 1989, p.226). O ciclo em direção à significação fecha-se deste modo: estímulos convencionais geram expectativas convencionais.

\section{Informação e percepção}

A capacidade de receber estímulos sensórios aurais, reconhecê-los como música e compreendê-los na relação que mantém entre si é chamada percepção musical. 
Percepção é um poder epistemológico natural do organismo, cujo exercício independe de qualquer contexto social. A experiência musical, entretanto, não é meramente perceptual. Está fundamentada em uma metáfora, surgindo quando um movimento irreal é ouvido em um espaço imaginário. Tal experiência ocorre somente dentro de uma cultura musical, na qual tradições de performance e escuta formatam as expectativas (SCRUTON, 1997, p.239).

A definição de Scruton evidencia o caráter de "fato cultural" comportado pela música, minimizando a possibilidade de confrontá-la como entidade autônoma, como "música em si", isolada e desvinculada do meio social de onde foi gerada. E mesmo a chamada música especulativa, em tese restrita aos problemas técnicos/estéticos nela mesma gerados, pressupõe o confronto com algum tipo de música anterior. A arte conceitual, de modo similar, quando põe em discussão o conceito de arte, o faz porque existe uma manifestação artística precedente, estabelecida, cujos fundamentos podem ser postos em cheque. Quando a tradição é confrontada há a necessidade do ouvinte conhecer a tradição, do contrário, não entenderá a proposta de contestação feita pelo autor. Pensemos na renovação que se deu na poesia. Os poetas concretistas certamente introduziram uma maneira totalmente nova de fazer e apresentar poesia, valendo-se da disposição gráfica do poema sobre o papel. Esta inovação desdobrou-se, posteriormente, em outras formas de manifestação artística hoje conhecidas por poesia visual. Os três exemplos a seguir mostram poesias visuais.

Marcelo Mota: Longe.

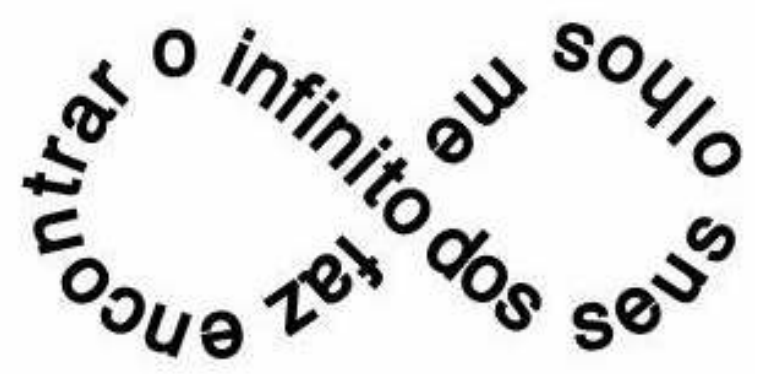

Rodrigo Ferreira: Infinito. 


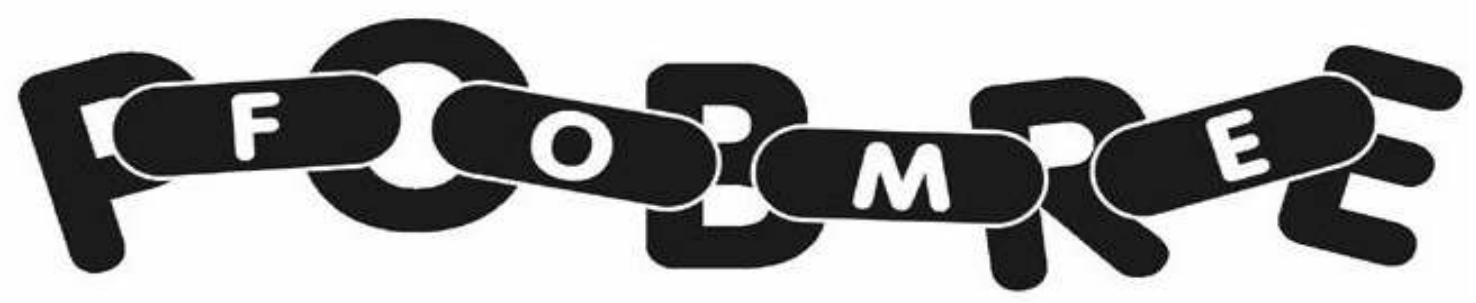

Marcelo Mota: Corrente.

Não se trata certamente do tipo de poesia que alguém menos avisado poderia esperar ao ser convidado para um sarau. Esses exemplos estão longe dos sonetos e outras formas parnasianas aparentadas. Não obstante, guardam características que possibilitam a compreensão da mensagem intencionada pelos autores. Ao lado do idioma comum e do apelo formal (isso é, apresentarem formas similares às dos objetos de que se apropriam) o plano espacial é trazido à evidência, já que essa poesia se desenvolve no espaço, e não apenas no conteúdo semântico literário. Dessa maneira, a compreensão do poema se dá associando aspectos simbólicos, semânticos e formais. Em Longe é óbvia a tentativa de expressar o conceito de distância por meio de uma analogia dimensional. Em Infinito o símbolo do infinito $^{23}$ (semelhante a um ' 8 ' deitado) fornece o suporte formal para o poema, cujo texto interliga-se criando a sensação de infinito, aquilo que não tem começo nem fim. A leitura do poema se iniciada em qualquer ponto, por exemplo, em "o infinito" ou "encontrar" irá gerar uma ciclicidade de modo que o fim da frase será seu começo. Nesta estrutura, portanto, confluem os parâmetros simbólicos, semânticos e formais. Em Corrente a semelhança formal aparece nos elos da corrente, contudo, encontra-se implícita a crítica social derivada do sentido metafórico que o poema comporta, ou seja, a associação em cadeia entre a pobreza e a fome. Há certamente na poesia visual uma renovação da arte da poesia, cujo entendimento é viabilizado pela conservação de elementos comuns às linguagens poéticas anteriores, sejam literárias ou imagéticas.

Voltando à citação inicial de Scruton (percepção, experiência, cultura), observa-se também uma remissão direta àquilo apontado por Meyer como sendo a preponderância que o contato com determinado estilo desempenha na compreensão musical. A música da prática comum, por exemplo, desenvolvia-se tendo como arcabouço organizacional o sistema de

\footnotetext{
${ }^{23}$ Segundo o historiador da matemática Karl Menninger o uso do 8 deitado como símbolo do infinito foi proposto pelo matemático inglês John Wallis (1616-1703) em 1655, no seu livro Aritmetica Infinitorum. De acordo com o professor de matemática Moises Roberto Perides o ícone já foi associado a uma ampulheta deitada, numa referência à duração de tempo que não tem fim, assim como já se pensou que derivasse da Fita de Möebius, mas esta é posterior ao símbolo. Uma das idéias mais aceitas é de que ele derivou da representação romana do número 1000, que se costumava usar para indicar grandes quantidades. Curiosamente, na Grécia antiga o símbolo do infinito era o 'pentagrama', ou as 'cinco retas' dispostas de modo a formar uma estrela de cinco pontas.
} 
tonalidades. O sistema tonal fornecia um paradigma de organização musical e a experiência com o estilo tonal agia formatando as expectativas inerentes a esse estilo. A música serial, por seu turno, buscou introduzir uma ordem previamente estabelecida às relações sonoras baseada em uma proposta teórica imposta desde fora, tendo como foco principal o aspecto estrutural da obra. Porém, o que é percebido no ato da escuta não é a "arquitetura" ou arcabouço teórico sobre o qual a composição foi baseada. O relevante para a compreensão musical são as respostas suscitadas nos ouvintes, justamente por perceberem relações sonoras implicativas que lhes são apresentadas. O ouvinte não precisa, por exemplo, entender a sintaxe harmônica compartilhada pelo repertório originário da prática comum ou os métodos de transposição e permutação próprios do serialismo para compreender a obra, inclusive porque os padrões de relações sonoras são específicos da peça musical que os utiliza, isto é, constituem a realização única de um conjunto de regras sintáticas. Tem-se então uma clara diferenciação entre as gramáticas composicional e perceptual. Meyer (Cf: 1994, p.267) estabelece a distinção entre dois tipos de compreensão: de um lado a compreensão das estruturas musicais e seus processos apresentados à mente do ouvinte (ocorrentes durante a percepção musical); de outro a descoberta do repertório de materiais tonais e das regras envolvidas na sua manipulação (que via de regra provém da análise musical).

Esta situação pode ser acrescida da afirmação de Scruton "não se pode dar significado convencional para uma frase musical", pois as regras de organização musical são sempre a posteriori, derivadas da tradição e da prática, como as regras da harmonia clássica, por exemplo. Convenções ou regras a priori tem preponderância no trabalho do compositor, mas sua obediência não é uma necessidade e tampouco é suficiente para lograr êxito. As convenções, como discutido anteriormente, são importantes por constituírem um corpus de características compartilhadas por interlocutores, o alfabeto, as palavras, os fonemas, as normas sintáticas, por exemplo, são convenções viabilizadoras da comunicação, porém, embora as palavras possuam uma carga semântica prévia compartilhada pelos interlocutores, quando postas em uma única frase adquirem sentidos diversos que deverão ser construídos em razão do contexto. Analogamente, em música existem regras a priori que gerenciam o uso dos elementos componentes de uma frase musical (como regras da harmonia, do dodecafonismo), mas o sentido desta frase não é convencionado, deve ser construído no ato da escuta. Surge, assim, uma espécie de conflito entre as gramáticas composicional e perceptual. O compositor pode construir uma obra a partir de um sistema intelectual, mas isto não significa que a mesma será ouvida como esse sistema sugere.

Todavia, o entendimento das normas e regras influencia a percepção. Já que percepção é um ato aprendido de discriminação, o contato prévio com a linguagem ou com determinado 
código age ditando o que deve ser discriminado e em que níveis. Nesse ponto, percepção está de certa forma vinculada à tradição e hábitos de escuta, pois "percebemos, entendemos e respondemos ao mundo, incluindo música, em termos de padrões e modelos, conceitos e classificações que foram estabelecidos em nossa tradição" (MEYER, 1994, p.273). Conclui-se também que a percepção não é passiva, pois participa da organização dos estímulos valendose de modelos aprendidos. Isto traz implícito que a compreensão da música complexa está na dependência da familiaridade e do aprendizado com esse repertório. Quanto mais familiarizado com o estilo, maior a percepção de organização, porém, por não aprendermos as linguagens complexas da música desde tenra idade, estas se tornam mais difíceis.

\section{Música contemporânea e comunicação}

Algumas conseqüências para percepção musical advieram das pesquisas e da constituição do repertório contemporâneo. A criação da música eletroacústica, por exemplo, promoveu uma grande reformulação nos modos de escuta. Alguns destes aspectos interferem com maior ou menor grau de contundência na compreensão e conseqüente comunicação musical. A seguir, são comentados alguns pontos da música contemporânea como analisados por Meyer.

A falta de familiaridade com repertório logicamente tem grande interferência no entendimento musical. Entre suas causas estão o aprendizado durante a infância, isto é, aquele que vem dos hábitos de escuta durante os primeiros anos de vida, mas que serão responsáveis por formatar a percepção durante o período adulto. Como esse aprendizado se dá com o estilo tonal, o confronto perceptual com outros repertórios sempre irá ocorrer de maneira comparativa com este estilo aprendido. Isto põe em relevo o fato da tradição formatar a percepção, que tenderá a balizar-se naquilo que tem na memória, pois "nossa habilidade em perceber relações depende em parte do que nossa experiência passada nos disse constituir uma relação" (ibidem, p.280).

Entendimentos similares são encontrados em diversos autores. Marcos Nogueira lembra que "a música pode comunicar não, meramente, um pensamento, mas uma experiência" (NOGUEIRA, 2007). E o conceito de experiência ganhou um alcance muito mais abrangente em razão de pesquisas atuais, passando "a ser entendido num sentido que inclui as dimensões perceptivas, motoras, emocionais, históricas, sociais e lingüísticas: tudo aquilo que nos faz humanos" (ibidem). Importante considerar que certas situações cognitivas provêm de experiências corporais, e não apenas conceituais. No processo cognitivo, atividades corporais são formas epistemológicas tão fundamentais que praticamente são impossíveis de serem abandonadas. Nogueira explica, baseado nas análises de Mark Johnson, que o sentido de equilíbrio é pré-conceitual, seu aprendizado dá-se pela experiência corporal, 
e não por abstração de definições ou regras dadas a priori. É como se dissesse que o corpo aprende, antes do cérebro, a noção de equilíbrio. Existe assim uma conexão esquemática que permite a compreensão experimental corporal do equilíbrio, transferida posteriormente para o nível da conceituação cerebral.

Diversos são os conceitos apreendidos por intermédio da experiência corporal, Nogueira cita contenção, força, ciclo, caminho, noções que possuem correspondentes no plano musical. A estes poderia acrescentar a noção de dor, além dos diversos tipos de sensações: térmicas (quente, frio, morno gelado), olfativas, gustativas, tácteis (duro, mole, macio), acústicas, texturais (aspereza, lisura). Em algumas destas já se pode perceber a contraparte que carregam para o domínio musical. A noção de equilíbrio implica simetria; contenção implica agrupamento, caminho implica percurso, direcionalidade. Outra noção, ao meu ver, importante no aprendizado geral, e com desdobramentos nas manifestações artísticas, é a noção de tensão, referindo-se a suspense, enigma, etc. A falta de ar ou suspensão de fôlego, o calafrio e a palpitação que uma situação de elevada tensão provoca só se dão a conhecer via experiência corporal, sua conceituação e abstração são realizadas a posteriori resgatando e projetando os esquemas das impressões fornecidas pela experiência corporal. Imagine-se a situação de uma criança que fez algum tipo de traquinagem. A mãe vendo aquele ato comenta: “quando seu pai chegar você vai ver só!”. Quando isso se dá pela primeira vez a criança não sabe qual será a reação do pai ao chegar; assim, ela cria uma expectativa, gerando uma tensão que se resolve com a chegada do pai e as atitudes que este venha a tomar. Assim, a idéia de tensão ou suspense foi vivenciada, experimentada, e não apreendida de modo abstrato. Este conhecimento gera, então, um esquema que é projetado metaforicamente de modo a formar o conceito de tensão. Todos esses conteúdos epistêmicos estão presentes no ato da escuta musical.

Outra experiência fundamental advinda de vivências ocorridas desde os primeiros meses após o nascimento são as noções prosódicas ou afetivas. Prosódia, aqui, não deve ser confundida com ortoépia, pois refere-se à percepção de inflexões vocálicas transmitidas por alguma pessoa. As sensações acústicas captadas pelos bebês são de suma importância na constituição de sua habilidade musical, fato comprovado experimentalmente. Um bebê que não consegue distinguir os estados afetivos correspondentes às diferentes inflexões vocálicas emitidas pelos pais terá problemas futuros no campo da percepção musical. Estes estados afetivos ou prosódicos emitidos pelos pais compõem o repertório de experiências acessadas no ato da escuta musical. Ninguém grita para fazer um bebê se acalmar, tampouco demonstra alegria valendo-se de sonoridades guturais, falando muito vagarosamente. Do contrário, para acalmar são usados acalantos suaves e tranqüilos, quando a intenção é assustar usa-se o grito, 
e para amedrontar ou causar mistério são usados sons graves, alongados e arrastados. Estas experiências estão de tal modo impregnadas em nossas mentes que são passíveis de ser tomadas como elementos convencionais, comportando, inclusive, um uso irônico.

As mudanças e revoluções ocorridas durante a história da música deram-se conservando uma grande parte do estilo. A música pós-tonal ocasionou, entretanto, uma diversidade estilística que rompeu fortemente com os padrões perceptuais, já que as obras complexas não conservaram um estilo comum (background perceptual). As revoluções no idioma do sistema tonal foram um processo linear e gradual. No serialismo, porém, não há um núcleo homogêneo estilístico para servir como ponto de origem (cf: MEYER, 1974, p. 279). Tomando-se como exemplo a produção de Debussy em comparação à de Schoenberg ou Webern, dar-se-á conta de que a música de Debussy por vezes nem é considerada como música de "vanguarda", a razão disso (e da maior aceitação dessa música pelo público em geral) vem da característica comentada acima, ou seja, de guardar certas semelhanças com o estilo tonal, já que nem todos os parâmetros são depostos. A música de Debussy, apesar de toda inovação que comporta, conserva uma sonoridade familiar com o estilo anterior e nenhum leigo põe em cheque o conceito de música quando a escuta, ao passo que a música de Webern, por exemplo, via de regra recebe a alcunha de antimúsica. A composição que rompe com todos os parâmetros da gramática perceptual tradicional, não conservando sequer um pequeno núcleo balizador para compreensão, dificultará ou não logrará sucesso no processo comunicativo.

A compreensão musical reside primordialmente na capacidade de promover associações entre os eventos sonoros. Estes eventos podem relacionar-se de maneira implicativa e funcional, como exposto sobre antecedente e conseqüente. A discriminação e articulação funcional é que propicia aos eventos musicais gerarem estruturas hierárquicas formalmente articuladas. "Uma vez que um evento musical implica ou é signo de algum outro evento musical somente para um observador ou ouvinte, a percepção de relações funcionais é o resultado de inferências feitas pelo ouvinte sobre as possíveis implicações de um evento musical" (MEYER, 1994, p.296). Com isso, percebe-se que a impossibilidade de promover conexões funcionais age comprometendo e/ou restringindo a compreensão. A música que rompe com cadeias associativas impede a inter-relação funcional entre os eventos musicais, fazendo com que os elementos constituintes da peça sejam percebidos como novos materiais, gerando assim componentes desconectados. Stravinsky já sentenciava que "o excesso gratuito deteriora a substância" (1996, p. 22). É claro que os contrastes precisam acontecer, do contrário haverá só a monotonia, porém uma situação inicial cujo equilíbrio é rompido, vai demandar uma terceira situação em que essa oposição seja resolvida, e a inexistência dessa 
resolução implicará no risco da captação apenas de eventos desconexos. Stravinsky neste ponto fala em equilíbrio e caos temporário, porém ressalva que "a arte não se rende ao caos" (idem, p.21). Considerem-se os exemplos seguintes:

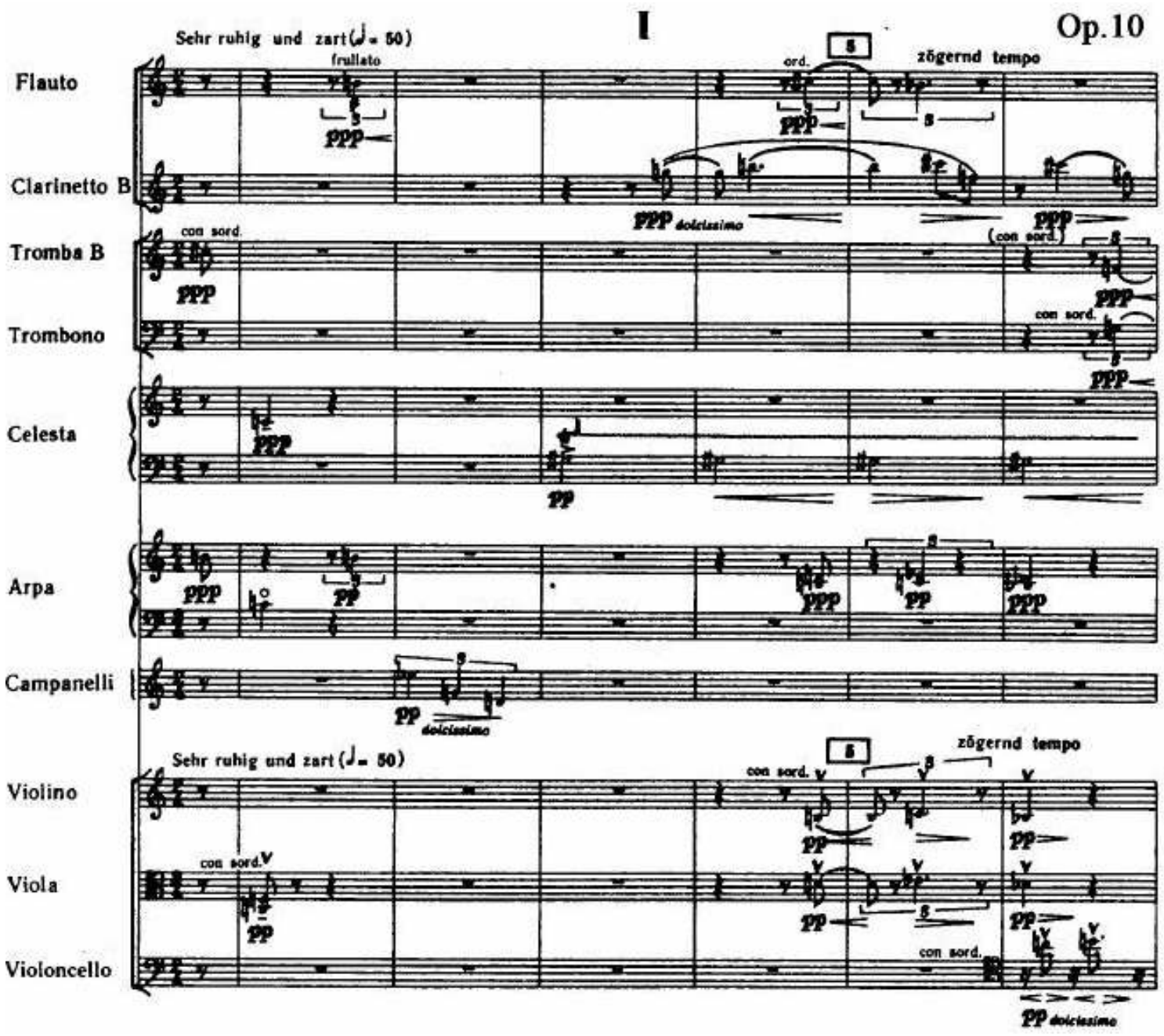

Exemplo 3-6: Webern, Cinco peças para Orquestra Op. 10 I, compassos 1-6, estruturação pontilhista. 

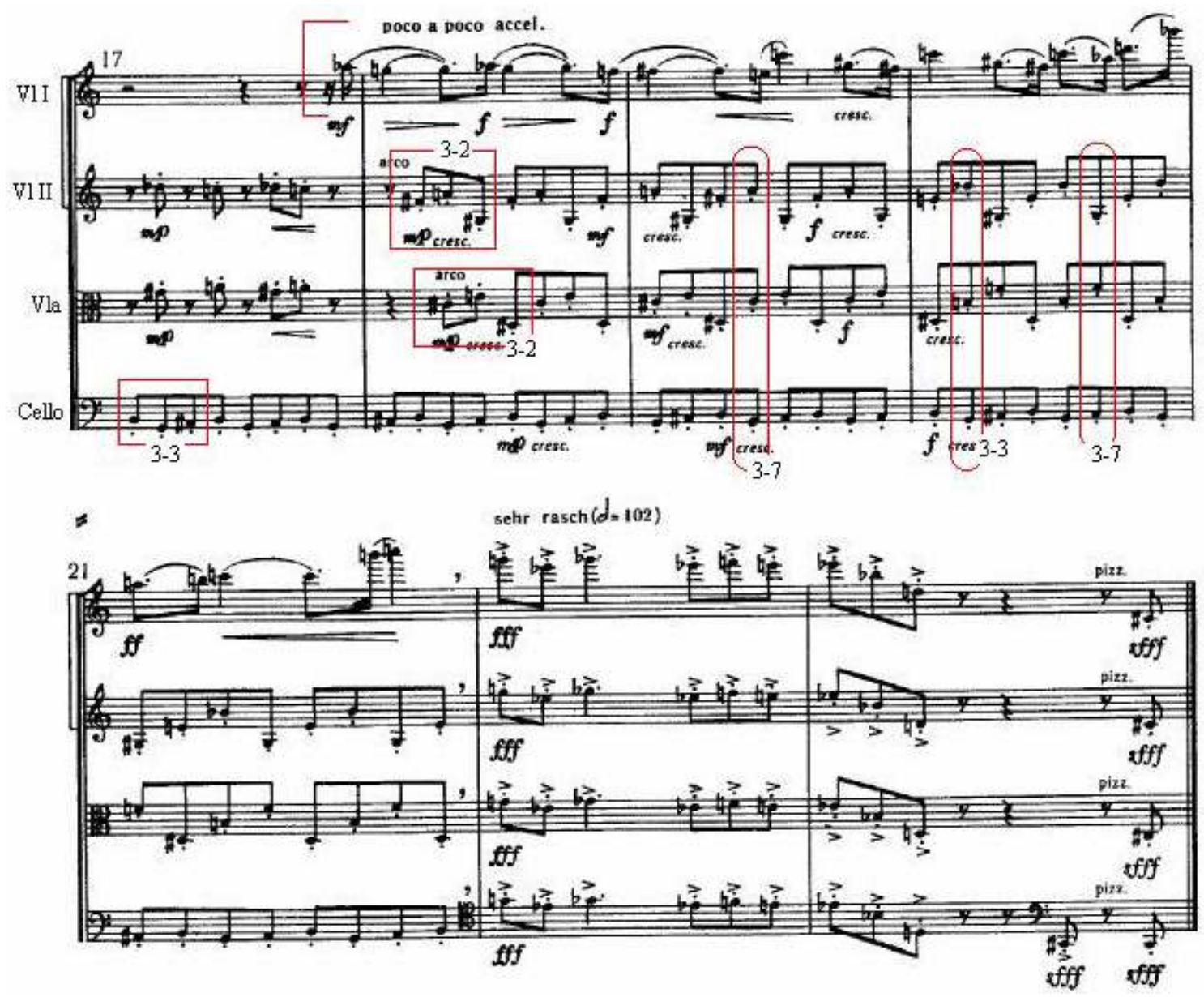

Exemplo 4-6: Webern, Cinco peças para quarteto de cordas, Op. 5 III, compassos 17-23. Separação e agrupamentos de níveis estruturais

Os dois exemplos anteriores (3-6 e 4-6) são extraídos de obras de Webern. O primeiro destes mostra uma passagem pontilhista na qual uma seqüência de eventos é como que pulverizada no espaço sonoro/temporal. Essa fragmentação rompe com diversos parâmetros (sobretudo timbre e registro) que asseguram boa continuidade ao fluxo discursivo. A associação entre esses 'pontos' sonoros dispersos no contexto torna-se mais complexa, pois a percepção de imediato não consegue selecionar e agrupar os eventos segundo relações de proximidade e similaridade, além de dificultar a diferenciação entre fundo e figura, ou seja, a posição dos componentes segundo os níveis em que se encontram no sistema, sejam estes primeiro plano, intermediário ou plano de fundo. Caso diferente se dá na passagem retirada das Cinco peças para quarteto de cordas (Ex. 4-6). Neste trecho é clara a separação dos três níveis estruturais do discurso. O Violino I realiza uma linha melódica, enquanto Violino II, Viola e Cello executam figuras de acompanhamento. Esses dois níveis são diferenciados pela intensidade, pela movimentação rítmica reiterada e, também, pelo número de classes de alturas presentes em cada linha. O primeiro violino executa uma coleção bem maior que os 
outros instrumentos, que repetem conjuntos de três notas. No compasso 18 o violino II e a viola imitam ritmicamente o violoncelo, cuja linha de 3 notas já havia sido iniciada desde o compasso 15. A forma de apresentação também auxilia a compreensão. Há a movimentação reiterada no baixo, seguida da entrada da linha melódica do violino I e a imitação pela viola e violino II. Associado a essa lógica rítmica, existe o fato de as classes alturas empregadas comporem conjuntos similares (3-2, 3-3, 3-7), fato que também favorece a percepção da coerência tonal. Ao final, após a suspensão do acelerando, as linhas confluem para um tutti em uníssono, reforçando sobremaneira o vínculo entre as partes.

Outro aspecto que favorece a compreensão e foi, de certo modo, abandonado pela música de vanguarda é a característica das músicas discursivas em derivar estruturas a partir de outras estruturas precedentes - um procedimento cujas partes novas são geradas ou evoluem a partir de elementos já apresentados. Esta característica aumenta a possibilidade da percepção relacionar as partes constituintes da obra. Há conexões e interconexões causais no fluxo discursivo, direcionando a percepção para a identificação gestaltica, isto é, de um todo unificado, no qual uma parte ou seção liga-se organicamente à outra. Contrariamente, a diversidade de componentes e a prolixidade de eventos podem comprometer a discriminação, relacionamento e agrupamento desses componentes. Dependendo do caso, pode também impedir a percepção de direcionalidade dos eventos envolvidos.

A dificuldade em promover implicações de ordem funcional faz com que os conseqüentes tenham baixa probabilidade de ocorrer. Com isso, o índice de informação é alto. Porém, essa situação revela-se contraditória, pois muita informação satura os níveis perceptuais do ouvinte, sendo desfavorável à compreensão. Quando tudo pode acontecer, qualquer coisa será esperada, conseqüentemente, não haverá desvios nas expectativas responsáveis pelo significado musical apregoado por Meyer. Daí inclusive, a constatação feita por muitos teóricos de que o serialismo integral e a música aleatória soam tão semelhantes. Soma-se também a esta situação a rápida taxa de apresentação de eventos, que justamente em razão da não familiaridade com as normas estilísticas e sintáticas deveria ser lenta, fato que compromete ainda mais a compreensão e inibe a comunicação. Constatação que retoma a questão da redundância, um aspecto identificado, inclusive, por compositores contemporâneos:

Como retomado diversas vezes em trabalhos respeitados, como os de Fred Lerdhal, entre outros pesquisadores voltados para esta problemática, um dos problemas da música atual estaria na falta de redundância; a eterna responsável pela falta de compreensibilidade. Neste caso sempre haveria algo para ser compreendido, e que, por supor a música como sendo uma linguagem que comunica algo, este papel não estaria sendo cumprido com eficiência. (FERRAZ, 2001, p.521) 
Meyer aponta três níveis de redundância: ao nível do estilo, ao nível da composicional e ao nível do repertório. A redundância de estilo ocorre quando as "relações musicais percebidas propiciam ao ouvinte poder aprender as restrições estilísticas (gramática e sintaxe, formas e processos) que governam a configuração musical” (MEYER, 1994, p.321). Redundância composicional é a redundância interna, intrínseca à própria obra, diz respeito aos padrões formados e postos em jogo na especificidade de cada composição. A redundância de repertório ocorre quando repetidas audições da mesma obra levam o ouvinte a conhecer e a tornar-se familiarizado com elementos estruturais desta composição.

É fácil perceber que quanto mais ouvimos o repertório de algum estilo específico, mais familiarizados com o mesmo nós ficamos. Esta característica quantitativa vale tanto para a música tradicional quanto para a contemporânea. Os meios atuais de gravação e de difusão também disponibilizam e perpetuam a música "complexa" (CDs, DVDs), possibilitando a memorização e, conseqüentemente, viabilizando o aumento da redundância ao nível do repertório. Mesmo com essa facilidade, a música de vanguarda "pós segunda guerra" ganhou pouca audiência e não se tornou parte freqüente do repertório de concerto. Isso se deve ao fato de que "seres humanos não são animais somente estatísticos. A menos que seja congruente com os limites dos processos cognitivo e perceptual humanos, a redundância ao nível do repertório não trará proveitos" (MEYER, 1994, p.323). Isso também se dá porque somente a memorização não assegura a compreensão.

\section{Considerações finais}

Em trabalhos cuja temática principal foca a comunicação em música, é possível vislumbrar uma espécie de dicotomia entre autores, divididos entre aqueles que admitem a comunicação musical e os que entendem que a música não é veículo de comunicação. No segundo grupo nota-se um traço em comum: os autores/compositores que negam possibilidades comunicativas à música têm, geralmente, como fundamentação para sua argumentação o fato da música não se estabelecer enquanto linguagem, retomando o antigo confronto entre verbal e não verbal. Silvio Ferraz enfatiza: "se a linguagem verbal está voltada a transmitir significações este não é o caso da música, ela não se ajusta à idéia de ser simplesmente um instrumento em função de um conceito". No mesmo artigo mais adiante conclui: "sendo assim, para buscarmos uma solução ao problema que nos propusemos, vale testarmos esses fatores aos quais a comunicação está associada: linguagem, reciprocidade, ligação social (confraternização)" (FERRAZ, 2001, p.519).

Nesta linha de raciocínio, o processo comunicativo deve ser viabilizado por um código compartilhado entre emissor e receptor. Já que a música não cumpre os requisitos para ser considerada como linguagem, conseqüentemente não se poderia falar em comunicação. De 
modo parecido com o realizado no presente capítulo (isto é, iniciar partindo da conceituação de arte), ao tratar da questão da comunicação musical, Ferraz também sugere uma definição de música, que segundo ele é:

um terreno cuja característica principal é a de ser um ponto de cruzamento, cuja base de fixação é o ritornelo - a dança dos elementos tomados por material, tornando sonoras forças antes não sonoras, como o tempo, a luz, a cor, as linhas, as fugas, os sentimentos, as relações humanas. Ou seja, não vem ao caso se há ou não uma ação de comunicar algo, mas sim a de por em ressonâncias pontos antes sem relação; tornar sonoras forças não sonoras de um modo distinto daqueles da poesia e daqueles da fala, mesmo quando atravessada pela linguagem verbal como nas canções.(FERRAZ, 2001, p.519).

Entendimentos semelhantes ao de Ferraz denotam um importante aspecto da composição contemporânea: a preocupação com o sonoro, antes do discursivo. Colocar em evidência o material sonoro composicional é focar atenção em suas características, sobretudo timbrísticas ou espectrais, é mergulhar no próprio som buscando a dessignificação do material responsável por seu engendramento, ou seja, abstrair-se do material. Esse mergulho, na medida em que não aporta, impede a percepção de formar teleologias, pois durante a fruição o ouvinte não consegue, ou ao menos lhe é dificultado, antever e compreender direcionalidades, promovendo uma espécie de viagem infinita (ou escuta nômade, como propõe Ferraz), viagem esta perceptualmente atrelada ao plano dos sentimentos sonoros, aproximado do entendimento kantiano de música enquanto mero jogo de sensações.

É lógico que este projeto composicional e de renovação da escuta é totalmente válido, e não é tomado aqui como alvo de críticas, mas apenas para observar que este ganho trouxe consigo os efeitos colaterais, neste caso, relacionados aos aspectos cognitivos. Vale lembrar que mesmo compositores contemporâneos não descartam as possibilidades comunicativas da música, como o próprio Ferraz na conclusão do referido artigo: "a música em si não comunica, embora ela também seja um espaço de comunicações possíveis se assim se quiser" (ibidem, p.519). O que existe são abordagens diferentes do mesmo objeto. Quando comparada à linguagem verbal, a música tem seu aspecto comunicativo comprometido, porém, vista na proposição pretendida neste projeto, como veículo para expressão de idéias, cujo sentido pode ser construído no ato da escuta, a possibilidade de comunicação é estabelecida. Logicamente, a intenção deste capítulo não foi encontrar uma sistematização de reações ou entendimentos unívocos dos auditores, mas sim, tentar especular sobre meios facultativos de propriedades cognitivas para viabilizar a compreensão, que é ligada inexoravelmente à percepção, portanto, ao ato da escuta. "E a escuta não fala apenas daquilo que foi disparado pelo som, mas daquilo que foi disparado por uma idéia de música" (FERRAZ, idem), e se há idéia, há "matéria" para ser comunicada. 
Por fim, há um entendimento errôneo postulado por alguns compositores de que a música de vanguarda é mais complexa porque se configura enquanto uma evolução da música tradicional; portanto, se é mais evoluída é melhor. Este tipo de valoração pode sustentar-se nas áreas tecnológicas, mas não se aplica no caso da música ou quaisquer manifestações sócio-culturais. Em música, não se pode intentar valoração estética baseada somente no critério do progresso tecnológico ou no grau de complexidade presente em uma obra, principalmente porque tais relações não são necessariamente percebidas durante o momento de sua fruição. Vem-me à mente uma peça que considero uma obra magna do repertório ocidental: Musica para cordas, percussão e orquestra, de Bartók. Durante sua escuta não há como depreender os cálculos de seção áurea ou as séries de Fibonaci empregadas por Bartók em seu processo composicional. Esses fatores inerentes ao grau de complexidade dessa obra só são deduzidos via análise. Desse modo, há uma clara separação entre as gramáticas perceptual e composicional.

Em face dessa breve incursão no texto de Meyer, pode-se especular algumas possíveis reformulações do pensamento composicional visando a restaurar a comunicação com o público, contudo sem prescindir das conquistas obtidas com as novas linguagens musicais. Logo de saída considere-se a assertiva:

A gramática composicional não combina com a gramática perceptual (...). A gramática da escuta repousa sobre nossa exigência de que a superfície musical deve ser analisada em eventos discretos, com uma organização métrica, simetrias, prolongações e paralelismos. A organização serial não produz, nela mesma, essas coisas. Trata-se de um sistema de permutações, enquanto nossa gramática da escuta é de elaboração: organizamos a superfície musical em termos de simetrias e prolongações, de uma maneira que não é tipicamente produzida por permutação. (Lerdahl \& Jackendoff apud SCRUTON, 1997, p.295).

Esta visão subentende a existência distinta entre os planos composicional e perceptual e aponta para a citada diferença entre as gramáticas da produção e da recepção. Sugere também que mecanismos cognitivos apresentam maior facilidade em operar a partir de elaborações, isto é, derivações de algum tipo de enunciado apresentado inicialmente, ao invés de focarem as inúmeras combinatórias possíveis deste enunciado. Assim, a tentativa em imputar uma ordem perceptual a partir de modelos ou projetos próprios da teoria da composição pode não ser bem sucedida, sobretudo considerando os hábitos adquiridos de escuta. A organização advém da percepção dos eventos sonoros e sua subseqüente relação em acordo com certos graus de semelhança entre esses estímulos sonoros. "Se o estímulo não é percebido como sendo similar, então ele vai falhar em criar coesão ou em formar um grupo ou unidade, e será percebido como separado, isolado, e "não significará nada" (MEYER, 1956, p.158). Idéias contrastantes, sem nenhum tipo de similaridade, produzem dispersão, difusão e novidade. Obviamente, os contrastes musicais existem, todavia são caracterizados em função 
do contexto. Gibson já enfatizava o fato do contexto influenciar a cognição, pois a cognição se dá pela distinção gradual a partir de conjuntos amorfos. Meyer, similarmente, fez entender contexto como o estilo e as regras dele derivadas, cuja simples existência condiciona a compreensão.

Quatro axiomas de Gibson apresentados em seu trabalho sobre o sentido da audição (Some Axioms, Musings and Hints on Hearing), poderiam sumarizar o processo de percepção, compreensão e comunicação musicais descrito neste capítulo: 1) boa escuta não depende apenas de ouvidos aguçados; 2) escuta depende do conhecimento; 3 ) no processo de escuta o todo vem antes da parte; 4) o mecanismo de projeção desempenha o papel principal na escuta. (GIBSON, p. 75-76).

Em vista disto, é justo afirmar que a atenção para com o plano perceptual deva ser uma constante. Se a expressão tradicional da tonalidade é executada por um número de eventos coordenados (por exemplo, progressões harmônicas, escalas, etc.) que concorrem para a compreensão musical, as novas linguagens musicais podem valer-se também de certos tipos de coordenação, que embora diminuam a taxa de informação com o aumento da previsibilidade, aumentam a redundância perceptual e, conseqüentemente, o significado. Ao mesmo tempo, é lícito pensar em novas relações funcionais, posto que a funcionalidade (ou relações de ordem implicativa entre elementos sonoros) age diretamente sobre os procedimentos de seleção e ordenação que irão viabilizar a compreensão da estrutura musical.

Como estágio final desse processo encontra-se a figura do intérprete, que na posse desses entendimentos pode basear sua atividade de maneira a ressaltar conexões funcionais. Interpretar também é comunicar. Assim, se o ouvinte é levado à compreensão de certas estruturas da obra pode-se dizer que a interpretação logrou êxito. 


\section{Conclusões}

A árvore, o fruto e a floresta 


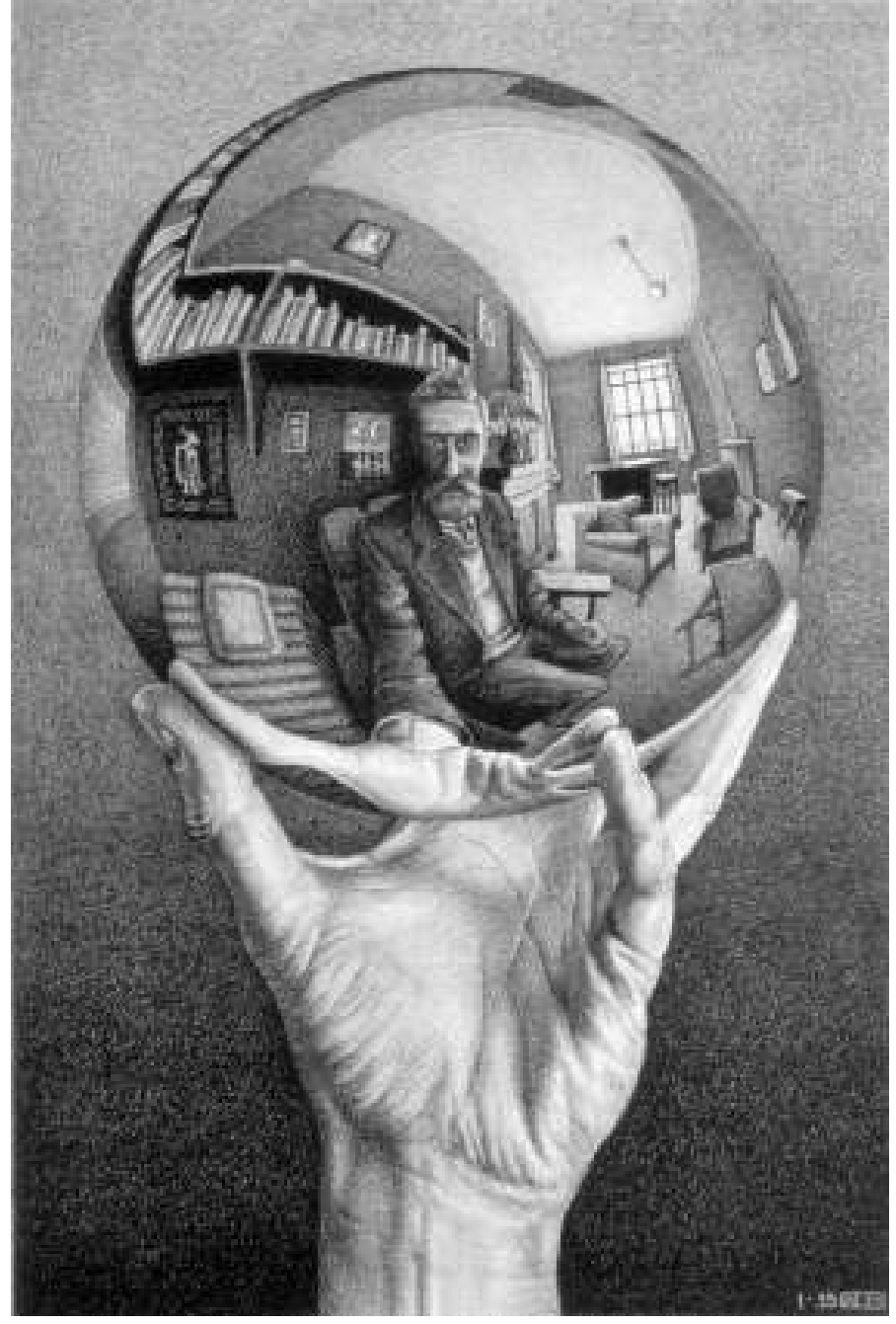

Maurits Escher: Hand with Reflecting Sphere (1935, litografia) 
Em 1967, Leonard Meyer, escrevendo de forma prognóstica, sugeriu que o futuro reservava para a música um lugar onde se daria a "coexistência de uma pletora de diferentes estilos musicais em um tipo de movimento browniano". Essa imagem criada por Meyer para retratar a situação futura não só da música, mas de todas a artes, é muito representativa e, coincidentemente, particularmente sugestiva para estas considerações finais.

No texto introdutório desse trabalho, eu havia apontado alguns pontos de contato entre a música e as ciências exatas. O texto de Meyer, ao indicar o movimento browniano como cenário de um tempo vindouro, apropriava-se de uma das primeiras reviravoltas epistêmicas causadas por Einstein. Por incrível que pareça aos nossos dias, no século XIX havia grande resistência em admitir a existência de átomos, pois os cientistas mantinham aversão às hipóteses que não pudessem ser observadas. Einstein tratou justamente do movimento browniano, permitindo afirmar indiretamente a existência dos átomos, em um dos primeiros artigos que publicou em 1905 (batizado de annus mirabilis, porque neste mesmo ano, este completo desconhecido, publicou cinco artigos que revolucionaram o mundo científico).

Movimento browniano é o nome dado em homenagem ao naturalista inglês Robert Brown, que chamou atenção ao pesquisar um fenômeno próprio de partículas suspensas em líquidos. Brown, em 1827, observou que grãos de pólen boiando num copo de água movimentavam-se constantemente de modo aparentemente aleatório e caótico, sem que nenhuma força os empurrasse. A primeira idéia foi achar que o pólen estivesse vivo, mas então Brown substituiu os grãos de pólen por pó de granito e pó de vidro e verificou a permanência da movimentação. À época, alguns cientistas já supunham que este movimento era causado pelo choque entre os átomos do líquido; porém, pela falta de recursos tecnológicos, não era possível comprovar esta hipótese, tampouco propor alguma teoria convincente para explicar o fenômeno. Somente com Einstein veio a resposta. Ele partiu do princípio que o movimento aleatório das partículas em suspensão era de fato causado pela colisão das moléculas de água. E embora os átomos fossem pequenos demais para serem observados, "seria possível estimar o seu tamanho calculando seu impacto cumulativo em objetos grandes - como um grão de pólen. Se a teoria atômica estivesse certa, então deveria ser possível, analisando o movimento browniano, calcular as dimensões físicas dos átomos" (www.searadaciencia.ufc.br). O problema foi, assim, solucionado.

Meyer, em sua analogia para descrever o estado futuro das artes, recorre à imagem aparentemente imóvel e calma de um copo d'água em repouso em cuja superfície grãos de poeira movem-se aleatoriamente. Tem-se assim, respectivamente, o meio aquoso e os grãos metaforicamente transferidos para o meio cultural e os artistas. Na superfície, o movimento artístico percorre direções aparentemente aleatórias, de modo a observar-se a pluralidade e a 
proliferação de estilos e estéticas convivendo em um mesmo meio sócio-cultural. Todavia, ao submergir neste líquido e penetrar seus meandros mais profundos, percebe-se que estas movimentações caóticas são na verdade motivadas por prescrições do próprio meio, ou seja, a exigência de renovação. Esta é uma das características deste nosso tempo, uma condição de eterna mudança e reformulação, na qual modismos alternam-se em velocidade supersônica e paradigmas são depostos em conexão 'banda larga', uma situação denominada por Meyer como estado permanentemente dinâmico.

Dado este contexto, urge lançar a pergunta: por que a proposição de um modelo de composição? Um modelo justamente não determina o engessamento ou continuísmo de um modo de atuação, o que é em si mesmo paradoxal ao ideário da contemporaneidade?

Minha primeira resposta à questão “por que um modelo de composição?” seria um tanto egoísta: para tentar resolver um problema particular, a saber, minhas idiossincrasias relacionadas ao ato composicional. Em suma, administrar minha vontade de criação e de expressão face às inconsistências de minha formação e ao contexto da música contemporânea.

Em 1994 na reedição do seu livro, Meyer acrescentou um poslúdio no qual avaliava as previsões de 1967. Nesta análise Meyer comenta seus acertos, mas detém-se, sobretudo, a discutir o impacto que a tecnologia de gravação e os meios de difusão exerceram sobre as artes, conduzindo à chamada indústria cultural ou mass media. Em sua opinião, a facilidade de adquirir música e escutá-la em casa levou à diminuição do público freqüentador de concerto e afetou as relações sociais, além de gerar impacto sobre a própria escuta musical. No entender de Meyer, a fruição da música na sala de concerto demanda uma atitude perceptual mais atenta, ao passo que a escuta 'caseira' (mesmo sem levar em conta a qualidade do aparelho que a reproduz) provoca uma audição casual. E é lícito especular que estas substituições de locais e de modos de percepção também afetaram a compreensão musical.

Embora suas previsões tenham sido acertadas, Meyer não poderia prever o impacto que a tecnologia da informática causaria em nossos dias. Atualmente, o computador se faz presente em todas as atividades exercidas e o curioso é que a era de hardwares e softwares só foi possível pela pesquisa de Claude Shannon que, durante seu mestrado, buscava solução para um problema pessoal: sua dificuldade em definir o que de fato era informação. $\mathrm{Na}$ procura pelo significado do termo, Shannon acabou por descobrir que a informação podia ser materializada, isto é, poderia ser convertida digitalmente (em bits) e tratada como qualquer fluxo de matéria, achado este que levou à passagem da tecnologia analógica para a digital.

Essa singular descoberta de um matemático transformou todos os outros campos do conhecimento, além de possibilitar a fabricação de CDs, DVDs, telefonia celular e a criação 
da Internet. Outrossim, modificou profundamente os modos de relacionamento social, na medida em que alterou contundentemente os meios de comunicação. As bases usadas por Shannon em sua pesquisa sobre informação foram matemáticas. Por conta disto, sua definição foi lograda em termos estatísticos considerando certeza $\mathrm{X}$ incerteza e prognóstico X resultado. A partir dos fundamentos obtidos com o trabalho de Shannon na área da informação, Meyer construiu sua própria obra no campo artístico, tratando das possibilidades comunicativas e de significação em música.

Em retrospecto: até aqui foi descrito percurso iniciado com Meyer em 1967, fazendo suas previsões para o período atual, antevisto como uma época de convivência entre diversos estilos e estéticas em um estado permanentemente dinâmico. Neste caminho, remontamos às pesquisas sobre o movimento browniano e sobre a teoria da informação. Estes aportes servirão para alicerçar a reflexão que se segue nos interesses imediatos que dominaram este trabalho.

É possível identificar a pluralidade como uma das características da modernidade. Este caráter plural revela-se não só nas inúmeras tendências estéticas concomitantes em nossos dias, mas também no interior do próprio objeto artístico que em sua constituição manifesta a contradição entre elementos fragmentários (assunto abordado no Capítulo 3 ao considerar justaposições e rupturas no fluxo discursivo). Este é um aspecto bastante comentado pelos estudiosos da chamada pós-modernidade. Jonathan Cross ${ }^{24}$, por exemplo, entende que na virada do século XIX para o XX houve um distanciamento da idéia de coerência orgânica presente na arte clássico-romântica. Esse ideário foi substituído pelo discurso fragmentário, não direcional e antiteleológico que caracteriza a arte moderna. Schoenberg, na coletânea Estilo e Idéia (cf: 1985, p.287), enfoca o assunto ao tratar da conexão de idéias musicais, cujas corretas articulações proporcionariam boa fluência ao discurso musical.

Abdicar da coerência orgânica e da boa fluência trouxe como conseqüência um libertar dos sons, cores e formas que passaram a ser tratadas em seu próprio direito, sem mais referirem a cânones ou modelagens pré-concebidas. Não existe, assim, um gênero ou modelo formal para remeter o objeto de arte realizado. Especificamente na música, o som (conseqüentemente, o timbre) enquanto material construtivo ascende ao primeiro plano em detrimento do parâmetro da altura, resultando na chamada composição sonora. As teorias tradicionais não oferecem ferramentas para lidar com essas novas maneiras de produção artística. Deste estado de coisas surge a necessidade de uma linguagem crítica capaz de dar

\footnotetext{
${ }^{24}$ Vide CROSS, Jonathan. Music theory and the challenge of modern music. In: POPLE, Anthony. Theory, analysis \& meaning in music. Cambridge: Cambridge University press, 2004, pp. 184-194.
} 
conta dessa situação, pois "a arte moderna não pretende ser sobre alguma coisa que não ela mesma" (CROSS, p.187). Esta arte precisa ser entendida em seus próprios termos, e é neste ponto que acredito assomar-se o valor da integração das técnicas analíticas, já que esta nova arte demanda envolvimento com os aspectos ligados a sua produção.

Meyer encarou esse desafio da música moderna, caracterizada por um 'estado permanentemente dinâmico' (ou browniano), valendo-se da teoria da informação, cujas proposições estatísticas lhe forneceram subsídios para avaliar as possibilidades comunicativas e de significação musical. Esta proposta tem o grande mérito de trazer ao plano técnico composicional questões ligadas à percepção e à recepção, ou seja, elementos cognitivos e estéticos. Contudo, os fatores poéticos inerentes ao processo composicional (que, como apontado no Capítulo 4, revelam-se como responsáveis pelos impactos no plano estésico) ainda careciam ser mais bem entendidos e desenvolvidos.

Isto posto, posso agora oferecer uma segunda resposta à pergunta feita acima (por que a pesquisa de um método em uma época avessa à continuidades?): para tentar achar um modelo de composição que satisfizesse meu intuito em encontrar a fluência no interior da descontinuidade, o equilíbrio na caoticidade, pontos de apoios perceptuais face o redemoinho fragmentário, um modo de atuação em meio à proliferação estilística moderna.

Esta busca acabou por levar a lugares a priori impensados, como foi o caso das especulações a respeito das possibilidades comunicativas da música pós-tonal. Comunicação foi aqui entendida como a construção de sentido durante a escuta musical - tema discutido no Capitulo 6. Este tópico resultou diretamente de minhas leituras de Meyer e de teóricos das ciências cognitivas, porém, foi uma tentativa de encontrar resposta para o seguinte problema que me preocupava: os princípios de estratificação e justaposição podem, em um primeiro momento, agir contra a compreensão musical, já que rompem o fluxo discursivo linear por meio de descontinuidades e simultaneidades. Como lidar com essa técnica sem prejudicar a compreensão da obra? Minha solução envolveu o resgate do conceito de função e promoveu considerações sobre as possibilidades de refuncionalização de estruturas gerativas da obra. Para tanto, os elementos justapostos no decurso composicional deveriam relacionar-se funcionalmente, ou seja, apresentariam algum traço de interdependência de modo a permitir serem congregados ao menos no final da obra (etapa descrita como síntese no processo de estratificação explicitado no Capítulo 3). A parte final de minha peça Trilhas Sonoras realiza de modo explícito este procedimento.

A idéia de refuncionalização guarda semelhança com o que o compositor Paulo Chagas ressaltou recentemente a respeito da obra de Willy Corrêa de Oliveira: 
a estética de Willy Correa de Oliveira opta pelo contraste e a oposição como princípio. Os temas revelam conflitos que no primeiro instante parecem ser inconciliáveis. Os materiais se sucedem como se tivessem negando uns aos outros. Entretanto, os elementos contrastantes vão se diluindo no processo global de desenvolvimento e, no final das contas, as diferenças passam a fazer parte de uma mesma estrutura (CHAGAS, 2008).

Durante meus estudos sobre refuncionalização, uma característica não muito comentada em música, mas de grande relevância nas artes plásticas, chamou minha atenção: a oposição fundo $\mathrm{X}$ figura. Em composição, normalmente entende-se esta oposição similarmente a tema $\mathrm{X}$ acompanhamento, ou schenkerianamente como plano de frente $\mathrm{X}$ plano de fundo. Todavia, há a possibilidade de introduzir nesta dicotomia o artifício da estratificação e a idéia de complementaridade, considerando-as enquanto processo de recursividade. Observe-se, por exemplo, o seguinte desenho de Maurits Escher:

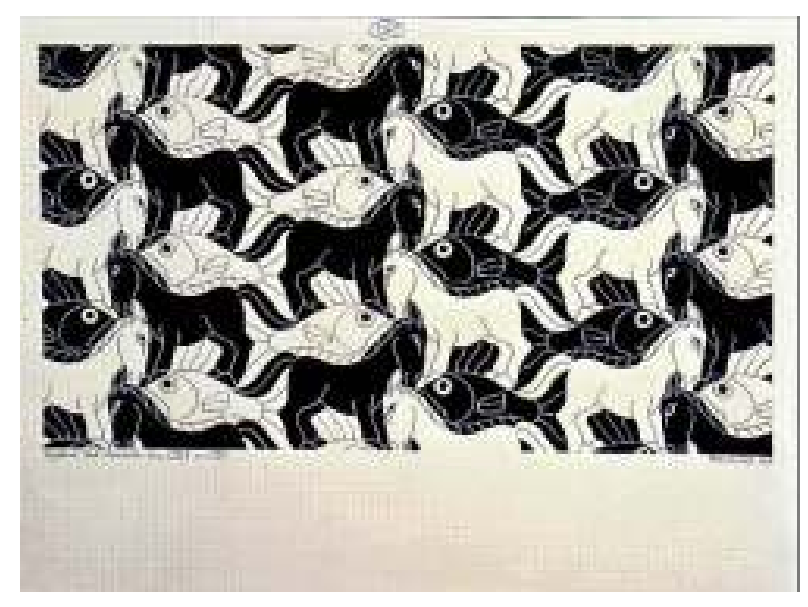

Ao contemplar a figura se é levado a enxergar dois planos da imagem, branco e preto, representando cavalos e peixes. Este desenho expõe claramente uma das marcas registradas de Escher, ou seja, a composição de planos simétricos derivados da utilização simultânea de fundo e figura. Hofstadter explica que quando uma figura (também nomeada de espaço positivo) é desenhada dentro de uma moldura, inevitavelmente surgirá sua forma complementar chamada de fundo ou espaço negativo. Ele postula, então, a distinção entre dois tipos de figura: cursiva e recursiva. Cursiva é uma figura cujo fundo é meramente um produto acidental do ato de desenhar. A figura recursiva é aquela cujo fundo pode ser visto como uma outra figura em seu direito próprio (cf. HOFSTADTER, p. 67).

Baseado nesse princípio, pareceu-me possível transferir a proposta de recursividade para o plano musical valendo-me do artifício da estratificação e da idéia de complementaridade. Uma parte da obra que tenha como material construtivo uma dada 
coleção de notas (constituindo um tema, por exemplo), automaticamente gera uma coleção complementar quando se considera o total cromático. (Isto foi mostrado no Exemplo 21-2 apresentando as formações escalares complementares). Em um discurso que mantenha rupturas e oposições, essas coleções complementares poderiam surgir repentinamente, por justaposição, sem períodos de transição, ou também ocorrer simultaneamente quando colocadas em camadas (estratificação). Outra possibilidade seria introduzi-las gradualmente por processos de transformação temática. Neste último modo, a percepção é favorecida, facilitando, de certa forma, a compreensão da obra, já que os contrastes não são súbitos e as diferenças são introduzidas linearmente de maneira a conduzir o ouvinte a percebê-las. Naomi Cumming descreve essa situação da seguinte maneira: "quando uma pessoa objetiva comunicar a percepção de aspectos variáveis de uma figura, ela não afirma categoricamente a presença daquele aspecto, mas intenta facilitar ao outro compartilhando a experiência perceptual, engajando-o em um ato de persuasão instrutiva" (CUMMING, In: POPLE, p.15). Concluí, em posse destas reflexões, que poderia conciliar estes artifícios de complementaridade, ruptura e fluência mantendo, também, o processo de estratificação. Neste caso, as estruturas apresentadas em camadas podem, posteriormente, ser transferidas para uma exposição linear (transformadas ou não) ou continuarem mantidas concomitantes (em estratos), porém, recebendo ênfases e destaques diversos de modo a trazê-las para o plano de frente, induzindo, então, o auditor a percebê-las e relacioná-las.

Sobre as possibilidades comunicativas da música, posso dizer que é um assunto ainda polêmico. Esta controvérsia ganhou espaço entre os autores no século XX, principalmente Adorno. Porém, o número de trabalhos dedicados a tratar deste tema aumentou consideravelmente com a ascensão das disciplinas na área de comunicação e da semiótica que se propuseram a tratar dos sistemas de signos enquanto linguagens. Muitos autores dedicamse a discutir a falta de comunicabilidade na música contemporânea, entendendo, de saída, que existe de fato uma crise na comunicação musical cujo responsável é o próprio compositor, já que este promoveu uma espécie de divórcio com o público ao apresentar obras ditas cerebrais e de difícil compreensão para os não iniciados no código musical. O compositor Paulo Chagas, por exemplo, é um dos que entendem haver de fato uma crise comunicativa na música contemporânea. Ele atribui essa crise à grande disseminação do cinema enquanto manifestação artística globalizada, capaz de estabelecer estereótipos musicais além de difundir somente a música composta na linguagem tradicional. Paradoxalmente, analisa Chagas, é possível compreender que mesmo a não comunicação revela em si a comunicação, pois "criticar a falta de comunicação, a ausência de uma linguagem comum, é também uma forma de se comunicar, é uma forma eficaz de atrair seguidores para uma causa 
aparentemente política, uma forma de manipular a mídia e criar novos significados" (CHAGAS, 2008).

Por outro lado, há compositores que defendem que a música não precisa servir como veículo para comunicação. Ela basta-se a si mesma, sendo totalmente desvinculada e desobrigada de transmitir quaisquer conteúdos afetivos ou ideológicos. Umberto Eco, contrariamente, afirma que qualquer fenômeno cultural permite ser analisado pela teoria da informação. O sociólogo Niklas Luhmann, por sua vez, afirma que a comunicação é a essência da sociedade e da cultura, não existe sociedade sem comunicação, sociedade é apenas comunicação. Portanto, conseqüentemente, a música e a arte não existem sem comunicação.

Do meu ponto de vista, enxergo no século XX uma produção musical contemporânea (posso adicionar experimental, pois se dedica a pesquisas de novas técnicas e processos para tratamento do material musical e, portanto, para a expressão artística) concomitante a todo um repertório de cunho mercadológico fomentado pela indústria do entretenimento. Nada contra o entretenimento, porém tenho sérias críticas à massificação cultural (discussão que escapa ao escopo deste trabalho). Neste contexto, é notável a majoritária produção e reprodução da música tonal (via rádio, TV, cinema, etc.) em contraposição à música não tonal, apregoada pelos compositores de vanguarda. Dado esta vasta supremacia da música tonal, as referências criadas pelos ouvintes são também oriundas deste repertório, de modo que é normal o estranhamento sentido quando estes são confrontados com a música não tonal.

Havendo o intuito do resgate da comunicação com o público, acredito ser válida a estratégia de ter em mente os hábitos de escuta gerados com repertório tonal tradicional (apresentados no Capítulo 6), utilizando-os como ponto de partida para elaboração composicional de modo a favorecer a construção de sentido durante a escuta.

Das inúmeras leituras e das diversas conversas e entrevistas que realizei com compositores brasileiros, posso pontuar um aspecto: me parece haver (mesmo de maneira velada) verdadeira restrição por qualquer coisa que remeta à tradição. Stravinsky diferenciava de maneira clara a oposição entre tradição e hábito, segundo ele, "a tradição é inteiramente distinta do hábito, já que o hábito é por definição uma aquisição inconsciente, e tende a tornar-se mecânico, ao passo que a tradição resulta de uma aceitação consciente e deliberada" (STRAVINSKY, 1996, p.58). A Sagração da Primavera foi considerada um insulto às convenções (musicais, teatrais e coreográficas). A pergunta que faço é: será que atualmente compor música tonal é insultar a convenção da modernidade que preconiza a obrigatória novidade? Gardner (cf: 1996, p.175), neste sentido, lembra que no começo do processo criador os compositores tendem a rejeitar o passado. Todavia, em algum momento da 
maturidade voltam-se para ele, revisitando e estudando-o. E, de certo modo, esse tipo de procedimento foi o cerne deste projeto. Minha hipótese, em meio a esta floresta de arrazoados e celeumas, foi admitir como possível o estabelecimento de um modelo composicional que também contemplasse a organização perceptual de modo a viabilizar a comunicação sem fazer uso de construções hierárquicas, como as do sistema tonal, valendo-se de estratificações, transformações temáticas e refuncionalizações. Os frutos colhidos, materializados em forma de obras musicais, devem servir como verificação da proposição inicial. Não houve, portanto, nenhum compromisso com a novidade no que se refere ao domínio estético, mas sim no plano técnico. Essa disputa entre tradição e a obrigação com o novo me lembra uma frase do compositor Claude Debussy, tido por muitos como revolucionário e responsável pela introdução da era pós-tonal: "qualificam-me revolucionário, mas não inventei nada. No máximo apresentei coisas antigas de uma maneira nova. Não existe nada novo em arte" (DEBUSSY, 1989, p.247).

Curiosamente, um fato (inclusive relacionado á comunicação musical) me chamou a atenção no início de minha pesquisa. Existe um traço comum à maioria dos métodos para ensino de composição: seus autores desde logo ressalvam a dificuldade ou impossibilidade de ensinar a alguém como escrever música. Flô Menezes disse-me que "a melhor aula de composição consiste em uma boa análise musical. $\mathrm{O}$ ato de compor, em si, é impossível de se ensinar. É a partir do feito que se refaz. E compor é refazer, ininterruptamente. Na verdade, é re-compor".

Se a impossibilidade comunicativa se faz sentir na objetividade da esfera didática escolar, quão mais complexo deve ser sua transposição para o domínio da recepção musical, onde as subjetividades duplicam-se? Por outro lado, apesar desses empecilhos, os professores de composição não deixam de tentar transmitir seus métodos. E talvez este aspecto sirva também como a terceira resposta para a pergunta anteriormente formulada (por que um modelo de composição musical?) que contestarei com uma citação: "Quando ouço eu esqueço. Quando vejo eu recordo. Quando faço eu entendo” (BRINDLE, 1986, p.3).

Obviamente há aspectos do processo de composição que não podem ser ensinados, pois não são passíveis de sistematização, como é o caso do processo criativo (ou concernente à criatividade) particular de cada um. O uso de ferramentas analíticas como princípio composicional não pretendeu suprir essa lacuna, mas sim propiciar uma ponte entre a análise musical enquanto "decomposição", isto é, análise usada enquanto forma de entendimento de uma obra, cujo procedimento compreende fragmentação, secção (fatiamento como se refere Nicholas Cook) e propicia vislumbrar a coerência interna da obra, para posteriormente passar ao processo de síntese que é, justamente, composição. Busquei, assim, a utilização de 
ferramentas de análise como ponto de partida, como origem motora de um processo, seja este classificado como algoritmo (Cope), Re-escritura (Ferraz) ou recomposição (Straus). A análise em si não é indispensável para fruição musical, qualquer pessoa pode apreciar música (e enfatizo, inclusive a música instrumental) sem possuir sequer a mínima iniciação nos seus meandros teóricos. Todavia, a realização de uma análise, seja por músicos ou críticos, significa buscar um entendimento mais profundo desta obra, permitindo descobrir aspectos não audíveis (como o uso de uma série de Fibonaci, por exemplo) ou não perceptíveis em um primeiro momento, mas que após a análise revelam-se quase que magicamente e passam a ser percebidos nas próximas audições da mesma obra, como é o caso de polimetrias, variações harmônicas, construções melódicas em camadas, gestos (musicais) similares, entre tantos outros casos que poderiam ilustrar essa peculiaridade da análise que incide diretamente sobre a percepção.

Emblemático da utilização da análise, e também um procedimento algoritmo, é o caso da música espectral. Essa corrente musical francesa importou para o universo instrumental o campo de intervenção espectral, isto é, a possibilidade de analisar e re-sintetizar eventos sonoros graças a ferramentas eletroacústicas. Os compositores ligados a essa corrente referem-na como uma atitude perante a composição em vez de um conjunto de técnicas, uma estética em vez de um estilo. A composição da música espectral está relacionada com as estruturas do timbre, cuja conformação acústica (ou espectro harmônico) é fornecida via análise matemática conhecida como Fast Fourier Transform (FFT) ou análise de Fourier.

Segundo o teorema de Fourier, qualquer som periódico pode ser decomposto em inúmeras ondas senoidais. Essas unidades mais elementares quando combinadas poderiam, em tese, reconstruir o som original. Este é o princípio da síntese aditiva, "construir sons complexos por meio da combinação de um largo número de ondas senoidais elementares" (FINEBERG, 2000, p.84). A grande vantagem desta técnica é conceitual. Ela fornece a maneira mais clara e intuitiva para conceber, ouvir e criar sons. Penetrar na estrutura interna microscópica de um som possibilita ouvir seus componentes de modo individualizado. Posteriormente, a composição aditiva, isto é, a adição de parciais sonoros, permite ouvir a resultante tímbrica global. Assim, os compositores da vertente espectral têm o algoritmo que poderia ser sumarizado, grosso modo, em duas etapas básicas: análise do espectro sonoro (via análise de Fourier) e síntese aditiva. Nestas duas etapas insere-se a proposta de trabalhar o parâmetro timbre, cujo espectro é, então, usado como princípio composicional tornando-se objeto de reconstituição no âmbito do processo construtivo ao longo de um contínuo temporal dilatado. 
De modo similar, a proposta aqui empreendida também permite ser descrita em duas etapas: análise e recomposição (procedimento abordado no Capítulo 2). A análise, como ponto de partida, visou a discriminar as estruturas gerativas, identificar e compreender o processo construtivo da obra analisada. A seguir, o processo pode ser refeito de modo variado, mantendo-se estruturas gerativas e alterando o processo construtivo; modificando as estruturas e conservando o processo de construção; invertendo-se um dos dois componentes; invertendo ambos (estruturas gerativas e o processo construtivo).

Quando sugiro a manutenção de estruturas gerativas, obviamente não me refiro à utilização literal do componente gerativo observado na análise realizada, mas sim na utilização de um elemento estrutural similar. Por exemplo, imagine-se uma peça cuja estrutura gerativa seja um motivo ou tema e o processo construtivo da obra seja o desenvolvimento temático. Optar por manter a estrutura gerativa implicaria em preservar a idéia, o conceito, a função do tema, ao invés de empregar o mesmo tema criado pelo compositor da peça analisada. Alterar o processo de construção (desenvolvimento), neste caso, poderia ser trabalhar composicionalmente o tema de modo a conferir-lhe nova função, tornando-o, por exemplo, figura de acompanhamento, bloco de contraste ou ruptura em meio ao fluxo musical, ou mesmo uma nova linha adicionada como camada - valendo-se do processo de estratificação. Proceder por inversão é simplesmente conservar a função da estrutura aferida via análise, porém, recompô-la em sentido contrário. Ascendente torna-se descendente, grave vira agudo, etc. Conceitos de fundo e figura, nesta acepção, são invertidos de modo a fazer com que o fundo torne-se figura e vice-versa. Meu Prelúdio 2 oferece boa exemplificação com respeito a esse procedimento de inversão, basta ouvi-lo e compará-lo com o Prelúdio 4 do Opus 28 de Chopin para se perceber as estruturas gerativas recompostas de modo invertido.

Por fim, vale um comentário sobre as ressalvas estéticas que podem ser lançadas às composições originais apresentadas. De modo geral, estas obras tiveram como objetivo exemplificar o modelo composicional proposto e verificar a funcionalidade do mesmo. Para tanto, julguei necessário que essas composições contemplassem formações e estéticas variadas. No entanto, pude notar em meio às várias conversas que tive com compositores, que estas foram avaliadas e criticadas em bases ideológicas. Segundo Flô Menezes, "todo ato criativo é, em si, inevitavelmente e potencialmente ideológico. Há, quer se queira ou quer não se queira, conteúdo político no ato da criação. A questão é a de tomar consciência disso e fazer as opções necessárias no tempo certo. As estratégias compositivas apenas reforçam ou relativizam as intenções políticas”. Aliando-me a este posicionamento, acrescentaria também dentre as bases ideológicas os compromissos políticos e estéticos dos indivíduos. Nesta 
vertente estética, considero notório o dado que a maioria das criticas feitas às minhas peças referiram-se ao fato das obras soarem como música tonal. Todavia, enfatizo que há somente uma peça tonal dentre as aqui relacionadas, o Prelúdio $n .1 \mathrm{em} \mathrm{Eb}$. Ser alvo dessas críticas deixou-me contente, pois concluí que sob o prisma eminentemente técnico as obras forneceram pouca munição para os avaliadores. Quando perguntei ao compositor Silvio Ferraz como deveria ser uma aula de composição ele respondeu: "o caminho é primeiro deseducar os movimentos congelados pela tradição". Aprendi, então, que resquícios da tradição se tornarão uma espécie de fardo que eu e outros compositores teremos que aprender a carregar.

Do ponto de vista estilístico, também acabei por descobrir que minha música é mais próxima de uma estética americana, embora deva ter ficado claro para aqueles que a ouviram o uso e abuso de elementos brasileiros, sobretudo no aspecto rítmico, característica esta que para mim é inevitável, pois provém de uma predileção antiga e sincera pela música do Brasil. Paulo Chagas apontou as seguintes diferenças entre as músicas européia e norte-americana: "para os europeus a música é um objeto de reflexão crítica. Os norte-americanos buscam, sobretudo, a harmonia. A música européia é marcada pela dialética, a música americana pelo transcendentalismo. São atitudes bem diferentes. Isto explica, parcialmente, porque os compositores europeus são mais radicais em relação ao passado e os norte-americanos mais presos à harmonia tonal". Tomando a harmonia em um sentido lato (isto é, estendendo o domínio eminentemente vertical e acórdico particular do sistema de tonalidades), devo concordar que minhas composições possam ser sim aparentadas dessa estética norteamericana.

Os compositores geralmente "conversam" com a comunidade de compositores, mantendo a discussão principalmente no plano técnico (relativos ao metier do compositor). Henry Pousser comenta que

as explicações de compositores sobre seu artesanato são como declarações feitas em confiança. O objetivo de tais declarações não é somente tornar pública algumas de suas observações particulares, trazendo à luz seus métodos. O objetivo é, antes, passar adiante para consideração de alguém competente suas próprias concepções e modos de proceder, visando a estimular um criticismo construtivo e frutífero e ganhar com essa troca de opiniões o máximo benefício intelectual. (Pousser: In: EIMERT \& STOCKHAUSEN, 1959, p. 44). 
Minha proposta aqui se distinguiu não no plano técnico, mas no receptor deste diálogo. Tive sempre em mente que no outro pólo dessa cadeia comunicativa estava o público em geral, ao qual não era exigido o conhecimento prévio do código composicional, pois o modelo aqui desenvolvido contemplava também os aspectos perceptuais de modo a favorecer a compreensão da obra.

A teoria do campo unificado que Einstein durante várias décadas procurou construir implicava em descrever todos os fenômenos do universo por meio de um único modelo teórico. O ponto de partida para sua empreitada foi saber quais elementos deveriam ser unificados. No seu caso, eram as interações fundamentais, as forças responsáveis por manterem coesas e relacionadas toda a matéria componente do universo. Partindo de uma idéia parecida, tentei reunir em um modelo alguns dos elementos responsáveis por manter unidade em uma composição, contemplando assim aspectos harmônicos, temáticos, texturais e formais. Obviamente, não estou de forma alguma me comparando a Einstein, mas valendome desta analogia para explicar meu intuito. Os cientistas empregam estas analogias com freqüência. Entre estas, a mais famosa e atual é a Teoria das Cordas (espécie de substituto da teoria do campo unificado), cuja imagem metafórica remete às vibrações características dos instrumentos de cordas. Naturalmente, há diferenças contumazes entre arte e ciência impedindo transferências metodológicas simples e diretamente entre esses domínios, por isso mesmo certos procedimentos devem ser relativizados. Todavia, a vontade de congregar no interior de um mesmo processo as distintas estruturas do universo musical me conduziu à proposição desse modelo composicional.

Em meio à floresta musical contemporânea acrescento mais este fruto de minhas pesquisas. Espero, sinceramente, que sirva de alimento para novas criações e especulações no campo pedagógico da composição musical. 


\section{Referências e Literatura Consultada}

ABBAGnANO, Nicola. Diccionario de Filosofia. Tradução Alfredo N. Gallett. Bogotá: Fundo de Cultura Económica. 1997.

ADORNO, Theodor W. Filosofia da Nova Música. Tradução Magda França. São Paulo: Editora Perspectiva, 1974.

AGAWU, Kofi. Analyzing music under the new musicological regime. In: Music Theory Online. Vol. 2, N. 4, 1996.

ALVES, José Orlando. Aspectos da Aplicação da Teoria dos Conjuntos na Composição Musical. Rio de Janeiro, 2000. Dissertação de Mestrado, Univ. Federal do Rio de Janeiro.

ALLEN, Warren D. Philosophies of Music History. New York: Dover Publications, 1962.

ALVES, Rubem. Filosofia da Ciência- introdução ao jogo e a suas regras. $6^{\mathrm{a}}$ edição. São Paulo: Edições Loyola, 2003.

ANTUNES, Jorge. O novo discurso musical que dá asas à criação. 2003. Disponível em: http://www.ex-machina.mus.br/artigos_antunes.htm .

APEL, Willi (ed). Harvard Dictionary of Music. $2^{\mathrm{a}}$ edição. Cambridge, Massachussetts: Harvard University Press, 22a impressão, 2000.

ARNOLD, Denis (Ed.). The New Oxford Companion to Music. New York: Oxford University Press, 1984.

ÁVILA, Myriam. Parataxe como conceito crítico. In: X Congresso Internacional ABRALIC, 2006, Rio de Janeiro. Disponível em:

http://paginas.terra.com.br/arte/dubitoergosum/simp27.htm (Consultada em 02/10/2008).

BALIBAR, Françoise. Einstein: o prazer de pensar. Tradução de Ana Deiró e Jorge Bastos. Rio de Janeiro: Objetiva, 2008.

BASSALO, José M. Filardo. Einstein e a Música. Disponível em:

http://www.searadaciencia.ufc.br/folclore (consultada 27 em dezembro de 2008)

BASSO, Alberto (org.). Analisi Musicale. In: Dizionario Enciclopedico Universale della Musica e dei Musicisti. Torino: Unione Tipografico-Editrice Torinese, p.80-84, 1989.

BAUR, John. Music theory through literature. Vol. II. New Jersey: Englewood Cliffs, 1985.

BENEDETTI, Danieli Longo \& CORRÊA, Antenor Ferreira. Le Tambeau de Couperin: considerações analíticas e musicológicas. Anais do SIMPEMUS 4. Curitiba, 2007, p. 62-73.

BENJAMIN, Thomas; HORVIT, Michael; NELSON, Robert. Techniques and Materials of Music. California: Thomson and Schirmer, 2003 ( $6^{\mathrm{a}}$ ed.).

BENSE, Max. Pequena Estética. São Paulo: Ed. Perspectiva, 1975. 
BENT, Ian D. “Analysis”. In: SADIE, Stanley (org.) The New Grove Dictionary of Music and Musicians. Londres: Macmillan, 1980, p. 340-388.

BENT, Ian D. e POPLE, Anthony. “Analysis”. In: The New Grove Online. Londres, 2001.

BERGAN, Ronald. Sergei Eisenstein: A Life in Conflict. Londres: Overlook Press, 1997.

BERRY, Wallace. Strutural Functions in Music. New York: Dover Publications, 1987.

BITONDI, Matheus G. A estruturação melódica em quatro peças contemporâneas. 2006. http://www.ia.unesp.br/pos/stricto/musica/teses/matheus_bitondi.pdf

BOULEZ, Pierre. Apontamentos de Aprendiz. Tradução Stella Moutinho, Caio Pagano e Lídia Bazarian. São Paulo: Editora Perspectiva, 1995.

BRINDLE, Reginald. Musical Composition. Nova York: Oxford University Press, 1986.

BUSH, ALAN. The Study and Teaching of Musical Composition. In: The Musical Times, Vol. 93, No. 1318, 1952, pp. 539-542.

BUSONI, Ferruccio. The Essence of Music - and other papers. Tradução Rosamund Ley. New York: Dover Publications, 1965.

CALDEIRA, Jorge. A Construção do Samba. São Paulo: Mameluco, 2007.

CHAGAS, Paulo. Gilberto e Willy: ética e estética. In: Anais do $4^{\circ}$ Encontro de Música e Mídia, SP, 2008.

CHRIST, William et al. Materials and Structure of Music. New York: Prentice Hall, 1980.

COLI, Jorge. "O que é arte?”. In: Coleção Primeiros Passos. 5a. Ed. São Paulo: Editora Brasiliense, 1984.

CONE, Edward T. "Stravinsky: the progress of a method". In: Perspectives of New Music 1. New York, outono de 1962, p. 18-26. Org. Benjamin Boretz e Edward Cone.

_. "Beyond Analysis”. In: Perspectives of New Music. No. 6, p.33-51, 1967.

. The Composer's voices. California: University of California Press, 1974.

COOK, Nicholas. A Guide to Musical Analysis. London: J. M . Dend \& Sons. 1987. . Analysis Through Composition. New York: Oxford University Press, 1996. . De l'ambiguité de la notion de "thème" pour l'analyse musicale. In: Analyse Musicale 13, 1988, 30-6.

COOK, Perry R. Music, Cognition and Computerized Sound. Massachusetts: MIT Press, 2001.

COOPER, Grossvenor \& MEYER, Leonard. The Rhythmic Structure of Music. Chicago: University of Chicago Press, 1963. 
COPLAND, Aaron, Como Escuchar La Musica. México: Fondo de Cultura Economica, 1986.

COPE, David. The Algorithmic Composer. Madison: A-R Editions, 2000.

CORRÊA, Antenor Ferreira. Estruturações Harmônicas Pós-tonais. São Paulo: Edunesp, 2006.

CORRÊA, Antenor Ferreira, \& BORTZ, Graziela. Stravinsky: o progresso de um método. Revista Música Hodie, Vol. 7, No. 1, 2007, p. 11-25.

COSTA, Rogério. Reflexões sobre a crise de comunicabilidade da música contemporânea: a música é linguagem? O que deve Comunicar a música? Revista Música Hodie, Vol. 4, $\mathrm{n}^{\mathrm{o}} 1$, pp. 75-90, 2004.

CRAFT, Robert. Stravinsky: glimpses of a life. New York: St. Martin Press, 1992. . Conversas com Igor Stravinsky. São Paulo: Perspectiva, 1984.

DAHLHAUS, Carl. Analysis and Value Judgment. Tradução Siegmund Levarie. New York: Pendragon Press, 1983.

il Mulino, 1988.

. Che Cos'è La Musica?. Tradução Angelo Bozzo. Bologna: Sociedade Editrice . Estética musical. Tradução Artur Morão. Lisboa: Edições 70, 1991.

Gedisa, 2003.

. Fundamentos de la Historia de la Música. Tradução Nélida Machain. Barcelona:

. "Harmony". In: SADIE, Stanley (org). The New Grove Dictionary of Music and Musicians. Londres: MacMillan, 1980, vol. 8, p.175-188.

. Schoenberg and the New Music. Trad. Derrick Puffett e Alfred Clayton. New York: Cambridge University Press, 1990.

. "Tonality". In: SADIE, Stanley (org). The New Grove Dictionary of Music and Musicians. Londres: MacMillan, 1980, vol. 19, p. 51-55.

DALlin, Leon. Techniques of Twentieth Century Composition. $3^{\mathrm{a}}$ edição. Iowa: WM. C. Brown Company Publishers, 1975.

DEBELLIS, Mark. The Paradox of Musical Analysis. In: British Journal of Music Education. London. Vol. 16, nº. 2, p. 83-99,1999.

DEBUSSY, Claude. Monsieur Croche e outros ensaios sobres música. Rio de Janeiro: Nova Fronteira, 1989.

DELATRE. P. "Função". In: Enciclopédia Einaudi. Lisboa: Imprensa Nacional-Casa da Moeda, 1992. Volume 21, p. $289-304$.

. “Teoria/Modelo". In: Enciclopédia Einaudi.Lisboa: Imprensa Nacional-Casa da Moeda, 1992. Volume 21, p. 223 - 287. 
DRETSKE, Fred. Knowledge \& the Flow of Information. Oxford: Basil Blackwell, 1981.

DEUTSCH, Diana (ed.). The Psychology of Music. San Diego: Academic Press, 1982.

DUNSBY, Jonathan e WHITTALL, Arnold. Music Analysis in Theory and Practice. Londres: Faber Music, 1988.

DUPRAT, Regis. “Análise, Musicologia e Positivismo”. Revista Música, São Paulo, v. 7, nº 1/2, p. 47-58, maio/novembro 1996.

ECO, Uumberto. A Definição de Arte. Trad. José M. Ferreira. São Paulo: Martins Fontes, 1986.

. A Estrutura Ausente. Tradução: Pérola de Carvalho. São Paulo: Perspectiva, 2001.

EIMERT, \& STOCKHAUSEN, K. Musical Craftsmanship. Londres: Universal Ed., 1959.

EISENSTEIN, Serguei. Reflexões de um cineasta. Tradução de Gustavo Doria. Rio de Janeiro: Jorge Zahar, 1969.

. A forma do filme. Trad. de Teresa Ottoni. Rio de Janeiro: Jorge Zahar, 1990.

ESCHER, Maurits. Biografias e figuras disponíveis em: http://www.mcescher.com

FERRARA, Lawrence. Philosophy and the analysis of music. New York: Greenwood Press, 1991.

FERRAZ, Silvio. Música e Repetição: a diferença na composição contemporânea. São Paulo: Educ/Fapesp, 1998.

. Idéias sobre composição: apresentação de Casa Vazia, Casa Tomada, Transições, Catedral das 5:45. In: Anais do VI Fórum CLM. PUC-USP, São Paulo, 2004, p.7-16.

. Música e comunicação: Ou, o que quer comunicar a música? In: Anais do XIII Encontro da ANPPOM, Belo Horizonte, 2001, p.515-523.

FICARELLI, Mário. Sinfonia $n^{\circ} 2$ Mhatuhabh. São Paulo, 1995. Tese de Livre Docência, Universidade de São Paulo - USP.

FINEBERG, Joshua. “Guide To The Basic Concepts And Techniques Of Spectral Music”. In: Contemporary Music Review. Vol. 19, parte 2, 2000, p.81-113.

FORTE, ALLEN. The Compositional Matrix. New York: Da Capo Press, 1974.

GARDNER, Howard. Mentes que criam. Tradução de Maria Veronese. Porto Alegre: Artes Médicas, 1996.

GIBSON, James. The Perception of Visual World. Boston: Greenwood Press, 1950.

GREEN, Douglass. Form in tonal music. New York: Holt, Rinehart and Winston Inc, 1965.

GREENE, Brian. O universo elegante. Trad. José Viegas Filho. São Paulo: Companhia das Letras, 2001. 
GRIFFITHS, Paul. Enciclopédia da Música do Século XX. Tradução Marcos Santarrita e Alda Porto. São Paulo: Martins Fontes, 1995.

. "Serialism". In: SADIE, Stanley (org). The New Grove Dictionary of Music and Musicians. Londres: MacMillan, 1980, p. 162-169.

GRITTEN, Anthony. Edward T. Cone's Stravinsky. The Progress of an Essay. In: The Musical Times. Vol. 139, N. ${ }^{\circ}$ 1862. April 1998, p 4-13.

HÁBA, Alois. Nuevo Tratado de Armonia. Trad. Ramón Barce. Madrid: Real Musical, 1984.

HAWKING, Stephen. O universo numa casca de noz. Trad. Ivo Korytowski. São Paulo: Mandarim, 2001.

HINDEMITH, Paul. Harmonia Tradicional. Trad. Souza Lima. São Paulo: Irmãos Vitale, 1949.

. The Craft of Musical Composition. Tradução de Arthur Mendel. New York: Associated Music Publishers, 1945.

HOFSTADTER, Douglas. Gödel, Escher, Bach: an eternal golden braid. New York: Vintage Books, 1980.

HONEGGER, Marc (org.). Analyse Musical. Science de La musique. Paris: Borda, 1976.

HUGLO, Michel. Tonary. In: SADIE, Stanley (org.) The New Grove Dictionary of Music and Musicians. Londres: Macmillan, 1980, p.55-59.

JACOB, Gordon. The Composer and his art. Connecticut: Greenwood Press, 1986.

JEPPESEN, Knud. Counterpoint: the polyphonic vocal style of the sixteenth century. Tradução Glen Haydon. New York: Dover Publications, 1992.

KERMAN, Joseph. Musicologia. Trad. Álvaro Cabral. São Paulo: Martins Fontes, 1987.

. How we got into analysis, and how to get out. Critical Inquiry, Vol. 7, No. 2, pp. 311-331. Chicago: Chicago University Press.

KINTON, Leslie. How we got out of analysis and how to get back in: a polemical re-appraisal of Joseph Kerman. In: Discourses in Music. Volume 5 N. 1, 2004.

KOELLREUTTER, H. J. Harmonia Funcional (introdução à teoria das funções harmônicas). São Paulo: Ricordi Brasileira, 1980 (?).

KOPP, David. "On the function of Function”. In: Music Theory on Line. Vol. 1, n. ${ }^{\circ}$ 3, 1995.

KOSTKA, Stefan M. Materials and Techniques of Twentieth-Century Music. $2^{\mathrm{a}}$ ed. New Jersey: Prentice-Hall Inc., 1999.

KOSTKA, Stefan \& PAYNE, Dorothy. Tonal Harmony - with an Introduction to TwentiethCentury Music. $4^{\mathrm{a}}$ ed. Boston: Mcgraw-Hill Inc., 2000. 
LACERDA, Marcos Branda. Breve resenha das contribuições de Schenker e Schoenberg para a análise musical. In: Revista Eletrônica de Musicologia, Vol. 2.1/Outubro de 1997.

LANSKY, Paul e PERLE, George. "Atonality”. In: SADIE, Stanley (org). The New Grove Dictionary of Music and Musicians. Londres: MacMillan, 1980, p. 669-673.

LENDVAI, Ernö. Bartók and Kodaly. Volume I. Tradução para o inglês realizada pelo autor. Budapeste: Zoltan Kodaly Pedagogical Institute of Music, 1976.

LESTER, Joel. Analytic Approaches to Twentieth-Century Music. New York: Norton, 1989. Press, 1996. . Compositional Theory in the Eighteenth Century. Cambridge: Harvard University LEWIN, David. Behind the Beyond. In: Perspectives of New Music. nº 7, p.59-69, 1969.

LEVI-STRAUSS, Claude. O cru e o cozido. Tradução de Beatriz Perrone-Moisés. São Paulo: Brasiliense, 1991.

MCFARLAND, Mark. Debussy: the origins of method. Journal of Music Theory, 48 (2), 295324, 2004.

MENDES, Gilberto. Uma Odisséia Musical: dos mares do sul expressionista à elegância pop/art decó. São Paulo, Edusp, 1994.

MENEZES, Flo. Apoteose de Schoenberg. Segunda edição. São Paulo: Ateliê Edit., 2002. (org.). Música Eletroacústica História e Estéticas. São Paulo: Edusp, 1996.

MEYER, Leonard. Music, the arts, and ideas. Chicago: University of Chicago Press, 1994. Press, 1973. . Explaining Music - essays and explorations. California: University of California . Emotion and Meaning in Music. Chicago: University of Chicago Press, 1956.

MITCHELL, Donald. The Language of Modern Music Londres: Faber and Faber, 1976.

MOJOLA, Celso. Rio de Janeiro, 2001. "Etiam Per Me Brasilia Magna". In: Cadernos do Colóquio. Rio de Janeiro: Uni-Rio, ano III, p. 144-152, dezembro 2001.

MOLINO, Jean. “O Fato Musical'. In: SEIXO, Maria Alzira (org.). Semiologia da Música. Lisboa: Vega Ed., (s.d.), p. 111 - 164. Primeira publicação em francês 1975.

MORGAN, Robert P. Twentieth-Century Music. New York: Norton \& Company, 1991.

NATTIEZ, J. Jacques. "Harmonia". In: Enciclopédia Einaudi.Lisboa: Imprensa NacionalCasa da Moeda, 1984. Volume 3, p. 245 - 271.

. "Melodia". In: Enciclopédia Einaudi.Lisboa: Imprensa Nacional-Casa da Moeda, 1984. Volume 3, p. $272-2297$. 
. "Tonal/Atonal". In: Enciclopédia Einaudi.Lisboa: Imprensa Nacional-Casa da Moeda, 1984. Volume 3, p. $331-356$.

NOGUEIRA, Marcos. Compondo com uma semântica do entendimento. Anais do XVII Congresso da ANPPOM, São Paulo, Unesp, 2007, cd-rom.

OLIVEIRA, Willy Corrêa de. Beethoven proprietário de um cérebro. São Paulo: Perspectiva, 1979 .

ONNEN, Frank. Mauricio Ravel. Trad. Felipe Lorda-Aláiz. Barcelona: Ed. Juventud, 1951. . Stravinsky. Trad. Enrique Mulder. Barcelona: Ed. Juventud, 1953.

ORENSTEIN, Arbie. Ravel-man and musician. New York: Dover Publications, 1991.

OWEN, Harold. Modal and Tonal Counterpoint - from Josquin to Stravinsky. New York: Schirmer Books, 1992.

PALISCA, Claude V. "Theory, theorists". In: SADIE, Stanley (org). The New Grove Dictionary of Music and Musicians. Londres: MacMillan, 1980, p. 741-762. . Musicology in the 1980's. New York: Da Capo Press, 1982.

PARKS, Richard. The music of Claude Debussy. New Haven: Yale University press, 1989.

PERSICHETTI, Vincent. Twentieth Century Harmony - Creative Aspects and Practice. New York: W. W. Norton \& Company, 1961.

POMIAN, K. "Estrutura". In: Enciclopédia Einaudi. Lisboa: Imprensa Nacional-Casa da Moeda, 1992. Volume 21, p. $141-182$.

POPLE, Anthony (Ed.). Theory, analysis and meaning in music. Cambridge: Cambridge University Press, 1994.

PRADO, J.A.R. de Almeida. Cartas Celestes - uma uranografia sonora geradora de novos processos composicionais. Campinas, 1985. Tese Doutorado, Universidade de Campinas.

PROGRAME NOTES. In: SADIE, Stanley (org.) The New Grove Dictionary of Music and Musicians. Londres: Macmillan, 1954, p. 941-944.

RAHN, John. Basic atonal theory. New York: Schirmer Books, 1980.

RETI, Rudolph R. Tonality, Atonality, Pantonality - a study of some trends in twentieth century music. Westport, Connecticut: Greenwood Press, 1978.

. The Thematic Process in Music. London: Faber and Faber, 1951.

RIBEIRO-PEREIRA, José Miguel. A theory of harmonic modulation: the plastic model of tonal syntax and the major-minor key system. Porto: Politema, 2005.

RIEMANN, Hugo. Riemann Musik-Lexikon. Mainz: B. Schott's Söhne, 1967. 
ROBINSON, J. Bradford. Carl Dahlhaus. In: Grove Music Online. 2000. Disponível em: www.grovemusic.com

ROEDERER, Juan. Introdução à Física e Psicofísica da Música. Tradução Alberto Luis da Cunha. São Paulo: Edusp, 1998.

ROSENBOOM, David. Cognitive Modelling and Musical Composition in the Twentieth Century: A Prolegomenon. In: Perspectives of New Music, Vol. 25, No. 1/2, 1987, p.439-446.

SANTOS, C. A. Einstein no Brasil. Disponível em: www.if.ufrgs.br/einstein/brasil.html .

SCHAFER, Murray. O Ouvido Pensante. Trad. Marisa Fonterrada. São Paulo: Ed. Unesp, 1991.

SCHENKER, Heinrich. Harmony. Tradução de Elisabeth Mann Borgese. Chicago: University of Chicago Press, 1980.

SCHOENBERG, Arnold. Funciones Estructurales de la Armonia. Tradução de Juan Luis Milán Amat. Barcelona: Labor, 1990.

. Harmonia. Trad. Marden Maluf. São Paulo: Editora Unesp, 2001.

. "Problems of Harmony". In: Style and Idea. Ed. Leonard Stein. Berkeley: University of California Press, 1985.

Edusp, 1993.

. Fundamentos da Composição Musical. Trad. Eduardo Seincman. São Paulo:

SCRUTON, Roger. The Aesthetics of Music. New York, Oxford University Press, 1997.

SHERMAN, Robert. Concept and Design in Music. Florida: Harcourt Brace Jovanovich, 1989.

SHIRLAW, Matthew. The Theory of Harmony. New York: Da Capo Press, 1969.

SIMMS, Bryan R. Music of Twentieth Century - style and Structure. New York: Schirmer, 1986.

SLONIMSKY, Nicolas. "Music in the Twentieth Century: Problems and Overviews". In: Classics Essays on Twentieth-Century Music. New York, Schirmer Books, 1983.

SOLOMON, Larry J. Symmetry as a compositional determinat. PHD Dissertation, revisão de 2002. Disponível em: www.solomonsmusic.net .

SONATA FORM. In: SADIE, Stanley (org). The New Grove Dictionary of Music and Musicians. Londres: MacMillan, 1980, vol. 17, p.497-508.

SOUZA, Rodolfo Coelho de. Sintaxe e Parataxe na Música Moderna e Pós-Moderna. In: Revista Opus, No. 13, p. 73-91, 2007.

STRAUS, Joseph. Remaking the past. Harvard: Harvard University press, 1990. 
. Introduction to post-tonal theory. Englewwod Cliffs, N.J.: Prentice Hall, 1990.

STRAVINSKY, Igor. Poética Musical em 6 lições. Tradução Luiz Paulo Horta. Rio de Janeiro: Jorge Zahar, 1996.

STUCKENSCHMIDT, H.H. Maurice Ravel - variations on his life and work. Tradução de Samuel Rosenbaum. Philadelphia: Chilton Book Company, 1968.

SWAFFORD, Jan. A question is better than an answer. Disponível em: http://www.charlesives.org/ives_essay/ (consulta realizada em 10/09/2008).

SZENDY, Peter (org.). Enseigner La Composition (de Schoenberg au multimedia). Paris: L'Harmattan-Ircam, 1998.

TITCHENER, John M. \& BROYLES, Michael E. Meyer, Meaning, and Music. In: The Journal of Aesthetics and Art Criticism, Vol. 32, No. 1, 1973, pp.17-25.

TREITLER, Leo. Structural and Critical Analysis. In: PALISCA, Claude (org). Musicology in the 80 's.

WEAVER, Warren. Introduction to: Claude Shannon's The Mathematical Theory of Communication. Disponível em: www.uoregon.edu/ felsing/virtual_asia/info

WHITTALL, Arnold. Analysis. In: ARNOLD, Denis (ed.). The New Oxford Companion to Music. New York: Oxford University Press, 1984.

WILSON, Paul. The Music of Béla Bartók. New Haven: Yale University Press, 1992.

ZAMPRONHA, Edson. Do grau à nota - o caminho do tonal ao atonal através da falsarelação e da anti-neutralização. In: Revista Arte e Cultura no 4. São Paulo: Anablume, 2006, p.105-138. 


\section{ANEXOS}

\section{Partituras das composições desenvolvidas com o método proposto:}

1. Trilhas Sonoras (para percussão: marimba, 2 break drums, 3 pratos e bumbo a pedal)

2. Impressão sol poente (para piano)

3. Metralhadora (para quinteto de cordas)

4. Prelúdio 1 em Eb (para piano)

5. Prelúdio 2 (para piano)

6. Prelúdio 3 (para piano)

7. Chiromancer's hands doesn't have lines (para piano, 2 percussionistas, clarinete, trompete e sons eletroacústicos)

8. Jericó (para 2 percussionistas, trompete, sons eletroacústicos e transformação eletroacústica em tempo real)

9. Veredas do Sertão (para quinteto de clarinetes) 


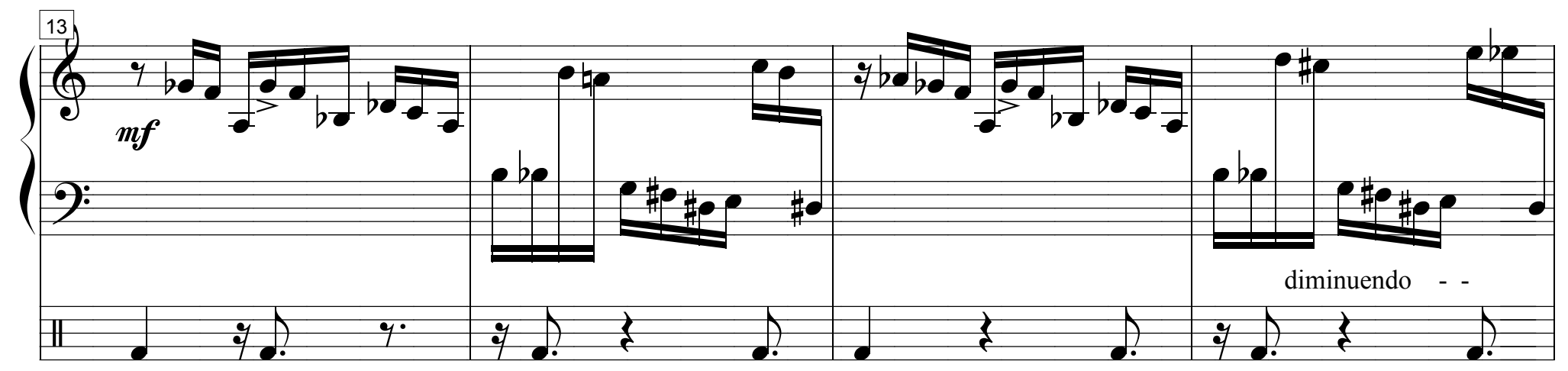
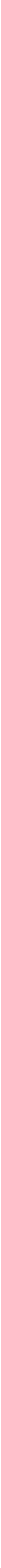


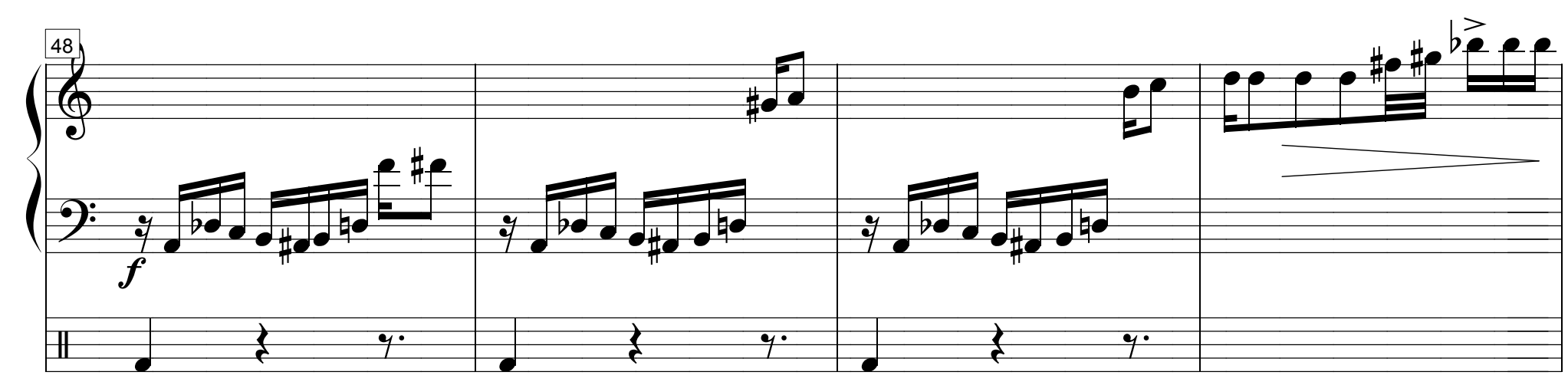

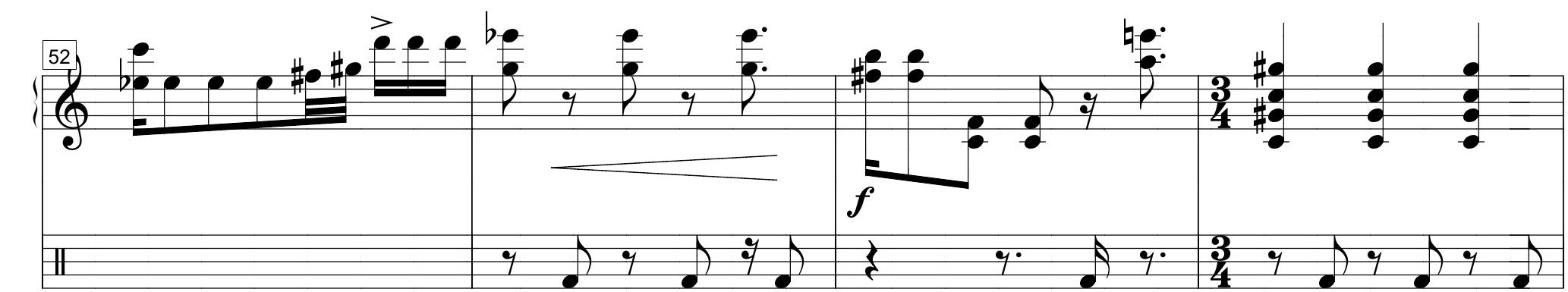
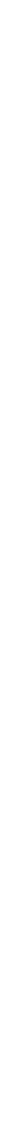

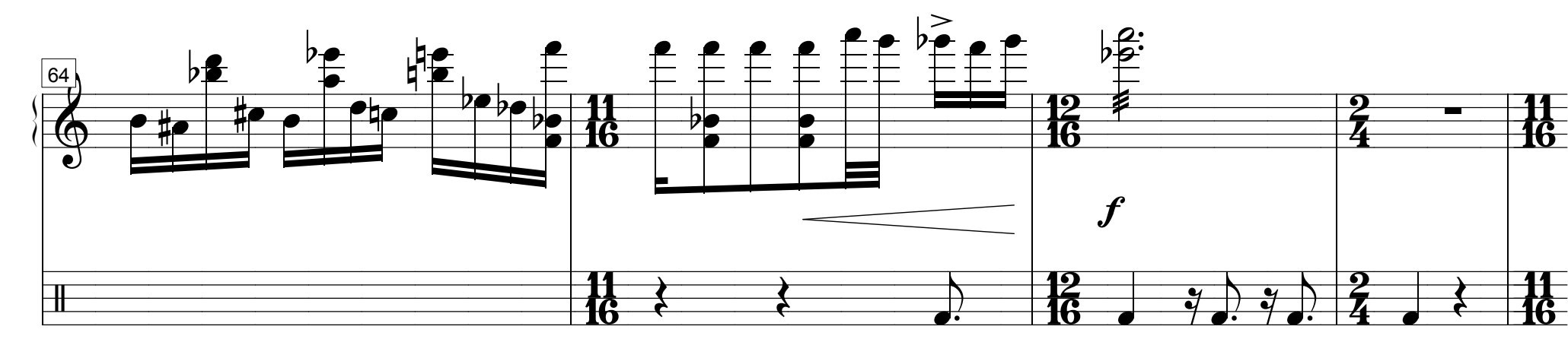



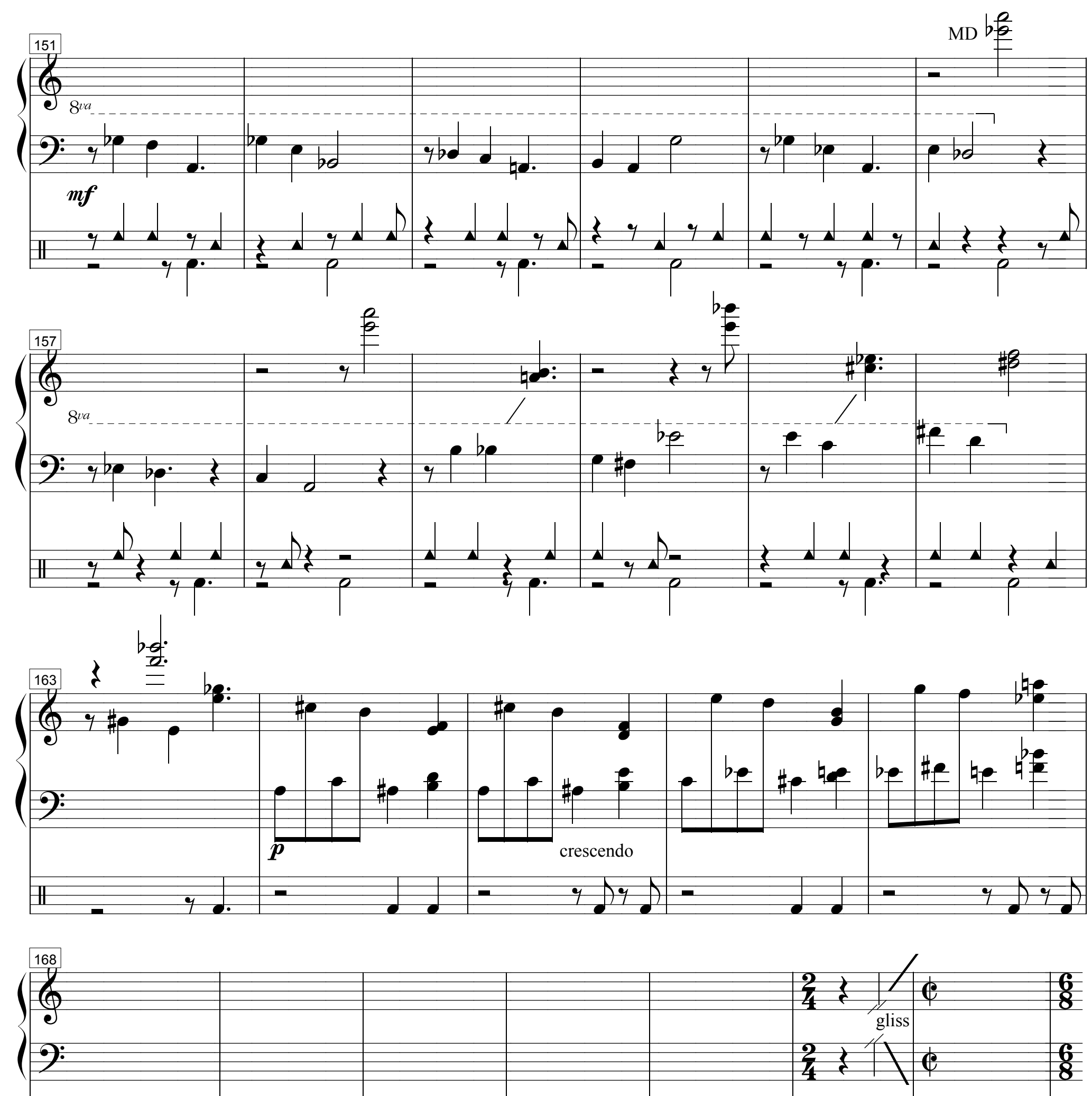

8

$\frac{6}{8}$

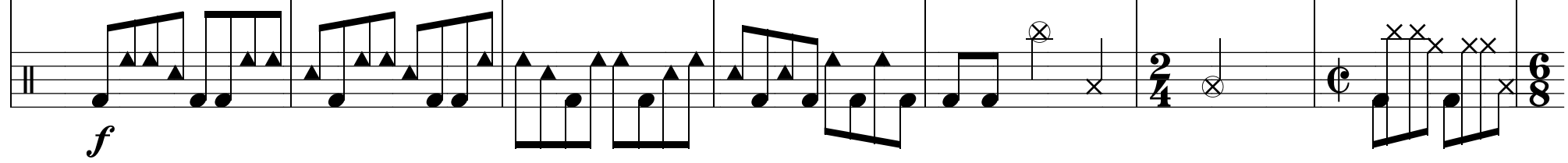

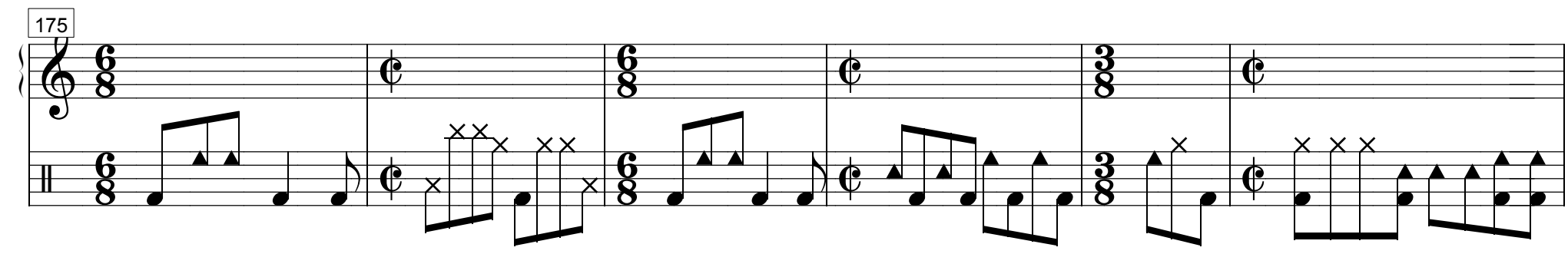



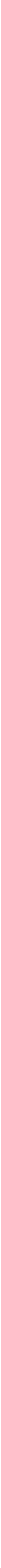

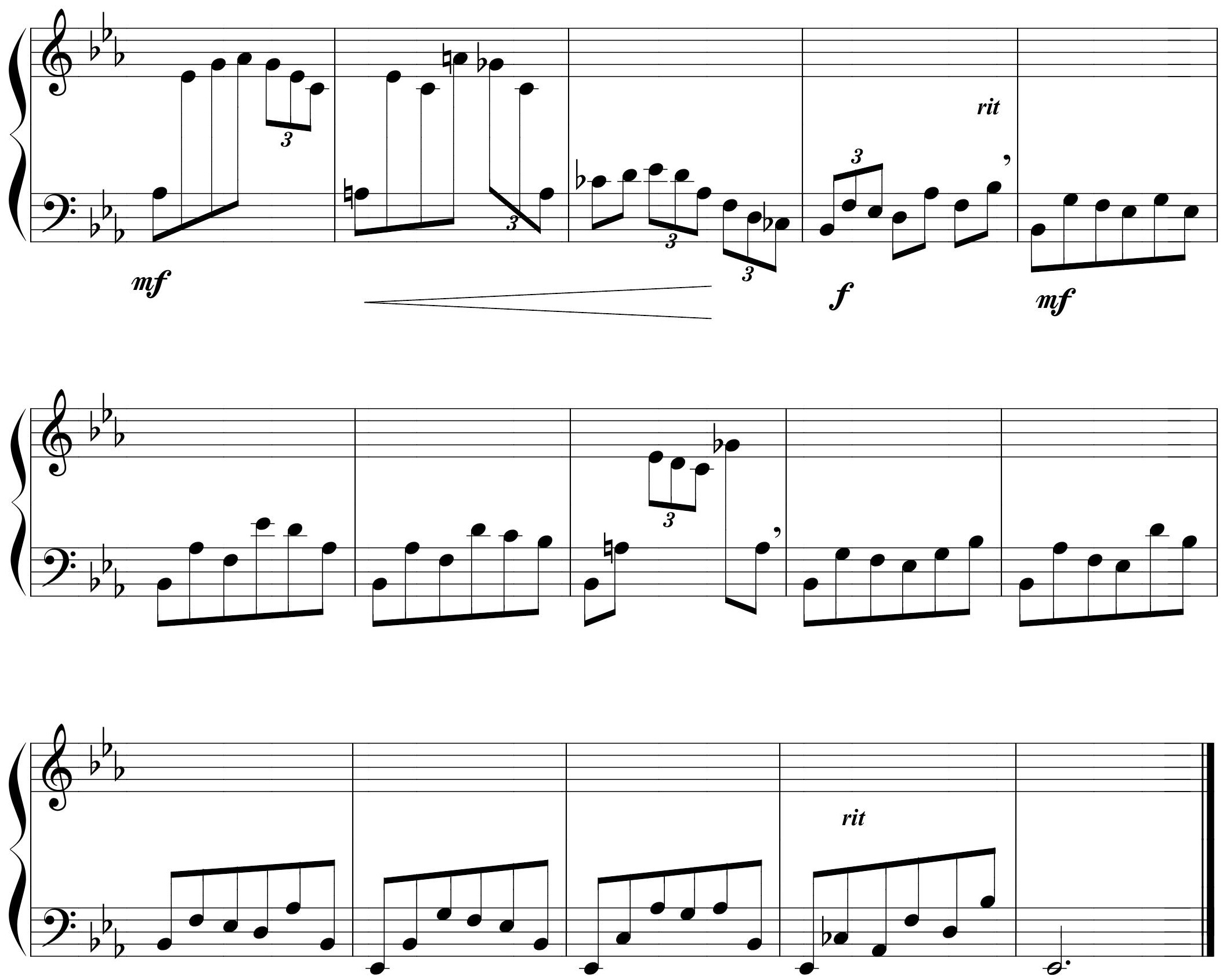
Enérgico $\quad \downarrow=82$
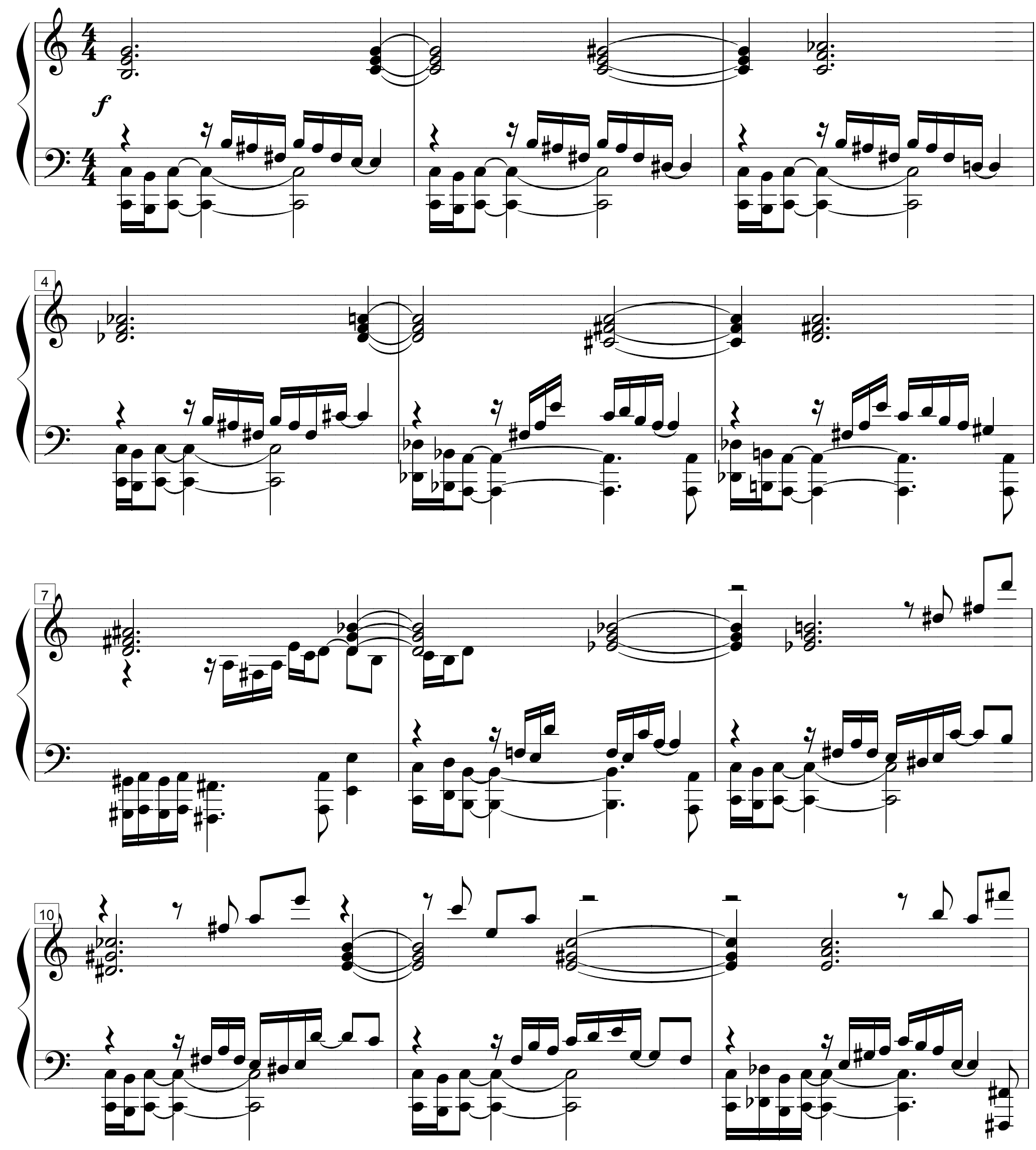


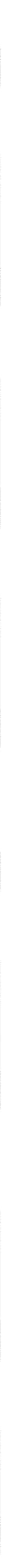

(19)

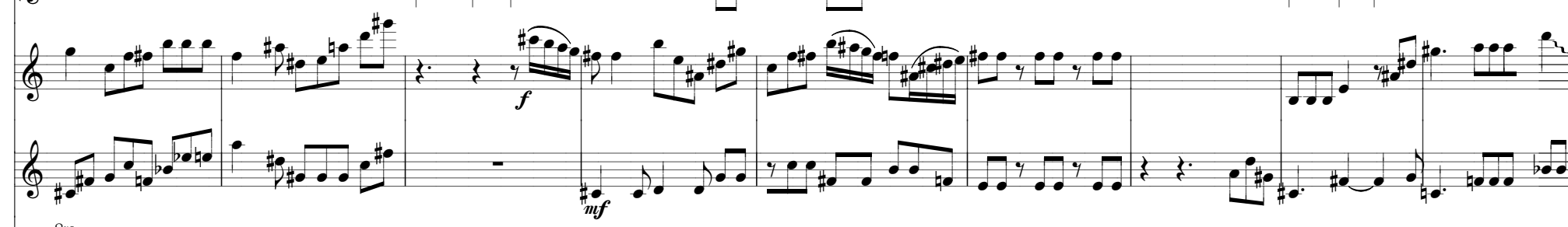

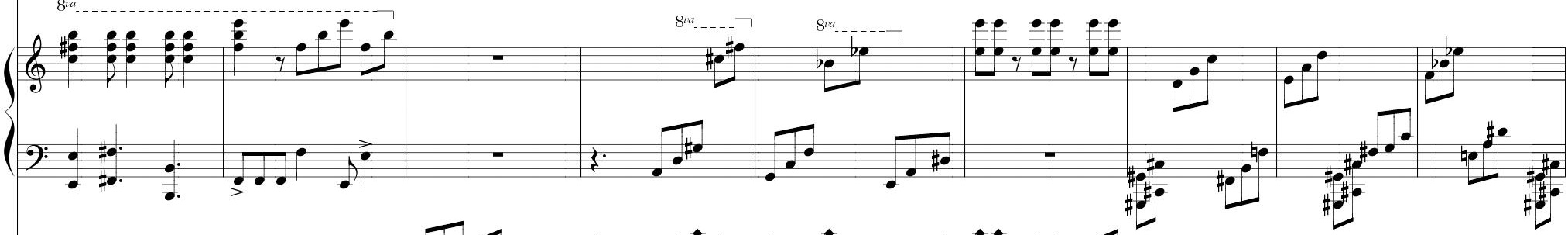

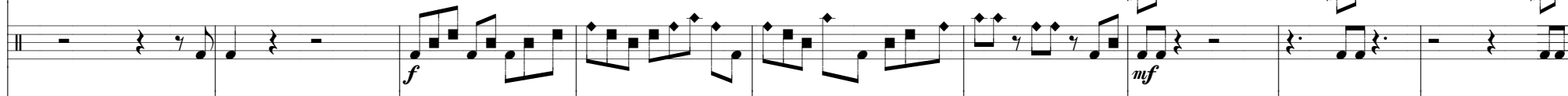
III 

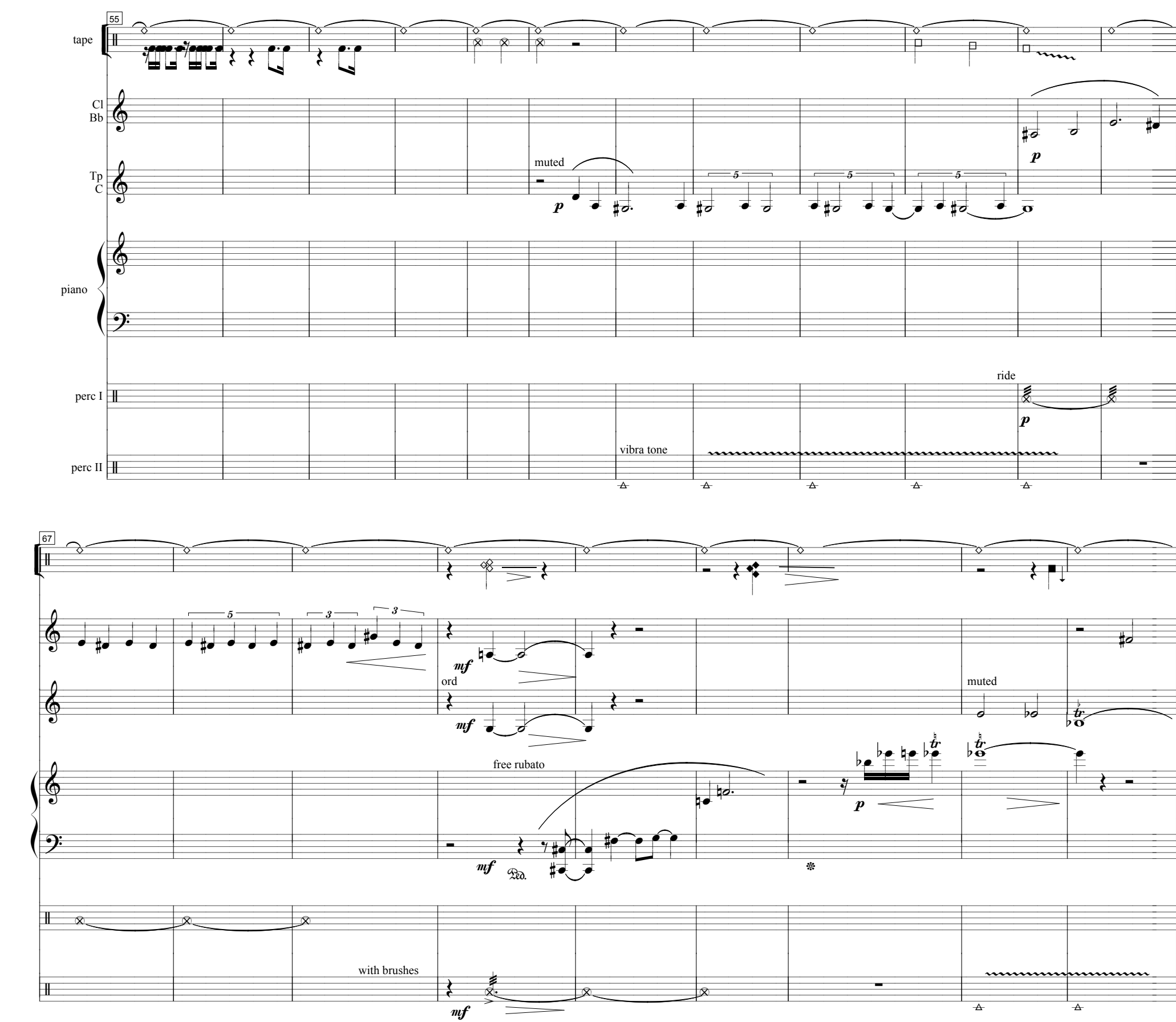

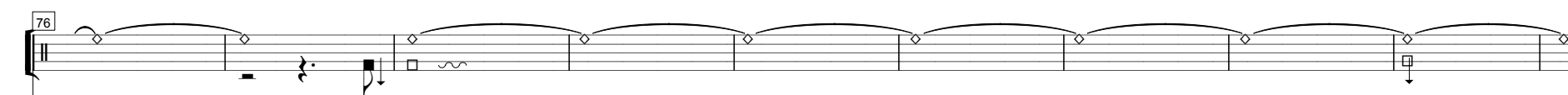
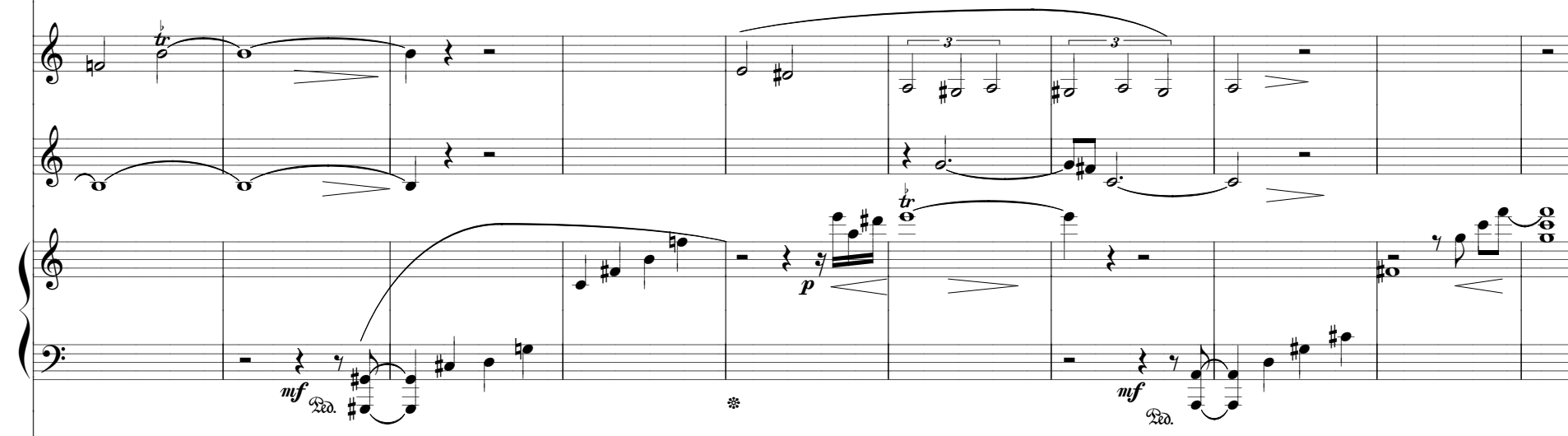

西
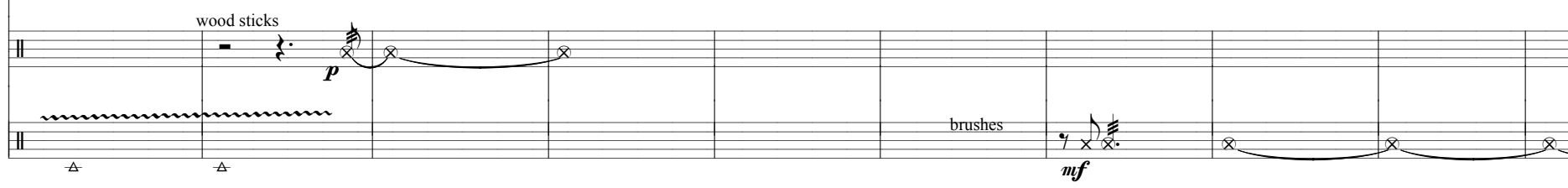
tape

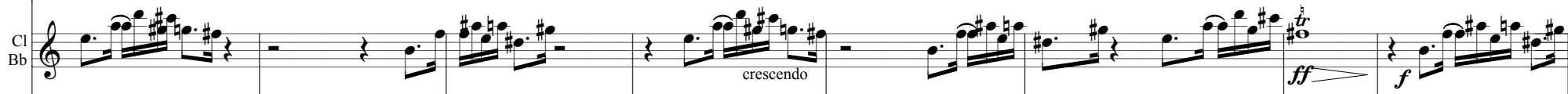

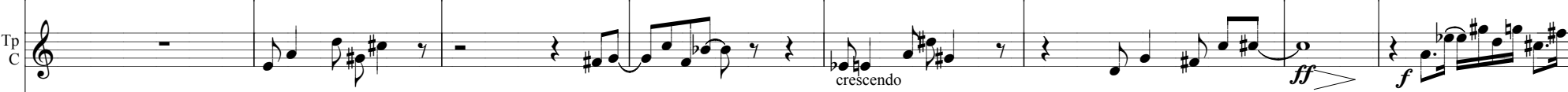

(3.

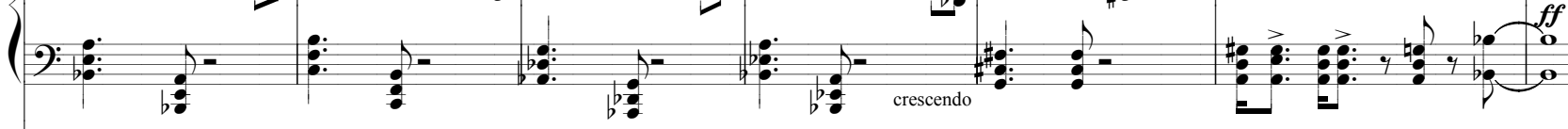

perc 10 E

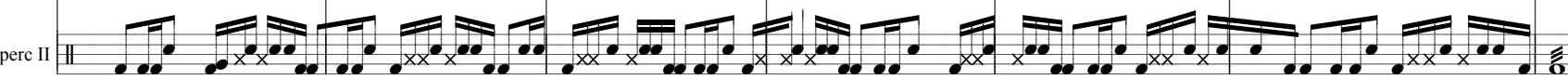

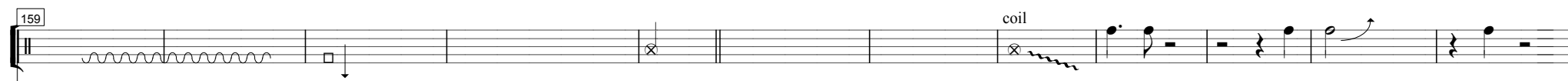

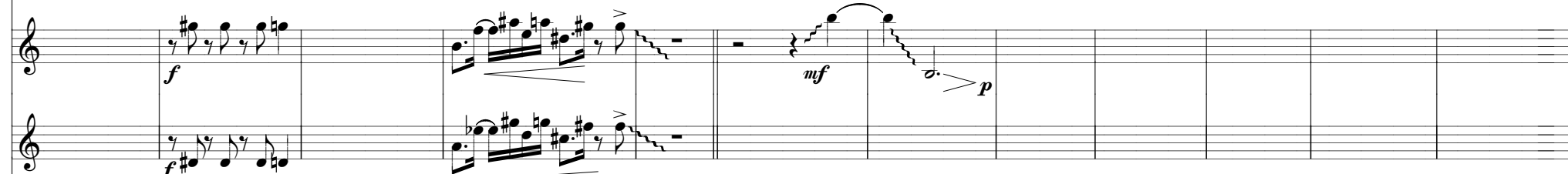

(

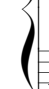
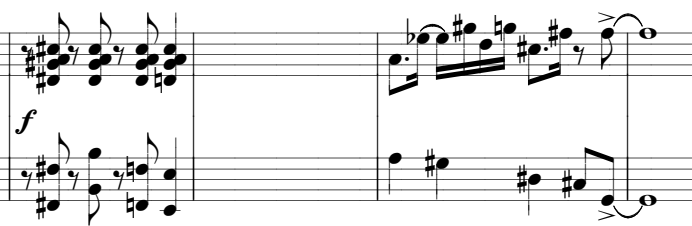

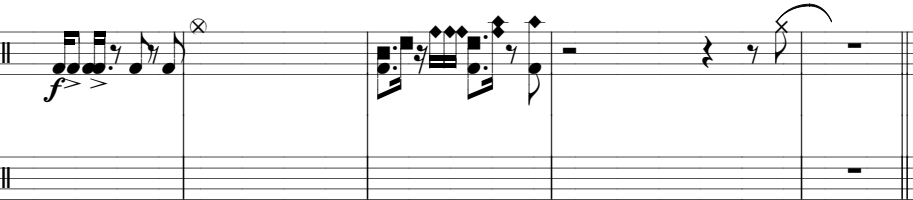

$\sqrt{1}$

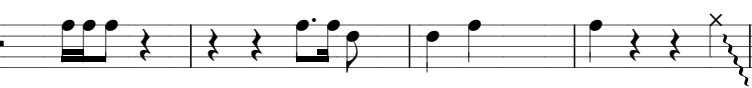

\{

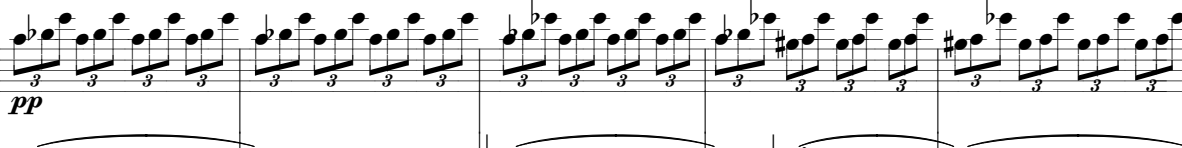

\&
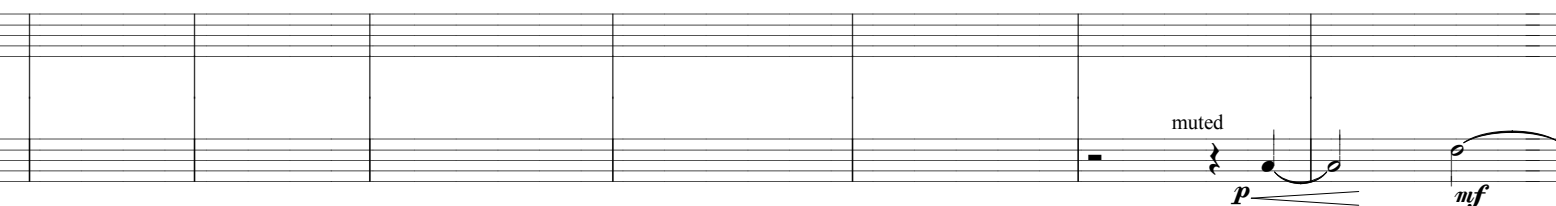

\footnotetext{
I
}

II

nuts or bambu chimes 
tape

c口́

${ }_{\mathrm{Tp}}^{\mathrm{Tp}} \varliminf_{0}$

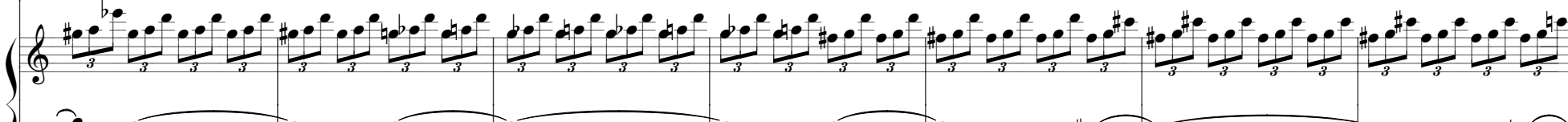
$(930)$

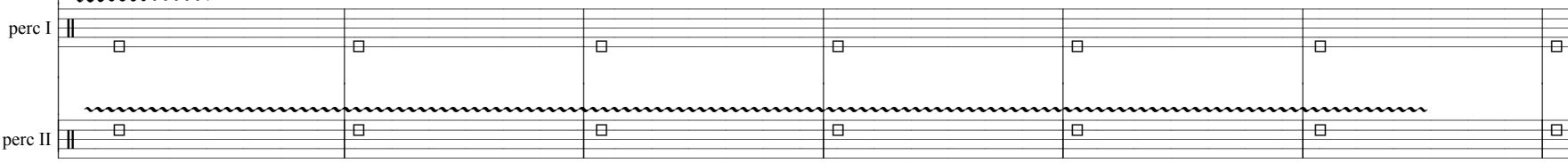

(11110

b

$\oint_{p}^{0}$

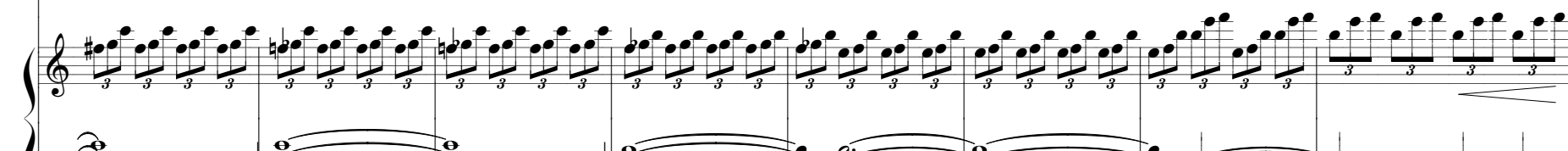

(1)

$\sqrt{12}$

\{

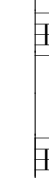

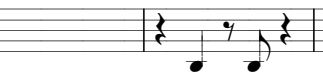

?. +2

?..?

ל

.
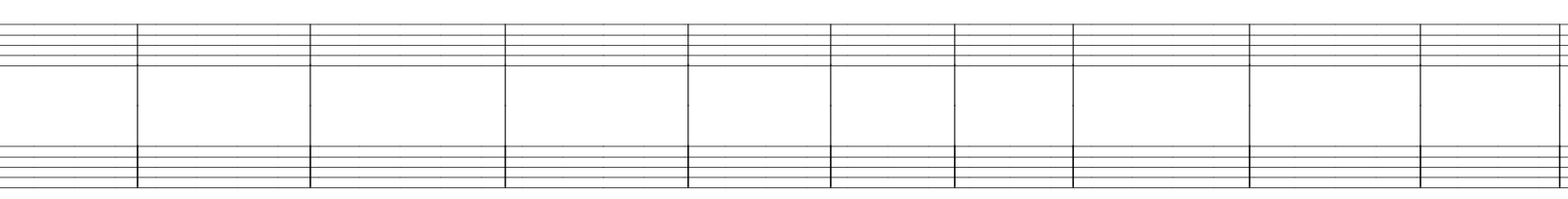

cymbal mallets 
tape

$\mathrm{Cl}$

Tp

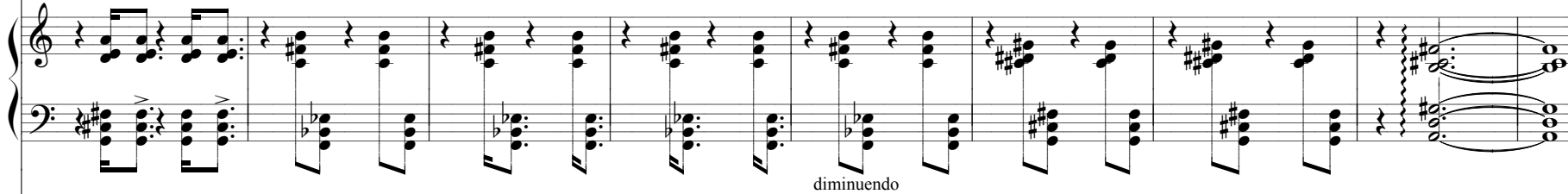

perc II $\# !$

[

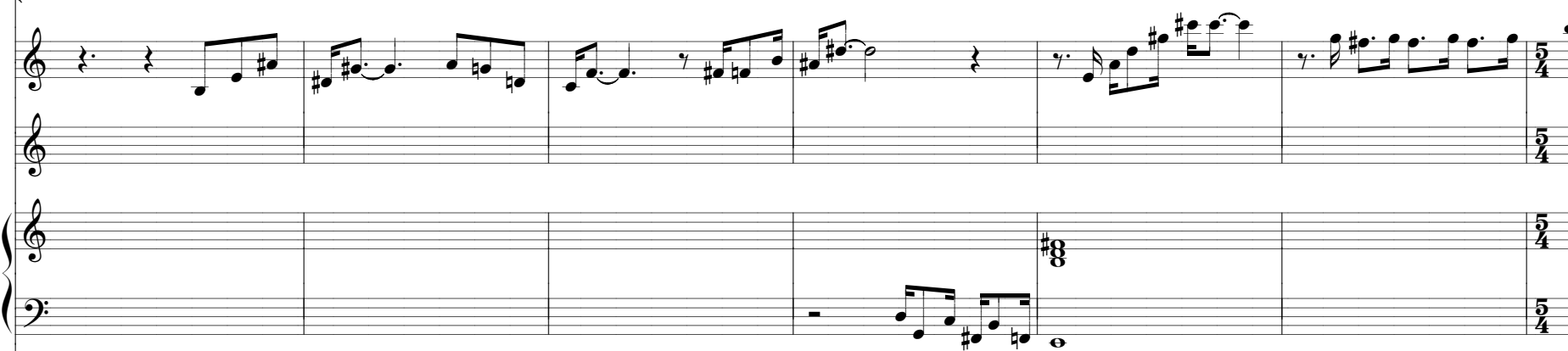

(ל)

(9)

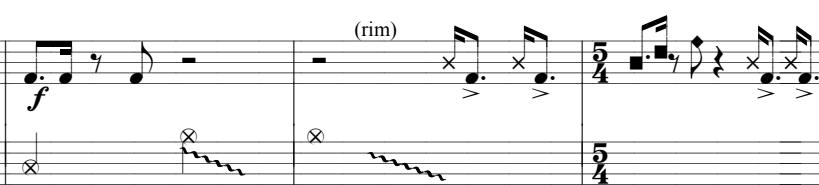

$\sqrt{27}$

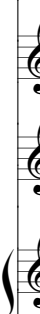

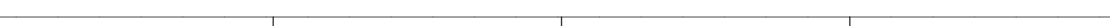

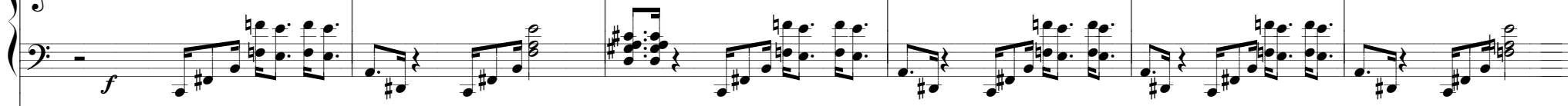

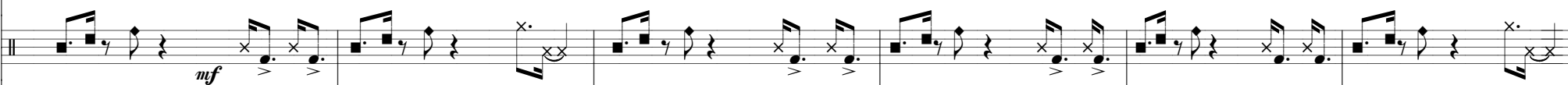




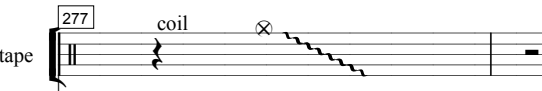

${ }_{\mathrm{Bb}}^{\mathrm{C}} \oint_{0}$

${ }_{\mathrm{Tp}}^{\mathrm{Tp}} \varrho$

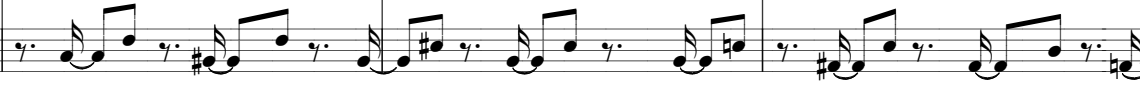

$\left\{\begin{array}{ll|l}\oint^{h-10} & \vdots\end{array}\right.$

$(2)-\cdots$

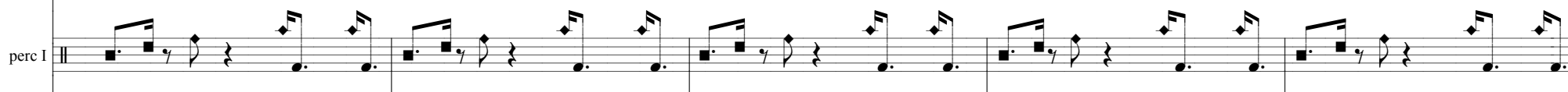

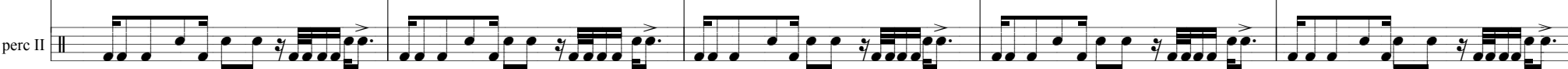
$\sqrt{282}$

$\oint_{1}$

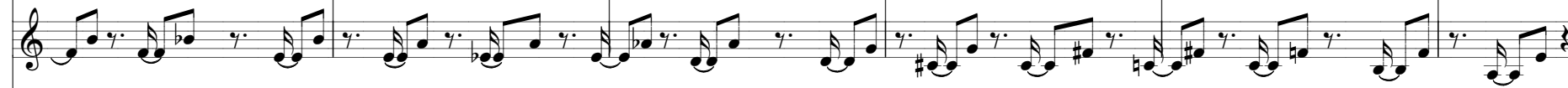

(乌

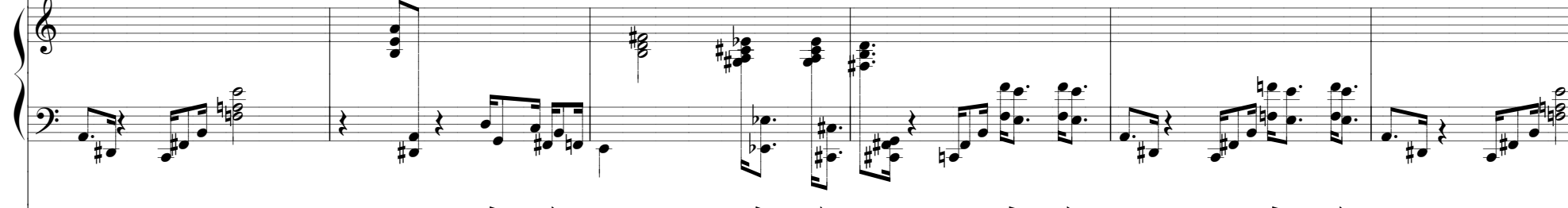

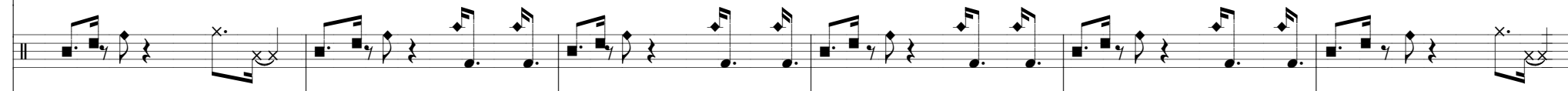

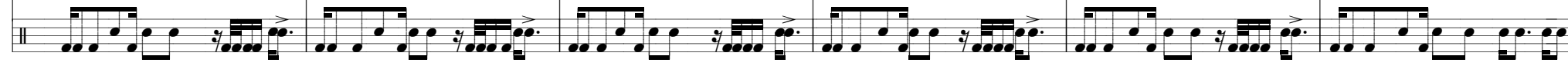
$\sqrt{288}$

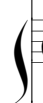
(1) $\oint_{9}$

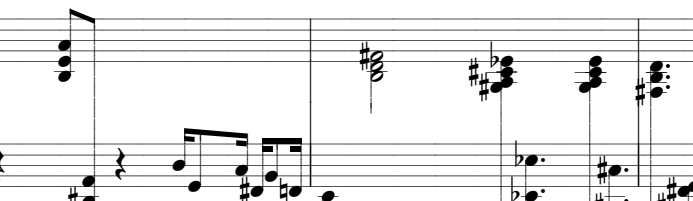


